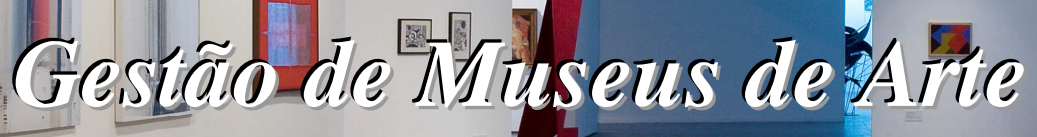
Colleçãa e Mectiaçãa 


\section{Universidade de São Paulo Programa de Pós-Graduação em Artes Visuais}

\section{GESTÃO DE MUSEUS DE ARTE Coleção e Mediação}

Ana Maria Antunes Farinha

Escola de Comunicações e Artes ECA USP

São Paulo

2012 


\title{
GESTÃO DE MUSEUS DE ARTE Coleção e Mediação
}

\author{
Ana Maria Antunes Farinha
}

Tese de doutorado apresentada ao Programa de Artes Visuais da Escola de Comunicações e Artes da Universidade de São Paulo - ECA USP, na área de concentração Teoria, Ensino e Aprendizagem da Arte, na Linha de Pesquisa História, Crítica e Teoria da Arte, sob a orientação da Profa. Dra. Elza Ajzenberg.

São Paulo, 2012 ECA USP 


\section{FOLHA DE APROVAÇÃO}

Autora: Ana Maria Antunes Farinha

Título: Gestão de Museus de Arte: Coleção e Mediação

Tese defendida e aprovada em: pela banca examinadora: 


\section{Dedicatória}

Aos meus pais Ivone e Fernando (in memorian), a Fernanda, Mauricio, Isadora e Daniel pela convivência, carinho, paciência, cuidados e tudo mais. 


\section{AGRADECIMENTOS}

A realização desse trabalho foi possível graças à participação direta e indireta de amigos, colegas de trabalho do MAC, alunos do curso de artes plásticas da FAAP entre muitos outros. Por essa razão agradeço a todos.

À Prof ${ }^{a}$ Elza Ajzenberg pelo estímulo, incentivo, disponibilidade e paciência durante o desenrolar da pesquisa - levando em conta minhas limitações de tempo, sempre tão exíguo.

Aos Prof ${ }^{\circ}$ s. Evandro Carlos Jardim e Edson Leite pela generosa contribuição na Banca de Qualificação, apresentando observações e indicações preciosas para a finalização da pesquisa.

Aos funcionários do Museu de Arte Contemporânea da USP - pelo apoio direto e indireto - sem o qual não conseguiria realizar a pesquisa. Particularmente aos diretores do MAC - Prof. Wolfgang Pfeiffer (in memorian), Prof ${ }^{a}$ Aracy Amaral, Prof ${ }^{a}$. Ana Mae Barbosa, Prof ${ }^{a}$ Lisbeth Gonçalves, Prof. Teixeira Coelho, Prof ${ }^{a}$ Elza Ajzenberg e Prof. Tadeu Chiarelli - que confiando no meu trabalho, propiciaram minha participação em importantes projetos do Museu, ao longo de minha trajetória, possibilitando assim que eu tivesse uma visão mais abrangente da Instituição.

A Bia, Claudinha e Elaine pelo envolvimento nos mais diversos assuntos, compartilhando sonhos, aflições e propondo caminhos sempre com muito bom humor. A Regina e Roseli que sempre se colocaram disponíveis para atender meus pedidos de ajuda - invariavelmente em caráter de urgência.

A Ale pelo envolvimento durante todo o processo de construção e finalização desse trabalho participação fundamental no direcionamento de questões tão complexas - sempre com muita delicadeza, disponibilidade e companheirismo.

Ao Paulo pelo apoio incondicional em todas as minhas iniciativas e ações. Compartilhou de questões - das mais dramáticas às mais divertidas - sempre com muita disposição, leveza e elegância.

Ao Marcos Moraes, amigo de todas as horas. No meio de sua atribulada agenda esteve sempre pronto a ouvir as minhas dúvidas - mostrando sempre o lado positivo de toda e qualquer questão e saídas possíveis. Companheiro de trabalho em diferentes frentes, responsável pela minha entrada na vida acadêmica. 


\section{RESUMO}

A presente pesquisa tem como objetivo investigar os mecanismos de gestão de museus de arte e os procedimentos que são adotados para que essas instituições culturais possam abrigar e ampliar suas coleções de arte, servindo à conservação e à mediação da arte. Refere-se à constituição dos acervos contemporâneos, ao desenvolvimento das formas de geri-los, e de mediá-los. Como eixo principal, discute-se a incorporação temporária de coleções privadas em acervos públicos, por determinação judicial. Dedica-se, especificamente, à reflexão sobre o acolhimento e a gestão de coleções temporárias e/ou transitórias, tomando como exemplo, o acervo do Museu de Arte Contemporânea da Universidade de São Paulo que dispõe de obras em regime de comodato, empréstimos e por determinação judicial. O estudo, ora apresentado, trata a questão dos museus sob a perspectiva de sua gestão patrimonial e interação com a sociedade, destacando seus aspectos históricos, culturais, econômicos e seus desafios para a exposição de arte contemporânea. Como estratégias metodológicas, adotam-se na pesquisa, suportes interdisciplinares, envolvendo História, História da Arte, Museologia, Estética e outras áreas do conhecimento. 


\section{ABSTRACT}

The purpose of this research aims to investigate the mechanisms of management of art museums and the procedures that are adopted so that these cultural institutions could shelter and broaden their art collections, serving the conservation and art mediation. It refers to the constitution of the contemporary collections, to the development of ways to manage and mediate them. As the main axis, this research discusses the temporary incorporation of private collections in public collections, under judicial court order. It is dedicated specifically to the reflection on the reception and management of temporary and/or transitional collections, taking as an example, the collection of the Museu de Arte Contemporânea da Universidade de São Paulo which has works by the means of free-lease agreement, on loan and under judicial court order. The present study addresses the question of museums from the perspective of their asset management and interaction with society, highlighting its historical, cultural, economic aspects and its challenges to the contemporary art exhibition. The methodological strategies adopted in the research, interdisciplinary support, involving history, art history, museum studies, aesthetics and other areas of knowledge. 


\section{PALAVRAS-CHAVE}

Gestão de Museus de Arte Contemporânea; Coleções sob Guarda Provisória e por Determinação Judicial; Mediação.

\section{KEY WORDS}

Management Museum of Contemporary Art, Collections under Provisional Guard and Judicial Determination; Mediation. 


\section{LISTA DE IMAGENS}

Capa Vista panorâmica da exposição "Coleções Sob Guarda Provisória do MAC USP" (detalhe), janeiro de 2008.

1 Painel das Musas (mosaico)

$2 \quad$ Frontispicio do Musei Wormiani Historia. 30

$3 \quad$ Frontispicio do Musei Wormiani Historia. 30

$4 \quad$ Frans Francken II, Kunst- und Raritätenkammer, 31

Kunsthistorisches Museum, Vienna, Áustria, c. 1620-1625.

5 Musaeum Ashmolianum, na Universidade de Oxford,

Londres, Inglaterra, 1659.

6 British Museum, Londres, Inglaterra, 1759.

33

Louvre, Paris, França, 1793. Destaque Pirâmide (Projeto de

I. M. Pei), 1989.

8 Tate Modern, Londres, Inglaterra, 2000.

36

Museu de Arte Moderna, MoMA, Nova York, EUA, 1929.

10 Sala expositiva do Museu de Arte Moderna, MoMA, Nova

38

York, EUA.

11 Centro Nacional Georges Pompidou, Paris, França, 1977.

40

12 New Museum of Contemporary Art, Nova York, EUA, 1977.

13 Fundação Guggenheim, Bilbao, Espanha, 1997.

43

Metropolitan Museum of Art, Nova York (EUA),1820.

Museu Nacional Centro de Arte Reina Sofia.

16 Laboratório de Pintura e Escultura, MAC USP.

63

17 Vista parcial da Reserva Técnica de Tridimensionais, MAC

64 USP.

18 Do Figurativismo ao Abstracionismo.

19 Pavilhão construído na Avenida Paulista, em 1951.

20 Registro da obra de Clemente Padín, $O$ artista a serviço da comunidade, 1974.

21 Umberto Boccioni, Formas Únicas da Continuidade, 1913.

85

22 Henri Moore. Figura Reclinada em Duas Peças: Pontos, 1969/1970.

23 Rosângela Rennó, Venetian Tour Scrapbook, Coleção MAC USP.

24 Jonathas de Andrade, Educação para Adultos, 2010, Coleção MAC USP.

25 Jorge Guinle, Sem título (detalhe da série Viagem de Lua de 
Mel), 1981.

$26 \quad$ Leda Catunda, Meias, 1989.

$27 \quad$ Frank Stella, The Founding (n\#6), 2004.

$28 \quad$ Aleksandr Rodtchenko, Moça com Leica, 1934.

29 Fachada atual do MAC USP, Pavilhão Ciccillo Matarazzo, 119

$3^{\circ}$. andar, Parque Ibirapuera.

$30 \quad$ Fachada atual do MAC USP Anexo (Reitoria USP).

31 Fachada MAC USP, na Cidade Universitária, 1992. 121

32 Fachada atual MAC USP, na Cidade Universitária. 121

33 Fachada atual MAC USP, Pavilhão da Agricultura (Parque 122

Ibirapuera), 2012.

34 Visão panorâmica da exposição $O$ Tridimensional no

123

Acervo MAC USP: Uma Antologia, inaugurada em 28 de janeiro de 2012.

35 Gerhard Richter, Claudius, 1986, exposto no MAC USP

126

Ibirapuera desde 2012.

36 Vista da exposição Poéticas da Natureza, 2007, MAC USP

129

Ibirapuera.

37 Vista da exposição Poéticas da Natureza, 2007, (destaque:

129

Rio Mata, 2000, Leda Catunda), MAC USP Ibirapuera.

38 Vista da exposição Arte-Antropologia-Representações e

130

Estratégias, 2008, MAC USP Cidade Universitária.

39 Vista da exposição Fotógrafos da Vida Moderna, 2008.

Arquivo Projetos Especiais e Produção de Exposições MAC USP.

40 Vista da exposição Fotógrafos da Cena Contemporânea, 2011, MAC USP Cidade Universitária.

41 Vista da exposição Coleções sob Guarda Provisória do MAC USP, 2009, MAC USP Ibirapuera.

131

42 Vista da exposição Coleção, Arte e Ciência, 2012, Centro Universitário Maria Antonia.

Vista da exposição Coleção, Arte e Ciência (detalhe Sala do MAC USP), 2012, Centro Universitário Maria Antonia. 


\title{
LISTA DE ABREVIATURAS
}

\author{
AAMAC Associação dos Amigos do Museu de Arte Contemporânea da \\ Universidade de São Paulo \\ CAAPC-SEC Comissão de Análise e Averiguação de Projetos Culturais da \\ Secretaria de Estado da Cultura \\ CONPRESP Conselho Municipal de Preservação do Patrimônio Histórico, \\ Cultural e Ambiental da Cidade de São Paulo. \\ DETRAN Departamento Estadual de Trânsito \\ ECA USP Escola de Comunicações e Artes da Universidade de São Paulo \\ EDUSP Editora da Universidade de São Paulo \\ FAPESP $\quad$ Fundação de Amparo à Pesquisa do Estado de São Paulo \\ FUNDUSP Fundo de Construção da Universidade de São Paulo \\ FUSP $\quad$ Fundação de Apoio à Universidade de São Paulo \\ IBAMA Instituto Brasileiro do Meio Ambiente, \\ IBRAM Instituto Brasileiro de Museus \\ ICOM International Council of Museums \\ IEB USP Instituto de Estudos Brasileiro da Universidade de São Paulo \\ INCCA International Network for the Conservation of Contemporary Art, \\ IPHAN Patrimônio Histórico e Artístico Nacional \\ JAC Jovem Arte Contemporânea \\ JDN Jovem Desenho Nacional \\ JGN Jovem Gravura Nacional \\ MAE USP Museu de Arqueologia e Etnologia da Universidade de São Paulo \\ MAC USP Museu de Arte Contemporânea da Universidade de São Paulo \\ MALBA Museu de Arte Latino-Americano de Buenos Aires \\ MAM SP Museu de Arte Moderna de São Paulo \\ MASP Museu de Arte de São Paulo Assis Chateaubriand
}




$\begin{array}{ll}\text { MinC } & \text { Ministério da Cultura } \\ \text { MoMA } & \text { Museu de Arte Moderna de Nova York } \\ \text { MNBA } & \text { Museu Nacional de Belas Artes } \\ \text { MP USP } & \text { Museu Paulista da Universidade de São Paulo } \\ \text { NEMO } & \text { Network of European Museum Organization } \\ \text { ONGs } & \text { Organizações Não-Governamentais } \\ \text { OSCIPs } & \text { Organizações da Sociedade Civil de Interesse Público } \\ \text { PRCEU } & \text { Pró-Reitoria de Cultura e Extensão Universitária da USP } \\ \text { SBM } & \text { Sistema Brasileiro de Museus } \\ \text { SEC } & \text { Secretaria do Estado da Cultura } \\ \text { SESI } & \text { Serviço Social da Indústria } \\ \text { SPHAN } & \text { Serviço do Patrimônio Histórico e Artístico Nacional } \\ \text { UNESCO } & \text { Organização das Nações Unidas para a Educação, a Ciência e a } \\ & \text { Cultura. } \\ \text { USP } & \text { Universidade de São Paulo }\end{array}$




\section{SUMÁRIO}

INTRODUÇÃO

GESTÃO DE COLEÇÕES E PATRIMÔNIO 25

Formação de Acervos de Arte 26

Coleção - Questões Patrimoniais 46

Conservação e Exposição 60

UM ACERVO "CONTEMPORÂNEO"

Aquisições (Compra e Doação) 73

Empréstimos e Comodatos 93

Por Determinação Judicial 103

COLEÇÕES SOB A GUARDA PROVISÓRIA 111

Destino: Museus Públicos 112

Recursos Materiais e Financeiros 124

$\begin{array}{ll}\text { Exibição e Mediação } & 128\end{array}$

CONSIDERAÇÕES FINAIS

REFERÊNCIAS BIBLIOGRÁFICAS

ANEXOS 153

Código de Ética ICOM

Roteiro para o Plano Diretor

Portaria Normativa $\mathrm{n}^{\mathrm{o}} 1$ IPHAN/Plano Museológico

Lista de Obras (adquiridas - compra e doação)

Lista de Obras (sob guarda provisória exibidas) 
A base material de um museu é sua coleção, criada, difundida, mantida e ampliada com base em valores estabelecidos, pela demanda ou por estudos, sendo habitual o interesse para que peças atestem raridade, exemplaridade, preciosidade (...) (LOURENÇO, 1999, p. 31). 
As formas de gestão dos acervos museológicos e os diferentes níveis de relacionamento com o público, geralmente, referem-se à base material da instituição, ou seja, à sua coleção, organizada, preservada, instrumentalizada e acrescida a partir de valores pré-estabelecidos (IDEM, p. 14). Os objetos são reunidos pela capacidade testemunhal e patrimonial, além de toda uma gama de outras qualidades, colhidas em diferentes épocas. Para a compreensão dos desafios e das práticas museológicas instituídas nas gestões dos museus atuais é preciso recorrer ao passado e investigar as origens e as diferentes proposições dessas instituições culturais.

$\mathrm{Na}$ formação das primeiras coleções e no processo de abertura desses acervos para o público em geral residem valores e pressupostos que regem a atual gestão de museus. As instituições museológicas carregam consigo, na maioria das vezes, uma herança marcadamente aristocrática e sacralizada que torna necessário o pleno conhecimento para o estabelecimento de novas diretrizes para o presente e para o futuro dessas instituições (GONÇALVES, 2004, p. 13) ${ }^{1}$.

\footnotetext{
${ }^{1}$ A palavra museu deriva da latina museum, que, por sua vez, vem do grego mouseîon, o templo dedicado às musas. Em sua origem, portanto, significa "casa das musas". As musas são nove, cada uma inspiradora e protetora de uma arte: Clio (história), Calíope (poesia épica), Euterpe (música), Melpômene (tragédia), Tália (comédia), Terpsícore (dança), Erato (poesia amorosa), Polímnia (hinos sacros) e Urânia (astronomia). Mouseîon é o termo utilizado pelo historiador Estrabão (Alexandria, século I a.C.) para designar um centro interdisciplinar de cultura e patrimônio, particularmente o dos palácios reais de Ptolomeu Soter ou Ptomoleu Filadelfo. O museu era parte integrante desses palácios. Assim, o ato de colecionar, ao lado do desejo de expor a coleção, fez emergir a constituição do museu.
} 
No passado, o termo mousê̂on atribuía sentido à tentativa de reunir conhecimentos produzidos pelo homem. Os artefatos que eram reunidos, colecionados e exibidos estavam voltados à busca de um saber universal (IDEM). No Renascimento, a prática das coleções de antiguidades intensificou-se, marcando o momento pela "curiosidade", ou seja, pela noção do "exótico". Objetos eram reunidos em gabinetes para a contemplação e a meditação (IDEM). Nesses "gabinetes de curiosidades", o objetivo era criar um microcosmo do mundo $^{2}$. No século XVI, a pintura e a escultura ganharam espaço nas coleções. Em 1580, por exemplo, Francisco I de Médici colocou sua coleção na Galleria degli Uffizi, dando destaque às pinturas e às esculturas (IDEM). Gradualmente, enfraqueceu-se a tradição de curiosidade e as coleções se especializaram, sendo abertas ao público e dando origem ao que hoje é concebido por museu.

Dos Médicis aos Rockfellers, a criação de um museu de arte, na maioria das vezes, está ligada à doação de uma coleção já constituída e estruturada, que carrega todas as particularidades de seu proprietário. Um dos maiores desafios dos museus de arte está na ampliação ou ainda na atualização do seu acervo, mantendo um padrão de qualidade e mérito, determinado por estudos e pesquisas (LOURENÇO, op. cit., p. 31). Muitas instituições estão sujeitas a toda sorte de oportunidade, uma vez que não podem contar, com uma política contínua de aquisição de obras, por falta de recursos materiais, financeiros e em casos muito específicos físicos (com espaços adequados para o abrigo das coleções). Para que a atualização da coleção seja ainda que precariamente realizada, os museus aceitam doações de obras ou ainda de coleções inteiras que, invariavelmente, demandarão recursos de natureza material e nem sempre atenderão na íntegra suas necessidades.

Uma reflexão sobre a gestão de bens patrimoniais e culturais em museus pode ser proporcionada pelo levantamento das seguintes indagações: Como são formados os acervos dos museus de arte contemporânea, particularmente os

\footnotetext{
${ }^{2}$ Geralmente, nos "gabinetes de curiosidades" eram guardados diversos artefatos, considerados "exóticos", desde animais empalhados, passando por tesouros dos templos antigos e das igrejas medievais até vegetais e minerais raros.
} 
brasileiros? Qual a procedência dos objetos e, principalmente, quais os critérios que envolvem a aquisição, doação e guarda de obras em acervos contemporâneos? Como um museu de arte contemporânea pode estruturar-se para gerir obras efêmeras e/ou ainda com suportes diferenciados - cada vez mais frequentes na arte contemporânea?

Uma das questões mais relevantes que delineia a gestão de museus é: a coleção seria o cerne para a existência dessas instituições, isto é, seria a coleção de obras contemporâneas o fator determinante para que um museu torne-se um museu de arte contemporânea? Esta indagação cerca o cotidiano das instituições museológicas e para respondê-la não basta somente ter presente que os objetos reunidos demonstrem capacidade testemunhal e patrimonial, além de qualidades compatíveis à aura simbólica inerente à obra de arte. É preciso aprofundar-se na realidade e nas ações vivenciadas por essas instituições para a atualização e ampliação de seus acervos.

No cotidiano das instituições museológicas nacionais e internacionais (aqui se colocam museus de arte, como Museu de Arte Moderna de Nova York, New Museum of Contemporary Art, Fundação Guggenheim, Centre George Pompidou, Museu de Arte de São Paulo, o Museu de Arte Moderna de São Paulo e o Museu de Arte Contemporânea da Universidade de São Paulo), o debate sobre a reordenação de seus papéis e funções está atrelado às constantes reformulações do espaço expositivo (inclui-se nesse âmbito, reformas e ampliações de edifícios), assim como as exigências impostas pela nova expografia. As chamadas "obras transgressoras" desafiam os parâmetros modernistas nos quais estão calcados os alicerces da constituição espacial e funcional dos museus (LARA FILHO, 2011). Como abrigar obras contemporâneas seguindo uma ordenação moderna? Simultaneamente, as funções dos museus transformam-se diametralmente às mudanças sociais.

Quando em 1974, o International Council of Museums (ICOM), colocou como função principal aos museus "o servir a sociedade e seu 
desenvolvimento", 3 a preocupação de prover o acesso ao público somou-se às funções tradicionais de colecionar, classificar e conservar os objetos (LARA FILHO, op. cit.). Contudo, o livre acesso não garante a fruição (vista como entendimento e compreensão) da obra de arte. O dilema está posto: priorizar o livre acesso e transformar o museu em showroom (com a popularização através de ações simplificadoras de seus conteúdos) ou mantê-lo na esfera sacralizada de templo destinado aos eleitos?

Na esfera da gestão de museus essa questão está tangente à definição do plano de funções, seus propósitos e finalidades, que a primeira vista, parecem termos e ações semelhantes, mas que se revelam elementos diferenciados na prática: as funções identificam-se com as atividades operacionais, ao passo que os propósitos são valores balizados pela política de aquisição de obras da instituição (IDEM). O museu deve deslocar seu eixo da função para o propósito? Não é o caso, uma vez que as funções não se separam dos propósitos, assim como os museus não podem ser vistos somente como "casa de custódia" das obras de arte (ANJOS, 2005). Nesse sentido, surgem questões tais como: será preciso criar novas formas de atuação frente à coleção para os museus na contemporaneidade? Quais as transformações necessárias para que o museu consiga expor, conservar e mediar a arte contemporânea?

No embate entre coleção, função e propósitos, talvez as formas de mediação possam indicar as alternativas para a gestão museológica de museus de arte contemporânea. Segundo Moacir dos Anjos, "o museu na contemporaneidade é um espaço de construção de uma ideia de estar no mundo" (IDEM). Essa ideia estende-se aos museus de arte. Isto é, o museu de arte contemporânea necessita ser o agenciador entre os objetos que constroem o mundo e o desejo do público. Nessa perspectiva, os recursos materiais e

\footnotetext{
3 "A museum is a non-profit making, permanent institution in the service of society and of its development, and open to the public, which acquires, conserves, researches, communicates and exhibits, for purposes of study, education and enjoyment, material evidence of people and their environment”. Em 2001, à última atualização do conceito de Museu, o ICOM acrescenta: "cultural centres and other entities that facilitate the preservation, continuation and management of tangible or intangible heritage resources (living heritage and digital creative activity)".http://icom.museum/hist_def_eng.html. Acesso em 8 de abril de 2004
} 
financeiros, a qualificação profissional e, especialmente, o público-alvo dessas instituições contam como elementos significativos dessa mediação. A pergunta central seria então: a arte contemporânea, exposta nos museus seria para quem? Tem-se um novo dilema tão forte quanto a gerência da coleção ou da função dos museus. Aqui fica claro que a gestão museológica não pode contemplar somente a coleção e a função, mas também as relações entre as pessoas, o museu e a coleção.

Questionam-se, então, as noções isoladas de função, coleção, propósitos e mediação na gestão de museus de arte contemporânea, colocando como foco da investigação a necessidade de articulação desta tríade para que o museu represente um espaço de interação e de reconhecimento do indivíduo e da sociedade. O estudo, ora apresentado, trata a questão dos museus sob a perspectiva de sua gestão patrimonial e sua interação com a sociedade, destacando seus aspectos históricos, culturais, econômicos e seus desafios para a atualização e exposição de arte contemporânea.

A presente pesquisa tem como objeto os mecanismos de gestão de museus de arte e os procedimentos que são adotados para que essas instituições culturais possam abrigar e ampliar a coleção, servindo à conservação e à mediação da arte contemporânea. Dedica-se, especificamente, ao acolhimento e à gestão de coleções temporárias e/ou transitórias, tomando como exemplo, o acervo do Museu de Arte Contemporânea da Universidade de São Paulo que dispõe de obras em regime de comodato, empréstimos e por determinação judicial, sendo que esta última categoria de ampliação do acervo será foco da análise. A prática museológica do MAC USP será tomada como estudo de caso para compreender os embates diários de uma instituição brasileira de arte contemporânea.

Como eixo central do estudo, apresenta-se a reflexão sobre a coleção de arte contemporânea em museus de arte dando ênfase à guarda provisória de coleções privadas em acervos públicos considerando-se, especialmente, que essas obras podem, em princípio, não permanecer junto aos acervos. Apresenta-se como exercício factível para a compreensão do que representa coleções 
particulares para a constituição e a organização de um acervo especializado em arte contemporânea. Em caso de incorporação temporária de obras, por determinação judicial, pode se indagar: os acervos públicos devem recebê-las? Zelar por sua conservação? Investir em restauro? E, em seguida, devolvê-las aos (particulares) antigos colecionadores? Como fica a questão do patrimônio público? Através da presente investigação é possível a identificação de questões que envolvem os mecanismos de incorporação de obras, de manutenção das obras e da pesquisa das mesmas, assim como a definição do que se constitui um acervo e uma coleção.

As estratégias metodológicas que envolveram a pesquisa tiveram como suportes relevantes estudos interdisciplinares, abrangendo História, História da Arte, Museologia, Estética, Patrimônio e Direito. Os subsídios arquitetônicos, estéticos, históricos e econômicos relativos às exposições nacionais e internacionais, também funcionaram como importantes elementos para a continuidade do trabalho. Mencione-se, ainda, a necessidade de realização de um levantamento específico sobre as vertentes relacionadas: à constituição dos acervos contemporâneos, ao desenvolvimento das formas de geri-los e mediá-los.

A presente pesquisa, em primeira instância, realizou um levantamento bibliográfico e uma leitura sistemática sobre os temas "história dos museus e coleções de arte", "incorporações e alienações de coleção de arte", "patrimônio e bens públicos", "gestão de museus" e "aquisição, conservação e exibição de obras contemporâneas em acervos museológicos". Além desses focos, organizou-se material em suas diversas interfaces, especialmente o material que expunha: as diversas e possíveis leituras da gestão de museus, as relações entre o conhecimento histórico e a memória e, por fim, as interações entre arte contemporânea/público por intermédio dos museus.

Os temas ligados ao estudo de museus já foram abordados em diferentes focos, por uma série de estudiosos nacionais e internacionais de reconhecido mérito, entre eles, assinalam-se os estudos de André Malraux, especialmente seu ensaio Museu Imaginário, que trata do histórico e das 
questões pertinentes ao papel dos museus na relação entre obra de arte e público. Em Museus Acolhem o Moderno, Maria Cecília França Lourenço traça um diagnóstico das instituições museológicas brasileiras centralizando-se nos museus de arte moderna e nos seus problemas de procedência dos acervos, nos mecanismos de continuidade entre diversas gestões e diretorias, além de questões éticas que envolvem a responsabilidade pública em preservar patrimônios, por vezes destituídos de todo e qualquer valor.

Brian O’Doherty, No Interior do Cubo Branco e Lisbeth Rebollo Gonçalves, Entre Cenografias - O Museu e a Exposição de Arte no Século XX tratam da recepção estética nas exposições de arte em museus. Esses estudos demonstram o desenvolvimento do discurso museológico e como ele se dá, em essência, por meio de exposições. O modo "limpo" de exibição do objeto artístico retratado em No Interior do Cubo Branco, reivindicado pelos aspectos de autonomia da obra moderna, é contraposto à teatralização e ao espetáculo presente nas novas cenografias que acompanham as exposições nacionais e internacionais discutidas em Entre Cenografias.

Outras investigações que tratam diretamente da administração de acervos, como os escritos de Ulpiano Bezerra de Meneses, Maria Ignez Mantovani Franco, Jean Marc Poinsot, Bruce Altshuler e diversos outros pesquisadores têm o auxílio de instituições voltadas à questão da preservação e do gerenciamento das instituições museológicas, como por exemplo, pode se mencionar o ICOM (Internacional Council of Museums), o IBRAM (Instituto Brasileiro de Museus) e outras associações correlatas que promovem o estudo e o diálogo da pesquisa dirigida ao cotidiano museal. As especificidades desta investigação, porém, demandam um recorte no horizonte de fontes de pesquisa. Vale ressaltar que essas particularidades apontam para o universo da tipologia dos "museus de arte" e nesse âmbito, um detalhamento ainda maior dirige o estudo para o "museu de arte contemporânea" e sua forma de tratar a coleção, sua função e sua mediação. 
Nas estratégias metodológicas, os contatos com fontes primárias têm prioridades no âmbito desta pesquisa. Fontes, tais como processos judiciais (aqui se deve destacar os emitidos pelo Dr. Fausto de Sanctis ${ }^{4}$, juiz titular da $6{ }^{\mathbf{a}}$. Vara Criminal Federal Especialista em Crimes contra o Sistema Financeiro Nacional em Lavagem de Valores, responsável pelo envio das três coleções privadas sob a guarda provisória do MAC USP), contratos de comodato, laudos técnicos, procedimentos de catalogação, coleta de depoimentos, entrevistas com especialistas na gestão museológica, artigos em jornais e revistas especializadas, textos e comunicados publicados em anais de eventos científicos da área de Museus e afins foram trabalhadas para a extração do máximo de informações possíveis. ${ }^{5}$ Outra fonte importante de pesquisa reside nos relatórios, documentos jurídicos e artigos publicados por dirigentes de instituições e órgãos governamentais e não-governamentais que compartilham dos dilemas inerentes às práticas museológicas dedicadas às artes contemporâneas tanto em âmbito nacional como internacional.

Deste modo, a pesquisa organiza-se a partir da seguinte estrutura:

Em Gestão de Coleções e Patrimônio: evoca-se a formação das primeiras coleções, focalizando atenção ao abrigo das coleções de arte contemporânea. Além disso, aprofunda-se nas especificidades que existem na constituição e na gerência dos museus de arte - o entendimento sobre as transformações e as constantes revisões pelas quais a instituição museológica passou é fundamental para as novas

\footnotetext{
${ }^{4}$ Dr. Fausto de Sanctis hoje é Desembargador Federal do Tribunal Regional Federal da $3^{\text {a }}$ Região (TRF3 - com sede na Capital do Estado de São Paulo e jurisdição sobre as Seções Judiciárias de São Paulo e Mato Grosso do Sul).

${ }^{5}$ Destaque-se a experiência de 32 anos da pesquisadora na atuação em museus e procedimentos no cotidiano destas instituições. Na administração do Museu de Arte Contemporânea da Universidade de São Paulo (MAC USP), é possível vivenciar os desafios da gestão museológica. A participação em conselhos, órgãos de congregações e associações da área, entre eles: o ICOM (International Council of Museums), o INCCA (International Network for teh Conservation of Contemporary Art), CAAPC - SEC (Comissão de Análise e Averiguação de Projetos Culturais da Secretaria de Estado da Cultura) o IBRAM (Instituto Brasileiro de Museus), o IPHAN/MinC (Departamento de Museus e Centros Culturais do Instituto de Patrimônio Histórico e Artístico Nacional), permite o conhecimento técnico das questões que envolvem as ações de outras instituições congêneres, tais como o Museu de Arte Moderna (MAM SP), a Pinacoteca do Estado de São Paulo, o Museu de Arte de São Paulo, entre outros.
} 
perspectivas apontadas na gestão atual de museus. Nessa parte, ocorre o questionamento sobre as funções estabelecidas dos museus de arte contemporânea, tais como coletar, documentar, catalogar, preservar e mediar o "encontro" entre obras e o público. Um dos aspectos mais relevantes a ser abordado reside na vivência dessas instituições, no que tange à pesquisa, à conservação e à difusão.

Em Um Acervo "Contemporâneo", destacam-se as formas de atualização e ampliação dos acervos, tais como aquisição, empréstimos, comodatos e por determinação judicial, tendo como estudo de caso, as formas de atualização do acervo que ocorrem no Museu de Arte Contemporânea da Universidade de São Paulo - uma experiência vivenciada (refletida e debatida no contexto da Universidade de São Paulo). A partir das práticas e procedimentos adotados nesse acervo observam-se os principais embates que cerca o cotidiano de instituições artístico-culturais voltadas à arte contemporânea, acrescentados pelo fato de ser um acervo público e de caráter universitário.

E, por fim, em Coleções sob a Guarda Provisória, tratam-se as questões mais emergentes sobre essa condição de preservar, manter e exibir coleções que não pertencem ao acervo das instituições museológicas e que têm origens, aspectos e especificidades materiais diversas. Colocam-se, nesse ponto, as questões ligadas à infraestrutura (tais como recursos humanos, materiais, físicos e financeiros - aqui, inclui-se a construção de suas sedes; a crescente profissionalização e constante necessidade de capacitação dos profissionais desse tipo de museu e sua inserção no circuito internacional de arte contemporânea) e, principalmente, toca-se no dilema existente entre coleções privadas em acervos públicos e a política de atualização dos acervos públicos. 
PA RTTIE II

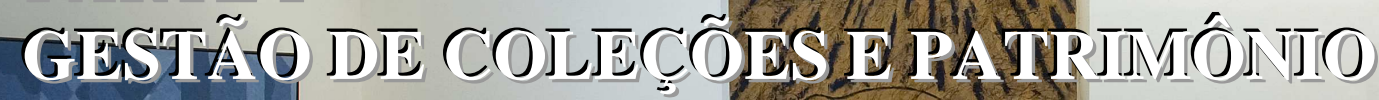




\section{Formação de Acervos de Arte}

Historicamente, as instituições museológicas carregam uma herança aristocrática e sacralizada. A constituição de acervos e a origem dos museus são associadas ao ato de colecionar: as oferendas aos deuses ou aos mortos, as relíquias e os objetos sagrados, os tesouros - todo e qualquer indicativo de memória sempre foi elemento formador de coleções (FRANCO, 2010, p. 50). Reconhecidamente, o ato de colecionar estimula o processo cognitivo humano. Através dos objetos e bens materiais o homem compreende o mundo ao seu redor (MARSHALL, 2005, p. 13) ${ }^{1}$. Os museus, ou ainda, "os templos das musas" são destinados ao colecionismo, ao exotismo, à ordenação e à classificação do mundo - são "lugares da memória" voltados ao prazer estético e a interesses sociais em diversos períodos (da antiguidade clássica, passando pela Idade Média e Renascimento, aos tempos da Revolução Francesa). Contudo, diga-se que os museus, nessas diferentes épocas, sempre são instrumentos da memória conservada pelas elites. Hoje, tentam estabelecer novas diretrizes direcionadas ao desenvolvimento humano e à cidadania, particularmente organizando projetos que envolvam a sociedade em todos os seus setores.

\footnotetext{
1 Francisco Marshall afirma que "Aristóteles é provavelmente, o primeiro colecionador sistemático da História. Coletava exemplares e os estudava à exaustão, ele próprio para escrever seu trabalho A Política, colecionou cerca de 158 constituições de cidade".
} 
Do ponto de vista dos papéis desempenhados pelas instituições culturais em nível internacional e nacional, os museus, a despeito de suas dificuldades, desempenham suas funções de centros de pesquisa, não se restringindo somente a atuar como depositários de objetos, mas procurando firmarem-se pela relevância de suas produções científicas e de suas pesquisas experimentais, ao lado das funções de catalogação, classificação das coleções e educação de seus diversos públicos. Os museus especializam-se na tentativa de exercerem um papel pioneiro na institucionalização de áreas de conhecimento, como a Paleontologia, Antropologia, a Fisiologia Experimental, a História e a Arte, rompendo a tradição naturalista que inauguram enquanto instituições (ROCHA, 2008, p. 32).

Os museus de arte tentam superar sua conotação "de templo", de "depósito de tesouros" ou de "casa de custódia" de obras. O perfil do museu como algo sacralizado ou "intocado" gradativamente perde espaço para uma concepção que aproxima o acervo museológico de seus usuários, pois a noção de bem público cresce juntamente com a ideia de cidadania. Nos ideais dessas instituições, seus gestores não são mais responsáveis por mitos e estereótipos, existentes entre a "cultura erudita" e a "cultura popular". Inspiram por transformar as entidades museológicas em lugares de produção crítica e de formação de cidadãos. Além de centros de pesquisa e produtores de conhecimento, os espaços museais também trazem a conotação de lugares ligados ao entretenimento, à educação e, sobretudo, à valorização do indivíduo e de suas potencialidades. E, nesse contexto, Meneses (1998), levanta uma discussão significativa centrada no museu com obras de arte em seu acervo, pois desde a antiguidade grega há o ideal de que a arte deve ser gerida pelos cidadãos da polis - dedicada ao bem público.

Sobre as relações existentes entre as obras de arte e os museus, como "guardiões do bem público", surgem indagações fundantes: como são formados os acervos dos museus de arte? Qual a procedência desses objetos e, principalmente, quais os critérios que envolvem a formação das primeiras coleções de arte? Em termos gerais, desde Alexandria, o termo museo, surge como uma referência a museion, lugar destinado aos estudos e discussões sábias 
(FRANCO, op. cit., p. 51). Na Idade Média, a arte que honra o sacro e as relíquias torna-se objeto de coleções reunidas em igrejas, mosteiros e propriedades dos senhores feudais (IDEM) ${ }^{2}$. A ação de colecionar renova-se em contextos científicos, adquirindo significados nas artes e nas ciências significados que ultrapassam o procedimento de classificação, atingindo o estatuto cultural, as cortes e o poder. No período medieval, príncipes da Igreja e governantes seculares acumulam tesouros e relíquias, tais como: vasos de luxo, joias e objetos exóticos. A partir desses objetos, surge uma forma mais privada de apreciação, o studiolo, um estúdio especialmente construído para abrigar os objetos essencialmente belos, pedras preciosas e esculturas ${ }^{3}-$ algo popular na Itália entre homens abastados. Oliviero Forza, em Treviso, constitui o primeiro studiolo de que se tem registro, em 1335 (IDEM).

No século XV, o colecionismo de objetos vindos do mundo natural e de culturas diversas fascina reis, príncipes, sacerdotes, membros das ordens militares e da nobreza, profissionais liberais e intelectuais e, com a descoberta do Novo Mundo, em 1492, um novo tipo de coleção ganha espaço - os chamados gabinetes de curiosidades, onde o mundo cultural e natural se mistura, reunindo objetos maravilhosos e exóticos de diversas procedências (IDEM). Surgem as coleções naturalia, de animais, plantas e minerais, constituindo uma enciclopédia da natureza. O studiolo, direcionado para a exuberância do novo, já não é suficiente para essa nova forma de colecionar o exótico e o natural.

De certa forma, os "gabinetes de curiosidades" são a evolução do studiolo, isto porque contém a naturalia, ou seja, o que é criado por força da natureza (pedras, plantas e animais) e a artificialidade, ou seja, o que é criado pela mão humana (armas, medalhas, instrumentos e outros artefatos) (BERTANI,

\footnotetext{
${ }^{2}$ A coroa de espinhos, os fragmentos do véu da Virgem Maria, os ossos de santos eram preservados para proteção dos devotos contra as epidemias, as enfermidades, as calamidades de todos os gêneros. Entre os tesouros acumulados, apresentavam-se peças litúrgicas de ourivesaria com pedras preciosas, cálices, cibórios, tapeçarias e pinturas com imagens piedosas.

${ }^{3}$ STUDIOLO - forma diminuta de studio, oriunda do latim "studium", significando lugar para estudar, pequeno quarto de estudar, móvel de escrever ou ainda pequeno armário com elementos centrais e laterais. Studiolo se configurou como lugar para a mente e para a memória, era uma expressão humanística dos séculos XV e XVI, que procurava abrigar o conhecimento acumulado até então.
} 
2006, p. 16). Os objetos são dispostos nas gavetas, como alegorias, representando os mundos animal, vegetal e mineral. Neles, os continentes e a pluralidade das ações humanas aludem ao triunfo da arte e da ciência sobre a natureza. Os "gabinetes" são também denominados de Kunstkammer ou theatrum memoriae uma enciclopédia de objetos, na qual as partes individuais ilustram seu lugar no mundo do conhecimento.

No século XVI, os museus tornam-se manifestações do desejo de totalidade e de universalidade - a partir dos objetos coletados em várias partes do mundo e posteriormente classificados, tem-se a ideia de organização de todo o conhecimento. Para Franco (2010), as coleções refletem essa vontade, enquanto bens patrimoniais e objetos possuídos - constituem um "universo aprisionado", na realidade. Essas coleções reunidas permitem a exempla do universo referido (IDEM). Até meados do século XVII, a América, por exemplo, é introduzida nos "gabinetes de curiosidades" de forma fragmentária e sintetizada, principalmente pela cultura material (IDEM). As descobertas ultramarinas inauguram a oposição e o intercâmbio entre o Novo e o Velho Mundo. Essa oposição se dá não somente na forma de coleta de antiguidades, como também nas viagens, que se multiplicam a partir do século $\mathrm{XV}$, deslocando as fronteiras e atingindo locais que a tradição coloca fora do alcance. Nas fronteiras expandidas pelas viagens ultramarinas, os museus adquirem relevância no que toca ao subsídio para a pesquisa à distância (IDEM).

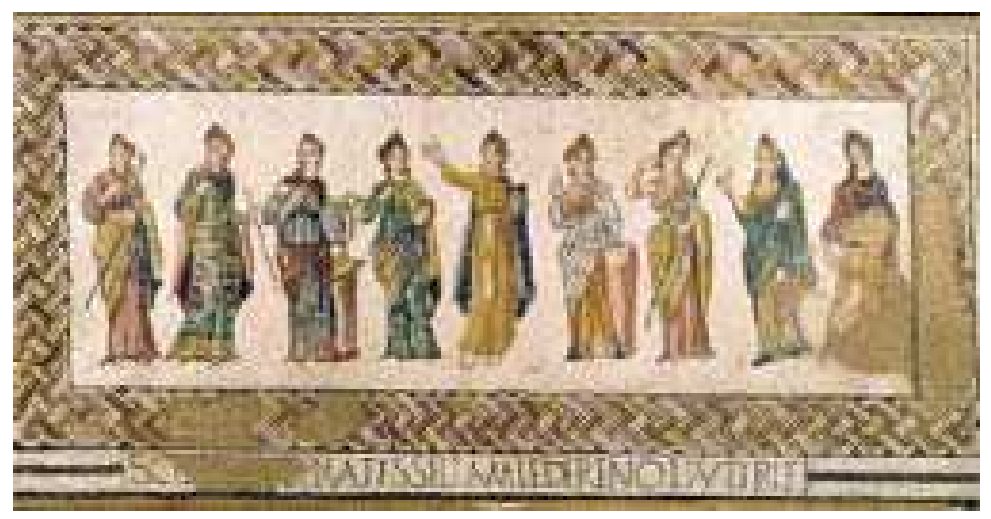

Figura 1. Painel das Musas (mosaico). Villa romana de Torre de Palma, IV d.C. Monforte Fonte: http://www.mnarqueologia-ipmuseus.pt/?a=3\&x=3\&p=3 

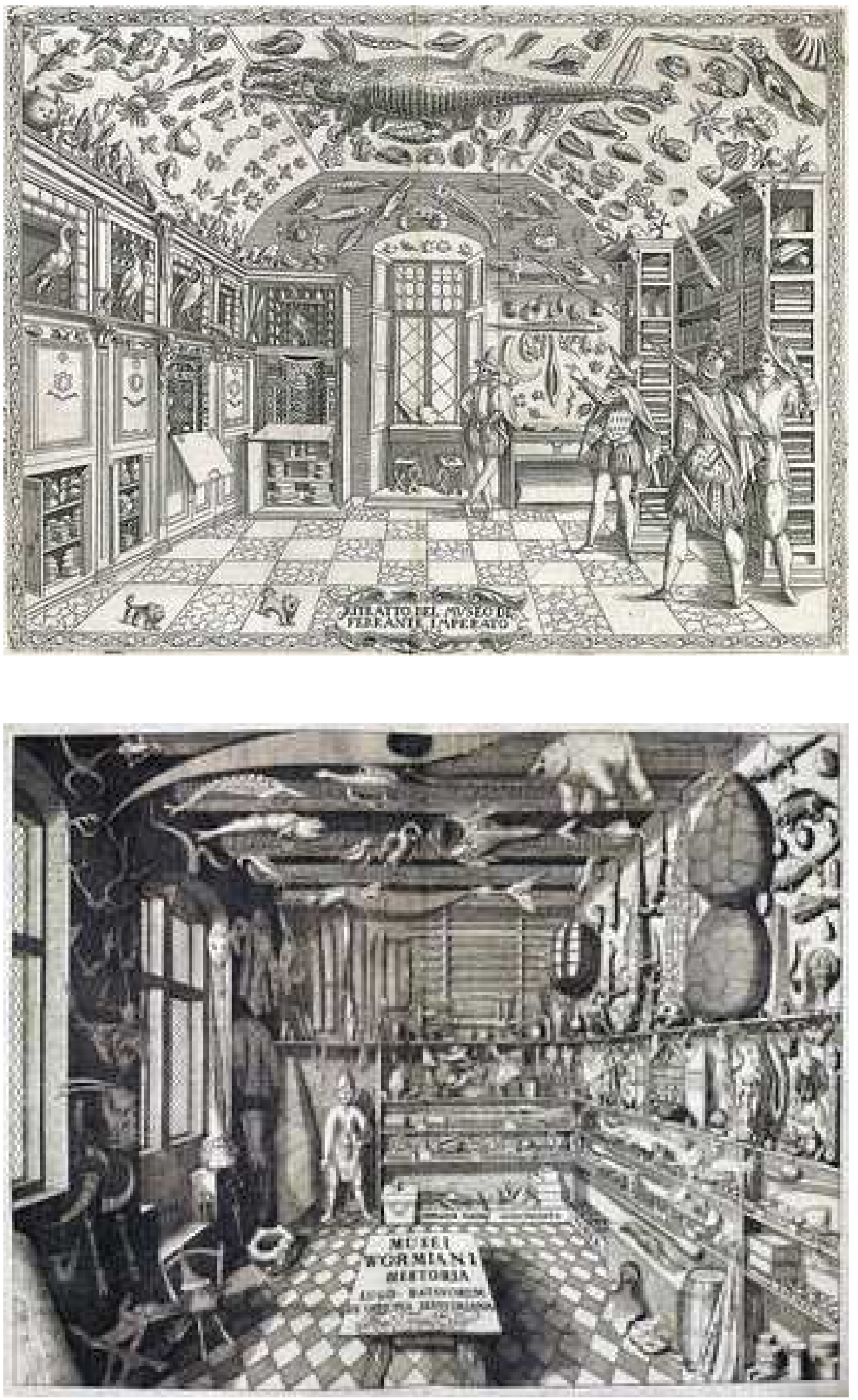

Figuras 2 e 3. Frontispicio do Museum Wormianum Historia, Worm, 1655.

Fonte: Ferrante Imperato: Dell'Historia Naturale, 1599; Ole Worm: Museum Wormianum, 1655. 
Durante o Renascimento, de um lado, tem-se Lorenzo de Médicis, como um dos colecionadores do período mais ambiciosos de Florença. Por outro lado, artistas, como Mantegna, já constituem em sua casa, em Mantova, um museu arqueológico. Contudo, é somente em 1537, que surge a galeria que Giovo dedica às musas, inspirando, em 1580, a criação da Galleria degli Uffizi, em Florença. Nesse lugar, Francisco I de Médicis deposita em destaque suas pinturas e esculturas em uma sala conhecida como "tribuna de mármore" (GONÇALVES, op. cit., p. 14). Os "gabinetes de curiosidades", visto como unidades basilares para a museologia moderna - uma ponte entre a Alexandria e as Universidades modernas (do século XIX ao atual) - expressam, sobretudo, o propósito científico, documental e analítico do ato de colecionar.

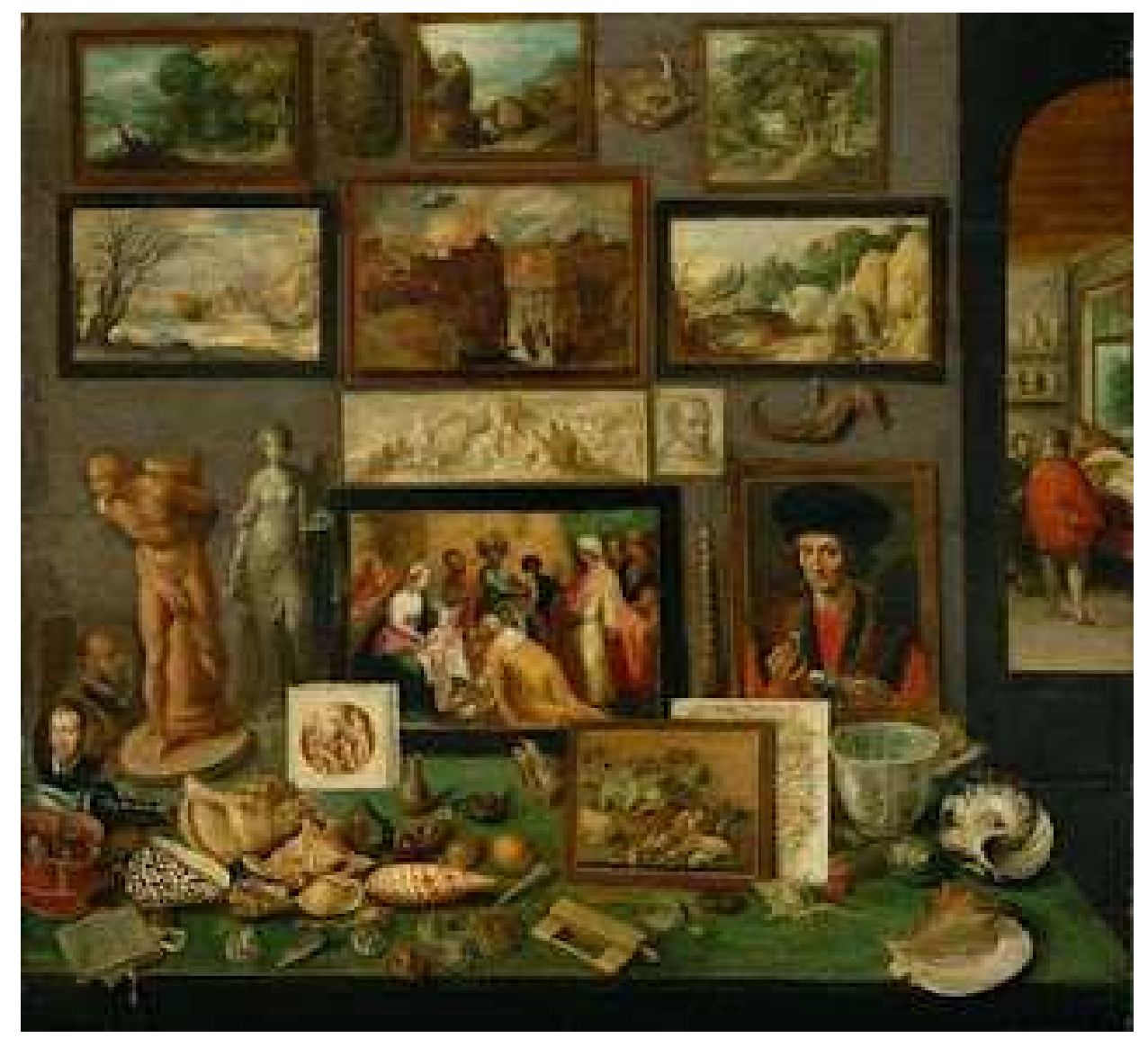

Figura 4. Frans Francken II, Kunst- und Raritätenkammer (c. 1620-1625, Kunsthistorisches Museum, Vienna). (Fonte: http://memoriasimagens.blogspot.com.br/2010/09/gabinetes-de-curiosidades.html acesso em 11/10/2012) 
O primeiro museu público se dá com a abertura do Musaeum Ashmolianum, na Universidade de Oxford, na Inglaterra, em 1659 - a atitude de Elias Ashmole de doar sua coleção ao Estado torna-se práxis em diversos outros países da Europa. Em São Petersburgo, Pedro, o Grande, abre ao público sua Kunstkamera, em 1714, com ordens para manter longe a plebe e dar acesso aos aristocratas e estrangeiros. A constituição de museus públicos se multiplica até 1753, quando o Parlamento inglês decide pela fundação do British Museum (FRANCO, op. cit., p. 51). Gradativamente, as coleções de artes, antes misturadas às curiosidades, são classificadas segundo princípios científicos e técnicos. Porém, as obras de arte ainda são posicionadas dentro de locais de arquitetura densa, uma pintura ao lado da outra com pouco espaço que as separassem - a partir de princípios decorativos de padrão e simetria.

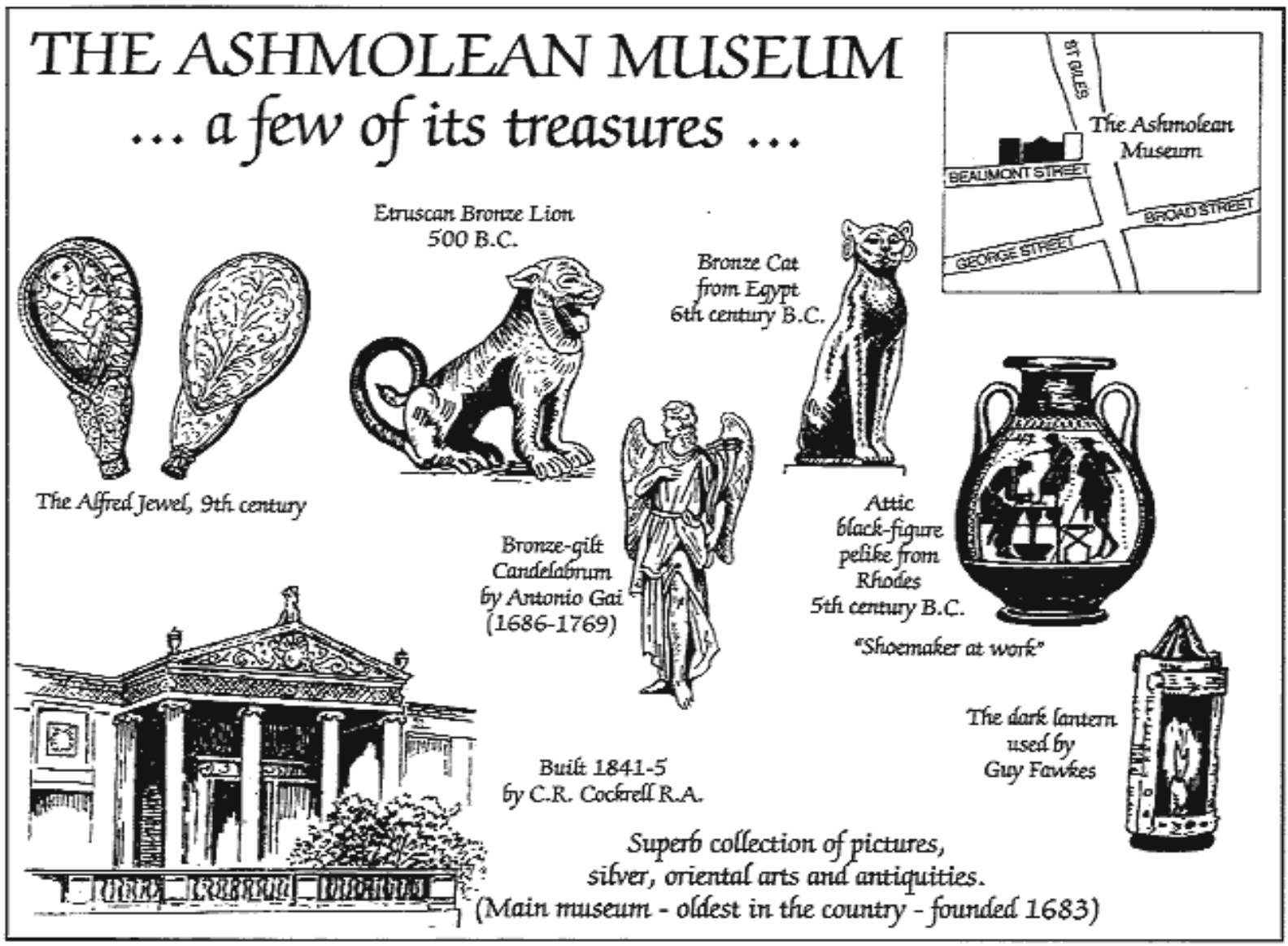

Figura 5. Musaeum Ashmolianum, na Universidade de Oxford, Inglaterra, em 1659 Fonte: http://www.dailyinfo.co.uk/guide/cartoonist/theashmoleanmuseum.html 


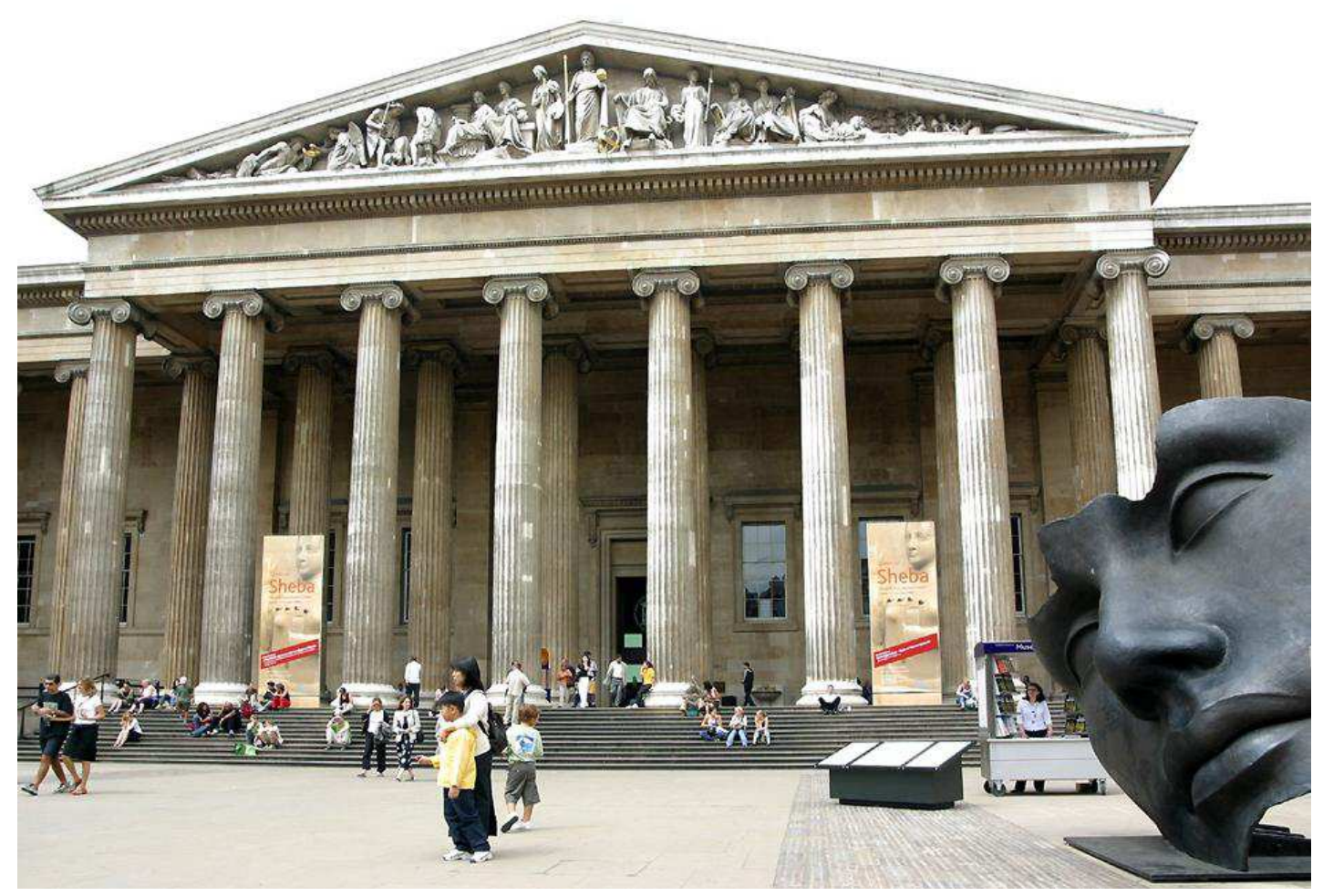

Figura 6. 1759 - Por votação o parlamento inglês decide comprar a coleção de Hans Sloane (1660-1753), o que dá origem ao British Museum. O acesso, entretanto, é reservado a visitantes credenciados.

Fonte: http://www.cityknown.com/Cities/Attraction.aspx?AttractionID=57

É o Iluminismo e, consequentemente, o surgimento das academias que proporciona essa separação das artes dos "objetos curiosos". Nas academias, os estudiosos conduzem às formas mais metódicas de abordar o mundo material e aos modos mais especializados de colecionar - a classificação racional e a descrição completa da natureza e, finalmente, da arte faz com que um novo projeto de aquisição de conhecimento por intermédio dos objetos surgisse.

O século XIX é considerado por muitos autores como "a época de ouro" dos museus. Essas instituições transformam-se em instituições de orgulho nacional, estreitamente vinculadas à política de Estado de cada país - e, nesse período, já se inclui a expansão dos museus norte-americanos. Para Altshuler (2010), nessa ocasião, os museus são vistos como engrenagens de aprimoramento moral e como mecanismos do progresso econômico nacional - características que são transplantadas da Inglaterra para os Estados Unidos, onde nos anos posteriores à Guerra Civil Americana, numerosos museus são criados (entre eles: 
o Metropolitan Museum of Art, em Nova York, e o Museum of Fine Arts, em Boston). Os modelos para a construção de seus edifícios são o Panteão romano e as vilas renascentistas de Palladio. Os países imperialistas estendem suas influências a regiões cada vez mais longínquas. Torna-se pertinente exibir os espólios de conquistas. Simultaneamente, orientações hegelianas e darwinistas sustentam que o progresso da civilização deve ser expresso pelo intermédio da exibição dos artefatos museológicos (AJZENBERG, 2010, p. 134). As coleções são fortemente acrescidas com os espólios de guerra e com a aquisição de acervos a baixos preços oriundos de países, tais como o Egito, a Grécia e a Itália. Os artefatos egípcios, gregos e romanos formam a base de coleções arqueológicas como as do Museé du Louvre (França), o British Museum (Inglaterra) e o Philadelphia Museum of Arte (Estados Unidos) (FRANCO, op. cit., p. 51).

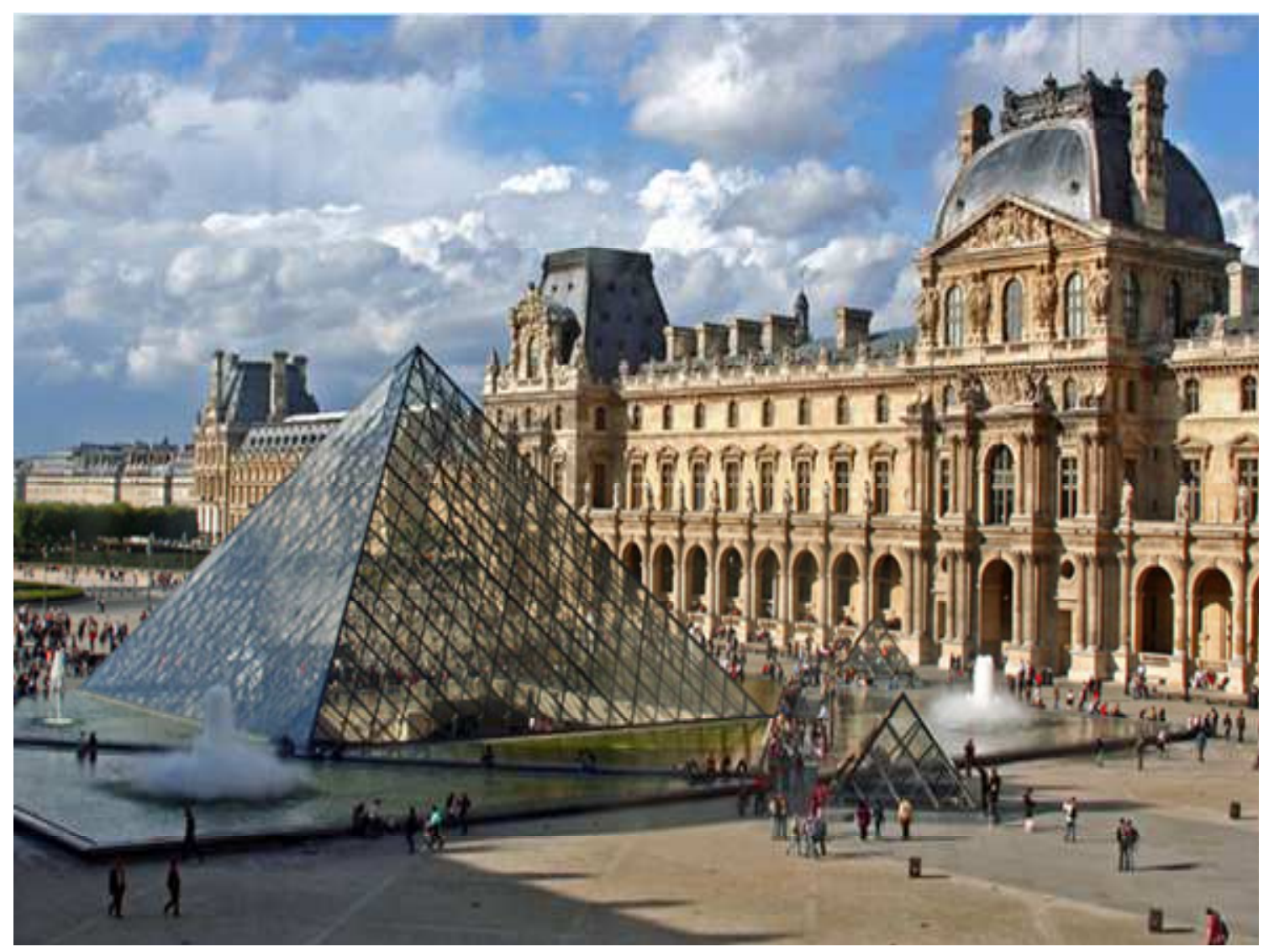

Figura 7. Louvre, Paris - Destaque Pirâmide (Projeto de I. M. Pei), 1989. Em 1793, durante a Revolução Francesa, parte do palácio real do Louvre é aberta ao público como um museu. Em maio de 1968, estudantes diziam: "É preciso queimar o Louvre", porque o museu é um "templo de valores burgueses".

Fonte: http://www.visitingdc.com/paris/louvre-museum-picture.asp 
Os museion, lugar das musas, abrigados em edifícios semelhantes aos templos ou aos santuários, fornecem a justificativa para as ambições imperialistas e para as histórias nacionais. A política liberal transforma os acervos em legados institucionais a serviço do ensino público. Essa nova perspectiva pública da instituição reafirma o seu nome, remetendo-se ao étimo helenista, igualado na matriz de inspiração, "lugar das musas". A transição das coleções exclusivamente privadas, ou reais, para os museus públicos é paulatina, ocorrendo, em grande parte, frente ao surgimento do Estado moderno. Como mencionado anteriormente, museus abertos a um público restrito já existem desde o século XVI, porém, à medida que o Iluminismo toma força, esses espaços assumem o papel de educadores públicos e árbitros do gosto e do conhecimento erudito, assumindo seu papel na "missão civilizadora". Do lugar que ocupam na vanguarda da intelectualidade, as coleções de história da arte que têm se desenvolvido a partir dos velhos continentes se tornam conservadoras, isto é, mantenedoras de uma ordem moral e da erudição necessária à apreciação estética.

Um princípio de subversão dessa ordem se dá em 1897 - quando o milionário da indústria do açúcar, Henry Tate, funda, originalmente, a Tate Gallery, a fim de expor quadros e esculturas de artistas britânicos contemporâneos que não eram aceitos nas instituições museológicas mais tradicionais de Londres. Porém, com o decorrer do tempo, a Tate inicia a exposição de obras antigas até que decide separar o acervo contemporâneo do antigo. Assim a Tate Gallery é dividida e construída em Millbank, onde é rebatizada como Tate Britain. O caso da Tate Gallery é sintomático do processo de especialização dos acervos que irá ocorrer após o século XIX e persistirá por todo o século posterior. Isto é, as coleções serão separadas de acordo com suas especificidades e categorias.

Atualmente, a Tate Gallery compreende quatro galerias: Tate Britain (aberta em 1897, exibe arte britânica), a Tate Liverpool (1988, única fora de Londres, exibe obras das outras tates), a Tate St. Ives (1993, exibe arte moderna de artistas britânicos) e a Tate Modern (2000). Das quatro instituições, destaca- 
se nesse estudo, a Tate Modern, especializada em arte moderna e contemporânea, que tem sua sede instalada em uma antiga central elétrica de Bankside, no distrito de Southwark, às margens do rio Tâmisa. A usina desativada em 1981 tem seu edifício convertido pelos arquitetos suíços Herzog e Meuron.

Tradicionalmente, a conversão de palácios, mansões ou edifícios públicos em museus é algo recorrente. Para a arte moderna e contemporânea, porém, os espaços arquitetônicos se abrem para o aproveitamento de antigas usinas, fábricas ou indústrias - algo que retorna à discussão mais adiante neste estudo, quando se tratará da gestão dos materiais e da infraestrutura das instituições museológicas.

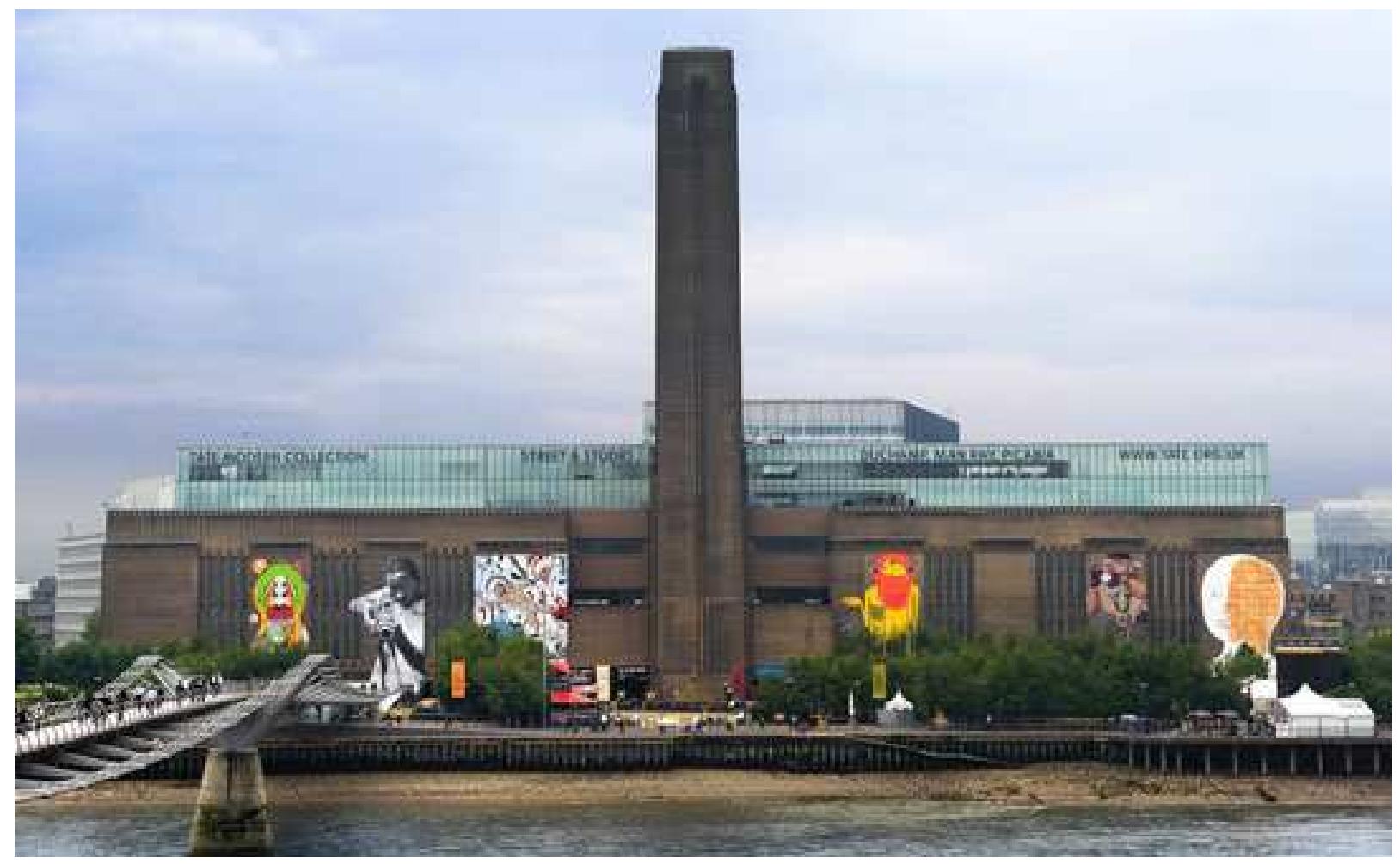

Figura 8. Tate Modern. O museu foi instalado na antiga central elétrica de Bankside, no distrito de Southwark, às margens do Tâmisa. A usina, projetada pelo arquiteto Sir Giles Gilbert Scott e construída em duas fases, entre 1947 e 1963, foi desativada em 1981 e o edifício foi reconvertido pelos arquitetos suíços Herzog e Meuron. Desde sua abertura, em 12 de maio de 2000, o museu promove importantes mostras temporárias de arte moderna e contemporânea, e tornou-se a terceira maior atração londrina. Fonte: www.tate.org.uk/visit/tate-modern 
Já na passagem do século XIX para o século XX, figuras como o colecionador J. Pierpont Morgan, admirador de arte e livros europeus, transforma o ato de colecionar e, de certa forma, a configuração das instituições museológicas. Além dos anseios curatoriais dos colecionadores americanos, sente-se sua forte presença na gestão e participação financeira, como mantenedores e patrocinadores. Magnatas, como William Randolph Hearst, Andrew Mellon, John D. Rockefeller Jr., Henry Clay Frick, Andrew Carnegier, Benjamin Altman, Samuel H. Kress e alguns outros estão empenhados em conseguir os objetos mais raros do "Velho Continente", além de adquirirem as obras das vanguardas artísticas modernas. Esses milionários da "Terra dos Homens Livres" (BERTANI, op. cit., p. 15) apostam firmemente na ideia da modernidade e nos movimentos artísticos, motivados pelo moderno, porém, mais do que colecionadores, tornam-se gestores dos seus acervos e de suas instituições museológicas - participam ativamente da organização das coleções e das mostras de exibição desses objetos.

No século XX, os museus de arte moderna disseminam-se cercados por arquitetura arrojada, estilo despojado e com a intenção de despertar a sensibilidade estética, a ousadia, o olhar de progresso de seus frequentadores voltados às vanguardas artísticas. Essa nova disposição transforma os museus completamente - o espaço não é mais o palácio ou o templo, assemelha-se muito mais com o galpão de uma indústria; as obras não são mais apresentadas acumuladas, mas de forma "clínica" (espaçadas e menos compulsivas em paredes brancas). A autonomia da obra precisa ser preservada pelo espaço. O Museu de Arte Moderna de Nova York - MoMA - surge em 1929, com o propósito de apresentar a arte livre e renovada de sua época (AJZENBERG, op. cit., p. 134). O MoMA organiza não somente exposições de sua coleção permanente, mas também, mostras temporárias e atividades didáticas, culturais e sociais, sempre em função da arte de seu tempo. 


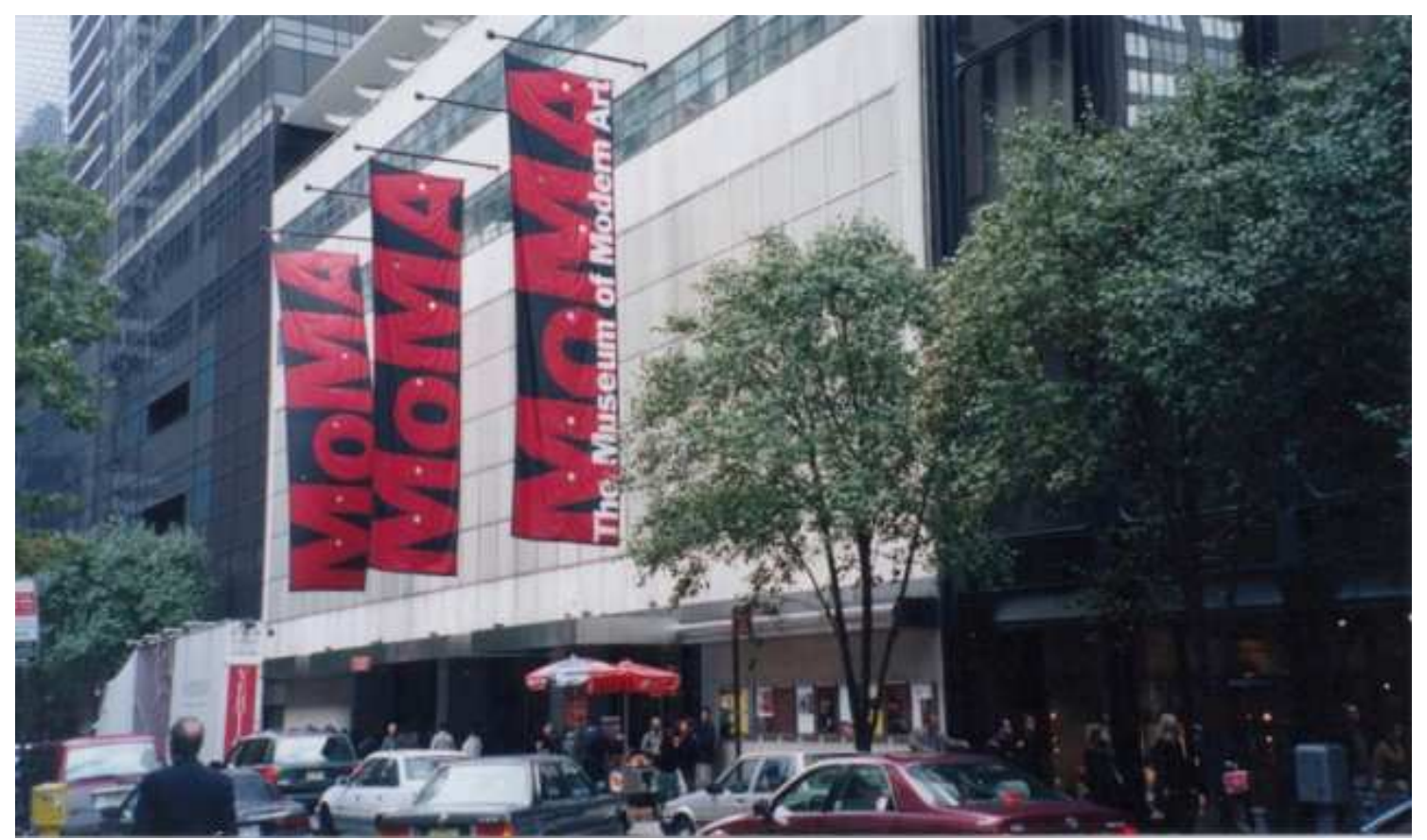

Figura 9. Museu de Arte Moderna de Nova York, MoMA, criado em 1929, surge com o propósito de legitimar a arte moderna. A constituição do MoMA e o reforço do termo "moderno", relativo à classificação das artes, geram equívocos e intransigências, como por exemplo, a noção de que a arte do passado é qualificada como acadêmica e morta. Porém, não se deve negar que a ideia de fundar museus em sintonia com o seu próprio tempo tem no MoMA sua maior configuração.

Fonte: www.moma.org

As categorias que regem a gestão museológica com a chegada dos museus de arte moderna tornam-se vitoriosas: perenidade, originalidade, unicidade, autenticidade e por fim, a crença na autonomia do objeto artístico. À luz dos estudos de O'Doherty (2002) o modo de exibição e mediação desse objeto artístico presente nos museus de arte moderna aparta a arte e a vida, uma vez que o objeto precisa ser retirado das interferências mundanas e submerso em "cubo branco" para que possa exercer sua plena visualidade e autonomia. A transformação deste "estado de coisas" tem início por volta dos anos de 1950 e ganha força a partir dos anos de 1960, com a emergência da arte contemporânea que se coloca avessa aos princípios museais. 


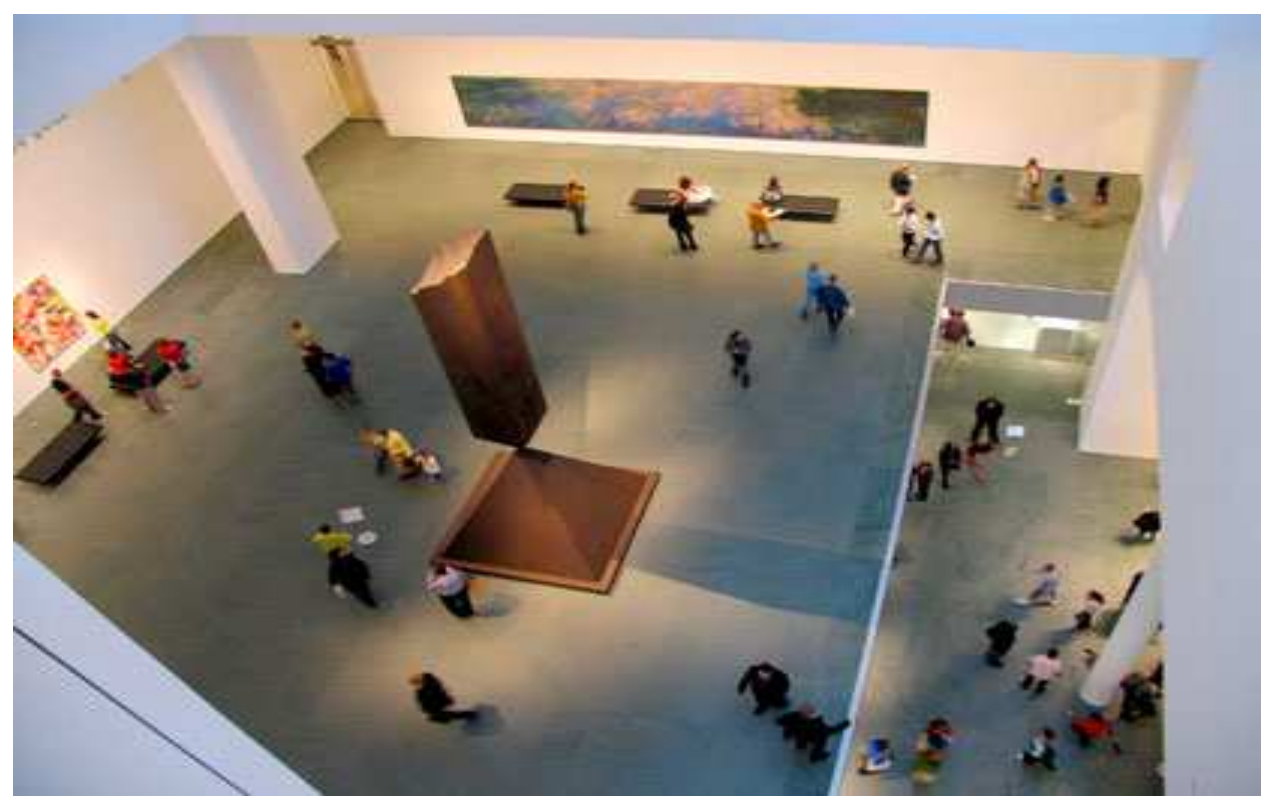

Figura 10. Sala expositiva do Museu de Arte Moderna de Nova York, MoMA. Disposição das obras no estilo "cubo branco".

Fonte: www.moma.org

Nas cinco últimas décadas, a quebra das metanarrativas, o fim da polaridade política (socialistas versus capitalistas), a emergência dos discursos das "minorias" (mulheres, crianças, minorias étnicas e homossexuais), a crescente globalização e a dissolução das fronteiras, constituem uma nova ordem mundial e a arte reverbera essas transformações, trazendo novas formas de abordagem da vida. Para Altshuler, os objetos artísticos, agora, são destituídos da aura da eternidade, do sentido de unicidade, de durabilidade e, muitas vezes, sem valor de mercadoria. A participação do espectador desfez a forma de exibição da obra de arte que supõe a contemplação à distância. Ao lado de uma nova forma de fazer e de ver a arte inicia-se o ataque às instituições, guardiães dos valores sociais conservadores (ALTSHULER, op. cit., p.54). Os ideais de maio de 1968 contestam o papel e as funções de museus, como por exemplo, o Louvre. Nesse momento, os ideais nacionalistas e elitizantes que ainda resistem nas instituições museológicas desde o século XIX já não são mais compatíveis com as intenções da arte contemporânea. 


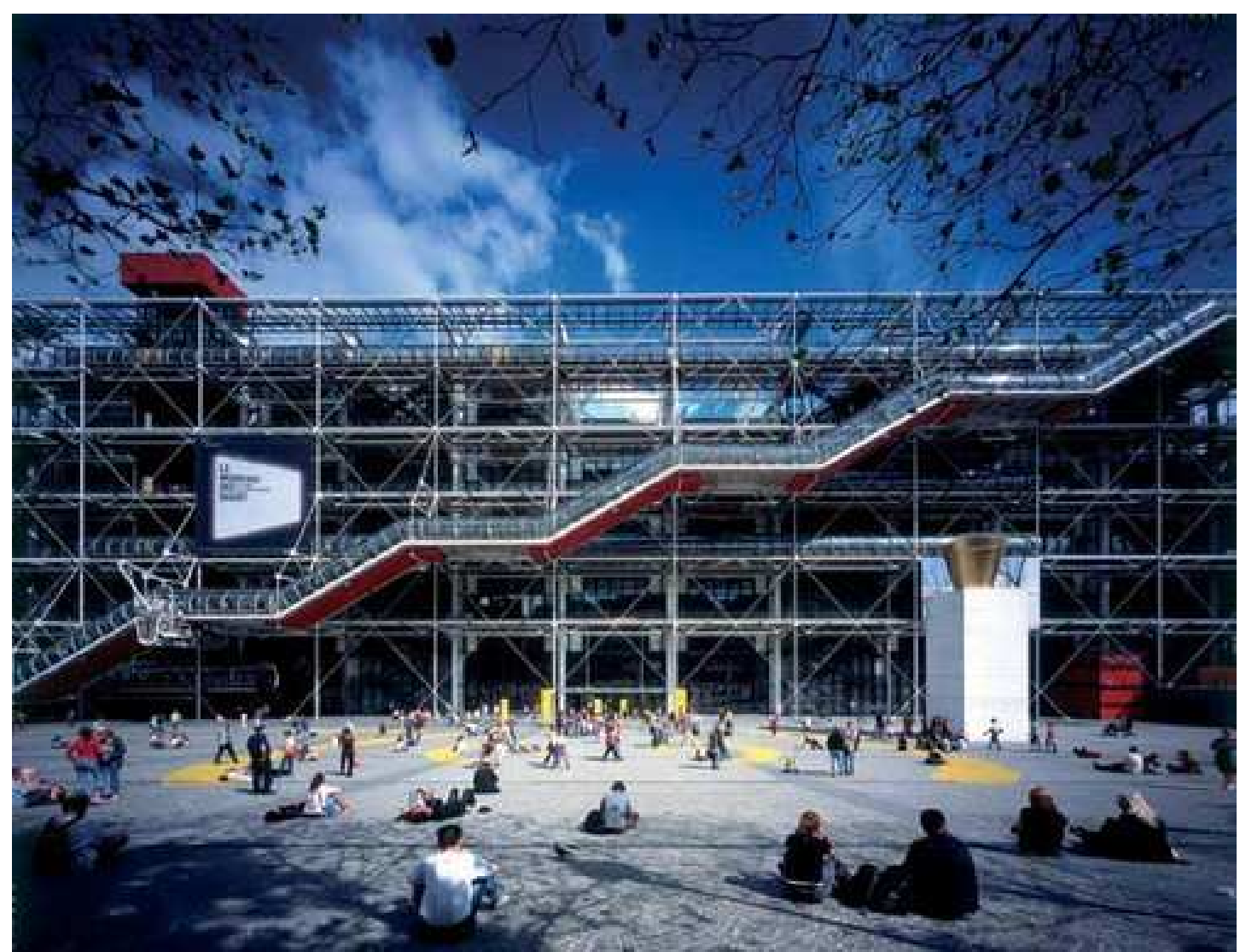

Figura 11. Centro Nacional Georges Pompidou, em Paris, criado em 1977.

Fonte: www.centrepompidou.fr/

O Centro Nacional Georges Pompidou, criado em 30 de janeiro de 1977, em Paris, traz uma nova proposta de espaço museológico e tem o forte propósito de ligar sua coleção ao contemporâneo, sintetizando as reivindicações de maio de 68 em sua ação educadora, acrescente-se, ainda, que suas instalações assumem as concepções arquitetônicas espetaculares dos museus da década de 1970. Tido como "um museu aberto, instrumento de difusão e comunicação permanente, cuja eficácia depende, antes de tudo, da estrutura arquitetônica em ligação com a vida urbana" (GONÇALVES, op. cit., 62), o Centro Nacional Georges Pompidou transforma-se em instrumento de informação e de interação social. Nesse espaço, as ações interdisciplinares e os debates próprios da arte contemporânea estão ligados aos questionamentos urbanos, políticos e culturais que são vividos por seus frequentadores. O Centro Pompidou torna-se um paradigma que revoluciona não somente a concepção do que seria um museu, mas também, abre espaço para a formação do que hoje se constituíram como centros culturais (MANTOAN, 
2010). Particularmente, o Centro torna-se um paradigma no que toca à afinidade das atividades culturais com as demandas de seu público frequentador e da pulsação do espaço ao seu redor, mais voltado ao desenvolvimento de ações do que à preservação de uma coleção de arte contemporânea permanente.

Contudo, se no Centro Nacional Georges Pompidou, as instalações têm mais força do que sua coleção permanente, no New Museum of Contemporary Art, fundado em Nova York, em 1977, se estabelece uma política de acervo radical: descarta-se a permanência das obras. Sua coleção, chamada de "semipermanente", consiste em adquirir, ao menos, uma obra de arte de cada exposição relevante que acontece em seu espaço e cada uma dessas peças deve ser retirada do acervo em no mínimo dez anos e no máximo vinte anos. As obras doadas ou adquiridas passam pelo mesmo processo - assim, o julgamento do tempo iminente à valorização artística não influencia no acervo contemporâneo, constantemente renovado. Porém, para Altshuler, o mesmo efeito do tempo transforma a política de acervo do Museu em algo problemático (ALTSHULER, op. cit.) - como descartar obras valorizadas (economicamente e esteticamente aqui se atribui a valoração de memória) na contemporaneidade? A preservação do patrimônio museológico expresso na valoração de sua coleção está em jogo nessa política de acervo semi-permanente. O quanto é contemporâneo um museu, frente às transformações aceleradas da arte e da vida em tempos globalizados?

Desde o final do século XX, acontece uma intensa revisão sobre o papel dos museus, sobre suas novas funções comunicativas e sobre sua capacidade em atrair um público maior, sobre as formas de manter e expor suas coleções, acompanhando o circuito internacional da arte contemporânea. Museus que possuem como características o fato de serem bens públicos têm em seu acervo, em seu público e em suas instalações questões desafiadoras. Nesse ponto, ganha dimensão relevante o caráter de semi-permanência da coleção de obras contemporâneas do New Museum of Contemporary Art para o presente estudo que trata da guarda provisória de obras contemporâneas. 


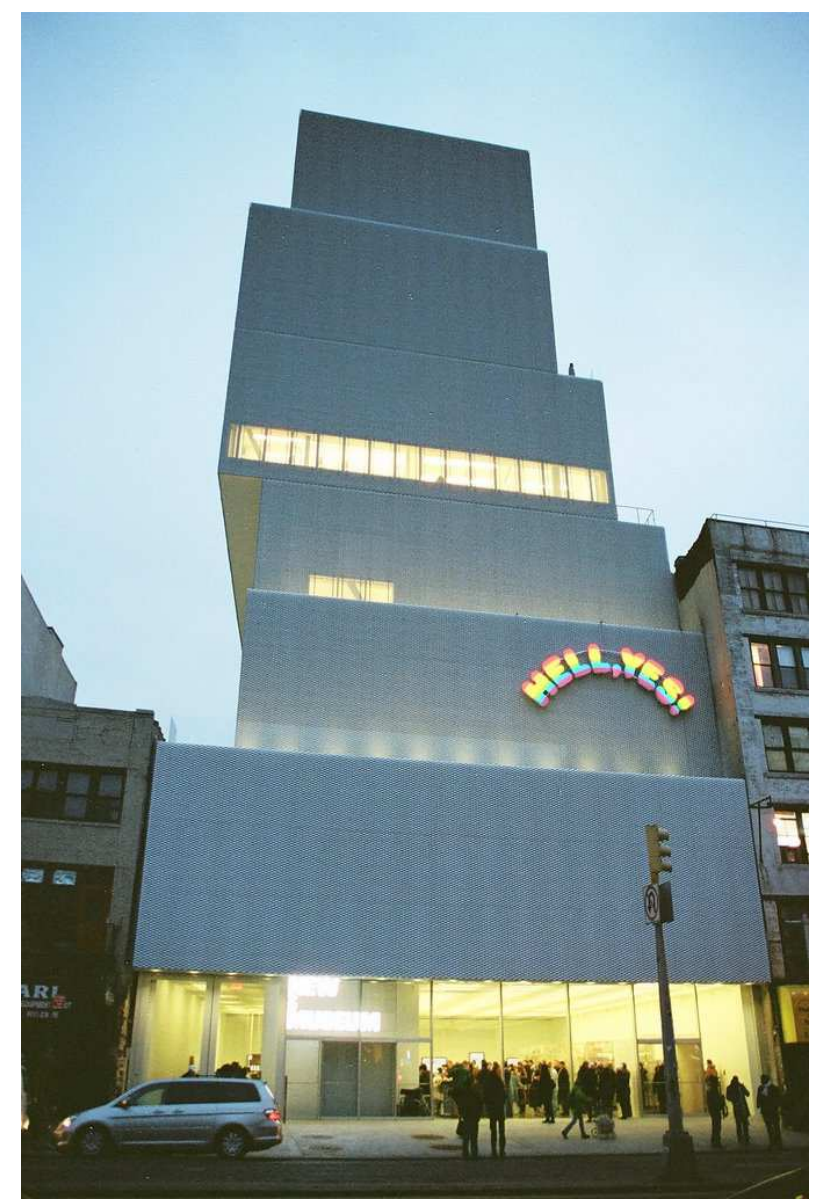

Figura 12. New Museum of Contemporary Art, fundado em Nova York, em 1977. Fonte: www.newmuseum.org/

Já na década de 1990, experiências como a do Guggenheim submetem o patrimônio museológico à questão da contemporaneidade das obras somada ao processo de globalização. Quando a Fundação Guggenheim decide abrir sua primeira filial em Bilbao, Espanha, 1997, desloca a preocupação da política de acervo para a capacidade de atração do público - as armas de sedução para garantir o público têm o espaço arquitetônico como aliado. Com cerca de 11.000 m2 e projeto arquitetônico de Frank O. Gehry, em um ano de funcionamento, já tinha recebido cerca de 1,3 milhão de visitantes (CYPRIANO, 2005). Além da eficácia mensurada pelo atendimento ao público, essa experiência transforma o padrão da gestão museológica, incluindo as noções de múltiplas sedes e diversos núcleos espalhados por um território socialmente praticado. 
Da formação das primeiras coleções, passando pela ideia de "bem público" até o deslocamento da preocupação para os espaços arquitetônicos e capacidade de atração do público, os museus empenham-se em salvaguardar valores caros às culturas nas quais estão imersos.

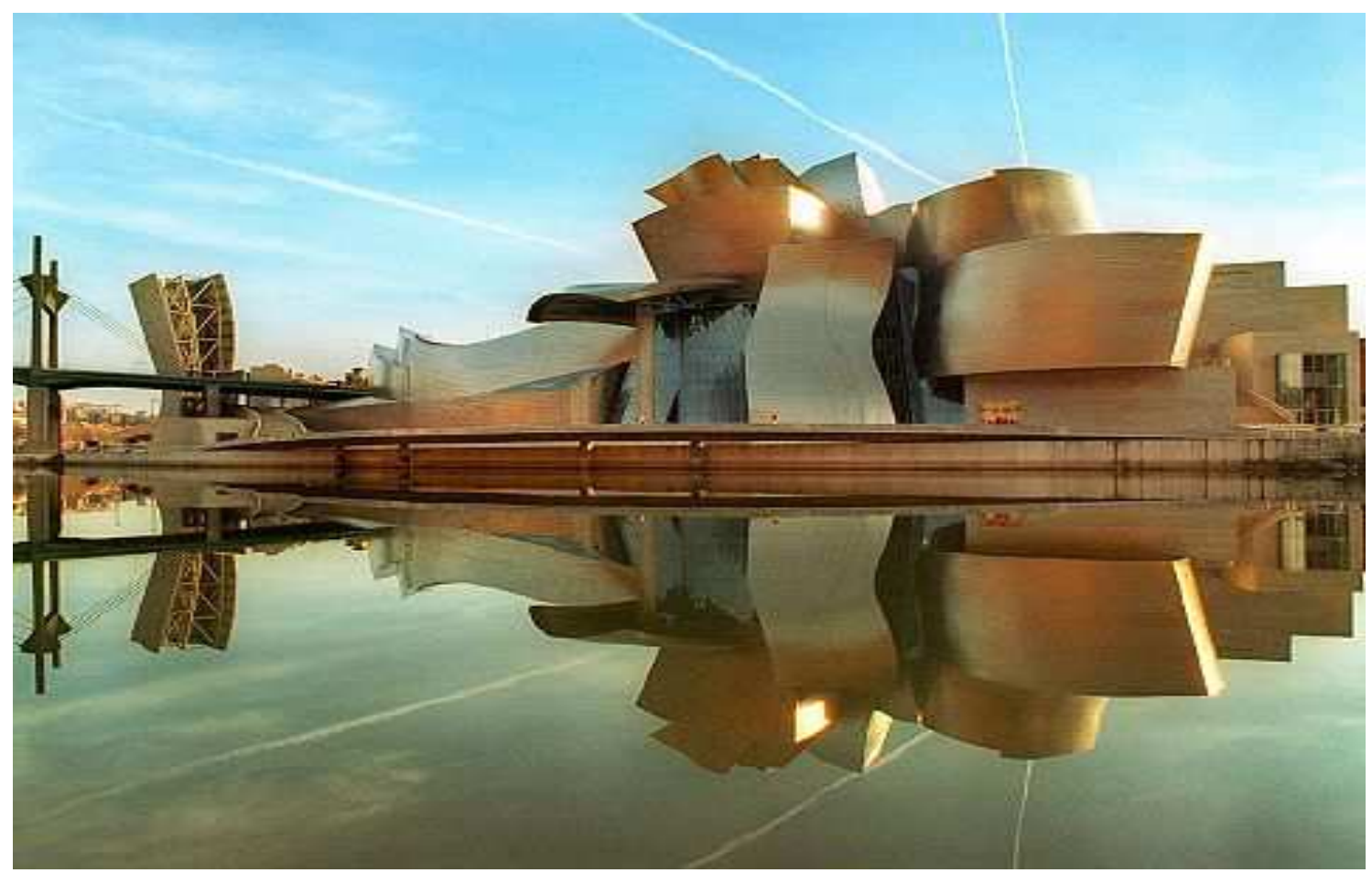

Figura 13. Fundação Guggenheim, Bilbao, Espanha, 1997. "Museus Espetáculos" - impressionam não tanto pelo seu acervo, mas por seu projeto arquitetônico, provocando impacto, sensibilizando o visitante e, deslocando a vida cultural para o entorno do "edifício-museu" -, considerado como uma obra de arte. Apesar do êxito de público, a Fundação Guggenheim não leva adiante os planos de mais filiais, programadas na França, no Brasil e na Áustria. No Brasil, por exemplo, os obstáculos estão ligados à ideia de que o projeto arquitetônico da nova sede somente pudesse ser realizado por arquitetos brasileiros. Fonte: www.guggenheim.org/

A partir do percurso histórico dos museus e de experiências como o Centro Pompidou, o New Museum e o Guggenheim, as questões patrimoniais e os bens culturais transformam-se no principal estímulo à proliferação de museus, departamentos e centros de formação dedicados à arte contemporânea. A noção de patrimônio, em instituições artístico-culturais dedicadas à contemporaneidade, reconhece-se como "capital". Isto significa passar do conceito de "tesouro intocável" a de "capital cultural" explorável, mas gerido e integrado ao capital 
social (LAGE \& LEITE, 2006). As instituições que preservam o patrimônio artístico-cultural, particularmente os museus, têm como função a mediação da interpretação dos significados e dos símbolos. A preservação e a conservação do patrimônio inserem-se na consciência patrimonial, sendo os contextos históricos e sociais essenciais para as estratégias preservacionistas. Hoje, a concepção de preservação do patrimônio que mais se aproxima das necessidades das sociedades contemporâneas é uma noção mais abrangente e participativa - na qual a gestão das instituições museológicas leva em consideração seu espaço socialmente praticado (IDEM).

Diante do histórico internacional dos museus e de sua direção frente ao abrigo da arte contemporânea, os museus brasileiros seguem trajetória paralela $(\text { CARVALHO, 2008) })^{4}$ : o advento dos museus de arte moderna, na década de 1950, foi inspirado pelo Museu de Arte Moderna de Nova York (MoMA) e em valores, tais como, arrojo, heroísmo, audácia, entusiasmo e progresso (tecnológico, econômico e político). Esses preceitos são repassados às elites brasileiras que tomam os projetos dos museus modernos brasileiros como uma porta de entrada ao capital internacional (LOURENÇO, op. cit., 14).

Em meados de 1940, São Paulo já não tem ares coloniais e provincianos. A cidade almeja ocupar um espaço cultural na vida do país compatível com o seu poder econômico: à época, concentra um respeitável parque industrial e uma elite determinada em inserir São Paulo no circuito nacional e internacional da arte. Alie-se a esse contexto, a aproximação com o "american way of life", ou seja, a forte presença norte-americana que se faz notar não somente na esfera política sobretudo com a tentativa de transformar o Brasil em área estratégica na América do Sul - mas também no panorama cultural, através da ação de instituições, tais como, o Instituto Cultural Brasil-Estados Unidos, ou ainda, a Escola de Sociologia e Política que recebe diversos docentes norte-americanos (IDEM).

\footnotetext{
${ }^{4} \mathrm{O}$ patrimônio-histórico brasileiro origina-se no período colonial, na região nordeste do país e em Minas Gerais, onde os ciclos econômicos da cana-de-açúcar, do ouro e de produtos como a madeira determina uma produção artística. A partir do século XIX, o poder econômico deslocase para a região sudeste e século posterior, a arte moderna está empenhada em criar uma arte nacional brasileira e moderna, segundo princípios estéticos das vanguardas europeias.
} 
O modelo norte-americano do MoMA, um museu privado, inspira outras gestões na América Latina. Os incentivos norte-americanos acrescidos da emergência de uma elite intelectual vinculada aos processos industriais são motivações para o desenvolvimento das artes visuais nacionais. Iniciam-se nesse período as coleções de obras de arte pelos colecionadores de arte moderna, tanto da arte produzida no Brasil como na Europa. Essas coleções particulares dão origem aos acervos de museus, tais como: o Museu de Arte de São Paulo - Assis Chateaubriand (MASP), o Museu de Arte Moderna de São Paulo (MAM SP), acervo esse, posteriormente, transferido para o Museu de Arte Contemporânea da Universidade de São Paulo (MAC USP).

Na constituição do Museu de Arte Moderna de São Paulo, destaca-se a ação de Nelson Rockfeller, Chefe do Bureau Interamericano - órgão responsável por promover "a cooperação interamericana e a solidariedade hemisférica". Rockfeller, banqueiro, ligado ao Museu de Arte Moderna de Nova York (MoMA), fornece as bases estatutárias do MoMA para que estas sirvam de modelo para o novo museu. Além de doar 18 peças para o acervo da instituição brasileira, em novembro de 1946. Nas doações de Rockfeller, encontram-se, por exemplo, Móbile Amarelo, Preto, Vermelho e Branco, s/d, de Alexander Calder; Composição, 1938, de Fernand Légèr, Quadro para Jovens, 1943 de Max Ernst, entre outros.

Passado aquele primeiro momento de criação desses museus por mantenedores, hoje, essas instituições devem encontrar novas formas de gestar suas coleções. Como esses acervos podem se atualizar, visto que agora, são gestados por fundações, órgãos públicos e outras formas de administração? No Brasil, mesmo não se tendo a "tradição" do mecenato, do patrocínio ou da gestão em arte, é possível transformar coleções particulares em patrimônio cultural que possa beneficiar à sociedade em geral? Essas indagações cercam o cotidiano das instituições museológicas e para respondê-las não basta somente ter presente que os objetos reunidos demonstram capacidade testemunhal e patrimonial, além de qualidades estéticas inerentes à obra de arte. É preciso aprofundar-se na realidade e nas ações vivenciadas por essas instituições. 


\section{Coleção - Questões Patrimoniais}

“(...) o museu deve aceitar que a sociedade em constante mudança" ${ }^{5}$.

ICOM's General Assembly in 1971

Como já observado anteriormente, a origem dos museus remonta à Antiguidade e desde lá seu conceito tem passado por constantes revisões. Ao lidar com o conhecimento, os museus modulam e moldam-se aos interesses dos homens em diferentes temporalidades (FRANCO, op. cit.). ${ }^{6}$ Quando surge o ICOM (Internacional Council of Museums), em 1946, as discussões sobre a função social dos museus na contemporaneidade intensificam-se e tomam dimensões mundiais ${ }^{7}$. A assembleia geral do ICOM, em 1971, é divisora de águas nesse percurso, isto porque o lema: “o museu a serviço do homem da

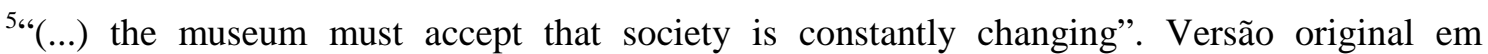
http://www.museum.or.jp/icom/resolutions. Acesso em 10 de agosto de 2007.

${ }^{6}$ Maria Ignez Mantovani Franco e diversos outros estudiosos oferecem uma trajetória dos museus evocando sua transformação ao longo da História. Se nos séculos XVI, os gabinetes de curiosidades (com suas diversas modalidades de objetos) são conservados pelos príncipes, reis e autoridades renascentistas, no século XIX, por exemplo, os museus são colocados como símbolos das potencialidades dos Estados e, assim, os objetos e as funções dos museus alteramse de acordo com os interesses dos homens em colecionar objetos que são caros à sua época.

7 Organização internacional de museus e profissionais de museus, a quem está confiada à conservação, à preservação e à difusão do patrimônio mundial - cultural e natural, presente e futuro, material e imaterial - para a sociedade. Criado em 1946, o ICOM é uma Organização não-governamental que mantém relações formais com a UNESCO, executando parte de seu programa para museus, tendo status consultivo no Conselho Econômico e Social da ONU.
} 
atualidade, do futuro" 8 é adotado e difundido entre os associados em diversas territorialidades. Essa proposição é reafirmada, três anos depois, quando esse mesmo órgão define museu como: "uma instituição permanente, sem finalidade lucrativa, a serviço da sociedade e de seu desenvolvimento, aberta ao público; que adquire, conserva, investiga, comunica e exibe, para fins de estudo, de educação e de deleite, testemunhos materiais do homem e do seu entorno" (IDEM).

Essa definição inclui, também: os sítios e os monumentos naturais, arqueológicos e etnográficos; os sítios e os monumentos históricos de caráter museológico, que adquirem, conservam e difundem a prova material dos povos e de seu entorno; as instituições que conservam coleções e exibem exemplares vivos de vegetais e animais - como os jardins zoológicos, botânicos, aquários e vivários; os centros de ciência e planetários; as galerias de exposição não comerciais; os institutos de conservação e galerias de exposição, que dependam de bibliotecas e centros arquivísticos; os parques naturais; as organizações internacionais, nacionais, regionais e locais de museus; os ministérios ou as administrações sem fins lucrativos, que realizem atividades de pesquisa, educação, formação, documentação e de outro tipo, relacionadas aos museus e à museologia; os centros culturais e demais entidades que facilitem a conservação e a continuação e gestão de bens patrimoniais, materiais ou imateriais e, por fim, qualquer outra instituição que reúna alguma ou todas as características do museu, ou que ofereça aos museus e aos profissionais de museus meios para realizar pesquisas nos campos da museologia, da educação ou da formação ${ }^{9}$.

Porém, as reformulações no conceito de museus e, consequentemente, em sua gestão não acontecem de modo linear e sem embates. Como exposto

\footnotetext{
${ }^{8}$ http://www.museum.or.jp/icom/resolutions. Acesso em 10 de agosto de 2007.

${ }^{9} \mathrm{~A}$ denominação de museu abrange: galerias permanentes, dependentes de bibliotecas ou de centros de documentação; os monumentos históricos, as partes de monumentos ou suas dependências, assim como os tesouros das igrejas, os locais históricos, arqueológicos e naturais, desde que abertos oficialmente à visitação pública; os jardins botânicos e zoológicos, aquários e aviários e outras instituições que apresentem espécimes vivos; os parques naturais. (art. 1 §2, arts. 3 e 4 do Estatuto). Informações em www.museus.gov.br/oqueemuseu_museusicom.htm. Acesso em 20 de outubro de 2009.
} 
anteriormente, as primeiras contestações aos museus surgem no imediato pós-II Guerra, contudo, adquirirem força a partir da propagação dos ideais "de maio de 1968" - processo de revolução cultural instituído por estudantes que motiva, sobretudo, a "luta pelo direito a maior felicidade na vida" (GONÇALVES, op. cit., p. 61) ${ }^{10}$. Na ação revolucionária, as concepções tradicionais de museu são vistas como alicerces institucionais e legitimadores dos valores burgueses. "Incendiar o Louvre" ou ter "a Gioconda no metrô" significa, naquela época, a abertura para a "democratização" da arte e, sobretudo, a mutação dos museustemplos em lugares dedicados à liberdade e à popularização do conhecimento (IDEM, p. 62) ${ }^{11}$. Para os adeptos da "revolução cultural", os museus-templos são vistos como instrumentos de manutenção de valores elitizados, sendo que o modo de funcionamento dessas instituições impede o livre acesso ao conhecimento (IDEM). As principais críticas concentram-se sobre a forma hermética como os museus apresentam suas coleções pressupondo um saber anterior para a leitura de suas proposições ditas "eruditas". Para reverter esse quadro, fez-se emergente a alteração das funções comunicativas dos museus: é preciso retirar o público da passividade que impera até então e estimulá-lo à criatividade e ao entendimento de seu lugar social. Reconhecer a necessidade de diminuir a distância entre museu e comunidade engatilha um mecanismo de mudanças que dá margem às tendências interdisciplinares e ao entendimento das relações sociais (IDEM).

As decorrências de maio de 1968 ecoam em diversos países e em todos os setores relacionados às instituiçõos culturais. Na gestão de museus de arte, por exemplo, durante a década de 1970, os setores educativos ganham força juntamente com a revitalização da identidade dos museus frente à sociedade de consumo - nessa direção, emerge o gosto pela teatralização, pelo espetáculo e pela organização cênica dos espaços das exposições (HUYSSEN, 1996, p. 223).

\footnotetext{
${ }^{10}$ Segundo Lisbeth Rebollo Gonçalves “(...) a efervescência sociocultural que vinha ocorrendo desde o imediato pós-II Guerra termina por apresentar-se como uma contestação global na chamada "revolução romântica" de maio de 1968 na França (...)".

${ }^{11}$ Reivindicam-se profundas alterações nos padrões de vida cotidiana, nas quais os espaços sociais e as manifestações poéticas e artísticas adquirem papel relevante.
} 
Surgem, ainda, lojas com souvenires, os cafés, os restaurantes, os cinemas, as salas de conferências e suportes diversos atrelados ao acervo e às salas expositivas. Os acontecimentos sociais também têm seu lugar nessa nova configuração de museu: as exposições dividem espaço com festas de casamento, aniversários, jantares, lançamento de grifes, entre eventos diversos (GONÇALVES, op. cit., p. 62).

Entre megaeventos e "museus-espetáculos", o Centro Nacional Georges Pompidou reúne o espírito de maio de 68, particularmente no que tange à ação educadora e às concepções arquitetônicas (IDEM). Simultaneamente, a invenção do Centro Pompidou surge em um momento em que a industrialização da cultura museal entra em vigor. A arquitetura arrojada deu ao Centro Pompidou o apelido de "refinaria" (o que confirma sua vocação urbano-industrial). O espaço abriga, desde seu início, ações interdisciplinares e debates ligados aos questionamentos urbanos, artísticos e sociais que são vividos por seu público visitante. Diversas instituições, inspiradas pelas atividades do Centro Nacional Georges Pompidou, decidem, ao seu modo, enfrentar o desafio de promover o encontro entre obras de arte e os mais diversos públicos (portadores de necessidades especiais, idosos, jovens e adolescentes sobre liberdade vigiada, presidiários em regime de readaptação social, entre outros). Aqui, o mais importante é tornar os "acervos museológicos" mais próximos de seus usuários.

Na tentativa de aproximar-se do público, a gestão de museus investe em instrumentais e procedimentos que possam propiciar condições para que o público estabeleça diferentes mediações a partir das interações entre as obras de arte e o espaço museológico (COSTA, 2004, p. 75). Aqui, torna-se importante dizer que o conceito de gestão não é entendido tão somente como preservação ou conservação do bem patrimonial - as coleções que constituem um acervo museológico. $\mathrm{O}$ conceito supõe também o recuperar e o atribuir novos significados e usos para a herança preservada. A gestão envolve, ainda, evidenciar os critérios, as estratégias de análise e de exposição, bem como as diversas interpretações sobre o objeto artístico (IDEM). À esfera dos espaços museológicos de arte, a visualidade das obras é o principal destaque, levando-se 
em conta a condição dos objetos artísticos como documentos plásticos que registram a memória social.

Na gestão de museu de arte, cabe à instituição, estimular o conhecimento sobre a produção artística, ativando a memória e a identidade social, pois este não pode ser visto somente como um local de "consumo de arte", mas de criação e de reflexão sobre a "cultura da arte", discutindo suas formulações, sua manutenção e transformações (GONÇALVES, op. cit., p. 74). Contudo, o modelo de gestão que une arte contemporânea, arquitetura e realidade social, praticado pelo Centro Pompidou seria o único existente? Esse modelo seria adaptável a outros contextos internacionais, particularmente à realidade brasileira? Quais outros modelos de gestão museal da arte contemporânea poderiam ser identificados? $\mathrm{Na}$ busca por respostas para tais indagações, a presente pesquisa procura conhecer a experiência em gestão de museus de arte especializada na questão contemporânea. Investiga-se, especialmente, a gestão das coleções temporárias que, a cada dia, tem sido prática recorrente em museus de arte contemporânea.

Vivencia-se, hoje, a época dos museus sem fronteiras. O rápido desenvolvimento tecnológico e as consequentes transformações sócioeconômicas e ambientais exigem cada vez mais o registro e a documentação do processo de mudança da realidade, preservação dos valores e dos bens culturais. O perfil de museu como algo sacralizado ou "intocado" gradativamente perde espaço para uma concepção que aproxima o acervo museológico de seus usuários. Frente à circulação das obras entre os grandes museus, às exposições imersas em circuitos internacionais e à multiplicação das oportunidades de entretenimento oferecidas ao público (CARVALHO, 2010, p. 35) ${ }^{12}$, as formas de gestão museológicas devem estar atentas às discussões que envolvem: a formação, a preservação e a exibição de suas coleções; às antigas e novas funções que os museus desempenham junto à sociedade que os circundam e, em

\footnotetext{
12 "Hollywood, Disneylândia, Guggenheim e Las Vegas constituem hoje sistemas normativos de memórias e culturas desenhadas, produzidas e distribuídas comercial e mediaticamente como espetáculo global. (...) É o triunfo político de um novo colonialismo do espetáculo". SUBIRATS, Eduardo. "Os museus da memória \& a memória dos museus".
} 
particular, como essas instituições estabelecem a mediação (o encontro) entre as obras de arte e o seu público fruidor.

Essas operações já são difíceis quando se trata das coleções adquiridas e devidamente incorporadas no patrimônio do museu (LADKIN, 2004, p. 20) ${ }^{13}$, ou seja, quando os objetos advêm por métodos comuns, como a doação, o legado, a compra, a troca, a recolha de campo e qualquer outro meio pelo qual o título (propriedade) é transferido para o museu (IDEM). A complexidade aumenta quando se trata de coleções que estão sob a guarda provisória, uma vez que são peças muitas vezes de propriedade particular, porém, devem ter o mesmo tratamento museológico do restante da coleção permanente. Uma investigação dedicada ao questionamento das noções isoladas de função, coleção e mediação na gestão de museus de arte contemporânea e adepta da articulação destes parâmetros pode representar uma contribuição relevante aos estudos dedicados à compreensão da gestão patrimonial da arte contemporânea (especialmente sua transitoriedade) e à sua interação com a sociedade, destacando seus aspectos históricos, econômicos e estéticos.

No museu de arte, a visualidade das obras é, à primeira vista, o principal destaque (não importando se são de propriedade ou não do museu). Leva-se em conta a condição dos objetos artísticos como documentos plásticos que registram a História. Cabe ao museu estimular o conhecimento sobre a produção artística, através da História da Arte, ativando a memória e a identidade social, pois este precisa assumir sua condição de lócus de criação e de reflexão sobre a arte, discutindo suas formulações, sua manutenção e transformações (MENESES, 2002, p. 32). E, nesse âmbito, a guarda provisória de coleções representa algo novo que pode influenciar no discurso expositivo. A questão da arte contemporânea em museus é, também, algo a ser discutido por algumas razões, entre elas: 1) como documentos históricos o que registram?; 2) por sua efemeridade matérica, o que trazem de transitório e o que trazem de permanente?

\footnotetext{
${ }^{13}$ A aquisição é o processo de obtenção de um bem ou coleção para o museu. Os objetos podem ser adquiridos de diversos modos, por exemplo, através de recolha de campo, doação ou legado através de transferência de outra instituição. A incorporação é a aceitação formal de um objeto ou coleção, registrado do museu.
} 
e, 3) por suas novas formas de inserção no acervo museológico, como a gestão de museus deve se portar?

Nesse contexto, as atenções recaem para a adequação da arte contemporânea em museus - algo que hoje soa anacrônico -, uma vez que, atualmente, se tem uma multiplicidade de museus com coleções exclusivamente dedicadas à arte contemporânea. Porém, essa especialização significa uma séria questão, discutida durante os anos de 1920, com precedentes no século XIX, como por exemplo, a decisão de se adquirir obras de artistas vivos no Museé des Artistes Vivants, em Paris, em 1818 e que hoje, ainda encontra sustentação quando se trata de museus sem acervo ou ainda com coleções semi-permanentes, como no caso do New Museum of Contemporary Art. Segundo Bruce Altshuler, em 1920, o que se discute é a inserção da arte de vanguarda, selecionada a partir de um filtro ideológico, no qual "moderno" significa algo de "ponta" (inovador, autônomo, disposto a romper com que é preestabelecido) (ALTSHULER, op. cit., p.p. 67-69). Não existe a preocupação conceitual ou ainda a noção de que a obra a ser adquirida deve passar pelo teste do tempo para garantir sua relevância estética ou não (IDEM, p. 69).

Ainda a partir dos estudos de Bruce Altshuler, o Museu de Arte Moderna de Nova York (o MoMA) teria no seu estatuto uma inovação: na política de acervo deste museu, obras antigas seriam removidas a fim de manter a coleção atualizada. Em 1931, o MoMA entra em acordo com o Metropolitan Museum of Art e obras que tivessem cerca de 70 anos após sua criação seriam repassadas gradualmente para o Metropolitan. Contudo, em 1953, os comissários do MoMA revogam essa resolução da política de acervo (IDEM, p. 76). Por que os comissários do MoMA voltam atrás? Sob a perspectiva histórica, são diversas as razões: o instinto de preservação do patrimônio ou salvaguarda dos bens culturais pode ser a principal delas. 


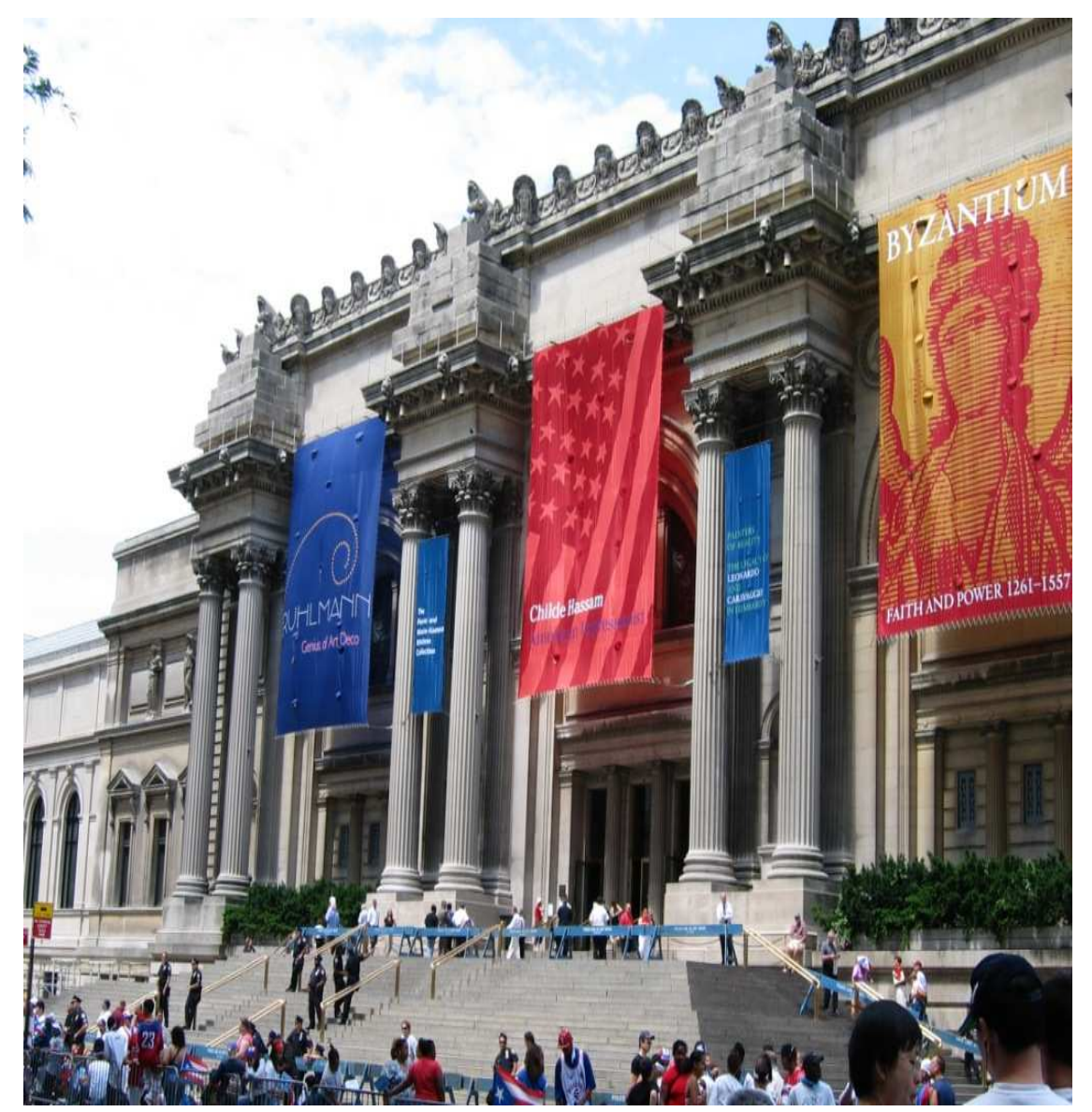

Figura 14. Metropolitan Museum of Art, Nova York (EUA). Fundado em 20 de fevereiro de 1820. Abriga uma importante coleção de pintura europeia dos séculos XII-XX e obras da arte antiga (grega, romana, egípcia e assíriobabilónica) e oriental. Estão também expostas pinturas e esculturas de artistas norte-americanos. São importantes as seções dedicadas a instrumentos musicais, armas e indumentária.

Fonte: www.metmuseum.org/

Nessa noção, reside a ideia de "sagrado", o próprio termo "patrimônio" está associado ao conceito de sagrado ou a noção de herança, memória do indivíduo, de bens de família que atribui a certos objetos, lugares ou bens materiais a isenção frente à utilidade imediata. Patrimônio, em inglês heritage, em espanhol herencia, implica a ideia de algo a ser deixado ou transmitido às gerações futuras. O olhar em questão é o da veneração e o do encantamento - um sentimento que supera o olhar puramente estético. Como construção social e "lugar da memória", o que irá ser considerado patrimônio depende do grupo, do período histórico e das questões ideológicas que permeiam a identidade que está 
sendo construída, simultaneamente, a esse conceito. Essa ideia de um patrimônio comum a um grupo social - definidor de sua identidade e, enquanto tal, merecedor de proteção - surge no final do século XVIII, com a visão moderna de história. Decretado como representativo da cultura, o bem se torna superior e emblemático.

Não se pode esquecer que bens patrimoniais que ofereçam referencial cultural ou histórico, tais como: monumentos, cidades históricas, museus, obras de arte, bibliotecas, festas, entre outras manifestações, podem se converter em atrativos turísticos (deslocamentos ou viagens culturais) capazes de gerar riquezas e empregos. Os bens culturais estão impregnados de sentidos que vão além de sua materialidade. A razão de um monumento ser considerado um patrimônio cultural ou artístico está não apenas em sua materialidade, mas na demonstração da engenhosidade humana que contém sua construção e, geralmente, no simbolismo que lhe é atribuído (LAGE \& LEITE, op. cit.) ${ }^{14}$. Essas motivações devem vir acompanhadas de necessária e especial atenção à conservação e manutenção dos bens patrimoniais. Devem garantir, também, a possibilidade de existência desses bens para a população residente e para gerações futuras. Talvez, por essas implicações o MoMA não tenha conseguido levar avante as transferências de suas obras para o Metropolitan - mesmo que o seu patrimônio tenha como novo local uma instituição americana, a transferência de seus "picassos", por exemplo, seria considerada como uma perda de bem cultural, vista aos olhos de seus comissários e, talvez, vista aos olhos de seus usuários.

A partir da tentativa de transferência de obras entre os museus, novas formas de abrigar os acervos contemporâneos na gestão museológica mostram-se experimentais e ainda insuficientes para coadunar uma instituição como o museu (que no século XIX, já simboliza o nacionalismo dos Estados emergentes

\footnotetext{
${ }^{14}$ A UNESCO passou a definir patrimônio cultural imaterial como sendo as práticas, as representações, as expressões, os conhecimentos e as técnicas, bem como os instrumentos, objetos, artefatos e lugares que lhe são associados, além das comunidades, dos grupos e, em alguns casos, dos indivíduos que se reconhecem como parte integrante dessa riqueza de recursos.
} 
exibindo as obras de artistas de uma dada região geográfica e que, no século $\mathrm{XX}$, transforma-se em ícone da modernidade, dedicado a colecionar e exibir obras que questionassem a tradição histórica artística), que ainda busca seu novo perfil no século XXI.

Para Altshuler (2010), o exemplo do New Museum, citado anteriormente, poderia ser um índice desse novo perfil museológico propício ao século XXI: a sede deste museu é grandiosa com vizinhança revitalizada, seu acervo totalmente dedicado à arte contemporânea (e que hoje é semi-permanente, porém, caminha para a permanência). Nesse ponto, as considerações de Altshuler unem-se às de Ulpiano Bezerra de Meneses quando este aborda os "new museums" como representação do capital cultural: "o primeiro requisito para ser sócio do New Museum diz respeito a afeto, se trata de construir novos espaços e se transformar em referências (...)" (MENESES, 2010, p. 74), ou seja, as obras de arte nesses museus e todo o conjunto que as envolvem guardam as memórias daquela localidade. As fronteiras disciplinares, as intersecções entre o erudito e o popular, são quebradas por essa conformação de museu e isto o transforma em um lugar financeiramente viável seja com patrocínio privado ou estatal. O modelo desses museus também precisa ser global transcendendo às localidades. Nessa direção, a tecnologia é instrumentalizada para trazer novidade ao público visitante, contudo, "a pressão progressiva de transformação do novo para o povo e pela novidade enfraquece as perspectivas de funcionamento desses museus" (IDEM, p. 75).

Ao mesmo tempo em que esses museus estão completamente imersos à lógica do mercado, também não deixam de representar - como qualquer outro museu - o lugar da memória e, no caso particular deste estudo, no "lugar da memória da arte contemporânea". O conceito de lugar da memória, utilizado com vigor por Ulpiano Bezerra de Meneses e procedente dos estudos do historiador francês Pierre Nora, informa que a memória internalizada no cotidiano dos indivíduos pode ser substituída pelos "lugares da memória", focos de condensação que se externalizam em lugares físicos, coisas, pessoas, instituições, 
comportamentos - vetores diversos de sentido material, simbólico ou funcional ${ }^{15}$. Os museus por excelências são "lugares da memória" e sua gestão deve levar em conta suas funções afetivas e subjetivas - sem esquecer as funções ligadas à contemplação estética, à informação e educação e ao desenvolvimento da imaginação (NORA, 1993, p. p. 7-23).

Nesse contexto, a memória nos museus de arte reflete os diversos modos pelos quais a coletividade e os indivíduos revivem o passado, experimentam o presente e prospectam o futuro. A partir de uma percepção dos objetos como documentos, é possível transformar a própria memória consagrada em coleções e em objeto de conhecimento crítico, compreendendo o processo histórico de incorporação de objetos e coleções como formas específicas de legitimar determinadas representações e identidades sociais nos museus (MENESES, 2010, p.p. 74-76).

Na concepção que vê os museus "como lugares da memória", inserem-se também os novos conceitos de instituição museológica, que compreendem as noções de museu como território, território-museu, museu-comunitário e ecomuseu - com suas dinâmicas locais. Nesses museus, os membros de uma comunidade tornam-se agentes do processo de formulação, execução e manutenção da instituição. O prefixo "eco" remete-se ao entorno natural e ao entorno social. "O que o ecomuseu postula, mais do que uma participação do público, é uma cooperação dos habitantes" (CLAIR, 1976, p.p. 2-4).

Essas novas maneiras de repensar o museu e sua interação com o seu entorno justificam a criação de sistemas integrados de museu e a criação de redes, como por exemplo, as que unem as instituições museológicas francesas e

\footnotetext{
${ }^{15} \mathrm{O}$ "lugar da memória" é um conceito que permite articular as práticas, os agentes, os referenciais e os conteúdos da memória é o de lugar da memória, analisando as aproximações e distanciamentos entre a memória coletiva e memória histórica. Para Pierre Nora, a memória emerge de um grupo social por ela unificado, e é esse grupo que determina "o que é memorável, e também como será lembrado. Os indivíduos se identificam com os acontecimentos públicos de importância para seu grupo". A partir desse argumento, Nora constrói a noção de - lugares da memória - que, segundo o autor, servem para garantir a fixação de lembranças e de sua transmissão, e estão impregnados de simbolismos, pois caracterizam acontecimentos ou experiências vividas pelos grupos, ainda que muitos de seus membros não tenham participado diretamente de tais eventos.
} 
espanholas ou ainda os Acervos Artístico-Culturais dos Palácios do Governo do Estado de São Paulo. A ideia do trabalho em redes interligadas na área museal conecta-se à profunda transformação social, indicada pela "sociedade em rede", que destaca a necessidade de troca de informação e de conhecimento quase que instantânea entre a sociedade, os grupos e as instituições.

As redes de museus europeias funcionam verticalmente, horizontalmente ou ainda por sistemas mistos. Essas redes são criadas, a partir de códigos internacionais de museus, como o código de deontologia do ICOM, além de documentos formalizados em congressos de museus, como é o caso da Carta Cultural Iberoamericana de Museus. O objetivo dessa documentação é abrir diversas possibilidades e recursos para cada parte integrada na rede, incentivando o potencial de criatividade e disponibilidade, bem como preencher lacunas com relação às necessidades de cada museu, criando linguagem e espaço cultural comum. Acrescentem-se às redes de âmbito nacional, estadual e regional, as redes internacionais e/ou transnacionais, como por exemplo, a Network of European Museum Organization (NEMO) e o próprio ICOM que podem ser considerados como uma estrutura de trabalho em rede. Outros exemplos são: a Rede Ibero América de Museus e a Rede Centro Americana de Museus. Nesses casos, as redes são mecanismos solidários que podem contribuir para diminuir as desigualdades entre os padrões dos museus da cada país (CARVALHO, 2008, p. 53). No caso das redes, a salvaguarda dos acervos continua sendo de responsabilidade do museu, porém, os procedimentos de gestão, preservação e manutenção deste acervo podem ser compartilhados entre as entidades que compõem a rede - alerta-se para o fato de que não se transita a coleção, ou seja, o bem patrimonial da instituição.

Em sistema de rede ou não, as instituições museológicas carregam a missão de assegurar a transmissão do patrimônio de geração a geração - tarefa que hoje está seriamente ameaçada por múltiplos fatores, entre eles: o desenvolvimento econômico, o crescimento das cidades, os conflitos armados, a degradação do meio ambiente e as consequências ocasionadas pelo turismo de massa entre outros. Nessa tarefa, entram os organismos reguladores. Os órgãos 
de preservação, tais como o Instituto do Patrimônio Histórico e Artístico Nacional (IPHAN), o Instituto Brasileiro do Meio Ambiente (IBAMA), o Sistema Brasileiro de Museus (SBM) e seus similares estaduais e municipais são responsáveis pela gestão de grande parte dos atrativos históricos, culturais e ambientais, buscando alternativas de sustentabilidade financeira ${ }^{16}$ e salvaguarda das coleções. Não é possível esquecer, ainda, os órgãos que tratam especificamente da questão museológica, tal como o ICOM, o INCA e o IBRAM (LAGE \& LEITE, op. cit., p. 51).

Todos esses condicionantes históricos expostos até aqui, acrescidos das transformações ocorridas no conceito de museu, de instalações arquitetônicas e das funções comunicativas retomam o sentido da gestão do museu, como ato simbólico que deve respeitar a condição sócio-histórica da comunidade na qual a instituição museológica se insere. As reflexões, ora apresentadas, subsidiam a configuração do eixo de estudos de Gestão de Museus de Arte: Coleção e Mediação, abordando a gestão dos museus como instrumental para a intermediação entre a obra de arte contemporânea e o público. Torna-se relevante o exame aprofundado sobre a relação do museu com seu acervo e a mediação deste com seu público. A partir dessa análise, em segundo estágio, pondera-se sobre as outras formas de atualização dos acervos de arte contemporânea - entre elas, os modelos de comodato e guarda provisória por determinação judicial.

Nesse sentido, tem-se a reflexão sobre a conservação e a mediação. São essas ações que legitimam a existência da instituição e depois a permanência de uma coleção, uma vez que são essas atividades que transparecem à comunidade. Os museus preservam a propriedade cultural, configurada a partir de suas coleções e especialistas que propõem novas interpretações e exercícios ao

\footnotetext{
${ }^{16}$ Coube a Mario de Andrade, autor de decreto que criou o Serviço do Patrimônio Histórico e Artístico Nacional (SPHAN), definir a cultura para o moderno Estado Brasileiro. Nesta tarefa Mário de Andrade contou com a colaboração de Rodrigo Melo Franco de Andrade, Manuel Bandeira, Afonso Arinos, Lúcio Costa e Carlos Drummond de Andrade. Desdobramentos dessas ações foram sentidos, por exemplo, na inclusão de cidades históricas, no tombamento de bens culturais. As cidades brasileiras inscritas foram Ouro Preto (MG), Congonhas (MG), Olinda (PE), Salvador (BA), São Luís (MA), Diamantina (MG), Cidade de Goiás (GO) e Brasília (DF).
} 
público. Um serviço museológico eficaz necessita despertar a confiança de seu público, uma vez que lida com o patrimônio e os bens culturais caros à comunidade - se torna necessário que a comunidade deposite na gestão do acervo o respaldo de confiabilidade para administrar e preservar seus bens culturais. A responsabilidade relacionada com a preservação e com a interpretação de qualquer aspecto do patrimônio cultural tangível e intangível (quer local ou nacionalmente) necessita promover esta confiança. Sob essa perspectiva, é preciso criar conscientização pública sobre o papel, o propósito do museu e o modo pelo qual este é gerido.

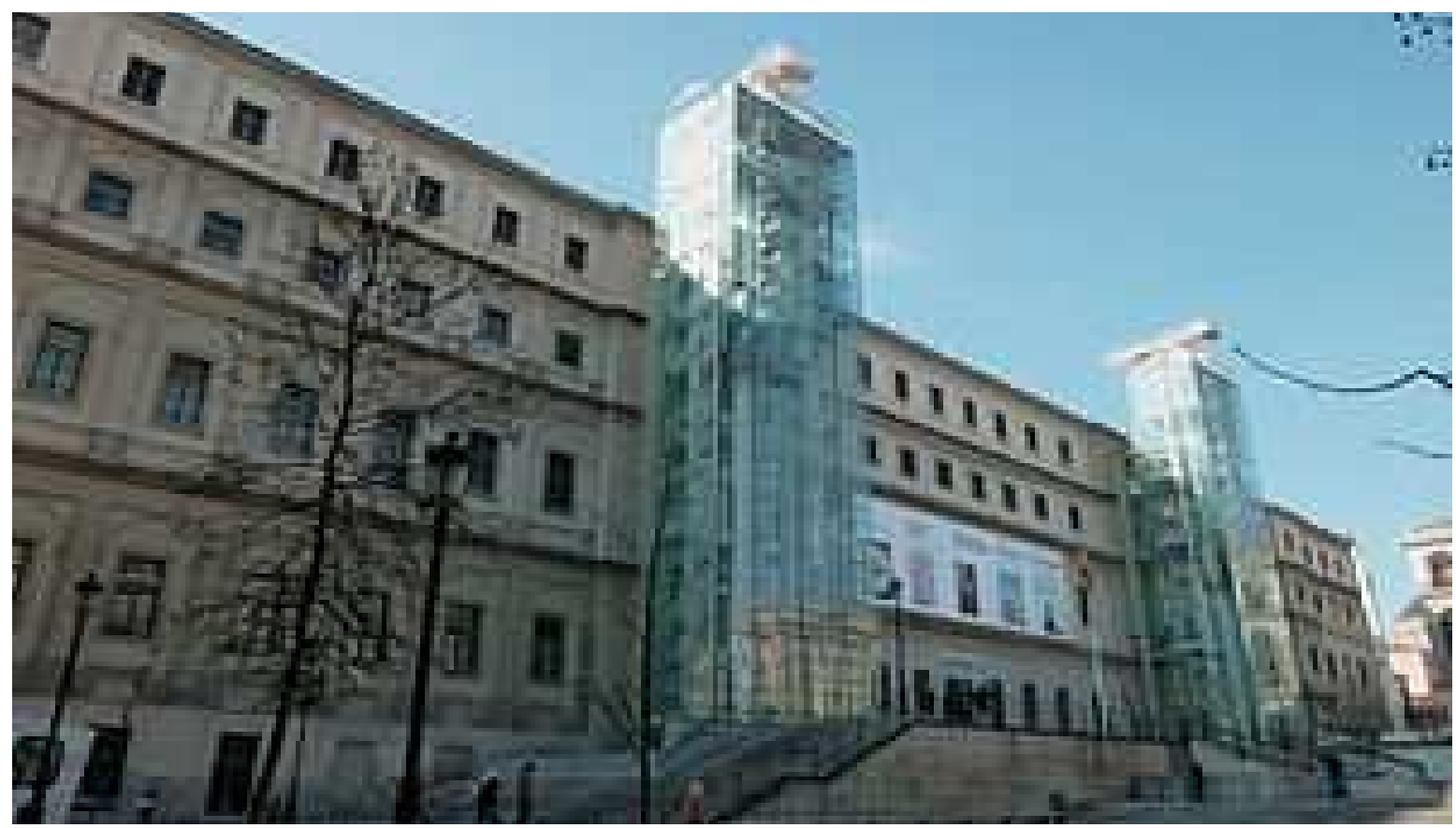

Figura 15. Museu Nacional Centro de Arte Reina Sofia. Fachada do museu, aqui se denota o austero edifício onde anteriormente residia o Hospital de São Carlos. Fonte: www.museoreinasofia.es/ 


\section{Conservação e Exposição}

A ideia de "coleção" vaza das paredes dos prédios dos museus, alcançando as cidades (BITTENCOURT).

Tradicionalmente, a gestão de museu sempre foi considerada uma parte relativamente sem relevância entre as ações museológicas. Isto porque a maioria das funções administrativas, tais como a manutenção de edifícios e as operações financeiras e de recursos humanos é, frequentemente, de responsabilidade dos departamentos ou órgãos estatais não relacionados diretamente com o cotidiano das instituições (BOYLAN, 2004). Porém, a inserção dos museus modernos, como já observado no caso do MoMA, transforma esse panorama, levando a um quadro de descentralização de tais funções e até mesmo a transferência de tais responsabilidades para os próprios museus. A gestão torna-se encargo do diretor da instituição que tem como instrumentais administrativos: o plano museológico, o plano diretor ${ }^{17}$, a declaração da missão do museu ${ }^{18}$, o estatuto e regimentos

\footnotetext{
${ }^{17}$ Documento que deve conter os procedimentos e a "maneira de agir" do museu durante o período de uma gestão (ver anexo I).

${ }^{18}$ Documento que estabelece a missão, os objetivos e as políticas, inclusive de sustentabilidade do museu. Segundo o ICOM, a missão do museu deve ser declarada de forma aberta e objetiva e pode ser baseada no nome do museu ou na natureza de seu acervo. Dessa forma, a missão deve definir as delimitações do acervo e apresentar o papel e a identidade pública da instituição. Quando a instituição museológica regulamenta a sua situação, sendo uma pessoa jurídica, ela necessita ter um regimento interno ou conjunto de regras que regem seu funcionamento (ver anexo II)
} 
internos ${ }^{19}$ que regulam as normas e os procedimentos internos das instituições museológicas.

Seja na noção tradicional, seja na sua versão moderna ou contemporânea, os museus têm a responsabilidade de adquirir, preservar e promover o seu acervo, através de ações museais (recolher, conservar e difundir), determinadas por critérios de valores que atribuem significado aos artefatos, conferindo-lhes atributos documentais e representacionais. A musealização é uma das formas de preservar o patrimônio cultural. Nesse âmbito, a gestão do acervo (LADKIN, op. cit., p.p. 16-17 $)^{20}$ torna-se algo vital para o desenvolvimento, a organização e a preservação das peças que cada museu abriga. Este acervo constitui um patrimônio público significativo que envolve, como já observado, o conceito de confiança, uma vez que esses objetos representam determinadas realidades ou entidades, constituindo-se em intermediários entre os espectadores e o mundo não visível - origens, eternidade, antepassados, entre outros valores - que representam. Essa valoração do patrimônio, por sua vez, traz tarefas à gestão museológica, como o estabelecimento de uma política de aquisição, catalogação, procedimentos de pesquisa e de empréstimo de obras, manuseio, conservação e acesso ao público. Todas essas medidas visam à preservação de uma obra após sua incorporação ao acervo.

Porém, os procedimentos antes da incorporação são tão ou mais importantes do que suas ações sucessoras. A decisão para a aquisição de novos objetos é, muitas vezes, tomada sem a consulta dos peritos sobre determinada preservação especial. Por essa razão, cada vez mais, a política de aquisição do museu exige a avaliação da condição e da conservação antes da incorporação de bens adicionais ou da aceitação de doações. No caso de acervos contemporâneos, são muitas as condicionantes que podem dificultar a preservação e a conservação

${ }^{19}$ O estatuto é caracterizado por normas jurídicas que são acordadas entre os sócios ou fundadores. Nele encontram-se a oficialização e a regulamentação de pessoa jurídica, seja ela uma sociedade, associação ou fundação.

20 “A gestão de acervo é o termo aplicado aos vários métodos legais, éticos, técnicos e práticos pelos quais as coleções do museu são formadas, organizadas, recolhidas, interpretadas e preservadas. A gestão do acervo foca-se na preservação das coleções, preocupando-se pelo seu bem-estar e segurança a prazo longo. (...) O termo 'gestão do acervo' também é utilizado para descrever as atividades específicas empreendidas pelo processo administrativo". 
de uma peça - essas restrições podem estar relacionadas à efemeridade dos materiais ou ainda às dimensões exageradas ou diminutas dos suportes que compõem a obra, ou, ainda, a obsolescência da técnica/tecnologia, além da existência de uma infinidade de outras características específicas. Por razões estéticas, históricas e patrimoniais, a questão da preservação do objeto artístico, nas instituições museológica ainda é ponto central na gestão do acervo: categorias como efemeridade, precariedade dos materiais e interação espectador e objeto são questões que colocam em xeque o cotidiano dessa gestão.

"Um dos maiores desafios na conservação de arte contemporânea é o grande leque de materiais que os artistas estão usando em seus trabalhos", relata Jim Coddington, chefe do departamento de conservação do MoMA (PAIM, 2010, p. 17). Com “o fazer artístico contemporâneo", as atividades de restaurar e de preservar ganham nova complexidade, que vai além da manutenção do objeto produzido, pensado e proposto pelo artista. Necessariamente implica no trabalho de análise da ideia do "propositor" e de qual papel a materialidade de sua obra tem na veiculação de seu projeto estético - percebe-se que essa situação é muito mais difícil, no caso das coleções que vêm por determinação judicial, uma vez que a instituição não tem as condições adequadas para avaliar uma determinada peça antes de seu abrigo na instituição museológica (item aprofundado mais adiante neste estudo).

Retornando aos aspectos relacionados à preservação de acervos, deve-se redirecionar-se a origem da palavra praeservare (latim), que significa "observar previamente", ou seja, prever os reais riscos e realizar procedimentos preventivos. Na preservação de obras de arte isto se traduziria na identificação dos possíveis riscos, frente a ação do tempo ou de algum agente deteriorante. $\mathrm{Na}$ discussão sobre preservação e manutenção do acervo, entra o conceito de gestão de risco do acervo, ou seja, a avaliação diante da possibilidade de perda, incluindo danos graduais e cumulativos no acervo. Segundo Stefan Michalski, conservador do Instituto de Conservação Canadense, há nove agentes de deterioração que provocam danos ou perda para o acervo: 1) forças físicas diretas; 2) ladrões, vândalos e visitantes e/ou funcionários distraídos; 3) incêndio; 
4) água; 5) pragas; 6) contaminantes; 7) radiação e temperatura incorreta e, 9) umidade relativa incorreta (MICHALSKI, 2004, p. 57). Para evitar esses fatores, é preciso envolver todos os especialistas do museu: particularmente, os profissionais que integram as equipes de curadoria, documentação, exposição, segurança - todos têm que contribuir na tarefa da preservação.

O setor que assume a responsabilidade de preservação é o de gestão do acervo, podendo ou não ser integrado pela equipe de conservação. Há aproximadamente cem anos, o único trabalho dos responsáveis pela preservação dos objetos do museu é o restauro. Nos últimos cinquenta anos, essa profissão transforma-se em "conservador/restaurador". A conservação abrange tratamentos que higienizam, estabilizam e fortalecem os objetos. Os conservadores também podem intervir em antigos danos, mantendo o registro da intervenção. Grande parte das instituições museológicas dispõe de profissionais especializados, contudo, nem todas dispõem de instalações físicas e equipamentos para o tratamento das obras.

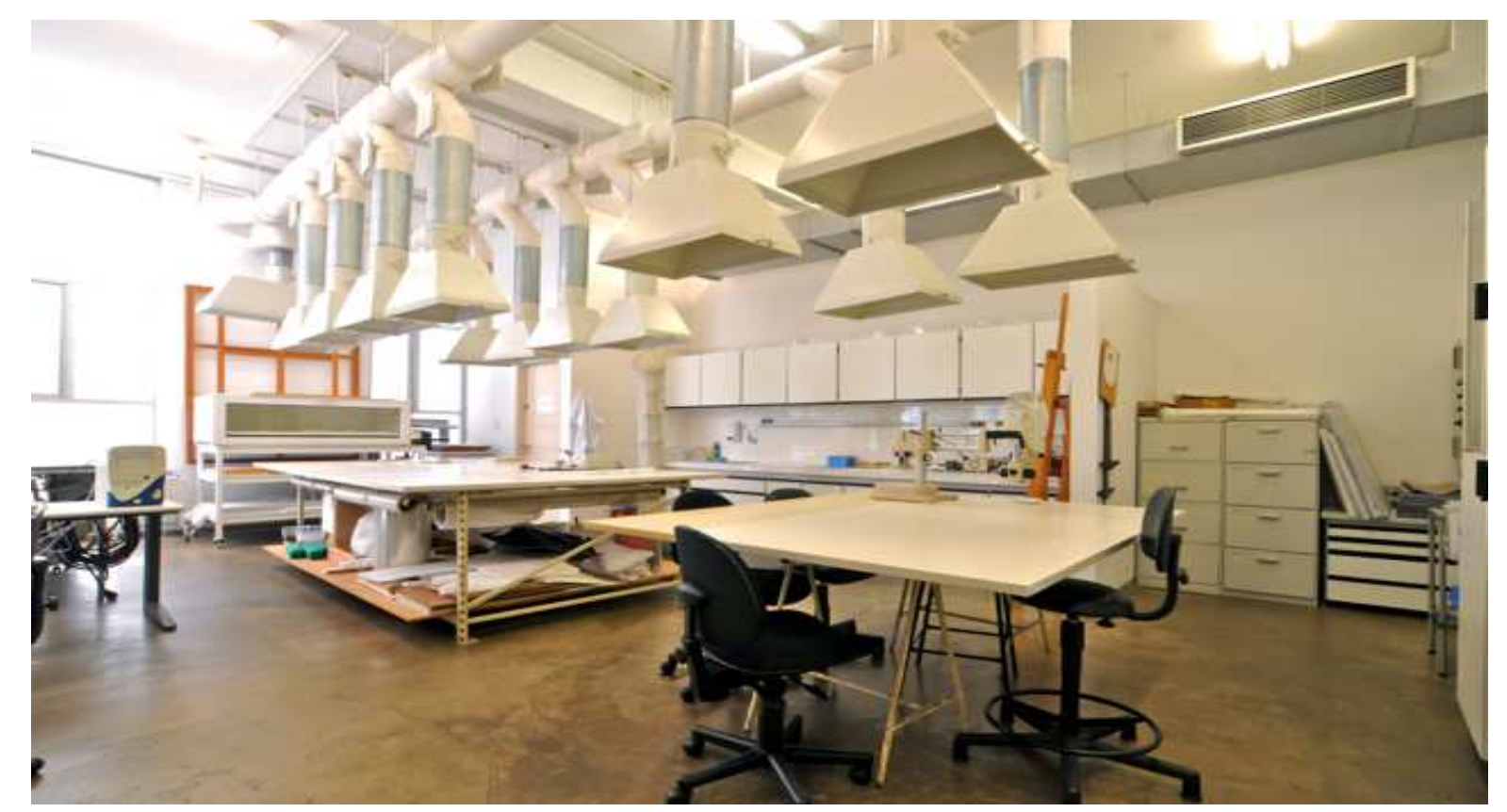

Figura 16. Laboratório de Pintura e Escultura, MAC USP. Fotografia: Juan Guerra. Fonte: Arquivo MAC USP. 
As ações voltadas à conservação, como já mencionado, envolvem a limpeza, a estabilização e o fortalecimento da obra. Resumem-se às medidas de controle realizadas direta ou indiretamente em um objeto ou acervo com a intenção de identificar e gerir os riscos de deterioração através de ações de monitoramento e de controle das condições ambientais, da aplicação de metodologias de manuseio, do acondicionamento, do armazenamento, da exposição e do transporte para a preservação. Isto é, a conservação torna-se um conjunto de procedimentos destinados a conter as deteriorações de um objeto ou resguardá-lo de danos. Identifica-se com os trabalhos de intervenções técnicas e científicas, periódicas ou permanentes, repetidos e continuados, aplicados diretamente sobre uma obra ou seu entorno, com o objetivo de prolongar sua vida útil e sua integridade.

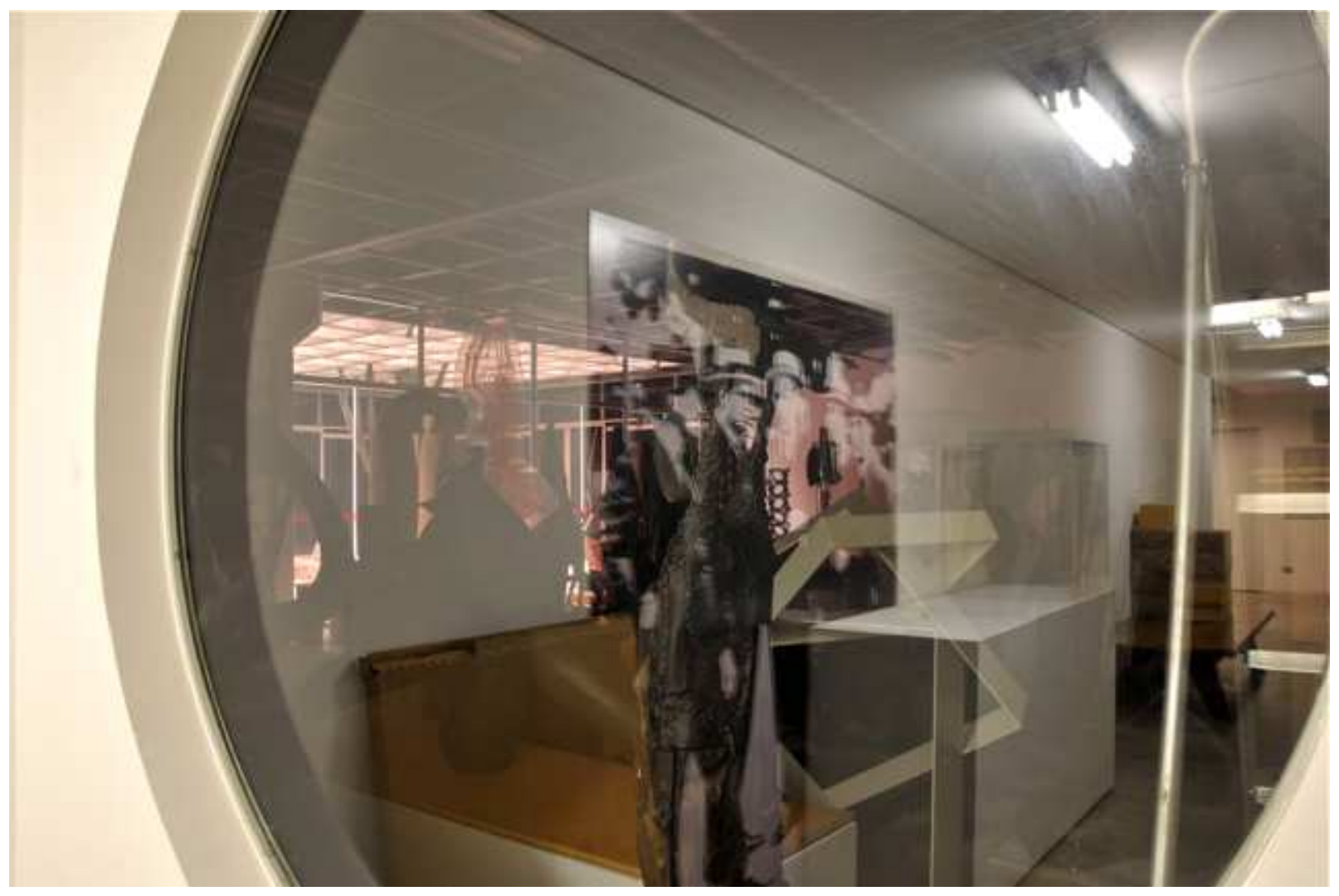

Figura 17. Vista parcial da Reserva Técnica de Tridimensionais, MAC USP. Fotografia: Juan Guerra. Fonte: Arquivo MAC USP. 
Nesse âmbito, insere as instalações museológicas integradas por locais de armazenamento e tratamento das obras, tais como laboratórios de restauro e, principalmente, a reserva técnica. A guarda de um acervo demanda uma reserva técnica, com condições físicas, mobiliários adequados, condições climáticas estáveis e condições de segurança apropriadas à conservação das obras. Essa área ultrapassa, muitas vezes, a área expositiva - aquela que o público tem acesso. Museus - como o Reina Sofia (com 18 mil obras) - possuem uma reserva técnica com vários andares. Já outros museus, como o Museu de Arte Latino-Americano de Buenos Aires (MALBA) com um acervo com cerca 500 peças, enfrentam problemas de espaço adequado por não estarem dotados de reservas técnicas (IDEM).

Além dos locais apropriados para as tarefas relacionadas ao armazenamento e ao restauro, o acervo artístico deve possuir um registro com todas as informações relativas à sua natureza, incluindo laudos técnicos periódicos (que registram o processo de deterioração, restaurações anteriores, manchas causadas pelo tempo, risco e trincas presentes). ${ }^{21}$ Entre os itens mais importantes para a preservação das obras, a garantia de estabilidade da temperatura e umidade relativa do ar é preocupação constante do conservador que deve buscar a menor oscilação possível no armazenamento e na exibição das obras. $\mathrm{O}$ ato de preservar versus o de exibir é um grande embate na gestão museológica. A palavra exposição, de origem latina, significa "exponere" - isto é, "pôr para fora", "entregar à própria sorte", também se pode compreender “mostrar, tornar aparente" (HERRERMAN. 2004, p. 98).

No âmbito museológico, ao lidar com o tratamento das obras apresentam-se diversas formas de mediação: a pesquisa, a catalogação, a curadoria, porém a exposição é a mediação mais reconhecida e aqui merece destaque. Como disponibilizar o objeto artístico contemporâneo ao público e preservá-lo, simultaneamente? As exposições constituem-se como as ações mais

\footnotetext{
${ }^{21}$ Metodologia de pesquisa que constitui o primeiro passo na atividade de conhecimento, de salvaguarda e de valorização dos bens culturais de um acervo, consistindo na sua descrição individual, padronizada e completa, para fins de identificação, classificação, análise e conservação.
} 
populares das instituições museológicas no que tange às atividades que envolvem a mediação. Em última instância, a exibição seria a seleção de peças e de informações relacionadas com os objetos apresentados nos circuitos expositivos e acrescidas da definição da melhor maneira de mostrá-lo. É na exposição que ocorre o contato direto entre o visitante e o acervo do museu: como controlar esse contato, mantendo a integridade das obras de arte contemporâneas? E, principalmente, como proceder quando a proposta do artista exige a interação corpórea com o espectador? Nas exposições, em princípio, qualquer indivíduo, independente da idade, estatuto social e econômico, só ou em grupo, tem a oportunidade e o espaço para ver/interagir com o objeto artístico (IDEM).

Isso se dá por intermédio de técnicas de exposição para que possam permitir a comunicação e a interação entre obra e espectador - "a exposição torna aparente ao olho e à mente" (IDEM). A exposição está no âmago das questões relacionadas ao colecionismo, quando se pensa na etimologia da palavra coleção (collectio, do latim) significa por em ordem - raciocinar e discursar, ou ainda, razão que se faz como discurso (CRUSCO, 2010, p. 12). Nessa perspectiva, o caráter narrativo da coleção é o fator fundamental de sua existência e está na origem do termo, assim como a exposição torna-se uma das funções comunicativas mais importantes do museu.

Para a exposição de arte, perspectivas sob o domínio da recepção, da crítica e da estética estão presentes, transformando-a em "uma apresentação intencionada, que estabelece um canal de contato entre um transmissor e um receptor, com o objetivo de influir sobre ele de uma determinada maneira, transmitindo-lhe uma mensagem" (GONÇALVES, op. cit., p. 29). Raramente, a obra de arte isolada no espaço é suficiente para comunicar ao visitante todas as relações trabalhadas em uma exposição. É preciso que se dê ao público informações sobre o objeto exposto (seja sobre o período da produção da obra; sobre o artista, sobre o movimento, sobre o percurso artístico, entre outras) (IDEM). É por intermédio da exposição que o visitante tem a oportunidade de captar quais os paradigmas culturais que direcionaram a apreciação estética durante determinado período. É sempre importante lembrar que, arte construída 
historicamente, torna-se índice cultural, que conta história, contextos e condições humanas. Por sua vez, exige iniciação, requer estudo, aquisição de repertório, para que esse material possa estabelecer relações estéticas e políticas.

Para autores, como Jean Davallon, a exposição seria um "discurso autorizado", constituindo, então, um espaço social de contato entre o espectador e um determinado conhecimento (DAVALLON, 1999). Outros autores, como René Vinçon, atribuem à exposição mais o sentido de ser "lugar social", destacando sua dimensão estética frente à experiência da arte, através dos objetos, e, ainda, sua aproximação de um conhecimento sensível à realidade (VINÇON, 1999). A partir das duas visões, a exposição de arte a torna pública, uma vez que é proporcionada para receptores/espectadores de diferentes perfis. É o perfil do visitante que deve ser levado em conta quando se estabelece no espaço expositivo relações cenográficas ou não, ou seja, o uso de apelos visuais para a interpretação das obras.

Mesmo o "cubo branco", expressão criada por O’Doherty, para se referir ao modelo de espaço expositivo inaugurado pelo MoMA, com paredes brancas e apelo racional, tem elementos mínimos que levam à interpretação das obras. Sob a égide do "cubo branco", os elementos que desviam a atenção do expectador da apreciação estética da obra são minimizados (O’DOHERTY, op. cit., p. 4). Isto porque o aspecto formal da obra é mais importante nessa concepção espacial. A obra deve ser autônoma, valer per si, qualquer interferência externa pode "contaminar" o ato de apreciação. Vinda do modernismo, essa concepção, determina que as experimentações devam pertencer ao terreno das pesquisas formais: a obra de arte deve se completar em sua materialidade. Essa "ausência" de contextualização ou outros recursos comunicativos requer do expectador certa experiência na leitura de obras e maior conhecimento dos processos relativos à história da arte. Note-se, ainda, que o "cubo branco" tornou-se "tradição" entre os museus dedicados ao moderno e já tem suas exceções entre os museus que lidam com o contemporâneo. Contudo, a seleção entre o uso da cenografia ou do “cubo branco" também é uma questão de gestão museológica, uma vez que é 
uma etapa dos diversos processos que constituem a organização de uma exposição.

Como resultante de uma série de procedimentos encadeados, a exposição é um campo vasto de interpretações que partem dos curadores ${ }^{22}$, perpassam especialistas que auxiliam na produção, na museografia e na montagem das ações e chegam ao público. Através de diferentes recursos - planejamento da disposição de objetos, vitrines ou outros suportes expositivos, legendas e sistemas de iluminação, segurança, conservação e circulação - a museografia torna possível apresentar o acervo, com o objetivo de transmitir, através da linguagem visual e espacial, a proposta de uma exposição. São diversas as naturezas das mostras: elas podem ser permanentes ou temporárias (nesse caso, curta, média ou longa duração); fixas ou itinerantes; compostas por obras que integram o acervo da instituição ou de outros acervos (ou ainda, como no objeto de estudo, obras sob a guarda provisória). No desenvolvimento das ações expositivas, a gestão museológica também está envolvida, uma vez que se tornam necessárias previsões de recursos financeiros, humanos e materiais para a sua realização.

A infraestrutura (como por exemplo, as instalações prediais, o orçamento e a equipe técnica) disponível para a organização de uma exposição determina diretamente a sua recepção estética - uma mesma exposição pode ser mais interessante em uma instituição museológica do que em outra. Todos os recursos expográficos (documentos, textos críticos, luz, distribuiç̧ão das obras no espaço, painéis e paredes com cor ou não, a criação de ambientes especiais, o uso de recursos tecnológicos, entre outros elementos) funcionam como recursos narrativos no ato de comunicação da exposição. São esses recursos que mediam os nexos entre obra de arte e visitante e, por intermédio deles, o sujeito vivencia concretamente a arte (GONÇALVES, op. cit., p.p. 34-35).

\footnotetext{
${ }^{22}$ Curadoria - designação genérica do processo de concepção, organização e montagem da exposição pública. Inclui todos os passos necessários à exposição de um acervo: conceituação, documentação e seleção do acervo, produção de textos, publicações e planejamento da disposição física dos objetos. Refere-se também ao cargo ou função exercida por aquele que é responsável por zelar pelo acervo de um museu.
} 
Nesse sentido, a ideia de museu, como espaço relacional entre os homens e os objetos toma fôlego: essa ideia tem implicações importantes no ponto de vista de sua gestão, isto porque sua posição, agora, é de gerenciador entre a arte e o desejo do público. A programação das exposições e os mecanismos de financiamento dessas mostras têm sido desafios da gestão museológica atual, uma vez que grandes exposições têm um circuito internacional. Exposições temporárias e itinerantes mostram, hoje, coleções mundiais até então nunca vistas pelo grande público. Obras e visitantes se deslocam de um lugar para outro, trazendo consigo as raízes culturais de suas origens, promovendo a integração, o conhecimento e a construção de novos paradigmas.

Contudo, certa inversão nos valores organizacionais dessas mostras tem colocado os museus em xeque. Por seu nível de especialização técnica e alto custo, as exposições que integram o circuito internacional são propostas por produtores culturais, como projetos fechados, aos museus - geralmente, já financiadas por empresas transnacionais que veem a arte como porta de entrada para negócios globais e locais.

O que normalmente acontece é que os museus aceitam a programação já fechada sem nenhuma possibilidade de articulação com seu próprio acervo ou com suas funções particulares. As instituições museológicas, em maior ou menor intensidade, adequam suas programações para atender a demanda de produtores privados e patrocinadores, deixando em segundo plano seu acervo ou ainda eximindo-se da formação de uma cultura visual entre os seus visitantes (ANJOS, op. cit.).

Essa formação do "olhar do público" remete à origem da constituição das instituições museológicas que se estruturou a partir da coleção. A memória constituída, derivada dos objetos selecionados segundo critérios de valor, não reside em um ato de colecionismo isento: está arraigada em contextos culturais específicos de épocas e localidades diversas e cada coleção traz as marcas de sua época e de seus patrocinadores. As exposiçõos imersas em circuito internacional, geralmente, proporcionam o conhecimento de grandes ícones da história da arte - 
algo que está globalizado - porém, as especificidades da comunidade na qual está cada uma de suas sedes temporárias não surgirão como prioridade. Talvez, somente como planos secundários durante a exibição.

De fato, hoje, os museus têm grandes desafios por serem considerados: fatores de revitalização urbana; instrumentos de atração do público (incluam-se as condicionantes que envolvem o turismo e o entretenimento); centros de pesquisa e de conhecimento; "guardiões da memória" e, plataforma para novas reflexões sobre a condição humana na contemporaneidade. De modo mais simples, os museus são instituições humanizadoras, que têm a capacidade de problematizar os temas que discutem a condição humana e que têm a potencialidade de salvaguardar e comunicar as expressões culturais, as referências patrimoniais e os indicadores da memória que a sociedade tem elaborado, construído, selecionado e reunido.

Até aqui se observa o relacionamento da instituição museológica como espaço relacional (entre obras e público), partindo-se do pressuposto de que o acervo é algo definido. Porém, essa ideia não corresponde à situação real, uma vez que um acervo sempre está em mutação e, frequentemente, em atualização/ ampliação - o que se constitui também em um desafio para a gestão museológica - não como já visto nos itens de conservação e mediação, mas focalizando, especialmente, as formas de atualização e ampliação das coleções.

Como manter um padrão de qualidade e mérito, determinado por estudos e pesquisas, em acervos específicos como os dedicados à arte contemporânea (que, sobretudo, ainda não tiveram o distanciamento do tempo para sua legitimação e musealização)? Como obter recursos para contar com uma política permanente de aquisição de obras e enfrentar, simultaneamente, as flutuações do mercado da arte? Quais são os mecanismos existentes para a incorporação de obras em acervos?

Como já mencionado nesse estudo, a criação de um museu de arte, na maioria das vezes, está ligada à doação de uma coleção já constituída e estruturada, que carrega todas as particularidades de seu proprietário 
(LOURENÇO, op. cit.). Essas coleções foram incorporadas a partir de doações de artistas, colecionadores e instituições. Frequentemente, os artistas também doam seus trabalhos para as instituições museológicas. A doação dos colecionadores e dos artistas são quase sempre os principais instrumentos de incorporação de obras ao acervo. Para se conhecer as ações que motivam essas doações, seria necessário abordar: o contexto em que ocorreram; os procedimentos adotados para a incorporação e, principalmente, as condições exigidas pelos doadores.

Nesse sentido, toma-se o histórico e o cotidiano do MAC USP. Como acervo público, esse museu às vésperas de completar 50 anos, pode servir como exempla na gestão de museus de arte contemporânea, demonstrando as dificuldades e os desafios existentes na gestão de coleções. Ao longo do percurso do MAC USP, é possível coletar subsídios importantes para o entendimento da gestão e da ampliação de museus de arte contemporânea. Isso se dá, a partir da observação dos processos de doação, compra e comodatos. Sob essa perspectiva, uma quarta forma de ampliação do acervo, não tão comum, se dá pelo acolhimento de coleções privadas, às vezes delegadas por ações judiciais aos acervos públicos. É o abrigo desse tipo de objeto artístico que constitui as preocupações da pesquisa ora desenvolvida, especialmente dedicando-se às coleções transferidas a Universidade de São Paulo, a partir de 2005. Assinalando, que de fato, o âmago do problema está na atualização de coleções contemporâneas. 
TPARTIE II

TUMM ACIRVO "CONTEMPORAANTEO"

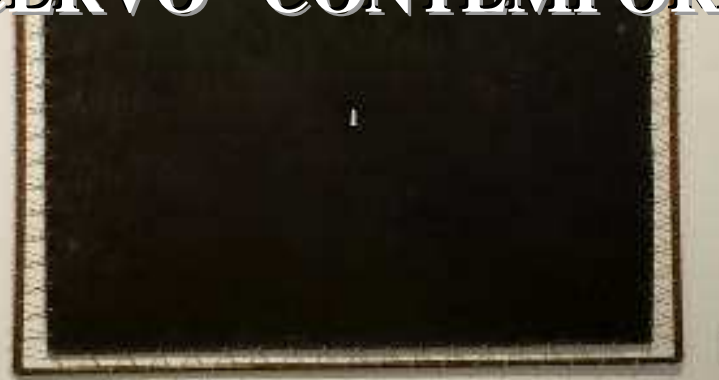




\section{Aquisições (Compra e Doações)}

O museu transforma a obra em objeto (MALRAUX)

No primeiro estágio do estudo ora desenvolvido discorre-se sobre as condições e sobre a formação das primeiras coleções de arte, com atenção dedicada aos embates que envolvem a coleção de obras de arte e, particularmente, à constituição de acervos voltados à questão da arte contemporânea. Privilegia-se, sobretudo, a experiência de instituições que ainda constituem o circuito internacional dos museus, particularmente a gestão do MoMA e o caráter de coleção semi-permanente do New Museum of Contemporary Art. Na sequência, inicia-se uma discussão sobre as motivações para a constituição das primeiras coleções de arte moderna no Brasil, com destaque para a cidade de São Paulo, evocando-se a criação do MAM SP, do MASP e, em momento posterior, o MAC USP.

Nesse contexto, as orientações verticalizam-se para o caso brasileiro, com ênfase nessas instituições museológicas da cidade de São Paulo, emergindo diversas indagações, entre elas: quais seriam as formas de ampliação desses acervos? Quais seriam as principais motivações que envolvem as aquisições, os comodatos e o acolhimento de obras em caráter temporário? Todas essas formas de ampliação do acervo seriam válidas e destinar-se-iam à função e aos 
propósitos dos museus? Com o intuito de responder a essas questões não basta discorrer sobre os conceitos nos quais se deitam as noções relativas ao que seria "uma compra", "uma doação" ou ainda a guarda provisória de obras. É preciso observar a prática cotidiana das instituições museológicas de modo aproximado. Assim sendo, recorre-se ao histórico do MAC USP e suas iniciativas para a ampliação de seu acervo.

O MAC USP possui características peculiares que, mormente, estão intrínsecas em sua origem. O perfil do acervo, constituído antes mesmo de sua fundação, em 1963, traz consigo elementos específicos que merecem densas reflexões. Nessa direção, ressalta-se que como lugar de produção de conhecimento, o Acervo do MAC USP está em constante revisão. As três coleções iniciais (MAM SP, Ciccillo e Yolanda Penteado) imprimem marcas profundas ao Museu. Especialistas desenvolvem pesquisas relevantes sobre essas primeiras coleções. Em contraposição ao número aproximado de 10.000 peças existentes atualmente no Acervo, despertam-se discussões relativas à modernidade e/ou à contemporaneidade do Museu; sobre os métodos utilizados para aquisição e/ou incorporação de obras, ou ainda, sobre as leituras e pesquisas possíveis em uma instituição museológica, inserida na esfera pública e em ambiente universitário.

A partir dessas considerações, remete-se ao percurso de incorporações/aquisições de obras do MAC USP, identificando os fatores históricos e estéticos que compõem o Acervo em sua conformação atual. Em 1963, o ato de transferência de 1.236 peças do acervo do MAM SP, efetivado por Francisco Matarazzo Sobrinho - o Ciccillo, marca a criação do MAC USP e, também, uma nova etapa de um longo processo, iniciado nos anos de 1940, quando diversos intelectuais têm a intenção de fundar um museu de arte moderna na cidade de São Paulo (AJZENBERG, 2006, p.p. 14-16) ${ }^{1}$.

\footnotetext{
${ }^{1}$ Intelectuais comprometidos com o ideário moderno, Mário de Andrade e Sérgio Milliet, desde os anos de 1930, discutem a criação de um museu destinado a abrigar as manifestações artísticas modernistas. Nessas discussões em torno do novo museu há divergências quanto à forma de organização. Porém, as opiniões convergem sobre a importância fundamental da criação de uma instituição como essa para a vida cultural da cidade.
} 
Ressalta-se aqui a contribuição de Ciccillo, como industrial e mecenas das artes no período. Registros apontam que Ciccillo se interessa por artes em momento antecedente aos acontecimentos da II Guerra Mundial. Porém, é durante viagem à Europa, acompanhado por sua esposa Yolanda Penteado, em 1946, que inicia uma coleção de arte internacional. Nessa oportunidade, Ciccillo conta com o auxílio de marchands, galeristas, artistas e críticos de arte radicados no Brasil, na França e na Itália (IDEM). Para o colecionador, o critério de aquisição centrava-se, principalmente em obras das vanguardas europeias, tais como, o expressionismo, o cubismo, o futurismo, a pintura metafísica, o abstracionismo, o dadaísmo e o surrealismo. Nesse primeiro momento, adquiriu obras de Picasso, Braque, Léger, Dufy, Kandinsky, Miró, Arp, Picabia, Gleizes, Lothe, entre outros. Além do auxílio profissional de especialistas em artes, devese levar em conta também o senso estético de Ciccillo e de Yolanda Penteado que norteia a compra das obras. Yolanda, pertencente à elite paulista dá preferência à École de Paris e aos modernistas brasileiros dos primeiros tempos aqui se deve lembrar que ela era sobrinha de Olívia Guedes Penteado, patrona das artes modernas de São Paulo, responsável pelos encontros dos modernistas na vila Kyrial, nos anos de 1920 e 1930 (PENTEADO, 1976) ${ }^{2}$.

Já Ciccillo demonstra profundo interesse pela paisagem, figuras e metier - elementos trabalhados de forma especial na pintura italiana e, no Brasil, pelos modernistas dos anos de 1930 e de 1940, representados pelo Grupo Santa Helena e outros pintores de descendência italiana atuantes ou não no País. Diante deste fato, torna-se natural a aquisição de obras de artistas de tal origem, entre eles: Modigliani, Carrá, Campigli, De Chirico, Casorati, de Pisis, Funi, Mafai, Sironi, Severini, Morandi, entre outros, que foram anexados à coleção de modo gradativo (AJZENBERG, 2006). Por volta de 1952, os gessos originais de

\footnotetext{
${ }^{2}$ Yolanda Penteado nasce na fazenda Empyreo, no município de Leme/SP. Incentivadora das artes e colecionadora, Yolanda frequenta a casa do senador José de Freitas Valle, o senhor da Vila Kyrial, no bairro de Vila Mariana em São Paulo e um dos idealizadores da Semana de Arte Moderna, em 1922. A casa do senador transformou-se no salão cultural mais importante da capital paulista, no início do século XX, abrigando grandes nomes das artes, como Lasar Segall, Brecheret, Anita Malfatti, Oswald de Andrade, Mário de Andrade, Guilherme de Almeida, Sarah Bernhardt e tantos outros.
} 
Desenvolvimento de uma Garrafa no Espaço, 1912 e Formas Únicas da Continuidade no Espaço, 1913, ambos de Umberto Boccioni são adquiridos de Benedetta Marinetti (viúva do poeta futurista) (IDEM).

Para muitos autores, as aquisições de Ciccillo e de Yolanda demonstram uma vontade de constituir um museu de arte em São Paulo, alinhando-se às ideias de Sérgio Milliet, Mário de Andrade e seus contemporâneos ${ }^{3}$. Sob essa perspectiva, evocam-se as ações de Milliet, como diretor da Biblioteca Municipal de São Paulo, na organização, desde os anos de 1940, de uma série de exposições de arte moderna na Biblioteca e na publicação de diversos textos nos jornais à época, fomentando o debate e a necessidade de se criar um museu de arte moderna.

Entre os anos de 1948 e 1949, o Museu de Arte Moderna tem sua primeira tentativa de estruturação, contando com a participação de representantes de diversas áreas das artes e da cultura. Esse grupo traça o perfil e a política de aquisição e de formação do acervo. Nos estatutos do MAM SP prevê-se a criação de comissões de cinema, arquitetura, folclore, fotografia, gráfica, música, pintura e escultura. A primeira sede do novo museu é instalada precariamente em uma sala do edifício dos Diários Associados, na Rua 7 de abril, cedida por Assis Chateaubriand que, no período, acaba de constituir o MASP ${ }^{4}$.

\footnotetext{
${ }^{3}$ Mergulhados na lógica da gestão de arte dedicada à modernidade, Yolanda Penteado e Ciccillo seguem a tendência da época, principalmente arraigada nos EUA - lugar onde, nas primeiras décadas do século XX, o mecenato torna-se mecanismo de legitimação social de milionários emergentes que surgem a partir de investimento nos setores industriais, bancários e petrolíferos. Essa forma de mecenato tem como definição alto grau de personalismo nas decisões, valorizando, sobremaneira, o prestígio social. Figuras como o colecionador J. Pierpont Morgan e John D. Rockfeller Jr. Apostam firmemente nos movimentos artísticos motivados pelo moderno, porém, mais do que colecionadores, tornam-se gestores dos seus acervos e de suas instituições museológicas - participam ativamente da organização das coleções e das mostras de exibição desses objetos.

${ }^{4}$ O MASP é inaugurado em 02 de outubro de 1947, por Assis Chateaubriand, fundador e proprietário dos Diários e Emissoras Associados, e pelo professor Pietro Maria Bardi, jornalista e crítico de arte na Itália, recém-chegado ao Brasil. No acervo estão obras da escola italiana, como Rafael, Andrea Mantegna, Botticceli e Bellini; de pintores flamengos como Rembrandt, Frans Hals, Cranach ou Memling. Entre os espanhóis, estão Velásquez e Goya. A maior parte do núcleo de arte europeia do MASP é de pintura francesa, sendo quatro retratos das filhas de Luiz XV, pintados por Nattier; alegorias das quatro estações por Delacroix. Do movimento impressionista, encontram-se várias obras de Renoir, Manet, Monet, Cézanne e Degas. Dos pósimpressionistas é possível encontrar várias telas de Van Gogh ou de Tolouse-Lautrec. Um dos
} 


\section{DO FIGURATIVISMO \\ AO ABSTRACIONISMO}

MUSEU DE ARTE MODERNA - SÃO PAULO
Figura 18. Do Figurativismo ao Abstracionismo. Sérgio Milliet e León Degand. MAM, SP, 1949, 20,7 x $15,5 \mathrm{~cm}$. Capa dura, 133pp. Edição trilíngue: Português/Inglês/Francês.

Do Figurativismo ao Abstracionismo, inaugurada em 8 de março de 1949, torna-se a primeira mostra do MAM SP. A exposição, organizada por León Degand, aprofunda a polêmica sobre a oposição entre arte figurativa (de representação da natureza) e a abstrata (que quase 20 anos antes, na Europa, é a "vanguarda" das artes plásticas) (AJZENBERG, 2006). A mostra tem grande repercussão nos jornais e movimenta o circuito nacional em torno da questão figurativismo versus abstracionismo, dando margem à proposta, na qual São Paulo deveria organizar uma exposição internacional de artes plásticas - aqui se tangencia o princípio de que o cenário nacional sempre estaria em descompasso com as ditas "vanguardas" internacionais.

A ideia ganha força no ano seguinte, durante a Bienal de Veneza. Em 1951, Ciccillo lança-se à realização desse projeto, por intermédio do MAM SP. Assessorado por Lourival Gomes Machado e Sérgio Milliet, prepara a grande mostra em um pavilhão construído no parque Trianon, onde hoje está a sede do MASP (AJZENBERG, 2004, p. 18). Para seus organizadores, a Bienal deveria 
colocar a arte moderna do Brasil em contato com a arte do resto do mundo e, simultaneamente, conquistar para São Paulo a posição de centro artístico mundial. Na I Bienal, em 1951, já se estabelece entre os regulamentos do evento, uma cláusula que dá origem às incorporações dos prêmios bienais. Todas as peças adquiridas por empresa e/ou instituição seriam aquisições do acervo do MAM SP (GONÇALVES, 2012) ${ }^{5}$.

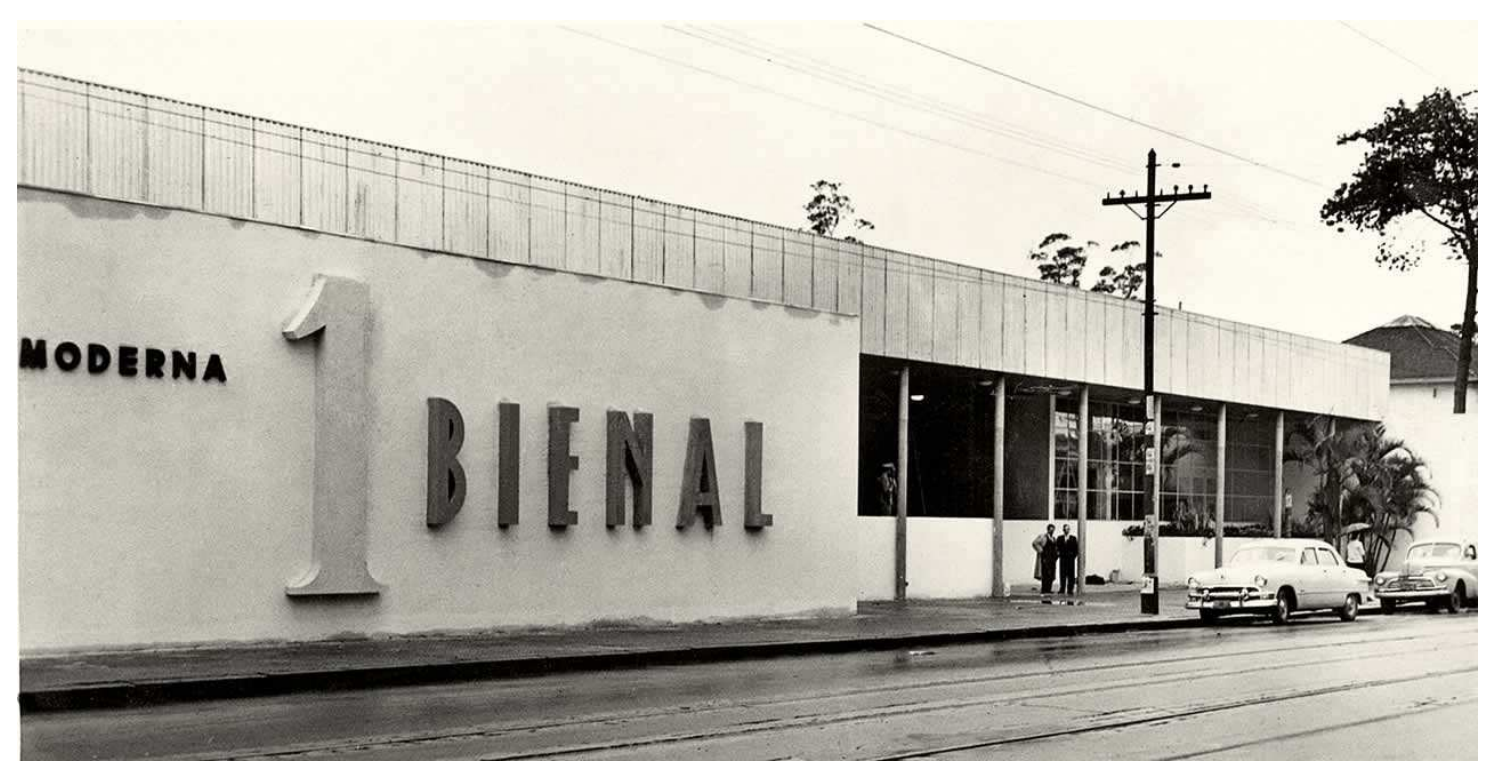

Figura 19. Pavilhão construído na Avenida Paulista, em 1951, para hospedar a primeira Bienal de São Paulo, onde hoje se localiza o MASP. Fonte: Arquivo Wanda Svevo, Fundação Bienal de São Paulo.

Em 1958, o MAM SP, instituição responsável pela organização das bienais, transfere-se para o atual Pavilhão Ciccillo Matarazzo, no Parque Ibirapuera. Nesse momento, surgem as dificuldades quanto à gestão do acervo. Além da necessidade de uma reserva técnica e do adequado acondicionamento das obras, enfrenta-se o problema de distinguir o que pertence ao Museu, o que era de fato doação de Ciccillo e de Yolanda, e o que não havia sido doado e está somente depositado no Museu. É importante lembrar que muitos trabalhos adquiridos por Ciccillo, pertencentes a sua coleção particular, permanecem sob a

\footnotetext{
${ }^{5}$ Exceto a doação de cerca de 500 desenhos realizada por Emiliano Di Cavalcanti ao MAM SP em 1952, o Museu reúne em sua primeira década 679 obras, das quais quase metade são relativas a prêmios da Bienal de São Paulo ou expostas e doadas através de suas edições.
} 
guarda do MAM SP e participam de eventuais mostras. Ciccillo, a partir das bienais, também adquire, em sua coleção particular, obras provenientes desses eventos - a coleção de Ciccillo cresce sob a guarda do MAM SP (AJZENBERG, 2006).

O método de gestão do MAM SP e a vinculação das finanças da Instituição ao seu presidente, Ciccillo, resultam na reformulação dos estatutos do Museu, em 1959. Já se encontra em pauta a separação das bienais do MAM SP e a extinção do Museu. Apesar da forte oposição nos meios intelectuais e artísticos, em 1962, surge a Fundação e o MAM SP encerra suas atividades ${ }^{6}$. Ao se tornar Fundação, a Bienal não tem mais o compromisso quanto à doação dos prêmios para qualquer outra entidade museológica. Contudo, no Acervo do MAM SP já se encontram cerca de 400 peças provenientes das bienais, sendo que 215 são premiações (IDEM). Através das premiações atribuídas nas Bienais, percebem-se alguns elementos importantes que dão orientação à constituição do acervo dos prêmios bienais.

Da I Bienal, a maioria dos prêmios regulamentares está presente no acervo do antigo MAM SP. A premiação de Max Bill (prêmio de escultura) e as implicações das propostas abstratas influenciam os jovens artistas brasileiros que veem na arte concreta uma inovação estética. Ivan Serpa (prêmio aquisição) torna-se um dos primeiros artistas concretistas do Rio de Janeiro. Ainda abstratos são os desenhos de Uhlmann (prêmio de desenho) e a escultura de Roszak

\footnotetext{
${ }^{6}$ Diversos diretores assumem a gestão do MAM SP até 1962, porém, a dedicação total ao Museu era muito difícil. Durante a organização das bienais, o MAM SP, atrelado à organização da Bienal, fica em segundo plano, o que impede, de certa forma, seu crescimento do ponto de vista museológico. Em 1961, Mário Pedrosa é responsável pela Bienal de São Paulo e diretor do Museu de Arte Moderna. Os conflitos com Ciccillo aumentam, gradativamente, assim como os problemas financeiros. Pedrosa tenta encontrar um patrocinador para o MAM SP, o que representaria uma saída para a sobrevivência da instituição, já que desde 1959, a Bienal passa a ser realizada com o apoio da Prefeitura de São Paulo e do governo federal. Simultaneamente, a Bienal se afirma e o Museu se retrai como entidade museológica. Quando Pedrosa constata a desesperança total para manter o MAM SP, retorna definitivamente para o Rio de Janeiro, enquanto Ciccillo resolve extinguir o museu em Assembleia, criando-se na Universidade de São Paulo um museu com a doação que ele faria de toda a sua coleção. Inconformada com o fato, a Sociedade de Amigos do MAM SP, mantendo sua razão jurídica e liderada por Arnaldo e Oscar Pedroso Horta, passa a lutar pelo renascimento do MAM SP, por meio de um esforço para reunir uma nova coleção a partir de doações de artistas e, em 1969, reconstitui suas atividades regulares, em sua nova sede sob a marquise do Parque Ibirapuera.
} 
(prêmio aquisição), de caráter expressionista. No contraponto, a gravura adere à figuração, com os trabalhos dos italianos Viviane (prêmio de gravura) e Ciarrochi (prêmio aquisição), dos ingleses Adams e Clough (prêmios aquisição), do expressionismo de Goeldi (prêmio regulamentar), Grassmann (prêmio aquisição) e, dos europeus Minguzzi e Richier (prêmios aquisição) (IDEM).

Em outras formas de premiação, as colônias estrangeiras presentes em São Paulo fazem sentir os efeitos de sua ação, através da aquisição de obras representantes de seus países, como por exemplo, os portugueses, com telas de Botelho e Júlio Rezende, e os italianos, com um bronze de Fanzini e um óleo de Birolli. As premiações também rendem homenagens às obras de Tarsila do Amaral e Sophie Tauber Arp que causam certa surpresa, uma vez que os trabalhos são datados de 1924 e 1931, respectivamente. O júri da Bienal justifica essas aquisições através da oportunidade de enriquecer o acervo com obras ícones para a história da arte ${ }^{7}$.

Em 1953, durante a II Bienal, as premiações prosseguem: a Bienal apresenta uma retrospectiva do cubismo e do futurismo, salas dedicadas a Picasso e Klee, além de obras de Laurens (prêmio pelo conjunto da obra), Rufino Tamayo (prêmio pintura internacional) e Di Cavalcanti e Alfredo Volpi (prêmio pintura nacional). Em 1955, a III Bienal homenageia Fernando Léger e no setor nacional, tem como artistas premiados: Milton Dacosta (prêmio pintura), Marcelo Grassmann (prêmio gravura), Carybé e Aldemir Martins (prêmio desenho).

A polêmica entre os artistas ditos "figurativos" e "abstratos" toma conta da IV Bienal. Torna-se necessária a intervenção direta de Ciccillo para garantir o resultado final dos prêmios. Pressionado por artistas brasileiros rejeitados, em sua maioria por adotarem uma postura figurativa, o júri concede premiação a Giorgio Morandi, pintor representante dessa vertente. $\mathrm{Na} \mathrm{V}$ Bienal, o júri em

\footnotetext{
${ }^{7}$ A grande ausência na I Bienal é de uma premiação para a delegação americana, composta por trabalhos de Pollock, Rothko, Mark Tobey e De Kooning. O júri não consegue perceber as novas posturas expressionistas abstratas frente à produção artística norte-americana. Não percebe que o eixo da arte contemporânea desloca-se de Paris para Nova York.
} 
atitude conciliadora concede o prêmio à escultora inglesa Bárbara Hepworth, enquanto os prêmios nacionais são atribuídos para artistas rejeitados na Bienal anterior, tais como Manabu Mabe e Marcelo Grassmann. Após a VI Bienal, os prêmios tornam-se esporádicos e não há mais o compromisso de incorporá-los ao acervo do MAM SP ou qualquer outra instituição museológica.

Em 08 de abril de 1963, Ciccillo consolida a doação de três coleções de arte moderna e contemporânea à Universidade de São Paulo. Essas doações foram realizadas em etapas. Em 1962, ocorre a primeira delas: composta por 429 obras (pinturas, esculturas, desenhos e gravuras - peças de sua coleção particular). A segunda, em 1963 - realizada em comum acordo com Yolanda Penteado - reúne 19 obras estrangeiras (pinturas e esculturas), de propriedade do casal. Essas doações foram acrescidas das 1.236 peças do MAM SP (IDEM). Note-se que as peças doadas por Nelson Rockfeller e os prêmios bienais estão nesse lote do antigo MAM SP.

Logo após as doações, o "o novo museu" desenvolve suas atividades no terceiro andar do Pavilhão Ciccillo Matarazzo, no Parque Ibirapuera (mesmo prédio onde se realizam as Bienais de São Paulo) ${ }^{8}$. Para sua direção é designado Walter Zanini, que recentemente, havia retornado ao Brasil, após uma estadia de cerca de seis anos na Europa, onde conclui a tese de doutorado. Envolvido pela história da arte e pela função do museu, Zanini assume antes do golpe militar (1964), preocupado em transformar o MAC USP em fórum de reflexão e lugar do fazer artístico.

Nos primeiros tempos, a designação "museu de arte contemporânea" sugere novas orientações para o acervo recentemente doado: seria uma distinção ao antigo museu de arte moderna, uma tentativa de apagamento de sua trajetória anterior? Afinal, a emergência de um museu contemporâneo seria um modo de

\footnotetext{
${ }^{8}$ O MAC USP, posteriormente, consegue instalar uma parte de seu acervo e uma biblioteca no campo da cidade universitária e passa a enriquecer tanto o diálogo com a Universidade, instigando os alunos a participar de suas atividades de pesquisa, ensino e extensão, como com a cidade.
} 
especialização/conceituação da nova instituição ${ }^{9}$. Seria uma forma de atualização do acervo e adequá-lo às novas denominações que surgem a partir dos questionamentos da arte e da antiarte que emergem entre os anos de 1960 e 1970? Aqui, assinalam-se as transformações sofridas no fazer artístico (a diluição das fronteiras entre as linguagens, o processo em detrimento da obra acabada, a desmaterialização do objeto e a utilização das tecnologias digitais). Essas alterações estão diretamente ligadas às novas formas de documentar, de catalogar, de preservar e de expor as obras de arte, somadas à urgência do envolvimento do artista em todas as práticas (IDEM).

O fato é que com a criação do MAC USP, o mecenato de Ciccillo e os prêmios vindos da Bienal não são mais a base para a ampliação do acervo do "novo museu". O desafio de ampliação da coleção passa para a responsabilidade da USP e, por conseguinte para o diretor do MAC USP. No livro organizado pelo Banco Safra há o registro da dificuldade dos primeiros tempos:

\begin{abstract}
A principal fonte de verbas para aquisição de obras ficou por conta da reitoria da USP. Assim, ao longo das várias crises pelas quais passou o País, o MAC foi uma das primeiras instituições a ter dificuldades com verbas. E, como é fácil imaginar, o MAC não conseguiu acompanhar o rápido desenvolvimento das artes plásticas da década de 60, nem a nível nacional, nem a nível internacional. Aliado a isto, constatamos o descompasso entre a política de aquisição e os movimentos e artistas determinantes no panorama geral da Arte Contemporânea (O MUSEU DE ARTE CONTEMPORÂNEA DA UNIVERSIDADE DE SÃO PAULO, 1990, p. 22).
\end{abstract}

No início das atividades do "novo museu”, destaca-se a disposição de recursos - mesmo que exíguos - da Universidade, instituição mantenedora do Museu. No período entre 1964 e 1988, o MAC USP - através de compras e

\footnotetext{
${ }^{9}$ Essa visão relacionada à emergência da distinção entre moderno (a) e contemporâneo (a) que se intensifica durante a primeira metade do século XX com o surgimento dos autointitulados museus de arte moderna e dos movimentos artísticos modernistas. No século XIX, as denominações "museus de artistas vivos", "museu de arte contemporânea" e "museu de arte moderna" são sinônimos e antônimos de "museu de arte antiga". Já a partir do século XX, são muitas vezes empregados para designarem instituições com tipologias diferentes. NORONHA, Elisa. Museu de Arte Contemporânea: Uma Estratégia de Abordagem. http://interative.org/2010/01/museucontemporaneo. Acesso em 03 de outubro de 2012.
} 
doações - ampliou sua coleção em 479 obras de artistas brasileiros e estrangeiros: entre 1964 e 1969, o MAC USP adquiriu 205 peças; já na década de 1970, esse número sobe para 261 obras e, espelhando o período de recessão econômica pelo qual passa a Universidade e o país na década de 1980, somente 18 obras são incorporadas à coleção. Nesse universo não estão incluídas as obras conceituais - que hoje se encontram em fase de catalogação. Os investimentos da USP destinados à ampliação da coleção do MAC USP podem ser visualizados pelo gráfico a seguir:
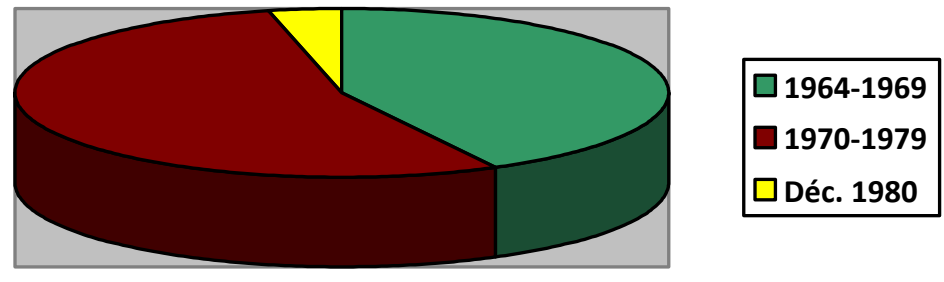

Gráfico 1. Aquisição de obras com recursos da USP entre os anos de 1964 e 1988. Fonte: Setor de Catalogação - Divisão Técnico-Científica de Acervo do MAC USP

Dentre as obras adquiridas com recursos provindos da USP, estão: Torso/Ritmo, 1915/1916, de Anita Malfatti; Retrato de Joaquim do Rego Monteiro, 1920, de Vicente do Rego Monteiro; Duas Figuras, 1933, de Lasar Segall; Conceito Espacial, 1965, de Lúcio Fontana; Expansão Controlada, 1967, de César Baldaccini; Sit...Cidade...y...Campo..., 1970, de Artur Barrio; Parla, 1982, de Cildo Meireles, entre outros (ver mais detalhadamente no anexo III). É perceptível que a seleção de obras parte do perfil moderno estabelecido pelo primeiro lote de obras, oriundo das doações de Ciccillo e Yolanda Penteado, mas também tenta acompanhar as novas experimentações que emergem após a década de 1960, além desse aspecto, a seleção se alterna entre obras importantes para a história da arte brasileira e obras que vieram ao Brasil, na ocasião de bienais e que permaneceram em face da aquisição pela Universidade. 
No percurso da instituição museológica, cada diretor estabelece estratégias para atualizar o Acervo. O primeiro diretor Walter Zanini (19631978), transforma o MAC USP em espaço para manifestações artísticas ligadas às novas experimentações. Aposta em propostas conceituais, happenings, novas tecnologias e na interação artista-obra-espectador. Em seus projetos, os novos artistas são privilegiados, permitindo exposições como Jovem Desenho Nacional (JDN); Jovem Gravura Nacional (JGN) e Jovem Arte Contemporânea (JAC), Prospectiva'74, Poéticas Visuais e Década de 70. A partir dessas iniciativas, a incorporação de obras fundamentadas na experimentação de novas linguagens e no uso de novos meios constitui-se como base do crescimento do acervo, sendo a contemporaneidade a marca principal das décadas de 1970 a 1990, quando as doações de obras realizadas pelos próprios artistas colocaram-se como fator principal para a atualização e ampliação qualitativa do seu acervo.

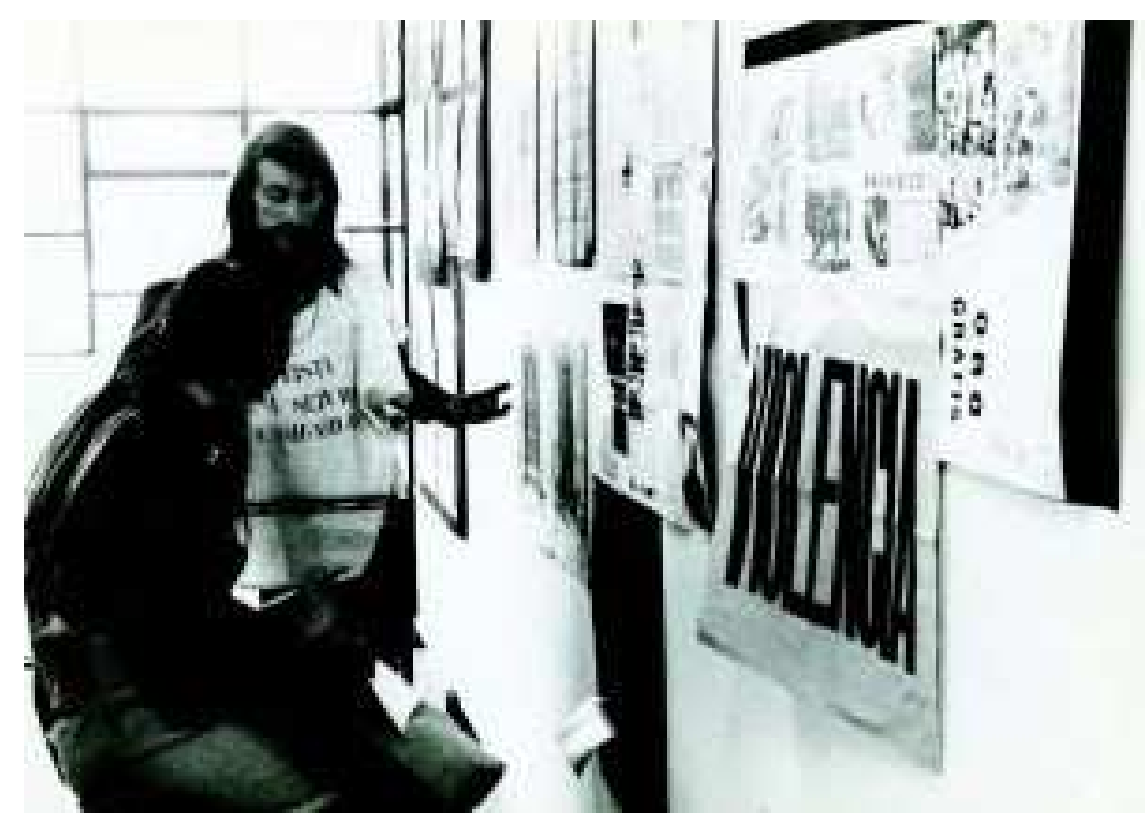

Figura 209. Registro da obra de Clemente Padín, O artista a serviço da comunidade, 1974, MAC USP. Fonte: Arquivo MAC USP. Na obra, o artista - aqui representado por outro artista, uma vez que Clemente Padín estava preso pela ditadura no Uruguai - explica ao público suas propostas conceituais.

É também dessa época, o único caso de permuta, existente até o momento no MAC USP: a ação envolveu a troca de uma cópia de bronze da escultura Formas Únicas da Continuidade, 1913, de Umberto Boccioni, e a 
escultura Figura Reclinada em Duas Peças: Pontos, 1969/1970, de Henry Moore que pertencia a Tate Gallery (Londres).

Do gesso original de Formas Únicas da Continuidade, adquirido por Ciccillo e posteriormente transferido para a Coleção MAC USP, tem-se o registro de quatro cópias em bronze - feitas após a morte de Boccioni: uma está no MoMA (1931); a segunda no Metropolitan Museum of Art (1942); a terceira, fundida em 1960, também se encontra na coleção do MAC USP e, a quarta e última foi fundida pelo MAC USP a pedido da Tate Gallery (1972). Outra versão foi fundida em 1972, mas não a partir do gesso original, e sim da versão de 1942 do Metropolitan e encontra-se no Museu de Arte Contemporânea de Los Angeles.

Já Figura Reclinada em Duas Peças: Pontos, de Henry Moore, além do gesso da Tate Gallery, tem uma cópia no parque National Mall (Washington DC). Representa um acréscimo importante à coleção MAC USP, uma vez que o escultor torna-se figura-chave para o entendimento da vertente tridimensional no cenário artístico internacional - a permuta era a chance de uma peça de Henry Moore estar presente em acervo público brasileiro.
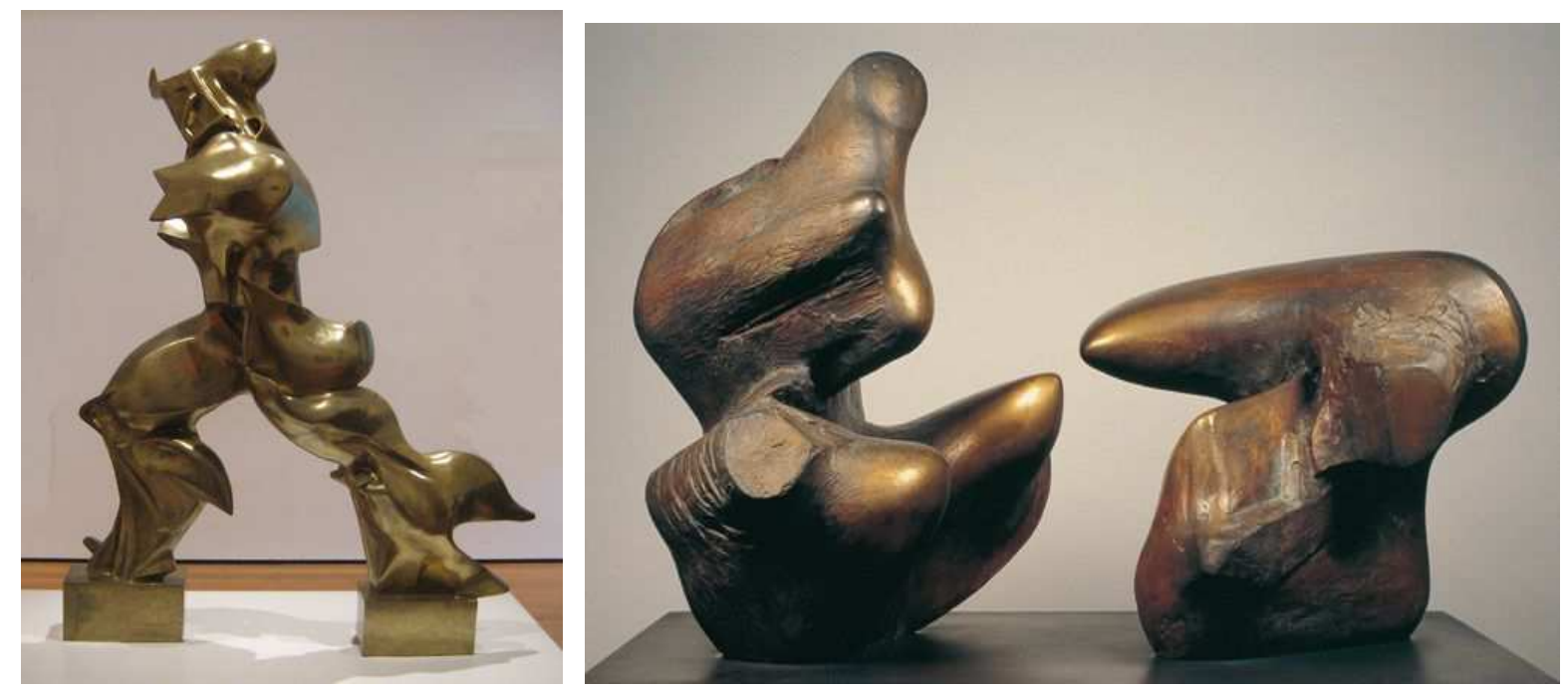

Figura 21. Umberto Boccioni, Formas Únicas da Continuidade, 1913 (bronze), Coleção MAC USP. Fotografia: Rômulo Fialdini (à esquerda).

Figura 22. Henri Moore. Figura Reclinada em Duas Peças: Pontos, 1969/1970 (bronze), Coleção MAC USP. Fotografia: Rômulo Fialdini (à direita). 
O segundo diretor, Wolfgang Pfeiffer (1978-1982), dedica atenção à organização de exposições de caráter histórico-didática aliada à programação relacionada às linguagens contemporâneas e à produção de jovens artistas. Destaca-se que nessa gestão, em 1978, o MAC USP recebe 26 peças do espólio de Yolanda Mohalyi (FARINHA, 2006) ${ }^{10}$. No mesmo ano, são incorporadas as obras de: Manabu Mabe, Antonio Gomide, Samson Flexor, Arcângelo Ianelli, João Calixto e Marco do Valle. Ainda nessa gestão, o Museu recebe a doação de 328 peças da coleção do crítico de arte Theon Spanudis (RIBEIRO, 2001) ${ }^{11}$. Os trabalhos revelam uma leitura muito pessoal do colecionador em relação à arte contemporânea brasileira, na qual os achados formais da arte concreta são comparados ao artesanato e ao imaginário popular. É possível dividir essa coleção entre arte concreta e arte naif.

Os procedimentos e normas museológicas que conduzem o MAC USP são definidos, em grande parte, pela atuação de Aracy Amaral (1982-1986), na diretoria da instituição. No entanto, a preocupação central está na adequação da coleção. É preciso inserir obras ligadas às novas tendências internacionais, tais como o neoexpressionismo e o retorno à figuração. Em 1985, a diretora estimula a criação da Associação dos Amigos do Museu de Arte Contemporânea da Universidade de São Paulo (AAMAC) para arrecadação de fundos além dos provenientes da USP. Em 1988, o MAC USP adquire com recursos da Reitoria da USP a obra Sem título, 1985, de Amílcar de Castro. Entre os anos de 1980 e 1990, o Museu promove a exposição Pintura como Meio, evidenciando a produção pictórica no cenário brasileiro. Nesse momento, o meio tradicional da pintura é utilizado a partir de novos pressupostos. A coleção do MAC USP incorpora obras de artistas exemplares: Iran do Espírito Santo, Regina Silveira, Paulo Monteiro, Daniel Senise, entre outros.

\footnotetext{
${ }^{10}$ Assinala-se que Pfeiffer já havia escrito sobre o trabalho da pintora e no mesmo ano da doação das peças, orienta o trabalho de Maria Lúcia Bortolo sobre a vida e obra de Yolanda.

${ }^{11}$ Theon Spanudis, psicanalista descendente de gregos, nascido em Izmir (Turquia) em 1915 e falecido em São Paulo em 1985 - cidade em que atuou no campo da psicanálise, da literatura e das artes. Sua coleção foi doada mediante cláusula de que deve ser exposta - como conjunto pelo menos uma vez por ano.
} 
Dedicada às questões que envolvem arte e educação, Anna Mae Barbosa (1986-1993), concentra esforços na questão da aprendizagem na leitura de imagens e na educação por meio das linguagens estéticas. Em 1992, o colecionador Marcantonio Vilaça dispõe, em comodato, 50 peças de jovens artistas brasileiros emergentes, que cobrem lacunas do acervo contemporâneo do MAC USP. No lote estão obras de artistas, tais como: Iole de Freitas, Jorge Guinle, Ernesto Neto, Gustavo Resende, Ângelo Venosa, Leda Catunda, Sérgio Romagnolo, Carlito Contini, Carlos Bevilacqua, Hilton Berredo, Jorge Duarte, Valeska Soares, Marcos Gianotti, entre outros (discute-se o comodato com mais detalhes mais adiante no presente estudo).

Em duas gestões (1994-1998 e 2006-2010), Lisbeth Rebollo Gonçalves realiza ações dirigidas à mediação do acervo e aos intercâmbios internacionais. Quanto à política de aquisição, as ações internacionais e as trocas com os artistas foram atividades priorizadas. Nesse contexto, as doações dos artistas são, novamente, os instrumentais básicos para a ampliação do acervo do MAC USP. Os intercâmbios com artistas latino-americanos - tais como, Bernadita Vattier e Sérgio Meirana, têm preocupações de atualizar a coleção com expressões contemporâneas próximas às poéticas latinas.

Em 2009, o MAC USP apresenta ao MinC (Lei Rouanet) programa de aquisição de obras que reúne cerca de 20 trabalhos de artistas brasileiros, tais como José Rufino, Divino Sobral, Laura Belém, Brígida Baltar e outros - essas obras contribuiriam para a atualização do acervo, abrangendo novas poéticas de artistas que não estão somente concentrados no eixo Rio/São Paulo, mas que, ao mesmo tempo, já têm um reconhecimento internacional, com menções na Bienal de Veneza e/ou na Bienal do Mercosul. Porém, o projeto não é levado adiante por ausência de patrocinadores e de recursos para a aquisição de obras selecionadas. Como as obras selecionadas, em sua maioria, estavam à disposição do mercado de arte, não foi possível sua reserva ao museu por tempo suficiente para que se providenciasse um potencial patrocinador. 
Em parceria com a Galeria de Arte do SESI, José Teixeira Coelho (19982002) dá intensa visibilidade ao Acervo MAC USP. É também responsável por obras civis que readequaram o edifício-sede do Museu, na Cidade Universitária. Já na questão que tange à atualização do acervo, em 1999, o Projeto Leonilson, constituído oficialmente em 1995 por um grupo de familiares e amigos do artista, doa para o MAC USP 6 peças, entre elas: Homem com Cometas, 1986. Nesse período, foi organizado o Programa de Novas Aquisições, contudo, esse não foi levado a cabo pela falta de recursos para a compra ${ }^{12}$. Aqui vale mencionar que as leis de incentivo e os editais culturais são mecanismos, inscritos por intermédio da AAMAC e da Fundação de Apoio a Universidade de São Paulo (FUSP), utilizados pelo MAC USP na ampliação de seu acervo, contudo, muitas vezes a ausência de apoiadores para esses projetos culturais são os maiores obstáculos.

No âmbito da atualização da coleção, em 2003, Elza Ajzenberg (20022006), realiza um tributo ao colecionador Marcantonio Vilaça. Da mostra participam obras do comodato, trabalhos do próprio acervo do Museu e produções recentes de artistas convidados, que mais tarde, foram incorporadas à coleção, tais como: Angelo Venosa, Marcos Gianotti, Berredo e Bevilacqua. Em 2005, a exposição Nave dos Insensatos, nasce de encontros de artistas, com o objetivo de pensar, avaliar e inserir novas obras no Acervo MAC USP. Participam dessa campanha expositiva, artistas, tais como, Amílcar de Castro, Antônio Henrique Amaral, Arcângelo Ianelli, Caciporé Torres, Carlos Vergara, Cláudio Tozzi, Cléber Machado, Guto Lacaz, Ivald Granato, José Roberto Aguilar, Luiz Paulo Baravelli, Maria Bonomi, Siron Franco, Sonia V. Brusky, Tomie Ohtake, Tomoshige Kusuno e Wesley Duke Lee. Dedica-se atenções à internacionalização do acervo a partir das doações de Salvatore Emblema, Luiz Fernando Pelaez e Benedetta Bonichi. Além disso, a busca de novos espaços para o abrigo do Acervo, que culmina com a destinação do prédio do antigo DETRAN

\footnotetext{
${ }^{12} \mathrm{O}$ programa de aquisição objetivava adquirir peças de artistas nacionais com projeção internacional, tais como Waltércio Caldas, Sandra Cinto, Rochelle Costi, Vik Muniz, Rosângela Rennó, Edgard Souza, Ana Maria Tavares e Tunga. Para viabilizar o programa, o MAC USP procurou à época os artistas e suas respectivas galerias (Galeria Brito Cimino, Galeria Luisa Strina, Casa Triângulo e Galeria Camargo Vilaça).
} 
para o MACUSP, tem início nessa gestão. Aqui, ressalta-se ainda que o primeiro lote de obras (cerca de 1500 peças) que chegam ao Museu, por determinação judicial, ocorre nesse período (tema da investigação ora apresentada e que será aprofundada na terceira parte do trabalho).

Na trajetória do MAC USP, Tadeu Chiarelli (2010-2014) dedica-se às poéticas visuais contemporâneas, elegendo peças de Jonathas de Andrade, Junior Suci, Fernando Lindote, Patrícia Osses, Sandra Cinto, Gustavo Von Ha, Luiz Braga, Shirley Paes Leme, Albano Afonso e outros artistas que produzem o que há de mais recente no cenário das artes atuais; assim como, revisita o acervo e incorpora obras de artistas como Arcângelo Ianelli, Marco Gianotti e gravuras mexicanas, além de artistas conceituais como Hervé Fischer e Isidoro Valcárcel Medina. Nessa perspectiva, a diretriz para a ampliação está direcionada pelas obras já presentes no acervo. São aquisições de obras contemporâneas que mantêm diálogos com a coleção do Museu. Optou-se, ainda, por selecionar artistas de várias gerações e com destacada atuação, não somente no eixo São Paulo/Rio de Janeiro, mas igualmente, em outros lugares do país, bem como artistas internacionais.

Em 2011, o MAC USP organiza a mostra Arte Contemporânea Brasileira que reúne obras de 10 artistas selecionados pela diretoria e equipe de docente do Museu (Jonathas de Andrade, Élida Tessler, Luiz Braga, Hudinilson Junior, Emmanuel Nassar, Alfredo Nicolaiewsky, Paulo Gomes, Ana Teixeira, Marcelo Silveira e Rosângela Rennó), cujo objetivo principal é apresentar a proposta de aquisição de obras que o Museu pretende realizar ${ }^{13}$. Dessas, as obras de Jonathas de Andrade e Rosângela Rennó já integram o Acervo MAC USP por intermédio da AAMAC e de patrocinadores. As demais aguardam a aprovação do projeto de aquisição e a disposição de recursos por patrocinadores. A AAMAC também adquiriu alguns livros de artistas, tais como Isidoro Valcárcel Medina (artista conceitual espanhol).

\footnotetext{
${ }^{13}$ A ideia primeira desta mostra surgiu quando o MAC USP, interessado em participar do Edital Procultura de Estímulo às Artes Visuais (edição 2010) do Ministério da Cultura, selecionou obra de 10 artistas brasileiros. (Apresentação da mostra Arte Contemporânea Brasileira. www.mac.usp.br. Acesso em 10 de julho de 2012).
} 


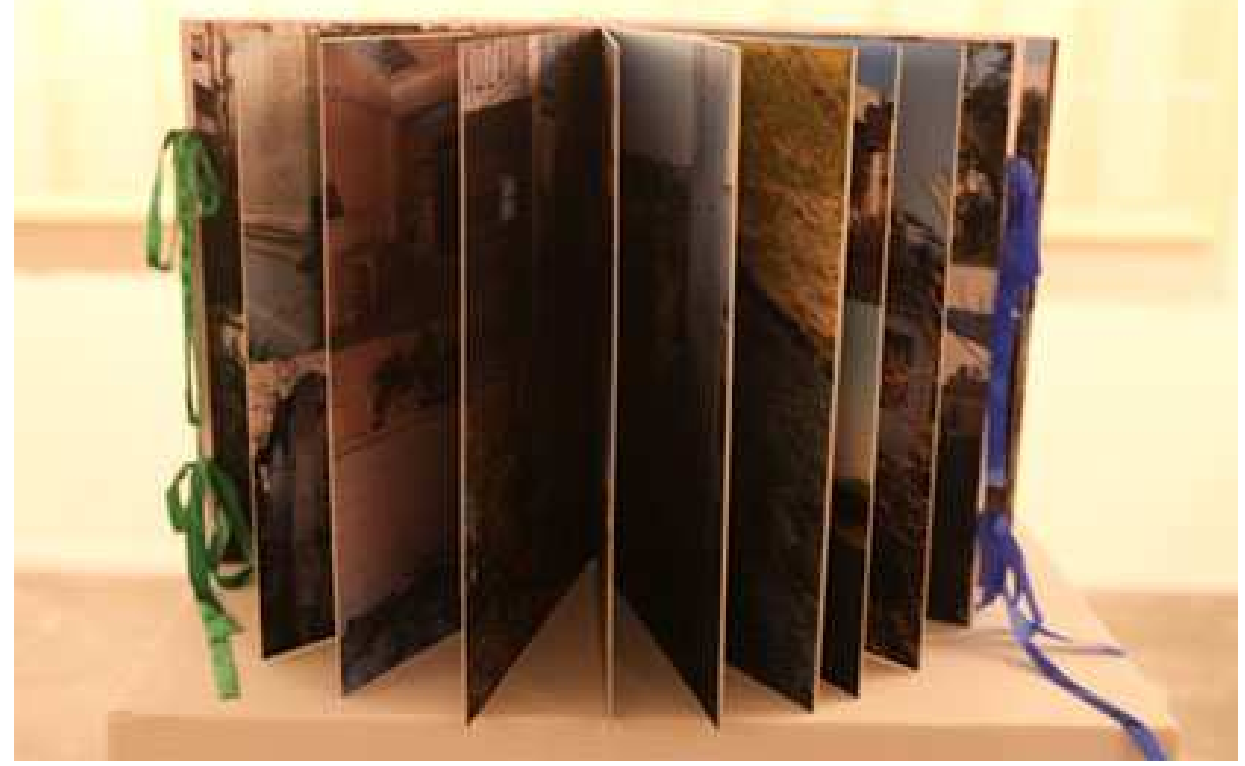

Figura 23. Rosângela Rennó, Venetian Tour Scrapbook, Coleção MAC USP. Fotografia: Juan Guerra.

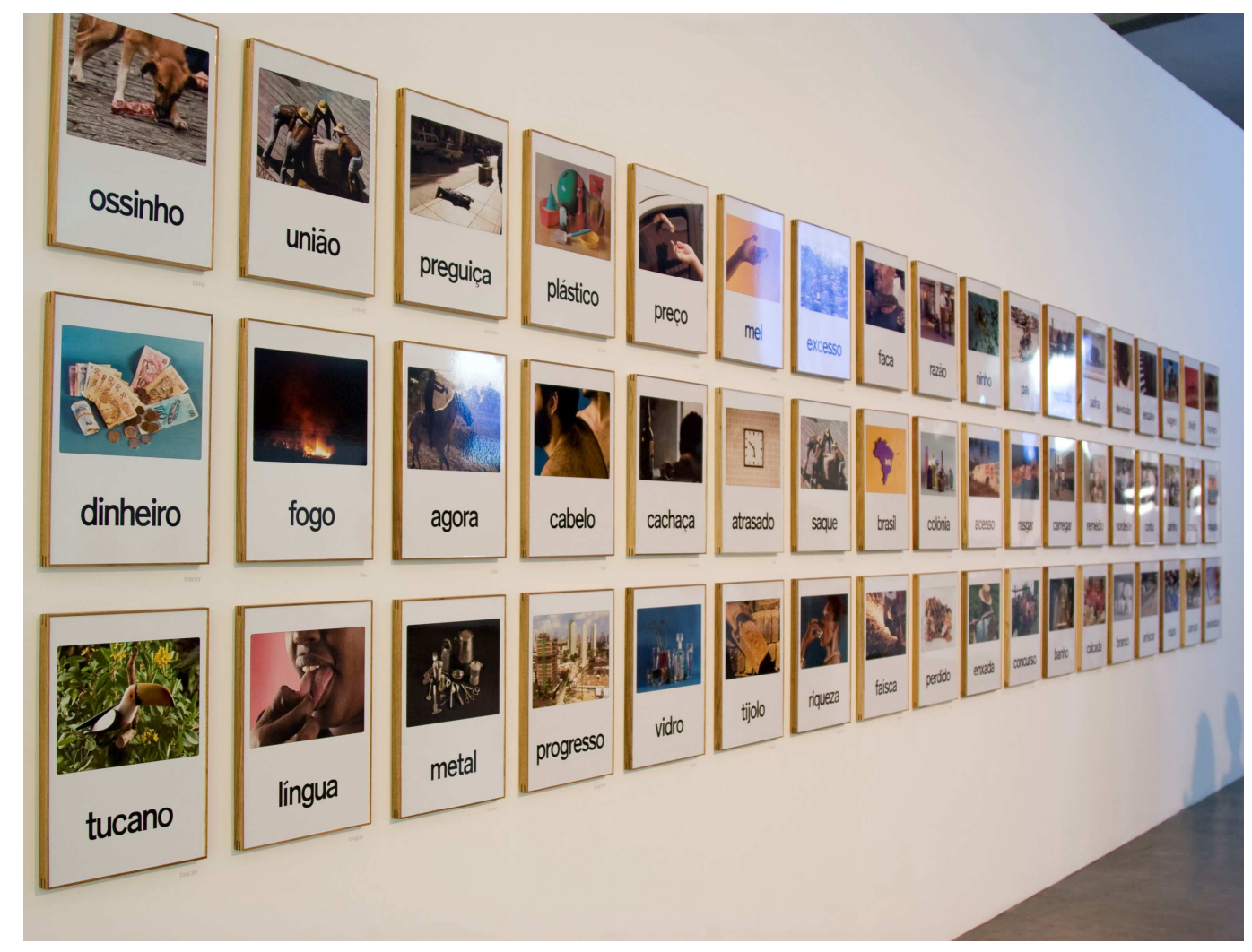

Figura 24. Jonathas de Andrade, Educação para Adultos, 2010, Coleção MAC USP. Fotografia: Juan Guerra. 
Herdeiro do MAM SP, o MAC USP carrega consigo um importante acervo de arte moderna. São obras que retratam as tendências europeias de meados do século $\mathrm{XX}$, passando por todo o modernismo brasileiro até os movimentos artísticos emergentes nos anos de 1960. O Acervo MAC USP corre o risco de impregnar-se do discurso modernista na formação do acervo, nas formas de documentação e na exibição das obras de arte. Na década de 1960, quando ocorre a mudança do sistema de arte moderna para a arte contemporânea, ou seja, a quebra de conceitos como originalidade, unicidade e autonomia valores caros à arte moderna, mas questionáveis na arte contemporânea (COSTA, op. cit., p. 73) - o MAC USP está reestruturando seu Acervo com dificuldades de recurso, apesar do uso das leis de incentivo e dos editais, esses dispositivos isoladamente não são suficientes para manter o processo de atualização da coleção.

Do histórico de obras incorporadas ao MAC USP, ao longo de seus 50 anos de existência, pode-se perceber que a ampliação do Acervo deve muito aos esforços de seus diretores, pesquisadores e, especialmente, aos colecionadores e artistas conscientes de seu papel social. A transformação de coleções particulares em patrimônio público fornece novas possibilidades, centradas principalmente na pesquisa, no ensino e na divulgação da arte contemporânea no país.

Nesse ponto, torna-se relevante assinalar que todas as doações passam pelo crivo dos especialistas do Museu, cujos pareceres são referendados pelo Conselho Deliberativo do MAC USP - a existência de um conselho é condição primordial para a gerência museológica de qualquer instituição - são os membros do Conselho que ratificam ou não a incorporação de uma determinada peça, equacionando a responsabilidade do diretor no que toca a seleção das obras. As normas e procedimentos que implicam a aquisição (compra, permuta ou doação) de obras marcam a responsabilidade do museu em receber um objeto, observando a documentação da peça, sua autenticidade, o seu estado de conservação e o seu valor de mercado. A documentação de um objeto pode ser composta por cartas, recibos de compra ou venda anterior, cópia de testamento do doador que se incorporará ao arquivo documental. 
Para a incorporação de uma obra no Museu, é de fundamental importância a apresentação de documentação que ateste a procedência e autenticidade da mesma (além da documentação fiscal - faturas, recibos ou outros documentos que comprovem a realização da transação comercial). Mais recentemente, outra preocupação presente diz respeito aos direitos autorais ${ }^{14}$. No MAC USP são frequentes as solicitações de empréstimo de obras, autorização para reprodução de imagens. Paralelamente, é grande o número de publicações que são produzidas pelo Museu que fazem uso de imagens de obras da coleção. Em razão das especificidades da lei brasileira, a Procuradoria Geral da Universidade orienta o Museu a solicitar aos artistas, herdeiros ou ainda proprietários das obras, que informem a condição da transferência da propriedade da obra, no que diz respeito à sua exibição.

Quando o museu recebe peças de caráter temporário, estas passam a ser de inteira e exclusiva responsabilidade da instituição museológica que as abriga, portanto, todos os procedimentos para a incorporação, mesmo que temporária, devem ser adotados (registro, catalogação, conservação, estudo e exibição). As condições físicas e estruturais da instituição são necessariamente levadas em consideração. Nessa direção, o museu deve ponderar se dispõe de espaço físico apropriado para o acolhimento das obras, assim como recursos materiais e humanos para a devida conservação da mesma ${ }^{15}$. Observa-se, desse modo, que a incorporação de uma obra de arte apresenta um conjunto de circunstâncias que impactam o cotidiano das instituições museológicas.

\footnotetext{
${ }^{14}$ Art. 77. Salvo convenção em contrário, o autor de obra de arte plástica, ao alienar o objeto em que ela materializa, transmite o direito de expô-las, mas não transmite ao adquirente o direito de reproduzi-la. Da Lei no. 9610/98 (Lei de Direito Autoral).

${ }^{15}$ Hoje, o MAC USP sofre com a falta de espaço físico para a guarda de sua coleção. Com a perspectiva de mudar-se para a nova sede no Parque Ibirapuera, essa questão estará equacionada, já que esse novo edifício possui cerca de $25.000 \mathrm{~m} 2$, sendo boa parte desse espaço reservado à área expositiva e à reserva técnica.
} 


\section{Empréstimos e Comodatos}

(...) a reunião de tantas obras-primas, e a ausência de tantas obras-primas, convoca, em imaginação, todas as obras (...) (MALRAUX).

Uma reflexão sobre as questões patrimoniais e bens culturais em museus pode decorrer do estudo de caso de guardas temporárias de obras e/ou coleções particulares em acervos públicos. Nessa condição, tem-se uma abordagem que é comum na prática museológica: o comodato. Apesar de ser uma prática ordinária, essa guarda temporária de obras suscita questões que são regularizadas pelo ICOM, IBRAM e IPHAN e, muitas vezes, evocam questões que envolvem decisões museológicas, formalizadas através de Termos contratuais.

A guarda provisória, por período determinado, refere-se a uma situação específica. É, invariavelmente, formalizada através de um Termo de Empréstimo e Recibo de Entrega de obras. Em termos gerais, esse empréstimo é utilizado para o complemento de exposições, nas quais o acolhimento de uma obra/coleção se torna necessário para que a realização e a leitura da exposição estejam de acordo com as expectativas do curador e do público. É prática recorrente entre instituições museológicas e/ou artístico-culturais, assim como entre colecionadores e instituições. O empréstimo pressupõe incorporação temporária e 
isso implica o atendimento de todas as obrigações condizentes à finalidade dessa cessão - a manutenção e preservação do objeto (transporte especializado, manuseio adequado, seguro e conservação durante o período da exposição).

No empréstimo de uma obra/coleção, leva-se em consideração o prazo de execução, duração e pós-produção de uma exposição - esse será o tempo estimado do empréstimo. Tem se claro que essa obra/coleção está em diálogo com outro acervo com objetivo e tempo determinados anteriormente à ação do empréstimo. Esse diálogo é firmado mediante o estabelecimento de contratos para o empréstimo de obras e/ou coleções por curto e por longo prazos. Vale ressaltar, que o prazo é importante no que diz respeito ao propósito e investimentos que serão realizados.

Exposições temporárias exigem a condição de guarda provisória de obras por empréstimo. Como prática recorrente entre instituições públicas e particulares, nacionais e estrangeiras, a apresentação dessas mostras chamadas de “curta duração”, oportuniza aos curadores (responsáveis pela seleção das obras) construírem uma narrativa que não vê barreiras na propriedade (posse) dos trabalhos a serem apresentados. Para a viabilização das exposições os produtores, sejam eles autônomos ou institucionais, recorrem - através da figura do empréstimo - a artistas, galerias, colecionadores e instituições para o atendimento dessa necessidade. Nesse caso, a instituição solicitante será responsável pelos custos relativos ao seguro, embalagem e transporte das obras cedidas, assim como pela conservação e segurança da obra/coleção que será exibida, no período acordado, visando a finalidade específica.

O MAC USP empresta muitas de suas obras a diversos museus nacionais e internacionais. Ressalta-se que o empréstimo de obras da coleção é formalizado através do Termo de Permissão de Uso ${ }^{16}$. Todos os procedimentos normatizados pelo ICOM e pelo IPHAN são observados. Comumente, não recorre ao

\footnotetext{
${ }^{16}$ Permissão: é ato administrativo negocial, discricionário e precário, pelo qual o Poder Público faculta ao particular a execução de serviços de interesse coletivo, ou o uso especial de bens públicos, a título gratuito ou renumerado, nas condições estabelecidas pela Administração. http://www.icom.org.br/codigo_etica_port.pdf. Acesso em 04 dez. 2012.
} 
empréstimo de obras de outras instituições, exceto quando realiza mostras que pretendem estabelecer diálogos entre obras externas e peças de seu próprio acervo, como exemplo desses casos, tem-se a exposição Magnelli, ocorrida entre julho e setembro de 2010, no espaço do MAC USP, no Parque Ibirapuera e que apresenta uma retrospectiva de Alberto Magnelli, com obras de museus, colecionadores internacionais e obras do MAC USP. A exposição Arte Contemporânea Brasileira, ocorrida em 2011, no espaço do MAC USP, na Cidade Universitária (e já citada nesse estudo), também, é um exemplo dessa prática, uma vez que as obras são tomadas por empréstimos dos artistas (seus proprietários) e/ou das galerias que os representam.

Se as ausências em uma exposição podem ser facilmente resolvidas com o empréstimo de obras em curto espaço de tempo, as lacunas em um acervo consolidado podem ocasionar a emergência do estabelecimento de contratos de longa duração. Com o objetivo de preencher lacunas o MAC USP, no início dos anos de 1990, optou por fixar contratos com colecionadores e artistas. Esses contratos são os ditos comodatos. Tratam-se de empréstimos gratuitos de bens infungíveis, por tempo determinado. As obrigações são negociadas entre as partes - embalagem, coleta, transporte, entre outras ações. A origem da proposição do comodato dá o indicativo das obrigações (ASSOCIAÇÃo CULTURAL DOS AMIGOS DO MUSEU CASA DE PORTINARI, 2010, p. 103) ${ }^{17}$.

Assinala-se que um museu que carrega o nome de "contemporâneo", como é o caso do MAC USP, deve sempre estar atento aos movimentos mais recentes da arte. Sob esse ponto de vista, o comodato torna-se um instrumento válido para a renovação deste acervo. Porém, essa condição cria uma série de demandas e implicações diretas quanto às práticas de conservação, manutenção e

\footnotetext{
${ }^{17}$ Obrigações do comodatário nos contratos: 1) conservar e guardar o bem emprestado como se for a sua; 2) responsabilizar-se pelas despesas normais com o uso e gozo da o bem emprestado e seu direito ao seu reembolso; 3 ) limitar o uso do bem emprestado ao estipulado no contrato ou de acordo com a sua natureza; 4) constituído em mora, além de responder pelo em emprestado, pagará aluguel do bem durante o atraso na devolução. Do prazo: nada impede ao comodatário, renunciar ao uso e gozo do bem emprestado, antes do findo o prazo do contrato, evidentemente sem nenhuma multa, porque ele será sempre beneficiário devido à gratuidade. Já o comodante precisa respeitar o prazo previsto no contrato ou a finalidade para a qual contrato foi celebrado, salvo se houver necessidade urgente e imprevista, devidamente reconhecida pelo juiz.
} 
exibição do acervo, visto que, ao final do comodato o proprietário receberá sua obra/coleção devidamente conservada. E, muitas vezes, a devolução desse conjunto de obras desfalca o acervo da instituição, gerando uma lacuna que será sentida por seus especialistas, mas principalmente pelo público visitante da instituição. Diante dessa situação, a opção pelo estabelecimento de tal procedimento deve ser previamente analisada, sendo que os "benefícios" que a instituição terá no período deverão ser suficientes para poder acolher o impacto da saída das obras ao final do contrato. Uma estratégia a ser considerada é a de que o comodante assuma o compromisso de ao final do contrato, dispor - se não do todo - de algumas das obras selecionadas pela instituição em caráter permanente (doação).

No primeiro comodato, firmado em 1992, com o colecionador Marcantonio Vilaça, a instituição fez uma opção pelo regime como forma de suprir deficiências estéticas e históricas existentes na coleção com a condição de permanência por prazo determinado por 20 anos. A coleção Marcantonio Vilaça é integrada por cerca de 50 trabalhos datados entre os anos de 1980 e 1990, tendo a presença de artistas, tais como: Leda Catunda, Sérgio Romagnolo, Jorge Guinle, Ernesto Neto, Ângelo Venosa, Paulo Monteiro, Daniel Senise, Marco Gianotti, Valeska Soares, Jorge Duarte, entre outros. Esses artistas emergiram de importantes ações e movimentos artísticos, tais como: Pintura como Meio, mostra promovida pelo MAC USP, Como vai Você Geração 80?, exposição organizada no Parque Lage (Rio de Janeiro) e os Panoramas de Arte, realizados pelo MAM SP. O galerista Marcantonio Vilaça incentiva a produção dessa geração de artistas que, até o momento do comodato, não possuía representatividade no acervo MAC USP. A assinatura do comodato representa outra forma de atualização do acervo - diferentes das adotadas desde os anos de 1960 e 1970, quando uma das soluções encontradas pela direção do MAC USP era instituir premiações-aquisições, ocorridas durante as JACs, ou ainda, utilizar recursos da Reitoria para a aquisição de obras.

Nos anos de 1980 e 1990, as transformações das artes estão ligadas, sobretudo, a um contexto estético que aponta para o esgotamento das tendências 
modernas predominantes durante os anos de 1960 e 1970. Por volta de 1981, o curador alemão Christos Joachimedes assinala que: "os estúdios dos artistas estão novamente cheio de potes de tinta" (ARCHER, 2001, p. 15). Na mesma direção, o crítico italiano Achille Bonito Oliva cunha a expressão "Transvanguarda", proclamando o ressurgimento da pintura como meio de expressão na arte internacional. Achille chama a atenção para a desmaterialização da obra "e a impessoalidade da execução que caracterizou a arte dos anos 70". Segundo o crítico, as tendências inspiradas em Marcel Duchamp, foram superadas, resgatando a ação pictórica (IDEM, p. 20).

Essa retomada da pintura e, de certa forma, da figuração rompe com a concepção de linearidade embotada à história da arte - até aquele momento. Surge uma multiplicidade de atitudes e abordagens no fazer artístico (IDEM). A busca da inspiração pode abranger um variável repertório de citações e uma multiplicidade de linguagens e materiais para a criação estética. Além disso, a arte libertava-se das antigas denominações ou visões e empregava técnicas e termos que fossem mais adequados às novas posturas estéticas. A profissionalização dos artistas e do mercado de arte, também se acirra. Galerias, escritórios e feiras ganham importância semelhante a tradicionais instituições museológicas e bienais internacionais. A promoção da arte emerge no mercado de consumo, alinhada à indústria cultural. Os novos espaços para a arte contemporânea aproximam-se dos consumidores e mostram em suas obras as grandes questões de seu tempo.

Como marchand e colecionador, Marcantonio Vilaça busca o que há de mais novo no cenário artístico brasileiro. "Era reconhecido no mercado de arte como o garimpeiro de novos valores" (AJZENBERG, 2003, p. 18). Convive intensamente com artistas jovens, tais como, Jac Leirner, Frida Baranek, Ivens Machado, entre outros. Na proposta de todos os artistas selecionados apresentase, em comum, a reflexão sobre seu próprio tempo. Divulga a produção desses artistas internacionalmente. Ernesto Neto e Vick Muniz, por exemplo, ficam conhecidos no México, Estados Unidos e Austrália, graças aos esforços do galerista. A divulgação da arte brasileira no mercado internacional é ponto 
crucial na ação de Marcantonio Vilaça: "Estamos adquirindo tradição e temos no que nos basear para criar no futuro, diferentemente do que aconteceu no Modernismo, onde os artistas da época precisavam buscar modelos na Europa. Hoje já temos ótimas referências" (JORNAL DA EXPOSIÇÃO - FRIDA IVENS NUNO VENOSA, 1992).

Vilaça é atento às movimentações do mercado, evitando obras de fácil rotulação ou classificação. Seleciona obras dirigidas às tendências orgânicas, como as de Angelo Venosa, das quais emergem evidências de um ser vivo ou mesmo de uma "carcaça de corpo" (CANTON, 2009). Ou ainda, opta por obras carregadas de pura inteligibilidade, a exemplo das criações de Nuno Ramos, nas quais, tela, feltro, breu, madeira e algodão lutam e mostram a forma em contínua descoberta e decomposição.

De Frida Baranek, escolhe as obras em sua forma bruta. Ao passo que de Sandra Tucci seleciona a delicadeza de sua poética. Iole de Freitas se faz presente por um trabalho de elaboração escultórica, no qual telas de arame e costura em metal remetem ao universo feminino (IDEM). De Valeska Soares, o colecionador prefere a sensualidade da fonte em mármore embebida pela essência de rosas. Leda Catunda, em obras de também difícil classificação, na década de 1980, completa a leitura desse cotidiano feminino (IDEM). Em Meias - tela presente na Coleção Marcantonio Vilaça - as séries de meias soquetes sujas impõem forte ritmo à composição, extravasando a moldura da obra (IDEM).

De Edgar Racy, Vilaça seleciona uma peça que produz calor, a partir de uma resistência elétrica, envolvendo o espectador. Na peça dos irmãos Eduardo e Paulo Climachauska existe a potencialidade da circulação da energia elétrica através de para-raios (IDEM). No trabalho de Ernesto Neto presente no comodato Marcantonio Vilaça no MAC USP, o artista emprega materiais como meias de nylon e bolas de isopor e chumbo, tencionando o espaço e evidenciando os contrastes entre opostos. Gustavo Resende trouxe os "duplos", reverenciando formas arquetípicas através do chumbo e do ferro (IDEM). 
Obras inclassificáveis quanto ao seu fazer artístico e aplicação de linguagens - os chamados híbridos - são, ainda, a obra de Carlos Bevilacqua, Passarinho, que parece flutuar em sua base (IDEM). Ao passo que Hilton Berredo, em sua série Pindorama, não é objeto e tão pouco pintura: são pneus recortados e coloridos, trançados como cipós. Sérgio Romagnolo, em São Jorge, modela o apelo popular em plástico - produto da indústria (IDEM). Fábulas e mitos encontram lugar no trabalho de Carlito Contini que se aventura no domínio dos materiais. Jorge Duarte apresenta inusitados readymades sobre telas monocromáticas (IDEM). Sua Ratoeira Inútil provoca estranhamento e aguça a imaginação do espectador. Paolo experimenta os elementos de readymades em sua alegre pintura de cores vivas e intensas (IDEM).

As telas integrantes da Coleção Marcantonio Vilaça merecem destaque. São verdadeiras representações da Transvanguarda Internacional, enunciada no país pela Grande Tela da XVIII Bienal de São Paulo (1985), da qual participaram pinturas de Daniel Senise e Paulo Monteiro. Senise optou por cobrir toda a superfície com formas monumentais compactadas dentro dos limites da tela. Já Paulo Monteiro, um dos artistas que pertenceu ao grupo Casa 7 que surgiu no mercado na primeira metade dos anos de 1980 como um dos mais promissores dessa geração, teve a sensação de solidão do homem contemporâneo como tema. Cristina Canale, participante da já citada mostra Como Vai Você, Geração 80, está na Coleção Marcantonio Vilaça com a tela Rio $40^{\circ}$, repleta de técnica pictórica e tratando dos temas caros à poética da artista: o mundo ao seu redor, jardins, flores e cachoeiras. Jorge Guinle, reconhecido pintor de meados dos anos de 1980, tem em sua produção artística telas classificadas como neoexpressionistas devido aos gestos enérgicos e apaixonados registrados em cores fortes, impregnadas de referências à história da arte. Contudo, na Coleção Marcantonio Vilaça presente no Acervo MAC USP tem-se uma série de desenhos - o caderno afetivo de ilustrações de uma suposta Viagem de Lua de Mel. 
O marchand Marcantonio Vilaça falece aos 37 anos de idade ${ }^{18}$, sendo considerado como um dos grandes responsáveis pela profissionalização da arte brasileira no período entre 1980 e 1990 . De colecionador ocasional, transformase em comprador seletivo e experiente. Aos 24 anos, já coleciona Daniel Senise, peças de Leonilson, Leda Catunda e tantos outros. Ao longo de sua vida acumula cerca de duas mil obras de significativos artistas contemporâneos. Cria uma rede de conexões. Colecionador por 22 anos, Vilaça mantém a pluralidade da coleção e a sua contemporaneidade. Incentiva a produção da nova e novíssima geração de artistas.

Das 50 peças selecionadas por Marcantonio Vilaça e depois oferecidas em comodato ao Museu de Arte Contemporânea da Universidade de São Paulo, 12 são desenhos da série Viagem de Lua de Mel de Jorge Guinle (1981), as outras peças se dividem entre esculturas, relevos, pinturas e híbridos "pintura-objetostridimensionais". Todas as peças são datadas entre os anos de 1985 e 1991 e, exceto Iole de Freitas (1945) e Jorge Guinle (1947), todos os artistas são nascidos a partir de 1954 - o que torna o trabalho dessa geração ainda em franco desenvolvimento. Atualmente, todos esses artistas têm uma carreira internacional e expõem no exterior, nas inúmeras bienais organizadas nos diferentes continentes, em exposições de arte brasileira e individuais em museus e galerias. Muito desse reconhecimento nacional e internacional deve-se aos esforços do marchand Marcantonio Vilaça.

Quando em 1992, o colecionador Marcantonio Vilaça decide colocar suas obras em comodato no MAC USP, a ocasião é também oportuna para a instituição museológica: planeja-se inaugurar a nova sede na Cidade Universitária. Em 22 de outubro, daquele ano, a mostra A Sedução dos Volumes abre o novo espaço, apresentando em seu segmento Pós-Moderno: outra escultura 22 obras, das quais dez peças pertencem ao novo comodato. De lá para

\footnotetext{
${ }^{18}$ A morte de Marcantonio Vilaça, aos 37 anos, foi perda irreparável e inestimável para a cultura brasileira: "Marcantonio fez nos anos 90 o caminho aberto por Thomaz nos 80 . Marcantonio, temperamentalíssimo, fez muitas reconciliações na vida com artistas, colecionadores, diretores e colegas de profissão. Foi surpreendido antes de fazê-las todas", falecendo em $1^{\circ}$ de janeiro de 2000. Em 2001, a Editora Cosac \& Naif lança o livro Marcantonio Vilaça.
} 
cá, todas as exposições do acervo que incluam obras das décadas de 1980 e 1990 são integradas por peças do comodato.

Nesse contexto, o comodato "Marcantonio Vilaça" torna-se importante para a dinâmica das atividades geridas pelo MAC USP. Atualmente, as obras que compõem esse comodato são significativas para a expressão contemporânea do Museu. Recentemente, o comodato foi rediscutido e acordado sob novas bases junto aos familiares de Marcantonio Vilaça, falecido em 2000. Aconteceram duas exposições que marcaram o significado dessas obras para o acervo: a primeira Marcantonio Vilaça - Passaporte Contemporâneo, ocorrida em agosto de 2003, no espaço do MAC USP, na Cidade Universitária, e a segunda Experiências Contemporâneas: Comodato Marcantonio Vilaça, no Acervo MAC USP, no espaço Centro Cultural Marcantonio Vilaça, no Tribunal de Contas da União, em Brasília, realizada em 2009. As obras desse comodato representam a profissionalização e internacionalização da arte brasileira. Essas obras transportam esses valores ao acervo MAC USP.
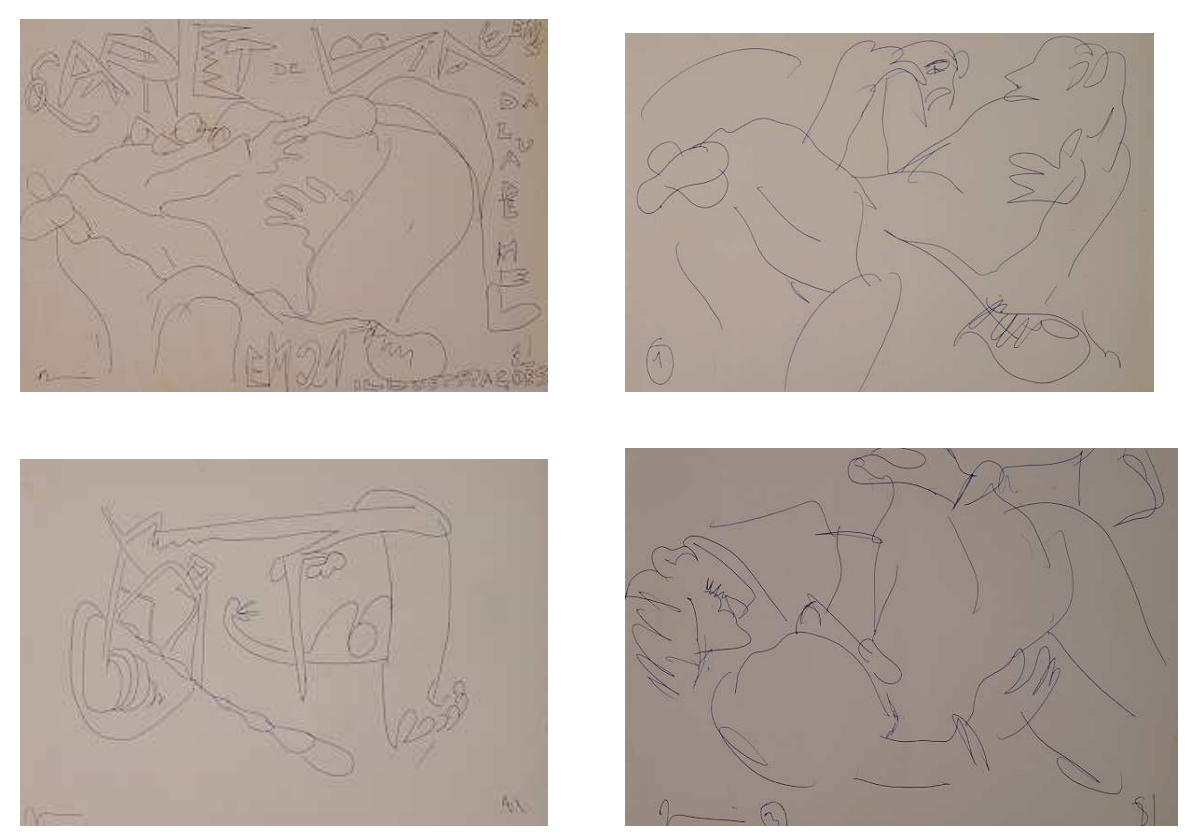

Figura 25. Jorge Guinle, Sem título (detalhe da série Viagem de Lua de Mel), 1981, caneta esferográfica s/ papel, 12 obras medindo 20,2 x 29,6 cm cada (Comodato Marcantonio Vilaça). Fotografia: Rômulo Fialdini. 


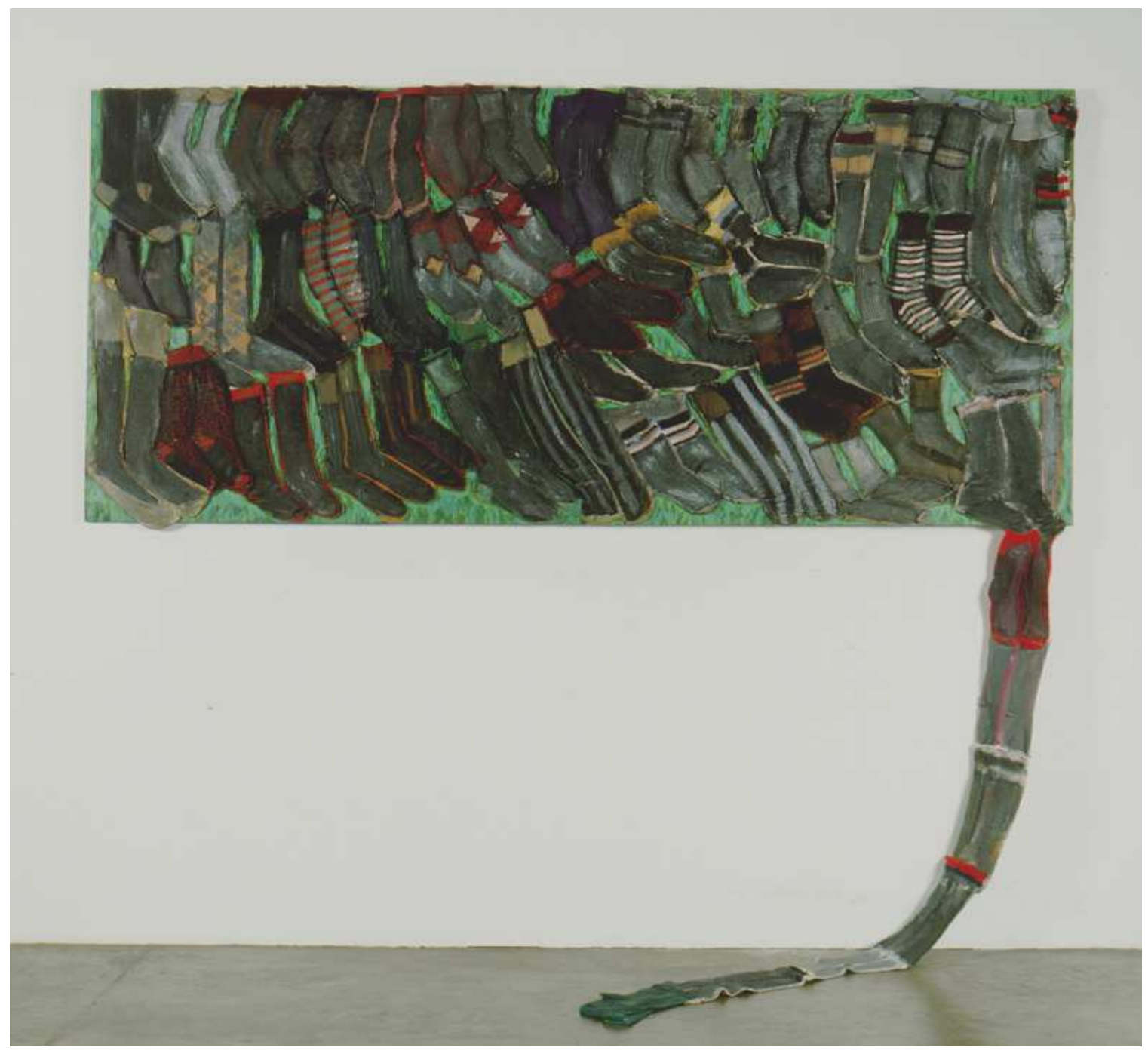

Figura 26. Leda Catunda, Meias, 1989, acrílica s/ meias s/ tela, 372 x 257 x 3 cm (Comodato Marcantonio Vilaça). Fotografia: Rômulo Fialdini. 


\section{Por Determinação Judicial}

Em novembro de 2005, o MAC USP tem sua coleção ampliada significativamente. Por determinação da 6 ${ }^{\mathrm{a}}$. Vara Federal Criminal de São Paulo, o MAC USP recebe a guarda e administração provisória de obras de arte provenientes de bens apreendidos pela Justiça Federal. Nesse processo, outras instituições públicas também receberam bens artísticos e históricos que integram a mesma coleção. Essa coleção, em seu estado original, é composta por mapas, cartas cartográficas, objetos arqueológicos, documentos históricos e obras de arte modernas e contemporâneas. Judicialmente, essa coleção foi entregue a instituições públicas adequadas a cada perfil museológico. Ao MAC USP cabem tarefas de coleta, inventário, conservação, restauração e guarda dos objetos artísticos modernos e contemporâneos.

Em condições processuais similares, em 2008, o MAC USP passa a abrigar duas novas coleções, que somadas à primeira, perfazem cerca de 2000 peças, em variados suportes e segmentos da arte moderna e contemporânea, de importantes artistas nacionais e internacionais, o que significa para o Museu um crescimento na ordem de $25 \%$ em seu acervo.

As telas, os tridimensionais e as obras em papel (desenhos, gravuras e aquarelas) depositadas para guarda provisória no Museu adequam-se e complementam a coleção, criando oportunidade para sua atualização, especialmente, no que diz respeito ao seu segmento contemporâneo. Obras de Damien Hirst, Frank Stella, Tunga entre outros integram este lote. 
Vale ressaltar que a obra de Frank Stella, The Founding (n\# 6), c. 2004, por suas dimensões, foi imediatamente exposta ao público, na sede do MAC USP, na Cidade Universitária, atraindo significativo número de visitantes ${ }^{19}$. Ressalta-se que a operação de acolhimento dessa obra envolveu uma logística inicial considerável, no que diz respeito ao processo de instalação da peça que necessitou da realização de reforço de estrutura do edifício para suportar o peso da obra e também trabalho minucioso de higienização que envolveu num período de 10 dias, o trabalho de 05 especialistas em dedicação exclusiva, além de contratação de outros serviços, tais como marcenaria e serralheria.

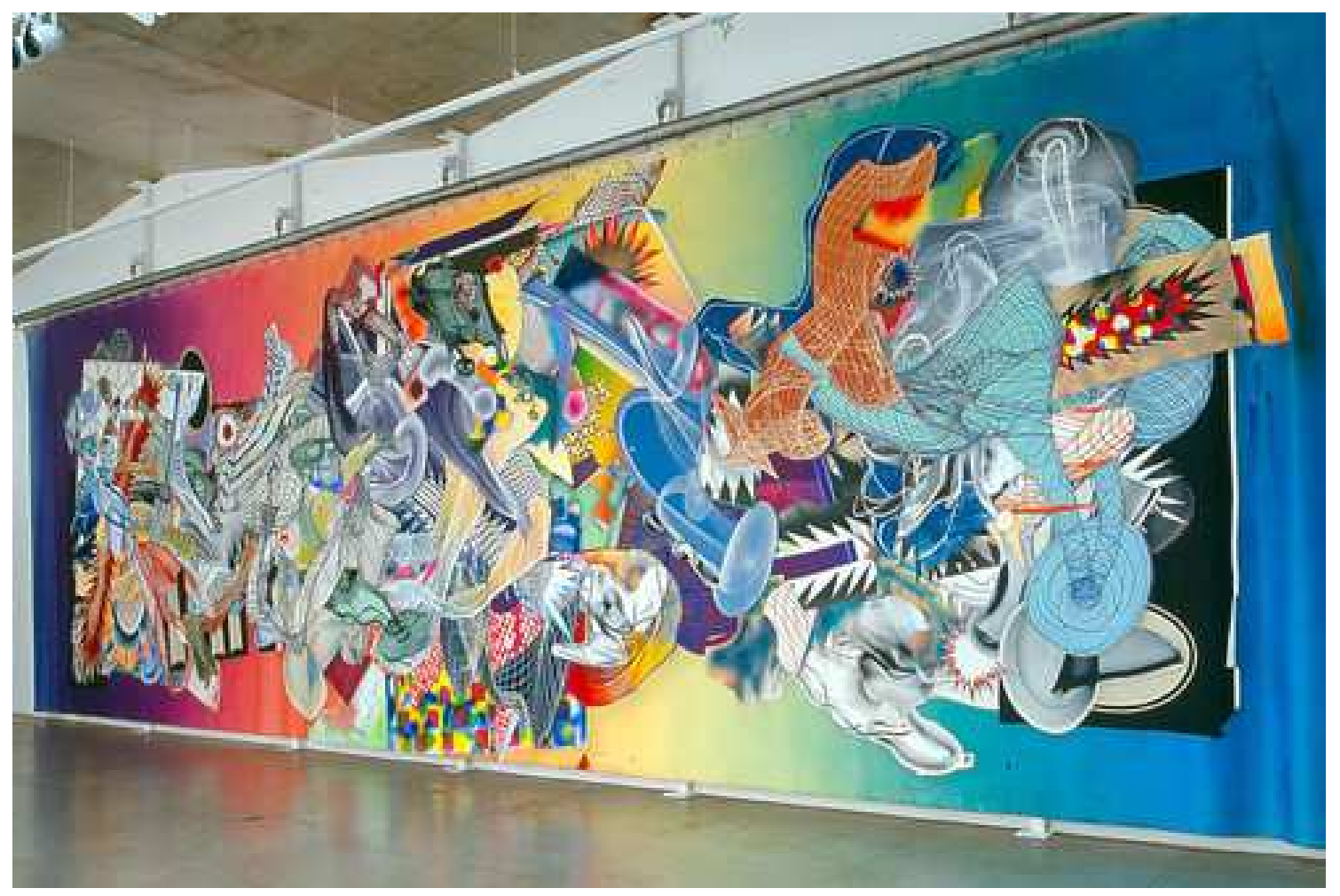

Figura 27. Frank Stella, The Founding (n\#6), 2004, acrílica e aerógrafo s/tela recortada, recortes de linóleo e resina plástica s/lona resinada, 1600 x $400 \mathrm{~cm}$. Acervo cedido pela Justiça Federal de São Paulo, nos termos dos autos no. 2005.61.81.900396-6 em trâmite na 6 . Vara Criminal Federal Especialista em Crimes contra o Sistema Financeiro Nacional em Lavagem de Valores. Atualmente, essa coleção está sob a responsabilidade a $2^{\mathrm{a}}$. Vara Falimentar do Estado de São Paulo, por decisão do Supremo Tribunal Federal. Fotografia: Rômulo Fialdini.

${ }^{19}$ Em 2004, Frank Stella participa, no Brasil, da exposição Frank Stella e Nuno Ramos: Afinidades e Diversidades, onde apresenta o painel The Founding (n\#6), com curadoria de Vanda Klabin. Nessa obra de grandes proporções que ocupa totalmente o campo visual do observador, Stella utiliza acrílica, aerógrafo, linóleo e resina plástica, gerando um campo expressivo para a descoberta da fatura da obra. 
Do conjunto de obras transferidas ao MAC USP destaca-se, ainda, a coleção de fotografias artísticas integrada por aproximadamente 1500 obras de grande valor cultural, que por sua abrangência e qualidade dá ao acervo do MAC USP, na área da fotografia, uma relevância que não encontra similar em outros museus nacionais ${ }^{20}$. Essas fotografias oferecem um panorama da história da fotografia do final do século XIX até o início deste século, contemplando fotógrafos modernos e contemporâneos, brasileiros e estrangeiros ${ }^{21}$.

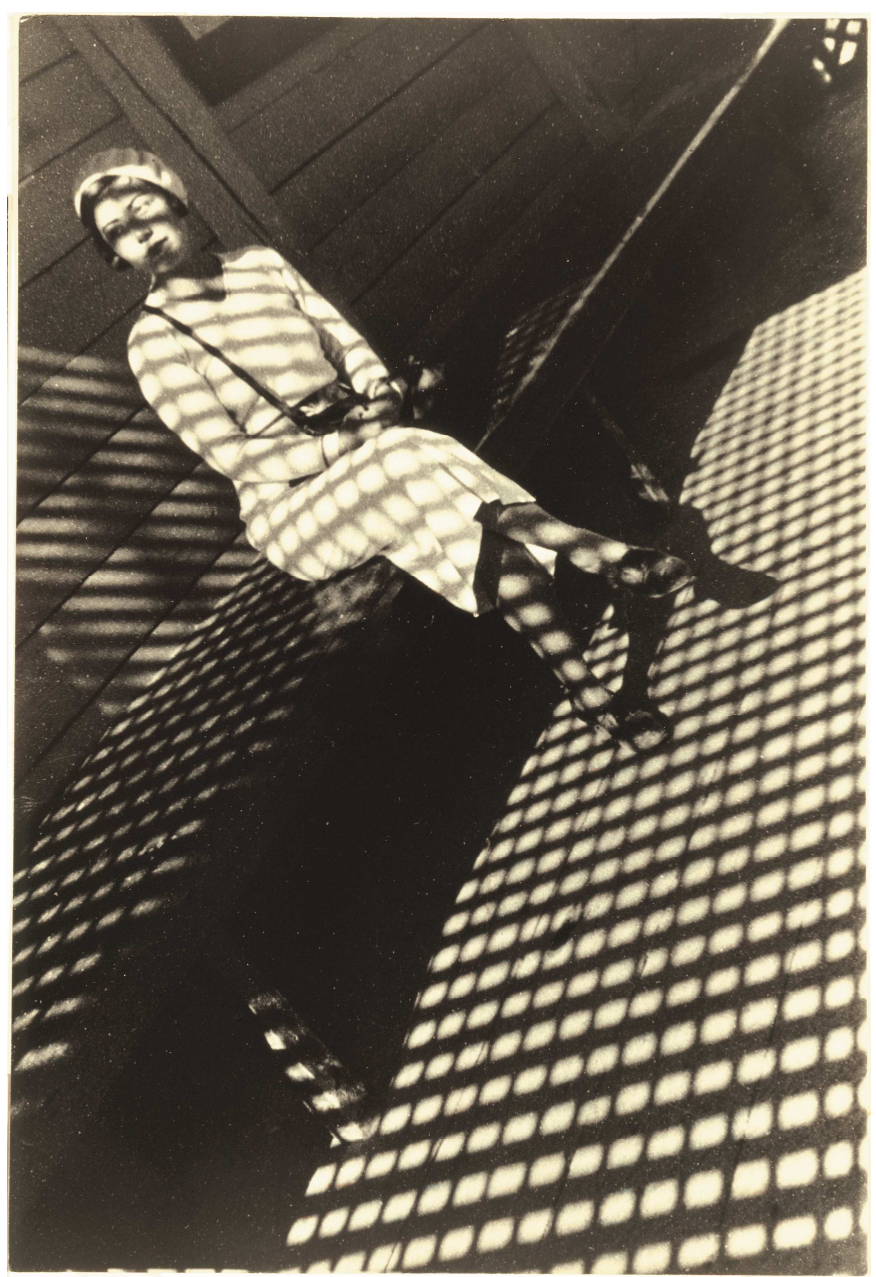

Figura 28. Aleksandr Rodtchenko, Moça com Leica, 1934, fotografia em gelatina e prata. Obra cedida ao MAC USP pela $6^{\text {a }}$ Vara Federal Criminal de São Paulo nos termos dos Autos $n^{\circ}$ 2005.61.81.900396-6.

20 Entre os fotógrafos de grande expressão, presentes nesta coleção, citando-se uns poucos nomes estão Henri Cartier-Bresson, Man Ray, Brassaï, Rodtchenko, Cindy Sherman, Thomas Ruff, Trace Moffart, Chris Bierrenbach, Cassio Vasconcelos, Rafael Assef, Athos Bulcão; Dora Maar; Edward Steichen; Étienne-Jules Marey; Eugene Smith; Geraldo de Barros; German Lorca; Hildegard Rosenthal; Horst Paul Horst; Imogen Cunningham; Jean Lecocq; Jean Manzon; Jacques Henri-Lartigue; Manuel Alvarez Bravo; Pierre Verger; Robert Doisneau; Robert Frank; Thomas Bouchard e Thomaz Farkas. Entrevista Helouise Costa em Notas: Calendário de Cultura e Extensão - junho/2006, in: www.usp.br/prc/calendário. Acesso em: 19 de novembro de 2009.

${ }^{21}$ Idem. 
A relevância da coleção recebida pelo Museu centra-se, sobretudo, nas possibilidades de desenvolvimento de pesquisas, da melhoria do ensino e da qualidade no atendimento da sociedade, que um museu universitário, como o MAC USP, é capaz de gerar. Estas obras, abrigadas pelo Museu, propiciaram a realização de exposiçõos de destaque, com repercussão no país e no exterior, como por exemplo, as mostras Poéticas da Natureza (2007), Arte e Antropologia (2008), Fotógrafos da Vida Moderna (2008) e Fotógrafos da Cena Contemporânea (2011) recebendo convites para itinerância em outros importantes museus brasileiros. Somem-se às estas, as exposições Aquisições Recentes (2007), Coleções sob Guarda Provisória (2010) e Coleção, Arte e Ciência (2011) apresentadas no MAC USP Ibirapuera e no Centro Maria Antônia. As ações que envolveram a realização dessas mostras serão alvo de detalhamento na próxima parte do presente estudo, contudo, os seus resultados reiteram a necessidade da incorporação definitiva de um acervo desta dimensão no MAC USP.

O desenvolvimento de programas de exposições dessas novas coleções vem estimulando a visitação de um público cada vez mais diversificado. Contempla o atendimento da demanda pelo acesso às coleções, legitimando a iniciativa da Justiça Federal em destinar coleções deste porte a museus públicos. As guardas temporárias de coleções particulares, por determinação judicial, é uma prática incomum - que teve sua primeira ação no MAC USP, em 2005, abrindo precedentes para novas determinações. Os caminhos e os desenlaces dessas ações ainda estão abertos: as obras ainda aguardam definição judicial. Hoje, o destino dessa coleção está sob a responsabilidade a 2a. Vara Falimentar do Estado de São Paulo, por decisão do Supremo Tribunal Justiça.

Contudo, a transferência desse patrimônio artístico-cultural da esfera particular para a pública é uma grande contribuição para a valorização dos museus, que devem propiciar interfaces de conhecimentos e subsidiar a ação educativa. Porém, como quantificar o trabalho empregado para a conservação e manutenção dessas obras? A exibição desses trabalhos ao público em geral pode ser a grande contribuição dessas instituições museológicas que guardam 
temporariamente essas coleções? Não há dúvida que o acervo do MAC USP está vocacionado para se tornar, cada vez mais, espaço criativo e interdisciplinar, aberto aos intercâmbios e experiências cidadãs, porém, a instituição deve continuar a receber essas obras sem a garantia de sua permanência?

A guarda provisória de coleções particulares em museus públicos apresenta-se como um grande desafio. A tentativa de preservar, manter e exibir essas coleções são ações desenvolvidas pela equipe técnica e de especialistas do MAC USP no desempenho das funções básicas de um museu - sujeito às normas nacionais e internacionais - este se constitui como um museu universitário ou, ainda, como um patrimônio público. Remete-se às noções de conservação, normas museológicas e patrimoniais discutidas nos capítulo anterior. No caso desse museu universitário, o acervo torna-se instrumental para o diálogo social e essas coleções temporárias o integram e o atualizam. O acervo com essas contribuições gera, de um lado, aprofundamento e novos conhecimentos sobre o fazer artístico e, de outro lado, aumenta sua responsabilidade social como agente transformador da realidade.

A partir da perspectiva jurídica, em 2005, por determinação da $6^{\mathrm{a}}$. Vara Federal Criminal de São Paulo, o Museu torna-se guardião e administrador provisório de cerca de 2000 peças de bens apreendidos, sequestrados ou arrestados pela Justiça Federal (aqui, deve-se assinalar que o MAC USP responsabiliza-se pelas obras modernas e contemporâneas dessa coleção). Em 2009, O Superior Tribunal de Justiça - STJ - suspende o sequestro de bens dessa coleção e determina que esses bens fiquem sob a guarda da $2^{\mathrm{a}}$ Vara de Falências e Recuperações Judiciais de São Paulo, através de formalização de Termo de Compromisso de fiel depositório. Esse juízo determina que a coleção permaneça no Museu até a decisão final do destino da coleção. Em 2008, situação semelhante torna possível a transferência de mais duas coleções apreendidas durante investigação promovida pela $6^{\mathbf{a}}$. Vara Federal Criminal de São Paulo criminal. A cessão de obras por determinação judicial é mecanismo pouco usual 
na história dos museus brasileiros (MACIEL \& BANDEIRA, 2010) ${ }^{22}$. Mais recentemente, em 2010, o MAC USP acolheu, a pedido do IPHAN, obra de Gerard Richter que foi apreendida pela Polícia Federal no aeroporto de Campinas e colocada sob a guarda daquela Instituição. No momento, o Museu aguarda a manifestação do IPHAN para formalizar a guarda temporária ou transferência definitiva ao Museu.

Fausto Martin de Sanctis - juiz titular da $6^{\mathbf{a}}$. Vara Federal Criminal de São Paulo, à época - no livro Crime Organizado e Lavagem de Dinheiro, discute as razões que o levaram a destinar obras de arte a museus e instituições artísticoculturais em São Paulo. $O$ autor argumenta que na guarda provisória e na administração de bens ocorreria grandes dificuldades de conservação de bens apreendidos, sequestrados ou arrestados pela Justiça criminal, frente à inexistência de condições do Estado em não dispor de local adequado e previsão de recursos para essas ações. Assim sendo, os juízes teriam somente duas soluções: o uso (guarda provisória o depósito legal) e/ou a venda antecipada. Segundo, o entendimento defendido pelo juiz da $6^{\mathrm{a}}$. Vara Federal Criminal de São Paulo "tem sido o de que uma obra de arte não deve pertencer a nenhuma pessoa, nem mesmo a um determinado local, já que cuida de bem da humanidade" (SANCTIS, 2009, p. 93).

Sob essa perspectiva, Fausto de Sanctis, em auto de sentença, explicita: “triste um país em que os poderes públicos não veem na CULTURA fonte de conhecimento e informação relevante: ALIMENTAÇÃO INTELECTUAL, não menos importante". O juiz evoca a Convenção sobre a Proteção do Patrimônio Mundial, Cultural e Natural, aprovada pela Conferência Geral da Organização das Nações Unidas para a Educação, a Ciência e a Cultura (UNESCO) em 16.11.1972, aprovada no Brasil pelo Decreto Legislativo n. 74, de 30.06.1977, e promulgada pelo Decreto n. 80.978, de 12.12.1877, consigna em seu artigo $1^{\circ}$. que tanto as obras do homem quanto os lugares notáveis são considerados

\footnotetext{
${ }^{22}$ Outros museus receberam a administração e a guarda de obras apreendidas pela Justiça Federal. Na década de 1980, tem-se o caso do Museu Nacional de Belas Artes (MNBA) que recebeu obras de um banco que abriu falência, contudo, não obteve de juiz a permissão para exibir essas obras ao público.
} 
patrimônios culturais, protegidos, portanto, pela Convenção (IDEM). Soma-se à base jurídica, o artigo 23, incisos III e IV, da Constituição Federal que prevê a responsabilidade dos Poderes da República pela proteção de bens de valor histórico, artístico e cultural, cabendo-lhes impedir qualquer descaracterização (IDEM, p. 93).

Cabe à figura do juiz, então, determinar e acautelar-se nas escolhas das entidades que receberão os bens apreendidos, sequestrados ou arrestados pela Justiça criminal. No caso específico, abordado pela presente investigação, Fausto de Sanctis destinou os bens culturais para o Centro Cultural da Marinha de São Paulo, a Secretaria do Estado da Cultura de São Paulo, a Fundação Memorial da América Latina, o Museu de Arte Sacra, além dos museus e instituições culturais que pertencem à Universidade São Paulo (Museu de Arqueologia e Etnologia MAE, Museu Paulista - MP, Museu de Arte Contemporânea - MAC e Instituto de Estudos Brasileiros - IEB). A razão para a escolha dessas entidades sustentase no entendimento à legislação de regência em face das disposições do artigo 24 do Decreto-Lei n. 25, de 30.11.1937, que regem que "todo o acervo existente em poder da Justiça foi confiado, a título provisório, àquelas instituições públicas, sempre objetivando garantir a unicidade das obras e o propósito do acervo de cada entidade" (IDEM, p. 203).

A questão que envolve a transferência, por determinação judicial, de obras de coleções privadas para coleções públicas é o eixo central desse estudo e toda a reflexão que se desenvolveu até aqui serviu para instrumentalizar essa problemática: os museus a despeito de todo o seu esforço para a criação de novos parâmetros de conduta e de relacionamento com suas comunidades ainda são vistos como "casa de custódia" de obras? Em outras palavras, vale à pena a essas instituições terem obras privadas em seus acervos, sabendo que elas podem ser reintegradas aos seus proprietários a qualquer momento? Guarda-se alguma semelhança ao processo inicial que constitui os primeiros museus de arte, ou seja, bens privados se tornariam públicos?

Todas essas indagações servem como motivação para o presente estudo. A decisão da $6^{\text {a }}$. Vara Criminal, em 2005, abriu os precedentes para se pensar 
como os museus portam-se diante das tradicionais e novas possibilidades de ampliação de seu acervo. Distinta dos empréstimos e dos comodatos, a guarda provisória por determinação judicial, não tem o prazo determinado para o encerramento da ação. Se nos comodatos, o fator tempo pode auxiliar na avaliação sobre os benefícios ou não de se manter determinada obra de arte junto ao acervo, na guarda provisória por determinação judicial isso não ocorre. Tão complexa como as demais formas de acolhimento de obras, a ampliação por determinação judicial, guarda especificidades que devem ser consideradas e estendidas para as condições gerais existentes na atualidade para a instituição museológica. 


\section{Destino: Museus Públicos}

No período entre 2005 e 2008, Dr. Fausto de Sanctis ${ }^{1}$, juiz titular da $6^{\mathrm{a}}$. Vara Criminal Federal Especialista em Crimes contra o Sistema Financeiro Nacional em Lavagem de Valores, responsável pelo envio das três coleções privadas ao MAC USP, atesta que existem grandes problemas na ação de conservação de bens apreendidos, sequestrados ou arrestados pela Justiça Criminal. Hoje, os depósitos da Justiça Federal, em São Paulo, guardam cerca de 10 mil obras de arte apreendidas pela Instituição, em operações policiais e decretos de falências de bancos (MACIEL \& BANDEIRA, op. cit.). Em grande parte as dificuldades se relacionam com os custos elevados que envolvem a administração e a conservação dos bens de terceiros. Essa condição impele aos magistrados medidas que possam evitar o depósito judicial, que muitas vezes coloca bens sob a custódia do Estado (sem utilização do bem e acelerando sua deterioração e/ou depreciação), visto o longo tempo que toma os trâmites intrínsecos aos processos judiciais (SANCTIS, op. cit., p. 73).

\footnotetext{
${ }^{1}$ Dr. Fausto de Sanctis hoje é Desembargador Federal do Tribunal Regional Federal da $3^{\mathrm{a}}$ Região (TRF3 - com sede na Capital do Estado de São Paulo e jurisdição sobre as Seções Judiciárias de São Paulo e Mato Grosso do Sul).
} 
Na visão de De Sanctis, duas alternativas são cabíveis para que haja a continuidade das apreensões, sequestros e arrestos nos casos de crimes contra o Sistema Financeiro e Lavagem de Valores e possa ser evitada a possibilidade de depósito judicial: o uso (guarda provisória judicial) ou a venda antecipada. Nesse ponto, deve se esclarecer que as apreensões, os sequestros e os arrestos de bens são ações restritivas e judiciais que tentam coibir os mecanismos ilícios que nutrem o crime organizado e a lavagem de dinheiro no Brasil. A lavagem de dinheiro e a criminalidade organizada permitem o enriquecimento ilícito de seus agentes. A questão do acúmulo de bens de supostos criminosos impõe uma resposta estatal imediata, uma vez que é através dos recursos financeiros que os agentes desenvolvem suas atividades ilícitas.

As obras de arte (como bens de consumo e de valoração), muitas vezes estão imersas nesse contexto de ilegalidade e são apreendidas até que o processo judicial chegue ao seu veredicto final. Por se constituírem como bens patrimoniais valiosos, a venda antecipada, apesar dos apelos dos credores (no caso de massa falida), não é medida usual para as obras de arte, restando como alternativa a guarda provisória. Cabe observar que a Lei de Drogas (Lei n. 11.343, de 23.08.2006, artigo $6^{\circ}$. $\S 1^{\circ}$. E $2^{\circ}$.), garante a restituição de bens somente se sua origem lícita for comprovada, seguindo a orientação das Convenções da ONU de Viena (Tráfico de Drogas, 1988, artigo 5º item 7), Palermo (Crime Organizado Transnacional, 2000, artigo 12, item 7), de Mérida (Corrupção, 2003, artigo 30, item 8), Convenção de Varsóvia do Conselho da Europa sobre Lavagem de Dinheiro (2005, artigo $3^{\circ}$, itens 1 e 2) e da Recomendação do Grupo de Ação Financeira Internacional sobre Lavagem de Dinheiro e Financeira ao Terrorismo (GAFI/FATF), no. 3.

A Lei de Lavagem de Dinheiro (Lei n. 9.613, de 03.03.1998, artigo $4^{\circ}$. $\S$ $2^{\circ}$.), atribui à autoridade judicial a determinação de nomear um administrador para os bens sob judice. Esse administrador, por razões evidentes, não pode ser familiar ou pessoa ligada diretamente aos supostos criminosos. Também não seria eticamente aceito ser um parente (até $3^{\circ}$. grau) do magistrado ou qualquer funcionário do poder judiciário (artigo 10 da Resolução do Conselho de Justiça 
Federal n. 435, de 29.04.2005). Desse modo, a escolha da figura desse administrador é algo bastante complexo, quando se trata de bens patrimoniais, como as obras de arte. Mesmo sendo guarda temporária, o responsável pela administração desses bens necessita atender requisitos ainda mais específicos, uma vez que deve garantir a integridade e a disponibilidade desses bens para o público em geral.

Amparado nas leis federais, estaduais e municipais, Fausto de Sanctis indica que o Estado poderia cumprir essa tarefa de administrador das obras de arte apreendidas, sequestradas e arrestadas. Segundo o magistrado, a Constituição Federal (promulgada em 05 de outubro de 1988), em seu artigo 23, incisos III e IV, dispõe ser de responsabilidade dos Podres Públicos (União, Estados, Distrito Federal e Munícipios) a proteção de “documentos, obras e outros bens de valor histórico, artístico e cultural (...)", bem ainda "impedir a evasão, a destruição e a descaracterização de obras de arte e de outros bens de valor histórico artístico e cultural". Além da evocação à Constituição, o juiz também cita os artigos 215 e 216, constantes da Seção II (Da Cultura), do Capítulo II (Da Educação, Da Cultura e do Desporto), do título VIII (Da Ordem Social):

\footnotetext{
"Art. 215. O Estado garantirá a todos o pleno exercício dos direitos culturais e acesso às fontes da cultura nacional, e apoiará e incentivará a valorização e a difusão das manifestações culturais".

"Art. 216. (...) $§ 3^{\circ}$. A lei estabelecerá incentivos para a produção e o conhecimento de bens e valores culturais."
}

A Constituição do Estado de São Paulo, no artigo 237, inserido na Seção I (Da Educação) do Capítulo III (Da Educação, da Cultura e dos Esportes e Lazer) dispõe ainda sobre as obrigações do Estado frente à acessibilidade à Educação e à Cultura. Fausto de Sanctis ainda referencia outros artigos, tais como o 259, o 260, o 262 e o 263 que tratam das questões educacionais, do incentivo às manifestações culturais e do fomento à cultura que deve ser uma ação efetiva do Estado. Some-se ainda a Lei Federal n. 8.313, de 23.12.1991 (Lei Rouanet), Lei Estadual de São Paulo, n. 8.819, de 10.10.1994 e as Leis 
Municipais de São Paulo ns. 10.923, de 30.12.1990, e 13.672, de 1.12.2003, que se tornam subsídios para a tomada de decisão que coloca a guarda das coleções privadas apreendidas e destinadas para órgãos estatais.

Para o magistrado, a proteção desses bens culturais deve ser de responsabilidade do Estado. Reforça sua opinião a partir da Convenção sobre a Proteção do Patrimônio Mundial, Cultural e Natural, aprovada pela Conferência Geral da Organização das Nações Unidas para a Educação, a Ciência e a Cultura - UNESCO, em 16.11.1972 e aprovada no Brasil pelo Decreto Legislativo n. 74, de 30.06.1977.

Calcado sobre essas leis, decretos e dispositivos jurídicos, Fausto de Sanctis - em exercício na $6^{\mathbf{a}}$. Vara Criminal - destina bens apreendidos, sequestrados e arrestados. Segundo suas palavras: “(...) não se pode dar tratamento idêntico a outros bens apreendidos, sequestrados ou arrestados pela Justiça, uma vez que o objeto de persecução penal seja uma obra de arte" (IDEM, p. 95). Vale mencionar, ainda, que a decisão de atribuir ao Estado a guarda provisória das obras apreendidas retira do judiciário a responsabilidade do depósito, administração e salvaguarda dessas coleções. Note-se que o judiciário assumidamente não dispõe de recursos financeiros e/ou humanos para o tratamento e conservação desses bens culturais. Para De Sanctis, o Estado representado pelos museus e órgãos artístico-culturais pode executar essas tarefas. Convém, aqui, perguntar se não seria somente uma transferência de responsabilidade e de despesas? Crê-se que ainda não é possível tal afirmação, sem levar em consideração uma série de fatores.

A partir desse ponto, torna-se relevante considerar quais foram os critérios de seleção e como transcorreu essa transferência de guarda provisória. Observe-se que Organizações Não-Governamentais (ONGs) e Organizações da Sociedade Civil de Interesse Público (OSCIPs) também poderiam ser selecionadas como instituições aptas a receberem a guarda provisória. No entanto, para o magistrado, instituições privadas ou pouco reconhecidas teriam chances reduzidas na recepção adequada de obras de arte sob essas condições. 
O processo que direcionou as coleções apreendidas para o MAC USP, teve como critério de escolha a ligação direta com a USP, instituição de ensino superior e órgão público, reconhecida pelo nível de excelência no compromisso que fixa pesquisa, ensino, cultura e extensão universitária. Entre essas instituições ligadas a USP, estão: o IEB, o MP, o MAC e o MAE. Externas à USP citam-se: o Museu de Arte Sacra, a Fundação Memorial da América Latina, o Centro Cultural da Marinha em São Paulo e, por fim, Acervo Artístico-Cultural dos Palácios do Governo do Estado de São Paulo.

De Sanctis afirma que seguindo o princípio de divulgação e disseminação da cultura, as obras de arte não deveriam ficar guardadas nas reservas técnicas dessas instituições. Elas deveriam ser expostas ao público e submetidas à pesquisa o caminho natural então, orienta-se aos museus públicos vinculados à Universidade. No ato de transferência das obras, a $6^{\mathrm{a}}$. Vara Criminal exigiu documento firmado pelo responsável da instituição museológica, no qual há o compromisso de zelo e exposição pública em período de tempo razoável (IDEM, p. 202).

Outro detalhe relevante: se deu por afinidade de acervo. "Não tem sentido entregar obra que não guarde relação com o acervo e/ou propósito do museu ou entidade cultural" (IDEM). Nota-se que a preocupação de adequar e complementar o acervo já existente surge como fator preponderante na decisão jurídica. A legislação de regência em face das disposições do artigo 24 do Decreto n. 25, de 30.11.1937, é atendida na medida em que todas as coleções foram destinadas a instituições públicas, mantendo a unicidade das obras e o propósito de cada acervo. Os museus e instituições localizam-se no "distrito culpa", evitando a dispersão, o descontrole e a elevação dos custos de remoção e seguro (IDEM).

A cautela do magistrado no ato de transferência da guarda provisória das obras de arte, dando prioridade aos museus vinculados ao Estado e, dentre eles, pertencentes a USP, é perfeitamente compreensível, posto que a intenção do ato consiste em zelo e disposição dessas coleções ao público. Destaca-se, nesse 
ponto, a tipologia dos museus universitários que como funções definidas pelo ICOM, devem: abrigar/formar coleções para o desenvolvimento de pesquisa, ensino e extensão; dar ênfase ao desenvolvimento de pesquisa a partir do acervo; manter disciplinas que valorizem as coleções e as pesquisas sobre as coleções; propor programas de extensão universitária e programas dirigidos a diferentes públicos.

Além dessas atribuições, acrescente-se que o museu universitário, imerso no meio acadêmico, deve usufruir dos benefícios dessa condição. Isto porque a Universidade como produtora de conhecimento pode proporcionar experiências inovadoras e fontes de recursos de diversas naturezas para as atividades dos museus universitários. Porém, em meio às vantagens, há, também, as desvantagens no exercício dos museus universitários (ALMEIDA, 2001, p. 79) ${ }^{2}$. Se por um lado, a principal característica do museu universitário é estar sob a responsabilidade de uma universidade, garantindo condições mínimas de salvaguarda do acervo, de recursos humanos e de espaço físico, por outro lado, no caso dos museus de arte, os altos valores do mercado de obras de arte, agregados à difícil definição de políticas de aquisição, criam problemas para a formação e a ampliação das coleções.

Diferentemente das coleções atreladas às ciências naturais ou à arqueologia, por exemplo, a coleção de arte (aqui se pensa diretamente na formação da coleção do MAC USP) não se compõe no âmbito das pesquisas universitárias (salvo raras exceções, quando docentes e alunos produzem obras decorrente de seus estudos acadêmicos), ou seja, não é o resultado decorrente do exercício de campo da pesquisa. Como se viu nas duas primeiras partes desta pesquisa, a coleção de arte presente no museu universitário se formou por doações (colecionadores e artistas), aquisições e outros modos de incorporação

\footnotetext{
${ }^{2}$ Ulpiano Bezerra de Meneses resumiu as vantagens do museu universitário: acesso direto às coleções para pesquisa; colaboração entre especialistas de museu e universidade; museu como laboratório para a formação específica e pedagógica; e formação museológica. Mas o autor alertou para o fato de que, apesar das vantagens acima descritas, os museus universitários sofrem de deformações, entre as quais a transformação do museu num instituto de pesquisas ou em recurso para formação universitária e a negligência na curadoria das coleções, principalmente quando os responsáveis trabalham em tempo parcial.
} 
que não dependem, necessariamente, da pesquisa universitária (IDEM, p. 217) ${ }^{3}$. O objeto de arte sempre estará dentro da lógica do mercado de arte - algo que a Universidade deve manter equilibrado, pois da mesma forma que procura se eximir de atuação no mercado, participa dele, particularmente quando acolhe obras de artistas, legitimando sua produção e, consequentemente, aumentando seu valor de mercado.

Ao longo do percurso que liga Universidade e grandes coleções de arte, verifica-se que há, ao menos, três grandes dificuldades nos itens que seriam garantidos pela presença da academia: característica/perfil das coleções que não se adequam à pesquisa, ao ensino e à extensão; ausência de pessoal qualificado para garantir a salvaguarda das coleções e, ausência ou limitação de espaço físico adequado para abrigar as coleções (IDEM, p. 17).

Quanto aos problemas relacionados à natureza das coleções deve-se ponderar que nem sempre essa se presta à tríade acadêmica (pesquisa/ensino/extensão) simultaneamente. Dessa forma, os museus universitários, especializados em arte, adquirem critérios mais rígidos na escolha das coleções que constituíram seu acervo, uma vez que elas devem atender aos preceitos universitários. Acrescente-se, ainda, que apesar do equilíbrio da tríade ser uma bandeira universitária, a ênfase na pesquisa em detrimento às atividades de extensão, fica evidente na valorização da carreira dos docentes/curadores - o que acaba por prejudicar a extensão nos museus universitários.

No que tange à formação de mão-de-obra qualificada, assinala-se que os servidores do museu integram os quadros da universidade com os mesmos direitos e obrigações de outros funcionários. Assim sendo, algumas atividades são especializadas e técnicas, dirigidas à prática museológica, porém, os setores básicos não dispõem dessa especialização, passando somente por treinamento específico para a rotina de museus. Ressalva-se que o MAC USP é reconhecido nacionalmente como formador de trabalhadores especializados (muitos dos

\footnotetext{
${ }^{3}$ No caso dos museus universitários de arte, eles vieram de fora das universidades, muitas vezes "prontos"- lotes de heranças, doações de coleções já formadas - sem qualquer relação com o ensino de arte na universidade.
} 
profissionais atuantes no mercado de artes, galerias e outras instituições museológicas nacionais saíram do quadro de funcionários do MAC USP). No nível dos docentes, deve-se alertar para a tripla exigência (ser excelente professor/pesquisador/curador) - na carreira universitária, retorna-se à questão da valorização da pesquisa, na qual o artigo científico tem mais relevância do que a mediação proporcionada pela realização de uma exposição (igualmente fruto de pesquisa).

Com relação ao espaço físico dos museus universitários, tomando como exemplo, o MAC USP, convém fazer uma pequena retrospectiva para a compreensão de suas limitações. Evoca-se, então o processo de transição dos edifícios que abrigam os museus, que passa dos templos e palácios para as fábricas, galpões e prédios com arquitetura arrojada. Já o MAC USP teve sua sede por muitos anos restrita ao terceiro andar do Pavilhão Ciccillo Matarazzo, no Parque Ibirapuera (conhecido como Prédio da Bienal). Esse prédio é constantemente tomado por realização de grandes exposições e eventos relacionados à Fundação Bienal, dificultando a programação sistemática de atividades públicas do MAC USP. Esse local, projetado por Oscar Niemeyer não é, originalmente, adequado para abrigar um museu, particularmente pela excessiva entrada de luz pelas fachadas de vidro. O MAC USP, instalado no

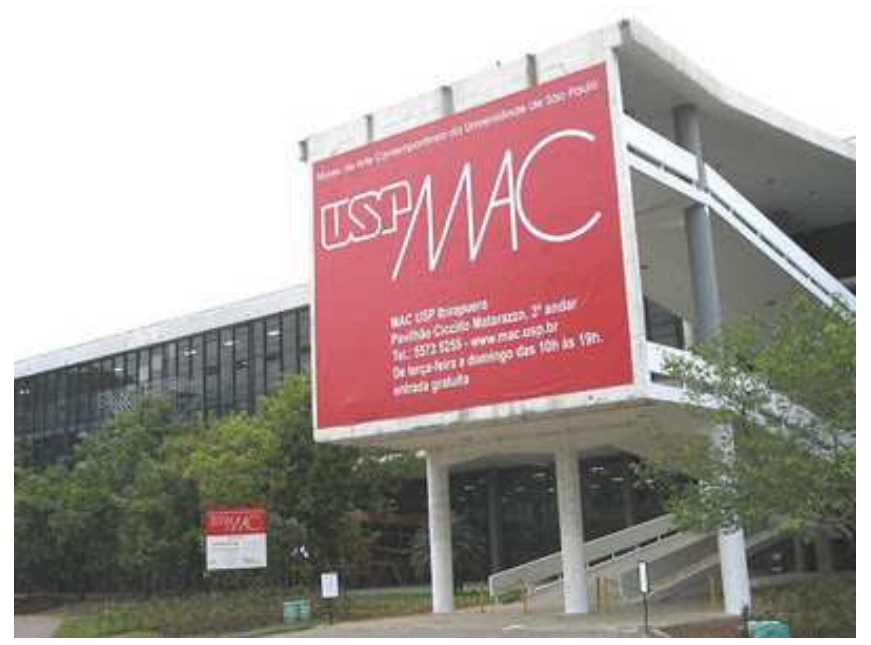
terceiro andar, realizou diversas adaptações e reformas com a finalidade de melhorar as condições de exposições e salvaguarda das obras, além de criar salas de trabalho. A área é de cerca de $5.500 \mathrm{~m} 2$, com pé direito de 4,95m, sendo o acesso pela rampa externa.

Figura 29. Fachada atual do MAC USP, Pavilhão Ciccillo Matarazzo, $3^{\circ}$. andar, Parque Ibirapuera. Fonte: Arquivo MAC USP 
Na década de 1980, a Reitoria cedeu o espaço que funcionava seu protocolo para instalar a sede provisória do MAC USP no campus da Cidade Universitária (conhecido como Maquinho ou MAC Anexo). O prédio era um pavilhão térreo com $900 \mathrm{~m} 2$ que foi adaptado (com construção de copa, secretaria, sanitários e um depósito interno), além de sofrer modificações na fachada para o controle de entrada de luz. Ao longo do tempo, o Maquinho vem sendo requisitado para atividades da Reitoria da USP, hoje, divide espaço com a Pró-Reitoria de Graduação e com a loja da Editora da Universidade de São Paulo (EDUSP).

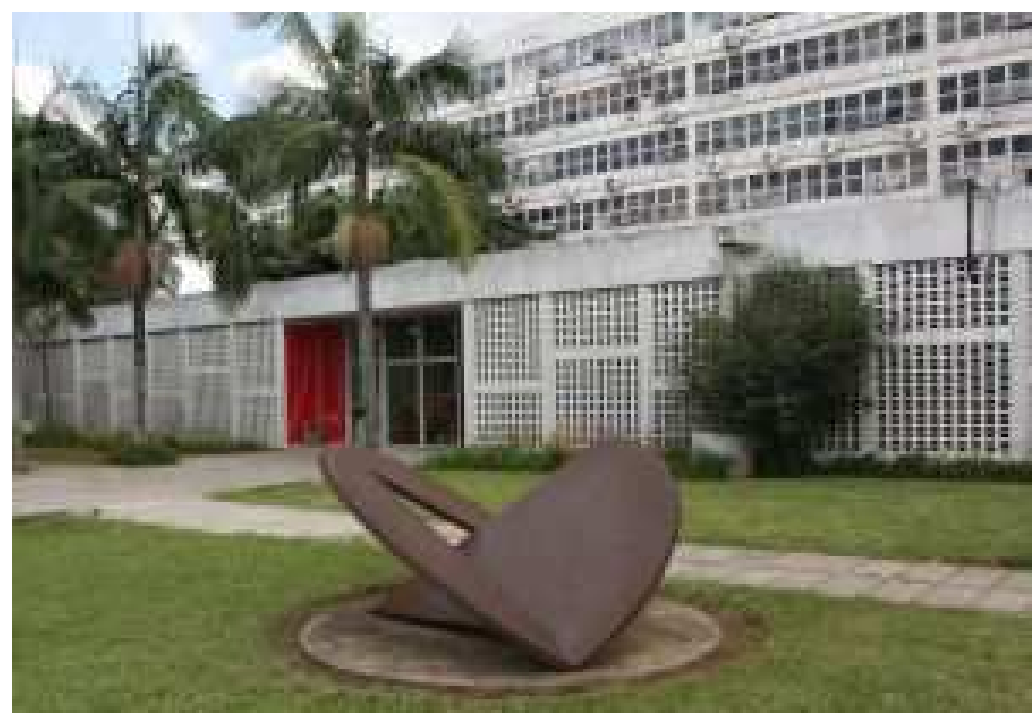

Figura 30. Fachada atual do MAC USP Anexo (Reitoria USP).

Fotografia: Milton Michida.

Em 1985, o MAC USP no campus aproveitaria a estrutura de um dos prédios residenciais não finalizados. Somente em 1988, com o apoio da Fundação Banco do Brasil, da Reitoria e do Fundo de Construção da USP (FUNDUSP), teve início a construção da sede. Em 1992, foi inaugurado o edifício do MAC USP - ainda com precariedades e necessidades de adequação. Em 2000, esse espaço em frente à Reitoria passou por grande reforma com o apoio da Fundação de Amparo à Pesquisa (FAPESP), incluindo climatização, reserva técnica, laboratórios e salas de trabalho - uma área com cerca de 3.800 $\mathrm{m} 2$. 


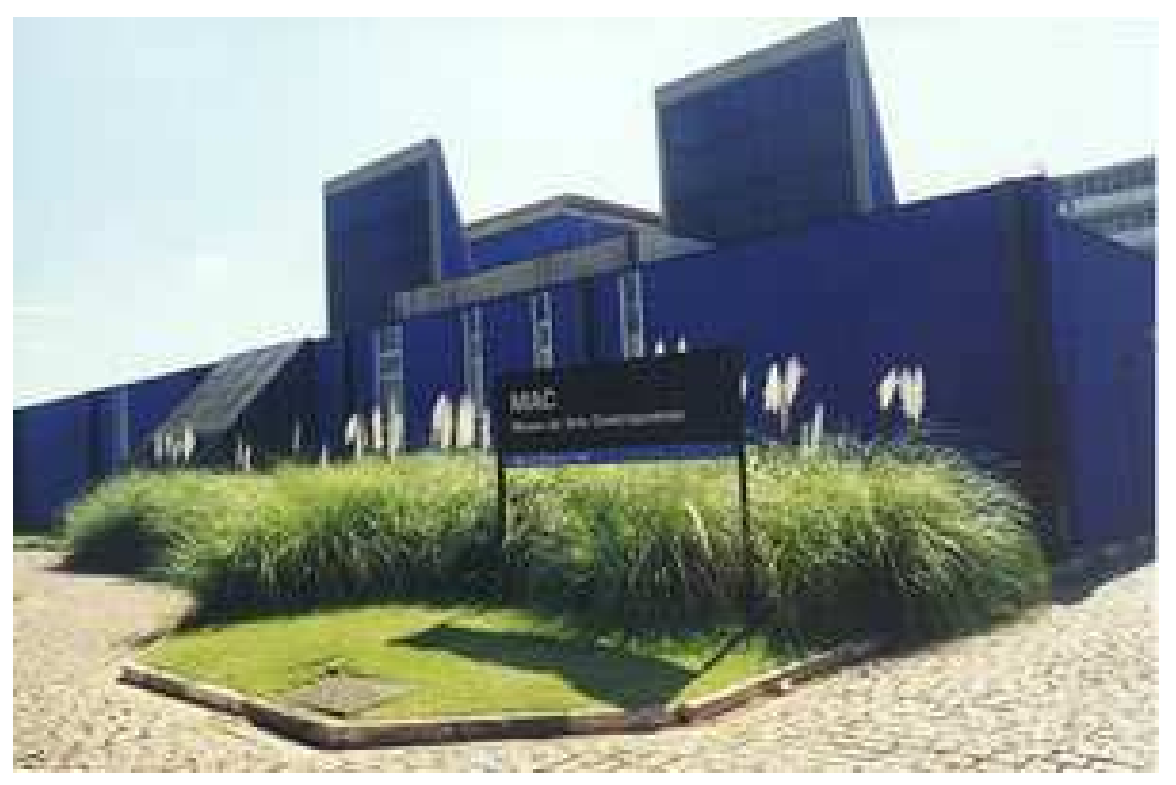

Figura 31. Fachada MAC USP, na Cidade Universitária, 1992.

Fonte: Arquivo MAC USP.

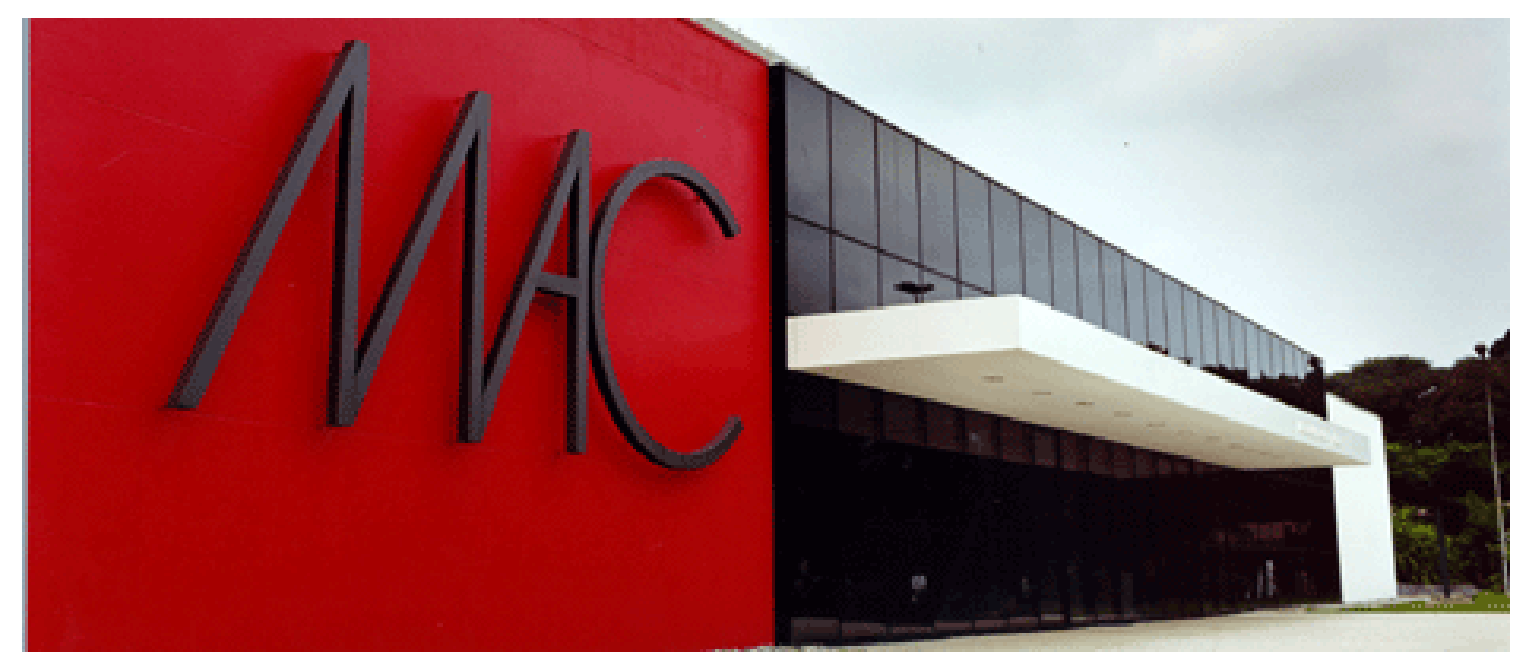

Figura 32. Fachada atual MAC USP, na Cidade Universitária. Fonte: Arquivo MAC USP.

Mais recentemente, o MAC USP está prestes a ocupar o Pavilhão da Agricultura (antigo Departamento Estadual de Trânsito - DETRAN), no Ibirapuera. O edifício, assim como o complexo do Parque Ibirapuera, leva a assinatura do arquiteto Oscar Niemeyer. O complexo está sendo reformado e adaptado com projeto da CPOS (Companhia de Projetos, Obras e Serviços do 
Estado de São Paulo). Com oito andares e três anexos, o museu terá um espaço de cerca de 30 mil m2 para exposições, laboratórios de conservação e restauro (pintura e escultura, papéis e fotografia), reservas técnicas, oficinas de trabalho, um restaurante panorâmico, café, loja e livraria. Com o edifício principal será possível, entre outras ações, criar áreas expositivas especializadas para o acervo das obras que o museu reuniu ao longo de sua existência: áreas especiais para artes gráficas, fotografia, para o acervo moderno e para o de arte contemporânea.

Alem do anexo expositivo, serão áreas destinadas a apresentar exposições resultantes da constante releitura e estudo que o Museu desenvolve sobre sua coleção.

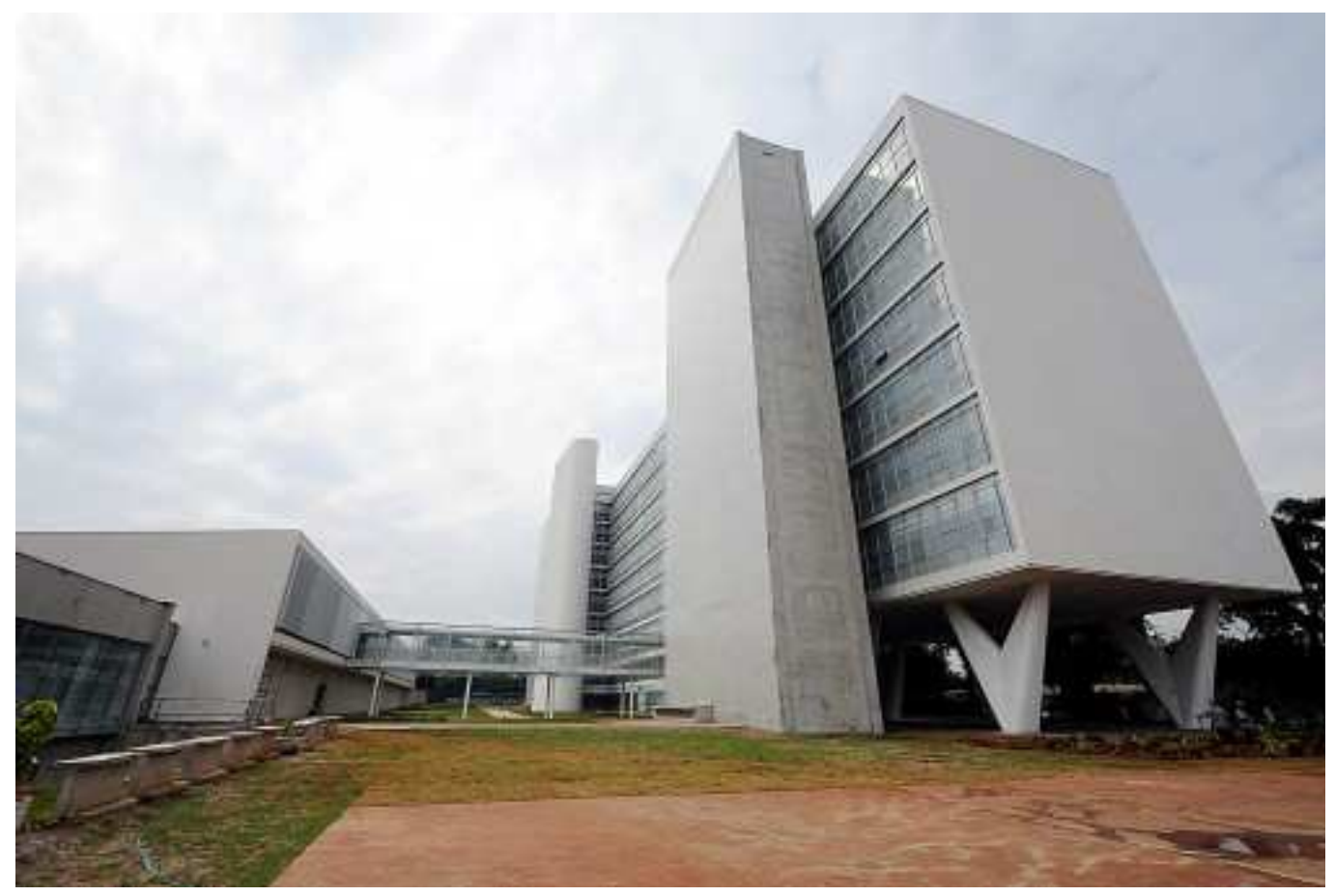

Figura 33. Fachada atual MAC USP, Pavilhão da Agricultura (Parque Ibirapuera), 2012.

Fotografia: Cecília Bastos/Jornal da USP

Em janeiro de 2012, o MAC USP organiza a exposição $O$ Tridimensional no Acervo MAC USP: Uma Antologia, marcando a ocupação do espaço térreo do edifício. As funções expositivas se darão de forma gradativa na nova sede, uma vez que serviços relacionados ao sistema de segurança, reservas técnicas, ar condicionado, entre outros, necessitam de um tempo de experimentação e adequações. 


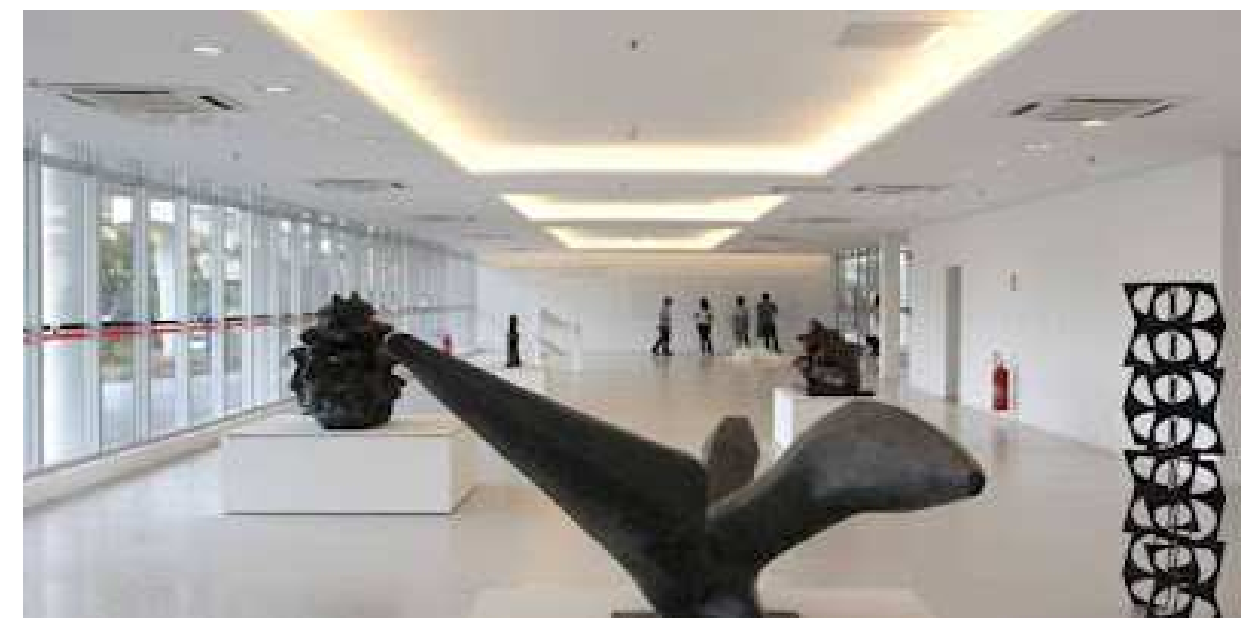

Figura 34. Visão panorâmica da exposição O Tridimensional no Acervo MAC USP: Uma Antologia, inaugurada em 28 de janeiro de 2012. Fotografia: Cecília Bastos/Jornal da USP

Assim, durante todo o seu histórico, as atividades do MAC USP são distribuídas em diferentes edifícios nos quais apresenta diversas exposições, o que dificulta suas operações, mas permite atingir diferentes públicos. A exposição das obras em diversas, ou em pelo menos duas sedes, (hoje as obras estão distribuídas em duas reservas técnicas - o MAC USP Ibirapuera e o MAC USP Cidade Universitária), não permite ao público ter a dimensão do tamanho real da coleção. A diversidade de endereços, à primeira vista, parece interessante para o público, mas também leva ao desconforto de não se saber aonde ir, para ver o quê. Além disso, some-se a restrição de horário imposta pelo esquema de funcionamento do campus da Cidade Universitária (restrito ao público em feriados e finais de semana).

Espera-se que a ocupação da nova sede do MAC USP, no Parque Ibirapuera, possa sanar algumas dessas dificuldades, uma vez que o edifício será totalmente voltado às exposições do acervo e à guarda da coleção, cabendo ao espaço na Cidade Universitária ser dedicado às atividades acadêmicas e administrativas, tais como, aulas de graduação, pós-graduação e extensão universitária. Quanto às obras que estão sob a guarda provisória, convém dizer que hoje elas estão em espaços próprios nos edifícios do MAC USP Cidade Universitária e do MAC Ibirapuera - seu lugar de guarda e tratamento é diferenciado do restante da coleção pertencente, de fato, ao MAC USP. 


\section{Recursos Materiais e Financeiros}

O primeiro acolhimento de coleções sob a guarda provisória, por determinação judicial, ocorreu em 2005, depois novos acolhimentos ocorreram em 2008 e 2010 (de forma mais pontual) - e desde a primeira experiência se observa que essa prática impacta os orçamentos, os recursos materiais e financeiros dos museus e órgãos públicos selecionados para receberem essas coleções. A despeito das dificuldades, já apontadas na presente discussão, no que toca ao contexto dos museus universitários e, particularmente o MAC USP, essas instituições museológicas aceitaram o desafio de receber obras advindas de coleções privadas sobre judice legal. Junto com essa decisão, existe o compromisso de destinar recursos humanos e materiais para as tarefas de remoção, embalagem e abrigo dessas obras - condição exigida pela $6^{\mathrm{a}}$. Vara Criminal à época para que essas instituições pudessem ser administradoras desses bens culturais.

Segundo Fausto de Sanctis, cada museu prestou contas, detalhando os gastos públicos para o fiel compromisso de suas tarefas (SANCTIS, op. cit., p. 203). Nos seus relatórios, os museus explicitam suas despesas com transporte, as dificuldades experimentadas para a remoção das obras, os projetos realizados para o acondicionamento do acervo em local ideal, a disponibilização e a contratação de pessoal especializado, a elaboração de laudo técnico, agendamento de exposições, entre outras ações. Note-se que as ações de remoção das obras (embalagem e transporte) foram emergenciais, uma vez que o depósito que abrigava o primeiro lote de obras possuía prazo determinado para ser desocupado e já apresentava condições 
inadequadas para a permanência das obras. Os laudos técnicos e a ação de inventário tiveram que ocorrer já nos espaços dos museus.

Nas ações do MAC USP, muitos procedimentos adotados para o acolhimento das obras impactaram a rotina da instituição. A Reitoria da USP destinou ao MAC USP recursos financeiros a fim dar atendimento às necessidades físicas e de recursos humanos para acolhimento e inventário da coleção. $\mathrm{O}$ trabalho foi desenvolvido por equipe multidisciplinar composta por pesquisadores, conservadores, catalogadores, fotógrafos, montadores, dentre outros técnicos, somados aos suportes administrativos e operacionais.

Os investimentos para o abrigo das coleções sob a guarda provisória, por determinação jurídica, vão além dos esforços realizados na fase inicial de recepção do primeiro lote de obras. Essas coleções tem uma condição especial frente às atividades do MAC USP, isto porque sua condição determina procedimentos que não existem nas coleções que realmente pertencem ao Museu. Como exemplo, dessa diferenciação, tem-se que essas coleções não integram a base de dados comum às outras coleções pertencentes ao MAC USP, visto que há a constante preocupação em se devolver as obras de forma mais ágil, caso sejam requisitas pela justiça federal.

Nesse quesito, torna-se relevante mencionar que a catalogação dessas obras se constitui como um trabalho em processo. A catalogação de uma obra vai além do registro fotográfico que a identifica, da definição da técnica e dimensões. Cada obra é estudada individualmente, busca-se a trajetória da mesma, o contexto em que foi produzida, entre outras informações. Dessa forma, essa catalogação passa por constante revisão e essa tarefa se intensifica a cada nova exposição que se organiza com essas obras.

Essas obras compartilham das mesmas reservas técnicas que guardam as obras da coleção do MAC USP. No espaço do MAC USP, no Parque Ibirapuera (Pavilhão Ciccillo Matarazzo - $3^{\circ}$. andar) foi criada, ainda, uma reserva técnica para abrigar as obras de grandes dimensões das coleções sob a guarda provisória. Essa tarefa demandou recursos que envolviam a infraestrutura do Museu precária desde sua fundação, como já se observou, no que tange aos seus espaços físicos. Não se 
deve esquecer ainda que obras, como o painel de Frank Stella, The Founding (n\# 6), c. 2004, exigiram adequações no edifício para sua instalação - que, estrategicamente, foi fixada em local que pode integrar uma exposição ou pode ser acondicionada para guarda. Entre 2010 e 2012, a tela Claudius, 1986, do artista Gerhard Richter, apreendida pela Receita Federal em 2009 e entregue ao IPHAN, que por sua vez solicitou ao MAC USP o seu acolhimento e guarda, recebeu tratamento similar ao painel de Frank Stella - trabalho realizado pela equipe MAC USP - e expôs ao público no espaço do MAC USP Ibirapuera.

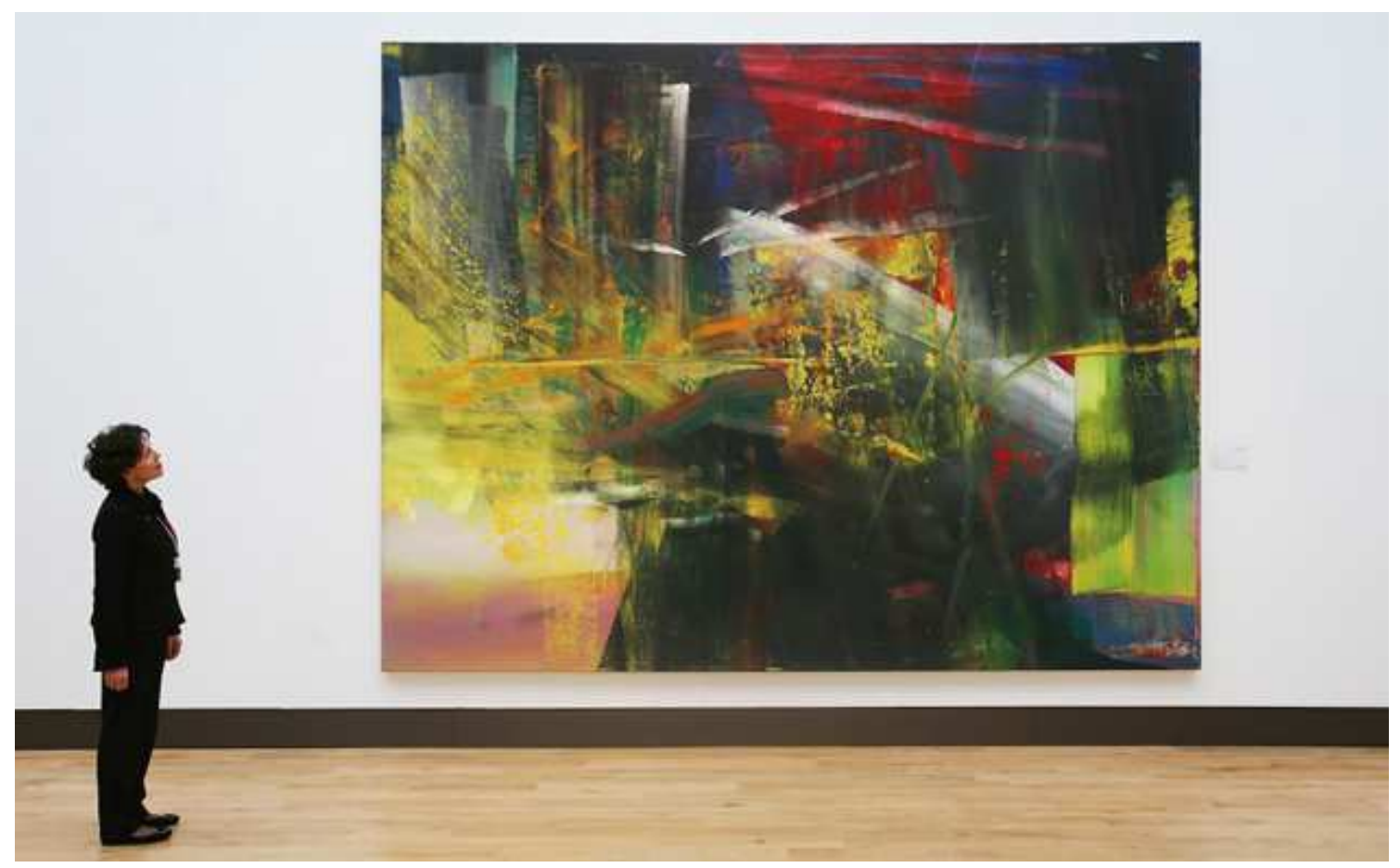

Figura 35. Gerhard Richter, Claudius, 1986, exposto no MAC USP Ibirapuera desde 2012.

Fonte: http://artobserved.com/2008/10/ao-roundup-2008-frieze-art-fair-sothebys-christies-and-phillips-londonauctions-art-market-inflection-point-reached/

A exigência da constância da exposição que acompanha a administração das coleções sob a guarda provisória torna-se outro fator que envolve a demanda de recursos físicos, financeiros, materiais e humanos, visto que para a realização de novas mostras, as obras passam por processos ligados à sua conservação (tais como, restauros e higienização), à sua catalogação (revisão dos dados técnicos pertinentes à obra), à sua montagem (a troca de suportes, molduras, entre outros materiais necessários) e, por fim, a extroversão dessas obras através de publicações, tais como: folders, catálogos, sites e outros materiais. 
Cabe mencionar que essas obras de arte recebem cuidados iguais as obras que pertencem ao Acervo MAC USP. Talvez, recebam tratamento ainda mais minucioso, uma vez que toda a sua documentação e seu estado de conservação necessita estar rigorosamente em ordem e atualizado, posto que a qualquer momento essas obras podem ser requisitadas pela justiça e retornar ao seus proprietários ou, ainda, servirem como bens patrimoniais passíveis de ressarcimento dos credores de uma possível massa falida. Hoje, o processo que motivou a apreensão das obras do primeiro lote de obras, vindo em 2005, ainda não se encerrou e continua tramitando na esfera federal.

Somado à condição de devolução constante dessas obras, há algo distinto que a separa das obras do Acervo MAC USP. O Museu não dispõe de autonomia para emprestá-las a outras instituições museológicas. Todas as ações que envolvem essas obras, extra-Museu necessitam de autorização prévia da Justiça hoje, por exemplo, a destinação do primeiro lote de obras, está sob a responsabilidade da 2 ${ }^{\mathrm{a}}$. Vara Falimentar do Estado de São Paulo, por decisão do Supremo Tribunal Justiça. Essas duas circunstâncias geram profunda instabilidade nas pesquisas realizadas sobre essas coleções.

As limitações que circundam essas coleções privadas sob a guarda de museus públicos, colocam questões relevantes: seria pertinente o gasto de recursos públicos para salvaguardar obras que não têm a garantia de permanência nesses acervos e, que talvez, possam retornar conservadas e valorizadas aos seus proprietários? Essa condição de zelar por obras que não são do Acervo não seria danosa às obras que, realmente, o integram, ocasionando a divisão dos esforços e dos recursos? Os recursos financeiros e materiais empreendidos para a salvaguarda dessas coleções valem à pena somente porque essas ampliam e atualizam o Acervo do Museu? Essas indagações são cada vez mais latentes na reflexão sobre a guarda provisória de obras por determinação judicial. Talvez, a exibição e a mediação dessas coleções possam ser argumentos que justifiquem o acolhimento dessas obras nos acervos públicos. 


\section{Exibição e Mediação}

A possibilidade da devolução das obras, a qualquer momento, motiva a imediata exibição e sua mediação (como se observa na primeira parte desse estudo, toma-se a exposição como a mediação mais direta e reconhecida no contexto dos museus). Desde a assinatura do termo de guarda e administração dessas coleções, a principal condição se traduz na disposição dessas coleções para o público. O MAC USP preocupa-se com esse quesito desde o primeiro momento: em fevereiro de 2006, exibe as obras de Frank Stella, The Founding (n\# 6), c. 2004 e de Leda Catunda, Rio e Mata, 2000, presentes na exposição Ciccillo - Acervo MAC USP, com curadoria de Elza Ajzenberg, realizada no MAC USP Cidade Universitária. A intenção da mostra consiste em apresentar uma retrospectiva da formação do Acervo MAC USP, reafirmando o caráter vanguardista de Ciccillo, destacando a iniciativa de transformar uma coleção particular em patrimônio público. A exposição enfatiza os três primeiros núcleos incorporados, passando pelas principais coleções adquiridas até a aceitação das obras sob a guarda provisória por determinação judicial. Assim, a curadoria explicita historicamente como um acervo "contemporâneo" pode atualizar e ampliar sua coleção.

Na sequência, em 2007, a exposição Poéticas da Natureza, com curadoria de Katia Canton, realizada no espaço do MAC USP Ibirapuera, exibe a obra Rio e Mata, 2000, de Leda Catunda, em diálogo com obras do Acervo MAC 
USP e com trabalhos de 48 artistas, que refletem sobre questões relativas à arte e o meio ambiente. Essa mostra é acompanhada pelo Congresso Poéticas $e$ Políticas da Natureza, realizado na Escola de Comunicações e Artes da USP (ECA USP), uma publicação de artigos e reflexões apresentados no evento científico, além de uma diversidade de atividades educativas que são motivadas pela exposição. A curadoria vale-se da obra "Rio e Mata" para estabelecer relações entre o Acervo e obras de artistas emergentes demonstrando seu potencial de contemporaneidade.
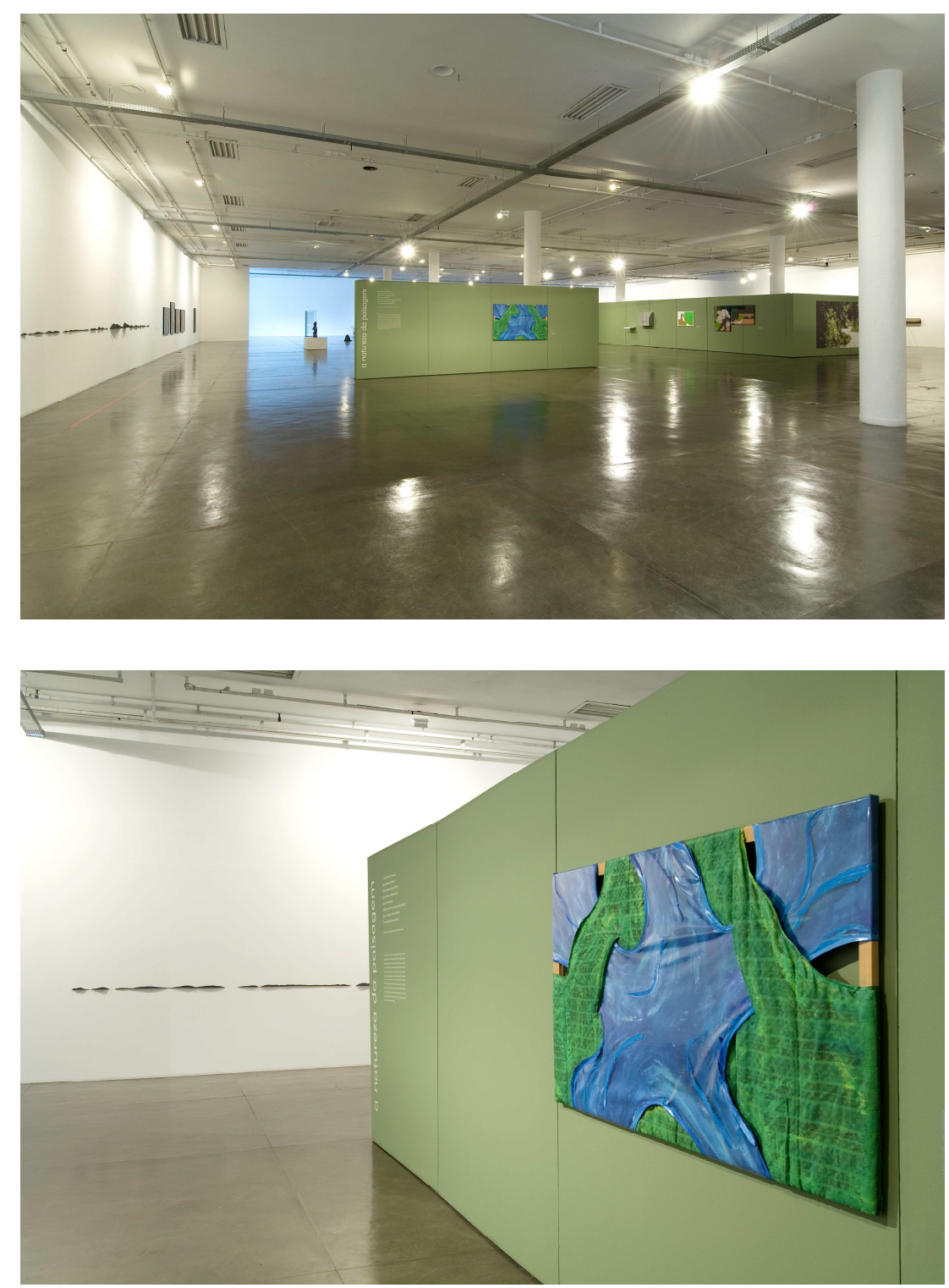

Figura 36. Vista da exposição Poéticas da Natureza, 2007, MAC USP Ibirapuera. Fotografia: Rômulo Fialdini. Arquivo MAC USP.

Figura 37. Vista da exposição Poéticas da Natureza, 2007, (destaque: Rio Mata, 2000, Leda Catunda), MAC USP Ibirapuera. Fotografia: Rômulo Fialdini. Arquivo MAC USP 
A exposição Arte-Antropologia - Representações e Estratégias, com curadoria de Cristina Freire e Helouise Costa, realizada em 2008, no MAC USP Cidade Universitária, exibiu pela primeira vez um conjunto de obras dessas coleções, ainda em diálogo com obras importantes pertencentes ao Acervo MAC USP, apontando os caminhos distintos que a arte usou e usa para abordar o "outro", da mesma forma como a antropologia tem como objeto o estudo da alteridade. Estruturada em seis módulos, a mostra tem início com a discussão sobre identidade nacional, proposta por modernistas, como em A Negra, de Tarsila do Amaral, marco central desse debate. O módulo A Fotografia como Representação faz uma revisão da produção contemporânea que aborda alteridades, seja no caso do brasileiro Mario Cravo Neto, seja nas imagens do Quênia da dupla Carol Beckwith e Ângela Fisher - essas fotografias pertencem ao lote das coleções sob a guarda provisória no MAC USP.

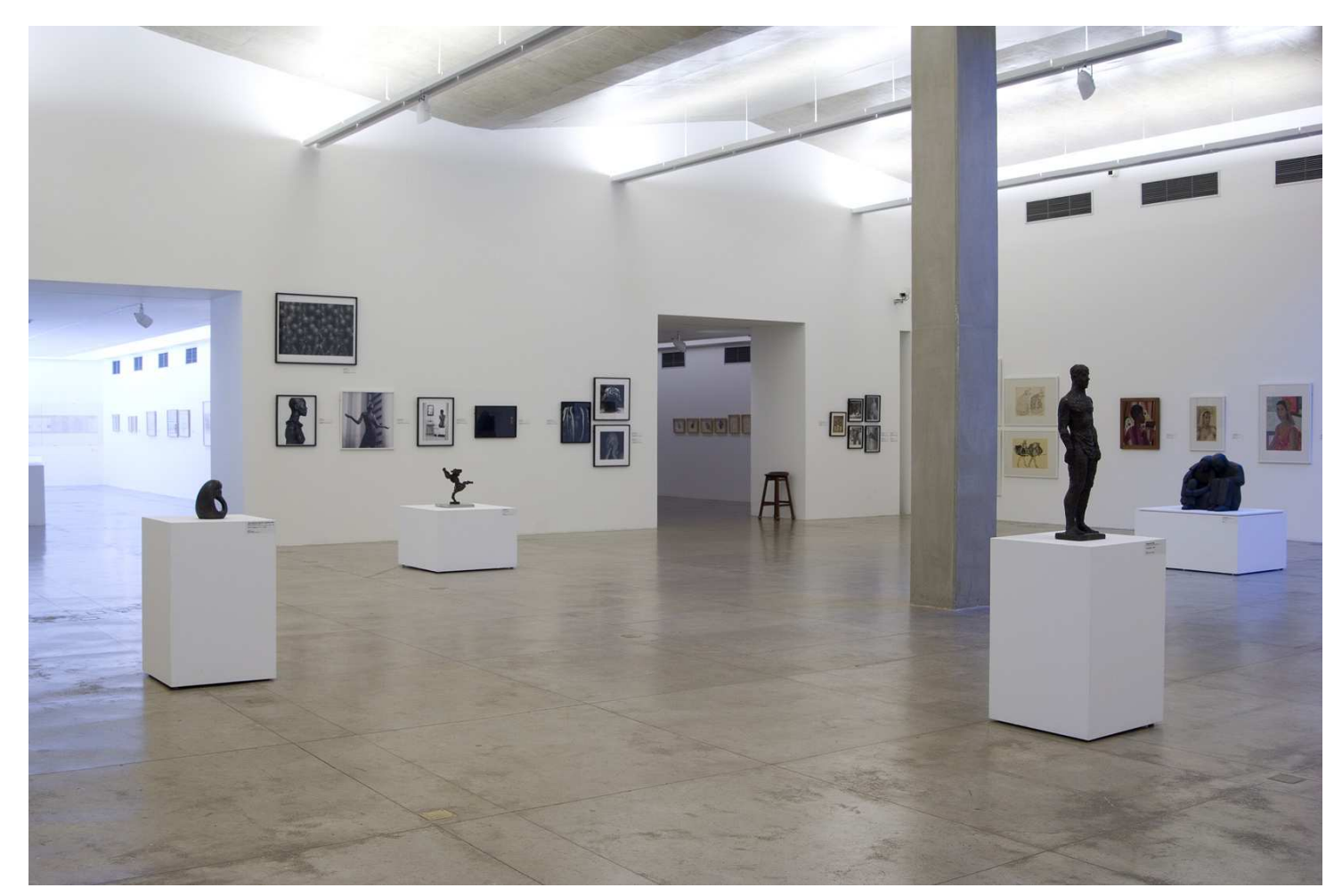

Figura 38. Vista da exposição Arte-Antropologia - Representações e Estratégias, 2008, MAC USP Cidade Universitária. Fotografia: Rômulo Fialdini. Arquivo MAC USP 
Já a exposição Fotógrafos da Vida Moderna, com curadoria de Helouise Costa, realizada em 2008, no MAC USP Ibirapuera, mergulha no universo das imagens realizadas na primeira metade do século $\mathrm{XX}$, por fotógrafos que marcaram a história da fotografia, alguns deles são: Brasaï, Henri CartierBresson, Man Ray, Pierre Verger, Robert Doisneau, entre outros. A mostra reuniu 124 fotografias do primeiro lote de coleções sob a guarda provisória no MAC USP, 19 do Acervo MAC e 11 do IEB.

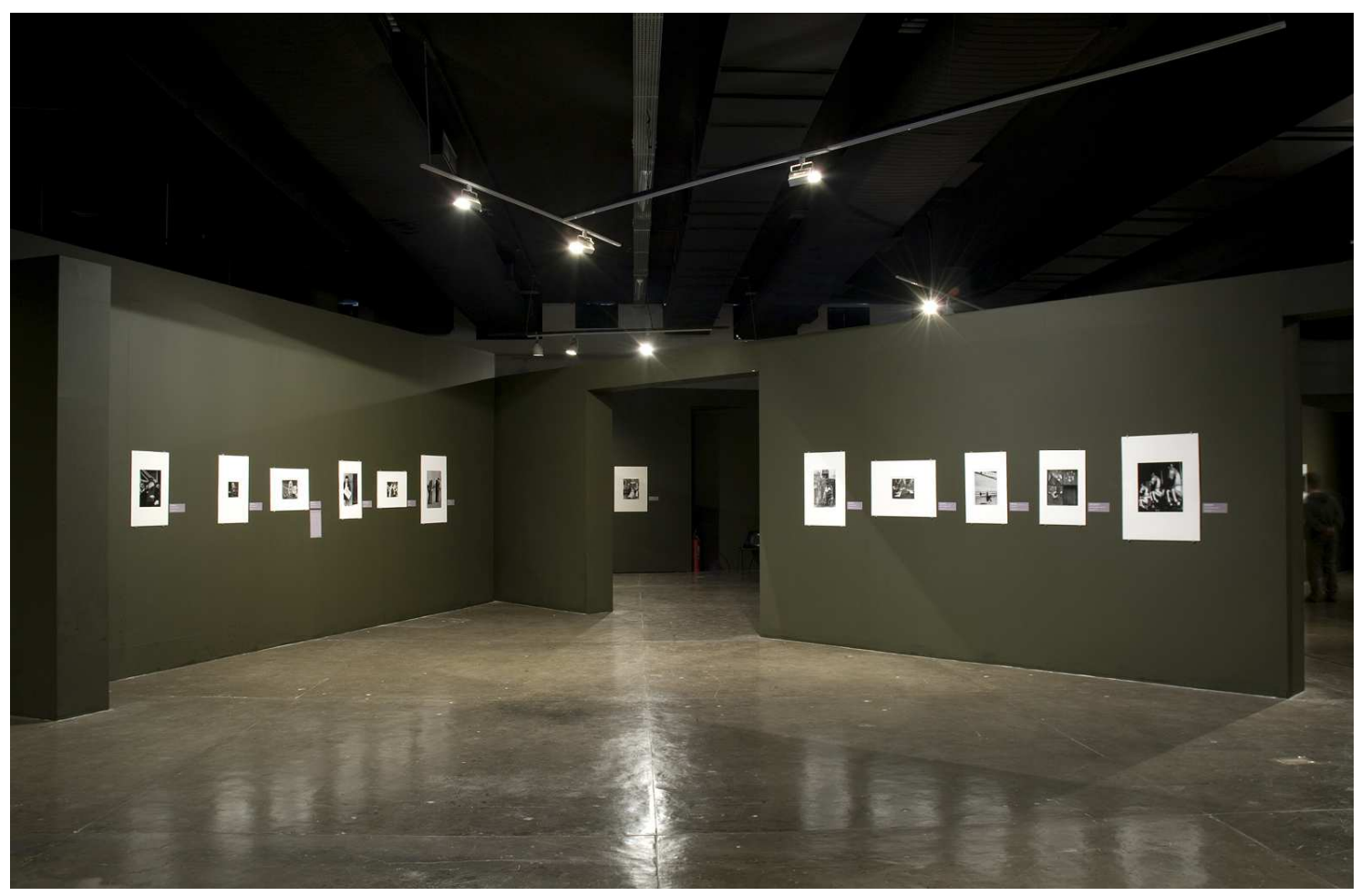

Figura 39. Vista da exposição Fotógrafos da Vida Moderna, 2008. Arquivo MAC USP

Em 2011, também com curadoria de Helouise Costa, realiza-se Fotógrafos da Cena Contemporânea, no MAC USP Cidade Universitária. Essa nova iniciativa reuniu um recorte de 63 imagens de 50 artistas, realizadas entre 1954 e 2003. Elas investigam o momento em que a fotografia abandona a teoria do instante decisivo, de Cartier-Bresson, e passa a apostar em territórios mais experimentais, nos quais as técnicas de montagem e encenação adquirem atenção especial. O tema das pessoas na praia, por exemplo, é abordado com cores e excessos por Daniel Klajmic e em preto e branco sóbrio por Claudio Edinger. 
Um dos núcleos da montagem dedica-se ao erotismo. Entre os nomes está o do italiano Oliviero Toscani, pivô de uma recente e polêmica campanha, envolvendo personalidades políticas aos beijos. Jeff Wall e Olafur Eliasson também integram a seleção. As duas exposições dedicadas à fotografia mostram de perto, o universo simbólico de boa parte das obras que estão sob a guarda provisória do MAC USP. Nessas imagens emerge mais fortemente o discurso contemporâneo que por sua vez precisa estar presente no Acervo.

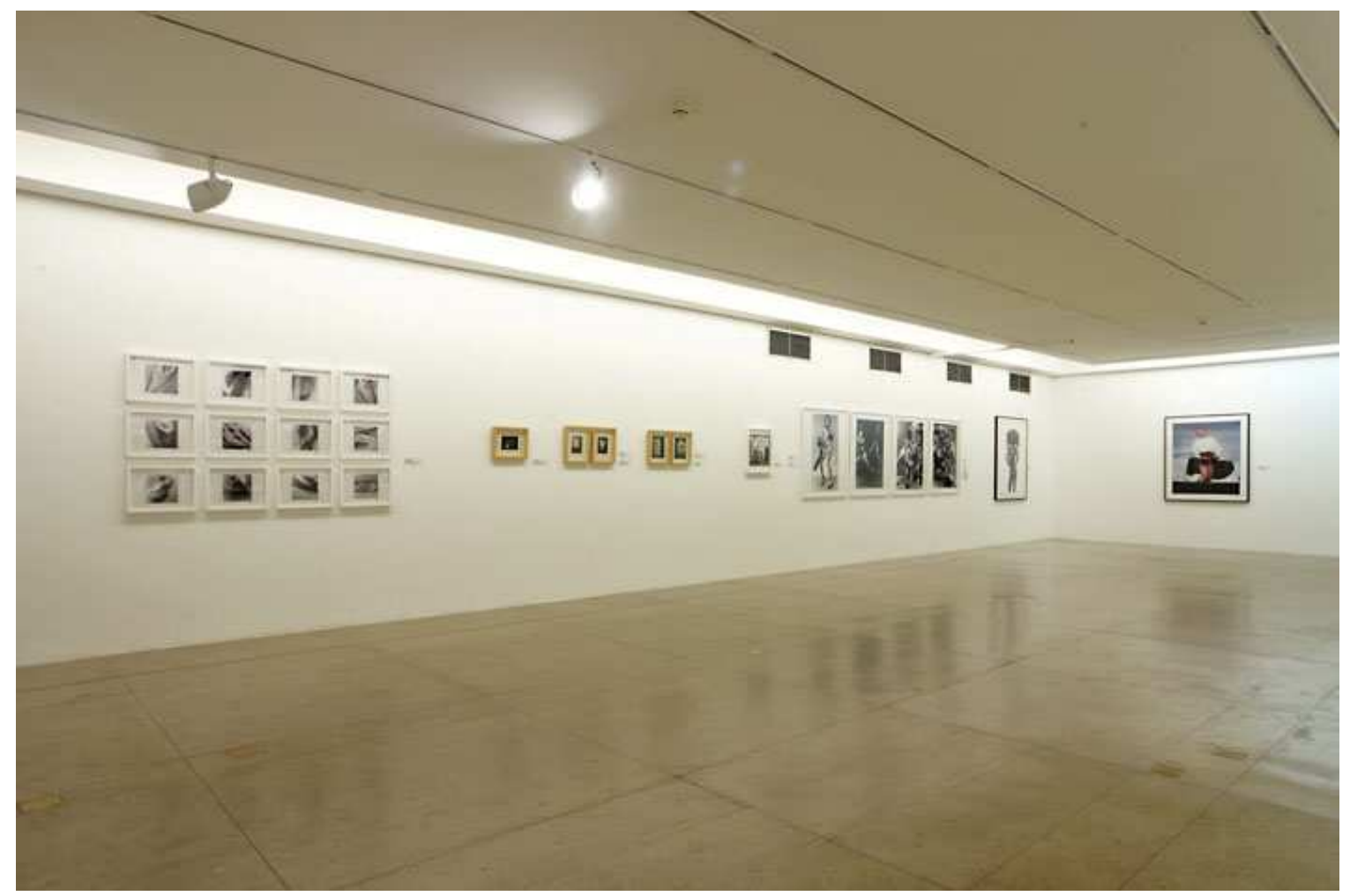

Figura 40. Vista da exposição Fotógrafos da Cena Contemporânea, 2011, MAC USP Cidade Universitária. Fotografia: Juan Guerra. Arquivo MAC USP

Em 2009, o MAC USP organiza a exposição Coleções sob Guarda Provisória, no MAC USP Ibirapuera, com um recorte de 118 obras (telas, gravuras e tridimensionais), reunindo as três coleções que, naquele momento, estão sob a administração do Museu que somadas dão um montante de 2 mil peças em variados suportes e segmentos da arte moderna e contemporânea, produzidas por expressivos artistas nacionais e internacionais. A exposição apresenta trabalhos de artistas como Joan Miró, Di Cavalcanti, Portinari, Amilcar de Castro, Cildo Meirelles, Emanoel Araújo, Ivaldo granato, Antonio Henrique 
Amaral, Amélia Toledo, Luis Áquila, Siron Franco, Dudi Maia Rosa, Luiz Sacilotto e Santuza Andrade, entre tantos outros. Uma vez mais, o MAC USP cumpre seu papel como administrador e dá ao público a oportunidade de extroversão desse patrimônio.

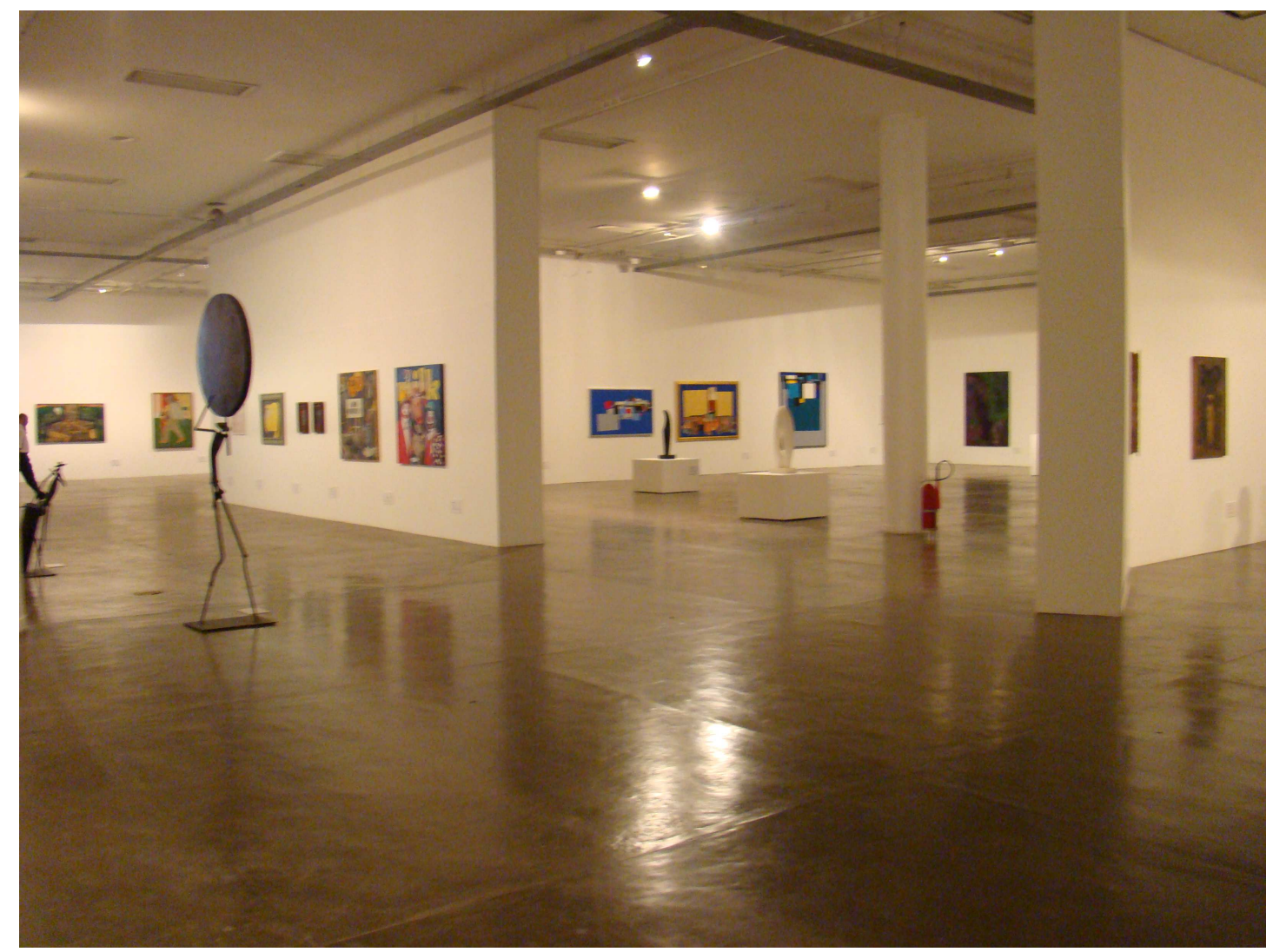

Figura 41. Vista da exposição Coleções sob Guarda Provisória do MAC USP, 2009, MAC USP Ibirapuera. Fotografia: Rômulo Fialdini. Arquivo MAC USP

Passados sete anos, após a recepção do primeiro lote de obras, ações, cada vez mais frequentes, exercem pressões para a devolução, para a venda (visando o pagamento de credores) ou para a manutenção dessas coleções nos museus públicos. A necessidade de mostrar à opinião pública que essas obras são valiosas pelo que representam como patrimônio público, gera iniciativas, como projetos de leis e declarações na imprensa de especialistas e pessoas notórias. ${ }^{4}$

\footnotetext{
${ }^{4}$ Com a intenção de dar respaldo legal aos museus e ao procedimento de cessão de guarda de obras apreendidas, o Projeto de Lei 2935/2008, que aguarda parecer da Comissão de
} 
Porém, os trâmites judiciais ainda não apontam o destino final dessas obras. Em abril de 2012, atendendo ao ofício 435/2012, da 6 ${ }^{\text {a }}$. Vara Criminal, o MAC USP devolveu 05 obras que estavam sob sua guarda provisória.

Em meio a esses acontecimentos, a Pró-reitora de Cultura e Extensão Universitária da Universidade de São Paulo (PRCEU) promove a exposição Coleção, Arte e Ciência, em 2012, no Centro Maria Antônia, envolvendo o MAC USP, o MP USP, o MAE USP e o IEB - todos órgãos administradores de coleções sob a guarda judicial. A exposição reúne objetos, obras de arte e documentos de âmbitos culturais bastante diversos, selecionados pelo seu grau de relevância, em meio a um conjunto maior que se encontra no acervo particular de cada uma das unidades.

O MAE USP cedeu objetos Kuarup - empregados para o ritual de homenagem aos mortos, praticado por indígenas brasileiros da região do Xingu e urnas funerárias amazônicas, que testemunham a história e a riqueza cultural dos primeiros habitantes do território brasileiro. Além das peças indígenas, há também a presença de itens da arqueologia egípcia.

Já o IEB forneceu séries cartográficas que ajudam a ilustrar os circuitos de produção, circulação e consumo dos mapas, com peças como cartas portulano, vistas topográficas holandesas, cartografia jesuítica, mapas-mundi japoneses, entre outros materiais. Os itens desta coleção abrangem mapas que datam do início do século XVI até finais do século XIX. Formada, em sua maioria, por mapas impressos, embora existam alguns documentos manuscritos de interesse para história da cartografia na época moderna, trata-se de material variado composto por mapas de grande difusão no mundo editorial. São selecionadas sete unidades temáticas que exemplificam diferentes contextos políticos e formas de apropriação ao longo do tempo: 1) cartas portulano, 2) mapas e vistas topográficas holandesas, 3) cartografia e diplomacia, 4) cartografia jesuítica e o IBRAM sobre cada peça apreendida, seja em atividades policiais, aduaneiras ou judiciais. 
etnografia, 5) mapas celestes, 6) mapas e comércio de longa distância e 7) mapas-mundi japoneses.

O MP apresentou um conjunto de instrumentos náuticos e de localização espacial, como astrolábios, telúrios, esferas armilares, sextantes, octantes e cronômetros, que despertam curiosidade e admiração em função de sua beleza e das potencialidades para a pesquisa e a produção de conhecimentos, entre as relações históricas do homem com a natureza, o espaço e o tempo.

O MAC USP optou por exibir obras importantes de artistas modernos, como Tarsila do Amaral e Joaquim Torres-García. Nas obras de arte contemporânea, destacam-se as obras de Cildo Meireles, Cindy Sherman, Jeff Koons ou Damien Hirst. Apontamentos sobre a arte atual no Brasil e no exterior mostram sua significativa heterogeneidade, sintetizando o quanto a absorção das coleções sob a guarda provisória no MAC USP amplia as possibilidades de estudo, gerando produções de interesse público sobre a situação da arte e da cultura do período.

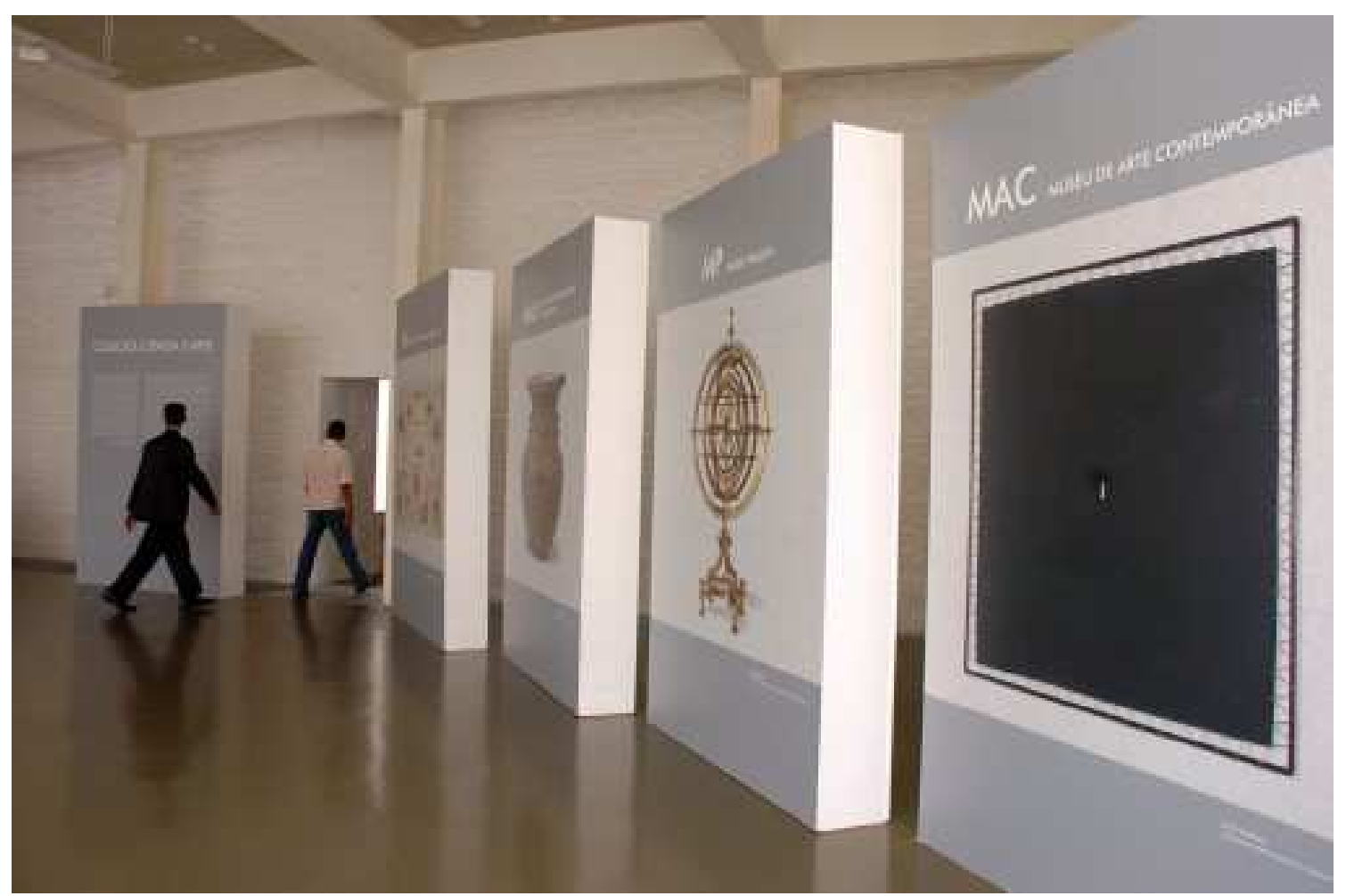

Figura 42. Vista da exposição Coleção, Arte e Ciência, 2012, Centro Universitário Maria Antonia. Fotografia: Cecília Bastos/Jornal da USP 


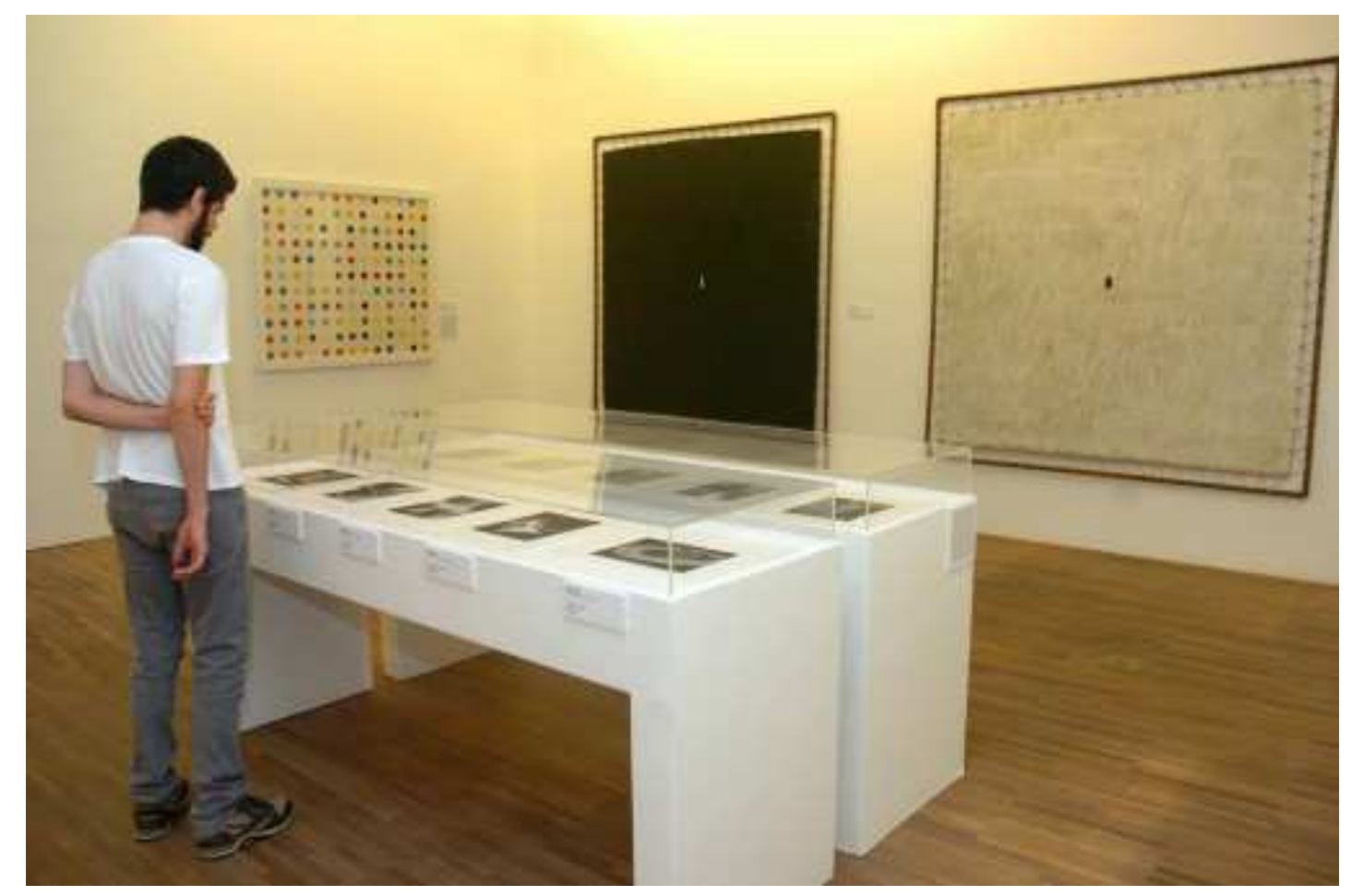

Figura 43. Vista da exposição Coleção, Arte e Ciência (detalhe Sala do MAC USP), 2012, Centro Universitário Maria Antonia. Fotografia: Cecília Bastos/Jornal da USP

As obras de Tarsila do Amaral, Torres-García e Man Ray apresentadas, sinalizam o quanto as obras sob a guarda provisória contribuem para os estudos sobre arte moderna, nacional e internacional, em seus segmentos brasileiro, latino-americano e europeu, sendo que a produção de Man Ray abre mais uma linha de pesquisa no Museu: o da fotografia no campo da vanguarda da primeira metade do século XX. As obras de Cildo Meireles, David Hockney, Cindy Sherman, Misha Gordin, Jeff Koons e Damien Hirst, por sua vez, enfatizam a presença da imagem fotográfica na arte contemporânea - um segmento do acervo do MAC USP bastante enriquecido a partir da chegada dessas coleções. A exposição Coleção, Arte e Ciência deu a oportunidade de visualizar um panorama das coleções que estão sob a guarda provisória da USP e mais do que isso, o tratamento que somente a Universidade, através do seu corpo de especialistas, pode contribuir ás coleções. 
As coleções sob a guarda provisória ainda estão parcialmente integradas ao Acervo MAC USP. Isto porque sua condição transitória preocupa o desenvolvimento da pesquisa sistemática sobre essas coleções - como pesquisar objetos que, talvez, em data não determinada não estejam mais acessíveis? Enfatiza-se, nesse ponto, que a exposição demanda de pesquisas e investigações de médio e longo prazos. Quando essas obras participam das exposições é porque essas ações são pensadas, tendo-as como primeira motivação.

Independente de sua transitoriedade no Acervo MAC USP não é possível negar que dificilmente um museu universitário pudesse adquirir obras de valores estéticos e históricos tão relevantes, em face do valor de mercado já atribuído. Somente colecionadores privados teriam condições de adquirir peças tão expressivas (aqui, cabe mencionar que também há peças que não são tão importantes assim, mas isso se pode atribuir à formação das coleções de arte que se orientam - como já se observou - pelo gosto pessoal do colecionador).

Por ocasião da destinação da coleção em 2005, o Conselho Municipal de Preservação do Patrimônio Histórico, Cultural e Ambiental da Cidade de São Paulo - CONPRESP deu início ao processo de tombamento da coleção, sob a resolução no 13/CONPRESP/2005, datada de 23 de dezembro de 2005, tendo por referência o inventário realizado pelas instituições. O processo continua em estudo, até o momento. Se o processo final decidir pelo tombamento, as obras não poderão sair de São Paulo, salvo autorização expressa do órgão.

O Conselho de Defesa do Patrimônio, Histórico, Arqueológico, Artístico e Turístico - CONDEPHAAT segue direção similar. O órgão de preservação do Estado de São Paulo, em sessão ordinária de 07 de julho de 2008, aprovou parecer de seu Conselheiro relator, favorável à abertura de processo de estudo de tombamento das obras que estão sob guarda. O Processo n 57941/08 de estudo de tombamento dos bens continua em andamento e por força do artigo 142, parágrafo único, e 146 do Decreto estadual 13.426/79 os bens culturais tem assegurada sua preservação e nenhuma ação poderá ser realizada, sem prévia autorização do órgão. 


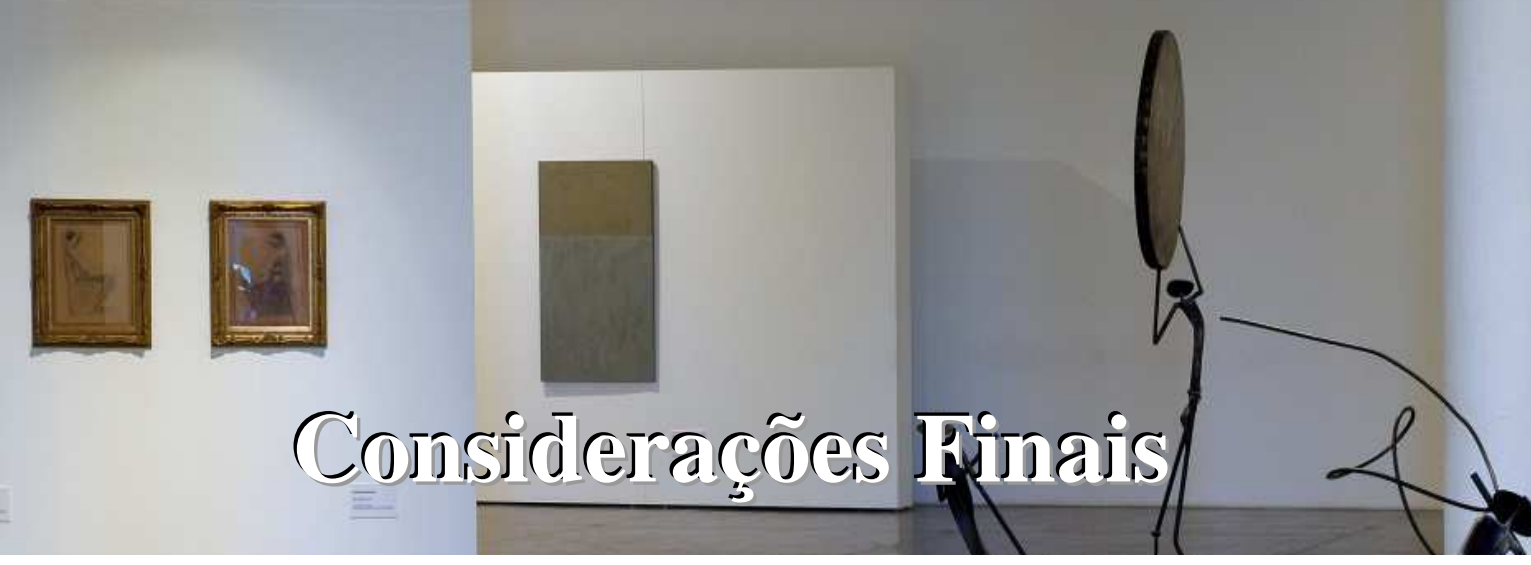

Por que os museus de arte e, particularmente, o MAC USP aceitam a guarda provisória de coleções de arte por determinação judicial? A resposta está na gestão dos museus de arte e na forma como esses constituem e mediam suas coleções. A compreensão dos fatores que envolvem as ações gestoras que movem os museus de arte, em especial o estudo de caso adotado nesta pesquisa (o MAC USP) é relevante para projetar novas perspectivas no que tange à gestão de coleções dedicadas à arte contemporânea.

Em 1963, a USP provavelmente aceitou as coleções de Ciccillo, de Yolanda e do MAM SP para aumentar o seu prestígio, baseada na crença de constituir um centro de produção de conhecimento em artes de excelência; de crescer fisicamente e, poder abrigar diversas outras coleções. Ressalta-se aqui que incorporações de coleções são atos administrativos embasados em convicções daqueles que deles participam: entre outros fatores, Ciccillo acreditava que a USP era a instituição mais adequada para receber suas obras e os dirigentes da USP acreditavam que a Universidade poderia acolher as coleções adequadamente. 
Da fundação do MAC USP, passando pelos anos de 1960 e 1980, o Museu conta com a ação dos seus diretores para estruturar-se como instituição museológica, para o aprimoramento de sua infraestrutura e para a profissionalização de sua equipe. Porém, é na ação de atualização e de ampliação do Acervo que a atuação desses diretores torna-se marcante. Cada qual à sua maneira lutou para que o MAC USP pudesse ser reconhecido nacional e internacionalmente. A caracterização como "um museu contemporâneo" também coloca o MAC USP como uma instituição distinta frente aos outros museus de arte. Os rápidos movimentos, revisões e transformações da arte nesses últimos 50 anos, impuseram ao Museu um paradoxo incômodo: manter-se como instituição museológica especializada em arte contemporânea nacional e internacional (a partir do acervo recebido do MAM SP), aliada à falta e às dificuldades de recursos para manter esse acervo atualizado.

As aquisições e/ou doações extraordinariamente conseguidas por seus diretores não são suficientes para que o Museu mantenha esse status, uma vez que precisa de constante atualização e ampliação do acervo. $O$ resgate dessa trajetória, focalizando o MAC USP como exemplo, é relevante para o entendimento das condições existentes na prática dos museus universitários, que enfrentam a exigência de aliar à sua coleção ações voltadas para a pesquisa, o ensino e a cultura e extensão. Os recursos da Universidade por mais disponíveis que sejam não se encontram em condições de competir com o mercado de arte contemporânea em vigência. Ao mesmo tempo, quando uma obra é incorporada ao Acervo do MAC USP (ou de qualquer outro museu universitário que tenha esse nível de exigência) é sinal que essa foi legitimada pela autoridade da Universidade. Esse mecanismo impõe valor agregado à obra e ao artista que será utilizado pelo mercado de arte.

Sob essa perspectiva, o MAC USP parecia condenado ao discurso modernista e não conseguiria alcançar a contemporaneidade da arte. Cabe mencionar aqui que o empréstimo de obras somente é adequado para casos específicos que normalmente estão relacionados com a organização de uma exposição e que, nesses casos, os contratos firmados são pontuais com prazos e 
obrigações estritamente definidos e/ou preestabelecidos. Durante a década de 1990, surge uma tentativa de atualização do acervo: o termo de comodato de longa duração. As 50 obras cedidas pelo colecionador Marcantonio Vilaça, através de termo de comodato, revigoraram o Acervo do MAC USP e abriram novas possibilidades de contratos similares entre colecionadores e instituições e até mesmo entre instituiçõos. Diferentemente do empréstimo de obras para uma ação pontual, o comodato - com prazo de vigência ampliado - dá às partes (comodatário e comodante) o tempo para a reflexão sobre a doação permanente ou não ou, ainda, dá ao comodatário o tempo necessário para a realização de atividades relacionadas à pesquisa, ao ensino e à extensão universitária, focando a coleção.

Já as coleções que estão sob a guarda provisória dos museus e que chegaram a esse termo porque foram apreendidas, sequestradas e arrestadas pela Justiça Federal constituem outra maneira de atualização e ampliação dos Acervos. Essa forma de incorporação de obras se mostra como uma experiência nova para a Justiça Federal e para os museus públicos que receberam essas obras. Excetuando a decisão tomada na década de 1980, que envolvia o Museu Nacional de Belas Artes (MNBA) e as obras pertencentes a um banco que abriu falência (MACIEL \& BANDEIRA) ${ }^{1}$, o juiz Fausto De Sanctis, titular da $6^{\mathbf{a}}$. Vara Federal Criminal de São Paulo, em 2005, tomou decisão distinta à boa parte dos juízes, responsáveis por designar administradores para as obras de arte suspeitas de constituírem patrimônio ilícito. Ao invés de manter as coleções de arte em acomodações inadequadas e não permitir o acesso ao público às peças por intermédio de exposições, Fausto de Sanctis, no uso de suas atribuições, designou o Estado como fiel depositário (seguindo a premissa de que o Estado deve proteger, valorizar e reabilitar seu patrimônio cultural e natural) através dos museus e órgãos públicos.

\footnotetext{
${ }^{1}$ As peças pertencentes a essa coleção foram confiadas pela Justiça Federal ao MNBA, porém, não permitiu ao museu carioca a exibição dessas peças ao público. Há três décadas essas obras estão isoladas na reserva técnica da instituição.
} 
Dos museus e órgãos públicos selecionados para receber as obras, os museus universitários da USP viram no acolhimento dessas coleções a possibilidade de ter acesso a peças significativas - que seriam inacessíveis à pesquisa em condições normais, visto que muitas vezes são obras internacionais ou até mesmo nacionais altamente reconhecidas, além do fato de pertencerem a coleções privadas e fechadas ao grande público. Para esse acolhimento, os museus tiveram que firmar junto a Justiça Federal o compromisso de zelar e exibir essas obras. Cada objeto integrante das coleções apreendidas foi enviado aos acervos que mais se adequavam aos seus perfis.

O MAC USP recebeu, em processos diversos, cerca 2000 obras (em três lotes iniciados em 2005, 2008 e, ao longo do tempo - 2009 e 2010 - obras mais pontuais), quase $25 \%$ de acréscimo ao seu Acervo. Esse acolhimento impactou os recursos materiais e financeiros do Museu. Nessa ação, o MAC USP foi apoiado pela Universidade, mas mesmo assim o acolhimento exigiu esforços na gestão da coleção do Museu. Nesse ponto, torna-se relevante abordar a questão que envolve a conservação e a mediação dessas obras, uma vez que, de modo permanente ou provisório, a instituição museológica tem a obrigação de salvaguardá-las.

A obrigação de salvaguarda somada à exigência de exposição dessas obras obriga a um redimensionamento das condições gerais do Museu. Há maior demanda por recursos materiais e humanos. A exigência de exposição bem como a conservação implica investimentos. Recorde-se que algumas doações são condicionadas à exibição permanente. Junto à atualização e à ampliação do Acervo, percebe-se que a infraestrutura do MAC USP e sua equipe profissional ao longo dos seus 50 anos - vêm se aperfeiçoando, sendo, portanto, a gestão do museu um desafio diário para a instituição. $\mathrm{O}$ acolhimento das coleções sob a guarda provisória somente faz intensificar essa demanda.

O prazo indeterminado de permanência dessas obras no Acervo MAC USP causa instabilidade na atividade de pesquisa; tensiona o cotidiano do tratamento dessas obras, além de ocasionar alterações na programação de 
exposições e de atividades da Instituição. O atual sistema de guarda provisória gera insegurança nos museus, que num primeiro momento são muitas vezes obrigados a guardar e preservar obras, para depois, num segundo momento, perdê-las a qualquer instante por decisão judicial. Nessa direção, assinala-se que o primeiro caso de devolução de obras, no MAC USP, deu-se com 05 obras que incluíam telas de Di Cavalcanti e Cândido Portinari, entregues aos seus proprietários em 2012 (importante destacar que essas obras ficaram sob a guarda do MAC USP de 2008 a 2012 e foram entregues em perfeitas condições de preservação).

“Quando solicito uma avaliação, não quero o valor econômico, mas sim cultural" ${ }^{\text {, }}$ declarou Fausto de Sanctis aos meios de comunicação. Essa afirmação expressa o significado das obras, vistas como bens e patrimônio cultural. É esse o tratamento que elas merecem e é, nessa visão, que e se baseiam a função e os propósitos dos museus. Não se pode encarar a instituição museológica como "casa de custódia", quando uma obra é destinada para guarda provisória dos museus universitários (como no exemplo selecionado para o recorte deste estudo - o MAC USP), ela passa a integrar o bem público - não está simplesmente “depositada". Ela passa a representar os valores caros àquela comunidade que é servida pela instituição museológica. Enfatiza-se que os acervos museológicos esforçam-se, cada vez mais, para aproximarem-se de seus usuários.

No caso do MAC USP, essa comunidade se estende da Universidade, passando pela cidade de São Paulo, Brasil, até atingir públicos internacionais. A possibilidade da perda desse bem é um prejuízo inestimável, envolvendo questões patrimoniais relativas a essa comunidade - não se deve esquecer que essas obras representam valores artísticos, históricos e culturais desses últimos dois séculos.

Em termos gerais, a transição do bem patrimonial do universo de colecionadores particulares para o acesso público é caminho que se mostra natural na trajetória das grandes coleções, como se observou ao longo desta

\footnotetext{
${ }^{2}$ Idem.
} 
pesquisa. Porém, o caminho inverso (do acesso público para o privado) é uma trilha possível a partir da devolução das obras aos proprietários e/ou mercado de arte, sendo algo difícil de ser aceito pela comunidade e pela opinião pública. A confiança que se pressupõe no exercício da gestão dos museus fica, no mínimo, sob suspeita diante dessa possibilidade.

Aos museus universitários, particularmente ao MAC USP, é preciso restabelecer essa confiança, visando, acima de tudo, o atendimento às demandas da sociedade e o acesso a essas coleções - necessidades prementes nesse momento. Nesse sentido, o MAC USP, como lugar de memória, luta para ficar, definitivamente, com essas coleções. Seu valor simbólico é comprovado e se reflete nas diversas exposições que já se organizaram ao redor dessas coleções. Ações do CONPRESP e CONDEPHAAT tentam, minimamente, preservar esse patrimônio no país, por intermédio de ações de tombamento das coleções que invariavelmente podem impedir a fragmentação dessas coleções, dando chances maiores para a aquisição por instituição museológica de experiência reconhecida. Aqui se assinala que o IPHAN prefere aguardar a decisão final da justiça para somente depois tomar a medida de tombamento.

A permanência ou não dessas obras no Museu é um debate aberto - aqui se tem a consciência de que as questões que envolvem essas obras sob a guarda provisória do MAC USP ainda estão em processo. Porém, frente a todas as dificuldades, é preciso dizer que o destino de obras por determinação judicial aos museus públicos e universitários, é uma ação válida para a atualização e ampliação e, principalmente, o acesso a essas coleções.

À luz dessas considerações, os primeiros passos para o desfecho do impasse que une a Justiça (essa não dispõe condições de salvaguardar e dar acesso público às obras apreendidas), aos museus (que veem na guarda provisória, o caminho para a guarda permanente e atualização de seu acervo) foram dados em 2005, a partir da decisão vinda da $6^{\mathrm{a}}$. Vara Criminal de São Paulo. O que resta agora são ações efetivas que possam garantir a permanência do acesso público a essas obras. Para a gestão dos museus de arte, a presença 
dessas obras, ainda que provisoriamente, intensificou e aperfeiçoou seus processos acadêmicos, museológicos e administrativos. A admissão das coleções de forma integral (obras modernas e contemporâneas) contribuiu para a atualização e ampliação do Acervo, alinhando-o, mesmo que temporariamente, às vertentes contemporâneas.

A despeito de todas as dificuldades apontadas ao longo desse estudo, o abrigo dessas obras e o direito de expô-las ao público valerão sempre à pena. $\mathrm{O}$ pensamento que moveu Ciccillo a realizar as doações que deram origem ao MAC USP continua presente no acolhimento dessas obras: a Justiça Federal acreditou que o MAC USP é o melhor lugar para abrigar essas obras e o MAC USP crê que pode acolhê-las e disponibilizá-las ao seu público. 


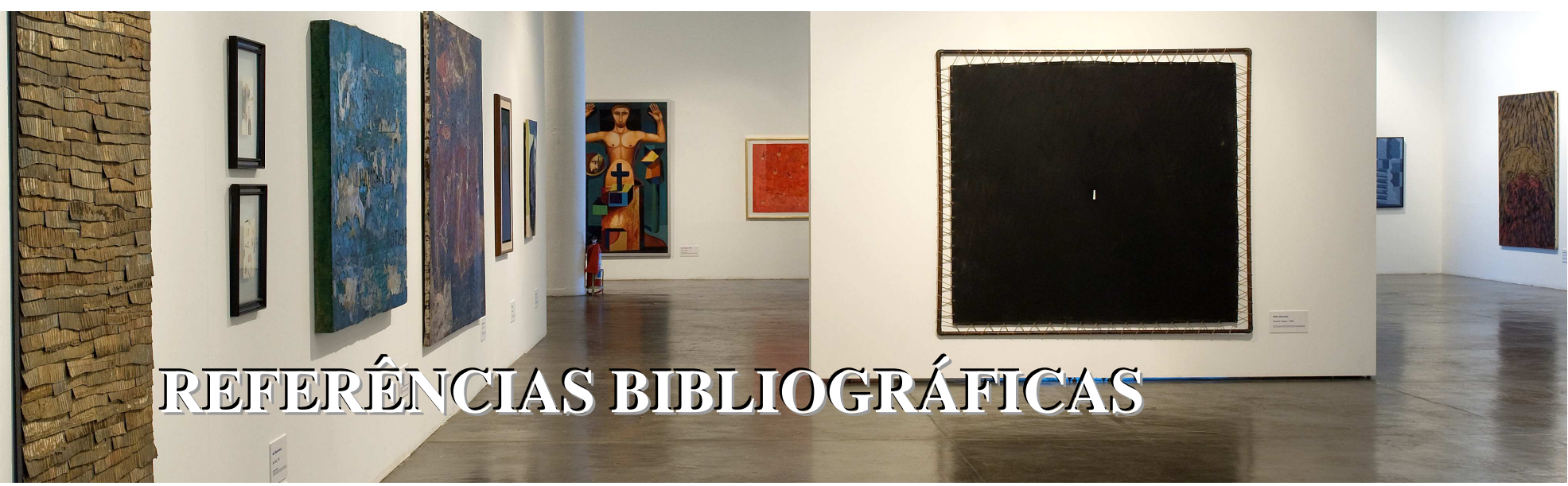




\section{Livros, Artigos, Teses e Dissertações}

AJZENBERG, Elza. "Museu como Agente Transformador". In: CARVALHO, Ana Cristina (org.). Anais dos Encontros Brasileiros de Palácios, CasasMuseus e Casas Históricas 2007-2010. São Paulo: Casa Civil/Acervo ArtísticoCultural dos Palácios do Governo do Estado de São Paulo, 2010, pp. 133-136.

AJZENBERG, Elza. Ciccillo: Acervo MAC USP - Homenagem a Francisco Matarazzo Sobrinho. São Paulo: MAC USP, 2006.

AJZENBERG, Elza. MAC Virtual: Prêmios Bienais. São Paulo: MAC USP, 2004.

AJZENBERG, Elza. Marcantonio Vilaça - Passaporte Contemporâneo. São Paulo: MAC USP, 2003.

ALMEIDA, Adriana Mortara. Museus e Coleções Universitários: Por que Museus de Arte na Universidade de São Paulo?. São Paulo: Escola de Comunicações e Artes da Universidade de São Paulo, 2001 (tese de doutorado).

ALTSHULER, Bruce. "Curadoria, Exposição e Educação no Museu de Arte". In: GONÇALVES, Lisbeth Rebollo. Sobre Museus: Conferências. São Paulo: MAC USP, 2010, pp. 43-66.

ALTSHULER, Bruce. "Colecionando arte contemporânea em museu e relações entre forma e conteúdo de exposições”. In: GONÇALVES, Lisbeth Rebollo. Sobre Museus: Conferências. São Paulo: MAC USP, 2010, pp. 65-93.

ARCHER, Michael. Arte Contemporânea - uma História Concisa. São Paulo: Martins Fontes, 2001.

ASSOCIAÇÃO CULTURAL DOS AMIGOS DO MUSEU CASA DE PORTINARI. Documentação e Conservação de Acervos Museológicos: Diretrizes. São Paulo: Governo do Estado de São Paulo, 2010.

BARBOSA, Veridiana Pinheiro Simons. Gestão de uma instituição museológica. São Paulo: Fundação Armando Álvares Penteado/Faculdade de Artes Plásticas, 2010 (Trabalho de Conclusão). 
BERTANI, Roberto. A Arte da Gestão de Conflitos: Processos e Procedimentos no Devir do Colecionismo. São Paulo: UNESP, 2006 (Dissertação de mestrado).

BLOOM, Philip. Ter e Manter - Uma História Íntima de Colecionadores e Coleções. São Paulo: Cia das Letras, 1992.

BOSSI, Ecléa. Memória e sociedade: lembranças de velhos. São Paulo: EDUSP, 1983.

BOYLAN, Patrick J.’Introdução". In: CONSELHO INTERNACIONAL DE MUSEUS. Como Gerir um Museu: Manual Prático. Paris: ICOM, 2004.

BRUNO, Maria Cristina Oliveira; NEVES, Kátia Regina Felipini (orgs.). Museus como agentes de mudança social e desenvolvimento: propostas e reflexões museológicas. São Cristóvão: Museu de Arqueologia de Xingó, 2008.

BRUNO, Cristina. Museologia e Museus: princípios, problemas e métodos. Cadernos de Sociomuseologia. Lisboa: Lusófona, 1997.

CLAIR, Jean. As origens da noção de ecomuseu. Cracap Information $n^{\circ}$. 2-3, 1976;

CANCLINI, Nestor. Consumidores e Cidadãos: conflitos multiculturais da globalização. Rio de Janeiro: Editora da UFRJ, 2001.

CANCLINI, Nestor. Culturas Híbridas: Estratégias para Entrar e Sair da Modernidade. São Paulo: EDUSP, 1998.

CANCLINI, Nestor. A Socialização da Arte. São Paulo: Cultrix, 1980.

CANTON, Katia. "A Coleção Marcantonio Vilaça no MAC USP”. In: Experiências Contemporâneas. Curadoria Lisbeth Rebollo Gonçalves. Brasília, TCU, Espaço Cultural Marcantonio Vilaça, 2009, s/p.

CARVAlHO, Ana Cristina Barreto de. Gestão de Patrimônio Museológico: As Redes de Museus. São Paulo: ECA USP, 2008 (tese de doutoramento apresenta na Escola de Comunicações e Artes da Universidade de São Paulo). 
COSTA, Helouise. "Práticas Museológicas em Museus de Arte". In: AJZENBERG, Elza. Arteconhecimento. São Paulo: MAC USP, 2004.

COSTA netTo, José Carlos. Direito Autoral no Brasil. Coordenação Helio Bicudo. São Paulo: FTD, 1998 (Coleção Juristas da atualidade/ coordenação Helio Bicudo)

CRUSCO, Sergio. "Colecionar é contar histórias". Revista Continum Itaú Cultural, n. 29, 2010.

CYPRIANO, Fabio. “Guggeheim às avessas”. Folha de S. Paulo. 11 abr. 2005, p. E1

DANTO, Arthur C. A Transfiguração do Lugar - Comum: uma filosofia da arte. São Paulo, Cosac Naify, 2005.

DAVALLON, J. L’Exposition à l'oeuvre. Paris/Montreal: L'Harmattan, 1999.

FARINHA, Ana Maria Antunes. Yolanda Mohalyi - O Moderno e o Contemporâneo na Coleção do Museu de Arte Contemporânea da Universidade de São Paulo. São Paulo: Programa de Pós-Graduação Interunidades em Estética e História da Arte da Universidade de São Paulo, 2006 (dissertação).

FRANCO, Maria Ignez Mantovani. "Formação de Acervo a partir de Coleções: A questão do gosto". In: CARVALHO, Ana Cristina (org.). Anais dos Encontros Brasileiros de Palácios, Casas-Museus e Casas Históricas 20072010. São Paulo: Casa Civil/Acervo Artístico-Cultural dos Palácios do Governo do Estado de São Paulo, 2010, pp. 50-54.

FREIRE, Cristina. "Do perene ao transitório: novos paradigmas para o museu de arte contemporânea". In: MAGALHÃES, Ana Gonçalves. Seminário Internacional Arquivos de Museus e Pesquisa. São Paulo: Museu de Arte Contemporânea da Universidade de São Paulo, 2010, pp. 93-100.

GONÇALVES, Lisbeth Rebollo. Entre Cenografias: o museu e a exposição de arte no século XX. São Paulo: EDUSP/FAPESP, 2004. 
MAGAlHÃES, Ana Gonçalves. Um Outro Acervo do MAC USP - PrêmiosAquisição da Bienal de São Paulo, 1951-1963. MAC USP: São Paulo, 2012 (folder de exposição).

HUYSSEN, Andreas. Memórias do Modernismo. Rio de Janeiro: Editora da UFRJ, 1996.

HERRERMAN, Yani. "Exposição, Exibições e Mostras". In: ICOM. Como Gerir um Museu. Manual Prático. UNESCO: Paris, 2004.

LAGE, Beatriz; LEITE, Edson. "Patrimônio Cultural Imaterial Brasileiro". In: AJZENBERG, Elza. Arteconhecimento. São Paulo: PGEHA, 2006, p. 49-59.

LADKIN, Nicola. "Gestão do Acervo". ICOM. Como Gerir um Museu. Manual Prático. UNESCO: Paris, 2004.

LE GOFF, Jacques. História e memória. São Paulo: Unicamp, 2003.

LEMOS, Carlos Alberto Cerqueira, O que é patrimônio histórico. 5. ed., São Paulo: Brasiliense, 2004.

LOURENÇO, Maria Cecília. Museus Acolhem o Moderno. São Paulo: EDUSP, 1999.

MACIEL, Edson Luiz Nahima e BANDEIRA, Regina. "Obras de Arte Apreendidas pela PF Permanecem sem Acesso do Público". Correio Braziliense. Brasília, 26 nov. 2010.

MAGAlHÃES, Ana Gonçalves. Um Outro Acervo do MAC USP - PrêmiosAquisição da Bienal de São Paulo, 1951-1963. MAC USP: São Paulo, 2012 (folder de exposição).

MALRAUX, A. O Museu Imaginário. Lisboa: Edições 70, 2000.

MANTOAN, Marcos. Experiências em Arte Contemporânea: Centro Cultural Banco do Brasil. São Paulo: Programa de Pós-Graduação Interunidades em Estética e História da Arte da Universidade de São Paulo, 2010 (dissertação). 
MARSHALL, Francisco. "Epistemologias Históricas do Colecionismo". In: Episteme, n. 20, Porto Alegre: UFRGS, 2005.

MARTINS, Carlos. Revelando um Acervo. São Paulo: BEI Comunicação, 2000.

MENESES, Ulpiano Bezerra de. "Para que serve um museu". CARVALHO, Ana Cristina (org.). Anais dos Encontros Brasileiros de Palácios, Casas-Museus e Casas Históricas 2007-2010. São Paulo: Casa Civil/Acervo Artístico-Cultural dos Palácios do Governo do Estado de São Paulo, 2010, pp. 74-81.

MENESES, Ulpiano Bezerra. "O museu e o problema do conhecimento". Anais do IV Seminário sobre Museus-Casas: Pesquisa e Documentação. Rio de Janeiro: Fundação Casa de Rui Barbosa, 2002.

MENESES, Ulpiano Bezerra. "Arquivo de artista, museus e pesquisa: reflexões de um historiador". In: MAGALHÃES, Ana Gonçalves. Seminário Internacional Arquivos de Museus e Pesquisa. São Paulo: Museu de Arte Contemporânea da Universidade de São Paulo, 2010, p.p. 10-21.

MENESES, Ulpiano Bezerra de. O olhar que suspende o relógio. In: Itaú Cultural Revista Eletrônica, São Paulo: Itaú Cultural, 1998.

MICHALSKI, Stefan. "Conservação e Preservação do Acervo". In: ICOM. Manual Prático. Paris: ICOM, 2004.

MURTA, Stela Maris e ALGANO, Celina (orgs.). Interpretar o patrimônio: um exercício do olhar. Belo Horizonte: Ed. UEMG; Território Brasilis, 2000.

MUSEU DE ARTE CONTEMPORÂNEA DA UNIVERSIDADE DE SÃO PAULO. Perfil de um Acervo. São Paulo: Techint, 1988.

MUSEU DE ARTE CONTEMPORÂNEA DA UNIVERSIDADE DE SÃO PAULO. MAC Collection. São Paulo: Comunique Editorial, 2003.

MUSEU DE ARTE CONTEMPORÂNEA DA UNIVERSIDADE DE SÃO PAULO. São Paulo: Banco Safra, 1990. 
NORA, Pierre. "Entre Memória e História: a Problemática dos Lugares", Projeto História, n. 10, dez. 1993, p. 7-28.

O MUSEU DE ARTE CONTEMPORÂNEA DA UNIVERSIDADE DE SÃO PAULO. São Paulo: Banco Safra, 1990, p. 22.

ORAMAS, Alicia Hernández. El papel del patrimonio em el progresso económico, social y cultural. El caso particular del turismo. PASOS. Revista de Turismo y Patrimonio Cultural, v. 2, n. 2, 2004, p. 307-310.

O’DOHERTY, Brian. No Interior do Cubo Branco, a ideologia no espaço da arte. São Paulo: Martins Fontes, 2002.

PAIM, Augusto. "Debaixo da ponta o iceberg". Revista Continum Itaú Cultural, n. 29, 2010.

PENTEADO, Yolanda. Tudo em Cor de Rosa. São Paulo: Editora Nova Fronteira, 1976.

POINSOT, Jean-Marc. "Incertezas e Evidências". In: GONÇALVES, Lisbeth Rebollo. Sobre Museus: Conferências. São Paulo: MAC USP, 2010, pp. 7-28.

POINSOT, Jean-Marc. "Arte Contemporânea e sua Exposição". In: GONÇALVES, Lisbeth Rebollo. Sobre Museus: Conferências. São Paulo: MAC USP, 2010, pp. 29-42.

RIBEIRO, Maria Izabel Branco. Construtivismo Fabulador: Uma Proposta de análise da Coleção Spanudis. São Paulo: ECA USP, 2001 (Tese de Doutorado).

ROCHA, Ana Cristina Souza. Museu de Arte Contemporânea da Universidade de São Paulo: Estratégias de Marketing e CRM. São Paulo: Universidade São Marcos, Dissertação de Mestrado, 2008.

SANCTIS, Fausto. Crime Organizado e Lavagem de Dinheiro: Destinação de Bens Apreendidos, Delação Premiada e Responsabilidade Social. São Paulo: Saraiva, 2009. 
SANTOS, Cecília Rodrigues dos. Novas fronteiras e novos pactos para o patrimônio cultural, São Paulo: Perspectiva, v. 15, no. 2, 2001.

SCHWARCZ, Lília Moritz. "O nascimento dos museus brasileiros, 1887-1910”. In: MICELI, Sérgio (org.). História das Ciências Sociais no Brasil. São Paulo: IDESP, 1998, v. 1.

SUBIRATS, Eduardo. "Os museus da memória \& a memória dos museus". In: CARVALHO, Ana Cristina (org.). Anais dos Encontros Brasileiros de Palácios, Casas-Museus e Casas Históricas 2007-2010. São Paulo: Casa Civil/Acervo Artístico-Cultural dos Palácios do Governo do Estado de São Paulo, 2010, pp. 35-38.

Um marchand em seu tempo. Jornal da Exposição - Frida Ivens Nuno Venosa. São Paulo: Casa das Rosas, 1992.

TIRAPELI, Percival, Arte e Etnias: São Paulo, São Paulo: UNESP/Imprensa Oficial, 2007.

VINÇON, R. Artifices d’exposition. Paris: L’Harmattan, 1999.

WILDER, Gabriela. "Tributo a Marcantonio Vilaça". In: AJZENBERG, Elza. Marcantonio Vilaça - Passaporte Contemporâneo. São Paulo: MAC USP, 2003, p. 26-29.

WYTHE, Deborah. "Reinstrumentalização dos arquivos de museus para o século XXI: novas coleções, novos públicos, novas parcerias, novas tecnologias". In: MAGALHÃES, Ana Gonçalves. Seminário Internacional Arquivos de Museus e Pesquisa. São Paulo: Museu de Arte Contemporânea da Universidade de São Paulo, 2010, pp. 28-58. 


\section{Infografia}

ANJOS, Moacir. (s/d) Desafios para os museus de arte no mundo contemporâneo (notas provisórias para um texto em elaboração). http://www.mamam.art.br/mam_opiniao/word/moacir_anjos_desafios.doc.

Acesso em 28 de fevereiro de 2005.

Apresentação da mostra Arte Contemporânea Brasileira. www.mac.usp.br. Acesso em 10 de julho de 2012.

BITTENCOURT, José. A face integrada de uma moeda multidimensional: Notas sobre a questão dos museus na atualidade. In http://www.revistamuseu.com.br/artigos/art_.asp?id=1119. Acesso em 13 de junho de 2002.

Entrevista Helouise Costa em Notas: Calendário de Cultura e Extensão junho/2006, in: www.usp.br/prc/calendário. Acesso em: 19 de novembro de 2009.

LARA FILHO, Durval de. O Museu no Século XXI ou o Museu do Século XXI? In: www.forumpermanente.org/.painel/artigos/dlf_museu/. Acesso em $17 \mathrm{de}$ junho de 2011;

NORONHA, Elisa. Museu de Arte Contemporânea: Uma Estratégia de Abordagem. http://interative.org/2010/01/museucontemporaneo. Acesso em 03 de outubro de 2012.

STEPHEN WEIL Apud. LARA FILHO, Durval de. O Museu no século XXI ou o Museu do Século XXI? HTTP://forumpermanente.org/.painel/artigos/dlf_museu/ Acesso em 22 de junho de 2011.

http://www.museum.or.jp/icom/resolutions. Acesso em 10 de agosto de 2007.

www.museus.gov.br/oqueemuseu_museusicom.htm. Acesso em 20 de outubro de 2009.

www.masp.uol.com.br. Acesso em 31 de julho de 2006. 


\section{ANEXOS}




\section{CÓDIGO DE ÉTICA PARA MUSEUS - ICOM}

O Código de Ética Profissional do ICOM foi aprovado por unanimidade na $15^{\text {a }}$ Assembléia Geral do ICOM realizada em Buenos Aires, Argentina, em 4 de novembro de 1986. Na 20ª Assembléia Geral realizada em Barcelona, Espanha, em 6 de julho de 2001, foi revisado e suas emendas foram aprovadas na $21^{\text {a }}$ Assembléia Geral realizada em Seul, Coréia do Sul, em 8 de outubro de 2004.

\section{ÍNDICE}

INTRODUÇÃO por Geoffrey Lewis

PREÂMBULO

Apresentação do Código de Ética para Museus

Padrões mínimos para museus

Traduções do Código de Ética para Museus

\section{GLOSSÁRIO}

\section{SECÇÕES}

1. Os museus preservam, interpretam e promovem aspectos do patrimônio natural e cultural da humanidade

- Definição institucional

- Recursos físicos

- Recursos financeiros

- Pessoal

2. Os museus que mantêm coleções as conservam em benefício da sociedade e de seu desenvolvimento

- Aquisição de coleções

- Alienação de coleções

- Preservação de coleções

3. Os museus conservam referências primárias utilizadas para fundamentar e aprofundar conhecimentos

- Referências primárias

- Aquisição e pesquisa em museus

4. Os museus possibilitam a valorização, a compreensão e a promoção do patrimônio natural e cultural

- Mostras e exposições

- Outros recursos

5. Os recursos dos museus possibilitam a prestação de outros serviços de interesse público

- Serviços de identificação

6. Os museus trabalham integrados com as comunidades de onde provêm seus acervos, assim como com aquelas onde prestam serviços

- Origem das coleções

- Respeito pelas comunidades onde prestam serviços

7. Os museus funcionam de acordo com a legislação

- Marco legal

8. Os museus atuam profissionalmente

- Conduta profissional

- Conflitos de Interesse 


\section{INTRODUÇÃO}

Esta edição do Código de Ética para Museus do ICOM é o resultado de seis anos de revisão. Após uma análise meticulosa do Código do ICOM à luz da prática contemporânea de museus, uma versão revisada, estruturada na edição anterior, foi publicada em 2001. Como cogitado na época, a versão atual foi completamente reestruturada para refletir a imagem e o ponto de vista dos profissionais de museus, e está baseada nos princípios básicos da prática profissional, elaborados para fornecer uma orientação ética ampla. O Código resultou de três períodos de consultas com os membros. Foi aprovado por aclamação na 21ª Assembléia Geral do ICOM em Seul, em 2004.

O caráter geral do documento continua a ser o de serviço para a sociedade, comunidade, público e seus diferentes segmentos, assim como a noção de profissionalismo dos que estão envolvidos nas atividades dos museus. Ainda que se observem mudanças de ênfase no documento, resultantes da nova estrutura que destaca pontos chaves e usa parágrafos menores, existem poucos elementos novos. As inovações são encontradas no parágrafo $\underline{2.11}$ e nos princípios esboçados nas seções $\underline{3,5 \mathrm{e}}$ 6.

O Código de Ética para Museus se constitui em instrumento de auto-regulamentação profissional em uma área chave nos serviços públicos, onde as legislações nacionais são variadas e muitas vezes inconsistentes. Estabelece padrões mínimos de conduta e procedimentos que podem ser utilizados por profissionais de museus em todo o mundo, assim como apresenta, em síntese, o que o público pode esperar desta profissão.

O ICOM publicou sua Ética de Aquisição em 1970 e um código completo de Ética Profissional em 1986. A edição atual - e o documento preliminar de 2001 devem muito à versão anterior. Entretanto, 0 trabalho mais importante de revisão e reestruturação recaiu sobre membros atuais do Comitê de Ética e suas contribuições em reuniões tanto presenciais quanto por meio eletrônico. Sua determinação para alcançar os objetivos dentro do cronograma é reconhecida com satisfação. Seus nomes estão listados abaixo.

Assim como seus precursores, o Código atual estabelece um padrão global mínimo sobre o qual instituições nacionais e grupos de especialistas podem se basear para responder a necessidades específicas. O ICOM incentiva o desenvolvimento de códigos de ética nacionais que atendam as necessidades das áreas especializadas e ficaria agradecido se recebesse cópias dos mesmos. Estas deverão ser enviadas para o Secretário Geral do ICOM, Maison de I'UNESCO, 1 rue Miollis, 75732 Paris Cedex 15, França. E-mail: secretariat@icom.museum

Geoffrey Lewis

Presidente, Comitê de Ética do ICOM

\section{Comitê de Ética do ICOM - Período de 2001 - 2004}

Presidente: Geoffrey Lewis (UK)

Membros: Gary Edson (Estados Unidos); Per Kåks (Suécia); Byung-mo Kim (Rep. da Coréia); Pascal Makambila (Congo) - 2002; Jean-Yves Marin (França); Bernice Murphy (Australia) 2002; Tereza Scheiner (Brasil); Shaje'a Tshiluila (República Democrática do Congo); Michel Van-Praët (França). 


\section{PREÂMBULO}

\section{Apresentação do Código de Ética para Museus}

Este Código de Ética para Museus foi elaborado pelo Conselho Internacional de Museus. Estabelece os preceitos de ética profissional mencionados nos Estatutos do ICOM. Este Código reproduz princípios amplamente aceitos pela comunidade internacional de museus. A associação ao ICOM e o pagamento de sua contribuição anual pressupõe a aceitação deste Código de Ética.

\section{Padrões mínimos para museus}

Este Código representa um padrão mínimo para museus. É estruturado por uma série de princípios fundamentados em diretrizes de práticas profissionais recomendáveis. Em alguns países, determinados padrões de referência são definidos por lei ou normas governamentais. Em outros, orientação e diretrizes sobre padrões mínimos podem ser obtidas a partir do "Credenciamento", "Registro" ou outros processos de reconhecimento público. Em países onde estes padrões não estejam regulamentados, as orientações podem ser obtidas por intermédio da Secretaria do ICOM, do Comitê Nacional ou do Comitê Internacional apropriado. Também se pretende que cada país individualmente e organizações especializadas, em conjunto com os museus, usem este Código como base para o desenvolvimento de padrões e normas complementares.

\section{Traduções do Código de Ética para museus}

O Código de Ética para Museus foi publicado em três versões: inglês, francês e espanhol. O ICOM incentiva a tradução do Código em outras línguas. No entanto, uma tradução só será considerada "oficial" se for aprovada por pelo menos um Comitê Nacional do país no qual a língua é falada, geralmente como a primeira língua. Quando a língua for falada em mais de um país é aconselhável que os Comitês Nacionais destes países sejam consultados. Sugere-se uma atenção especial para a necessidade de excelência profissional e lingüística na elaboração das traduções oficiais. A língua das versões utilizadas para as traduções do Código e os nomes dos Comitês Nacionais envolvidos devem ser indicados. Estas condições não impedem que sejam feitas traduções parciais ou integrais deste Código para uso educativo. 


\section{GLOSSÁRIO}

Atividades geradoras de receitas

Avaliação

Conflito de interesses

Conservador-restaurador

Diligência obrigatória

Direção

Museu

Comércio

Organização sem fins lucrativos

Padrão mínimo

Patrimônio cultural

Patrimônio natural

Procedência

Profissionais de museus
Atividades que objetivem ganho financeiro ou lucro em benefício da instituição.

Autenticação e avaliação de um objeto ou espécime. Em alguns países, o termo é usado para avaliações independentes de bens oferecidos para doação que utilizem benefícios fiscais.

Existência de interesses pessoais ou privados que provoquem contradições de princípios em ambientes de trabalho, interferindo ou parecendo interferir na objetividade das decisões tomadas.

Funcionário de museu ou profissional autônomos capacitado para efetuar a identificação, preservação, conservação e restauração de bens culturais. Maiores informações, no ICOM News 39 (1), p5-6 (1986).

Exigência de que sejam tomadas as providências necessárias para esclarecer os aspectos de um caso antes de serem definidas as medidas a adotar, identificando principalmente a origem e a história de uma obra oferecida para aquisição ou uso, antes de aceitá-la.

Pessoas ou organizações definidas nos regimentos dos museus como responsáveis por sua manutenção, desenvolvimento estratégico e previsão de recursos.

Um museu é uma instituição permanente, sem fins lucrativos, a serviço da sociedade e de seu desenvolvimento, aberta ao público, que adquire, conserva, pesquisa, divulga e expõe, para fins de estudo, educação e lazer, testemunhos materiais e imateriais dos povos e seu ambiente.

Compra ou venda de bens para ganho pessoal ou institucional.

Um organismo legalmente estabelecido fundação ou associação - cuja receita (incluindo superávit ou lucro) é utilizada em benefício de sua própria atividade.

Padrão que deverá ser alcançado por todos os museus e seus profissionais. Alguns países têm normas e regulamentos próprios com padrões mínimos.

Qualquer bem ou conceito considerado de importância estética, histórica, científica ou espiritual.

Qualquer bem natural, fenômeno ou conceito considerado de importância científica ou valor espiritual para uma comunidade.

A história completa da proveniência de um objeto, desde sua descoberta ou criação até o presente, de forma que sua autenticidade e posse possam ser definidas.

Os profissionais de museus envolvem os funcionários de museus ou instituições similares (remunerados ou não), como definido no Artigo 2, parágrafos 1 e 2, dos Estatutos do 
Título de propriedade legal

Título de propriedade válido
ICOM, que tenham formação especializada ou que possuam experiência prática equivalente em qualquer campo necessário à gestão e atividade de um museu, assim como os profissionais autônomos que respeitem o Código de Ética do ICOM e que trabalhem para museus ou instituições como as definidas no estatuto mencionado. Não inclui pessoas que promovam ou trabalhem com produtos comerciais ou equipamentos utilizados em museus e em seus serviços.

Direito de propriedade de um objeto legalmente reconhecido segundo a legislação do país. Em alguns países isto pode consistir em um direito conferido, às vezes considerado insuficiente para as exigências de uma diligência obrigatória.

Direito incontestável de propriedade de um objeto respaldado em sua procedência, desde sua descoberta ou produção.

\section{Os museus preservam, interpretam e promovem aspectos do patrimônio mundial.}

Princípio: Os museus são responsáveis pelo patrimônio natural e cultural, material e imaterial. As direções e os encarregados das estratégias e da coordenação dos museus têm como responsabilidade principal a proteção e a valorização deste patrimônio, assim como prover os recursos humanos, físicos e financeiros necessários para tanto.

\section{DEFINIÇÃO INSTITUCIONAL}

\subsection{Documentos de habilitação}

A direção deve assegurar que o museu tenha um ato constitutivo escrito e registrado - um estatuto ou outro documento reconhecido, conforme as leis nacionais - que expresse claramente a situação jurídica do museu, sua missão, seu caráter permanente e sua natureza (uma organização sem fins lucrativos).

\subsection{Declaração da missão, objetivos e políticas}

A direção deve elaborar, difundir e cumprir um estatuto que defina a missão, os objetivos e a política do museu, assim como o papel e a composição de sua diretoria.

\section{RECURSOS FÍsICOS}

\subsection{Instalações}

A direção deve assegurar instalações e ambiente adequados para que o museu desempenhe as funções básicas definidas em sua missão.

\subsection{Acesso}

A direção deve assegurar que todos tenham pleno acesso ao museu, suas coleções e informações durante horários razoáveis e por períodos regulares. Deve ser dada atenção diferenciada aos portadores de necessidades especiais.

\subsection{Saúde e segurança}

A direção deve assegurar que as normas de saúde, segurança e acessibilidade sejam aplicadas a funcionários e visitantes.

\subsection{Prevenção de riscos}

A direção deve desenvolver e utilizar normas para proteger o público, funcionários, o acervo e outros equipamentos contra acidentes causados pela natureza ou pelo homem. 
A direção deve garantir segurança adequada para as coleções contra furto ou dano, em expositores, mostras, áreas de trabalho, reservas técnicas ou quando em trânsito.

\subsection{Seguro e indenização}

Quando for utilizado um seguro comercial para as coleções, a direção deve garantir que a cobertura seja adequada e que inclua objetos em trânsito, sob empréstimo e outros que possam estar sob a responsabilidade do museu. Quando houver previsão de indenizações é necessário garantir que os materiais que não sejam de propriedade do museu também estejam cobertos.

\section{RECURSOS FINANCEIROS}

\subsection{Finanças}

A direção deve assegurar que haja recursos financeiros suficientes para manter e desenvolver as atividades do museu. A contabilidade dos recursos deve ser feita de forma profissional.

\subsection{Política para geração de receitas}

A direção deve ter diretrizes em relação às fontes de receitas que possam ser geradas através de atividades próprias do museu ou originárias de fontes externas. Independente da origem dos fundos, os museus devem manter o controle sobre o conteúdo e a integridade de seus programas, exposições e atividades. As atividades desenvolvidas para gerar receitas não devem contrariar as normas da instituição ou prejudicar o seu público. (Ver 6.6).

\section{PESSOAL}

\subsection{Política de emprego}

A direção deve assegurar que todas as medidas relativas ao pessoal sejam tomadas de acordo com as normas do museu e com a legislação vigente.

\subsection{Nomeação de diretor ou coordenador}

O diretor ou coordenador de um museu é um posto chave e sua indicação deve levar em consideração o conhecimento e as habilidades específicas que são necessárias para exercer o cargo. Estas qualidades devem incluir capacidade intelectual e experiência profissional específica, além de reconhecido comportamento ético.

\subsection{Acesso às direções}

O diretor ou coordenador de um museu deve ser diretamente responsável por seus atos e ter acesso direto às estruturas administrativas superiores.

\subsection{Capacitação de profissionais de museus}

É indispensável a admissão de profissionais qualificados, com a capacitação necessária para atender ao conjunto das responsabilidades a cargo dos museus. (Veja também $\underline{2.18} ; \underline{2.24} ; \underline{8.12}$ ).

\subsection{Formação de pessoal}

Os profissionais de museus devem ter oportunidades de formação permanente e de atualização profissional para manter a capacitação e eficiência das equipes.

\subsection{Conflito ético}

A direção nunca deve exigir que os profissionais de museus ajam de maneira conflitante com as disposições deste Código de Ética, com a legislação nacional ou com outro código de ética profissional.

\subsection{Profissionais de museus e voluntários}

A direção deve ter normas estabelecidas sobre o trabalho voluntário que promovam o bom relacionamento entre voluntários e funcionários dos museus.

\subsection{Voluntários e ética}

A direção deve assegurar que os voluntários, ao participarem de atividades próprias dos museus, conheçam o Código de Ética, assim como a legislação e os regulamentos vigentes. 


\section{Os museus que mantêm coleções as conservam em benefício da sociedade e de seu desenvolvimento}

Princípio: Os museus têm a responsabilidade de adquirir, preservar e promover suas coleções, contribuindo para salvaguardar o patrimônio natural, cultural e científico. Seus acervos constituem um patrimônio público significativo, têm um estatuto legal especial e são protegidos por legislação internacional. Intrínseco a esta confiança pública está o conceito de guarda, que abrange a propriedade legítima, a permanência, a documentação, o acesso e a alienação responsável.

\section{AQUISIÇÃO DE COLEÇÕES}

\subsection{Política de aquisição}

A direção de cada museu deve instituir e utilizar normas que se refiram à aquisição, preservação e uso das coleções. As normas devem esclarecer a situação dos objetos que não serão registrados, conservados ou expostos. (Veja 2.7;2.8).

\subsection{Título de propriedade válido}

Nenhum objeto ou espécime deve ser adquirido por compra, doação, empréstimo, legado ou intercâmbio, sem que o museu comprove a validade de seu título de propriedade. Um atestado ou um título de propriedade legal reconhecido em determinado país não é necessariamente um título de propriedade válido para museus.

\subsection{Procedência e diligência obrigatória}

Todos os esforços devem ser feitos antes de uma aquisição para garantir que qualquer objeto ou espécime oferecido para a compra, doação, empréstimo, legado ou intercâmbio não tenha sido ilegalmente obtido ou exportado de seu país de origem, ou de qualquer país intermediário, no qual ele possa ter sido adquirido legalmente (incluindo o próprio país do museu). Por isso uma diligência obrigatória deve restabelecer a história completa do objeto desde sua descoberta ou produção.

2.4 Bens e espécimes provenientes de trabalhos não científicos ou não autorizados.

Os museus não devem adquirir bens quando existam indícios de que sua obtenção envolveu dano ou destruição não autorizada, não científica ou intencional de monumentos, sítios arqueológicos, geológicos, espécimes ou ambientes naturais. Da mesma forma, a aquisição não deve ocorrer sem que as autoridades legais ou governamentais e o proprietário ou ocupante da terra estejam cientes das descobertas.

\subsection{Materiais culturalmente "sensíveis"}

Os acervos de remanescentes humanos e de material de caráter sagrado devem ser adquiridos somente se os mesmos puderem ser preservados com segurança, e tratados com respeito. Isto deve ser feito de acordo com padrões profissionais, resguardando os interesses e crenças das comunidades, grupos religiosos ou étnicos dos quais os objetos, quando conhecido, se originaram. (Veja também $3.7 ; \underline{4.3}$ ).

\subsection{Espécimes geológica ou biologicamente protegidos}

Os museus não devem adquirir espécimes biológicos ou geológicos que tenham sido coletados, vendidos ou transferidos em desacordo com a legislação ou tratados locais, nacionais, regionais ou internacionais relativos à proteção da vida animal ou da natureza.

\subsection{Acervos de organismos vivos}

Quando as coleções incluírem espécimes botânicos ou zoológicos vivos, cuidados especiais devem ser tomados em relação ao ambiente natural e social dos quais se originam, assim como em relação à legislação local, nacional, regional, internacional ou aos tratados relativos à proteção da vida animal ou da natureza.

\subsection{Acervos educativos}

As normas para os acervos podem incluir orientações específicas para acervos educativos, onde a ênfase é a preservação de processos culturais, científicos ou técnicos ao invés dos próprios objetos, ou quando os objetos ou espécimes forem preparados para manuseio com função educativa. (Veja também 2.1).

\subsection{Aquisições excepcionais}

A aquisição de objetos ou espécimes fora das normas estabelecidas pelo museu só pode ser feita em 
circunstâncias excepcionais. A direção deve atender às recomendações profissionais disponíveis e à opinião das partes interessadas. Estas recomendações deverão abranger a importância dos objetos ou espécimes para o patrimônio cultural ou natural, assim como o interesse de outros museus em colecionar tais acervos. Mesmo nestas circunstâncias, objetos sem um título de propriedade válido não devem ser adquiridos. (Veja também 3.4).

\subsection{Aquisições por membros da direção e funcionários}

É necessário avaliar cuidadosamente qualquer oferta de objetos, tanto para venda, doação ou outra forma de cessão que permita incentivo fiscal por parte de membros da diretoria, de profissionais do museu, de suas famílias ou de pessoas vinculadas.

\subsection{Depositários em última instância}

Nenhuma disposição deste Código de Ética deve impedir que um museu desempenhe o papel de depositário autorizado de espécimes ou bens de proveniência desconhecida, ilicitamente coletados ou recuperados no território sob sua jurisdição.

\section{ALIENAÇÃO DE COLEÇÕES}

\subsection{Direito de alienação ou outros}

Quando um museu possui normas que permitam alienações, ou quando adquiriu objetos sujeitos a condições especiais de descarte, as exigências e os procedimentos estabelecidos devem ser integralmente cumpridos. Quando a aquisição inicial foi compulsória ou feita em condições especiais, estas exigências devem ser observadas a menos que seu atendimento seja impossível ou prejudicial à instituição e, se for o caso, a autorização deve ser feita de acordo com as normas.

\subsection{Descarte de acervo dos museus}

O descarte de um objeto ou espécime do acervo de um museu só deve ser feito com o pleno conhecimento da importância do mesmo, seu estado (se recuperável ou não recuperável), sua situação legal e a repercussão que pode resultar de tal ação.

\subsection{Responsabilidade pelo descarte}

A decisão de descarte deve ser de responsabilidade da direção, juntamente com o diretor do museu e o curador da coleção em questão. Condições especiais podem ser previstas para acervos de caráter educativo. (Veja 2.7; 2.8).

\subsection{Descarte de objetos retirados das coleções}

Cada museu deve ter normas definindo os procedimentos a serem adotados para o descarte definitivo de um objeto do acervo por meio de doação, transferência, troca, venda, repatriação ou destruição, que permita a transferência de propriedade sem restrições para a entidade beneficiária. Relatórios detalhados de todos os processos de descarte devem ser conservados, registrando os objetos envolvidos e o seu destino. Como regra geral, todo acervo descartado deve ser preliminarmente oferecido a um outro museu.

\subsection{Renda da alienação de coleções}

As coleções de museus são mantidas sob proteção pública e não podem ser tratadas como mercadorias. Os recursos ou compensações recebidas da alienação ou transferência de objetos ou espécimes do acervo de um museu devem ser usados somente em benefício do mesmo e, principalmente, para novas aquisições.

\subsection{Compra de coleções alienadas}

Não deve ser permitido que profissionais de museus, direções, seus familiares ou vinculados adquiram objetos que tenham sido descartados de acervos pelo quais eram responsáveis.

\section{PRESERVAÇÃO DEACERVOS}

\subsection{Permanência de acervos}

O museu deve estabelecer e aplicar normas para garantir que seu acervo (tanto permanente quanto temporário) e as informações associadas sejam devidamente registrados, estejam disponíveis para uso corrente e possam ser repassados para as gerações futuras nas melhores condições possíveis, considerando o conhecimento e os recursos contemporâneos disponíveis. 


\subsection{Delegação da responsabilidade das coleções}

A responsabilidade profissional envolvendo a preservação de acervos deve ser atribuída a pessoas com conhecimento e habilidade compatíveis, ou que sejam adequadamente supervisionadas. (Veja também 8.11).

\subsection{Documentação das coleções}

As coleções dos museus devem ser documentadas de acordo com padrões profissionais. Esta catalogação deve incluir uma identificação e descrição completa de cada item, seu contexto, procedência, estado de conservação, tratamento e localização atual. Estes registros devem ser mantidos em ambiente seguro e estar apoiados por sistemas de recuperação que permitam o acesso aos dados por funcionários e outros usuários habilitados.

\subsection{Proteção contra calamidades}

Atenção especial deve ser dada ao desenvolvimento de políticas para a proteção das coleções durante conflitos armados e outros desastres causados pela natureza ou pelo homem.

\subsection{Segurança de acervos e de informações}

O museu deve tomar cuidados para evitar a revelação de informações pessoais delicadas ou relacionadas a assuntos confidenciais, quando os dados dos acervos forem disponibilizados ao público.

\subsection{Conservação preventiva}

A conservação preventiva é um elemento importante na política de preservação de acervos dos museus. É responsabilidade básica dos profissionais dos museus prover e manter ambientes adequados para a preservação das coleções sob sua guarda, tanto em reserva técnica, como em exposição ou trânsito.

\subsection{Conservação e restauração de acervos}

O museu deve monitorar o estado de conservação dos acervos para poder determinar quando um objeto ou espécime necessita trabalhos de preservação, restauração ou serviços especializados de um conservador/ restaurador. O principal objetivo neste sentido deve ser o da estabilização da degradação do objeto ou espécime. Todos os procedimentos de conservação devem ser documentados e na medida do possível, reversíveis, assim como todas as intervenções devem ser claramente identificadas.

\subsection{Bem estar de animais vivos}

Um museu que mantiver animais vivos deve assumir plena responsabilidade por sua saúde e bem estar. Deve elaborar e adotar normas de segurança, aprovadas por especialistas em veterinária, para a proteção de seus profissionais e visitantes, assim como dos animais. Qualquer modificação genética deve ser claramente identificável.

\subsection{Uso pessoal dos acervos de museus}

Não deve ser permitido aos profissionais de museus, à direção, suas famílias, pessoas vinculadas ou outros se apropriarem de objetos da coleção do museu para uso pessoal, mesmo que temporário.

\section{Os museus conservam referências primárias para a criação e o aprofundamento do conhecimento}

Princípio: Os museus têm responsabilidades específicas com a sociedade em conseqüência da tutela, disponibilidade e interpretação das referências primárias reunidas e conservadas em seus acervos.

\section{REFERÊNCIAS PRIMÁRIAS}

\subsection{Acervos como referências primárias}

A política de aquisição de acervo do museu deve salientar a importância das coleções como fontes primárias de informações. Na prática, deve-se evitar que isto seja definido por tendências intelectuais circunstanciais ou pela rotina do museu.

\subsection{Disponibilidade das coleções}

Os museus têm a responsabilidade de dar pleno acesso às suas coleções e às informações 
existentes, respeitando restrições decorrentes de razões confidenciais ou de segurança.

\section{AQUISIÇÃO E PESQUISA EM MUSEUS}

\subsection{Coletas de campo}

Os museus que promovem coletas de campo devem desenvolver práticas condizentes com padrões acadêmicos, atendendo à legislação nacional, internacional e os tratados existentes sobre a matéria. Trabalhos de campo só devem ser empreendidos com o devido respeito e consideração pelas comunidades locais, seus recursos ambientais, práticas culturais e esforços para valorizar o patrimônio natural e cultural.

\subsection{Coleta excepcional de referências primárias}

Em casos excepcionais, um objeto sem procedência determinada pode ter valor intrínseco tão importante para o conhecimento que seja de interesse público preservá-lo. A aceitação de um objeto desta natureza na coleção de um museu deve ser decidida por especialistas no assunto em questão, sem preconceitos nacionais ou internacionais. (Veja também 2.11).

\subsection{Pesquisas}

As pesquisas efetuadas por profissionais de museus devem estar relacionadas aos propósitos e objetivos do mesmo, além de obedecer às normas legais, éticas e acadêmicas.

\subsection{Análises destrutivas}

Quando técnicas analíticas destrutivas forem empreendidas, uma documentação completa do material analisado, dos resultados e das pesquisas efetuadas, incluindo publicações, deve integrar o registro permanente do objeto.

\subsection{Remanescentes humanos e materiais de caráter sagrado}

A pesquisa em remanescentes humanos e em materiais de caráter sagrado deve ser realizada de acordo com padrões profissionais, considerando os interesses e as crenças da comunidade e dos grupos étnicos e religiosos dos quais os bens se originaram, sempre que isto for conhecido. (Veja também $2.5 ; \underline{4.3}$ ).

\subsection{Reserva de direitos de pesquisas}

Quando profissionais de museus preparam materiais para uma exposição ou para documentar pesquisa de campo deve haver um termo de acordo claro com o museu patrocinador sobre todos os direitos relativos ao trabalho realizado.

\subsection{Conhecimento público}

Os profissionais de museus têm obrigação de compartilhar seus conhecimentos e experiências relevantes com colegas, bolsistas ou alunos. Devem respeitar e reconhecer aqueles com os quais aprenderam e devem repassar os avanços técnicos e as experiências que possam ser úteis a outras pessoas.

\subsection{Cooperação entre museus e outras instituições}

Profissionais de museus devem reconhecer e apoiar a necessidade de cooperação e intercâmbio entre instituições com interesses e políticas de aquisição similares. Principalmente com instituições de educação superior e serviços públicos, em que a pesquisa possa gerar acervos importantes, mas onde para os quais não existam condições de preservação em longo prazo.

\section{Os museus possibilitam a valorização, o entendimento e a promoção do patrimônio natural e cultural}

Princípio: Os museus têm o importante dever de promover seu papel educativo, de atrair e ampliar a visitação da sua comunidade, localidade ou grupo que representa. Ainteração com a comunidade e a promoção de seu patrimônio são parte integrante do papel educativo dos museus.

\section{MOSTRAS E EXPOSIÇÕES}

\subsection{Mostras, exposições e atividades especiais}

Mostras e exposições temporárias, físicas ou eletrônicas, devem estar de acordo com a missão, a 
política e os objetivos do museu. Não devem comprometer a qualidade, a preservação e ou a conservação das coleções.

\subsection{Interpretação das exposições}

Os museus devem garantir que a informação que apresentam em mostras ou exposições esteja bem fundamentada, precisa e que aborde corretamente os grupos e crenças representados.

\subsection{Exposição de materiais "sensíveis"}

Remanescentes humanos e materiais de caráter sagrado precisam ser expostos de acordo com padrões profissionais, levando em consideração, quando conhecidos, os interesses e as crenças dos membros da comunidade, grupos religiosos ou étnicos, dos quais os bens se originaram. Eles devem ser expostos com cuidado e respeito, sem ferir a dignidade humana de qualquer grupo social.

\subsection{Remoção de exposição pública}

As solicitações para a retirada da exposição pública dos remanescentes humanos ou de materiais de caráter sagrado, feitas pelas comunidades de onde estes bens se originaram, devem ser tratadas com cuidado, respeito e sensibilidade. Pedidos para devolução deste tipo de material devem ser tratados da mesma forma. As normas do museu devem definir claramente os procedimentos para atender a estes pedidos.

4. 5 Exposição de material semprocedência Os museus devem evitar mostrar ou utilizar material de origem questionável ou sem procedência definida. Devem estar cientes que a exposição ou utilização destes objetos pode ser considerada como um indulto e contribuir para o tráfico de bens culturais.

\section{OUTROS RECURSOS}

\subsection{Publicações}

A informação promovida por museus, por qualquer mídia, deve estar bem fundamentada, precisa e também considerar, com responsabilidade, as questões científicas, as sociedades ou crenças apresentadas. As publicações dos museus não devem comprometer os padrões institucionais.

\subsection{Reproduções}

Os museus devem respeitar a integridade do objeto original quando forem feitas cópias, réplicas ou reproduções de peças das coleções. Todas estas cópias devem ser marcadas como reproduções de maneira durável.

\section{Os recursos dos museus possibilitam a prestação de outros serviços de interesse público}

Princípio: Os museus utilizam uma variedade de especializações, habilidades e recursos materiais que têm aplicações muito maiores que em seu próprio âmbito. Isto permite aos museus compartilhar seus recursos e prestar outros serviços públicos como atividades de extensão. Estes serviços devem ser realizados de forma a não comprometer a missão do museu.

\section{SERVIÇOS DE IDENTIFICAÇÃO}

\subsection{Identificação de objetos ilicitamente adquiridos}

Quando os museus prestam serviços de identificação, não devem proceder de maneira que possam ser acusados de tirar proveito, direta ou indiretamente, desta atividade. A identificação e autenticação de objetos que se considere ou suspeite de terem sido adquiridos, transferidos, importados ou exportados de forma ilegal, não deve ser divulgada antes que as autoridades competentes sejam notificadas.

\subsection{Autenticação e avaliação}

Os museus podem fazer avaliações para o seguro de seus acervos. Informações sobre o valor monetário de outros objetos só devem ser dadas sob requisição formal de outros museus ou de autoridades públicas, legalmente competentes. Entretanto, quando o museu for o beneficiário de uma obra ou espécime, sua avaliação deve ser feita por consultoria independente. 


\section{assim como com aquelas às quais prestam serviços}

Princípio: Os acervos dos museus refletem o patrimônio natural e cultural das comunidades de onde provêm. Desta forma, eles podem ter valores que vão além dos objetos e podem envolver referências à identidade nacional, regional, local, étnica, religiosa ou política. Conseqüentemente, é importante que as atividades dos museus observem estas possibilidades.

\section{ORIGEM DAS COLEÇÕES}

\subsection{Cooperação}

Os museus devem promover o intercâmbio de conhecimentos, documentação e coleções com museus e organizações culturais dos países e comunidades de onde estes provêm. A possibilidade de estabelecer parcerias com museus em países ou áreas que tenham perdido parte significativa de seu patrimônio deve ser avaliada.

\subsection{Devolução de bens culturais}

Os museus devem estar preparados para iniciar a discussão sobre a devolução de bens culturais aos países ou povos de onde se originem. Isto deve ser feito de maneira imparcial, baseada preferencialmente em princípios científicos, profissionais ou humanitários e na legislação local, nacional e internacional vigente, ao invés de ações governamentais ou políticas.

\subsection{Restituição do patrimônio cultural}

Quando um país ou povo busca a restituição de um bem cultural ou natural que tenha sido exportado ou transferido em desacordo com os princípios estabelecidos nas convenções nacionais e internacionais, (desde que isto possa ser comprovado), o museu envolvido, se for legalmente autorizado, deve tomar as providências necessárias para viabilizar a restituição.

\subsection{Bens culturais de um país ocupado}

Os museus devem se abster de comprar ou adquirir bens culturais de um território militarmente ocupado e respeitar integralmente as leis e convenções que dispõem sobre a importação, exportação e transferência de bens culturais ou naturais.

\section{RESPEITO ÀS COMUNIDADES ONDE SE PRESTAM SERVIÇOS}

\subsection{Comunidades contemporâneas}

Nos locais onde as atividades do museu envolverem comunidades existentes ou seu patrimônio, as aquisições só devem ser feitas de comum acordo, sem que se explore o proprietário ou informante. $\mathrm{O}$ respeito à vontade da comunidade envolvida deve prevalecer.

\subsection{Financiamento de serviços comunitários}

A busca de recursos para desenvolvimento de atividades que envolvam comunidades contemporâneas, não deve prejudicar seus interesses. (Veja 1.10).

\subsection{Uso de acervos de comunidades contemporâneas}

$\mathrm{O}$ tratamento pelos museus de acervos de comunidades existentes requer respeito pela dignidade humana e pelas tradições e culturas que os utilizam. Estes acervos devem ser utilizados para promover o bem estar humano, o desenvolvimento social, a tolerância e o respeito pela defesa de expressão multisocial, multicultural e multilinguística. (Veja 4.3).

\subsection{Apoio das organizações da comunidade}

Os museus devem criar condições favoráveis para receber apoio comunitário (ex.: associações de amigos de museus e outras entidades). Devem reconhecer a importância destas parcerias e incentivar o relacionamento harmônico entre as comunidades e os profissionais dos museus.

\section{Os museus funcionam de acordo com as leis}

Princípio: Os museus devem funcionar de acordo com a legislação internacional, regional ou local e com compromissos decorrentes de tratados. Além disso, a direção deve cumprir todas as responsabilidades legais ou quaisquer condições relativas aos diferentes aspectos do museu, seu funcionamento e acervo. 


\section{ESTRUTURAL LEGAL}

\subsection{Legislação local e nacional}

Os museus devem atender à legislação nacional e local e respeitar as normas de outros países na medida em que elas interfiram em seu funcionamento.

\subsection{Legislação internacional}

As ações dos museus devem reconhecer a legislação internacional listada abaixo, que é utilizada como referência na aplicação do Código de Ética do ICOM:

- $\quad$ UNESCO - Convenção para a Proteção do Patrimônio Cultural em caso de Conflito Armado (A Convenção de Haia, Primeiro Protocolo, 1954, e Segundo Protocolo, 1999);

- UNESCO - Convenção sobre a Forma de Proibir e Prevenir a Importação, Exportação e Transferência de Bens Culturais llícitos (1970);

- Convenção sobre o Comércio Internacional de Espécies em Extinção da Fauna e Flora Silvestres (1973);

- UN Convenção sobre Diversidade Biológica (1992);

- Unidroit - Convenção sobre Bens Culturais Roubados e llegalmente Exportados (1995);

- UNESCO - Convenção sobre a Proteção do Patrimônio Cultural Submarino (2001);

- UNESCO - Convenção para a Salvaguarda do Patrimônio Cultural Imaterial (2003).

\section{Os museus atuam profissionalmente.}

Princípio: Os profissionais de museus devem observar as normas e a legislação vigente, manter a dignidade e honrar sua profissão. Devem proteger o público contra comportamentos profissionais ilegais ou antiéticos. Todas as oportunidades devem ser aproveitadas para educar e informar ao público a respeito da missão, objetivos e aspirações da profissão museal a fim de desenvolver um melhor entendimento público sobre a contribuição dos museus para a sociedade.

\section{CONDUTA PROFISSIONAL}

\subsection{Familiaridade com a legislação vigente}

Todo profissional de museu deve estar familiarizado com a legislação internacional, nacional e local vigente e com as condições de prestação de serviços. Deve evitar situações que possam ser interpretadas como condutas profissionais indevidas.

\subsection{Responsabilidade profissional}

Os profissionais de museus têm a obrigação de seguir as políticas e as normas da instituição empregadora. Entretanto, eles podem perfeitamente se opor às práticas que pareçam prejudiciais ao museu, à profissão e à ética profissional.

\subsection{Conduta profissional}

Lealdade aos colegas e ao museu empregador é uma importante responsabilidade profissional e deve ser baseada em fidelidade aos princípios éticos fundamentais aplicáveis à profissão como um todo. Os profissionais devem obedecer aos dispositivos do Código de Ética do ICOM e conhecer os códigos e políticas aplicáveis ao trabalho em museus.

\subsection{Responsabilidades acadêmicas e científicas}

Os profissionais de museus devem desenvolver a pesquisa, preservação e uso de informações referentes às coleções. Portanto, eles devem abster-se de executar qualquer atividade ou envolverse em circunstâncias que possam resultar em perdas de informações acadêmicas e científicas.

\subsection{Tráfico}

Os profissionais de museus não devem apoiar o tráfico ou comércio ilícito de bens naturais e culturais, direta ou indiretamente.

\subsection{Confidencialidade}

Os profissionais de museus deve manter em sigilo informações confidenciais obtidas em função de seu trabalho. Além disso, as informações sobre objetos levados ao museu para identificação são 
confidenciais e não devem ser divulgadas ou repassadas para qualquer pessoa ou instituição sem a expressa autorização do proprietário.

\subsection{Segurança dos museus e dos acervos}

Informações sobre sistemas de segurança do museu, de coleções particulares e de locais reservados que se conheçam no desempenho de funções devem ser mantidos em absoluto sigilo pelos profissionais de museus.

\subsection{Exceção à obrigação de confidencialidade}

O princípio da confidencialidade fica subordinado à obrigação legal de apoiar a polícia ou outra autoridade competente na investigação de bens suspeitos de furto, aquisição ou transferência ilegal.

\subsection{Independência pessoal}

Ainda que um profissional tenha direito à independência pessoal, ele deve reconhecer que nenhum negócio privado ou interesse profissional possam estar completamente desvinculados da instituição empregadora.

\subsection{Relações profissionais}

Os profissionais de museus estabelecem relações de trabalho com numerosas pessoas dentro e fora do museu onde trabalham. É esperado que prestem seus serviços profissionais de forma eficiente e eficaz.

\subsection{Consulta profissional}

É uma responsabilidade profissional consultar outros colegas dentro e fora do museu quando o conhecimento disponível for insuficiente para assegurar uma decisão eficaz.

\section{CONFLITOS DE INTERESSE}

\subsection{Presentes, favores, empréstimos ou outros benefícios pessoais}

Profissionais de museus não devem aceitar presentes, favores, empréstimos ou outros benefícios pessoais que possam ser oferecidos devido às funções que desempenhem. Ocasionalmente, pode ocorrer a doação e o recebimento de presentes por cortesia profissional, mas isto deve ocorrer sempre em nome da instituição envolvida.

\subsection{Empregos externos ou interesse em negócios}

Profissionais de museus, apesar de terem o direito a uma relativa independência pessoal devem entender que nenhum negócio privado ou interesse particular pode estar completamente separado da instituição empregadora. Não devem ter outro emprego remunerado ou aceitar comissões externas que sejam, ou possam ser consideradas, incompatíveis com os interesses do museu.

\subsection{Comércio de patrimônio natural e cultural}

Profissionais de museus não devem participar direta ou indiretamente do comércio (compra ou venda para obtenção de lucro) de bens do patrimônio natural ou cultural.

\subsection{Relações com comerciantes}

Profissionais de museus não devem aceitar presentes, hospedagem ou qualquer forma de recompensa de um comerciante, leiloeiro ou outra pessoa, como indução à compra ou alienação de bens do museu ou para efetuar ou evitar uma ação judicial. Além disso, profissionais de museus não devem indicar comerciantes, leiloeiros ou avaliadores específicos para pessoas físicas.

\subsection{Coleções privadas}

Profissionais de museus não devem competir com sua instituição na aquisição de bens ou em qualquer atividade de coleta pessoal. No caso de atividades privadas de coleta, a direção e o profissional do museu devem estabelecer compromissos que devem ser cumpridos integralmente.

\subsection{Uso do nome e do logo do ICOM}

Os membros do ICOM não podem utilizar a denominação "Conselho Internacional de Museus", "ICOM" ou o seu logotipo, para promover ou apoiar qualquer atividade ou produto com fins lucrativos.

\subsection{Outros Conflitos de Interesse}

Na eventualidade da ocorrência de conflitos de interesse entre um indivíduo e o museu, os interesses do museu devem prevalecer. 


\section{ROTEIRO PARA O PLANO DIRETOR}

\begin{tabular}{|c|c|}
\hline ESTRATÉGIA & $\begin{array}{l}\text { Focalizar as ESTRATÉGIAS realmente importantes para o sucesso do museu a longo prazo: é importante que a " "missầo"t" e } \\
\text { as estratégias para atingi-la sejam claramente elaboradas. }\end{array}$ \\
\hline INTEGRAÇÃO & Todas as atividades essenciais do museu devem ser INTEGRADAS num único plano diretor. \\
\hline SINTESE & $\begin{array}{l}\text { O documento deve ser concentrado nas questōes ESSENCIAIS, pois: } \\
\text { a) um documento sintético é mais facilmente usado no cotidiano } \\
\text { b) comunica de forma sucinta as intenções e aspirậós aos parceiros (internos e externos) } \\
\text { c) um plano mais sucinto tem mais probabilidades de ser lido. }\end{array}$ \\
\hline CLAREZA & $\begin{array}{l}\text { Deve definir CLARAMENTE os objetivos para o ano em curso e como eles serão alcançados: } \\
\text { a)Como será alcançado, ou scja, qual a estratégia? } \\
\text { b)Quais os recursos disponiveis para sua realização? } \\
\text { c) Quem (pessoas/setor) é responsável por sua concretizaçào? } \\
\text { d) Qual o prazo para sua concretização? } \\
\text { e)Que indicadores/medidas serão usados para monitorar o progresso do objetivo estipulado? }\end{array}$ \\
\hline REALISMO & $\begin{array}{l}\text { O nủmero de metas e objetivos deve ser limitado àquilo que possa ser REALIŻ̉VEL, tendo a clareza de não ser excessivamente } \\
\text { ambicioso, mas também nâo limitar-se por causa de pequenas dificuldades. }\end{array}$ \\
\hline COERÊNCIA & Os objetivos devem estar COERENTEMENTE relacionados à missão ou finalidade do museu. \\
\hline PRAZO & $\begin{array}{l}\text { Na maior parte dos casos, um plano diretor abrange um periodo entre } 2 \text { a } 5 \text { anos. A duraçầ mais apropriada irá variar de } \\
\text { uma instituiçâo para outra. Instituiçōes mantidas com recursos públicos normalmente têm base anual de recursos, sendo } \\
\text { assim é complexo estabelecer um PRAZO muito longo; aconselha-se o uso de uma margem de } 2 \text { a } 3 \text { anos. É essencial que o } \\
\text { plano diretor seja revisado anualmente. }\end{array}$ \\
\hline
\end{tabular}




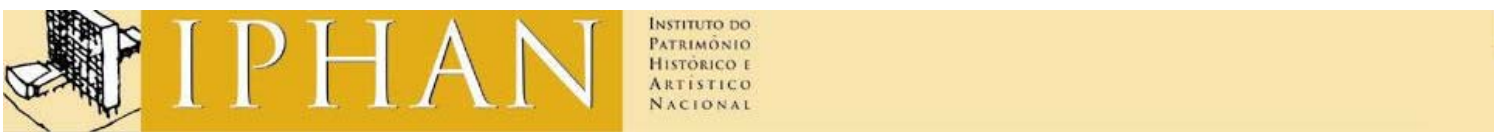

Portaria Normativa $n^{\circ}$ 1, de 5 de julho de 2006 (DOU de 11/07/2006)

Dispõe sobre a elaboração do Plano Museológico dos museus do Instituto do Patrimônio Histórico e Artístico Nacional, e dá outras providências.

O Presidente do Instituto do Patrimônio Histórico e Artístico Nacional (IPHAN), no uso de suas atribuições legais e regimentais, especialmente no disposto no inciso V do art. 21 do Anexo I do Decreto no 5.040, de 07 de abril de 2004, e na Portaria IPHAN n 302, de 07 de julho de 2004, e considerando a necessidade de organização da gestão dos museus do IPHAN, capaz de propiciar o estabelecimento de maior racionalidade e eficiência do fazer museal; resolve:

Art. $1^{\circ}$ Instituir parâmetros gerais de organização da gestão das instituições museológicas do IPHAN, compreendendo o Plano Museológico como ferramenta básica de planejamento estratégico, de sentido global e integrador, indispensável para a identificação da missão da instituição museal e para a definição, o ordenamento e a priorização dos objetivos e das ações de cada uma de suas áreas de funcionamento.

Parágrafo único. Por seu caráter político, técnico e administrativo, o Plano Museológico é instrumento fundamental para a sistematização do trabalho interno e para a atuação do museu na sociedade.

Art. $2^{\circ}$ O Plano Museológico trata de estabelecer a missão e os programas do museu, as suas diretrizes de funcionamento e as orientações necessárias para o desenvolvimento de projetos e atividades específicos.

Art. $3^{\circ}$ A elaboração do Plano Museológico baseia-se em diagnóstico completo da instituição, levando em conta os pontos fortes e frágeis, as ameaças e oportunidades, os aspectos socioculturais, políticos, técnicos, administrativos e econômicos pertinentes à atuação do museu.

Parágrafo único. O diagnóstico, de caráter participativo, é parte integrante do Plano Museológico, que deve ser apresentado de forma clara e precisa, contando na sua elaboração com a atuação direta da equipe do museu, além de colaboradores externos.

Art. $4^{\circ}$ Os projetos que compõem os programas do Plano Museológico têm como características:

I - A exeqüibilidade e a adequação às especificações dos programas distintos, inclusive o cronograma de execução.

II - A explicitação da metodologia adotada.

III - A descrição das ações planejadas.

IV - A indicação de um sistema de avaliação permanente.

Art. $5^{\circ} \mathrm{O}$ Plano Museológico adotado para os museus do IPHAN é composto pelas seguintes partes: seus do IPHAN é composto pelas seguintes partes:

I - Identificação da Instituição:

a) Definição operacional, com apresentação das características gerais da instituição, destacando sua trajetória e histórico de suas coleções e de seu território. 
b) Identificação da missão, com apresentação da missão, do campo de atuação, da função social, da missão, do campo de atuação, da função social, das metas e objetivos da instituição.

\section{II - Programas:}

a) Programa institucional, aquele que trata do desenvolvimento e da gestão política, técnica e desenvolvimento e da gestão política, técnica e administrativa do museu.

b) Programa de gestão de pessoas, aquele que apresenta as ações destinadas à valorização, capacitação senta as ações destinadas à valorização, capacitação e bem estar do conjunto de trabalhadores do museu, e bem estar do conjunto de trabalhadores do museu, independentemente do tipo de contratação, assim independentemente do tipo de contratação, assim como aponta um diagnóstico da situação funcional como aponta um diagnóstico da situação funcional existente e das necessidades de ampliação do quadro existente e das necessidades de ampliação do quadro de pessoal, incluindo estagiários e servidores. de pessoal, incluindo estagiários e servidores.

c) Programa de acervos, aquele que organiza o gerenciamento dos diferentes tipos de acervos da instituição, incluindo os de origem arquivística e bibliográfica, podendo ser dividido em diferentes bibliográfica, podendo ser dividido em diferentes subprogramas, tais como: aquisição, documentação, subprogramas, tais como: aquisição, documentação, conservação e restauração.

d) Programa de exposições, aquele que trata de todos os espaços e processos de exposição do todos os espaços e processos de exposição do museu, sejam eles intra ou extramuros, de média ou curta duração.

e) Programa educativo e cultural, aquele que compreende os projetos e atividades educativo-culturais desenvolvidos pelo museu, destinados a diferentes desenvolvidos pelo museu, destinados a diferentes públicos e articulados com diferentes instituições.

f) Programa de pesquisa, aquele que contempla o processamento e a disseminação de informações, processamento e a disseminação de informações, destacando as linhas de pesquisa institucional e destacando as linhas de pesquisa institucional e de projetos voltados para estudos de público, de projetos voltados para estudos de público, de patrimônio cultural, de museologia, da história institucional e de outros estudos.

g) Programa arquitetônico, aquele que trata da identificação, da conservação e da adequação dos espaços livres e construídos, bem como das áreas de entorno livres e construídos, bem como das áreas de entorno da instituição, contendo descrição dos espaços e da instituição, contendo descrição dos espaços e instalações, além de informar sobre os aspectos de instalações, além de informar sobre os aspectos de acessibilidade, conforto ambiental, circulação, identidade visual e possibilidades de expansão.

h) Programa de segurança, aquele que trata de todos os aspectos relacionados à segurança do museu, da edificação, do acervo e dos públicos interno e externo, incluindo, além de sistemas, equipamentos e instalações, a definição de rotinas de segurança e estratégias de emergência.

i) Programa de financiamento e fomento, aquele que trata do planejamento de estratégias voltadas para captação, aplicação e gerenciamento dos recursos

econômicos oriundos de diversas fontes. 
j) Programa de difusão e divulgação, aquele que trata da divulgação e popularização dos projetos e atividades da instituição, além da disseminação, difusão e consolidação da imagem institucional nos âmbitos local, regional, nacional e internacional; podendo ser dividido em diferentes subprogramas, tais como: editorial, de intercâmbio institucional, de comunicação social, de comunicação visual e outros.

Parágrafo único. Na consolidação do Plano Museológico deve-se considerar o caráter transversal dos Programas.

Art. $6^{\circ}$ O Plano Museológico, por seu caráter interdisciplinar, será elaborado de forma participativa, envolvendo o conjunto dos servidores do museu e de outras áreas do IPHAN, além de especialistas e consultores externos.

Art. $7^{\circ} \mathrm{O}$ Plano Museológico deverá ser avaliado permanentemente e revisado com um intervalo mínimo de 3 (três) e máximo de 5 (cinco) anos.

Art. $8^{\circ}$ A elaboração e a revisão do Plano Museológico devem estar em consonância com as diretrizes da Política Nacional de Museus, instituída pelo Ministério da Cultura.

Art. $9^{\circ} \mathrm{O}$ Departamento de Museus e Centros Culturais do IPHAN supervisionará a elaboração e a execução dos Planos Museológicos.

Art. $10^{\circ}$ Os museus do IPHAN elaborarão ou adaptarão seus Planos Museológicos no prazo máximo de 1 (um) ano, a contar da data de publicação desta Portaria.

Art. $11^{\circ}$ Esta Portaria entra em vigor na data de sua publicação.

LUIZ FERNANDO DE ALMEIDA 


\section{ACERVO MAC USP - adquiridas em 1964}

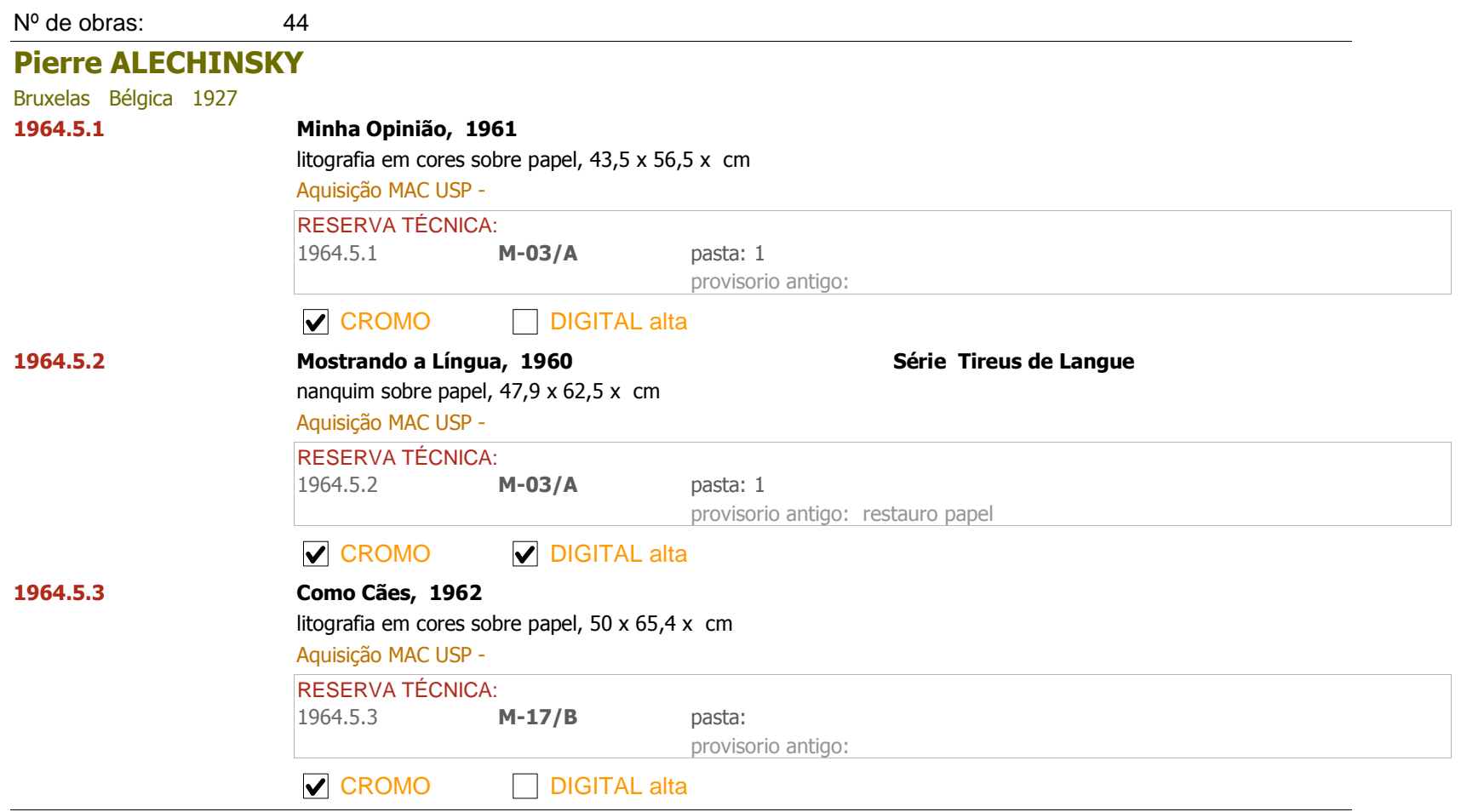

\section{Antonio Henrique AMARAL}

São Paulo, SP Brasil 1935 1964.5.4

Desenho no 5, 1962

nanquim sobre papel, $50,5 \times 70 \times \mathrm{cm}$

Aquisição MAC USP -

RESERVA TÉCNICA:

\begin{tabular}{lll} 
1964.5.4 & M-09/A & pasta: 1 \\
& provisorio antigo: \\
$\square$ CROMO \\
\hline DIGITAL alta
\end{tabular}

\section{Vera Chaves BARCELLOS}

Porto Alegre, RS Brasil 1938

\subsection{Abstração de Noite, 1964}

xilografia em cores sobre papel, $38,5 \times 32 \times \mathrm{cm}$

Aquisição MAC USP -

RESERVA TÉCNICA:

1964.32 M-14/C pasta:

provisorio antigo: expo ENTRE ATOS

\section{Edith BEHRING}

Rio de Janeiro, RJ Brasil 1916

Gravura I, 1955

Rio de Janeiro, RJ Brasil 1996

água-tinta sobre papel, $65,4 \times 50,2 \times \mathrm{cm}$

Aquisição MAC USP -

RESERVA TÉCNICA:
1964.24.1
$\mathrm{M}-03 / \mathrm{C}$
pasta: 1
provisorio antigo:

1964.24 .2

\section{CROMO $\square$ DIGITAL alta}

Gravura II, 1957

água-forte e água-tinta em cores sobre papel, $50,5 \times 65,5 \times \mathrm{cm}$

Aquisição MAC USP -

RESERVA TÉCNICA:

1964.24.2 M-03/C pasta: 1

provisorio antigo:

CROMO $\square$ DIGITAL alta 


\section{Orixá, 1961}

São Paulo, SP Brasil 1965

pena, papel, semente, espinha de peixe, espelho e guache sobre cartão sobre tecido, $72 \times 61,5 \times \mathrm{cm}$

Aquisição MAC USP -

\begin{tabular}{|c|c|c|}
\hline \multicolumn{3}{|c|}{ RESERVA TÉCNICA: } \\
\hline 1964.5 .9 & P-084/A & $\begin{array}{l}\text { pasta: } \\
\text { provisorio antigo: sala } 4 \text { - guardar }\end{array}$ \\
\hline
\end{tabular}

\section{Alan DAVIE}

Grangemouth Escócia 1920

1964.5.10 Jogo de Bili no 2, 1962

óleo sobre tela, $182,2 \times 151,3 \times \mathrm{cm}$

Aquisição MAC USP - Prêmio Regulamentar Pintura Estrangeira VII Bienal de São Paulo, 1963

RESERVA TÉCNICA:

1964.5.10 P-074/A pasta:

provisorio antigo: expo IBIRA MODERNISMOS

José GAMARRA

Tacuarembo Uruguai 1934 1964.5.11

\section{Pintura 63.502, 1963}

óleo sobre tela, $129,9 \times 150,2 \times \mathrm{cm}$

Aquisição MAC USP -

RESERVA TÉCNICA:

1964.5.11 P-045/B pasta:

provisorio antigo: expo MEMORIAL

$\checkmark$ CROMO $\square$ DIGITAL alta

\section{JAGOBO PAN}

Barcelona Espanha 1922

1964.24.6

\section{"Vivencies", 1963}

Campos do Jordão, SP Brasil 1996

óleo e nanquim sobre tela, $73,3 \times 92 \times \mathrm{cm}$

Aquisição MAC USP -

RESERVA TÉCNICA:

1964.24.6 P-059/B pasta:

provisorio antigo:

CROMO $\square$ DIGITAL alta

\section{Tomoshige KUSUNO}

Yubari Japão 1935

1964.19.1

Página 3, 1964

óleo, gesso, palha de aço e tecido sobre aglomerado de madeira, $110 \times 79,7 \times \mathrm{cm}$

Aquisição MAC USP -

RESERVA TÉCNICA:

$\begin{array}{lll}\text { 1964.19.1 } & \text { P-089/A } & \text { pasta: } \\ & \text { provisorio antigo: expo ENTRE ATOS }\end{array}$

$\checkmark$ CROMO $\square$ DIGITAL alta

Wesley Duke LEE

São Paulo, SP Brasil 1931 1964.24.7

\section{São Paulo, SP Brasil 2010}

\section{"Arkadin d'y Saint Amer", 1962/64}

tinta pvc, pastel e folha de ouro sobre papel sobre tela, $157,3 \times 157,6 \times \mathrm{cm}$

Aquisição MAC USP -

RESERVA TÉCNICA:

\begin{tabular}{|c|c|c|}
\hline 1964.24.7 & P-044/B & $\begin{array}{l}\text { pasta: } \\
\text { provisorio antigo: expo SEDE }\end{array}$ \\
\hline
\end{tabular}

\section{Zbigniew MAKOWSKI}

Varsóvia Polônia 1930 1964.5.12

\section{Espinhos n 2, 1962}

nanquim sobre papel sobre madeira, $58,5 \times 84,3 \times \mathrm{cm}$

Aquisição MAC USP -

RESERVA TÉCNICA:

1964.5.12 P-

pasta:

P-105/A - definir trainel

provisorio antigo: restauro papel

\section{CROMO \\ $\square$ DIGITAL alta}




\section{Vladmir MAKUC}

Solkan Pri Gorici Iugoslávia 1925

1964.5.13

\section{Galo Negro, 1962}

água-forte e água-tinta em cores sobre papel, 39,9 x 53,3 x cm

Aquisição MAC USP -

RESERVA TÉCNICA:

1964.5.13 M-06/C pasta: 1

provisorio antigo:

1964.5.14

$\checkmark$ CROMO $\square$ DIGITAL alta

\section{Asno, 1962}

água-forte e água-tinta em cores sobre papel, 50,5 x 65,8 x cm

Aquisição MAC USP -

RESERVA TÉCNICA:

1964.5.14 M-06/C pasta: 1

provisorio antigo:

$\checkmark$ CROMO $\square$ DIGITAL alta

\section{Anita MALFATTI}

São Paulo, SP Brasil 1889 1964.5.15

Torso / Ritmo, 1915/16

São Paulo, SP Brasil 1964

carvão e pastel sobre papel, $61 \times 46,6 \times \mathrm{cm}$

Aquisição MAC USP - Adquirida na VII Bienal de São Paulo, 1963

RESERVA TÉCNICA:

1964.5.15 P-107/A pasta: expo LASAR SEGALL

provisorio antigo: expo CCBB RIO DE JANEIRO

$\boldsymbol{V}$ CROMO $\boldsymbol{V}$ DIGITAL alta

\section{Eugeniusz MARKOWSKI}

Varsóvia Polônia 1912 1964.5.16

\section{Cortejo, 1962}

Varsóvia Polônia 2007

óleo sobre tela, $132,4 \times 120,3 \times \mathrm{cm}$

Aquisição MAC USP -

RESERVA TÉCNICA:

1964.5.16 P-076/B pasta:

provisorio antigo:

$\checkmark$ CROMO $\square$ DIGITAL alta

\section{Remo MARTINI}

Hex Bélgica 1917

1964.14

\section{O Nascimento de meu Anão, 1963}

madeira, vidro, ferro, estanho, zinco e válvula de rádio, 125 x 143,8 x 12 cm

Aquisição MAC USP -

RESERVA TÉCNICA:

1964.14 P-035 pasta:

provisorio antigo:

$\square$ CROMO $\square$ DIGITAL alta

\section{Fernando ODRIOZOLA}

Oviedo Espanha 1921 1964.19.2

Cálice Vermelho, 1964

São Paulo, SP Brasil 1986

nanquim sobre madeira, 49,6 6 51,5 x cm

Aquisição MAC USP -

$\begin{array}{lll}\begin{array}{l}\text { RESERVA TÉCNICA: } \\ 1964.19 .2\end{array} & \begin{array}{l}\text { pasta: } \\ \text { provisorio antigo: }\end{array} \\ \square \text { CROMO } \\ \square \text { DIGITAL alta }\end{array}$

\section{Paulo Rossi OSIR}

São Paulo, SP Brasil 1890 1964.5.17

\section{São Paulo, SP Brasil 1959}

Olivais, Cervo Ligure, 1927

óleo sobre tela, $57,2 \times 67,1 \times \mathrm{cm}$

Aquisição MAC USP -

RESERVA TÉCNICA:

\begin{tabular}{lll} 
1964.5.17 & P-053/A & pasta: \\
& \multicolumn{1}{l}{ provisorio antigo: expo SEDE } \\
$\square$ CROMO & $\checkmark$ DIGITAL alta
\end{tabular}




\section{Eduardo PAOLOZZI}

Leith, Edimburgo Escócia 1924

1964.5.19

1964.5.21

\section{"Auto Head", 1954}

serigrafia sobre papel, $63 \times 50,5 \times \mathrm{cm}$

Aquisição MAC USP -

RESERVA TÉCNICA:

\begin{tabular}{|c|c|c|}
\hline 1964.5 .19 & M-07/A & $\begin{array}{l}\text { pasta: } 1 \\
\text { provisorio antigo: }\end{array}$ \\
\hline
\end{tabular}

\section{Herói como Enigma, 1963}

serigrafia em cores sobre papel, $91,4 \times 58,3 \times \mathrm{cm}$

Aquisição MAC USP -

RESERVA TÉCNICA:

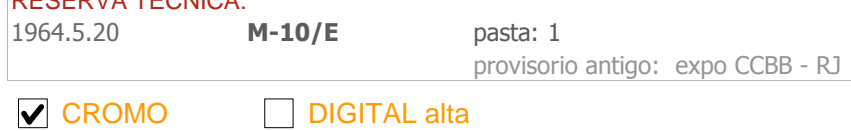

\section{Ídolo Hermafrodita no 1, 1962}

alumínio, 179,2 x 70 × 58,2 cm

Aquisição MAC USP -

RESERVA TÉCNICA:

1964.5.21 E- pasta:

provisorio antigo:

$\checkmark$ CROMO $\boldsymbol{\vee}$ DIGITAL alta

\section{Vilma PASQUALINI}

Rio de Janeiro, RJ Brasil 1930 1964.5.18

\section{Corpo de Mulher, 1963}

óleo sobre madeira, $115,5 \times 71,8 \times \mathrm{cm}$

Aquisição MAC USP -

RESERVA TÉCNICA:

1964.5.18 P-075/B pasta:

provisorio antigo:

CROMO $\square$ DIGITAL alta

\section{Arthur Luiz PIZA}

São Paulo, SP Brasil 1928 1964.5.26

\section{Telamosaico no 58, 1963}

óleo e papelão sobre tela, $89,5 \times 146$ x cm

Aquisição MAC USP - Adquirida do artista

RESERVA TÉCNICA:

$\begin{array}{lll}1964.5 .26 & \text { P-014/A } & \text { pasta: } \\ & & \text { provisorio antigo: expo MEMORIAL } \\ \square \text { CROMO } & \checkmark \text { DIGITAL alta }\end{array}$

\section{Francisco REBOLO GONSALES}

São Paulo, SP Brasil 1902 1964.9

Cena de Jogo num Bar, 1938

óleo sobre tela, $45 \times 61,5 \times \mathrm{cm}$

Aquisição MAC USP -

RESERVA TÉCNICA:

1964.9 P-007/A pasta:

provisorio antigo: expo IBIRA MODERNISMOS

\section{Gilvan SAMICO}

Recife, PE Brasil 1928 1964.5.22

\section{Comedor de Folhas, 1962}

xilografia em cores sobre papel, $61,2 \times 48,5 \times \mathrm{cm}$ Aquisição MAC USP -

\section{RESERVA TÉCNICA:}

1964.5.22 M-17/D pasta:

provisorio antigo: 
óleo sobre tela, $80 \times 130,1 \times \mathrm{cm}$

Aquisição MAC USP -

RESERVA TÉCNICA:

\begin{tabular}{|c|c|c|}
\hline 1964.5 .23 & P-068/A & $\begin{array}{l}\text { pasta: } \\
\text { provisorio antigo: }\end{array}$ \\
\hline
\end{tabular}

\section{Francisco STOCKINGER}

Traum Áustria 1919 1964.19.3

\section{Agressão, 1963}

Porto Alegre, RS Brasil 2009

ferro e madeira, $156,6 \times 23,7 \times 29,6 \mathrm{~cm}$

Aquisição MAC USP -

RESERVA TÉCNICA:

1964.19.3 E- pasta:

provisorio antigo:

$\checkmark$ CROMO $\square$ DIGITAL alta

\section{Silvano VESCOVI}

Mattuglie, Fiume Itália 1929

1964.22.2

Pintura, 1961

óleo sobre tela, $136,8 \times 136,5 \times \mathrm{cm}$

Aquisição MAC USP -

RESERVA TÉCNICA:

1964.22.2 P-068/A pasta:

provisorio antigo: restauro pintura

$\square$ CROMO $\square$ DIGITAL alta

\section{Jean Pierre VIELFAURE}

Argel Argélia 1930

1964.24.8 Um Instante Fascinador de Astros, 1962

nanquim sobre recortes de papel sobre papel, $24,7 \times 24,9 \times \mathrm{cm}$

Aquisição MAC USP -

RESERVA TÉCNICA:

1964.24.8 M-19/A pasta: 1

provisorio antigo:

\section{Nicolas VLAVIANOS}

Atenas Grécia 1929

\section{O Esperado II, 1964}

ferro, $163,5 \times 50 \times 43 \mathrm{~cm}$

Aquisição MAC USP -

RESERVA TÉCNICA:
$1964.11 \quad$ E-
pasta:
provisorio antigo:

$\checkmark$ CROMO $\square$ DIGITAL alta

\section{David WEINRIB}

New York E.U.A. 1924

1964.5.24

\section{Espacial III, 1963}

acrílico, aço laminado e madeira, $110 \times 100 \times 63 \mathrm{~cm}$

Aquisição MAC USP -

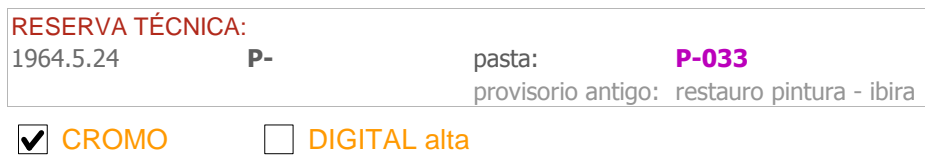

\section{Yo YOSHITOME}

Shimane Ken Japão 1925 1964.5.25

\section{Energia I, 1963}

óleo e areia sobre madeira, $122 \times 200 \times \mathrm{cm}$

Aquisição MAC USP -

RESERVA TÉCNICA:

1964.5.25 P-048/A pasta:

provisorio antigo: expo SEDE

CROMO $\square$ DIGITAL alta




\section{Luigi ZANOTTO}

Veneza Itália 1919

1964.22.3
Totalidade, 1964

papel e barbante plastificado montado sobre papelão, $44,2 \times 36,5 \times 5 \mathrm{~cm}$

Aquisição MAC USP -

RESERVA TÉCNICA:

1964.22 .3

P-

pasta: restauro papel

provisorio antigo: restauro pintura 


\section{ACERVO MAC USP - adquiridas em 1965}

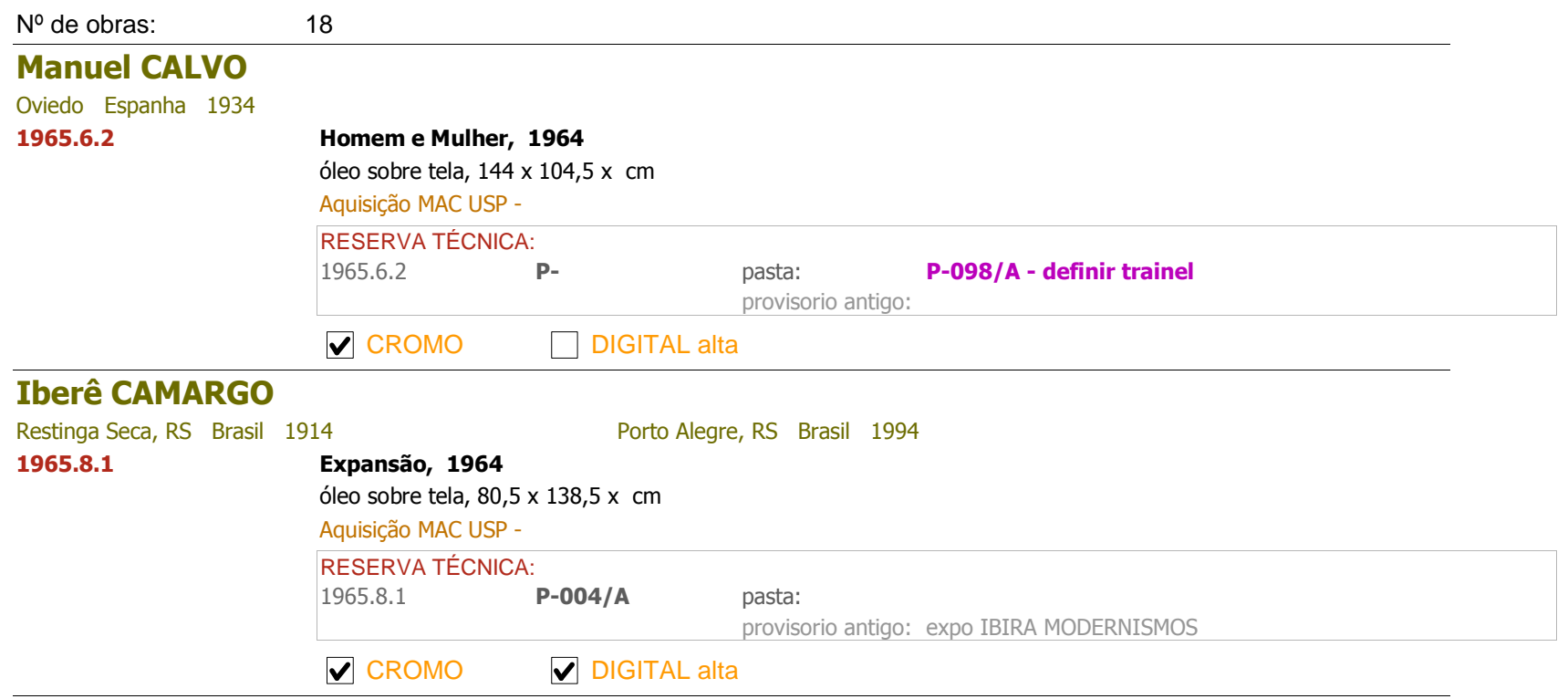

\section{Míriam CHIAVERINI}

São Paulo, SP Brasil 1940 1965.8.2

\section{Vietnan, 1965}

xilografia sobre papel, $119,3 \times 79,3 \times \mathrm{cm}$

Aquisição MAC USP -

RESERVA TÉCNICA:

1965.8.2 M-SOBRE 17/31 pasta:

provisorio antigo: expo ENTRE ATOS

$\checkmark$ CROMO $\square$ DIGITAL alta

\section{Antônio DIAS}

Campina Grande, PB Brasil 1944

1965.12

\section{Fumaça do Prisioneiro, 1964}

óleo e látex sobre madeira, 120,6 × 93,3 ×6,8 cm

Aquisição MAC USP -

RESERVA TÉCNICA:

1965.12 P-089/A pasta:

provisorio antigo: expo ENTRE ATOS

$\sqrt{\boldsymbol{V} \text { CROMO }} \boldsymbol{\nabla}$ DIGITAL alta

\section{Donato FERRARI}

Guardiagrele Itália 1933 1965.14

\section{Objeto Azul com Pêndulo, 1965}

resina poliéster sobre estopa, papelão, madeira e ferro, $119,5 \times 68,5 \times 9,5 \mathrm{~cm}$

Aquisição MAC USP -

RESERVA TÉCNICA:

$\begin{array}{lll}1965.14 & \text { P-062 } & \begin{array}{l}\text { pasta: } \\ \text { provisorio antigo: expo SEDE }\end{array} \\ \square \text { CROMO } & \square \text { DIGITAL alta }\end{array}$

\section{Bin KONDO}

Anton, Manchuria China 1937 1965.8.3

\section{Fábula, 1965}

óleo sobre madeira, $109,5 \times 79,5 \times \mathrm{cm}$

Aquisição MAC USP -

RESERVA TÉCNICA:

1965.8.3 P-069/B

provisorio antigo: expo SEDE

CROMO $\square$ DIGITAL alta




\section{Walter LINCK}

Berna Suíça 1903 1965.8.4

\section{Vegetativo no III, 1958}

ferro e aço, 100,3 x $181 \times 8 \mathrm{~cm}$

Aquisição MAC USP .

RESERVA TÉCNICA:

1965.8.4

$\checkmark$ CROMO $\square$ DIGITAL alta

\section{Ivan SERPA}

Rio de Janeiro, RJ Brasil 1923 1965.10

Figura, 1964

Rio de Janeiro, RJ Brasil 1973

óleo sobre tela, $100 \times 114,5 \times \mathrm{cm}$

Aquisição MAC USP -

RESERVA TÉCNICA:

1965.10 P-005/A pasta:

provisorio antigo: expo ENTRE ATOS

$\checkmark$ CROMO $\square$ DIGITAL alta

\section{Geraldo TRINDADE LEAL}

Santana do Livramento, RS Brasil 1927

1965.6.1.1

1965.6.1.2

1965.6.1.3

1965.6.1.4

1965.6.1.5

1965.6.1.6

\section{Sem título, 1964}

xilografia sobre papel, $30 \times 41,4 \times \mathrm{cm}$

Aquisição MAC USP - Adquirida do artista

RESERVA TÉCNICA:

$\begin{array}{ll}\text { 1965.6.1.1 M-13/D } & \text { pasta: } \\ & \\ & \text { provisorio antigo: }\end{array}$

\section{CROMO $\square$ DIGITAL alta}

\section{Sem título, 1964}

xilografia sobre papel, 30 x 41,4 x cm

Aquisição MAC USP - Adquirida do artista.

RESERVA TÉCNICA:

$\begin{array}{lll}\text { 1965.6.1.2 } & \text { M-13/D } & \text { pasta: } 1 \\ & \text { provisorio antigo: } \\ \square \text { CROMO } & \end{array}$

\section{Sem título, 1964}

DIGITAL alta

xilografia sobre papel, $30 \times 41,4 \times \mathrm{cm}$

Aquisição MAC USP - Adquirida do artista

RESERVA TÉCNICA:

$\begin{array}{lll}\text { 1965.6.1.3 } & \text { M-13/D } & \text { pasta: } \\ & & \text { provisorio antigo } \\ \square \text { CROMO } & \square \text { DIGITAL alta }\end{array}$

\section{Sem título, 1964}

Álbum Gravuras de Trindade Leal

Álbum Gravuras de Trindade Leal

Álbum Gravuras de Trindade Leal

xilografia sobre papel, $30 \times 41,4 \times \mathrm{cm}$

Aquisição MAC USP - Adquirida do artista

RESERVA TÉCNICA:

$\begin{array}{lll}\text { 1965.6.1.4 } & \text { M-13/D } & \text { pasta: } \\ & & \text { provisorio antigo: } \\ \square \text { CROMO } & \square \text { DIGITAL alta }\end{array}$

\section{Sem título, 1964}

Álbum Gravuras de Trindade Leal

xilografia sobre papel, 30 x 41,4 x cm

Aquisição MAC USP - Adquirida do artista

RESERVA TÉCNICA:

$\begin{array}{lll}\text { 1965.6.1.5 } & \text { M-13/D } & \text { pasta: } \\ & & \text { provisorio antigo: } \\ \square \text { CROMO } \\ \end{array}$

\section{Sem título, 1964}

Álbum Gravuras de Trindade Leal

xilografia sobre papel, $30 \times 41,4 \times \mathrm{cm}$

Aquisição MAC USP - Adquirida do artista

RESERVA TÉCNICA:

$\begin{array}{lll}\text { 1965.6.1.6 } & \text { M-13/D } & \begin{array}{l}\text { pasta: } \\ \text { provisorio antigo: }\end{array} \\ \boldsymbol{V} \text { CROMO } \\ \end{array}$


1965.6.1.7

1965.6.1.8

1965.6.1.9

1965.6.1.10
Sem título, 1964

xilografia sobre papel, $30 \times 41,4 \times \mathrm{cm}$

Aquisição MAC USP - Adquirida do artista

RESERVA TÉCNICA:

1965.6 .1

$M-13 / D$

pasta:

provisorio antigo:

\section{CROMO $\square$ DIGITAL alta}

Sem título, 1964

xilografia sobre papel, 30 x 41,4 x cm

Aquisição MAC USP - Adquirida do artista

RESERVA TÉCNICA:

1965.6.1. M-13/D pasta:

provisorio antigo:

\section{CROMO $\square$ DIGITAL alta}

Sem título, 1964

xilografia sobre papel, $30 \times 41,4 \times \mathrm{cm}$

Aquisição MAC USP - Adquirida do artista

RESERVA TÉCNICA:

1965.6.19 M-13/D pasta:

provisorio antigo:

\section{CROMO $\square$ DIGITAL alta}

\section{Sem título, 1964}

xilografia sobre papel, $30 \times 41,4 \times \mathrm{cm}$

Aquisição MAC USP - Adquirida do artista

RESERVA TÉCNICA:

$\begin{array}{ll}\text { 1965.6.1.10 M-13/D } & \text { pasta: } \\ & \text { provisorio antigo: }\end{array}$

CROMO $\square$ DIGITAL alta
Álbum Gravuras de Trindade Leal

\section{Álbum Gravuras de Trindade Leal}

\section{Álbum Gravuras de Trindade Leal}

Álbum Gravuras de Trindade Leal 


\section{ACERVO MAC USP - adquiridas em 1966}

№ de obras:

62

\section{Anna Letycia}

Teresópolis, RJ Brasil 1929

1966.13.8

Gravura I, 1965

ponta seca sobre papel, $37,9 \times 56,8 \times \mathrm{cm}$

Aquisição MAC USP - Adquirida do artista

RESERVA TÉCNICA:

1966.13.8 M-03/A pasta: 1

provisorio antigo:

1966.13 .9

CROMO

DIGITAL alta

Gravura II, 1965

água-forte em cores sobre papel, $52,8 \times 27,8 \times \mathrm{cm}$

Aquisição MAC USP - Adquirida do artista

RESERVA TÉCNICA:

1966.13.9 M-03/A pasta: 1

provisorio antigo: expo MEMORIAL

$\square$ CROMO $\square$ DIGITAL alta

\section{Edith BEHRING}

Rio de Janeiro, RJ Brasil 1916 1966.13.35

Gravura V, 1966

Rio de Janeiro, RJ Brasil 1996

água-forte em cores sobre papel, $65,1 \times 49,8 \times \mathrm{cm}$

Aquisição MAC USP - Adquirida do artista

RESERVA TÉCNICA:

1966.13.35 M-03/C pasta: 1

provisorio antigo:

1966.15.1

CROMO

$\square$ DIGITAL alta

\section{Gravura I, 1964}

água-tinta em cores sobre papel, $56,5 \times 76,1 \times \mathrm{cm}$

Aquisição MAC USP -

RESERVA TÉCNICA:

1966.15.1 M-09/B pasta: 1

provisorio antigo:

\section{$\square$ CROMO $\square$ DIGITAL alta}

1966.15.2 Gravura II, 1966

água-tinta em cores sobre papel, $69,8 \times 50,3 \times \mathrm{cm}$

Aquisição MAC USP -

RESERVA TÉCNICA:

1966.15.2 M-03/C pasta: 1

provisorio antigo:

$\square$ CROMO $\square$ DIGITAL alta

\section{Leonello BERTI}

Florença Itália 1927 1966.15.3

Multidão, 1966

Aquisição MAC USP -

RESERVA TÉCNICA:

1966.15.3 P-

pasta:

RT Pintura sala 4 - definir trainel

provisorio antigo: restauro pintura

CROMO $\square$ DIGITAL alta

\section{Maria BONOMI}

Meina Itália 1935

\section{Escada, 1966}

xilografia sobre papel, $121,5 \times 98,5 \times \mathrm{cm}$

Aquisição MAC USP -

RESERVA TÉCNICA:

\begin{tabular}{|c|c|c|c|}
\hline 1966.15 .4 & M-34 & $\begin{array}{l}\text { pasta: } \\
\text { provisorio antigo: }\end{array}$ & $\begin{array}{l}\text { M- chão } \\
\text { : expo BONOMI BRASÍLIA }\end{array}$ \\
\hline
\end{tabular}

\section{CROMO $\square$ DIGITAL alta}


Anteprojeto, 1966

xilografia em cores sobre papel sobre madeira, $70 \times 60 \times \mathrm{cm}$

Aquisição MAC USP -

RESERVA TÉCNICA:

1966.15.5 P-109/B pasta:

provisorio antigo: expo BONOMI BRASÍLIA

$\square$ CROMO $\quad \square$ DIGITAL alta

\section{Lothar CHAROUX}

Viena Áustria 1912

1966.8 .2

\section{Desenho, 1956}

São Paulo, SP Brasil 1987

guache sobre papel sobre madeira, $61 \times 61 \times \mathrm{cm}$

Aquisição MAC USP - Adquirida do artista

RESERVA TÉCNICA:

1966.8.2 P-106/A pasta:

provisorio antigo: expo MAMSP

$\boldsymbol{V}$ CROMO $\boldsymbol{V}$ DIGITAL alta

\section{Waldemar CORDEIRO}

Roma Itália 1925

1966.13.1

Movimento, 1951

São Paulo, SP Brasil 1973

têmpera sobre tela, 90,1 x 95,3 x cm

Aquisição MAC USP -

RESERVA TÉCNICA:

1966.13.1 P-039/A pasta:

provisorio antigo: expo IBIRA MODERNISMOS

$\checkmark$ CROMO $\boldsymbol{\vee}$ DIGITAL alta

\section{Jean DEWASNE}

Lille França 1921

1966.13.2

\section{Sem título, s.d.}

serigrafia em cores sobre papel, $63,8 \times 49 \times \mathrm{cm}$

Aquisição MAC USP -

RESERVA TÉCNICA:

1966.13.2 M-04/B pasta: 1

provisorio antigo: expo FRANCESES IBIRA

$\checkmark$ CROMO $\square$ DIGITAL alta

\section{Cícero DIAS}

Recife, PE Brasil 1908 1966.13.3

\section{Sem título, s.d.}

Paris França 2003

serigrafia em cores sobre papel, $64 \times 49 \times \mathrm{cm}$

Aquisição MAC USP -

RESERVA TÉCNICA:

1966.13.3 M-04/B pasta: 1

provisorio antigo: expo REITORIA 02 - ANTE-SALA DO gabinete

$\square$ CROMO $\square$ DIGITAL alta

\section{Kazmer FEJER}

Pecs Hungria 1923

1966.8.1

\section{Sem título, 1956}

Sesimbra Portugal 1989

acrílico, 25,2 x 29,9 × $11 \mathrm{~cm}$

Aquisição MAC USP - Adquirida do artista

$\begin{array}{ll}\begin{array}{l}\text { RESERVA TÉCNICA: } \\ \text { 1966.8.1 }\end{array} & \begin{array}{l}\text { pasta: } \\ \text { provisorio antigo: }\end{array} \\ \square \text { CROMO }\end{array}$

\section{Hermelindo FIAMINGHI}

São Paulo, SP Brasil 1920 1966.13.4
Elevação Vertical com

esmalte sintético sobre aglomerado de madeira, $60 \times 60 \times \mathrm{cm}$

Aquisição MAC USP -

RESERVA TÉCNICA:

$\begin{array}{lll}\text { 1966.13.4 } & \text { P-039/A } & \text { pasta: } \\ & & \text { provisorio antigo: expo CONSTRUTIVOS } \\ \boldsymbol{V} \text { CROMO } & \boldsymbol{V} \text { DIGITAL alta }\end{array}$


óleo sobre tela, $46,2 \times 116,1 \times \mathrm{cm}$

Aquisição MAC USP - Adquirida do artista

\begin{tabular}{lll}
\hline RESERVA TÉCNICA: & & \\
1966.8 .5 & P- & pasta:
\end{tabular}

$\checkmark$ CROMO $\square$ DIGITAL alta

\section{Anna Bella GEIGER}

Rio de Janeiro, RJ Brasil 1933

\subsubsection{A um Azul Profundo, Ilimitado..., 1965}

água-tinta e relevo em cores sobre papel, 59,8 x 49,4 × cm

Aquisição MAC USP - Adquirida da artista;

Hors Concour na II Jovem Gravura Nacional

RESERVA TÉCNICA:

\begin{tabular}{|c|c|c|}
\hline 1966.15 .6 & M-05/B & $\begin{array}{l}\text { pasta: } 1 \\
\text { provisorio antigo: expo ENTRE ATOS }\end{array}$ \\
\hline
\end{tabular}

\section{Jef GOLYSCHEFF}

Cherson Ucrânia 1897 1966.8.3

\section{Recife, 1964}

Paris França 1970

óleo sobre tela, $79,4 \times 93,8 \times \mathrm{cm}$

Aquisição MAC USP -

RESERVA TÉCNICA:

1966.8.3 P-005/B pasta:

provisorio antigo:

CROMO $\square$ DIGITAL alta

\section{Marcelo GRASSMANN}

São Simão, SP Brasil 1925 1966.15.7

\section{Gravura II, 1966}

água-forte e água-tinta em cores sobre papel, $56,5 \times 44,7 \times \mathrm{cm}$

Aquisição MAC USP - Adquirida do artista

RESERVA TÉCNICA:

$\begin{array}{lll}1966.15 .7 & \text { M-16/C } & \begin{array}{l}\text { pasta: } \\ \text { provisorio antigo: expo ENTRE ATOS }\end{array} \\ \square \text { CROMO } & \square \text { DIGITAL alta }\end{array}$

\section{Hans GRUDZINSKI}

Batchka Iugoslávia 1921

1966.13.5

\section{A Noiva vai à Cidade, 1966}

Aquisição MAC USP - Adquirida do artista RESERVA TÉCNICA:

1966.13.5 M-05/C pasta: 1

provisorio antigo:

$\square$ CROMO $\square$ DIGITAL alta

\section{Eli HEIL}

Palhoça, SC Brasil 1929 1966.13.6

\section{Curral, 1964}

óleo sobre tela, $70 \times 80 \times \mathrm{cm}$

Aquisição MAC USP -

RESERVA TÉCNICA:

\begin{tabular}{|c|c|c|}
\hline 1966.13 .6 & P-056/B & $\begin{array}{l}\text { pasta: } \\
\text { provisorio antigo: }\end{array}$ \\
\hline
\end{tabular}

\section{Heinz KÜHN}

Berlim Alemanha 1908 1966.13.7

\section{Relevo Visual, 1966}

São Paulo, SP Brasil 1987

acrílica sobre isopor recortado, 99,5 × 99,5 × $23 \mathrm{~cm}$

Aquisição MAC USP -

RESERVA TÉCNICA:

\begin{tabular}{|c|c|c|}
\hline 1966.13 .7 & P-093 & $\begin{array}{l}\text { pasta: } \\
\text { provisorio antigo }\end{array}$ \\
\hline
\end{tabular}




\section{Maurício Nogueira LIMA}

Recife, PE Brasil 1930

1966.13.10

Objeto Rítmico no 1, 1953

guache sobre aglomerado de madeira, 38,4 x 39,7 x cm

Aquisição MAC USP -

RESERVA TÉCNICA:

1966.13.10 P-012/B pasta:

provisorio antigo: expo SEDE

$\checkmark$ CROMO $\boldsymbol{\nabla}$ DIGITAL alta

\section{Avatar da Silva MORAES}

Bagé, RS Brasil 1933

1966.13.11

1966.13.12

\section{Caixa 5, 1966}

vidro, poliéster, madeira, veludo e alumínio, 31,8 x 15,2 × 9,4 cm

Aquisição MAC USP -

RESERVA TÉCNICA:

1966.13.11 E-

pasta:

provisorio antigo: expo ENTRE ATOS

\section{CROMO $\square$ DIGITAL alta}

Caixa 6, 1966

vidro, acrílico, madeira, poliéster e fio de algodão, 32 × 15 × 9,8 cm

Aquisição MAC USP -

RESERVA TÉCNICA:

1966.13.12 E- pasta:

provisorio antigo: expo ENTRE ATOS

CROMO $\square$ DIGITAL alta

\section{Richard MORTENSEN}

Copenhague Dinamarca 1910 1966.13.13

\section{Sem título, s.d.}

Roskilde Dinamarca 1993

serigrafia em cores sobre papel, $48,9 \times 63,8 \times \mathrm{cm}$

Aquisição MAC USP -

RESERVA TÉCNICA:

\begin{tabular}{|c|c|c|}
\hline 1966.13 .13 & M-06/E & $\begin{array}{l}\text { pasta: } 1 \\
\text { provisorio antigo: }\end{array}$ \\
\hline
\end{tabular}

\section{Ismael NERY}

Belém, PA Brasil 1900

1966.15.8

\section{Figura, c.1927/28}

Rio de Janeiro, RJ Brasil 1934

óleo sobre tela, $105 \times 69,2 \times \mathrm{cm}$

Aquisição MAC USP - Adquirida de Giuseppe Baccaro

RESERVA TÉCNICA:

1966.15.8 P-028/B pasta:

provisorio antigo: expo IBIRA MODERNISMOS

1966.15 .9

\section{CROMO}

DIGITAL alta

Composição, s.d.

aquarela e grafite sobre papel, $20,5 \times 26,8 \times \mathrm{cm}$

Aquisição MAC USP - Adquirida de Giuseppe Baccaro

RESERVA TÉCNICA:

1966.15.9 M-07/A pasta: 1

provisorio antigo: expo BELO HORIZONTE

1966.15 .10

1966.15 .11

Nu, s.d.

\section{DIGITAL alta}

aquarela sobre papel, $25,8 \times 18,2 \times \mathrm{cm}$

Aquisição MAC USP - Adquirida de Giuseppe Baccaro

RESERVA TÉCNICA:

1966.15.10 M-07/A pasta: 1

provisorio antigo: restauro papel

\section{CROMO \\ DIGITAL alta}

Banhistas, s.d.

nanquim sobre papel, $21,4 \times 27,6 \times \mathrm{cm}$

Aquisição MAC USP - Adquirida de Giuseppe Baccaro

RESERVA TÉCNICA:
1966.15.11
M-17/A
pasta:
M-32/A - refazer ppt e guardar

provisorio antigo: expo IBIRA MODERNISMOS 
Casal, s.d.

nanquim sobre papel, $23,2 \times 15,7 \times \mathrm{cm}$

Aquisição MAC USP - Adquirida de Giuseppe Baccaro

RESERVA TÉCNICA:

1966.15.12 M-07/A pasta: 1

provisorio antigo: restauro papel

1966.15 .13

CROMO

DIGITAL alta

\section{Composição Surrealista I (Um Dirigível e um Epitáfio}

com a Palavra LEX), s.d.

nanquim sobre papel, $21,3 \times 27,8 \times \mathrm{cm}$

Aquisição MAC USP - Adquirida de Giuseppe Baccaro

RESERVA TÉCNICA:

1966.15.13 M-17/A pasta: M-32/A - refazer ppt e guardar

\section{CROMO $\square$ DIGITAL alta}

1966.15.14 Três Mulheres com Auscultador, s.d.

nanquim sobre papel, $16 \times 12 \times \mathrm{cm}$

Aquisição MAC USP - Adquirida de Giuseppe Baccaro

RESERVA TÉCNICA:

1966.15.14 M-16/E

\section{CROMO $\square$ DIGITAL alta}

1966.15 .15

Autorretrato, s.d.

crayon sobre papel, $22,7 \times 17 \times \mathrm{cm}$

Aquisição MAC USP - Adquirida de Giuseppe Baccaro

RESERVA TÉCNICA:

1966.15.15 M-16/E pasta: provisorio antigo: expo SEDE

1966.15.16

CROMO

$\square$ DIGITAL alta

\section{Composição Surrealista II, s.d.}

grafite sobre papel, 28,1 x 21,2 $\times$ cm

Aquisição MAC USP - Adquirida de Giuseppe Baccaro

RESERVA TÉCNICA:

1966.15.16 M-16/E pasta: M-32/A - refazer ppt e guardar

$\checkmark$ CROMO $\square$ DIGITAL alta

1966.15.17 Figura Surrealista com Personagem Masculino

Deitado, s.d.

nanquim e grafite sobre papel, $21,7 \times 16,2 \times \mathrm{cm}$

Aquisição MAC USP - Adquirida de Giuseppe Baccaro

RESERVA TÉCNICA:

1966.15.17 M-16/E pasta: M-32/A - refazer ppt e guardar

\section{CROMO $\square$ DIGITAL alta}

1966.15.18 Grupo com Cinco Figuras, s.d.

nanquim sobre papel, $23 \times 16 \times \mathrm{cm}$

Aquisição MAC USP - Adquirida de Giuseppe Baccaro

RESERVA TÉCNICA:

1966.15.18 M-16/E pasta:

provisorio antigo: expo gabinete 044a

CROMO $\square$ DIGITAL alta

\section{Fayga OSTROWER}

Lodz Polônia 1920

1966.13.14

1966.13.15

\section{4, 1959}

Rio de Janeiro, RJ Brasil 2001

água-tinta e buril sobre papel, $37,8 \times 56,6 \times \mathrm{cm}$

Aquisição MAC USP -

RESERVA TÉCNICA:

\begin{tabular}{|c|c|c|}
\hline 1966.13 .14 & M-07/A & $\begin{array}{l}\text { pasta: } 2 \\
\text { provisorio antigo: restauro papel - desmontar }\end{array}$ \\
\hline
\end{tabular}

\section{8, 1959}

água-tinta em cores sobre papel, $38 \times 51,1 \times \mathrm{cm}$

Aquisição MAC USP -

RESERVA TÉCNICA:

1966.13.15 M-34 pasta: $\quad$ RT - colocar na moldura

CROMO $\square$ DIGITAL alta 
1966.13 .16

1966.13.17

1966.13.18

1966.13.19
1966.13 .22

1966.13.23

1966.13.24

5912, 1959

xilografia em cores sobre papel, 37,5 x 53,6 x cm

Aquisição MAC USP -

RESERVA TÉCNICA:

1966.13.16 M-07/A pasta: 2

provisorio antigo: restauro papel - desmontar

CROMO $\square$ DIGITAL alta

6102,1961

xilografia em cores sobre papel, 64,7 x 95 x cm

Aquisição MAC USP -

RESERVA TÉCNICA:

1966.13.17 M-10/D pasta: 1

provisorio antigo: expo SECRETARIA GERAL - EXPEDIENTE

CROMO $\square$ DIGITAL alta

6614, 1966

xilografia em cores sobre papel, 50,9 x 68,5 x cm

Aquisição MAC USP - Adquirida do artista

RESERVA TÉCNICA:

1966.13.18 M-07/A pasta: 2

provisorio antigo: expo ENTRE ATOS

$\square$ CROMO $\square$ DIGITAL alta

6621, 1966

xilografia em cores sobre papel, 56,6 x 33,8 x cm

Aquisição MAC USP - Adquirida do artista

RESERVA TÉCNICA:

1966.13.19 M-07/A pasta: 2

provisorio antigo: expo ENTRE ATOS

$\checkmark$ CROMO $\square$ DIGITAL alta

\section{Isabel PONS}

Barcelona Espanha 1912

1966.13.20

\section{Pássaro e Fonte, 1960}

Rio de Janeiro, RJ Brasil 2002

áqua-forte e relevo em cores sobre papel, 65,1 x 48,5 x cm

Aquisição MAC USP - Adquirida do artista

RESERVA TÉCNICA:

1966.13.20 M-07/D pasta: 1

provisorio antigo:

\section{$\checkmark \mathrm{CROMO}$ \\ DIGITAL alta}

Azulão, 1961

água-forte, buril e relevo em cores sobre papel, 45,1 x 56,2 $2 \mathrm{~cm}$

Aquisição MAC USP - Adquirida do artista

RESERVA TÉCNICA:

1966.13.21 M-07/D pasta: 1

provisorio antigo:

$\checkmark$ CROMO $\square$ DIGITAL alta

Pássaro V.I.P., 1961

água-forte e relevo em cores sobre papel, 49,9 x 65,1 x cm

Aquisição MAC USP - Adquirida do artista

RESERVA TÉCNICA:

1966.13.22

$\mathrm{M-14/C}$

pasta:

provisorio antigo: chão reserva papel - troca gaveta

CROMO

DIGITAL alta

Chuva, 1962

água-forte, relevo e buril em cores sobre papel, $63,8 \times 50 \times \mathrm{cm}$

Aquisição MAC USP - Adquirida do artista

RESERVA TÉCNICA:

1966.13.23 $\mathbf{M - 1 4 / C}$

provisorio antigo: chão reserva papel - troca gaveta

\section{CROMO $\square$ DIGITAL alta}

Grande Personagem, 1962

água-forte, buril e relevo em cores sobre papel, $50 \times 63,8 \times \mathrm{cm}$

Aquisição MAC USP - Adquirida do artista

RESERVA TÉCNICA:

1966.13.24 M-07/D provisorio antigo: 
água-forte e verniz mole em cores sobre papel, $64 \times 50,1 \times \mathrm{cm}$

Aquisição MAC USP - Adquirida do artista

RESERVA TÉCNICA:

\begin{tabular}{|c|c|c|}
\hline 1966.13 .25 & M-07/D & $\begin{array}{l}\text { pasta: } 1 \\
\text { provisorio antigo: }\end{array}$ \\
\hline
\end{tabular}

1966.13.26

\section{Caminho das Estrelas, 1966}

ponta seca e relevo sobre papel, $65,1 \times 49,8 \times \mathrm{cm}$

Aquisição MAC USP - Adquirida do artista

RESERVA TÉCNICA:

1966.13.26 M-07/D pasta: 1

provisorio antigo:

$\square$ CROMO $\square$ DIGITAL alta

\section{Candido PORTINARI}

Brodósqui, SP Brasil 1903

1966.15.19

Cangaceiro atirando, 1956

Rio de Janeiro, RJ Brasil 1962

óleo sobre madeira, 50,6 x 61,5 x cm

Aquisição MAC USP -

RESERVA TÉCNICA:

1966.15.19 P-030/A pasta:

provisorio antigo: expo MEMORIAL

\section{Marília RODRIGUES}

Belo Horizonte, MG Brasil 1937

1966.13.27

\section{Árvore, 1963}

água-tinta e relevo em cores sobre papel, 50,1 x 59,9 x cm

Aquisição MAC USP - Adquirida do artista

RESERVA TÉCNICA:

$$
\begin{array}{ll}
\text { 1966.13.27 M-07/E } & \text { pasta: } 1 \\
& \text { provisorio antigo: }
\end{array}
$$

1966.13.28 Montanha, 1964

água-tinta, água-forte e relevo em cores sobre papel, $54,5 \times 47,6$ × cm

Aquisição MAC USP - Adquirida do artista

$\begin{array}{ll}\text { RESERVA TÉCNICA: } & \\ \text { 1966.13.28 } & \text { M-07/E pasta: } 1 \\ & \end{array}$

CROMO $\square$ DIGITAL alta

\section{Hissao SAKAKIBARA}

Yokohama Japão 1937

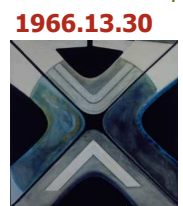

\section{Ritmo Preto II, 1966}

óleo sobre tela, $100 \times 100 \times \mathrm{cm}$

Aquisição MAC USP -

RESERVA TÉCNICA:

1966.13.30 P-039/B pasta:

provisorio antigo: expo SEDE

\section{Lasar SEGALL}

Vilna Lituânia 1891 1966.15.21

\section{Duas Figuras, 1933}

São Paulo, SP Brasil 1957

guache sobre papel, $46,5 \times 70 \times \mathrm{cm}$

Aquisição MAC USP -

RESERVA TÉCNICA:

1966.15.21 M-17/D pasta: aula GABINETE

$\checkmark$ CROMO $\square$ DIGITAL alta

\section{Takeo SHIMIZU}

Dairen, Manchuria China 1935

$\begin{array}{ll}1966.13 .31 & \text { E- } \\ & \text { provisorio antigo: }\end{array}$




\section{Luis SOLARI}

Fray Bentos, Rio Negro Uruguai 1918

1966.8.6

O Peixe Grande, 1963

nanquim sobre recortes de papel sobre papelão, $40,5 \times 52,5 \times \mathrm{cm}$

Aquisição MAC USP - Adquirida do artista

RESERVA TÉCNICA:

$\begin{array}{lll}1966.8 .6 & \text { M-08/B } & \text { pasta: } 1 \\ \text { provisorio antigo: }\end{array}$

\section{José Assumpção SOUZA}

Recife, PE Brasil 1924

1966.13.33

\section{Gravura I, 1964}

água-tinta em cores sobre papel, $44,7 \times 56,6 \times \mathrm{cm}$

Aquisição MAC USP - Adquirida do artista

RESERVA TÉCNICA:

$\begin{array}{ll}\text { 1966.13.33 M-08/B } & \text { pasta: } 1 \\ & \text { provisorio antigo: }\end{array}$

\subsubsection{Gravura II, 1966}

água-tinta em cores sobre papel, $45,3 \times 56,5 \times \mathrm{cm}$

Aquisição MAC USP - Adquirida do artista

RESERVA TÉCNICA:
1966.13.34
M-08/B
pasta: 1
provisorio antigo:

CROMO $\square$ DIGITAL alta

\section{João Suzuki}

Mirandópolis, SP Brasil 1935

1966.15.20

Exercício de Integração no 1, 1966

fio plástico, ferro e óleo sobre madeira, $104 \times 209 \times 11 \mathrm{~cm}$

Aquisição MAC USP -

RESERVA TÉCNICA:

$\begin{array}{lll}1966.15 .20 & \text { P- } & \begin{array}{l}\text { pasta: } \\ \text { provisorio antigo: expo ENTRE ATOS }\end{array} \\ \square \text { CROMO } & \square \text { DIGITAL alta }\end{array}$

\section{Caciporé TORRES}

Araçatuba, SP Brasil 1932

1966.13.32

\section{A Montanha Azul, 1965}

ferro, $88 \times 70 \times 26,5 \mathrm{~cm}$

Aquisição MAC USP - Participação na VIII Bienal de São Paulo, 1965

O artista recebeu indicação de aquisição por parte do júri de premiação da VIII Bienal de São Paulo;

O MAC USP adquiriu a obra em 10/1966

RESERVA TÉCNICA

1966.13.32 E- pasta:

provisorio antigo: expo ENTRE ATOS

$\checkmark$ CROMO $\boldsymbol{\nabla}$ DIGITAL alta

\section{Geraldo TRINDADE LEAL}

Santana do Livramento, RS Brasil 1927

1966.8.4

\section{Braço de Ferro, 1957}

xilografia sobre papel, $27,5 \times 35,4 \times \mathrm{cm}$

Aquisição MAC USP - Adquirida do artista

RESERVA TÉCNICA:

$\begin{array}{lll}\text { 1966.8.4 } & \text { M-08/C } & \text { pasta: } 1 \\ \text { provisorio antigo: }\end{array}$

\section{Franz WEISSMANN}

Knittelfeld Áustria 1911 1966.13.36

\section{Torre, 1957}

Rio de Janeiro, RJ Brasil 2005

ferro, $169 \times 62,7 \times 37,2 \mathrm{~cm}$

Aquisição MAC USP - Adquirida do artista

RESERVA TÉCNICA:

$\begin{array}{lll}1966.13 .36 & \text { E- } & \begin{array}{l}\text { pasta: } \\ \text { provisorio antigo: }\end{array} \\ \end{array}$




\section{ACERVO MAC USP - adquiridas em 1967}

№ de obras: $\quad 35$

\section{Sara ÁVILA}

Nova Lima, MG Brasil 1932

1967.1.6.1/2

\section{Desenho 4, 1967}

frottage sobre papel sobre aglomerado de madeira, $81,5 \times 120 \times \mathrm{cm}$

Aquisição MAC USP -

RESERVA TÉCNICA:

1967.1.6.1/2 P- pasta: restauro papel

provisorio antigo: restauro pintura - ibira

$\checkmark$ CROMO $\square$ DIGITAL alta

\section{Waldemar da COSTA}

Belém, PA Brasil 1904

1967.1.1

Curitiba, PR Brasil 1982

Estático Semovente XIII, 1966

óleo e ouro sobre aglomerado de madeira, $103 \times 118 \times \mathrm{cm}$

Aquisição MAC USP -

RESERVA TÉCNICA:

1967.1.1 P-076/B pasta:

provisorio antigo: expo ENTRE ATOS

\section{CROMO $\square$ DIGITAL alta}

\section{Raymond DAUSSY}

Cherbourg França 1918

1967.4.1

\section{Em Nossas Costas, 1965}

óleo sobre tela, $64,8 \times 80,6 \times \mathrm{cm}$

Aquisição MAC USP -

RESERVA TÉCNICA:

1967.4.1 P-059/B pasta:

provisorio antigo:

CROMO $\square$ DIGITAL alta

\section{Sérvulo ESMERALDO}

Crato, CE Brasil 1929

1967.4.2

Litanie, 1959

água-tinta e buril em cores sobre papel, $32,9 \times 44,4 \times \mathrm{cm}$

Aquisição MAC USP -

$\begin{aligned} & \text { RESERVA TÉCNICA: } \\ & \text { 1967.4.2 } \\ & \text { M-16/B }\end{aligned}$
$\square$ CROMO
$\square$ DIGITAL alta

1967.4 .3

Falaise, 1960

água-tinta e buril sobre papel, 50,1 x $38 \times \mathrm{cm}$

Aquisição MAC USP -

RESERVA TÉCNICA:

\begin{tabular}{|c|c|c|}
\hline 1967.4 .3 & $\mathrm{M}-17 / \mathrm{B}$ & pasta: \\
\hline
\end{tabular}

1967.4.4 "Cible", 1965

buril e água-tinta em cores sobre papel, $33 \times 24,9 \times \mathrm{cm}$

Aquisição MAC USP -

RESERVA TÉCNICA:

1967.4.4 M-04/E pasta: 1

provisorio antigo:

CROMO $\square$ DIGITAL alta

\section{Lucio FONTANA}

Rosario, Santa Fé Argentina 1899

1967.4.5

\section{Conceito Espacial, 1965}

óleo sobre tela, $92,4 \times 73,2 \times \mathrm{cm}$

Aquisição MAC USP - Adquirida na Galeria XXème Siècle em Paris

RESERVA TÉCNICA:

1967.4.5 P-048/B pasta:

CROMO $\square$ DIGITAL alta 


\section{Georg HADELER}

Treunenfeld, Niedersachsen Alemanha 1939

1967.1.2

A Herança de Ícaro, 1964

litografia sobre papel, $97,5 \times 72,7 \times \mathrm{cm}$

Aquisição MAC USP -

RESERVA TÉCNICA:

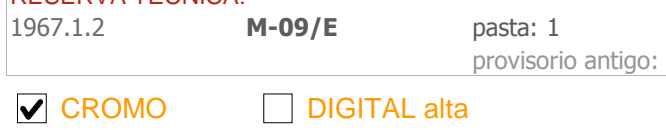

\section{Hans HARTUNG}

Leipzig Alemanha 1904 1967.4.6

\section{Sem título, 1961/64}

Antibes França 1989

óleo sobre tela, $38,1 \times 99,9 \times \mathrm{cm}$

Aquisição MAC USP - Adquirida na Galerie de France em Paris

RESERVA TÉCNICA:

1967.4.6 P-016/A pasta:

provisorio antigo: expo IBIRA MODERNISMOS

$\checkmark$ CROMO $\boldsymbol{\square}$ DIGITAL alta

\section{Abelardo da HORA}

São Lourenço da Mata, PE Brasil 1924

1967.1.9

Desamparados, 1947

concreto, $55 \times 57 \times 31 \mathrm{~cm}$

Aquisição MAC USP - Adquirida do artista

$\begin{array}{ll}\text { RESERVA TÉCNICA: } & \text { pasta: } \\ \begin{array}{ll}\text { 1967.1.9 } & \text { provisorio antigo: }\end{array} \\ \end{array}$

$\square$ CROMO $\square$ DIGITAL alta

\section{Paul JENKINS}

Kansas City, Missouri E.U.A. 1923

1967.4.7

Fenômenos de Adivinhação, 1964/65

óleo sobre tela, $146 \times 114 \times \mathrm{cm}$

Aquisição MAC USP - Adquirida na Galeria Karl Flinker em Paris

RESERVA TÉCNICA:

\begin{tabular}{lll} 
1967.4.7 & P-046/B & pasta: \\
& & provisorio antigo: \\
\hline & CROMO & $\boldsymbol{V}$ DIGITAL alta
\end{tabular}

\section{Bin KONDO}

Anton, Manchuria China 1937

1967.1.3

Gente Estranha n० 3, 1967

óleo sobre madeira, 109,3 x 79,5 x cm

Aquisição MAC USP -

RESERVA TÉCNICA:
1967.1.3
P-050/B
pasta:
provisorio antigo: expo SEDE

\section{Frans KRAJCBERG}

Kozienice Polônia 1921

1967.4.8

\section{Relevo no I, 1960}

guache sobre papel em relevo sobre tela, 70,2 x 200,2 2 $2 \mathrm{~cm}$

Aquisição MAC USP - Adquirida por intermédio de M. G. di San Lazzaro na Galeria XX Siècle de Paris

RESERVA TÉCNICA:

\begin{tabular}{lll} 
1967.4.8 & P-110/B & pasta: \\
& provisorio antigo: expo SEDE \\
\hline $\boldsymbol{V}$ CROMO & $\boldsymbol{V}$ DIGITAL alta
\end{tabular}

\section{Juan LANGLOIS}

Buenos Aires Argentina 1926

1967.4.9

Campo de Iniciação (Por um Templo sem Deus), 1963

óleo sobre tela, 114 x 194,5 x cm

Aquisição MAC USP -

RESERVA TÉCNICA:

1967.4.9 P-051/A pasta:

provisorio antigo:

CROMO $\square$ DIGITAL alta




\section{Walter LEWY}

Bad Oldesloe Alemanha 1905

1967.1.10

\section{Pintura, 1965}

São Paulo, SP Brasil 1995

óleo sobre tela, $80,5 \times 179 \times \mathrm{cm}$

Aquisição MAC USP -

RESERVA TÉCNICA:

\begin{tabular}{|c|c|c|}
\hline 1967.1.10 & P-081/A & $\begin{array}{l}\text { pasta: } \\
\text { provisorio antigo: }\end{array}$ \\
\hline
\end{tabular}

\section{MARIA CARMEN}

Recife, PE Brasil 1935

1967.1.4

\section{Desenho no 2, 1965}

nanquim sobre papel, $96,7 \times 36,2 \times \mathrm{cm}$

Aquisição MAC USP -

RESERVA TÉCNICA:

1967.1.4 M-17/C pasta:

provisorio antigo:

$\checkmark$ CROMO $\square$ DIGITAL alta

\section{Andrzej MEISSNER}

Krakow Polônia 1929

1967.4.10

O Entalhado, 1966

madeira, $135 \times 46 \times 29 \mathrm{~cm}$

Aquisição MAC USP -

RESERVA TÉCNICA:

$\begin{array}{lll}\text { 1967.4.10 } & \text { P-062 } & \text { pasta: } \\ & & \text { provisorio antigo: }\end{array}$

$\square$ CROMO $\square$ DIGITAL alta

\section{Vicente do Rego MONTEIRO}

Recife, PE Brasil 1899

1967.1.11

\section{Deposição, c.1966}

Recife, PE Brasil 1970

óleo sobre tela, $109 \times 134 \times \mathrm{cm}$

Aquisição MAC USP -

RESERVA TÉCNICA:

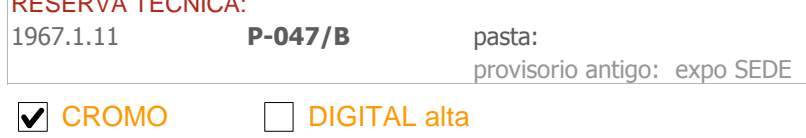

\section{Ladislav NOVAK}

Turnov, Bohemia República Tcheca 1925

A Tinta Bolor, 1965

monotipia sobre papel, $39,8 \times 42 \times \mathrm{cm}$

Aquisição MAC USP -

$\begin{array}{ll}\text { RESERVA TÉCNICA: } & \\ \text { 1967.4.11 M-07/A } & \text { pasta: } 1 \\ & \text { provisorio antigo: }\end{array}$

\section{Fernando ODRIOZOLA}

Oviedo Espanha 1921

\section{Sem título, 1966}

São Paulo, SP Brasil 1986

ferro e nanquim sobre madeira, $51 \times 40 \times 3 \mathrm{~cm}$

Aquisição MAC USP -

\begin{tabular}{|c|c|c|c|}
\hline \multicolumn{4}{|c|}{ RESERVA TÉCNICA: } \\
\hline 1967.1 .5 & P- & $\begin{array}{l}\text { pasta: } \\
\text { provisorio antigo: }\end{array}$ & $\begin{array}{l}\mathbf{P - 1 1 8 / A} \\
\text { P-118/A - guardar }\end{array}$ \\
\hline
\end{tabular}

$\checkmark$ CROMO $\square$ DIGITAL alta

\section{Rossini PEREZ}

Macaíba, RN Brasil 1932

1967.4.19

Gravura, 1961

água-tinta em cores sobre papel, 50 x 64,7 x cm

Aquisição MAC USP -

RESERVA TÉCNICA:

1967.4.19 M-07/C pasta: 1

provisorio antigo:

$\square$ CROMO $\quad \square$ DIGITAL alta


água-tinta em cores sobre papel, $44,5 \times 56 \times \mathrm{cm}$ Aquisição MAC USP -

RESERVA TÉCNICA:

$\begin{array}{ll}\text { 1967.4.20 } & \text { M-07/C } \\ & \text { provisorio antigo: }\end{array}$

1967.4 .21

CROMO $\square$ DIGITAL alta

Debandada, 1964

água-tinta em cores sobre papel, 55,8 x $45 \times \mathrm{cm}$

Aquisição MAC USP -

RESERVA TÉCNICA:

\begin{tabular}{|c|c|c|}
\hline 1967.4 .21 & $\mathrm{M}-07 / \mathrm{C}$ & $\begin{array}{l}\text { pasta: } 1 \\
\text { provisorio antigo: expo ENTRE ATOS }\end{array}$ \\
\hline
\end{tabular}

1967.4.22

\section{CROMO $\square$ DIGITAL alta}

Outro Continente, 1965

água-tinta em cores sobre papel, 49,9 x 64,8 $8 \mathrm{~cm}$

Aquisição MAC USP -

RESERVA TÉCNICA:

1967.4.22 M-07/C pasta: 1

provisorio antigo: expo ENTRE ATOS

$\checkmark$ CROMO $\square$ DIGITAL alta

\section{Arthur Luiz PIZA}

São Paulo, SP Brasil 1928 1967.4.12

1967.4 .13

1967.4.14

1967.4 .15

1967.4 .16

1967.4.17

\section{Gravura, 1956}

água-tinta sobre papel, $77,6 \times 55,2 \times \mathrm{cm}$

Aquisição MAC USP -

RESERVA TÉCNICA:

1967.4.12 M-07/C pasta: 1

provisorio antigo:

$\square$ CROMO $\square$ DIGITAL alta

\section{Eclosão, c.1957}

buril em cores sobre papel, $65 \times 49,5 \times \mathrm{cm}$

Aquisição MAC USP -

RESERVA TÉCNICA:

1967.4.13 M-07/C pasta: 1

provisorio antigo:

$\square$ CROMO $\square$ DIGITAL alta

\section{Transparência, 1960}

buril em cores sobre papel, $64,7 \times 49,6 \times \mathrm{cm}$

Aquisição MAC USP -

RESERVA TÉCNICA:

1967.4.14 M-07/C pasta: 1

provisorio antigo:

\section{CROMO \\ $\square$ DIGITAL alta}

Cosmogonia, 1961

buril sobre papel, $76 \times 56 \times \mathrm{cm}$

Aquisição MAC USP -

RESERVA TÉCNICA:

$\begin{array}{ll}\text { 1967.4.15 } & \text { M-14/D } \\ \square \text { CROMO } & \text { provisorio antigo: chão reserva papel - troca gaveta }\end{array}$
$\square$ DIGITAL alta

Três Matérias, 1964

buril em cores sobre papel, $96,4 \times 74,6 \times \mathrm{cm}$

Aquisição MAC USP -

\begin{tabular}{|c|c|c|}
\hline \multicolumn{3}{|c|}{ RESERVA TÉCNICA: } \\
\hline 1967.4.16 & M-10/E & $\begin{array}{l}\text { pasta: } 1 \\
\text { provisorio antigo: expo ENTRE ATOS }\end{array}$ \\
\hline
\end{tabular}

$\checkmark$ CROMO $\square$ DIGITAL alta

"Labours", c.1963

buril em cores sobre papel, $76 \times 56,5 \times \mathrm{cm}$

Aquisição MAC USP -

\begin{tabular}{|c|c|c|}
\hline \multicolumn{3}{|c|}{ RESERVA TÉCNICA: } \\
\hline 1967.4.17 & $M-17 / D$ & $\begin{array}{l}\text { pasta: } \\
\text { provisorio antigo: }\end{array}$ \\
\hline
\end{tabular}

CROMO $\square$ DIGITAL alta 
Grande Moitiê, s.d.

buril em cores sobre papel, 50,1 x 65,7 x cm

Aquisição MAC USP -

RESERVA TÉCNICA:

1967.4.18 M-07/C pasta: 1

provisorio antigo:

$\square$ CROMO $\square$ DIGITAL alta

\section{Pierre SOULAGES}

Rodez, Aveyron França 1919

1967.4.23

\section{Composição, 1959}

óleo sobre tela, $129,5 \times 88,6 \times \mathrm{cm}$

Aquisição MAC USP - Adquirida na Galerie de France em Paris

RESERVA TÉCNICA:

1967.4.23 P-080/A pasta:

provisorio antigo: expo IBIRA MODERNISMOS

$\boldsymbol{\vee}$ CROMO $\boldsymbol{V}$ DIGITAL alta

\section{Juan VENTAYOL}

Montevidéu Uruguai 1915 1967.1.7

Arco Real, 1966

1971

óleo, madeira e treliça de palha sobre tela, $100,5 \times 100,5 \times \mathrm{cm}$

Aquisição MAC USP -

RESERVA TÉCNICA:

1967.1.7 P- Pasta: P-118/B - definir trainel

provisorio antigo: restauro pintura - ibira

$\checkmark$ CROMO $\square$ DIGITAL alta

\section{Mary VIEIRA}

São Paulo, SP Brasil 1927 1967.1.12

\section{Basileia Suíça 2001}

"Polivolume: Disco Plástico", Idéia para uma

Progressão Serial, 1953/62

alumínio anodizado, 36,6 x 36,6 × 34 cm

Aquisição MAC USP - Adquirida da artista

RESERVA TÉCNICA:

1967.1.12 E- pasta:

provisorio antigo: expo ESCULTURA AVENTURA SEDE

CROMO $\quad \boldsymbol{V}$ DIGITAL alta

\section{Yo YOSHITOME}

Shimane Ken Japão 1925

$\mathbf{1 9 6 7 . 1 . 8}$

\section{Drama 3, 1967}

óleo sobre tela, $140,5 \times 200 \times \mathrm{cm}$

Aquisição MAC USP -

RESERVA TÉCNICA:

$\begin{array}{lll}\text { 1967.1.8 } & \text { P-069/B } & \begin{array}{l}\text { pasta: } \\ \text { provisorio antigo: expo SEDE }\end{array} \\ \square \text { CROMO } & \square \text { DIGITAL alta }\end{array}$




\section{ACERVO MAC USP - adquiridas em 1968}

№ de obras: 12

Antonio Henrique AMARAL

São Paulo, SP Brasil 1935

1968.4.1.1

O Idolatrado, 1967

Álbum O Meu e o Seu

xilografia em cores sobre papel, 54 x 37 x cm

Album o Meu eoseu Aquisição MAC USP -

\begin{tabular}{|c|c|c|}
\hline \multicolumn{3}{|c|}{ RESERVA TÉCNICA: } \\
\hline 1968.4.1.1 & $M-13 / D$ & $\begin{array}{l}\text { pasta: } \\
\text { provisorio antigo: expo ENTRE ATOS }\end{array}$ \\
\hline
\end{tabular}

1968.4.1.2

Realidades, Culpas?, 1967

Álbum 0 Meu e o Seu

xilografia em cores sobre papel, 37,1 x 54,1 x cm

Aquisição MAC USP -

RESERVA TÉCNICA:

$\begin{array}{lll}\text { 1968.4.1.2 } & \text { M-13/D } & \text { pasta: } \\ & & \text { provisorio antigo: expo ENTRE ATOS }\end{array}$

1968.4.1.3

1968.4.1.4

1968.4.1.5

1968.4.1.6

1968.4.1.7

1968.4 .2

Passatempo Século XX, 1967

Álbum 0 Meu e o Seu

xilografia em cores sobre papel, 54 × 36,9 x cm

Aquisição MAC USP -

RESERVA TÉCNICA:

$\begin{array}{lll}\text { 1968.4.1.3 } & \text { M-13/D } & \text { pasta: } \\ & \text { provisorio antigo: expo ENTRE ATOS }\end{array}$

$\square$ DIGITAL alta

Madona, 1967

Álbum 0 Meu e o Seu

xilografia em cores sobre papel, $54 \times 37 \times \mathrm{cm}$

Aquisição MAC USP -

RESERVA TÉCNICA:

1968.4.1.4 M-13/D

provisorio antigo:

$\checkmark$ CROMO $\square$ DIGITAL alta

Sem Saída, 1967

Álbum 0 Meu e o Seu

xilografia em cores sobre papel, 36,8 x 54 x cm

Aquisição MAC USP -

RESERVA TÉCNICA:

1968.4.1.5 M-13/D

provisorio antigo: expo ENTRE ATOS

\section{CROMO $\square$ DIGITAL alta}

Personagem Contemporâneo, 1967

Álbum O Meu e o Seu

xilografia em cores sobre papel, $37 \times 54$ x cm

Aquisição MAC USP -

RESERVA TÉCNICA:

1968.4.1.6 M-13/D pasta:

provisorio antigo: expo ENTRE ATOS

\section{CROMO $\square$ DIGITAL alta}

Um + um = dois?, 1967

Álbum 0 Meu e o Seu

xilografia em cores sobre papel, $36,9 \times 54 \times \mathrm{cm}$

Aquisição MAC USP -

RESERVA TÉCNICA:

1968.4.1.7 M-13/D pasta:

provisorio antigo: expo ENTRE ATOS

CROMO

$\square$ DIGITAL alta

País da Margarida do Festival da Alegria, 1968

xilografia sobre papel, $89,9 \times 60,7 \times \mathrm{cm}$

Aquisição MAC USP -

RESERVA TÉCNICA:

1968.4.2 M-09/A pasta: 1

provisorio antigo:

CROMO $\square$ DIGITAL alta 
Marselha França 1921

1968.1

Expansão Controlada, 1967

poliuretano, $221,5 \times 171,4 \times 116,7 \mathrm{~cm}$

Aquisição MAC USP - Prêmio Regulamentar Bienal de São Paulo IX Bienal de São Paulo, 1967

RESERVA TÉCNICA:

$\begin{array}{lll}1968.1 & \text { E- } & \text { pasta: } \\ & \text { provisorio antigo: expo FRANÇA SEDE } \\ \square & \boldsymbol{V} \text { CROMO } & \boldsymbol{V} \text { DIGITAL alta }\end{array}$

\section{Claude DUPUY}

Beyssenac França 1940

1968.29.1

\section{Painel para um Marquês, 1965}

madeira, $100 \times 40,5 \times 9,8 \mathrm{~cm}$

Aquisição MAC USP - Adquirida do artista em junho/1967

RESERVA TÉCNICA:

1968.29.1 P-035 pasta:

provisorio antigo: restauro pintura

\section{Jean-Marc MELOUX}

Paris França 1937

1968.29.2

Tríptico para uma Máscara e uma Roda Dentada, 1966

cimento, madeira e metal, $73 \times 96,5 \times 12 \mathrm{~cm}$

Aquisição MAC USP - Adquirida do artista em junho/1967

\begin{tabular}{lll}
\hline $\begin{array}{l}\text { RESERVA TÉCNICA: } \\
\text { 1968.29.2 }\end{array}$ & E-02/D & pasta: \\
& provisorio antigo:
\end{tabular}

Ramon VERGARA GREZ

Mejillones, Antofagasta Chile 1923

1968.7

Espelho da Lua (Dia Claro), 1965

óleo sobre tela, $160 \times 110,5 \times \mathrm{cm}$

Aquisição MAC USP - Adquirida do artista

RESERVA TÉCNICA:

$\begin{array}{lll}1968.7 & \text { P-078/B } & \begin{array}{l}\text { pasta: } \\ \text { provisorio antigo: expo SEDE TRAÇOS DE RAZÃO }\end{array} \\ \square \text { CROMO } & \square \text { DIGITAL alta }\end{array}$




\section{ACERVO MAC USP - adquiridas em 1969}

№ de obras:

34

\section{Isolde BAUMGART}

Munique Alemanha 1935

1969.1.29

\section{O Interior, 1966}

água-forte em cores sobre papel, 53,2 × 38,9 x cm

Aquisição MAC USP - Adquirida do artista

RESERVA TÉCNICA:

1969.1.29 M-03/C pasta: 1

provisorio antigo:

\section{Anne BREIVIK}

Steinkjer Noruega 1932 1969.1.30
1969.1.2

1969.1 .3

1969.1 .4

1969.1 .5

1969.1 .6

\section{Figura, c.1918}

Isloysing, 1965

buril sobre papel, $39,5 \times 52,5 \times \mathrm{cm}$

Aquisição MAC USP - Adquirida do artista

RESERVA TÉCNICA:

1969.1.30 M-03/D pasta: 1

provisorio antigo:

$\square$ CROMO $\quad \square$ DIGITAL alta

\section{Antônio GOMIDE}

Arasil 1895

aquarela e grafite sobre papel, $20,8 \times 9,1 \times \mathrm{cm}$

Aquisição MAC USP - Adquirida de Giuseppe Baccaro

RESERVA TÉCNICA:

1969.1.1 M-05/B pasta: 1

provisorio antigo: expo GABINETE SEDE 018a

$\square$ CROMO $\square$ DIGITAL alta

Dançarinas, c.1920

aquarela sobre papel, $20,9 \times 20,4 \times \mathrm{cm}$

Aquisição MAC USP - Adquirida de Giuseppe Baccaro

RESERVA TÉCNICA:

1969.1.2 M-05/B pasta: 1

provisorio antigo: expo SEGALL

\section{CROMO $\square$ DIGITAL alta}

Duas Mulheres, c.1920

aquarela sobre papel, $15,5 \times 10,3 \times \mathrm{cm}$

Aquisição MAC USP - Adquirida de Giuseppe Baccaro

RESERVA TÉCNICA:

1969.1.3 M-05/B pasta: 1

provisorio antigo: expo GABINETE SEDE 018a

\section{CROMO $\square$ DIGITAL alta}

Estudo para Estamparia no 1, c.1920

Série Estudos para Decoração

aquarela sobre papel, $21,4 \times 35,5 \times \mathrm{cm}$

Aquisição MAC USP - Adquirida de Giuseppe Baccaro

RESERVA TÉCNICA:

1969.1.4 M-05/B pasta: 1

provisorio antigo: expo GABINETE SEDE 018a

\section{CROMO $\square$ DIGITAL alta}

Estudo para Estamparia no 2, c.1920

Série Estudos para Decoração aquarela sobre papel, $43,7 \times 28,7 \times \mathrm{cm}$

Aquisição MAC USP - Adquirida de Giuseppe Baccaro

RESERVA TÉCNICA:

1969.1.5 M-05/B pasta: 1

provisorio antigo: expo GABINETE SEDE 018a

\section{CROMO $\square$ DIGITAL alta}

Estudo para Estamparia no 3, c.1920

Série Estudos para Decoração aquarela sobre papel, $17,8 \times 14,1 \times \mathrm{cm}$

Aquisição MAC USP - Adquirida de Giuseppe Baccaro

RESERVA TÉCNICA:

1969.1.6 M-37 pasta:

provisorio antigo: 

aquarela sobre papel, $19 \times 13,9 \times \mathrm{cm}$

Aquisição MAC USP - Adquirida de Giuseppe Baccaro RESERVA TÉCNICA:
1969.1.7
M-37
pasta:
provisorio antigo:

1969.1 .8

1969.1.9

1969.1 .10

1969.1.11

1969.1.12

1969.1.13

1969.1.14

1969.1.15

\section{CROMO}

Estudo para Estamparia no 5, c.1920

aquarela sobre papel, $18,7 \times 13,7 \times \mathrm{cm}$

Aquisição MAC USP - Adquirida de Giuseppe Baccaro

RESERVA TÉCNICA:

$\begin{array}{lll}\text { 1969.1.8 } & \text { M-37 } & \begin{array}{l}\text { pasta: } \\ \text { provisorio antigo: }\end{array} \\ \square \text { CROMO } \\ \square \text { DIGITAL alta }\end{array}$

Estudo para Estamparia no 6, c.1920

aquarela sobre papel, 19,2 x 14,4 x cm

Aquisição MAC USP - Adquirida de Giuseppe Baccaro

RESERVA TÉCNICA:

$\begin{array}{ll}\text { 1969.1.9 } & \text { M-37 } \\ & \text { pasta: } \\ & \text { provisorio antigo: }\end{array}$

CROMO

DIGITAL alta

Estudo para Estamparia no 7, c.1920

aquarela sobre papel, $17,9 \times 13,8 \times \mathrm{cm}$

Aquisição MAC USP - Adquirida de Giuseppe Baccaro

RESERVA TÉCNICA:

$\begin{array}{lll}1969.1 .10 & \text { M-37 } & \begin{array}{l}\text { pasta: } \\ \text { provisorio antigo: }\end{array} \\ \square \text { CROMO } \\ \square \text { DIGITAL alta }\end{array}$

Estudo para Estamparia no 8, c.1920

aquarela sobre papel, $19,2 \times 14 \times \mathrm{cm}$

Aquisição MAC USP - Adquirida de Giuseppe Baccaro

RESERVA TÉCNICA:

\begin{tabular}{lll}
1969.1 .11 & M-37 & $\begin{array}{l}\text { pasta: } \\
\text { provisorio antigo }\end{array}$ \\
$\square$ CROMO \\
\hline
\end{tabular}

Estudo para Estamparia no 9, c.1920

aquarela sobre papel, 19,2 x 14,7 x cm

Aquisição MAC USP - Adquirida de Giuseppe Baccaro

RESERVA TÉCNICA:

1969.1.12

M-37

pasta:

provisorio antigo:

\section{$\square$ CROMO $\square$ DIGITAL alta}

Estudo para Estamparia no 10, c.1920

aquarela sobre papel, $18,7 \times 13,8 \times \mathrm{cm}$

Aquisição MAC USP - Adquirida de Giuseppe Baccaro

RESERVA TÉCNICA:

1969.1.13

M-37

pasta:

provisorio antigo:

\section{$\square$ CROMO $\square$ DIGITAL alta}

Estudo para Estamparia no 11, c.1920

aquarela sobre papel, $18,6 \times 14,3 \times \mathrm{cm}$

Aquisição MAC USP - Adquirida de Giuseppe Baccaro

RESERVA TÉCNICA:

1969.1.14

M-37

pasta:

provisorio antigo:

\section{$\square$ CROMO $\square$ DIGITAL alta}

Estudo para Estamparia no 12, c.1920

aquarela sobre papel, $19 \times 13,2 \times \mathrm{cm}$

Aquisição MAC USP - Adquirida de Giuseppe Baccaro

RESERVA TÉCNICA:

1969.1.15

M-37

pasta:

provisorio antigo:
Série Estudos para Decoração

Série Estudos para Decoração

\section{Série Estudos para Decoração}

\section{Série Estudos para Decoração}

\section{Série Estudos para Decoração}

\section{Série Estudos para Decoração}

\section{Série Estudos para Decoração}

$\square$ CROMO $\square$ DIGITAL alta


aquarela sobre papel, $19 \times 13,9 \times \mathrm{cm}$

Aquisição MAC USP - Adquirida de Giuseppe Baccaro

\section{RESERVA TÉCNICA:}

$\begin{array}{lll}\text { 1969.1.16 } & \text { M-37 } & \text { pasta: } \\ & \text { provisorio antigo: }\end{array}$

1969.1.17

Estudo para Estamparia no 14, c.1920

Série Estudos para Decoração

aquarela sobre papel, $18,6 \times 13,8 \times \mathrm{cm}$

Aquisição MAC USP - Adquirida de Giuseppe Baccaro

RESERVA TÉCNICA:

$\begin{array}{ll}\text { 1969.1.17 } & \text { M-37 } \\ & \text { provisorio antigo: }\end{array}$

\section{CROMO $\square$ DIGITAL alta}

1969.1.18 Estudo para Estamparia no 15, c.1920

Série Estudos para Decoração

aquarela sobre papel, $20,2 \times 16,2 \times \mathrm{cm}$

Aquisição MAC USP - Adquirida de Giuseppe Baccaro

RESERVA TÉCNICA:

$\begin{array}{ll}\text { 1969.1.18 } & \text { M-37 } \\ & \text { pasta: } \\ & \text { provisorio antigo: }\end{array}$

\section{CROMO \\ DIGITAL alta}

1969.1.19

Estudo para Estamparia no 16, c.1920

aquarela sobre papel, 19,4 x 13,9 x cm

Aquisição MAC USP - Adquirida de Giuseppe Baccaro

RESERVA TÉCNICA:

$\begin{array}{lll}\text { 1969.1.19 } & \text { M-37 } & \text { pasta: } \\ & \text { provisorio antigo: } \\ \square \text { CROMO } & \square \text { DIGITAL alta }\end{array}$

1969.1 .20

Estudo para Estamparia no 17, c.1920

aquarela sobre papel, $18,4 \times 12,8 \times \mathrm{cm}$

Aquisição MAC USP - Adquirida de Giuseppe Baccaro

RESERVA TÉCNICA:

$\begin{array}{lll}1969.1 .20 & \text { M-37 } & \text { pasta: } \\ & \text { provisorio antigo: expo PINACOTECA } \\ \square \text { CROMO } & \square \text { DIGITAL alta }\end{array}$

1969.1.21

1969.1.22

Estudo para Estamparia no 18, c.1920

Série Estudos para Decoração

aquarela sobre papel, 19,5 x $14 \times \mathrm{cm}$

Aquisição MAC USP - Adquirida de Giuseppe Baccaro

RESERVA TÉCNICA:

\begin{tabular}{lll}
$\begin{array}{l}\text { 1969.1.21 } \\
\text { M-37 }\end{array}$ & $\begin{array}{l}\text { pasta: } \\
\text { provisorio antigo: }\end{array}$ \\
$\square$ CROMO \\
\hline
\end{tabular}

Duas Figuras I, 1922

aquarela sobre papel, $28,6 \times 17,1 \times \mathrm{cm}$

Aquisição MAC USP - Adquirida de Giuseppe Baccaro

RESERVA TÉCNICA:

\begin{tabular}{|c|c|c|c|}
\hline 1969.1.22 & $M-16 / C$ & $\begin{array}{l}\text { pasta: } \\
\text { provisorio antigo: }\end{array}$ & $\begin{array}{l}\text { montagem } \\
\text { expo gabinete } 018 \mathrm{~b}\end{array}$ \\
\hline
\end{tabular}

Pierrô e Colombina, 1922

aquarela sobre papel, $42 \times 25 \times \mathrm{cm}$

Aquisição MAC USP - Adquirida de Giuseppe Baccaro

RESERVA TÉCNICA:

$\begin{array}{lll}\text { 1969.1.23 } & \text { M-05/B } & \begin{array}{l}\text { pasta: } 1 \\ \text { provisorio antigo: }\end{array} \\ \square \text { CROMO } & \square \text { DIGITAL alta }\end{array}$

Ponte Saint Michel, 1923

crayon sobre papel, $35,5 \times 21,4 \times \mathrm{cm}$

Aquisição MAC USP - Adquirida de Giuseppe Baccaro

RESERVA TÉCNICA:

1969.1.24 M-05/B pasta: 1

provisorio antigo: expo FAAP

CROMO $\square$ DIGITAL alta 
Aquisição MAC USP - Adquirida de Giuseppe Baccaro RESERVA TÉCNICA:

\begin{tabular}{|c|c|c|}
\hline 1969.1 .25 & M-05/B & $\begin{array}{l}\text { pasta: } 1 \\
\text { provisorio antigo: expo GABINETE SEDE 019a }\end{array}$ \\
\hline
\end{tabular}

1969.1 .26

Estudo para Painel, c.1930

aquarela e grafite sobre papel, $23,9 \times 37,4 \times \mathrm{cm}$

Aquisição MAC USP - Adquirida de Giuseppe Baccaro

RESERVA TÉCNICA:

1969.1.26 M-05/B pasta: 1

provisorio antigo: expo GABINETE SEDE 019a

1969.1.27

CROMO

$\square$ DIGITAL alta

Estudo para Mural, c.1933

aquarela sobre papel, $33,1 \times 24 \times \mathrm{cm}$

Aquisição MAC USP - Adquirida de Giuseppe Baccaro

RESERVA TÉCNICA:

1969.1.27 M-05/B pasta: 1

provisorio antigo: expo GABINETE SEDE 019b

1969.1 .28

\section{CROMO}

$\square$ DIGITAL alta

Estudo para Mural, c.1933

aquarela sobre papel, $33,2 \times 24 \times \mathrm{cm}$

Aquisição MAC USP - Adquirida de Giuseppe Baccaro

RESERVA TÉCNICA:
1969.1.28
M-05/B
pasta: 1
provisorio antigo: expo GABINETE SEDE 019b

$\square$ CROMO $\square$ DIGITAL alta

\section{Miodrag NAGORNI}

Vlasotince Iugoslávia 1932

1969.1.31

Amebe, 1966

buril sobre papel, $66,2 \times 48,1 \times \mathrm{cm}$

Aquisição MAC USP - Adquirida do artista

RESERVA TÉCNICA:

1969.1.31 M-06/E pasta: 1

provisorio antigo:

\section{Zdenka RUSOVA}

Praga República Tcheca 1939

1969.1.32

Pequeno Perfil, 1967

ponta seca sobre papel, $78 \times 60,3 \times \mathrm{cm}$

Aquisição MAC USP - Adquirida do artista

RESERVA TÉCNICA:

1969.1.32 M-10/E pasta: 1

provisorio antigo:

CROMO $\square$ DIGITAL alta

\section{Kenji YOSHIDA}

Osaka Japão 1924

1969.1.33

\section{Chave da Vida, 1964}

água-forte em cores sobre papel, 49,9 x 65,3 x cm

Aquisição MAC USP - Adquirida do artista

\section{RESERVA TÉCNICA:}

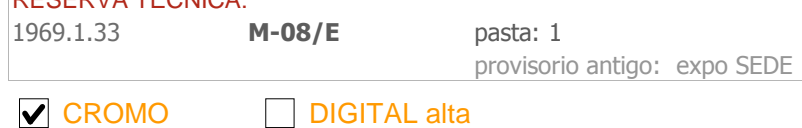

1969.1.34

Bruma Primaveril, 1967

água-forte em cores sobre papel, 64,4 x 49,3 x cm

Aquisição MAC USP - Adquirida do artista

RESERVA TÉCNICA:

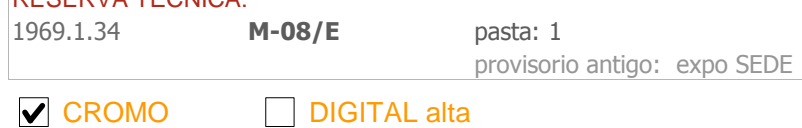




\section{ACERVO MAC USP - adquiridas em 1970}

№ de obras: $\quad 4$

\section{Josef ALBERS}

Bottrop, Westfalen Alemanha 1888

New Haven, Connecticut E.U.A. 1976

1970.1.1

Homenagem ao Quadrado: Signo Raro, 1967

óleo sobre aglomerado de madeira, $101,5 \times 101,5 \times \mathrm{cm}$

Aquisição MAC USP - Adquirida do artista

RESERVA TÉCNICA:

1970.1.1 P-010/A pasta:

provisorio antigo: expo IBIRA MODERNISMOS

$\checkmark$ CROMO $\square$ DIGITAL alta

\section{Marcelo BONEVARDI}

Buenos Aires Argentina 1929

Santuário Solar, 1967

1994

acrílica e cimento sobre tela e madeira, $71 \times 101,9 \times 6,3 \mathrm{~cm}$

Aquisição MAC USP - Prêmio Regulamentar Bienal de São Paulo X Bienal de São Paulo, 1969. Adquirida da Coleção The Chase Manhattan Bank U.S.A.

RESERVA TÉCNICA:

1970.1.2 P-025/B pasta:

provisorio antigo: expo MEMORIAL

$\checkmark$ CROMO $\square$ DIGITAL alta

Camille GRAESER

Carouge Suíça 1892

1970.1.3

Translocation A, 1969

óleo sobre tela, $120,5 \times 120,5 \times \mathrm{cm}$

Aquisição MAC USP - Adquirida do artista

RESERVA TÉCNICA:

\begin{tabular}{lll} 
1970.1.3 & P-039/A & $\begin{array}{l}\text { pasta: } \\
\text { provisorio antigo: }\end{array}$ \\
$\square$ CROMO \\
\hline
\end{tabular}

\section{Kozo MIO}

Nagoya Japão 1923

1970.1.4.1/2

\section{Perspectiva no Espaço C, 1969}

acrílica a aerógrafo sobre aglomerado de madeira, 211,5 x 324 x cm

Aquisição MAC USP - Adquirida do artista

RESERVA TÉCNICA:

1970.1.4.1

P-055/A

pasta:

1970.1.4.2

P-055/B

provisorio antigo:

pasta:

$\checkmark$ CROMO $\square$ DIGITAL alta 


\section{ACERVO MAC USP - adquiridas em 1971}

№ de obras:

42

\section{Jan Jaromir ALEKSIUN}

Wroclaw Polônia 1940

1971.11.1

Transplante, 1969

linoleografia em cores sobre papel, $52 \times 60 \times \mathrm{cm}$

Aquisição MAC USP -

RESERVA TÉCNICA:

1971.11.1 M-03/A pasta: 1

provisorio antigo:

Cláudia ANDUJAR

Neuchatel Suíça 1931

1971.5.1

Inês, 1971

fotografia pb sobre papel e acrílico sobre madeira, $101 \times 76,5 \times 2 \mathrm{~cm}$

Aquisição MAC USP -

RESERVA TÉCNICA:

1971.5.1 P-108/A pasta:

provisorio antigo: expo UM DIA TERÁ QUE TER TERMINADO

$\checkmark$ CROMO $\square$ DIGITAL alta

\section{Cláudia ANDUJAR e George LOVE}

\begin{tabular}{|c|c|c|c|}
\hline \multirow[t]{3}{*}{1971.5 .2} & \multicolumn{3}{|c|}{$\begin{array}{l}\text { Sem título, } 1970 \\
\text { fotografia pb sobre papel sobre madeira, } 111,5 \times 111,5 \times \mathrm{cm} \\
\text { Aquisição MAC USP - }\end{array}$} \\
\hline & $\begin{array}{l}\text { RESERVA TÉCNICA: } \\
\text { 1971.5.2 P- }\end{array}$ & $\begin{array}{l}\text { pasta: } \\
\text { provisorio antigo: }\end{array}$ & $\begin{array}{l}\mathbf{P - 1 0 7 / A} \text { - definir trainel } \\
\text { restauro papel }\end{array}$ \\
\hline & \multicolumn{3}{|c|}{$\square$ DIGITAL alta } \\
\hline
\end{tabular}

\section{Vera Chaves BARCELLOS}

Porto Alegre, RS Brasil 1938

Álbum Vera C. Barcellos e Romanita Martins

serigrafia em cores sobre papel, 47,7 x 32,7 x cm Aquisição MAC USP -

RESERVA TÉCNICA:
1971.5.3.1
M-13/E
pasta:
provisorio antigo: expo UM DIA TERÁ Q TER TERMINADO IBIRA

\section{$\square$ CROMO $\quad \square$ DIGITAL alta}

1971.5.3.2

A Dama, 1970

Álbum Vera C. Barcellos e Romanita Martins

serigrafia em cores sobre papel, 47,7 x 32,7 x cm

Aquisição MAC USP -

RESERVA TÉCNICA:
1971.5.3.2
M-13/E
pasta:

provisorio antigo: expo UM DIA TERÁ Q TER TERMINADO IBIRA

$\square$ CROMO $\square$ DIGITAL alta

1971.5.3.3

O Nascer, 1970

Álbum Vera C. Barcellos e Romanita Martins

serigrafia em cores sobre papel, $47,7 \times 32,8 \times \mathrm{cm}$

Aquisição MAC USP -

RESERVA TÉCNICA:

1971.5.3.3 M-13/E pasta:

provisorio antigo: expo UM DIA TERÁ Q TER TERMINADO IBIRA

$\square$ CROMO $\square$ DIGITAL alta

1971.5.3.4

O Renascer, 1970

Álbum Vera C. Barcellos e Romanita Martins

serigrafia em cores sobre papel, $47,7 \times 32,7 \times \mathrm{cm}$

Aquisição MAC USP -

RESERVA TÉCNICA:

1971.5.3.4 M-13/E pasta:

provisorio antigo: expo UM DIA TERÁ Q TER TERMINADO IBIRA

$\square$ CROMO $\square$ DIGITAL alta 
serigrafia em cores sobre papel, $47,7 \times 32,7 \times \mathrm{cm}$

Aquisição MAC USP -

RESERVA TÉCNICA:

1971.5.3.5 M-13/E pasta:

provisorio antigo: expo UM DIA TERÁ Q TER TERMINADO IBIRA

CROMO $\square$ DIGITAL alta

\section{Maureen BISILLIAT}

Surrey Inglaterra 1931

1971.7.2

Sem título, 1968

Série Pele Preta

fotografia pb sobre papel, $27,4 \times 32,6 \times \mathrm{cm}$

Aquisição MAC USP

RESERVA TÉCNICA:

1971.7.2 M-11/C pasta: 1

provisorio antigo: expo ENTRE ATOS

1971.7 .3

$\square$ CROMO $\square$ DIGITAL alta

\section{Sem título, 1968}

Série Pele Preta

fotografia pb sobre papel, $38,8 \times 35,3 \times \mathrm{cm}$

Aquisição MAC USP -

RESERVA TÉCNICA:

1971.7.3 M-11/C pasta: 1

provisorio antigo: expo ENTRE ATOS

1971.7.4

$\square$ CROMO $\square$ DIGITAL alta

\section{Sem título, 1968}

Série Pele Preta

fotografia pb sobre papel, $35,2 \times 26,8 \times \mathrm{cm}$

Aquisição MAC USP -

RESERVA TÉCNICA:

1971.7.4 M-11/C pasta: 1

provisorio antigo: expo ENTRE ATOS

1971.7 .5

1971.7.6

1971.7.7

$\square$ CROMO $\square$ DIGITAL alta

Sem título, 1968

Série Pele Preta

fotografia pb sobre papel, $27 \times 35,2 \times \mathrm{cm}$

Aquisição MAC USP -

RESERVA TÉCNICA:

1971.7.5 M-11/C pasta: 1

provisorio antigo: expo ENTRE ATOS

$\square$ CROMO $\square$ DIGITAL alta

\section{Sem título, 1968}

Série Pele Preta

fotografia pb sobre papel, $34,8 \times 27,3 \times \mathrm{cm}$

Aquisição MAC USP -

RESERVA TÉCNICA:

1971.7.6 M-11/C pasta: 1

provisorio antigo: expo ENTRE ATOS

\section{CROMO $\square$ DIGITAL alta}

Sem título, 1968

Série Pele Preta

fotografia pb sobre papel, $35,3 \times 27,1 \times \mathrm{cm}$

Aquisição MAC USP -

RESERVA TÉCNICA:

1971.7.7 M-11/C pasta: 1

provisorio antigo: expo ENTRE ATOS

\section{CROMO $\square$ DIGITAL alta}

Sem título, 1968

Série Pele Preta

fotografia pb sobre papel, $35,3 \times 27,3 \times \mathrm{cm}$

Aquisição MAC USP -

\begin{tabular}{|c|c|}
\hline RESERVA TÉCNICA: & \\
\hline 1971.7.8 M-11/C & $\begin{array}{l}\text { pasta: } 1 \\
\text { provisorio antigo: expo ENTRE ATOS }\end{array}$ \\
\hline
\end{tabular}

\section{$\square$ DIGITAL alta}

Sem título, 1968

Série Pele Preta

fotografia pb sobre papel, $42,4 \times 34,8 \times \mathrm{cm}$

Aquisição MAC USP -

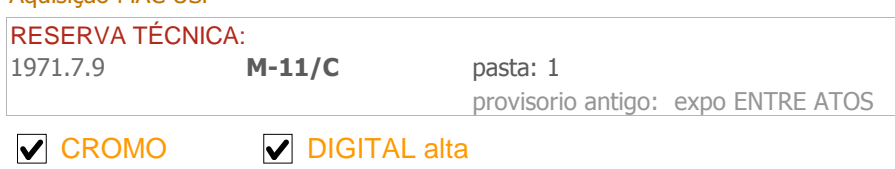




\section{Stanislaw BORYSOWSKI}

Lviv Ucrânia 1906

1971.11.3

\section{Gravura CZ, 1960}

Torun Polônia 1988

água-forte e água-tinta em cores sobre papel, 46 × 40,2 x cm

Aquisição MAC USP -

RESERVA TÉCNICA:

1971.11.3 M-03/D pasta: 1

provisorio antigo:

$\square$ CROMO $\square$ DIGITAL alta

\section{Janusz KARWACKI}

Polônia 1940

1971.11.5 Escola Espanhola de Equitação IV, 1967

litografia em cores sobre papel, $56,8 \times 48,8 \times \mathrm{cm}$

Aquisição MAC USP -

RESERVA TÉCNICA:

1971.11.5 M-05/E pasta: 1

provisorio antigo: M-32/A - guardar

$\square$ CROMO $\square$ DIGITAL alta

\section{Romanita MARTINS}

Santiago do Boqueirão, RS Brasil 1940

1971.5.3.6 Sinal 1, 1970

Álbum Vera C. Barcellos e Romanita Martins

serigrafia em cores sobre papel, $47,7 \times 32,7 \times \mathrm{cm}$

Aquisição MAC USP -

RESERVA TÉCNICA:

$\begin{array}{ll}\text { 1971.5.3.6 M-13/E } & \text { pasta: } \\ & \end{array}$

\section{$\square$ CROMO $\square$ DIGITAL alta}

1971.5.3.7

\section{Sinal 2, 1970}

Álbum Vera C. Barcellos e Romanita Martins

serigrafia em cores sobre papel, $47,7 \times 32,7 \times \mathrm{cm}$

Aquisição MAC USP -

RESERVA TÉCNICA:

$\begin{array}{lll}\text { 1971.5.3.7 } & \text { M-13/E } & \begin{array}{l}\text { pasta: } \\ \text { provisorio antigo: }\end{array} \\ \square \text { CROMO } & \square \text { DIGITAL alta }\end{array}$

1971.5.3.8

Sinal 3, 1970

Álbum Vera C. Barcellos e Romanita Martins

serigrafia em cores sobre papel, $47,7 \times 32,7 \times \mathrm{cm}$

Aquisição MAC USP -

RESERVA TÉCNICA:

\begin{tabular}{|c|c|c|}
\hline 1971.5.3.8 & $M-13 / E$ & $\begin{array}{l}\text { pasta: } \\
\text { provisorio antigo: }\end{array}$ \\
\hline
\end{tabular}

1971.5.3.9

Por Vinte Centavos, 1970

serigrafia em cores sobre papel, 47,7 x 32,7 x cm

Álbum Vera C. Barcellos e Romanita Martins

Aquisição MAC USP -

RESERVA TÉCNICA:

$\begin{array}{lll}\text { 1971.5.3.9 } & \text { M-13/E } & \text { pasta: } \\ & \text { provisorio antigo: } \\ \square \text { CROMO } & \square \text { DIGITAL alta }\end{array}$

1971.5.3.10 Por um Cruzeiro, 1970

serigrafia em cores sobre papel, $47,6 \times 32,7 \times \mathrm{cm}$

Álbum Vera C. Barcellos e Romanita Martins

Aquisição MAC USP -

RESERVA TÉCNICA:

1971.5.3.10 M-13/E pasta:

provisorio antigo:

$\square$ CROMO $\square$ DIGITAL alta

\section{Cristiano MASCARO}

Catanduva, SP Brasil 1944 1971.9.1

Sem título, 1969

Série 0 Enterro de Barrientos

fotografia pb sobre papel sobre aglomerado de madeira, $27,3 \times 40,2 \times \mathrm{cm}$

Aquisição MAC USP -

RESERVA TÉCNICA:
1971.9.1
$\mathrm{P}-072 / \mathrm{B}$
pasta:
provisorio antigo: expo UM DIA TERÁ Q TER TERMINADO IBIRA

\section{CROMO $\square$ DIGITAL alta}


fotografia pb sobre papel sobre aglomerado de madeira, $27,3 \times 40,3 \times \mathrm{cm}$

Aquisição MAC USP -

RESERVA TÉCNICA:

1971.9.2 P-072/B pasta:

provisorio antigo: expo UM DIA TERÁ Q TER TERMINADO IBIRA

1971.9.3

1971.9.4

1971.9.5

1971.9.6

1971.9.7

1971.9 .8

1971.9.9

1971.9.10

\section{CROMO $\square$ DIGITAL alta}

Sem título, 1969

fotografia pb sobre papel sobre aglomerado de madeira, $40,1 \times 27,4 \times \mathrm{cm}$

Aquisição MAC USP -

RESERVA TÉCNICA:

1971.9.3 P-072/A pasta:

provisorio antigo: expo UM DIA TERÁ Q TER TERMINADO IBIRA

\section{CROMO $\square$ DIGITAL alta}

Sem título, 1969

Série 0 Enterro de Barrientos

fotografia pb sobre papel sobre aglomerado de madeira, $40,3 \times 27,2 \times \mathrm{cm}$

Aquisição MAC USP -

RESERVA TÉCNICA:

1971.9.4 P-072/A pasta:

provisorio antigo: expo UM DIA TERÁ Q TER TERMINADO IBIRA

\section{CROMO $\square$ DIGITAL alta}

Sem título, 1969

Série 0 Enterro de Barrientos

fotografia pb sobre papel sobre aglomerado de madeira, $27,3 \times 40,3 \times \mathrm{cm}$

Aquisição MAC USP -

RESERVA TÉCNICA:

1971.9.5 P-072/A pasta:

provisorio antigo: expo UM DIA TERÁ Q TER TERMINADO IBIRA

\section{CROMO $\square$ DIGITAL alta}

Sem título, 1969

Série 0 Enterro de Barrientos

fotografia pb sobre papel sobre aglomerado de madeira, $40,2 \times 27,3 \times \mathrm{cm}$

Aquisição MAC USP -

RESERVA TÉCNICA:

1971.9.6 P-072/A pasta:

provisorio antigo: expo UM DIA TERÁ Q TER TERMINADO IBIRA

\section{CROMO $\square$ DIGITAL alta}

\section{Sem título, 1969}

Série 0 Enterro de Barrientos

fotografia pb sobre papel sobre aglomerado de madeira, $40,3 \times 27,4 \times \mathrm{cm}$

Aquisição MAC USP -

RESERVA TÉCNICA:

1971.9.7 P-072/A pasta:

provisorio antigo: expo UM DIA TERÁ Q TER TERMINADO IBIRA

\section{$\square$ CROMO $\square$ DIGITAL alta}

Sem título, 1969

Série 0 Enterro de Barrientos

fotografia pb sobre papel sobre aglomerado de madeira, $27,4 \times 40,4 \times \mathrm{cm}$

Aquisição MAC USP -

RESERVA TÉCNICA:

1971.9.8 P-072/A pasta:

provisorio antigo: expo UM DIA TERÁ Q TER TERMINADO IBIRA

\section{$\square$ CROMO $\quad \square$ DIGITAL alta}

Sem título, 1969

Série 0 Enterro de Barrientos

fotografia pb sobre papel sobre aglomerado de madeira, $40,2 \times 27,2 \times \mathrm{cm}$

Aquisição MAC USP -

RESERVA TÉCNICA:

1971.9.9 P-072/A pasta:

provisorio antigo: expo UM DIA TERÁ Q TER TERMINADO IBIRA

$\square$ CROMO $\square$ DIGITAL alta

Sem título, 1969

Série O Enterro de Barrientos

fotografia pb sobre papel sobre aglomerado de madeira, $40,3 \times 27,3 \times \mathrm{cm}$

Aquisição MAC USP -

RESERVA TÉCNICA:

1971.9.10 P-072/A pasta:

CROMO $\square$ DIGITAL alta 


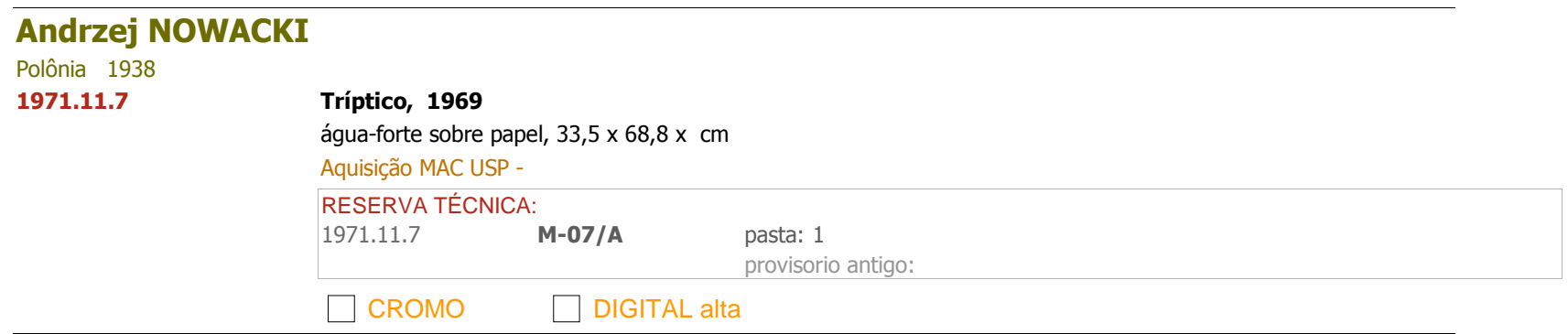

\section{Jan NOWAK}

Polônia 1930

1971.11.8

\section{Cidade II, 1966}

litografia em cores sobre papel, 59,7 x 79,4 x cm

Aquisição MAC USP -

RESERVA TÉCNICA:

1971.11.8 M-10/D pasta: 1

provisorio antigo:

\section{Roman OPALKA}

Abbeville França 1931 1971.11.9

\section{Do Interior, 1969}

água-forte sobre papel, $72,5 \times 59,3 \times \mathrm{cm}$

Aquisição MAC USP -

RESERVA TÉCNICA:

$\begin{array}{lll}1971.11 .9 & \text { M-10/D } & \text { pasta: } 1 \\ & \text { provisorio antigo: expo FRANCESES IBIRA } \\ \boldsymbol{\square} \text { CROMO } & \boldsymbol{\square} \text { DIGITAL alta }\end{array}$

\section{Danuta OSADCZY}

Polônia

1971.11.10

Luzes, s.d.

linoleografia sobre papel, $62,6 \times 48,6 \times \mathrm{cm}$

Aquisição MAC USP -

RESERVA TÉCNICA:

1971.11.10 M-07/A pasta: 1

provisorio antigo:

Jozef PAKULSKI

Kiev Ucrânia 1900

1971.11.11

Wianki, 1959

DIGITAL alta

$\square$ CROMO $\square$ DIGITAL alta

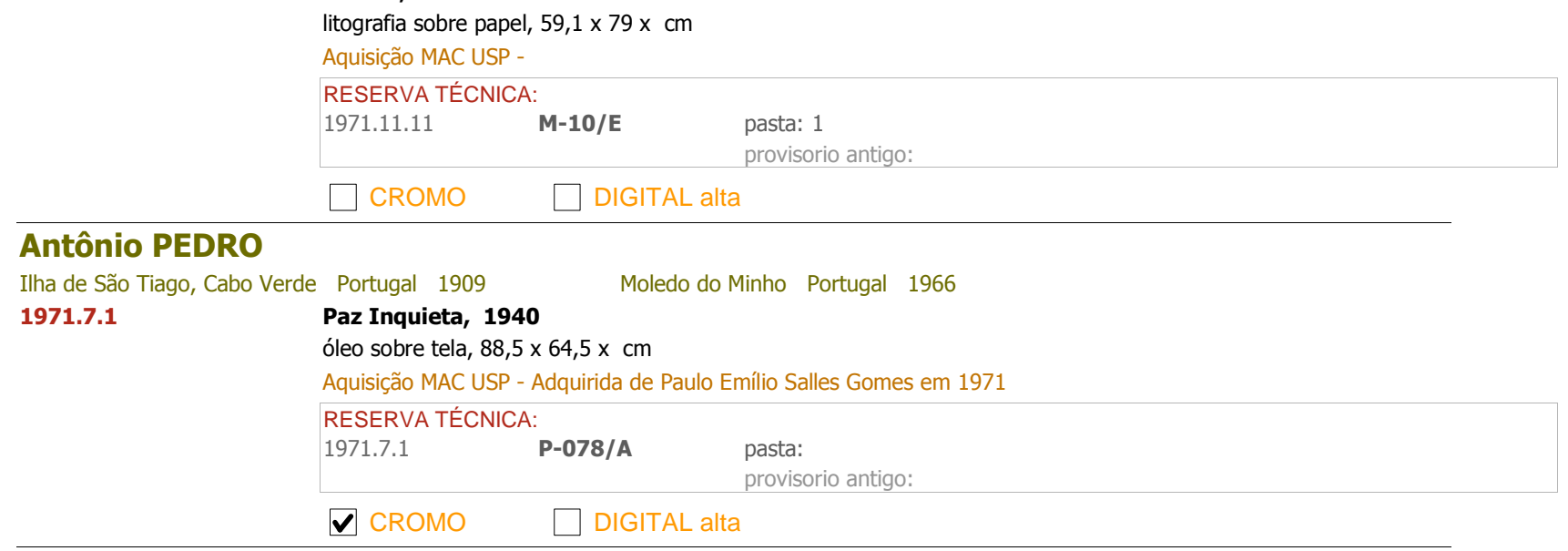

\section{Roman STARAK}

Zabrze Polônia 1929

1971.11.14

\section{Paisagem da Silésia II, 1965}

litografia sobre papel, $48,5 \times 62,7 \times \mathrm{cm}$

Aquisição MAC USP -

RESERVA TÉCNICA:

$\begin{array}{lll}1971.11 .14 & \text { M-08/B } & \text { pasta: } 1 \\ & \text { provisorio antigo: }\end{array}$




\section{Aleksander TUREK}

Varsóvia Polônia 1933

1971.11.15

\section{Balé, 1969}

litografia em cores sobre papel, $86,6 \times 67,5 \times \mathrm{cm}$

Aquisição MAC USP .

RESERVA TÉCNICA:

$\begin{array}{lll}1971.11 .15 & \text { M-11/A } & \begin{array}{l}\text { pasta: } 1 \\ \text { provisorio antigo: M-32/A - guardar }\end{array} \\ \square \text { CROMO } & \square \text { DIGITAL alta }\end{array}$

1971.11.16

Flores, 1969

litografia em cores sobre papel, 86 x 67 x cm

Aquisição MAC USP -

RESERVA TÉCNICA:

$\begin{array}{lll}\text { 1971.11.16 } & \text { M-11/A } & \text { pasta: } 1 \\ & \text { provisorio antigo: } \\ \square \text { CROMO } & \square \text { DIGITAL alta }\end{array}$




\section{ACERVO MAC USP - adquiridas em 1972}

№ de obras: $\quad 66$

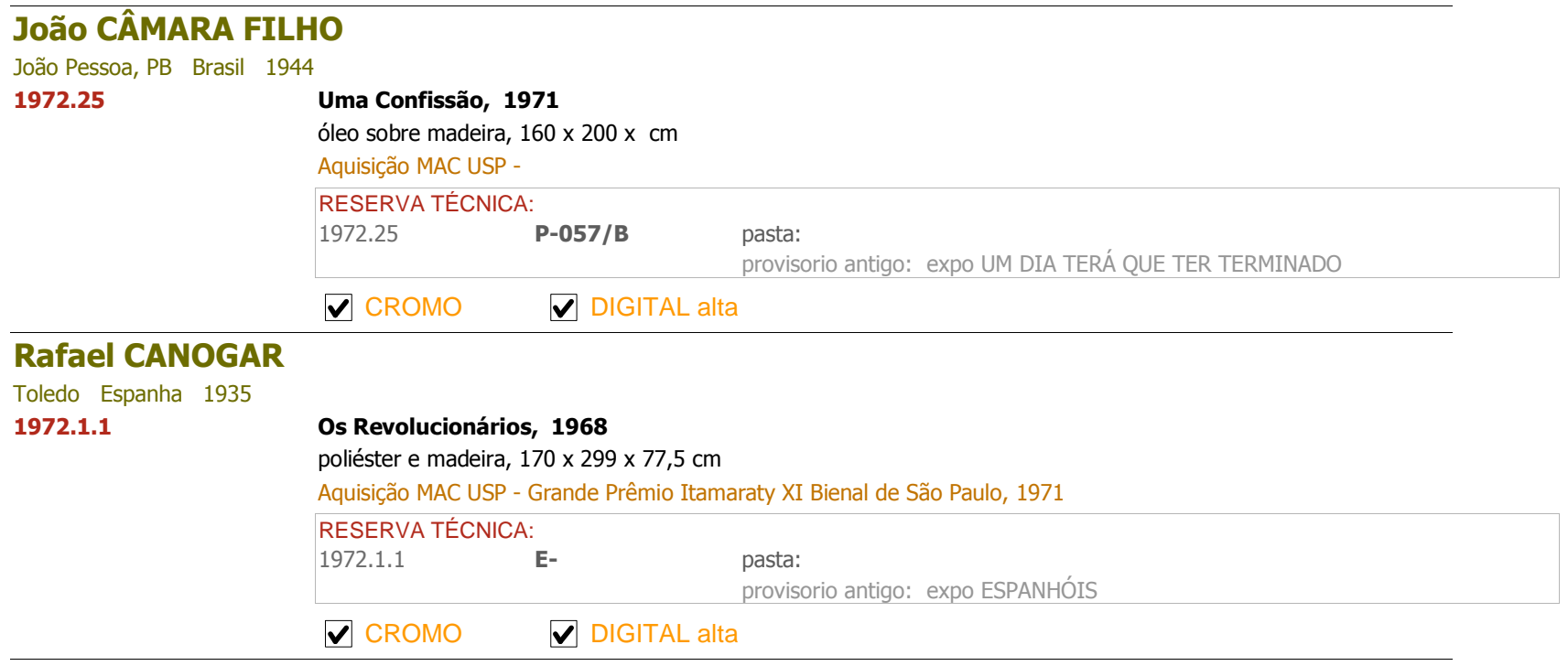

\section{Moema CAVALCANTI}

Recife, PE Brasil 1942

1972.30.22

Velha e Porta II, 1972

fotografia pb sobre papel, $24,3 \times 18 \times \mathrm{cm}$

Aquisição MAC USP -

RESERVA TÉCNICA:

1972.30.22 M-11/C pasta: 1

provisorio antigo:

1972.30.23 Menina de Tracunhaen, 1972

fotografia pb sobre papel, $17,4 \times 23,6 \times \mathrm{cm}$

Aquisição MAC USP -

RESERVA TÉCNICA:

1972.30.23 M-11/C pasta: 1

provisorio antigo:

\section{Lothar CHAROUX}

Viena Áustria 1912

1972.3.2

São Paulo, SP Brasil 1987

Desenho no 2 / Equilíbrio Restabelecido, 1967

guache sobre papel sobre aglomerado de madeira, $68 \times 68 \times \mathrm{cm}$

Aquisição MAC USP - Adquirida do artista

RESERVA TÉCNICA:

\begin{tabular}{|c|c|c|}
\hline 1972.3.2 & M-34 & $\begin{array}{l}\text { pasta: } \\
\text { provisorio antigo: expo ENTRE ATOS }\end{array}$ \\
\hline
\end{tabular}

1972.3.3 Círculos, 1971

polimer e guache sobre papel sobre aglomerado de madeira, $100 \times 70 \times \mathrm{cm}$

Aquisição MAC USP - Adquirida do artista

RESERVA TÉCNICA:

1972.3.3 M-35 pasta: restauro papel provisorio antigo:

$\square$ CROMO $\square$ DIGITAL alta

\section{Paulo CLETO}

São Paulo, SP Brasil 1948

1972.30.24

Sem título, 1972

fotografia pb sobre papel, $32,9 \times 27,8 \times \mathrm{cm}$

Aquisição MAC USP -

RESERVA TÉCNICA:

$\begin{array}{lll}1972.30 .24 & \text { M-11/C } & \text { pasta: } 1 \\ \text { provisorio antigo: }\end{array}$


Sem título, 1972

fotografia pb sobre papel, $32,6 \times 27,8 \times \mathrm{cm}$

Aquisição MAC USP -

RESERVA TÉCNICA:

1972.30.25 M-11/C pasta: 1

provisorio antigo:

1972.30 .26

\section{CROMO $\square$ DIGITAL alta}

Sem título, 1972

fotografia pb sobre papel, $25 \times 32,9 \times \mathrm{cm}$

Aquisição MAC USP -

RESERVA TÉCNICA:

1972.30.26 $\mathbf{M - 1 1 / C}$ pasta: 1

provisorio antigo:

1972.30.27

\section{CROMO $\square$ DIGITAL alta}

Sem título, 1972

fotografia pb sobre papel, $25 \times 32,8 \times \mathrm{cm}$

Aquisição MAC USP -

RESERVA TÉCNICA:

1972.30.27 $\mathbf{M - 1 1 / C}$ pasta: 1

provisorio antigo:

1972.30 .28

\section{CROMO $\square$ DIGITAL alta}

Sem título, 1972

fotografia pb sobre papel, $25,1 \times 33 \times \mathrm{cm}$

Aquisição MAC USP -

RESERVA TÉCNICA:

1972.30.28 $\mathbf{M - 1 1 / C}$ pasta: 1

provisorio antigo:

$\square$ CROMO $\square$ DIGITAL alta

\section{Marita CRESPI}

São Paulo, SP Brasil 1941

1972.30.30

\section{A Porta, 1972}

fotografia pb sobre papel sobre cartão, $20,1 \times 29,5 \times \mathrm{cm}$

Aquisição MAC USP -

RESERVA TÉCNICA:

1972.30.30 M-11/C pasta: 1

provisorio antigo:

1972.30 .31

\section{Luz I, 1972}

fotografia pb sobre papel sobre cartão, 24 x 17,2 x cm

Aquisição MAC USP -

RESERVA TÉCNICA:

1972.30.31 M-11/C

provisorio antigo:

1972.30 .32

1972.30.33

$\square$ CROMO $\square$ DIGITAL alta

Luz II, 1972

fotografia pb sobre papel sobre cartão, $23,8 \times 17,2 \times \mathrm{cm}$

Aquisição MAC USP -

RESERVA TÉCNICA:

1972.30.32 M-11/C

provisorio antigo:

\section{CROMO $\square$ DIGITAL alta}

Luz III, 1972

fotografia pb sobre papel sobre cartão, $23,8 \times 17,4 \times \mathrm{cm}$

Aquisição MAC USP -

RESERVA TÉCNICA:

1972.30.33 M-11/C

CROMO $\square$ DIGITAL alta 


\section{Arnaldo FERRARI}

São Paulo, SP Brasil 1906

1972.11
Dinamismo, 1967

São Paulo, SP Brasil 1974

óleo sobre tela, $100 \times 135 \times \mathrm{cm}$

Aquisição MAC USP -

RESERVA TÉCNICA:

1972.11 P-078/B pasta:

provisorio antigo: expo ENTRE ATOS

\section{Bruno GIRONCOLI}

Villach, Karnten Áustria 1936

1972.1.2

\section{Isolationen, 1969}

guache e nanquim sobre papel, $90 \times 62,7 \times \mathrm{cm}$

Aquisição MAC USP -

RESERVA TÉCNICA:

$\begin{array}{ll}\text { 1972.1.2 M-09/E } & \text { pasta: } 1 \\ & \\ & \text { provisorio antigo: }\end{array}$

1972.1.3 Isolationen Film, 1969

DIGITAL alta

guache, grafite e nanquim sobre papel, $90 \times 62,8 \times \mathrm{cm}$

Aquisição MAC USP -

RESERVA TÉCNICA:

1972.1.3 M-09/E pasta: 1

provisorio antigo:

$\checkmark$ CROMO $\square$ DIGITAL alta

\section{Carmen GRACIA}

Mendoza Argentina 1935 1972.22.13

1972.22.14

\section{Retrato do Bisavô, 1964}

água-forte em cores sobre papel, 75,2 x 52,4 x cm

Aquisição MAC USP -

RESERVA TÉCNICA:

$\begin{array}{lll}\text { 1972.22.13 } & \text { M-05/B } & \text { pasta: } 1 \\ & \text { provisorio antigo: } \\ \square \text { CROMO } & \square \text { DIGITAL alta }\end{array}$

\section{O Eterno Olhar do Irmão, 1967}

água-forte em cores sobre papel, $75 \times 52 \times \mathrm{cm}$

Aquisição MAC USP -

RESERVA TÉCNICA:

$\begin{array}{lll}\text { 1972.22.14 } & \text { M-05/B } & \text { pasta: } 1 \\ \text { provisorio antigo: }\end{array}$
$\square$ CROMO $\square$ DIGITAL alta

\section{Heiner KIELHOLZ}

Rheinfelden Suíça 1942

1972.1.4.1/4

\section{Cão Dálmata, 1971}

acrílica e fotografia pb sobre tela sobre aglomerado de madeira, $240 \times 360 \times \mathrm{cm}$

Aquisição MAC USP - Adquirida na XI Bienal de São Paulo, 1971

RESERVA TÉCNICA:

1972.1.4.1/4 P-092 pasta:

provisorio antigo: expo GABINETE

$\checkmark$ CROMO $\square$ DIGITAL alta

\section{Ivan KUDRNA}

Praga República Tcheca 1943 1972.30.2

Sem título, 1972

Série Banho

fotografia pb sobre papel, $33,9 \times 23,5 \times \mathrm{cm}$

Aquisição MAC USP -

RESERVA TÉCNICA:

1972.30.2 M-11/D

\section{CROMO $\square$ DIGITAL alta}

1972.30 .3

\section{Sem título, 1972}

fotografia pb sobre papel, $33,9 \times 23,8 \times \mathrm{cm}$

Aquisição MAC USP -

RESERVA TÉCNICA:

\begin{tabular}{|c|c|c|}
\hline 1972.30 .3 & $M-11 / D$ & $\begin{array}{l}\text { pasta: } 1 \\
\text { provisorio antigo: }\end{array}$ \\
\hline
\end{tabular}

CROMO $\square$ DIGITAL alta 
fotografia pb sobre papel, $33,7 \times 23,7 \times \mathrm{cm}$

Aquisição MAC USP -

RESERVA TÉCNICA:

\begin{tabular}{|c|c|c|}
\hline 1972.30 .4 & $M-11 / D$ & $\begin{array}{l}\text { pasta: } 1 \\
\text { provisorio antigo: }\end{array}$ \\
\hline
\end{tabular}

1972.30 .5

Sem título, 1972

Série Banho

fotografia pb sobre papel, $33,9 \times 23,8 \times \mathrm{cm}$

Aquisição MAC USP -

RESERVA TÉCNICA:

1972.30.5 M-11/D pasta: 1

\section{CROMO $\square$ DIGITAL alta}

1972.30.6

\section{Sem título, 1972}

Série Banho

fotografia pb sobre papel, $33,4 \times 23,4 \times \mathrm{cm}$

Aquisição MAC USP -

RESERVA TÉCNICA:

$\begin{array}{lll}1972.30 .6 & \text { M-11/D } & \text { pasta: } 1 \\ \text { provisorio antigo: } & \\ \square \text { CROMO DIGITAL alta } & \end{array}$

1972.30.7

\section{Sem título, 1972}

Série Banho

fotografia pb sobre papel, $33,8 \times 23,7 \times \mathrm{cm}$

Aquisição MAC USP -

RESERVA TÉCNICA:

\begin{tabular}{|c|c|c|}
\hline 1972.30 .7 & $M-11 / D$ & $\begin{array}{l}\text { pasta: } 1 \\
\text { provisorio antigo: }\end{array}$ \\
\hline
\end{tabular}

1972.30 .8

\section{Sem título, 1972}

fotografia pb sobre papel, 17,2 x 22,7 x cm

Série Uma Tarde na Cachoeira

Aquisição MAC USP -

RESERVA TÉCNICA:

$\begin{array}{ll}\begin{array}{l}\text { 1972.30.8 } \\ \square \text { CROMO }\end{array} & \text { M-11/D } \\ \square \text { DIGITAL alta } & \text { provisorio antigo: }\end{array}$

1972.30 .9

\section{Sem título, 1972}

Série Uma Tarde na Cachoeira

fotografia pb sobre papel, $22,8 \times 17,2 \times \mathrm{cm}$

Aquisição MAC USP -

RESERVA TÉCNICA:

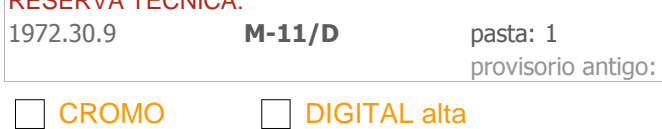

1972.30.10

Sem título, 1972

Série Uma Tarde na Cachoeira

fotografia pb sobre papel, $22,8 \times 17,3 \times \mathrm{cm}$

Aquisição MAC USP -

RESERVA TÉCNICA:

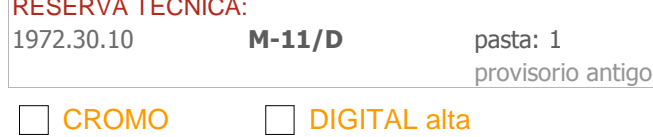

1972.30.11

Sem título, 1972

Série Uma Tarde na Cachoeira

fotografia pb sobre papel, 17,2 $222,7 \times \mathrm{cm}$

Aquisição MAC USP -

RESERVA TÉCNICA:

$\begin{array}{ll}\begin{array}{l}\text { 1972.30.11 } \\ \text { M-11/D }\end{array} & \text { pasta: } 1 \\ \text { provisorio antigo: }\end{array}$

1972.30.12

Sem título, 1972

Série Uma Tarde na Cachoeira

fotografia pb sobre papel, $17,4 \times 22,7 \times \mathrm{cm}$

Aquisição MAC USP -

RESERVA TÉCNICA:

$\begin{array}{ll}\begin{array}{l}\text { RESERVA TECNICA: } \\ \text { 1972.30.12 }\end{array} & \begin{array}{l}\text { p-11/D } \\ \text { provisorio antigo: }\end{array} \\ \square \text { CROMO } & \square \text { DIGITAL alta }\end{array}$

CROMO $\square$ DIGITAL alta 
fotografia pb sobre papel, $22,7 \times 17,2 \times \mathrm{cm}$

Aquisição MAC USP -

RESERVA TÉCNICA:

1972.30.13 M-11/D pasta: 1

provisorio antigo:

1972.30.14

\section{CROMO $\square$ DIGITAL alta}

Sem título, 1972

Série Uma Tarde na Cachoeira

fotografia pb sobre papel, $22,7 \times 17,3 \times \mathrm{cm}$

Aquisição MAC USP -

RESERVA TÉCNICA:

1972.30.14 M-11/D pasta: 1

provisorio antigo:

$\square$ CROMO $\square$ DIGITAL alta

\section{Tomoshige KUSUNO}

Yubari Japão 1935

1972.3.1

\section{Minúsculo e Maiúsculo, 1965}

nanquim, grafite e óleo sobre caixa de madeira, 52,5 x 160 × $160 \mathrm{~cm}$

Aquisição MAC USP - Adquirida do artista

RESERVA TÉCNICA:

1972.3.1 E- pasta:

provisorio antigo: expo ENTRE ATOS

$\checkmark$ CROMO $\boldsymbol{V}$ DIGITAL alta

\section{Judith LAUAND}

Pontal, SP Brasil 1922 1972.3.4

\section{Espaço Virtual, 1960}

têmpera sobre tela, $45 \times 45 \times \mathrm{cm}$

Aquisição MAC USP - Adquirida do artista RESERVA TÉCNICA:
1972.3.4
P-
pasta: $\quad$ P-118/B
provisorio antigo: restauro pintura

$\boldsymbol{V}$ CROMO $\square$ DIGITAL alta

\section{Vicente do Rego MONTEIRO}

Recife, PE Brasil 1899

1972.30.1

Recife, PE Brasil 1970

Retrato de Joaquim do Rego Monteiro, 1920

óleo sobre tela, $42,5 \times 32 \times \mathrm{cm}$

Aquisição MAC USP - Adquirida de Marcelle Monteiro

RESERVA TÉCNICA:
1972.30 .1
P-015/B
pasta:
provisorio antigo: expo ARTE MODERNA BRASIL
$\checkmark$ CROMO $\square$ DIGITAL alta

\section{Oswaldo Takeshi OYAKAWA}

1972.30.29 Espaço Circular, s.d.

fotografia pb sobre papel, $24,1 \times 30 \times \mathrm{cm}$

Aquisição MAC USP -

RESERVA TÉCNICA:
1972.30.29
M-11/D
pasta: 1
provisorio antigo: expo PALÁCIO

\section{Yago PERICOT}

Masnou Espanha 1929

1972.1.5

1972.1 .6

\section{Greve Estudantil, 1967}

água-forte e água-tinta sobre papel, 41,5 x 39,5 x cm

Aquisição MAC USP -

RESERVA TÉCNICA:

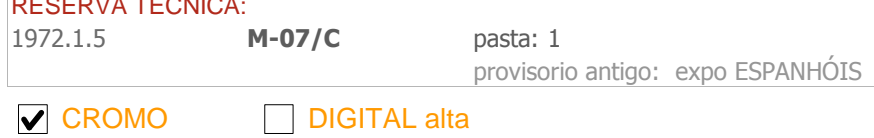

Arranha-Céus, 1968

água-forte sobre papel, 57 × 36,8 x 7,3 cm

Aquisição MAC USP -

RESERVA TÉCNICA:

\begin{tabular}{lll}
$\begin{array}{l}\text { 1972.1.6 } \\
\text { P }\end{array}$ & $\begin{array}{l}\text { pasta: } \\
\text { provisorio antigo: }\end{array}$ & $\begin{array}{l}\text { restauro papel } \\
\text { sala } 4 \text { - guardar }\end{array}$ \\
\hline$\square$ DIGITAL alta &
\end{tabular}




\section{Hans PERSOONS}

Antuerpia Bélgica 1942

1972.1.7

Vitrine de Neuroses, 1970

plástico e estrutura de madeira, 183,5 × 183,8 x $10 \mathrm{~cm}$

Aquisição MAC USP -

RESERVA TÉCNICA:

1972.1.7 P- Pasta: P-103/B - definir trainel

provisorio antigo: restauro pintura - ibira

$\checkmark$ CROMO $\square$ DIGITAL alta

\section{Omar RAYO}

Roldanillo Colômbia 1928

1972.22.15

\section{Tilodiran, 1971}

acrílica sobre tela, $143 \times 143 \times \mathrm{cm}$

Aquisição MAC USP - Prêmio Bienal de São Paulo XI Bienal de São Paulo, 1971

RESERVA TÉCNICA:

1972.22.15 P-027/A pasta:

provisorio antigo: expo MEMORIAL

$\checkmark$ CROMO $\square$ DIGITAL alta

\section{Euclides SANDOVAL}

Franca, SP Brasil 1935

fotografia pb sobre papel sobre cartão, $27,9 \times 23,4 \times \mathrm{cm}$

Aquisição MAC USP -

RESERVA TÉCNICA:

$\begin{array}{ll}\text { 1972.30.15 M-11/E } & \text { pasta: } 1 \\ & \text { provisorio antigo: }\end{array}$

1972.30.16

\section{CROMO $\square$ DIGITAL alta}

\section{Sem título, 1972}

Série Criança e Cadeiras

fotografia pb sobre papel sobre cartão, $24 \times 29,7 \times \mathrm{cm}$

Aquisição MAC USP -

RESERVA TÉCNICA:

$\begin{array}{lll}\text { 1972.30.16 } & \text { M-11/E } & \begin{array}{l}\text { pasta: } 1 \\ \text { provisorio antigo: }\end{array} \\ \square \text { CROMO } & \square \text { DIGITAL alta }\end{array}$

1972.30.17

\section{Sem título, 1972}

Série Criança e Cadeiras

fotografia pb sobre papel sobre cartão, $21 \times 26,6 \times \mathrm{cm}$

Aquisição MAC USP -

RESERVA TÉCNICA:

$\begin{array}{lll}\text { 1972.30.17 } & \text { M-11/E } & \text { pasta: } 1 \\ & \text { provisorio antigo: }\end{array}$

\section{Sem título, 1972}

Série Criança e Cadeiras

fotografia pb sobre papel sobre cartão, $23 \times 29,2 \times \mathrm{cm}$

Aquisição MAC USP -

RESERVA TÉCNICA:

$\begin{array}{lll}1972.30 .18 & \text { M-11/E } & \begin{array}{l}\text { pasta: } 1 \\ \text { provisorio antigo }\end{array} \\ \square \text { CROMO } & \square \text { DIGITAL alta }\end{array}$

1972.30.19

Sem título, 1972

Série Criança e Cadeiras

fotografia pb sobre papel sobre cartão, $23,4 \times 30 \times \mathrm{cm}$

Aquisição MAC USP -

RESERVA TÉCNICA:

$\begin{array}{lll}1972.30 .19 & \text { M-11/E } & \begin{array}{l}\text { pasta: } 1 \\ \text { provisorio antigo: }\end{array} \\ \square \text { CROMO } & \square \text { DIGITAL alta }\end{array}$

Sem título, 1972

fotografia pb sobre papel sobre cartão, $27,4 \times 23,3 \times \mathrm{cm}$

Aquisição MAC USP -

RESERVA TÉCNICA:

\begin{tabular}{|c|c|c|}
\hline 1972.30.20 & M-11/E & $\begin{array}{l}\text { pasta: } 1 \\
\text { provisorio antigo: }\end{array}$ \\
\hline
\end{tabular}


fotografia pb sobre papel sobre cartão, 22,6 x 29,9 x cm

Aquisição MAC USP -

RESERVA TÉCNICA:

1972.30.21 M-11/E pasta: 1

provisorio antigo:

\section{Mira SCHENDEL}

Zurique Suíça 1919

1972.22.2

1972.22 .3

1972.22 .4

1972.22 .5

\section{Desenho 72 - 1, 1972}

nanquim, letra adesiva e papel artesanal sobre papel, $49,3 \times 25,4 \times \mathrm{cm}$

Aquisição MAC USP -

RESERVA TÉCNICA:

\begin{tabular}{|c|c|c|}
\hline 1972.22.2 & M-37 & $\begin{array}{l}\text { pasta: } \\
\text { provisorio antigo: expo RECIFE }\end{array}$ \\
\hline
\end{tabular}

\section{$\checkmark$ CROMO $\square$ DIGITAL alta}

Desenho 72 - 2, 1972

nanquim, letra adesiva e papel artesanal sobre papel, $49,3 \times 25,4 \times \mathrm{cm}$

Aquisição MAC USP -

RESERVA TÉCNICA:

$\begin{array}{ll}\text { 1972.22.3 } & \text { M-37 } \\ & \text { provisorio antigo: expo RECIFE }\end{array}$

\section{CROMO $\square$ DIGITAL alta}

Desenho 72 - 3, 1972

nanquim, letra adesiva e papel artesanal sobre papel, $49,3 \times 25,3 \times \mathrm{cm}$

Aquisição MAC USP -

RESERVA TÉCNICA:

1972.22.4 M-37 pasta:

provisorio antigo: expo IAC

\section{CROMO $\square$ DIGITAL alta}

Desenho 72 - 4, 1972

nanquim, letra adesiva e papel artesanal sobre papel, $49,2 \times 25,3 \times \mathrm{cm}$

Aquisição MAC USP -

RESERVA TÉCNICA:

1972.22.5 M-37 pasta:

provisorio antigo: expo IAC

\section{CROMO $\square$ DIGITAL alta}

Desenho 72 - 5, 1972

nanquim, letra adesiva e papel artesanal sobre papel, $49,2 \times 25,4 \times \mathrm{cm}$

Aquisição MAC USP -

RESERVA TÉCNICA:

1972.22.6 M-37

provisorio antigo: expo IAC

\section{CROMO \\ DIGITAL alta}

Desenho 72 - 6, 1972

nanquim, letra adesiva e papel artesanal sobre papel, $49,3 \times 25,5 \times \mathrm{cm}$

Aquisição MAC USP -

RESERVA TÉCNICA:

$\begin{array}{ll}\text { 1972.22.7 } & \text { pasta: } \\ & \\ & \text { provisorio antigo: expo IAC }\end{array}$

\section{CROMO $\square$ DIGITAL alta}

Desenho 72 - 7, 1972

nanquim, letra adesiva e papel artesanal sobre papel, $49,3 \times 25,4 \times \mathrm{cm}$ Aquisição MAC USP -

RESERVA TÉCNICA:

$\begin{array}{lll}1972.22 .8 & \text { M-37 } & \text { pasta: } \\ & \text { provisorio antigo: expo UM DIA TERÁ QUE TER TERMINADO }\end{array}$

Desenho 72 - 8, 1972

nanquim, letra adesiva e papel artesanal sobre papel, $49,5 \times 25,5 \times \mathrm{cm}$ Aquisição MAC USP -

RESERVA TÉCNICA:

$\begin{array}{ll}\text { 1972.22.9 } & \text { M-37 } \\ & \end{array}$

CROMO $\square$ DIGITAL alta 
1972.22 .11

\section{CROMO $\square$ DIGITAL alta}

Desenho 72 - 10, 1972

nanquim, letra adesiva e papel artesanal sobre papel, $49,3 \times 25,3 \times \mathrm{cm}$

Aquisição MAC USP -

RESERVA TÉCNICA:

1972.22.11 M-37 pasta:

provisorio antigo: expo UM DIA TERÁ QUE TER TERMINADO

1972.22.12 Desenho 72 - 11, 1972

\section{DIGITAL alta}

nanquim, letra adesiva e papel artesanal sobre papel, $49,5 \times 25,5 \times \mathrm{cm}$

Aquisição MAC USP -

RESERVA TÉCNICA:

\begin{tabular}{lll}
$\begin{array}{lll}1972.22 .12 & \text { M-36 } & \begin{array}{l}\text { pasta: } \\
\text { provisorio antigo: }\end{array} \\
\square \text { CROMO } & \square \text { DIGITAL alta }\end{array}$ \\
\hline
\end{tabular}

\section{Amélia TOLEDO}

São Paulo, SP Brasil 1926

1972.22.1

\section{Poço, 1967/69}

aço, acrílico e cordas de metal, 50 × $100 \times 100 \mathrm{~cm}$

Aquisição MAC USP -

RESERVA TÉCNICA:
1972.22.1
E-
pasta:
provisorio antigo: expo ENTRE ATOS
$\checkmark$ CROMO $\square$ DIGITAL alta

\section{Antônio Carlos de VIANNA ANTUNES}

Porto Alegre, RS Brasil 1945 1972.32.1

Abstrações Ritmadas, s.d.

fotografia pb sobre papel, $23,6 \times 18,1 \times \mathrm{cm}$

Aquisição MAC USP -

RESERVA TÉCNICA:

$\begin{array}{lll}1972.32 .1 & \text { M-11/E } & \text { pasta: } 1 \\ & \text { provisorio antigo: }\end{array}$

1972.32.2 Molduras, s.d.

fotografia pb sobre papel, $24 \times 18,1 \times \mathrm{cm}$

Aquisição MAC USP -

RESERVA TÉCNICA:

$\begin{array}{ll}\text { 1972.32.2 } & \text { M-11/E } \\ & \text { provisorio antigo: }\end{array}$

Haruhiko YASUDA

Wakayama Japão 1930

1972.1.8.1/2

\section{Museu do Homem no 3, 1971}

aço inoxidável, $31 \times 250 \times 250 \mathrm{~cm}$

Aquisição MAC USP - Prêmio Bienal de São Paulo XI Bienal de São Paulo, 1971

RESERVA TÉCNICA:
1972.1.8.1/2
E-
pasta: $\quad$ expo NOVA SEDE IBIRA
provisorio antigo: expo hiroshima IBIRA
$\checkmark$ CROMO $\quad \boldsymbol{V}$ DIGITAL alta

\section{Abelardo ZALUAR}

Niterói, RJ Brasil 1924

1972.3.5

\section{Vasados em Azul, 1970}

acrílica e grafite sobre cartão sobre madeira, $90 \times 90 \times \mathrm{cm}$ Aquisição MAC USP -

RESERVA TÉCNICA:

$\begin{array}{ll}\text { 1972.3.5 P-051/B } & \text { pasta: } \\ & \text { provisorio antigo: }\end{array}$

CROMO $\square$ DIGITAL alta 
Vasados em Azul e Rosa, 1971

acrílica e grafite sobre cartão sobre madeira, $90 \times 90 \times \mathrm{cm}$

Aquisição MAC USP -

RESERVA TÉCNICA:

P-

pasta:

P-112/B - definir trainel

CROMO $\square$ DIGITAL alta 


\section{ACERVO MAC USP - adquiridas em 1973}

\begin{tabular}{l} 
№ de obras: \\
\hline Luiz ALPHONSUS \\
Belo Horizonte, MG Brasil 1948
\end{tabular}

1973.5.4

Sem título, 1973

Série Corte na Paisagem

guache, nanquim e ecoline impermeabilizado sobre papel sobre papelão, $36,4 \times 50,9 \times \mathrm{cm}$

Aquisição MAC USP - Adquirida do artista

RESERVA TÉCNICA:

1973.5.4 M-03/A pasta: 1

provisorio antigo:

1973.5.5

\section{CROMO $\square$ DIGITAL alta}

Sem título, 1973 Série Corte na Paisagem

guache, nanquim e ecoline impermeabilizado sobre papel, $36,3 \times 50,9 \times \mathrm{cm}$

Aquisição MAC USP - Adquirida do artista

RESERVA TÉCNICA:

1973.5.5 M-03/A pasta: 1

provisorio antigo: expo SEDE 40 Anos

$\checkmark$ CROMO $\square$ DIGITAL alta

Artur BARRIO

Porto Portugal 1945 1973.18.1.1/9
1973.18.2.1/27

Sit.....Cidade...........Campo..., 1970

diapositivo em cores $35 \mathrm{~mm}, 2,4 \times 3,5 \times \mathrm{cm}$

Aquisição MAC USP - Adquirida do artista

RESERVA TÉCNICA:

1973.18.1.1/9 M-30/D pasta:

provisorio antigo: expo UM DIA TERÁ Q TER TERMINADO IBIRA

\section{$\square$ CROMO $\square$ DIGITAL alta}

Situação Ambiente K, 1970

diapositivo em cores $35 \mathrm{~mm}, 2,4$ × 3,5 x cm

Aquisição MAC USP - Adquirida do artista

RESERVA TÉCNICA:
1973.18.2.1/27
M-30/D
pasta:
provisorio antigo: restauro papel
CROMO $\square$ DIGITAL alta

\section{Mirella BENTIVOGLIO}

Klagenfurt Áustria 1922

1973.12.3

\section{História de Amor, 1968}

fotografia pb sobre papel sobre madeira, $69,5 \times 48,7 \times \mathrm{cm}$

Aquisição MAC USP -

RESERVA TÉCNICA:

1973.12.3 P-073/B pasta:

provisorio antigo:

$\square$ CROMO $\square$ DIGITAL alta

1973.12.4 Gaiola (HO), 1969

serigrafia em cores sobre papel sobre papelão, $72,9 \times 51,3 \times \mathrm{cm}$

Aquisição MAC USP -

RESERVA TÉCNICA:

1973.12.4 M-03/C pasta: 1

provisorio antigo:

$\checkmark$ CROMO $\square$ DIGITAL alta

\section{Vittorio GOBBIS}

Treviso Itália 1894 1973.5.6

Figura de Mulher, 1968

óleo sobre tela, 53,5 × $44 \times \mathrm{cm}$

Aquisição MAC USP - Adquirida da família do artista RESERVA TÉCNICA:
1973.5.6
P-060/B
pasta:
provisorio antigo: 


\section{Cildo MEIRELES}

Rio de Janeiro, RJ Brasil 1948

1973.5.1

Espaços Virtuais - Cantos, 1973

Série Projeto para Ambiente

acrílica e grafite sobre papel, $50,6 \times 36,3 \times \mathrm{cm}$

Aquisição MAC USP - Adquirida do artista

RESERVA TÉCNICA:

1973.5.1 M-06/D pasta: 1

provisorio antigo: expo UM DIA TERÁ QUE TER TERMINADO

\section{$\checkmark$ CROMO $\square$ DIGITAL alta}

1973.5.2

\section{Espaços Virtuais - Cantos, 1973}

Série Projeto para Ambiente

acrílica e grafite sobre papel, $50,8 \times 36,3 \times \mathrm{cm}$

Aquisição MAC USP - Adquirida do artista

RESERVA TÉCNICA:

1973.5.2 M-06/D pasta: 1

provisorio antigo: expo UM DIA TERÁ QUE TER TERMINADO

$\checkmark$ CROMO $\square$ DIGITAL alta

1973.5.3

Espaços Virtuais - Cantos, 1973

Série Projeto para Ambiente

acrilica e grafite sobre papel, 49,8 × 35,3 $\times \mathrm{cm}$

Aquisição MAC USP - Adquirida do artista

RESERVA TÉCNICA:

1973.5.3 M-06/D pasta: 1

provisorio antigo: expo UM DIA TERÁ QUE TER TERMINADO

$\checkmark$ CROMO $\square$ DIGITAL alta

\section{Hermann PAINITZ}

Viena Áustria 1938

1973.12.1

Retrato das Eleições Nacionais de 10 de Outubro (2),

1971

acrílica e nanquim sobre tela, $190 \times 200 \times \mathrm{cm}$

Aquisição MAC USP -

RESERVA TÉCNICA:

1973.12.1 P-050/B pasta:

provisorio antigo:

1973.12.2 Retrato de Erika Mis 1, 1971

grafite, crayon, nanquim, recortes de cartão e fotografia pb sobre papel, 61 × 83,2 x cm

Aquisição MAC USP -

RESERVA TÉCNICA:

1973.12.2 M-10/D pasta: 1

provisorio antigo:

\section{Kuniichi SHIMA}

Tokyo Japão 1935

1973.12.5.1/20

\section{Jornal, 1973}

serigrafia em cores sobre jornal, $81,4 \times 54,8 \times \mathrm{cm}$

Aquisição MAC USP - Adquirida do artista

RESERVA TÉCNICA:

1973.12.5.1/20 M-08/A pasta: 1

provisorio antigo: expo SEDE

\section{François STAHLY}

Konstanz Alemanha 1911 1973.13

\section{Festa, 1959}

DIGITAL alta

bronze patinado, $107 \times 182 \times 74,5 \mathrm{~cm}$

Aquisição MAC USP -

RESERVA TÉCNICA:

1973.13 interno pasta: expo NOVA SEDE IBIRA

provisorio antigo: expo jardim INTERNO ANEXO

$\checkmark$ CROMO $\square$ DIGITAL alta




\section{ACERVO MAC USP - adquiridas em 1974}

№ de obras: $\quad 46$

\section{Gabriel BORBA}

São Paulo, SP Brasil 1942

1974.36.1.1/15 Deconstrução, Versão III, 1973

diapositivo pb $35 \mathrm{~mm}, 2,4 \times 3,5 \times \mathrm{cm}$

Aquisição MAC USP -

RESERVA TÉCNICA:

1974.36.1.1/15 M-30/D pasta:

provisorio antigo:

Iberê CAMARGO

Restinga Seca, RS Brasil 1914 1974.14.1

Carretéis, 1959

Porto Alegre, RS Brasil 1994

água-tinta sobre papel, 44,8 x 56 x cm

Aquisição MAC USP -

RESERVA TÉCNICA:

1974.14.1 M-03/E pasta: 1

provisorio antigo: expo MAMSP

1974.14 .2

CROMO

DIGITAL alta

Carretéis com Frutos, 1959

água-tinta sobre papel, $65,4 \times 45 \times \mathrm{cm}$

Aquisição MAC USP -

RESERVA TÉCNICA:

1974.14.2 M-03/E pasta: 1

provisorio antigo: expo SEDE 40 Anos

1974.14.3

CROMO

$\square$ DIGITAL alta

Conjunto de Carretéis, 1960

água-tinta sobre papel, $52 \times 76 \times \mathrm{cm}$

Aquisição MAC USP -

RESERVA TÉCNICA:

$\begin{array}{lll}1974.14 .3 & \text { M-03/E } & \text { pasta: } 1 \\ & & \text { provisorio antigo: } \\ \square \text { CROMO } \\ \end{array}$

1974.14.4 Presença de Carretel, 1960

água-tinta sobre papel, $48 \times 63 \times \mathrm{cm}$

Aquisição MAC USP -

RESERVA TÉCNICA:

1974.14.4 M-03/E pasta: 1

provisorio antigo:

1974.14.5

$\square$ CROMO $\square$ DIGITAL alta

\section{Gravura I, 1968}

água-forte, água-tinta e relevo sobre papel, 56,3 x 75,6 x cm

Aquisição MAC USP -

RESERVA TÉCNICA:

1974.14.5 M-03/E pasta: 1

provisorio antigo:

1974.14.6 Gravura IV, 1968

DIGITAL alta

água-forte e água-tinta sobre papel, $56 \times 75,7 \times \mathrm{cm}$

Aquisição MAC USP -

RESERVA TÉCNICA:

1974.14.6 M-03/E pasta: 1

provisorio antigo:

$\square$ CROMO $\square$ DIGITAL alta

Figura III, 1973

água-tinta sobre papel, $75,9 \times 56,2 \times \mathrm{cm}$

Aquisição MAC USP -

RESERVA TÉCNICA:

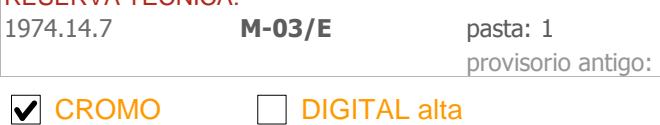




\section{Luís CAMARGO}

São Paulo, SP Brasil 1954

1974.10.3

Edek, 1973

Série Tango

aquarela e caneta hidrográfica sobre papel, $19,8 \times 12,6 \times \mathrm{cm}$

Aquisição MAC USP .

RESERVA TÉCNICA:

1974.10.3 M-03/E pasta: 1

provisorio antigo:

1974.10.4

$\checkmark$ CROMO $\square$ DIGITAL alta

Happening, 1973

Série Tango

nanquim e aquarela sobre papel, $17,4 \times 19,7 \times \mathrm{cm}$

Aquisição MAC USP -

RESERVA TÉCNICA:

1974.10.4 M-03/E pasta: 1

$\checkmark$ CROMO $\square$ DIGITAL alta

1974.10.5

Tio Eugênio, 1973

provisorio antigo:

aquarela e caneta hidrográfica sobre papel, $21,6 \times 15,9 \times \mathrm{cm}$

Série Tango

Aquisição MAC USP -

RESERVA TÉCNICA:

1974.10.5 M-03/E pasta: 1

provisorio antigo:

1974.10 .6

\section{CROMO $\square$ DIGITAL alta}

Happening, 1973

Série Tango

aquarela e caneta hidrográfica sobre papel, 20,1 x 15,8 x cm

Aquisição MAC USP -

RESERVA TÉCNICA:

1974.10.6 M-03/E pasta: 1

provisorio antigo:

1974.10 .7

CROMO

Happening, 1973

Série Tango

nanquim sobre papel, $11,6 \times 14,4 \times \mathrm{cm}$

Aquisição MAC USP -

RESERVA TÉCNICA:

1974.10.7 M-03/E pasta: 1

provisorio antigo:

\section{CROMO $\square$ DIGITAL alta}

1974.10 .8

Artur e Aline, 1973

Série Tango

nanquim, aquarela e caneta hidrográfica sobre papel, $15 \times 15,1 \times \mathrm{cm}$

Aquisição MAC USP -

RESERVA TÉCNICA:

1974.10.8 M-03/E pasta: 1

provisorio antigo:

$\checkmark$ CROMO $\square$ DIGITAL alta

Artur e Aline, 1973

Série Tango

nanquim sobre papel, $12,9 \times 12,4 \times \mathrm{cm}$

Aquisição MAC USP -

RESERVA TÉCNICA:

1974.10.9

M-03/E

pasta: 1

provisorio antigo:

\section{CROMO \\ $\square$ DIGITAL alta}

1974.10.10

Tio Eugênio e Tia Eugênia, 1973

Série Tango

aquarela, nanquim e caneta hidrográfica sobre papel, $18,3 \times 26,8 \times \mathrm{cm}$

Aquisição MAC USP -

RESERVA TÉCNICA:

1974.10.10 M-03/E

CROMO $\square$ DIGITAL alta

1974.10.11

Eleonora e Artur, 1973

Série Tango

nanquim sobre papel, $13,2 \times 12,2 \times \mathrm{cm}$

Aquisição MAC USP -

RESERVA TÉCNICA:

$\begin{array}{ll}\text { 1974.10.11 M-03/E } & \text { pasta: } 1 \\ & \text { provisorio antigo: }\end{array}$

CROMO $\square$ DIGITAL alta 
aquarela e caneta hidrográfica sobre papel, 19,5 x 28,2 x cm

Aquisição MAC USP -

RESERVA TÉCNICA:

\begin{tabular}{|c|c|c|}
\hline 1974.10.12 & M-03/E & $\begin{array}{l}\text { pasta: } 1 \\
\text { provisorio antigo: }\end{array}$ \\
\hline
\end{tabular}

\section{Fernando COCCHIARALE}

Rio de Janeiro, RJ Brasil 1951

1974.10.2

Stella-Estrela-Star, 1973

guache, papel e letra adesiva sobre papel sobre aglomerado de madeira, $23,7 \times 31,5 \times \mathrm{cm}$

Aquisição MAC USP -

\begin{tabular}{|c|c|c|}
\hline \multicolumn{3}{|c|}{ RESERVA TÉCNICA: } \\
\hline 1974.10 .2 & M-34 & $\begin{array}{l}\text { pasta: } \\
\text { provisorio antigo: }\end{array}$ \\
\hline CRC & & \\
\hline
\end{tabular}

\section{Paulo HERKENHOFF}

Cachoeiro de Itapemirim, ES Brasil 1949

1974.10.14

\section{"Baby Food", 1973}

crayon sobre jornal e tecido sobre papel, $66,2 \times 47,7 \times \mathrm{cm}$

Aquisição MAC USP -

RESERVA TÉCNICA:

1974.10.14 P- $\quad$ pasta: 1 RT papel - definir trainel

provisorio antigo: expo UM DIA TERÁ Q TER TERMINADO IBIRA

1974.10.15 "Baby Food", 1973

\section{DIGITAL alta}

"Baby Food", 1973

crayon sobre jornal e tecido sobre papel, $66 \times 47,6 \times \mathrm{cm}$

Aquisição MAC USP -

\begin{tabular}{lll}
\hline $\begin{array}{l}\text { RESERVA TÉCNICA: } \\
\text { 1974.10.15 }\end{array}$ & $\begin{array}{l}\text { pasta: } 1 \\
\text { provisorio antigo: }\end{array}$ & $\begin{array}{l}\text { RT papel - definir trainel } \\
\text { expo UM DIA TERÁ Q TER TERMINADO IBIRA }\end{array}$ \\
$\square$ CROMO &
\end{tabular}

1974.10.16 "Baby Food", 1973

crayon sobre jornal e tecido sobre papel, $66,2 \times 47,7 \times \mathrm{cm}$

Aquisição MAC USP -

RESERVA TÉCNICA:

1974.10.16 M-33

provisorio antigo: expo UM DIA TERÁ Q TER TERMINADO IBIRA

CROMO $\square$ DIGITAL alta

1974.10.17 "Baby Food", 1973

crayon sobre jornal e tecido sobre papel, $66,2 \times 47,8 \times \mathrm{cm}$

Aquisição MAC USP -

\begin{tabular}{llll}
\hline RESERVA TÉCNICA: & & \\
1974.10.17 & P- & pasta: 1 & RT papel - definir trainel
\end{tabular}

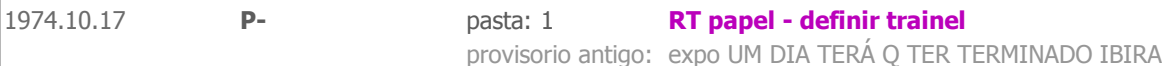

CROMO $\square$ DIGITAL alta

\section{Mauro KLEIMAN}

Rio de Janeiro, RJ Brasil 1950

1974.10.13

Escrita, 1973

nanquim sobre papel, $69,9 \times 59,9 \times \mathrm{cm}$

Aquisição MAC USP -

RESERVA TÉCNICA:

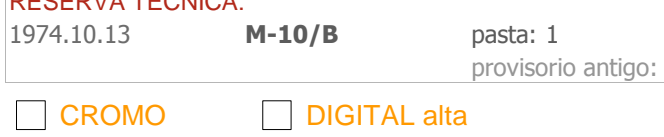

\section{LE CORBUSIER}

La Chaux-de-Fonds Suíça 1887 Roquebrune-Cap-Martin França 1965

1974.2.1

De outro modo que na Terra, 1963

litografia em cores sobre papel, 72,9 x 49,4 x cm

Aquisição MAC USP -

RESERVA TÉCNICA:

$\begin{array}{ll}\text { 1974.2.1 } & \text { M-06/B } \\ & \text { provisorio antigo: }\end{array}$

CROMO $\square$ DIGITAL alta




\section{Vicente do Rego MONTEIRO \\ Recife, PE Brasil 1899}

1974.10.18

Tupã, 1920

Recife, PE Brasil 1970

aquarela e nanquim sobre papel, $35,5 \times 24,5 \times \mathrm{cm}$

Aquisição MAC USP - Adquirida de Marcelle Monteiro

RESERVA TÉCNICA:
1974.10.18
M-16/E
pasta:
M-32/A - refazer ppt e guardar

provisorio antigo: expo IBIRA MODERNISMOS

1974.10.19

1974.10.20

$\square$ CROMO

\section{$\square$ DIGITAL alta}

Mani Oca / O Nascimento de Mani, 1921

aquarela e nanquim sobre papel, $28 \times 36,5 \times \mathrm{cm}$

Aquisição MAC USP - Adquirida de Marcelle Monteiro

RESERVA TÉCNICA:

1974.10.19 M-16/E pasta: M-32/A - refazer ppt e guardar

provisorio antigo: expo IBIRA MODERNISMOS

\section{$\checkmark$ CROMO $\square$ DIGITAL alta}

\section{O Boto, 1921}

aquarela e nanquim sobre papel, $35,4 \times 26 \times \mathrm{cm}$

Aquisição MAC USP - Adquirida de Marcelle Monteiro

RESERVA TÉCNICA:

1974.10.20 M-16/E pasta: M-32/A - refazer ppt e guardar

provisorio antigo: expo IBIRA MODERNISMOS

1974.10 .21

\section{$\mathrm{CROMO}$}

\section{$\square$ DIGITAL alta}

A Morte do Prisioneiro, 1920

aquarela e nanquim sobre papel, $35,8 \times 28,5 \times \mathrm{cm}$

Aquisição MAC USP - Adquirida de Marcelle Monteiro

RESERVA TÉCNICA:

$\begin{array}{lll}\text { 1974.10.21 } & \text { M-16/E } & \begin{array}{l}\text { pasta: } \\ \text { provisorio antigo: expo GABINETE SEDE 039b }\end{array} \\ \square \text { CROMO } & \square \text { DIGITAL alta }\end{array}$

A Noite sai da Noz de Tucunã, 1921

aquarela e nanquim sobre papel, $32,7 \times 28,1 \times \mathrm{cm}$

Aquisição MAC USP - Adquirida de Marcelle Monteiro

RESERVA TÉCNICA:

1974.10.22 M-06/E pasta: 1

provisorio antigo: expo IBIRA MODERNISMOS

\section{CROMO $\square$ DIGITAL alta}

\section{Um Tuchauã, 1921}

aquarela e nanquim sobre papel, $28,4 \times 16 \times \mathrm{cm}$

Aquisição MAC USP - Adquirida de Marcelle Monteiro

RESERVA TÉCNICA:

1974.10.23 M-16/E pasta:

provisorio antigo: expo GABINETE SEDE 040a

1974.10.24 Uma Jovem, 1921

aquarela e nanquim sobre papel, $28,4 \times 15,9 \times \mathrm{cm}$

Aquisição MAC USP - Adquirida de Marcelle Monteiro

RESERVA TÉCNICA:

1974.10.24 M-16/E

provisorio antigo: expo FIAT BH

1974.10.25 Coaraci / O Sol, 1921

aquarela e nanquim sobre papel, $28,6 \times 16,3 \times \mathrm{cm}$

Aquisição MAC USP - Adquirida de Marcelle Monteiro

RESERVA TÉCNICA:

$\begin{array}{ll}\text { 1974.10.25 M-16/E } & \text { pasta: } \\ & \text { provisorio antigo: expo FIAT BH }\end{array}$

1974.10.26 Tatu Açu / O Tatu Grande, 1921

aquarela e nanquim sobre papel, $28,6 \times 16 \times \mathrm{cm}$

Aquisição MAC USP - Adquirida de Marcelle Monteiro

$\begin{array}{lll}\text { RESERVA TÉCNICA: } & & \\ 1974.10 .26 \quad \text { M-16/E } & \text { pasta: } \\ & \text { provisorio antigo: }\end{array}$

CROMO $\square$ DIGITAL alta 
Máscaras e Túnicas da Festa de Thieboah, 1921

aquarela e nanquim sobre papel, $26,1 \times 34,4 \times \mathrm{cm}$

Aquisição MAC USP - Adquirida de Marcelle Monteiro

RESERVA TÉCNICA:

1974.10.27 M-06/E pasta: 1

provisorio antigo: expo FIAT BH

\section{CROMO $\square$ DIGITAL alta}

1974.10.28 Cenário para o Bailado da Lua-iaci, 1921

aquarela e nanquim sobre papel, $26,6 \times 29,9 \times \mathrm{cm}$

Aquisição MAC USP - Adquirida de Marcelle Monteiro

RESERVA TÉCNICA:

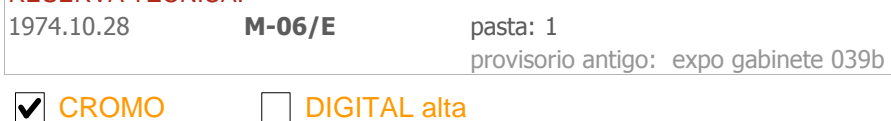

MONTEZ MAGNO

Timbaúba, PE Brasil 1934 1974.6

\section{Oelena, 1969}

óleo sobre tela, $170 \times 170 \times \mathrm{cm}$

Aquisição MAC USP -

RESERVA TÉCNICA:

$1974.6 \quad$ P-083/A pasta:

provisorio antigo: P-098/A - definir trainel

$\square$ CROMO $\square$ DIGITAL alta

\section{Jean OTTH}

Lausanne Suíça 1940

1974.35.1.1/12

Interrogações Plásticas, 1971

Série No III

diapositivo em cores $35 \mathrm{~mm}, 2,4 \times 2,3 \times \mathrm{cm}$

Aquisição MAC USP -

\begin{tabular}{|c|c|c|}
\hline \multicolumn{3}{|c|}{ RESERVA TÉCNICA: } \\
\hline 1974.35.1.1/12 & $M-30 / D$ & $\begin{array}{l}\text { pasta: } \\
\text { provisorio antigo: }\end{array}$ \\
\hline
\end{tabular}

1974.35.2.1/30

Masculino Feminino, 1971

Série $N^{\circ}$ IV

diapositivo em cores $35 \mathrm{~mm}, 2,4 \times 2,3 \times \mathrm{cm}$

Aquisição MAC USP -

RESERVA TÉCNICA:

$\begin{array}{lll}\text { 1974.35.2.1/30 } & \text { M-30/D } & \text { pasta: } \\ & \text { provisorio antigo: }\end{array}$

1974.35.3.1/5

Os Limites, 1971

Série No XXII

diapositivo em cores $35 \mathrm{~mm}, 2,4 \times 2,3 \times \mathrm{cm}$

Aquisição MAC USP -

RESERVA TÉCNICA:

1974.35.3.1/5 M-30/D pasta:

provisorio antigo:

\section{CROMO $\square$ DIGITAL alta}

"Land Art", 1971

diapositivo em cores $35 \mathrm{~mm}, 2,4 \times 2,3 \times \mathrm{cm}$

Aquisição MAC USP -

RESERVA TÉCNICA:

$\begin{array}{lll}\text { 1974.35.4.1/9 } & \text { M-30/D } & \begin{array}{l}\text { pasta: } \\ \text { provisorio antigo: }\end{array} \\ \square \text { CROMO } & \end{array}$

1974.35.5.1/7

Sombras, 1971

Série $N^{0}$ IX

Série No VIII

diapositivo em cores $35 \mathrm{~mm}, 2,4 \times 2,3 \times \mathrm{cm}$

Aquisição MAC USP -

RESERVA TÉCNICA:

$\begin{array}{ll}\text { 1974.35.5.1/7 M-30/D } & \text { pasta: } \\ & \\ & \text { provisorio antigo: }\end{array}$

CROMO $\square$ DIGITAL alta 
diapositivo em cores $35 \mathrm{~mm}, 2,4$ x 2,3 x cm

Aquisição MAC USP -

RESERVA TÉCNICA:

1974.35.6.1/12 M-30/D pasta:

provisorio antigo:

CROMO $\square$ DIGITAL alta

\section{Amador de Carvalho PEREZ}

Rio de Janeiro, RJ Brasil 1952

1974.10.1

Jóquei, 1973

grafite e caneta hidrográfica sobre papel, $20,9 \times 21,9 \times \mathrm{cm}$

Aquisição MAC USP -

RESERVA TÉCNICA:

1974.10.1 M-07/C pasta: 1

provisorio antigo:

$\square$ CROMO $\square$ DIGITAL alta

\section{Nelson RAMOS}

Dolores Uruguai 1932

1974.28

Três Verticais, 1970

óleo sobre tela, $79 \times 98 \times \mathrm{cm}$

Aquisição MAC USP - Adquirida do artista

RESERVA TÉCNICA:

1974.28 P-020/A pasta:

provisorio antigo: expo TRANSEUNTES

$\checkmark$ CROMO $\square$ DIGITAL alta

Jean TINGUELY

Fribourg Suíça 1925 1974.2.2
Sem título, s.d.

Berna Suíça 1991

litografia em cores e colagem sobre papel, 90,1 x 69 × cm

Aquisição MAC USP -

RESERVA TÉCNICA:

$\begin{array}{lll}\text { 1974.2.2 } & \text { M-11/A } & \text { pasta: } 1 \\ & & \text { provisorio antigo: } \\ \boldsymbol{V} \text { CROMO } & \boldsymbol{V} \text { DIGITAL alta }\end{array}$




\section{ACERVO MAC USP - adquiridas em 1975}

№ de obras: 12

\section{DAREL VALENÇA LINS}

Palmares, PE Brasil 1924

1975.6.1

Multidão, 1965

água-forte sobre papel, 45,3 $366,2 \times \mathrm{cm}$

Aquisição MAC USP - Adquirida de Anna Maria Baccaro

RESERVA TÉCNICA:

1975.6.1 M-04/B pasta: 1

provisorio antigo: expo IBIRA MODERNISMOS

1975.6.2 Roda Gigante, 1954

\section{DIGITAL alta}

água-forte e água-tinta sobre papel, $43,8 \times 61,5 \times \mathrm{cm}$

Aquisição MAC USP - Adquirida de Anna Maria Baccaro

RESERVA TÉCNICA:

1975.6.2 M-04/B pasta: 1 restauro papel

$\checkmark$ CROMO $\square$ DIGITAL alta

\section{Samson FLEXOR}

Soroca, Bessarabia Romênia 1907 1975.16.4

\section{Geométrico Grande, 1954}

óleo sobre tela, 160,5 x 179,5 x cm

Aquisição MAC USP - Adquirida de Margot Flexor

RESERVA TÉCNICA:
1975.16.4
P-
pasta:
provisorio antigo: expo FLEXOR

\section{Anna Bella GEIGER}

Rio de Janeiro, RJ Brasil 1933

1975.16.1

\section{Verde, Verdes, 1974}

serigrafia, água-forte e fotogravura em cores sobre papel, 75,8 x 56 x cm

Aquisição MAC USP - Adquirida da artista

RESERVA TÉCNICA:

1975.16.1 M-05/B pasta: $1 \quad$ M-31/E - tirar ppt e guardar

provisorio antigo: expo UM DIA TERÁ QUE TER TERMINADO

1975.16.2 Iguais, 1974

serigrafia, água-forte, fotogravura em cores e papel metalizado sobre papel, $76 \times 56,3 \times \mathrm{cm}$

Aquisição MAC USP -

RESERVA TÉCNICA:

1975.16.2 M-17/C pasta:

provisorio antigo: expo UM DIA TERÁ Q TER TERMINADO IBIRA

$\square$ CROMO $\quad \square$ DIGITAL alta

\section{Henrique OSWALD}

Rio de Janeiro, RJ Brasil 1918 1975.16.3.1

Sem título, s.d.

Rio de Janeiro, RJ Brasil 1965

água-forte e água-tinta sobre papel, 50,1 x 40,3 x cm

Aquisição MAC USP - Adquirida da Sra Jacyra Oswald

RESERVA TÉCNICA:

\begin{tabular}{|c|c|c|}
\hline 1975.16.3.1 & $M-12 / C$ & $\begin{array}{l}\text { pasta: } \\
\text { provisorio antigo: }\end{array}$ \\
\hline CROMC & & \\
\hline
\end{tabular}

1975.16.3.2

\section{Sem título, c.1963/64}

água-forte e água-tinta sobre papel, 50,1 x 40,5 x cm

Aquisição MAC USP - Adquirida da Sra Jacyra Oswald

RESERVA TÉCNICA:

$\begin{array}{lll}\begin{array}{l}\text { 1975.16.3.2 } \\ \square \text { CROMO }\end{array} & \text { M-12/C } & \text { pasta: } \\ \text { provisorio antigo: }\end{array}$

Álbum Henrique Oswald / Ed. Póstuma de 7 Gravuras Originais

Álbum Henrique Oswald / Ed. Póstuma de 7 Gravuras Originais 
água-forte sobre papel, 40,5 x 50,2 x cm

Originais

Aquisição MAC USP -

RESERVA TÉCNICA:

\begin{tabular}{lll}
$\begin{array}{l}\text { 1975.16.3.3 } \\
\text { M-12/C }\end{array}$ & $\begin{array}{l}\text { pasta: } \\
\text { provisorio antigo: }\end{array}$ \\
$\square$ CROMO \\
\hline
\end{tabular}

1975.16.3.4

Sem título, s.d.

Álbum Henrique Oswald / Ed. Póstuma de 7 Gravuras Originais

água-forte sobre papel, 40,3 x 50,1 x cm

Aquisição MAC USP - Adquirida da Sra Jacyra Oswald

RESERVA TÉCNICA:

1975.16.3.4 M-12/C pasta:

provisorio antigo:

$\square$ CROMO $\square$ DIGITAL alta

Sem título, s.d.

Álbum Henrique Oswald / Ed. Póstuma de 7 Gravuras Originais

água-forte e água-tinta sobre papel, 40,2 x 49,9 x cm

Aquisição MAC USP - Adquirida da Sra Jacyra Oswald

RESERVA TÉCNICA:

1975.16.3.5 M-12/C pasta:

provisorio antigo:

$\square$ CROMO $\square$ DIGITAL alta

Sem título, s.d.

água-forte e água-tinta sobre papel, 40,5 x 50,1 x cm

Aquisição MAC USP - Adquirida da Sra Jacyra Oswald

RESERVA TÉCNICA:

1975.16.3.6 M-12/C pasta: provisorio antigo:

\section{CROMO $\square$ DIGITAL alta}

Sem título, s.d.

Álbum Henrique Oswald / Ed. Póstuma de 7 Gravuras Originais

água-forte e água-tinta sobre papel, 50,1 x 40,4 x cm

Aquisição MAC USP - Adquirida da Sra Jacyra Oswald

RESERVA TÉCNICA: provisorio antigo:

Álbum Henrique Oswald / Ed. Póstuma de 7 Gravuras Originais

$\square$ CROMO $\square$ DIGITAL alta




\section{ACERVO MAC USP - adquiridas em 1976}

№ de obras:

11

José Pedro COSTIGLIOLO

Montevidéu Uruguai 1902

1976.27

1985

Retângulos e Quadrados CXXIV, 1976

acrílica sobre tela, 100,6 x 100,8 x cm

Aquisição MAC USP -

RESERVA TÉCNICA:

1976.27 P-006/A pasta:

provisorio antigo:

Milton DACOSTA

Niterói, RJ Brasil 1915

1976.7.2

Sem título, 1963

água-forte sobre papel, 45,3 x 62,2 x cm

Aquisição MAC USP - Adquirida de Anna Maria Baccaro

RESERVA TÉCNICA:

1976.7.2 M-04/B pasta: 1

provisorio antigo:

1976.7 .3

\section{CROMO}

\section{DIGITAL alta}

Sem título, 1967

água-forte sobre papel, 33,6 x 48,1 x cm

Aquisição MAC USP - Adquirida de Anna Maria Baccaro

RESERVA TÉCNICA:

1976.7.3 M-04/B pasta: 1

provisorio antigo:

$\checkmark$ CROMO $\square$ DIGITAL alta

\section{Axel LESKOSCHEK}

Graz Áustria 1889

1976.7.4

\section{Encontro, 1942}

Viena Áustria 1975

xilografia sobre papel, $25 \times 25,5 \times \mathrm{cm}$

Aquisição MAC USP - Adquirida de Anna Maria Baccaro

RESERVA TÉCNICA:

1976.7.4 M-06/B pasta: 1

provisorio antigo: expo GABINETE SEDE 032a

$\square$ CROMO $\square$ DIGITAL alta

\section{Roberto MAGALHÃES}

Rio de Janeiro, RJ Brasil 1940

Sem título, 1963

xilografia sobre papel, $44 \times 68 \times \mathrm{cm}$

Aquisição MAC USP - Adquirida de Anna Maria Baccaro

RESERVA TÉCNICA:

1976.7.1 M-06/C pasta: 1

provisorio antigo:

$\checkmark$ CROMO $\square$ DIGITAL alta

\section{Manoel MARTINS}

São Paulo, SP Brasil 1911 1976.22.1

Ilustração de Poema, c.1942

São Paulo, SP Brasil 1979

xilografia sobre papel, $27,2 \times 19,5 \times \mathrm{cm}$

Aquisição MAC USP -

RESERVA TÉCNICA:

\begin{tabular}{|c|c|c|}
\hline 1976.22 .1 & M-06/D & $\begin{array}{l}\text { pasta: } 1 \\
\text { provisorio antigo: }\end{array}$ \\
\hline
\end{tabular}

1976.22 .2

Apanhadora de Papel, s.d.

xilografia sobre papel, $22,5 \times 19,7 \times \mathrm{cm}$

Aquisição MAC USP -

RESERVA TÉCNICA:

1976.22.2 M-16/E pasta:

provisorio antigo: expo SANTA HELENA

CROMO $\square$ DIGITAL alta 
Cidade / Rua Direita, s.d.

xilografia sobre papel, $30,3 \times 24,1 \times \mathrm{cm}$

Aquisição MAC USP -

RESERVA TÉCNICA:

1976.22.3 M-06/D pasta: 1

provisorio antigo:

1976.22 .4

CROMO $\square$ DIGITAL alta

Guerra, s.d.

xilografia sobre papel, $22 \times 29,7 \times \mathrm{cm}$

Aquisição MAC USP -

RESERVA TÉCNICA:

1976.22.4 M-16/E pasta:

provisorio antigo:

CROMO $\square$ DIGITAL alta

\section{François MORELLET}

Cholet, Maine-et-Loire França 1926

1976.11.1

Plura Edizioni, 1961/75

serigrafia sobre papel, $68,9 \times 68,8 \times \mathrm{cm}$

Aquisição MAC USP -

RESERVA TÉCNICA:

1976.11.1

M-36

pasta:

provisorio antigo: expo FRANCESES IBIRA

1976.11.2

$\checkmark$ CROMO $\square$ DIGITAL alta

Meissner, s.d.

serigrafia em cores sobre papel, $60 \times 59,9 \times \mathrm{cm}$

Aquisição MAC USP -

RESERVA TÉCNICA:

1976.11.2 M-10/C

pasta: 1

provisorio antigo: expo FRANCESES IBIRA

$\checkmark$ CROMO $\square$ DIGITAL alta 


\section{ACERVO MAC USP - adquiridas em 1977}

№ de obras: $\quad 15$

\section{Luiz BARTH}

Taquara, RS Brasil 1941 1977.5.5

1977.5.6

\section{Reestruturação Icônica I, 1974}

serigrafia em cores sobre papel, $66,3 \times 48,3 \times \mathrm{cm}$

Aquisição MAC USP - Adquirida do artista RESERVA TÉCNICA:

$\begin{array}{ll}\text { 1977.5.5 M-03/C } & \text { pasta: } 1 \\ & \text { provisorio antigo: }\end{array}$

\section{CROMO $\square$ DIGITAL alta}

Reestruturação Icônica VIII, 1976

serigrafia em cores sobre papel, $66,2 \times 48,1 \times \mathrm{cm}$

Aquisição MAC USP - Adquirida do artista

RESERVA TÉCNICA:

1977.5.6 M-03/C pasta: 1

provisorio antigo:

$\square$ CROMO $\square$ DIGITAL alta

\section{Edith BEHRING}

Rio de Janeiro, RJ Brasil 1916 1977.5.7

\section{Alagado, 1968}

Rio de Janeiro, RJ Brasil 1996

água-tinta em cores sobre papel, $56,7 \times 75,7 \times \mathrm{cm}$

Aquisição MAC USP - Adquirida da artista

RESERVA TÉCNICA:

$\begin{array}{ll}\text { 1977.5.7 M-09/B } & \text { pasta: } 1 \\ & \text { provisorio antigo: }\end{array}$

1977.5.8

\section{CROMC}

DIGITAL alta

\section{Barcos, 1975}

água-tinta em cores sobre papel, $56,5 \times 75,9 \times \mathrm{cm}$

Aquisição MAC USP - Adquirida da artista

RESERVA TÉCNICA:
1977.5.8
M-09/B
pasta: 1
provisorio antigo:
CROMO
DIGITAL alta

\section{Mário CRAVO NETO}

Salvador, BA Brasil 1947 1977.17.1.1/4

\section{Placas, 1976}

\section{Odetto GUERSONI}

Jaboticabal, SP Brasil 1924 1977.7.1

1977.7 .2

$\square$ CROMO $\square$ DIGITAL alta

\section{São Paulo, SP Brasil 2007}

Gradiação Justaposta IX, 1975

serigrafia em cores sobre papel, $89,9 \times 61,9 \times \mathrm{cm}$

Aquisição MAC USP - Adquirida do artista RESERVA TÉCNICA:
1977.7.1
M-09/E
pasta: 1
provisorio antigo:

\section{CROMO $\square$ DIGITAL alta}

Formas Justapostas XCII, 1975

serigrafia em cores sobre papel, 90,1 x 61,8 x cm

Aquisição MAC USP - Adquirida do artista

RESERVA TÉCNICA:
1977.7.2
M-09/E
pasta: 1
provisorio antigo: 


\section{Thereza MIRANDA}

Rio de Janeiro, RJ Brasil 1928

1977.5.3

III Pisac, 1976

Série Multidões

fotogravura e relevo em cores sobre papel, $75,7 \times 56 \times \mathrm{cm}$

Aquisição MAC USP - Adquirida da artista

RESERVA TÉCNICA:

$\begin{array}{lll}\text { 1977.5.3 } & \text { M-06/E } & \text { pasta: } 1 \\ & \text { provisorio antigo: }\end{array}$

1977.5.4

V Feira da Curva - Bolívia, 1976

Série Multidões

fotogravura em cores sobre papel, $75,8 \times 56,1 \times \mathrm{cm}$

Aquisição MAC USP - Adquirida da artista

RESERVA TÉCNICA:

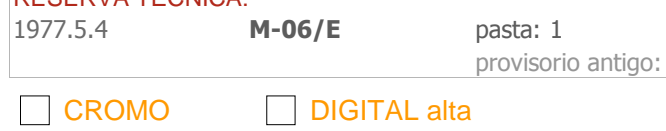

\section{Fayga OSTROWER}

Lodz Polônia 1920

1977.5.1

7113, 1971

Rio de Janeiro, RJ Brasil 2001

xilografia em cores sobre papel, $61,9 \times 80,4 \times \mathrm{cm}$

Aquisição MAC USP -

RESERVA TÉCNICA:

\begin{tabular}{|c|c|c|c|}
\hline 1977.5 .1 & $M-10 / D$ & $\begin{array}{l}\text { pasta: } 1 \\
\text { provisorio antigo: }\end{array}$ & $\begin{array}{l}\text { restauro papel } \\
\text { expo PRÓ-REITORIA PESQUISA } 2 \text { - SALA PRÓ-REITOR }\end{array}$ \\
\hline
\end{tabular}

1977.5 .2

7402, 1974

litografia e serigrafia em cores sobre papel, $75,3 \times 98,9 \times \mathrm{cm}$

Aquisição MAC USP -

RESERVA TÉCNICA:

1977.5.2 M-10/D pasta: 1

provisorio antigo:

$\square$ CROMO $\square$ DIGITAL alta

Julio Plaza

Madrid Espanha 1938

1977.5.11

1977.5.12

\section{São Paulo, SP Brasil 2003}

\section{Duchamp vs. Vasarely, 1974}

serigrafia sobre papel, $94,3 \times 66,2 \times \mathrm{cm}$

Aquisição MAC USP - Adquirida do artista

RESERVA TÉCNICA:
1977.5.11
M-10/E
pasta: 2
M-31/E - tirar ppt e guardar
provisorio antigo: expo UM DIA TERÁ QUE TER TERMINADO

\section{$\checkmark$ CROMO $\square$ DIGITAL alta}

\section{F. Léger / Duchamp, 1974}

serigrafia sobre papel, $94,3 \times 66,2 \times \mathrm{cm}$

Aquisição MAC USP - Adquirida do artista

RESERVA TÉCNICA:

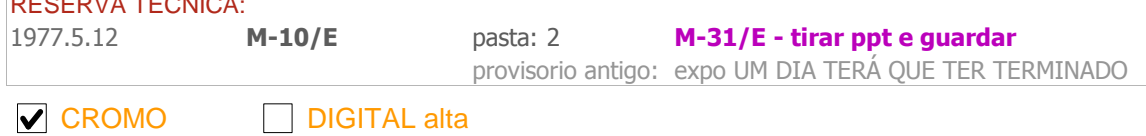

\section{Regina SILVEIRA}

Porto Alegre, RS Brasil 1939 1977.5.9

\section{Destrutura Urbana 4, 1975}

serigrafia em cores sobre papel, $51,8 \times 69,2 \times \mathrm{cm}$

Aquisição MAC USP -

RESERVA TÉCNICA:

$\begin{array}{lll}1977.5 .9 & \text { M-17/D } & \text { pasta: } \\ & \text { provisorio antigo: }\end{array}$

1977.5.10

\section{Destrutura para Paisagem, 1975}

serigrafia em cores sobre papel, $52 \times 69,1 \times \mathrm{cm}$

Aquisição MAC USP -

RESERVA TÉCNICA:

$\begin{array}{lll}\text { 1977.5.10 } & \text { M-08/B } & \text { pasta: } 1 \\ & \text { provisorio antigo: expo SEDE 40 Anos }\end{array}$




\section{ACERVO MAC USP - adquiridas em 1978}

№ de obras: 1

\section{León FERRARI}

Buenos Aires Argentina 1920

1978.4

\section{Lembranças de Meu Pai, 1977}

aço inoxidável, $100 \times 50 \times 50 \mathrm{~cm}$

Aquisição MAC USP - Adquirida do artista

RESERVA TÉCNICA:

1978.4

E-

pasta:

$\checkmark$ CROMO $\square$ DIGITAL alta 


\section{ACERVO MAC USP - adquiridas em 1979}

№ de obras: 45

\section{Renina KATZ}

Rio de Janeiro, RJ Brasil 1925 1979.30.1.1

1979.30.1.2

1979.30.1.3

1979.30.1.4

1979.30.1.5

1979.30.1.6

1979.30.1.7

1979.30.1.8
Cidade, 1948/56

xilografia sobre papel, $41,1 \times 31,8 \times \mathrm{cm}$

Álbum Antologia Gráfica

Aquisição MAC USP -

RESERVA TÉCNICA:

1979.30.1.1 M-12/B

provisorio antigo: P-111/112 - desmontar e guardar

\section{CROMO $\square$ DIGITAL alta}

Retirantes, 1948/56

Álbum Antologia Gráfica

xilografia em cores sobre papel, 41,1 x 31,8 x cm

Aquisição MAC USP -

RESERVA TÉCNICA:

1979.30.1.2 M-12/B

provisorio antigo: P-111/112 - desmontar e guardar

$\checkmark$ CROMO $\square$ DIGITAL alta

Retirantes, 1948/56

Álbum Antologia Gráfica

xilografia em cores sobre papel, $41,1 \times 31,8$ x cm

Aquisição MAC USP -

\begin{tabular}{|c|c|}
\hline RESERVA TÉCNICA: & \\
\hline 1979.30.1.3 M-12/B & $\begin{array}{l}\text { pasta: } \\
\text { provisorio antigo: P-111/112 - desmontar e guardar }\end{array}$ \\
\hline
\end{tabular}

Retirantes, 1948/56

Álbum Antologia Gráfica

xilografia sobre papel, $41,1 \times 31,8 \times \mathrm{cm}$

Aquisição MAC USP -

RESERVA TÉCNICA:

$\begin{array}{lll}\text { 1979.30.1.4 } & \text { M-12/B } & \text { pasta: } \\ & \text { provisorio antigo: expo gabinete 025b }\end{array}$

Retirantes, 1948/56

Álbum Antologia Gráfica

xilografia em cores sobre papel, 41,1 x 31,8 x cm

Aquisição MAC USP -

RESERVA TÉCNICA:

1979.30.1.5 M-12/B pasta:

provisorio antigo:

\section{CROMO $\square$ DIGITAL alta}

Favela, 1948/56

Álbum Antologia Gráfica

linoleografia em cores sobre papel, $41,1 \times 31,8 \times \mathrm{cm}$

Aquisição MAC USP -

RESERVA TÉCNICA:

1979.3016 M-12/B pasta:

provisorio antigo: expo gabinete $026 \mathrm{~b}$

\section{CROMO $\square$ DIGITAL alta}

Campo, 1948/56

Álbum Antologia Gráfica

linoleografia sobre papel, 41,1 x 31,8 x cm

Aquisição MAC USP -

RESERVA TÉCNICA:

1979.30.1.7 M-12/B pasta:

provisorio antigo:

\section{CROMO $\square$ DIGITAL alta}

Retirantes, 1948/56

Álbum Antologia Gráfica

xilografia em cores sobre papel, 41,1 x 31,8 x cm

Aquisição MAC USP -

RESERVA TÉCNICA:

1979.30.1.8 M-12/B pasta:

provisorio antigo: expo gabinete $026 \mathrm{a}$

CROMO $\square$ DIGITAL alta 
1979.30.1.10

1979.30.1.11

1979.30.1.12

1979.30.1.13

1979.30.1.14

1979.30.1.15

1979.30.1.16

1979.30.1.17

\section{Camponeses, 1948/56}

xilografia em cores sobre papel, 41,1 x 31,8 x cm

Aquisição MAC USP -

RESERVA TÉCNICA:

1979.30.1.10 M-12/B pasta:

provisorio antigo: expo gabinete 028a

\section{CROMO $\square$ DIGITAL alta}

Mulata, 1948/56

Álbum Antologia Gráfica

xilografia sobre papel, $41,1 \times 31,8 \times \mathrm{cm}$

Aquisição MAC USP -

RESERVA TÉCNICA:

\begin{tabular}{|c|c|c|}
\hline 1979.30.1.11 & M-12/B & $\begin{array}{l}\text { pasta: } \\
\text { provisorio antigo: expo GABINETE SEDE 028b }\end{array}$ \\
\hline
\end{tabular}

\section{CROMO $\square$ DIGITAL alta}

Retirantes, 1948/56

Álbum Antologia Gráfica

xilografia em cores sobre papel, $41,1 \times 31,8 \times \mathrm{cm}$

Aquisição MAC USP -

RESERVA TÉCNICA:

$\begin{array}{lll}\begin{array}{l}\text { 1979.30.1.12 } \\ \text { M-12/B }\end{array} & \begin{array}{l}\text { pasta: } \\ \text { provisorio antigo: expo gabinete 026a }\end{array} \\ \square \text { CROMO } & \square \text { DIGITAL alta }\end{array}$

Camponeses, 1948/56

Álbum Antologia Gráfica

xilografia sobre papel, $41,1 \times 31,8 \times \mathrm{cm}$

Aquisição MAC USP -

RESERVA TÉCNICA:

\begin{tabular}{lll} 
1979.30.1.13 & M-12/B & $\begin{array}{l}\text { pasta: } \\
\text { provisorio antigo: expo gabinete 028a }\end{array}$ \\
$\boldsymbol{V}$ CROMO \\
\hline
\end{tabular}

\section{Favela, 1948/56}

Álbum Antologia Gráfica

linoleografia em cores sobre papel, $41,1 \times 31,8 \times \mathrm{cm}$

Aquisição MAC USP -

RESERVA TÉCNICA:

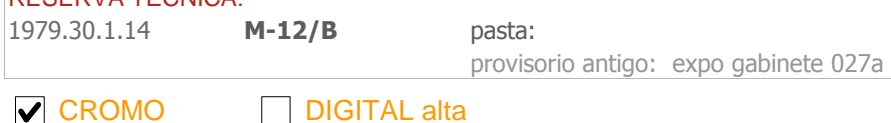

Retirantes, 1948/56

Álbum Antologia Gráfica

xilografia em cores sobre papel, $41,1 \times 31,8 \times \mathrm{cm}$

Aquisição MAC USP -

RESERVA TÉCNICA:

$\begin{array}{lll}\text { 1979.30.1.15 } & \text { M-12/B } & \begin{array}{l}\text { pasta: } \\ \text { provisorio antigo: expo gabinete 025b }\end{array} \\ \boldsymbol{V} \text { CROMO } & \square \text { DIGITAL alta }\end{array}$

Favela, 1948/56

Álbum Antologia Gráfica

xilografia em cores sobre papel, $41,1 \times 31,8 \times \mathrm{cm}$

Aquisição MAC USP -

RESERVA TÉCNICA:

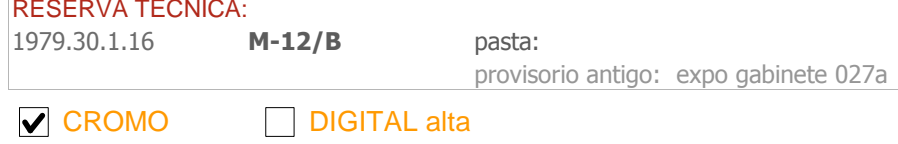

Zé, $1948 / 56$

Álbum Antologia Gráfica

xilografia sobre papel, $41,1 \times 31,8 \times \mathrm{cm}$

Aquisição MAC USP -

RESERVA TÉCNICA:

1979.30.1.17 M-12/B pasta:

provisorio antigo: expo gabinete $028 \mathrm{~b}$ 
1979.30.1.20

Retirantes, 1948/56

Álbum Antologia Gráfica

xilografia em cores sobre papel, $41,1 \times 31,8 \times \mathrm{cm}$

Aquisição MAC USP -

RESERVA TÉCNICA:

$\begin{array}{ll}\text { 1979.30.1.20 } & \text { M-12/B } \\ & \text { provisorio antigo: expo gabinete 025b }\end{array}$

\section{Retirantes, 1948/56}

Álbum Antologia Gráfica

xilografia em cores sobre papel, $41,1 \times 31,8 \times \mathrm{cm}$

Aquisição MAC USP -

\section{RESERVA TÉCNICA:}
1979.30.1.21
M-12/B
pasta:
provisorio antigo: expo gabinete $025 b$

\section{DIGITAL alta}

\section{CROMO}

\section{Camponesas, 1948/56}

xilografia sobre papel, 41,1 x 31,8 x cm

Aquisição MAC USP -

RESERVA TÉCNICA:

$\begin{array}{lll}1979.30 .1 .22 & \text { M-12/B } & \text { pasta: } \\ \text { provisorio antigo: } & \\ \square \text { CROMO } & \square \text { DIGITAL alta }\end{array}$

\section{Trabalhadores, 1948/56}

xilografia sobre papel, $41,1 \times 31,8$ x cm

Aquisição MAC USP -

\section{RESERVA TÉCNICA:}

\begin{tabular}{|c|c|c|}
\hline 1979.30.1.23 & M-12/B & $\begin{array}{l}\text { pasta: } \\
\text { provisorio antigo: }\end{array}$ \\
\hline
\end{tabular}

Pau de Sebo, 1948/56

Álbum Antologia Gráfica

Álbum Antologia Gráfica

Álbum Antologia Gráfica

xilografia sobre papel, $41,1 \times 31,8 \times \mathrm{cm}$

Aquisição MAC USP -

RESERVA TÉCNICA:

$\begin{array}{lll}\begin{array}{l}\text { 1979.30.1.24 } \\ \square \text { CROMO }\end{array} & \text { M-12/B } & \begin{array}{l}\text { pasta: } \\ \text { provisorio antigo: }\end{array} \\ \square \text { DIGITAL alta }\end{array}$

\section{Quintal, 1948/56}

Álbum Antologia Gráfica

xilografia em cores sobre papel, $41,1 \times 31,8$ x cm

Aquisição MAC USP -

RESERVA TÉCNICA:

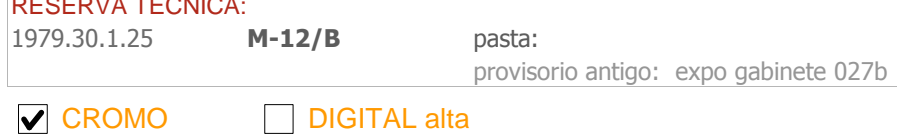

Morte no Laranjal, 1948/56

Álbum Antologia Gráfica

Aquisição MAC USP -

RESERVA TÉCNICA:

1979.30.1.26 M-12/B pasta:

provisorio antigo:

CROMO $\square$ DIGITAL alta


1979.30.1.28

1979.30.1.29

1979.30.1.30

1979.30.1.31

1979.30.1.32

1979.30.1.33

1979.30.1.34

1979.30.1.35

\section{CROMO $\square$ DIGITAL alta}

Retirantes, 1948/56

Álbum Antologia Gráfica

xilografia sobre papel, 41,1 x 31,8 x cm

Aquisição MAC USP -

RESERVA TÉCNICA:

1979.30.1.28 M-12/B pasta:

provisorio antigo: expo gabinete $026 a$

\section{CROMO $\square$ DIGITAL alta}

\section{Favela, 1948/56}

xilografia em cores sobre papel, $41,1 \times 31,8 \times \mathrm{cm}$

Aquisição MAC USP -

RESERVA TÉCNICA:

1979.30.1.29 M-12/B pasta:

provisorio antigo: P-111/112 - desmontar e guarda

\section{$\checkmark$ CROMO $\square$ DIGITAL alta}

\section{Favela, 1948/56}

Álbum Antologia Gráfica

xilografia em cores sobre papel, $41,1 \times 31,8 \times \mathrm{cm}$

Aquisição MAC USP -

RESERVA TÉCNICA:

$\begin{array}{lll}\text { 1979.30.1.30 } & \text { M-12/B } & \begin{array}{l}\text { pasta: } \\ \text { provisorio antigo: }\end{array} \\ \square \text { CROMO } \\ \end{array}$

\section{Cidade, 1948/56}

Álbum Antologia Gráfica

xilografia sobre papel, $41,1 \times 31,8 \times \mathrm{cm}$

Aquisição MAC USP -

RESERVA TÉCNICA:

$\begin{array}{lll}\text { 1979.30.1.31 } & \text { M-12/B } & \text { pasta: } \\ & & \text { provisorio antigo: expo gabinete 028b } \\ \square \text { CROMO } & \square \text { DIGITAL alta }\end{array}$

\section{Favela, 1948/56}

Álbum Antologia Gráfica

xilografia sobre papel, $41,1 \times 31,8 \times \mathrm{cm}$

Aquisição MAC USP -

RESERVA TÉCNICA:

1979.30.1.32 M-12/B pasta:

provisorio antigo: expo gabinete $027 a$

\section{$\square$ CROMO $\square$ DIGITAL alta}

Favela, 1948/56

Álbum Antologia Gráfica

xilografia em cores sobre papel, $41,1 \times 31,8 \times \mathrm{cm}$

Aquisição MAC USP -

RESERVA TÉCNICA:

1979.30.1.33 M-12/B pasta:

provisorio antigo: P-111/112 - desmontar e guardar

\section{$\checkmark$ CROMO $\square$ DIGITAL alta}

Retirantes, 1948/56

Álbum Antologia Gráfica

xilografia sobre papel, $41,1 \times 31,8 \times \mathrm{cm}$

Aquisição MAC USP -

RESERVA TÉCNICA:

1979.30.1.34 M-12/B pasta:

provisorio antigo:

$\square$ CROMO $\square$ DIGITAL alta

Favela, 1948/56

Álbum Antologia Gráfica

xilografia em cores sobre papel, 41,1 x 31,8 x cm

Aquisição MAC USP -

RESERVA TÉCNICA:

1979.30.1.35 M-12/B pasta: expo LASAR SEGALL

provisorio antigo: expo gabinete 027a 
xilografia em cores sobre papel, 41,1 x 31,8 x cm Aquisição MAC USP -

RESERVA TÉCNICA:

$\begin{array}{ll}\text { 1979.30.1.36 } & \text { M-12/B } \\ & \text { provisorio antigo: }\end{array}$

1979.30.1.37

1979.30.1.38

1979.30.1.39

1979.30.1.40

1979.30.1.41

1979.30.1.42

1979.30.1.43

1979.30.1.44

\section{Pescadores, 1948/56}

\section{DIGITAL alta}

linoleografia em cores sobre papel, 41,1 x 31,8 x cm

Aquisição MAC USP -

RESERVA TÉCNICA:
1979.30.1.37
$\mathrm{M}-12 / B$
pasta:
provisorio antigo: expo gabinete 027b

\section{Álbum Antologia Gráfica}

\section{Álbum Antologia Gráfica}

\section{Favela, 1948/56}

\section{DIGITAL alta}

xilografia em cores sobre papel, $41,1 \times 31,8$ x cm

Aquisição MAC USP -

RESERVA TÉCNICA:
1979.30.1.38
M-12/B
pasta:
provisorio antigo: expo gabinete $027 \mathrm{a}$

\section{$\checkmark$ CROMO $\square$ DIGITAL alta}

\section{Meninos, 1948/56}

Álbum Antologia Gráfica

linoleografia em cores sobre papel, $41,1 \times 31,8 \times \mathrm{cm}$

Aquisição MAC USP -

RESERVA TÉCNICA:

$\begin{array}{lll}\text { 1979.30.1.39 } & \text { M-12/B } & \begin{array}{l}\text { pasta: } \\ \text { provisorio antigo: expo gabinete 027b }\end{array} \\ \square \text { CROMO } & \square \text { DIGITAL alta }\end{array}$

\section{Retirantes, 1948/56}

Álbum Antologia Gráfica

xilografia em cores sobre papel, 41,1 x 31,8 x cm

Aquisição MAC USP -

RESERVA TÉCNICA:

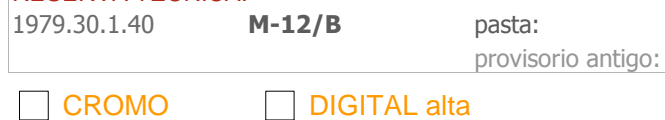

\section{Barqueiro, 1948/56}

xilografia em cores sobre papel, $41,1 \times 31,8 \times \mathrm{cm}$

\section{Álbum Antologia Gráfica}

Aquisição MAC USP -

$\begin{array}{ll}\text { RESERVA TÉCNICA: } & \\ \text { 1979.30.1.41 } & \text { M-12/B } \\ & \text { pasta: } \\ & \text { provisorio antigo: expo gabinete 027b }\end{array}$

\section{$\checkmark$ CROMO $\square$ DIGITAL alta}

Favela, 1948/56

Álbum Antologia Gráfica

xilografia em cores sobre papel, 41,1 x 31,8 x cm

Aquisição MAC USP -

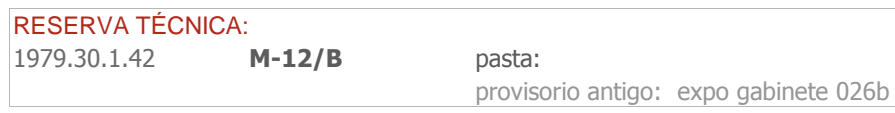

\section{$\boldsymbol{V}$ CROMO $\square$ DIGITAL alta}

Trabalhadores, 1948/56 Álbum Antologia Gráfica

linoleografia sobre papel, $41,1 \times 31,8 \times \mathrm{cm}$

Aquisição MAC USP -

RESERVA TÉCNICA:

\begin{tabular}{|c|c|c|}
\hline 1 & & \\
\hline 1979.30.1.43 & $M-12 / B$ & $\begin{array}{l}\text { pasta: } \\
\text { provisorio antiqo: }\end{array}$ \\
\hline CROMO & & \\
\hline
\end{tabular}

Florista, 1948/56

Álbum Antologia Gráfica

linoleografia sobre papel, 41,1 x 31,8 x cm

Aquisição MAC USP -

RESERVA TÉCNICA:

1979.30.1.44 M-12/B pasta:

provisorio antigo:

$\square$ CROMO $\square$ DIGITAL alta


xilografia em cores sobre papel, 41,1 x 31,8 x cm

Aquisição MAC USP -

RESERVA TÉCNICA:

1979.30.1.45 M-12/B

pasta: provisorio antigo: expo gabinete $026 a$

$\checkmark$ CROMO $\square$ DIGITAL alta 


\section{ACERVO MAC USP - adquiridas na década de 1980}

№ de obras:

18

Almir MAVIGNIER

Rio de Janeiro, RJ Brasil 1925

1982.8

Interpenetração de Estruturas Azul e Verde sobre

Vermelho, 1977

óleo sobre tela, $24 \times 32 \times \mathrm{cm}$

Aquisição MAC USP - O valor da obra foi doado à Associação Comunitária Monte Azul de São Paulo

RESERVA TÉCNICA:

$1982.8 \quad$ P-078/B pasta:

provisorio antigo:

$\checkmark$ CROMO $\square$ DIGITAL alta

\section{Wifredo LAM}

Sagua la Grande Cuba 1902 1983.8

\section{Sem título, 1968}

Paris França 1982

litografia em cores sobre papel, $74,2 \times 51,7 \times \mathrm{cm}$

Aquisição MAC USP - Adquirida de Fawij Andrzej Raskin

RESERVA TÉCNICA:

\begin{tabular}{|c|c|c|}
\hline 1983.8 & M-06/A & $\begin{array}{l}\text { pasta: } 1 \\
\text { provisorio antigo: expo MEMORIAL }\end{array}$ \\
\hline
\end{tabular}

\section{Roberto Sebastian MATTA}

Santiago Chile 1911

1983.9

\section{Composição, s.d.}

Paris França 2002

litografia em cores sobre papel sobre cartão, 56 × 70,9 x cm

Aquisição MAC USP - Adquirida de Fawij Andrzej Raskin

RESERVA TÉCNICA:

\begin{tabular}{|c|c|c|}
\hline 1983.9 & $M-10 / C$ & $\begin{array}{l}\text { pasta: } 1 \\
\text { provisorio antigo: expo MEMORIAL }\end{array}$ \\
\hline
\end{tabular}

Adir Sodré de SOUZA

Rondonópolis, MT Brasil 1962

$1983.10 \quad$ Turista no Pantanal, 1983

óleo sobre tela, $89 \times 70 \times \mathrm{cm}$

Aquisição MAC USP -

RESERVA TÉCNICA:

1983.10 P-040/A pasta:

provisorio antigo:

$\checkmark$ CROMO $\square$ DIGITAL alta

\section{Cildo MEIRELES}

Rio de Janeiro, RJ Brasil 1948

1985.1.1.1/5 Parla, 1982

granito, madeira e couro, $125 \times 50,2 \times 110 \mathrm{~cm}$

Aquisição MAC USP - Adquirida na Galeria Luísa Strina em São Paulo

RESERVA TÉCNICA:

1985.1.1.1/5 E-06 pasta: expo NOVA SEDE IBIRA

provisorio antigo: expo VOLPI

$\boldsymbol{\nabla}$ CROMO $\square$ DIGITAL alta

\section{Siron FRANCO}

Goiás Velho, GO Brasil 1947 1985.2

\section{Título Proibido, 1984}

óleo sobre tela, $180 \times 170 \times \mathrm{cm}$

Aquisição MAC USP - Adquirida do artista

RESERVA TÉCNICA:

1985.2 P-052/B pasta:

provisorio antigo: expo MEMORIAL

CROMO $\square$ DIGITAL alta




\section{Regina SILVEIRA}

Porto Alegre, RS Brasil 1939

1985.6.1

\section{Símile 4, 1983}

litografia sobre papel, $50 \times 69,5 \times \mathrm{cm}$

Aquisição MAC USP - Adquirida da artista

RESERVA TÉCNICA:

$\begin{array}{lll}\text { 1985.6.1 } & \text { M-08/B } & \text { pasta: } 1 \\ & \text { provisorio antigo: expo VOLPI } \\ \square \text { CROMO } & \square \text { DIGITAL alta }\end{array}$

\section{Regina SILVEIRA}

Porto Alegre, RS Brasil 1939

1985.6.2

\section{Símile 5, 1983}

litografia sobre papel, $50 \times 70,2 \times \mathrm{cm}$

Aquisição MAC USP - Adquirida da artista

RESERVA TÉCNICA:

\begin{tabular}{lll}
1985.6 .2 & M-08/B & pasta: 1 \\
provisorio antigo: & \\
$\square$ CROMO \\
\hline
\end{tabular}

\section{Anna Bella GEIGER}

Rio de Janeiro, RJ Brasil 1933

1985.9.1

\section{$n^{\circ} 11,1980$}

serigrafia, relevo e aquarela em cores sobre papel, $50,2 \times 70,3 \times \mathrm{cm}$

Aquisição MAC USP - Adquirida da artista

RESERVA TÉCNICA:

$\begin{array}{lll}\text { 1985.9.1 } & \text { M-05/B } & \text { pasta: } 1 \\ \text { provisorio antigo: }\end{array}$

\section{Anna Bella GEIGER}

Rio de Janeiro, RJ Brasil 1933

1985.9.2

\section{Local da Ação no 4, 1980}

serigrafia e relevo em cores sobre papel, $75,8 \times 56 \times \mathrm{cm}$

Aquisição MAC USP - Adquirida da artista

RESERVA TÉCNICA:

1985.9.2 M-05/B pasta: 1

provisorio antigo:

$\square$ CROMO $\square$ DIGITAL alta

\section{Rubem GRILO}

Pouso Alegre, MG Brasil 1946

1985.17.1

\section{Palco e Platéia, 1984}

xilografia sobre papel, $30,2 \times 41,6 \times \mathrm{cm}$

Aquisição MAC USP - Adquirida do artista

RESERVA TÉCNICA:

\begin{tabular}{|c|c|c|}
\hline 1985.17 .1 & $M-16 / D$ & $\begin{array}{l}\text { pasta: } \\
\text { provisorio antigo: }\end{array}$ \\
\hline
\end{tabular}

\section{Rubem GRILO}

Pouso Alegre, MG Brasil 1946

1985.17.2

\section{Laços de Amizade, 1985}

xilografia sobre papel, $29,8 \times 44,1 \times \mathrm{cm}$

Aquisição MAC USP - Adquirida do artista

RESERVA TÉCNICA:

1985.17.2 M-05/C pasta: 1

provisorio antigo: expo SEDE 40 Anos

$\square$ CROMO $\square$ DIGITAL alta

\section{Anna Letycia}

Teresópolis, RJ Brasil 1929

1985.18.1

\section{Sem título, 1984}

água-tinta em cores sobre papel, $29,4 \times 59,5 \times \mathrm{cm}$

Aquisição MAC USP - Adquirida da artista

RESERVA TÉCNICA:

1985.18.1 M-03/A pasta: 1

provisorio antigo: expo SEDE 40 Anos

CROMO $\square$ DIGITAL alta




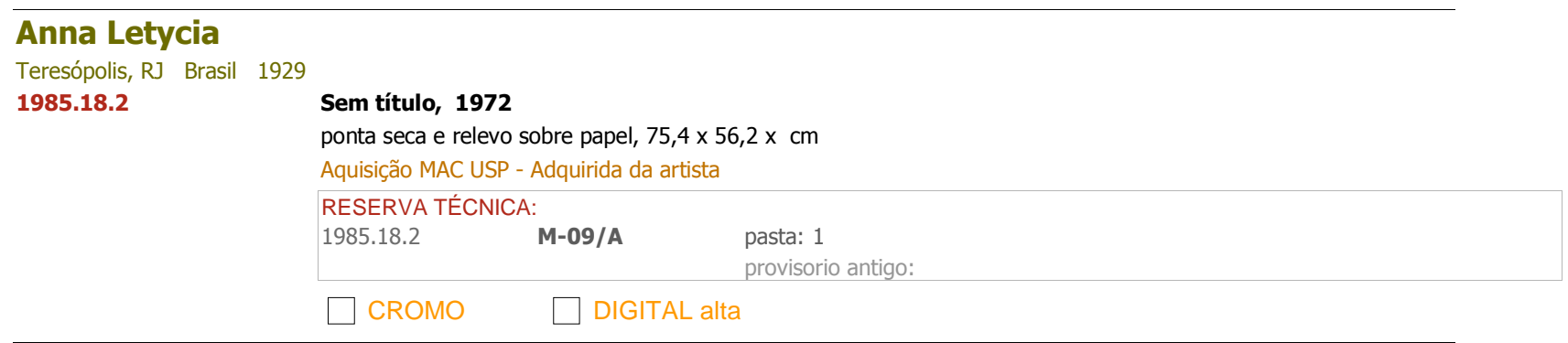

\section{Marcelo LIMA}

Rio de Janeiro, RJ Brasil 1952 1986.1.1

\section{Sem título, 1984}

Série O Sonho da Razão

litografia e xilografia em cores sobre papel, 57 x 76,4 x cm

Aquisição MAC USP - Adquirida do artista

RESERVA TÉCNICA:

1986.1.1 M-10/C pasta: 1

provisorio antigo:

$\square$ CROMO $\quad \square$ DIGITAL alta

\section{Marcelo LIMA}

Rio de Janeiro, RJ Brasil 1952

1986.1.2

\section{Sem título, 1984}

Série O Sonho da Razão

áqua-forte e água-tinta sobre papel, 76,1 x 56,1 x cm

Aquisição MAC USP - Adquirida do artista

RESERVA TÉCNICA:

1986.1.2 M-10/C pasta: 1

provisorio antigo:

$\checkmark$ CROMO $\square$ DIGITAL alta

\section{Abraham PALATNIK}

Natal, RN Brasil 1928

1986.23

Aparelho Cinecromático, 1958

objeto cinético (caixa de madeira revestida de laminado, tela de nylon, lâmpadas e motor), 112 × 74 × $20 \mathrm{~cm}$

Aquisição MAC USP e Doação AAMAC -

RESERVA TÉCNICA:
1986.23 P-093 pasta: $\quad$ expo IBIRA MAC EM OBRAS

provisorio antigo: atelier do artista R]

$\boldsymbol{V}$ CROMO $\boldsymbol{V}$ DIGITAL alta

\section{Amílcar de CASTRO}

Paraisópolis, MG Brasil 1920 1988.19

\section{Sem título, 1985}

aço, $110 \times 250 \times 250 \mathrm{~cm}$

Aquisição Reitoria USP .

RESERVA TÉCNICA:

1988.19 externo pasta: expo jardim externo ANEXO

$\boldsymbol{V}$ CROMO $\boldsymbol{V}$ DIGITAL alta


MAC USP Ibirapuera

CURADOR: Katia Canton

DATA: 26/04/08 - 24/08/08

Documentado por: Cristina Cabral

\section{LEME, SHIRLEY PAES}

$1995.14 \quad$ Memória III

1991

40

galho seco de madeira e arame

$\begin{array}{lllll}225 & \times 50 & \times & 41\end{array}$

Doação artista

Data entrada: 26/04/08 Data saída: 24/08/08

Obs.:

\section{MARTINS, MARIA}

1963.3.574

O Implacável

1947

12

bronze patinado

$\begin{array}{llllll}74 & \times 117,6 \quad \times \quad 19,5 & \mathrm{~cm}\end{array}$

Doação MAMSP

Data entrada: 26/04/08 Data saída: 24/08/08

Obs.:

1963.3.575 Calendário da Eternidade

13

bronze

$\begin{array}{llllll}42,2 & \times \quad 44,6 \quad x \quad 12,9 & \end{array}$

Doação MAMSP

Data entrada: 26/04/08 Data saída: 24/05/08

Obs.: Retirada em 24/05/08 por motivos técnicos

RESENDE, José

1967.7.2

Bibelô: a Secção da Montanha

1967

43

madeira revestida de laminado, acrílico e terra
116,3
$x \quad 30$
$\times \quad 72,4$
$\mathrm{cm}$

Prêmio Aquisição I Jovem Arte Contemporânea

Data entrada: 26/04/08 Data saída: 24/08/08

Obs:

\section{RICHIER, GERMAINE}

1963.3.320

bronze

$\begin{array}{llll}119 \quad \times \quad 30 & \text { x } 26 & \mathrm{~cm} \\ \text { Doação MAMSP } & & & \\ \text { Data entrada: } & 26 / 04 / 08\end{array}$

Obs.:

Obra pertencente à Coleção Edemar Cid Ferreira sob custódia do MAC USP que participa da mostra:

Leda CATUNDA

14 Rio e Mata, 2000

Obras NÃO pertencentes ao Acervo que participam da mostra:

Albano AFONSO

7 Pintura de Luz, 2005

18,1 Série: Floresta, 2003

18,2 Série: Floresta, 2003

Brígida BALTAR

57,11 Coleta de Maresia, 2001

57,12 Coleta de Maresia, 2001

57,21 Coleta de Maresia, 2001

57,31 Coleta de Maresia, 2001

57,41 A Coleta da Neblina, 1996/2001

57,51 A Coleta da Neblina, 1996/2001

57,61 A Coleta da Neblina, 1996/2001

57,71 A Coleta da Neblina, 1996/2005

59 Coletas, 1998/2005 - filme

Renata BARROS

37 A coisa aqui tá preta, 2008

Tatiana BLASS

19 Rio das Pedras, 2007

20 Mato, 2005 
Ernesto BONATO

45 Série Travessia/Homem Pau, 2008

46 Série Traversée, 2003

Regina CARMONA

32 Série: Filos (Os Filamentos entre o Céu e a Terra), 2007

33 Série: To Bollo (Isto era), 2007

Sandra CINTO

64 Sem título - Série Mergulho, 2008

Alzira FRAGOSO

17 Inútil Paisagem, 2008

Sonia GUGGISBERG

55 Sem título, 2006

Bettina Vaz GUIMARÃES

53 Sem título, 2007

Cao GUIMARÃES

63 Concerto para Clorofila, 1998/2005 - vídeo

Claudia JAGUARIBE

25 A Chuva, 2007

26,1 A Biblioteca I, 2007

26,2 A Biblioteca II, 2007

26,3 A Biblioteca III, 2007

26,4 A Biblioteca IV, 2007

Tadeu JUNGLE

16 Através da Amazônia, 2007

Nair KREMER

42 Sal da Terra (Alegoria da Paisagem da Montanha de Gaspar David Friedrich, 1810), 2008

Georgia KYRIAKAKIS

3 Elevações, 2003

Renato LEAL

5 Sem título - Série: Céu, 2007

Shirley Paes LEME

41,1 Sem título - Série: Burning, 2000

41,2 Sem título - Série: Burning, 2000

41,3 Sem título - Série: Correr o Risco, 2000

41,4 Sem título - Série: Correr o Risco, 2000

Fabrício LOPEZ

24 Andarilho, 2007

LUIZ HERMANO

35 Casulo, 2007

Célia MACEDO

56 Sem título (Gotas), 2007

Mariana MAGALHÃES

8,1 Árvore 8, 2005

8,2 Árvore 5, 2005

8,3 Árvore 9, 2005

Christiana MEIRELES

9,1 Cravinhos - Série: Paisagens Transitórias, 2005

9,2 Pontal - Série: Paisagens Transitórias, 2006

9,3 Itatiaia - Série: Paisagens Transitórias, 2005

9,4 Campos - Série: Paisagens Transitórias, 2005

Marcelo MOCHON

49 Requadro, 2002 


\section{Vik MUNIZ}

28 Narcissus after Caravaggio - Série: Pictures of Junk, 2005

29 Atalanta and Hippomenes after Guido Reni - Série: Pictures of Junk, 2006

30 Vulcan forges Cupid's Arrows after Alessandro Tiarini - Série: Pictures of Junk, 2007

31 Bacchus astride a Barrel after Rubens - Série: Pictures of Junk, 2006

\section{Débora MUSZKAT}

52 Sem título (Bola), 2008

\section{NAZARENO}

6 As Boazinhas, 2005

\section{Ana NITZAN}

60,1 Um Conto VII, 2006

60,2 Um Conto I, 2006

61,1 Um Conto VIII, 2006

61,2 Um Conto V, 2006

Anne Cartault d'OLIVE

47 Pequenos Compromissos II - Um Casaco de Pele como Presente, 2007

48 Pequenos Compromissos I - Cada um quer convencer o outro que ele é um pouco parecido com ele, 2007

\section{Tsuyoshi OZAWA}

34 Vegetable Weapon: Pucheiro/Rio de Janeiro, 2005

Mariana PALMA

38 Sem título, 2007

39,1 Sem título, 2005

39,2 Sem título, 2005

39,3 Sem título, 2005

PAZÉ

22 Floresta sem FIM, 2005

23 Pelotão de Fuzilamento, 2005

Fernando PIOLA

50,1 Praça Vermelha - DOPS, 2006

50,2 Panorama Praça Vermelha, 2006

50,3 Praça Vermelha - Luz, 2006

Adriana ROCHA

27 Sem título - Série: Sépias no 10, 2006

Marina SALEME

62,1 Portantes, 2003

62,2 Portantes, 2003

Regina SARETTA

58,1 Série Caos - De onde viemos, 2006

58,2 Série Caos - De onde viemos, 2006

Taro SHINODA

54 Gardening, 2002/2003

Katrin SIGURDARDOTTIR

1,1 Kangchenjunga, Índia, 2008

1,2 From the Mariposa Trail, 2008

1,3 Crillon Lake, Alaska, 2008

1,4 Peuterey Ridge, French Alps, 2008

2 Coulise (Detalhe), 2008

Christophe SPOTO

15 Romã, 2008

Eduardo SRUR

51 Bóia, 2007

Marcela TIBONI

11,1 Pintura de Paisagem II, 2005

11,2 Pintura de Paisagem III, 2005

11,3 Pintura de Paisagem I, 2005

Afonso TOSTES 
Janaina TSCHÄPE

4,1 Glandulitera Maris - Série: Melantropics I, 2005

4,2 Kartofilis Mutabilis - Série: Melantropics I, 2005

4,3 Sanguisorbas Danis - Série: Melantropics I, 2005

4,4 Indigus Gentilis - Série: Melantropics I, 2005

\section{Fernando VELAZQUEZ}

44 Tríptico, 2008 (vídeo-instalação)

Outros materiais:

a) Na parede: texto e cartaz do programa educativo Acervo: Roteiro de Visitas - José Resende

Obs, Geral: 


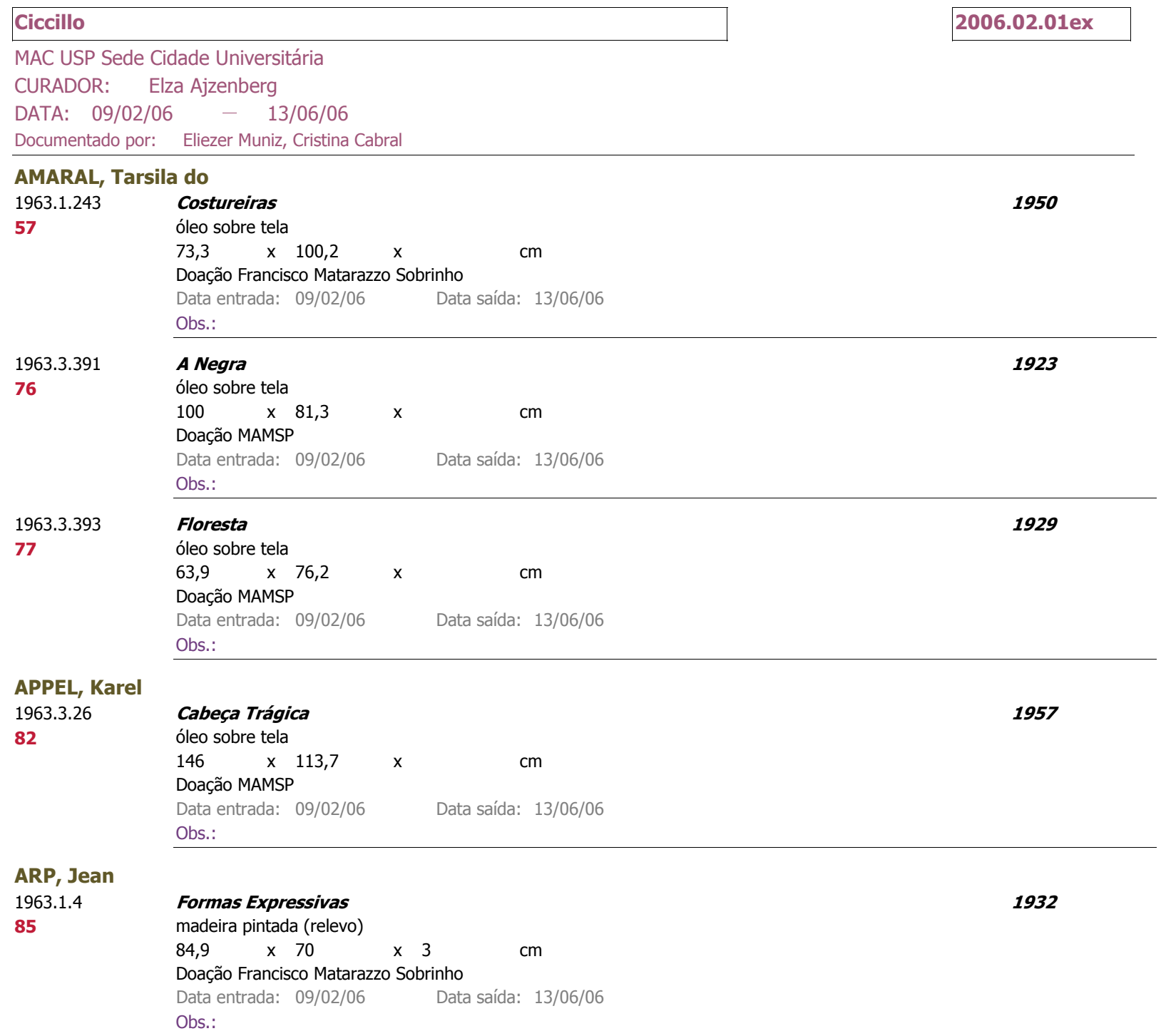

\section{BALLA, Giacomo} 1963.1.5

óleo sobre tela

$1906 / 07$

36

$\begin{array}{llll}48,3 & \times 75 \quad \mathrm{~cm}\end{array}$

Doação Francisco Matarazzo Sobrinho

Data entrada: 09/02/06 Data saída: 26/05/06

Obs.: Retirada em 26/05/2006, na primeira etapa de desmontagem da exposição

\section{BÉRARD, HONORÉ MARIUS}

1963.1.11

60

1963.1.12

64

1963.1.13

63

\section{Ondas de Alegria e de Paz}

óleo sobre tela

$\begin{array}{lllll}130 & x & 162,7 & x & c m\end{array}$

Doação Francisco Matarazzo Sobrinho

Data entrada: 09/02/06_ Data saída: 13/06/06

Obs.:

Sinfonia Litúrgica

1938

óleo sobre tela

$194,8 \quad x \quad 114,3 \quad x \quad c m$

Doação Francisco Matarazzo Sobrinho

Data entrada: 09/02/06 Data saída: 13/06/06

Obs.:

\section{Noturno}

1939

óleo sobre tela

92,5 $x \quad 65,5 \quad x$

Doação Francisco Matarazzo Sobrinho

Data entrada: 09/02/06

Data saída: 13/06/06

Obs.:

1918 
madeira, metal, hastes de metal e contas de cristal
$155 \times 100$
x 150
$\mathrm{cm}$

Doação artista

Data entrada: 09/02/06 Data saída: 26/05/06

Obs.: Retirada em 26/05/2006, na primeira etapa de desmontagem da exposição

\section{BOCCIONI, Umberto}

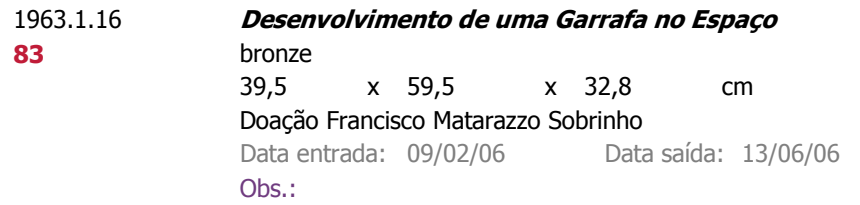

1963.1.17

Formas Únicas da Continuidade no Espaço bronze

$116 \quad \times \quad 85 \quad \times 38 \quad \mathrm{~cm}$

Doação Francisco Matarazzo Sobrinho

Data entrada: 09/02/06 Data saída: 26/05/06

Obs.: Retirada em 26/05/2006, na primeira etapa de desmontagem da exposição

\section{BRAQUE, GEORGES}

1963.2.1

Natureza-morta

s.d.

43

óleo sobre tela

$54,1 \quad x \quad 65,2 \quad x \quad c m$

Doação Yolanda Penteado e Francisco Matarazzo Sobrinho

Data entrada: 09/02/06 Data saída: 13/06/06

Obs.:

\section{BRECHERET, VICTOR \\ 1973.4 .2 \\ 84 terracota \\ $33 \quad x \quad 97,5 \quad x \quad 30,7 \quad \mathrm{~cm}$ \\ Doação Simone Bordat \\ Data entrada: 09/02/06 Data saída: 13/06/06 \\ Obs.:}

\section{CALDER, ALEXANDER}

\begin{tabular}{|c|c|c|}
\hline \multirow[t]{5}{*}{$\begin{array}{l}1963.1 .29 \\
33\end{array}$} & $\begin{array}{l}\text { Grande Móbile Branco } \\
\text { metal pintado }\end{array}$ & 1948 \\
\hline & $158 \times 220 \quad \times \quad 90$ & \\
\hline & Doação Francisco Matarazzo Sobrinho & \\
\hline & Data entrada: $09 / 02 / 06 \quad$ Data saída: $26 / 05 / 06$ & \\
\hline & Obs.: Retirada em 26/05/2006, na primeira etapa de desmontagem da exposição & \\
\hline \multirow{6}{*}{$\begin{array}{l}1963.3 .86 \\
9\end{array}$} & Móbile Amarelo, Preto, Vermelho e Branco & s.d. \\
\hline & metal pintado & \\
\hline & $93 \quad \times 130$ & \\
\hline & Doação MAMSP & \\
\hline & Data entrada: $09 / 02 / 06$ & \\
\hline & Obs.: Retirada em 26/05/2006, na primeira etapa de desmontagem da exposição & \\
\hline \multicolumn{3}{|c|}{ CAMPIGLI, Massimo } \\
\hline \multirow{5}{*}{$\begin{array}{l}1963.2 .5 \\
50\end{array}$} & Mulheres ao Piano & 1946 \\
\hline & óleo sobre tela & \\
\hline & $\begin{array}{llll}69,5 & \times 80 & x & \mathrm{~cm}\end{array}$ & \\
\hline & Doação Yolanda Penteado e Francisco Matarazzo Sobrinho & \\
\hline & $\begin{array}{l}\text { Data entrada: } 09 / 02 / 06 \quad \text { Data saída: } 13 / 06 / 06 \\
\text { Obs.: }\end{array}$ & \\
\hline \multicolumn{3}{|c|}{ CARRÀ, CARLO } \\
\hline 1963.1.36 & Banho de Marinheiros & 1935 \\
\hline \multirow[t]{4}{*}{48} & óleo sobre tela & \\
\hline & $80,3 \quad x \quad 112,5 \quad x$ & \\
\hline & Doação Francisco Matarazzo Sobrinho & \\
\hline & $\begin{array}{l}\text { Data entrada: } 09 / 02 / 06 \quad \text { Data saída: } 13 / 06 / 06 \\
\text { Obs.: }\end{array}$ & \\
\hline
\end{tabular}




\section{CARVALHO, FLÁVIO DE}

1963.3.439

Retrato de José Lins do Rego

óleo sobre tela

$81 \quad \times \quad 65 \quad x \quad c m$

Doação MAMSP

Data entrada: 09/02/06 Data saída: 13/06/06

Obs.:

\section{CASORATI, Felice}

$\begin{array}{lll}\text { 1963.1.42 } & \text { Maternidade } \\ \text { 47 } & \text { óleo sobre tela } & \\ & 91,3 \quad \times \quad 65,7 \quad \times \quad c m \\ & \text { Doação Francisco Matarazzo Sobrinho } \\ & \text { Data entrada: } 09 / 02 / 06 \quad \text { Data saída: 13/06/06 } \\ & \text { Obs.: }\end{array}$

\section{CHAGALL, MARC}

1963.1.46

Sem título

1949

51

litografia em cores sobre pape

$80 \quad x \quad 59,5 \quad x$

Doação Francisco Matarazzo Sobrinho

Data entrada: 09/02/06

Obs.:

CHASTEL, ROGER

1963.3.92

80
Namorados no Café

óleo sobre tela

$161,7 \quad \times \quad 97$

Doação MAMSP

Data entrada: 09/02/06

Obs.:
Data saída: 13/06/06

$\mathrm{cm}$
1947

\section{CHRISTO}

1989.16

Telefone Embrulhado, Projeto para 212-9664437

1988

26

litografia em cores, polietileno, barbante sobre papel sobre cartão

$1950 / 51$

$56 \times 38 \quad x \quad c m$

Doação artista

Data entrada: 09/02/06 Data saída: 26/05/06

Obs.: Retirada em 26/05/2006, na primeira etapa de desmontagem da exposição

\section{CORDEIRO, WALDEMAR}

1966.13 .1

Movimento

1951

32

têmpera sobre tela

90,1 $\quad$ X 95,3

Aquisição MAC USP

Data entrada: 09/02/06

$x$

$\mathrm{cm}$

Obs.: Retirada em 26/05/2006, na primeira etapa de desmontagem da exposição

\section{CUIXART, MODESTO}

1963.1.58 Pintura no 4

$1 \quad$ óleo sobre tela

$270,3 \quad x \quad 194,8 \quad x \quad c m$

Doação Francisco Matarazzo Sobrinho

Data entrada: 09/02/06 Data saída: 26/05/06

Obs.: Retirada em 26/05/2006, na primeira etapa de desmontagem da exposição

\section{DE CHIRICO, GIORGIO}

1963.1 .59

O Enigma de um Dia

1914

34

óleo sobre tela

$83 \times 130 \times$

Doação Francisco Matarazzo Sobrinho

Data entrada: 09/02/06

Data saída: 26/05/06

Obs.: Retirada em 26/05/2006, na primeira etapa de desmontagem da exposição

\section{DE FIORI, ERNESTO}

1963.1.70 Marinha

1939

66

óleo sobre tela

90,4 $x \quad 99,3 \quad x$

Doação Francisco Matarazzo Sobrinho

Data entrada: 09/02/06

Obs.: 
DI CAVALCANTI, EMILIANO

1963.1.275

Marinha

1949

70

óleo sobre tela

$65 \quad x \quad 80,7 \quad x \quad c m$

Doação Francisco Matarazzo Sobrinho

Data entrada: 09/02/06 Data saída: 13/06/06

Obs.: Retirada em 20/03/06 por motivos técnicos: Retorna em 28/04/06

\section{DOMELA, CÉSAR}

1963.1.74

Sem título

1942

35

madeira, metal e acrílico

$54,2 \times 42,6 \quad x \quad 4,3 \quad \mathrm{~cm}$

Doação Francisco Matarazzo Sobrinho

Data entrada: 09/02/06 Data saída: 26/05/06

Obs.: Retirada em 26/05/2006, na primeira etapa de desmontagem da exposição

\section{DOMINGUEZ, OSCAR}

1963.2.7

Sem título

1950

75

óleo sobre tela

$100 \times 250,6 \quad x \quad c m$

Doação Yolanda Penteado e Francisco Matarazzo Sobrinho

Data entrada: 09/02/06 Data saída: 13/06/06

Obs.:

DUFY, RAOUL

1963.2.8

42

\section{Natureza-morta}

s.d.

óleo sobre tela

45,8 $x \quad 55,2 \quad x \quad \mathrm{~cm}$

Doação Yolanda Penteado e Francisco Matarazzo Sobrinho

Data entrada: 09/02/06 Data saída: 13/06/06

Obs.:

\section{ERNST, MAX}

1963.3.124

\section{Quadro para Jovens}

1943

8

óleo sobre tela

$60,2 \quad x \quad 75,5 \quad x$

Doação MAMSP

Data entrada: 09/02/06 Data saída: 26/05/06

Obs.: Retirada em 26/05/2006, na primeira etapa de desmontagem da exposição

\section{ESPÍRITO SANTO, Iran do}

1986.19 .2

23

\section{Sem título}

esmalte sintético sobre lona

$129 \times 222 \quad x$

Doação AAMAC

Data entrada: 09/02/06 Data saída: 26/05/06

Obs.: Retirada em 26/05/2006, na primeira etapa de desmontagem da exposição

\section{FONTANA, LUCIO}

1967.4.5 Conceito Espacial

20 óleo sobre tela

92,4 $\quad x \quad 73,2 \quad x \quad c m$

Aquisição MAC USP

Data entrada: 09/02/06_Data saída: 26/05/06

Obs.: Retirada em 26/05/2006, na primeira etapa de desmontagem da exposição

\section{GIANNOTTI, MARCO}

2004.5

óleo e verniz sobre tela

$200 \times 200$

Doação artista

Data entrada: 09/02/06 Data saída: 26/05/06

Obs.: Retirada em 26/05/2006, na primeira etapa de desmontagem da exposição

\section{GLEIZES, ALBERT}

1963.1.83

55
Paisagem

óleo sobre tela

$50,3 \quad x \quad 65,4 \quad x$

Doação Francisco Matarazzo Sobrinho

Data entrada: 09/02/06

Obs.:
1995

1985

1965

1912 


\section{GOMIDE, ANTÔNIO}

1963.1.326

óleo sobre tela

$\mathrm{cm}$

Doação Francisco Matarazzo Sobrinho

Data entrada: 09/02/06 Data saída: 13/06/06

Obs.:

\section{GUIDI, VIRGILIO}

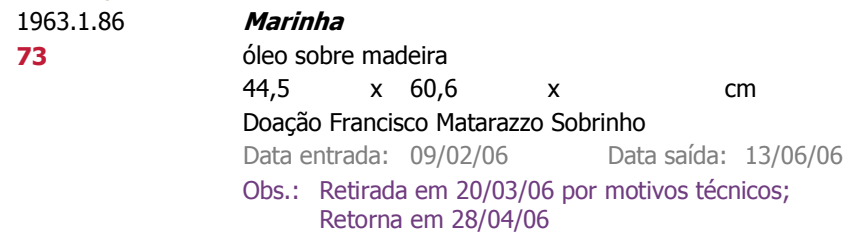

\section{GUIGNARD, ALBERTO DA VEIGA}

1963.1.333

Ouro Preto

1951

72

óleo sobre madeira

$40,1 \quad x \quad 50,1 \quad x \quad c m$

Doação Francisco Matarazzo Sobrinho

Data entrada: 09/02/06 Data saída: 13/06/06

Obs.: Retirada em 20/03/06 por motivos técnicos; Retorna em 28/04/06

\section{IANELLI, ARCANGELO}

2002.2

19

\section{KANDINSKY, WASSILY}

\subsubsection{7}

7
Composição Clara

óleo sobre tela

$73 \times 92,3 \quad x$

Doação Francisco Matarazzo Sobrinho

Data entrada: 09/02/06

Data saída: 26/05/06

Obs.: Retirada em 26/05/2006, na primeira etapa de desmontagem da exposição

\section{LAURENS, HENRI}

1963.1.102

Torso

65

chumbo

$66,5 \times 47,7 \quad x \quad 48,4 \quad \mathrm{~cm}$

Doação Francisco Matarazzo Sobrinho

Data entrada: 09/02/06 Data saída: 13/06/06

Obs.:

LE MOAL, JEAN

1963.1.124

Fim do Dia

1946

61

óleo sobre tela

$116,1 \quad x \quad 81,6 \quad \mathrm{~cm}$

Doação Francisco Matarazzo Sobrinho

Data entrada: 09/02/06 Data saída: 13/06/06

Obs.:

\section{LÉGER, Fernand}

1963.2.10

O Vaso Azul

1948

óleo sobre tela

$\begin{array}{lllll}73,3 & x & \mathbf{c m} & \end{array}$

Doação Yolanda Penteado e Francisco Matarazzo Sobrinho

Data entrada: 09/02/06 Data saída: 13/06/06

Obs.: 
LHOTE, ANDRÉ 1963.1.106 Natureza-morta com Leque

\section{MAGNELLI, ALBERTO}

1963.1.113

óleo sobre tela

$\begin{array}{cccc} & x & 97 & \mathrm{~cm}\end{array}$

Data entrada: 09/02/06 Data saída: 13/06/06

Obs.:

MALFATTI, ANITA

$\begin{array}{llll}1963.1 .345 & \text { Porto de Mônaco } & & \\ 68 & \text { óleo sobre tela } & & \\ & 54 & \text { x } 64,5 & \mathrm{~cm}\end{array}$

1963.3 .566

\section{A Boba}

$1915 / 16$

78 óleo sobre tela

$61 \times 50,6 \quad x \quad c m$

Doação MAMSP

Data entrada: 09/02/06 Data saída: 13/06/06

Obs.:

\section{MARINI, MARINO}

1963.2 .13

Grande Cavalo

11 bronze

$215 \times 205 \times 107 \quad \mathrm{~cm}$

Doação Yolanda Penteado e Francisco Matarazzo Sobrinho

Data entrada: 09/02/06 Data saída: 26/05/06

Obs.: Retirada em 26/05/2006, na primeira etapa de desmontagem da exposição

\section{MATISSE, HENRI}

1963.2.14

41
Natureza-morta

óleo sobre tela

$27,4 \times 41$

Doação Yolanda Penteado e Francisco Matarazzo Sobrinho

Data entrada: 09/02/06 Data saída: 13/06/06

Obs.:

\section{1}

\section{Personagem atirando uma Pedra num Pássaro}

1926

1963.2.15

87 guache sobre papelão

$56,5 \times 72,2 \quad x$

Doação Yolanda Penteado e Francisco Matarazzo Sobrinho

Data entrada: 09/02/06 Data saída: 13/06/06

Obs.: 
MODIGLIANI, AMEDEO

1963.2.16

Autorretrato

1919

óleo sobre tela

$100 \times 64,5 \quad x \quad c m$

Doação Yolanda Penteado e Francisco Matarazzo Sobrinho

Data entrada: 09/02/06 Data saída: 13/06/06

Obs.:

\section{MOHALYI, YOLANDA}

1982.3.5

Em Alguma Parte

1970

2

Óleo sobre tela

$175 \times 150$

Espólio Yolanda Mohalyi

Data entrada: 09/02/06_Data saída: 26/05/06

Obs.: Retirada em 26/05/2006, na primeira etapa de desmontagem da exposição

1982.3.7

\section{Outono}

1972

3

óleo sobre tela

$170 \times 155,5 \quad x \quad c m$

Espólio Yolanda Mohalyi

Data entrada: 09/02/06

Data saída: 26/05/06

Obs.: Retirada em 26/05/2006, na primeira etapa de desmontagem da exposição

\section{MOORE, HENRY}

1972.20

Figura Reclinada em Duas Peças: Pontos

bronze

$71 \quad \times \quad 118,5 \quad \times \quad 65 \quad \mathrm{~cm}$

Permuta com Tate Gallery of London

Data entrada: 09/02/06 Data saída: 26/05/06

Obs.: Retirada em 26/05/2006, na primeira etapa de desmontagem da exposição

\section{MORANDI, GIORGIO}

\begin{tabular}{|c|c|c|}
\hline \multirow{3}{*}{$\begin{array}{l}1963.1 .126 \\
40\end{array}$} & \multicolumn{2}{|l|}{ Natureza-morta } \\
\hline & \multicolumn{2}{|l|}{ óleo sobre tela } \\
\hline & $28,2 \quad x \quad 38,8$ & $\mathrm{~cm}$ \\
\hline & \multicolumn{2}{|c|}{ Doação Francisco Matarazzo Sobrinho } \\
\hline & $\begin{array}{l}\text { Data entrada: 09/02/06 } \\
\text { Obs.: }\end{array}$ & Data saída: $13 / 06 / 06$ \\
\hline
\end{tabular}

NADOR, MÔNICA

1986.24.1.1/3

Sem título

1985

21

acrílica sobre tela

$\begin{array}{lllll}109 & \times \quad 435 & \times & c m\end{array}$

Doação AAMAC

Data entrada: 09/02/06 Data saída: 26/05/06

Obs.: Retirada em 26/05/2006, na primeira etapa de desmontagem da exposição

\section{OHTAKE, TOMIE}

1985.14

Vermelho

1985

4

acrílica e óleo sobre tela

$\begin{array}{lllll}170 & x & 170 & x & c m\end{array}$

Doação artista

Data entrada: 09/02/06 Data saída: 26/05/06

Obs.: Retirada em 26/05/2006, na primeira etapa de desmontagem da exposição

\section{OITICICA, HÉLIO}

1986.14.2

Metaesquema II

1958

31

guache sobre cartão

$55 \quad x \quad 63,9 \quad x$

Doação Projeto Hélio Oiticica

Data entrada: 09/02/06

Data saída: 26/05/06

Obs.: Retirada em 26/05/2006, na primeira etapa de desmontagem da exposição

\section{PANCETTI, José}

óleo sobre tela

$47,3 \times 57,2 \quad x$ Sobrinh

Doação Francisco Matarazzo Sobri

Data entrada: 09/02/06

Data saída: 13/06/06

Obs.: 
óleo sobre madeira

$51,9 \quad x \quad 72,6 \quad x$

Doação Francisco Matarazzo Sobrinho

Data entrada: 09/02/06 Data saída: 13/06/06

Obs.:

\section{PICABIA, FRANCIS}

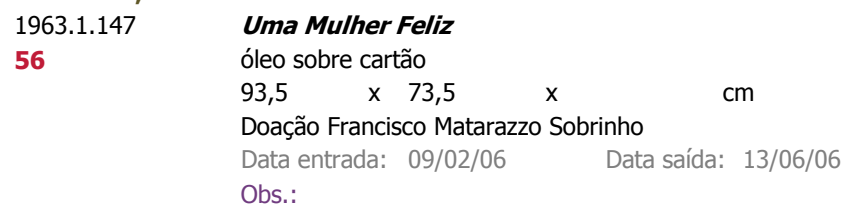

\section{PICASSO, PABLO}

1963.2.19

Figuras

1945

52

óleo sobre tel

$55,4 \quad x \quad 46,6 \quad x$

Doação Yolanda Penteado e Francisco Matarazzo Sobrinho

Data entrada: 09/02/06 Data saída: 13/06/06

Obs.:

PLAZA, Julio

1977.5.11

30

\section{Duchamp vs. Vasarely}

1974

serigrafia sobre pape

94,3 $\times$ 66,2

Aquisição MAC USP

Data entrada: 09/02/06 Data saída: 26/05/06

Obs.: Retirada em 26/05/2006, na primeira etapa de desmontagem da exposição

\section{PORTINARI, CANDIDO}

1963.1.380 Retrato de Paulo Rossi Osir

1935

59

óleo sobre tela

$55 \quad x \quad 46,2 \quad x \quad c m$

Doação Francisco Matarazzo Sobrinho

Data entrada: 09/02/06 Data saída: 13/06/06

Obs.:

\section{REBOLO GONSALES, FRANCISCO}

1963.1.382

Paisagem

1942

71

óleo sobre tela

$59,1 \quad \times \quad 73$

Doação Francisco Matarazzo Sobrinho

Data entrada: 09/02/06 Data saída: 13/06/06

Obs.: Retirada em 20/03/06 por motivos técnicos;

Retorna em 28/04/06

\section{ROMAGNOLO, SÉRGIO}

$1992.5 \quad$ Sem título

1991

24

plástico modelado

$\begin{array}{lllll}234 & \times 310 & \times \quad 56 & \mathrm{~cm}\end{array}$

Doação artista

Data entrada: 09/02/06_Data saída: 26/05/06

Obs.: Retirada em 26/05/2006, na primeira etapa de desmontagem da exposição

\section{ROSAI, OTTONE}

1963.1.170

Estalagem

óleo sobre tela

1932

39

$70,3 \quad x \quad 55,6 \quad x$

Doação Francisco Matarazzo Sobrinho

Data entrada: 09/02/06 Data saída: 13/06/06

Obs.:

\section{SANTOMASO, GIUSEPPE}

1963.3.330 Amanhecer sobre Foices

1953 81

óleo sobre tela

$150,6 \quad x \quad 121 \quad x$

Doação MAMSP

Data entrada: 09/02/06 Data saída: 13/06/06

Obs.: 
SCHENDEL, MIRA

1972.22.7

Desenho 72 - 6

1972

27

nanquim, letra adesiva e papel artesanal sobre pape

$\begin{array}{lllll}49,3 & \times & 25,5 & \mathrm{~cm}\end{array}$

Aquisição MAC USP

Data entrada: 09/02/06 Data saída: 26/05/06

Obs.: Retirada em 26/05/2006, na primeira etapa de desmontagem da exposição

1972.22.11

Desenho 72 - 10

1972

28

nanquim, letra adesiva e papel artesanal sobre papel

$\begin{array}{llll}49,3 & \times 25,3 & \mathrm{~cm}\end{array}$

Aquisição MAC USP

Data entrada: 09/02/06 Data saída: 26/05/06

Obs.: Retirada em 26/05/2006, na primeira etapa de desmontagem da exposição

1979.2.306

Sem título

1972

29

letra adesiva e papel artesanal sobre papel

$\begin{array}{llll}49,2 & x \quad 25,4 & \mathrm{~cm}\end{array}$

Doação Theon Spanudis

Data entrada: 09/02/06 Data saída: 26/05/06

Obs.: Retirada em $26 / 05 / 2006$, na primeira etapa de desmontagem da exposição

\section{SILVA, QUIRINO DA}

1963.1.404 Retrato de Francisco Matarazzo Sobrinho

1936

37

óleo sobre tela

75,3 $3 \quad \mathrm{~cm}$

Doação Francisco Matarazzo Sobrinho

Data entrada: 09/02/06 Data saída: 26/05/06

Obs.: Retirada em 26/05/2006, na primeira etapa de desmontagem da exposição

SILVEIRA, REGINA

1994.10.23

Inflexões

1987

22 acrílica sobre recorte de aglomerado de madeira

$\begin{array}{llll}150 & \times \quad 245 & \mathrm{~cm}\end{array}$

Doação artista

Data entrada: 09/02/06 Data saída: 26/05/06

Obs.: Retirada em 26/05/2006, na primeira etapa de desmontagem da exposição

SINGIER, GUSTAVE

1963.1.190 Ladainhas da Virgem

1946

$62 \quad$ óleo sobre tela

$100,1 \quad x \quad 81,3 \quad x \quad c m$

Doação Francisco Matarazzo Sobrinho

Data entrada: 09/02/06 Data saída: 13/06/06

Obs.:

\section{SIRONI, MARIO}

1963.1 .192

Os Emigrantes

1930

49

óleo sobre madeira

$\begin{array}{llll}68,8 & \times \quad 79,2 & \mathrm{~cm}\end{array}$

Doação Francisco Matarazzo Sobrinho

Data entrada: 09/02/06 Data saída: 13/06/06

Obs.:

TÀPIES, Antoni

1963.3.353

Ásia

1951

88

óleo sobre tela

80,6 $\quad$ X $100 \quad \mathrm{~cm}$

Doação MAMSP

Data entrada: 09/02/06 Data saída: 13/06/06

Obs.:

TOLEDO, AMÉLIA

1972.22.1

Poço

$1967 / 69$

25

aço, acrílico e cordas de metal

$50 \times 100 \quad \times \quad 100 \quad$ cm

Aquisição MAC USP

Data entrada: 09/02/06

Data saída: 26/05/06

Obs.: Retirada em 26/05/2006, na primeira etapa de desmontagem da exposição 
$90 \quad x \quad 51,6 \quad x \quad c m$

Doação Francisco Matarazzo Sobrinho

Data entrada: 09/02/06 Data saída: 13/06/06

Obs.: Retirada em 20/03/06 por motivos técnicos; Retorna em 28/04/06

\section{VASARELY, VICTOR}

1963.1.218 Chillan

1951

$89 \quad$ óleo sobre tela

$\begin{array}{lllll}86,6 & \times 80 & \times & c m\end{array}$

Doação Francisco Matarazzo Sobrinho

Data entrada: 09/02/06 Data saída: 13/06/06

Obs.:

\section{VENOSA, ÂNGELO}

CM1992.1.24

Sem título

1989

10

fibra de vidro e madeira

$170 \times 355 \times 20 \quad \mathrm{~cm}$

Comodato (Coleção Marcantonio Vilaça)

Data entrada: 09/02/06 Data saída: 26/05/06

Obs.: Retirada em 26/05/2006, na primeira etapa de desmontagem da exposição

2004.2

Sem título

2003

12

espelho, acrílico e correntes de meta

$154 \times 54 \times 100 \quad \mathrm{~cm}$

Doação artista

Data entrada: 09/02/06 Data saída: 26/05/06

Obs.: Retirada em 26/05/2006, na primeira etapa de desmontagem da exposição

\section{VOLPI, ALFREDO}

1963.1.415 Reunião à Mesa

1943

38

óleo sobre tela

$81,4 \quad x \quad 60,3 \quad \mathrm{~cm}$

Doação Francisco Matarazzo Sobrinho

Data entrada: 09/02/06 Data saída: 13/06/06

Obs.: Retirada em 08/06/06 para participar de outra mostra no MAC USP

ZANINI, MÁRIO

$\begin{array}{llll}1963.1 .419 & \text { Igreja de São Vicente } & & \\ \mathbf{5 8} & \text { óleo sobre tela } & & \\ & 33,3 \quad \times \quad 45,8 & \text { x } & \mathrm{cm} \\ & \text { Doação Francisco Matarazzo Sobrinho } & \\ & \text { Data entrada: } 09 / 02 / 06 & \text { Data saída: } & \text { 13/06/06 } \\ & \text { Obs.: } & & \end{array}$

Obras NÃO pertencentes ao Acervo MAC USP que participam da mostra:

Leda CATUNDA

13 Rio e Mata, 2000 - óleo s/ recortes de tecido e plástico

Proveniente da Coleção Edemar Cid Ferreira, sob guarda temporária do MAC USP por decisão judicial

Valeska SOARES

15 Tonight, 2002 - DVD em cores

(cópia de original pertencente à Galeria Fortes Villaça)

Frank STELLA

90 The Foundling ( $\mathrm{n \#} \mathrm{6),} \mathrm{c.} 2004$ (Kleinst Novellas Series) - acrílica e aerógrafo s/ tela recortada, recortes de linóleo e resina plástica $\mathrm{s} /$ lona resinada

Proveniente da Coleção Edemar Cid Ferreira, sob guarda temporária do MAC USP por decisão judicial

Outros materiais em exposição:

a) Vitrine sobre Yolanda Penteado: fotos, livro auto-biográfico "Tudo em cor-de-rosa", revista Vogue, cópias de páginas do caderninho de anotações (Davos, 1947)

Obs. Geral:" Primeira etapa da desmontagem da exposição em 26/05/2006: Galerias 2, 3, 4 e corredor de acesso à Galeria 5;

Em 13/06/06, o nome da exposição foi alterado para Núcleo Histórico, uma vez que, da montagem original, só foram mantidas as galerias 5, 6 e 7 e a parede do Gabinete de Papel 
MAC USP Sede Cidade Universitária

CURADOR: Cristina Freire e Helouise Costa

DATA: 17/05/07 - 14/10/07

Documentado por: Cristina Cabral

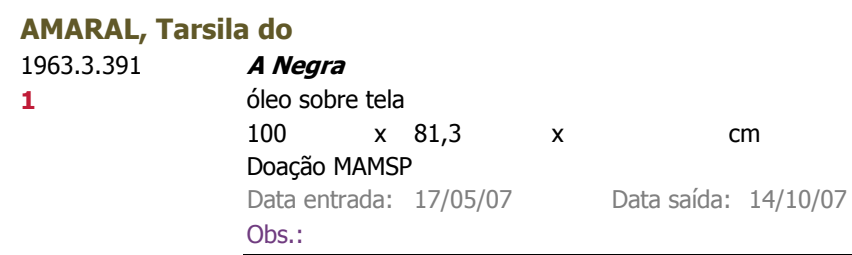

fotografia pb sobre papel e datilografia sobre envelope
18,5 $\times 25,4$
$\mathrm{x}$
$\mathrm{cm}$

Doação artista

Data entrada: 17/05/07 Data saída: 14/10/07

Obs.: exposta em vitrine

\subsubsection{1/16 A Constelação da Tartaruga}

41 caneta hidrográfica e fotografia pb sobre papel

$1981 / 82$
30,3
$\times 462$
$\mathrm{x}$
$\mathrm{cm}$
Doação artista
Data entrada: 17/05/07 Data saída: 14/10/07
Obs.:

1982.9.38.1/16

\section{A Constelação da Tartaruga}

$1981 / 82$

caneta hidrográfica e fotografia pb sobre papel
30,3
$x \quad 462$
$x \quad c m$
Doação artista
Data entrada: 17/05/07 Data saída: 14/10/07
Obs.:

\section{BISILLIAT, MAUREEN}

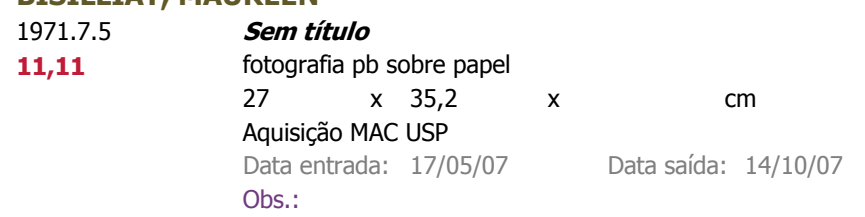

1971.7.6

10

971.7.7

12

\section{Sem título}

fotografia pb sobre papel

$\begin{array}{llll}34,8 & x \quad 27,3 & \end{array}$

Aquisição MAC USP

Data entrada: 17/05/07

Obs.:

1923 
Obs.:

\section{CARVALHO, FLÁVIO DE}

1963.5.1

72

1963.5 .2

85

1963.5 .3

86

74

1963.5.5

83

1963.5 .6

77

963.5 .7

76

1963.5.9

79

1963.5.10

80

\section{A Burguesa}

1953

guache sobre cartolina

$63,8 \times 44,2 \quad x \quad c m$

Doação artista

Data entrada: 17/05/07 Data saída: 11/02/08

Obs.: Retirada em 11/02/2008

1953
$\mathrm{cm}$
$58,7 \quad x \quad 30,3$
$x$

Data saída: 11/02/08

Data entrada: 17/05/07

Obs.: Retirada em 11/02/2008

A Louca

1953

guache sobre cartolina

$\begin{array}{rrrr}56,9 & \mathrm{~cm}\end{array}$

Doação artista

Data entrada: 17/05/07_ Data saída: 11/02/08

Obs.: Retirada em 11/02/2008

\section{A Professora}

1953

guache sobre cartolina

$\begin{array}{rrrr}63,9 & \times \quad 44,3 & \mathrm{~cm}\end{array}$

Doação artista

Data entrada: 17/05/07 Data saída: 11/02/08

Obs.: Retirada em 11/02/2008

\section{Caipira}

1953

guache sobre cartolina

$\begin{array}{lllll}57,8 & x \quad 38,5 & \mathrm{~cm}\end{array}$

Doação artista

Data entrada: 17/05/07_ Data saída: 11/02/08

Obs.: Retirada em 11/02/2008

A Cangaceira

1953

guache sobre cartolina

$\begin{array}{llll}58,1 & \times 39 & \mathrm{~cm}\end{array}$

Doação artista

Data entrada: 17/05/07 Data saída: 11/02/08

Obs.: Retirada em 11/02/2008

1953

guache sobre cartolina

$\begin{array}{lllll}57,8 & \times \quad 37,4 & \mathrm{~cm}\end{array}$

Doação artista

Data entrada: 17/05/07 Data saída: 11/02/08

Obs.: Retirada em 11/02/2008

Mulher do Povo I

1953

guache sobre cartolina

$\begin{array}{lllll}63,8 & \times \quad 44,3 & \mathrm{~cm}\end{array}$

Doação artista

Data entrada: 17/05/07 Data saída: 11/02/08

Obs.: Retirada em 11/02/2008

Mulher do Povo II

1953

guache sobre cartolina

$\begin{array}{rrrr}63,8 & \times \quad 44,3 \quad \mathrm{~cm}\end{array}$

Doação artista

Data entrada: 17/05/07 Data saída: 11/02/08

Obs.: Retirada em 11/02/2008 
1963.5.11

81

1963.5 .13

84

1963.5.14

75

1963.5.15

88

1963.5 .17

73

1963.5 .18

82

1963.5.19

78

1963.5.22

87

Mulher do Povo III

guache sobre cartolina

$\begin{array}{lllll}63,8 & x \quad 44,2 & \mathrm{~cm}\end{array}$

Doação artista

Data entrada: 17/05/07 Data saída: 11/02/08

Obs.: Retirada em 11/02/2008

O Fantasma da Horta

1953

guache sobre cartolina

$\begin{array}{lllll}57,5 & \times 36 & \mathrm{~cm}\end{array}$

Doação artista

Data entrada: 17/05/07 Data saída: 11/02/08

Obs.: Retirada em 11/02/2008

1953

rêutico

guache sobre cartolina

$\begin{array}{lllll}58,1 & \times \quad 42 \quad \mathrm{~cm}\end{array}$

Doação artista

Data entrada: 17/05/07 Data saída: 11/02/08

Obs.: Retirada em 11/02/2008

o Homem Santo

1953

guache sobre cartolina

$57,5 \times 40,2 \quad x$

Doação artista

Data entrada: 17/05/07 Data saída: 11/02/08

Obs.: Retirada em 11/02/2008

1953

guache sobre cartolin

$\begin{array}{lllll}63,8 & \times \quad 44,2 & \mathrm{~cm}\end{array}$

Doação artista

Data entrada: 17/05/07 Data saída: 11/02/08

Obs.: Retirada em 11/02/2008

\section{O Ser Vegetal}

1953

guache sobre cartolina

$57,3 \times 40,2 \quad x \quad c m$

Doação artista

Data entrada: 17/05/07 Data saída: 11/02/08

Obs.: Retirada em 11/02/2008

o Trabalhador

1953

guache sobre cartolina

$\begin{array}{lllll}63,8 & \mathrm{x} & \mathrm{cm}\end{array}$

Doação artista

Data entrada: 17/05/07_ Data saída: 11/02/08

Obs.: Retirada em 11/02/2008

Ser Mitológico

1953

guache sobre cartolina

$60,7 \quad x \quad 44,4 \quad x \quad c m$

Doação artista

Data entrada: 17/05/07 Data saída: 11/02/08

Obs.: Retirada em 11/02/2008

CRAVO JR., MÁRIO

1963.3 .460

Capoeirista

1955

38

ferro

$37,5 \times 32 \times 19$

Doação MAMSP

Data entrada: 17/05/07 Data saída: 14/10/07

Obs.:

\section{DE FIORI, ERNESTO}

$1987.15 \quad$ O Brasileiro

1938

36 bronze

$81,5 \times 24 \quad \times \quad 16,5 \quad \mathrm{~cm}$

Doação Ornella Heins Psillakis

Data entrada: 17/05/07

Obs.: 
DI CAVALCANTI, EMILIANO

1963.3.726

guache sobre papel

$50,3 \quad x \quad 34,7 \quad x$

Doação MAMSP

Data entrada: 17/05/07 Data saída: 14/10/07

Obs.:

1963.3.756 Sem título (Casal e Criança)

1929

5,11

crayon e aquarela sobre papel

$37,9 \times 32,6 \quad x$

Doação MAMSP

Data entrada: 17/05/07 Data saída: 14/10/07

Obs.:

1963.3.931 Sem título (Perfil Feminino)

1941

grafite sobre papel

$31,7 \quad \times \quad 22,2 \quad x$

Doação MAMSP

Data entrada: 17/05/07 Data saída: 14/10/07

Obs.:

1963.3.971

Sem título (Retrato de Mulher)

1942

5,12

nanquim sobre papel

$30,9 \times 22,1$

Doação MAMSP

Data entrada: 17/05/07 Data saída: 14/10/07

Obs.:

1963.3.1019 Sem título (Retrato de Homem)

1945

6,12

carvão sobre papel

$\begin{array}{lllll}46,9 & x \quad 32,6 & \mathrm{~cm}\end{array}$

Doação MAMSP

Data entrada: 17/05/07 Data saída: 14/10/07

Obs.:

\section{EHRENBERG, FELIPE}

1977.18.21.1/2 A Informação muda a Imagem

57 fotocópia, nanquim e caneta hidrográfica sobre papel colado sobre papel pautado

1976

$27,5 \quad \times 44 \quad \mathrm{~cm}$

Doação artista

Data entrada: 17/05/07 Data saída: 14/10/07

Obs.

1977.18.22 A Informação muda a Imagem

1977

58

fotocópia, carimbo e nanquim sobre papel colado sobre papel

$32 \times 50 \quad x \quad c m$

Doação artista

Data entrada: 17/05/07 Data saída: 14/10/07

Obs.:

\section{FRAJMUND, RAYMOND}

2007.4.1.1 Sem título

1958

90

fotografia pb sobre papel

$26,5 \quad \times \quad 40$

Doação artista

Data entrada: 17/05/07_ Data saída: 11/02/08

Obs.: A fotografia ainda não fazia parte do Acervo MAC USP quando participou da mostra; Retirada em 11/02/2008

2007.4.1.2

Sem título

1958

91,11

fotografia pb sobre papel

$\begin{array}{llll}40,1 & \mathrm{~cm}\end{array}$

Doação artista

Data entrada: 17/05/07 Data saída: 11/02/08

Obs.: A fotografia ainda não fazia parte do Acervo MAC USP quando participou da mostra; Retirada em 11/02/2008

fotografia pb sobre papel

$26,4 \quad x \quad 40,2 \quad \mathrm{~cm}$

Doação artista

Data entrada: 17/05/07 Data saída: 11/02/08

Obs.: A fotografia ainda não fazia parte do Acervo MAC USP quando participou da mostra; Retirada em 11/02/2008 
Doação artista

Data entrada: 17/05/07 Data saída: 11/02/08

Obs.: A fotografia ainda não fazia parte do Acervo MAC USP quando participou da mostra; Retirada em 11/02/2008

2007.4.1.5

91,22

2007.4.1.6

91,23

2007.4.1.7

91,31

2007.4.1.8

91,32

2007.4.1.9

91,33

2007.4.1.10

92,11

2007.4.1.11

92,12

2007.4.1.12

92,21

2007.4.1.13

92,22

\section{Sem título}

fotografia pb sobre papel

$26,5 \quad x \quad 40$

Doação artista

Data entrada: 17/05/07 Data saída: 11/02/08

Obs.: A fotografia ainda não fazia parte do Acervo MAC USP quando participou da mostra; Retirada em 11/02/2008

\section{Sem título}

fotografia pb sobre papel

$26,5 \quad x \quad 40$

Doação artista

Data entrada: 17/05/07 Data saída: 11/02/08

Obs.: A fotografia ainda não fazia parte do Acervo MAC USP quando participou da mostra; Retirada em 11/02/2008

\section{Sem título}

1958

fotografia pb sobre papel

$26,4 \times 40,1 \quad x$

Doação artista

Data entrada: 17/05/07 Data saída: 11/02/08

Obs.: A fotografia ainda não fazia parte do Acervo MAC USP quando participou da mostra; Retirada em 11/02/2008

\section{Sem título}

fotografia pb sobre pape

$26,5 \times 40 \quad x$

Doação artista

Data entrada: 17/05/07 Data saída: 11/02/08

Obs.: A fotografia ainda não fazia parte do Acervo MAC USP quando participou da mostra; Retirada em 11/02/2008

\section{Sem título}

1958

fotografia pb sobre papel

$26,5 \times 40,1$

Doação artista

Data entrada: 17/05/07_Data saída: 11/02/08

Obs.: A fotografia ainda não fazia parte do Acervo MAC USP quando participou da mostra; Retirada em 11/02/2008

\section{Sem título}

1958

fotografia pb sobre papel

$\begin{array}{llll}26,5 & \mathrm{~cm}\end{array}$

Doação artista

Data entrada: 17/05/07 Data saída: 11/02/08

Obs.: A fotografia ainda não fazia parte do Acervo MAC USP quando participou da mostra Retirada em 11/02/2008

\section{Sem título}

fotografia pb sobre papel

$40 \times 26,5 \quad \mathrm{~cm}$

Doação artista

Data entrada: 17/05/07 Data saída: 11/02/08

Obs.: A fotografia ainda não fazia parte do Acervo MAC USP quando participou da mostra; Retirada em 11/02/2008

\section{Sem título}

1958

fotografia pb sobre papel

$40 \times 26,5 \quad x \quad c m$

Doação artista

Data entrada: 17/05/07 Data saída: 11/02/08

Obs.: A fotografia ainda não fazia parte do Acervo MAC USP quando participou da mostra Retirada em 11/02/2008

fotografia pb sobre papel

$40 \quad x \quad 26,5 \quad x$

Doação artista

Data entrada: 17/05/07 Data saída: 11/02/08

Obs.: A fotografia ainda não fazia parte do Acervo MAC USP quando participou da mostra Retirada em 11/02/2008 
Obs.: A fotografia ainda não fazia parte do Acervo MAC USP quando participou da mostra; Retirada em 11/02/2008

2007.4.1.15

93,12

2007.4.1.16

93,21

2007.4.1.17

93,22

2007.4.1.18

94,11

2007.4.1.19

94,12

2007.4.1.20

94,21

2007.4.1.21

94,22

2007.4.1.22

94,3

2007.4.1.23

95,11

\section{Sem título}

fotografia pb sobre papel

$40 \times 26,5 \quad x$

Doação artista

Data entrada: 17/05/07 Data saída: 11/02/08

Obs.: A fotografia ainda não fazia parte do Acervo MAC USP quando participou da mostra; Retirada em 11/02/2008

\section{Sem título}

fotografia $\mathrm{pb}$ sobre papel

$40 \times 26,5 \quad x$

Doação artista

Data entrada: 17/05/07 Data saída: 11/02/08

Obs.: A fotografia ainda não fazia parte do Acervo MAC USP quando participou da mostra; Retirada em 11/02/2008

\section{Sem título}

1958

fotografia pb sobre papel

$40 \times 26,5 \times$

Doação artista

Data entrada: 17/05/07 Data saída: 11/02/08

Obs.: A fotografia ainda não fazia parte do Acervo MAC USP quando participou da mostra; Retirada em 11/02/2008

\section{Sem título}

fotografia pb sobre papel

$40,1 \quad x \quad 26,4 \quad x$

Doação artista

Data entrada: 17/05/07 Data saída: 11/02/08

Obs.: A fotografia ainda não fazia parte do Acervo MAC USP quando participou da mostra; Retirada em 11/02/2008

\section{Sem título}

1958

fotografia pb sobre papel

$40 \quad x \quad 26,5 \quad \mathrm{~cm}$

Doação artista

Data entrada: 17/05/07 Data saída: 11/02/08

Obs.: A fotografia ainda não fazia parte do Acervo MAC USP quando participou da mostra; Retirada em 11/02/2008

\section{Sem título}

1958

fotografia pb sobre papel

$40 \times 26,5 \quad \mathrm{~cm}$

Doação artista

Data entrada: 17/05/07 Data saída: 11/02/08

Obs.: A fotografia ainda não fazia parte do Acervo MAC USP quando participou da mostra; Retirada em 11/02/2008

\section{Sem título}

fotografia pb sobre papel

$\begin{array}{llll}40,1 & \mathrm{~cm}\end{array}$

Doação artista

Data entrada: 17/05/07_ Data saída: 11/02/08

Obs.: A fotografia ainda não fazia parte do Acervo MAC USP quando participou da mostra; Retirada em 11/02/2008

\section{Sem título}

fotografia pb sobre papel

$40 \times 26,5 \quad x$

Doação artista

Data entrada: 17/05/07 Data saída: 11/02/08

Obs.: A fotografia ainda não fazia parte do Acervo MAC USP quando participou da mostra; Retirada em 11/02/2008

\section{Sem título}

fotografia pb sobre papel

$26,5 \times 40$

Doação artista

Data entrada: 17/05/07 Data saída: 11/02/08

Obs.: A fotografia ainda não fazia parte do Acervo MAC USP quando participou da mostra; Retirada em 11/02/2008 
Obs.: A fotografia ainda não fazia parte do Acervo MAC USP quando participou da mostra; Retirada em 11/02/2008

2007.4.1.25

95,13

2007.4.1.26

95,21

2007.4.1.27

95,22

2007.4.1.28

95,23

2007.4.1.29

95,31

2007.4.1.30

95,32

2007.4.1.31

96,1

2007.4.1.32

96,21

2007.4.1.33

96,22

Sem título

fotografia pb sobre papel

$26,5 \times 40,1 \quad x$

Doação artista

Data entrada: 17/05/07 Data saída: 11/02/08

Obs.: A fotografia ainda não fazia parte do Acervo MAC USP quando participou da mostra; Retirada em 11/02/2008

\section{Sem título}

fotografia pb sobre papel

$26,5 \times 40,1 \quad x$

Doação artista

Data entrada: 17/05/07 Data saída: 11/02/08

Obs.: A fotografia ainda não fazia parte do Acervo MAC USP quando participou da mostra; Retirada em 11/02/2008

\section{Sem título}

1958

fotografia pb sobre papel

$26,5 \times 40 \quad x$

Doação artista

Data entrada: 17/05/07 Data saída: 11/02/08

Obs.: A fotografia ainda não fazia parte do Acervo MAC USP quando participou da mostra; Retirada em 11/02/2008

\section{Sem título}

fotografia pb sobre papel

$26,4 \times 40$

Doação artista

Data entrada: 17/05/07_ Data saída: 11/02/08

Obs.: A fotografia ainda não fazia parte do Acervo MAC USP quando participou da mostra; Retirada em 11/02/2008

\section{Sem título}

1958

\section{fotografia pb sobre papel}

$26,5 \times 40$

Doação artista

Data entrada: 17/05/07 Data saída: 11/02/08

Obs.: A fotografia ainda não fazia parte do Acervo MAC USP quando participou da mostra; Retirada em 11/02/2008

\section{Sem título}

1958

fotografia pb sobre papel

$40 \times 26,5 \quad x \quad c m$

Doação artista

Data entrada: 17/05/07_ Data saída: 11/02/08

Obs.: A fotografia ainda não fazia parte do Acervo MAC USP quando participou da mostra; Retirada em 11/02/2008

\section{Sem título}

1958

fotografia pb sobre papel

$40 \quad x \quad 26,4 \quad \mathrm{~cm}$

Doação artista

Data entrada: 17/05/07 Data saída: 11/02/08

Obs.: A fotografia ainda não fazia parte do Acervo MAC USP quando participou da mostra; Retirada em 11/02/2008

\section{Sem título}

fotografia pb sobre papel

$26,4 \quad x \quad 40,1 \quad x$

Doação artista

Data entrada: 17/05/07 Data saída: 11/02/08

Obs.: A fotografia ainda não fazia parte do Acervo MAC USP quando participou da mostra; Retirada em 11/02/2008

\section{Sem título}

fotografia pb sobre papel

$26,5 \times 40,2 \quad x$

Doação artista

Data entrada: 17/05/07 Data saída: 11/02/08

Obs.: A fotografia ainda não fazia parte do Acervo MAC USP quando participou da mostra; Retirada em 11/02/2008 
Doação artista

Data entrada: 17/05/07_ Data saída: 11/02/08

Obs.: A fotografia ainda não fazia parte do Acervo MAC USP quando participou da mostra; Retirada em 11/02/2008

2007.4.1.35

96,31

2007.4.1.36

96,32

2007.4.1.37

96,33

2007.4.1.38

96,41

2007.4.1.39

96,42

2007.4.1.40

96,43

\section{Sem título}

fotografia pb sobre papel

$26,5 \times 40$

Doação artista

Data entrada: 17/05/07

Data saída: 11/02/08

Obs.: A fotografia ainda não fazia parte do Acervo MAC USP quando participou da mostra; Retirada em 11/02/2008

\section{Sem título}

fotografia pb sobre papel

$26,5 \times 40 \quad x$

Doação artista

Data entrada: 17/05/07 Data saída: 11/02/08

Obs.: A fotografia ainda não fazia parte do Acervo MAC USP quando participou da mostra; Retirada em 11/02/2008

\section{Sem título}

fotografia pb sobre papel

$26,5 \times 40,1 \quad x$

Doação artista

Data entrada: 17/05/07 Data saída: 11/02/08

Obs.: A fotografia ainda não fazia parte do Acervo MAC USP quando participou da mostra; Retirada em 11/02/2008

\section{Sem título}

fotografia pb sobre papel

$26,4 \quad x \quad 40,1 \quad x$

Doação artista

Data entrada: 17/05/07 Data saída: 11/02/08

Obs.: A fotografia ainda não fazia parte do Acervo MAC USP quando participou da mostra; Retirada em 11/02/2008

\section{Sem título}

\section{fotografia pb sobre papel}

$26,5 \times 40,1$

Doação artista

Data entrada: 17/05/07 Data saída: 11/02/08

Obs.: A fotografia ainda não fazia parte do Acervo MAC USP quando participou da mostra; Retirada em 11/02/2008

\begin{tabular}{lr}
\hline Sem título & 1958
\end{tabular}

fotografia pb sobre papel

$\begin{array}{llll}26,5 & \mathrm{~cm}\end{array}$

Doação artista

Data entrada: 17/05/07 Data saída: 11/02/08

Obs.: A fotografia ainda não fazia parte do Acervo MAC USP quando participou da mostra; Retirada em 11/02/2008

\section{GUIGNARD, ALBERTO DA VEIGA}

1963.3.508 Festa em Família

13 óleo sobre madeira

$53,8 \quad$ Oleo sobre madeira
X 38,6

Doação MAMSP

Data entrada: 17/05/07 Data saída: 14/10/07

Obs.:

\section{ISHIKAWA, MÁRIO}

1989.24.83.1 Sem título 


\section{JORGE, SÉRGIO VITAL TAFNER}

1985.21.2

7,11

$\begin{aligned} & \\ & 1985.21 .4 \\ & 7,12\end{aligned}$

7,12

LÊNIO

17,11

fotografia em cores sobre papel

$39,4 \times 29,6 \quad x$

Doação artista

Data entrada: 17/05/07 Data saída: 14/10/07

Obs.:

\section{Sem título (Caravelas - BA)}

fotografia em cores sobre papel

$39,3 \times 29,7 \quad x$

Doação artista

Data entrada: 17/05/07 Data saída: 14/10/07

Obs.:

Oxalá

nanquim sobre papel
1984

$\mathrm{cm}$
1984

$\mathrm{cm}$

1957

50,3 $x$ 69,7 $x$

Doação Francisco Matarazzo Sobrinho

Data entrada: 17/05/07 Data saída: 14/10/07

Obs.:

1963.3.551 Ogun

1957

17,12

nanquim sobre papel

$\begin{array}{llll}50,3 & \times \quad 70 \quad \mathrm{~cm}\end{array}$

Doação MAMSP

Data entrada: 17/05/07 Data saída: 14/10/07

Obs.:

1963.3.552 Omolu

18,12

nanquim sobre pape

$\begin{array}{lllll}52 & x \quad 33,8 & \mathrm{~cm}\end{array}$

Doação MAMSP

Data entrada: 17/05/07 Data saída: 14/10/07

Obs.:

18,11

\section{Iấ}

nanquim sobre papel

$70 \times 50,4$

Doação MAMSP

Data entrada: 17/05/07 Data saída: 14/10/07

Obs.:

MEDINA, Isidoro Valcárcel

1976.40.1.1/12 12 Exercícios de Medição sobre a Cidade de Córdoba

65,3

fotocópia e heliografia sobre papel

$130 \times 340 \quad \mathrm{~cm}$

Doação artista

Data entrada: 17/05/07 Data saída: 14/10/07

Obs.: exposta em vitrine

1977.18.239.1 Retratos de Rua

1975

46

datilografia, fotografia $\mathrm{pb}$, hidrográfica e tipografia sobre papel colados sobre papel

$35,3 \times 100,2 \quad x \quad c m$

Doação artista

Data entrada: 17/05/07 Data saída: 14/10/07

Obs.:

1977.18.239.2 Retratos de Estúdio

1976

datilografia, fotografia $\mathrm{pb}$, hidrográfica e tipografia sobre papel colados sobre papel

$\begin{array}{llll}35,3 & x \quad 100,2 & \mathrm{~cm}\end{array}$

Doação artista

Data entrada: 17/05/07 Data saída: 14/10/07

Obs.: 
datilografia, fotografia $\mathrm{pb}$, hidrográfica e tipografia sobre papel colados sobre papel

$35,3 \times 100,2 \quad x \quad c m$

Doação artista

Data entrada: 17/05/07_ Data saída: 14/10/07

Obs.:

1977.29.1.1/41 Informe e Resumo Geral de Atividades na América do Sul

1976

65,1

carimbo e fotocópia sobre papel

$\begin{array}{llll}31,5 & \mathrm{~cm}\end{array}$

Doação artista

Data entrada: 17/05/07 Data saída: 14/10/07

Obs.: exposta em vitrine

MÍCOLI, ROBERTO

1999.5 .1

Colar Mehináku

1996

31

madeira pintada

$240 \times 30 \times 30 \quad \mathrm{~cm}$

Doação artista

Data entrada: 17/05/07 Data saída: 14/10/07

Obs.:

\section{MONTEIRO, VICENTE DO REGO}

1974.10.19 Mani Oca / O Nascimento de Mani

29,11 aquarela e nanquim sobre papel

$\begin{array}{lllll}28 & \times 36,5 & \mathrm{~cm}\end{array}$

Aquisição MAC USP

Data entrada: 17/05/07 Data saída: 14/10/07

Obs:

1974.10.20 O Boto

1921

28,12

aquarela e nanquim sobre papel

$\begin{array}{lllll}35,4 & \times 26 & \mathrm{~cm}\end{array}$

Aquisição MAC USP

Data entrada: 17/05/07 Data saída: 14/10/07

Obs.:

1974.10.22 A Noite sai da Noz de Tucunã

28,11

aquarela e nanquim sobre papel

$32,7 \quad x \quad 28,1 \quad x$

Aquisição MAC USP

Data entrada: 17/05/07

Data saída: $14 / 10 / 07$

Obs.:

1974.10.25 Coaraci / O Sol

1921

30,11

aquarela e nanquim sobre papel

28,6 $x \quad 16,3 \quad x$

Aquisição MAC USP

Data entrada: 17/05/07_ Data saída: 14/10/07

Obs.:

1974.10.26 Tatu Açu / O Tatu Grande

30,12 aquarela e nanquim sobre papel

$28,6 \times 16 \quad \times$

Aquisição MAC USP

Data entrada: 17/05/07 Data saída: 14/10/07

Obs.:

1974.10.27 Máscaras e Túnicas da Festa de Thieboah

1921

29,12 aquarela e nanquim sobre papel

$\begin{array}{lllll}26,1 & x \quad 34,4 & \mathrm{~cm}\end{array}$

Aquisição MAC USP

Data entrada: 17/05/07 Data saída: 14/10/07

Obs.:

\section{OSIR, PAULO ROSSI}

1963.1.365 Sem título

1956

pastel sobre papel

48,4 $x \quad 31,1 \quad x$

Doação Francisco Matarazzo Sobrinho

Data entrada: 17/05/07

Data saída: 14/10/07

Obs. 


\section{PANCETTI, José}

1972.8.29

Sem título

s.d.

14

crayon e óleo sobre papel

$\begin{array}{llll}69,9 \times 50 \quad \mathrm{~cm} & \mathrm{c}\end{array}$

Doação Pola Rezende

Data entrada: 17/05/07 Data saída: 14/10/07

Obs.:

\section{PARODI, JOSÉ LATERZA e PLÁ, JOSEFINA}

$\begin{array}{lllll}1963.3 .259 & \text { Ritmo Indígena no } 1 & & & \\ 35 & \text { terracota } & & & \\ & 23 \quad \times \quad 16 & & 17,5 & \mathrm{~cm} \\ & \text { Doação MAMSP } & & & \\ & \text { Data entrada: 17/05/07 } & & \text { Data saída: 14/10/07 } \\ & \text { Obs.: } & & \end{array}$

PLAZA, Julio 1974.30.84.1/10

51

Evolução / Revolução

1971

fotografia $\mathrm{pb}$ sobre papel

$\begin{array}{llll}76 & \times \quad 78 & \mathrm{~cm}\end{array}$

Doação artista

Data entrada: 17/05/07 Data saída: 14/10/07

Obs.: montagem em seqüência linear

\section{PORTILLOS, ALFREDO}

1976.31.2

Comunidade

1974

60
$69,7 \times 69,3 \quad x$
Doação artista
Data entrada: 17/05/07 Data saída: 14/10/07
Obs.:

\section{REZENDE, POLA}

1972.8.44

Casal

1948

37

bronze

$57 \times 64,5 \quad \times \quad 46 \quad \mathrm{~cm}$

Doação artista

Data entrada: 17/05/07 Data saída: 14/10/07

Obs.:

\section{SEGALL, LASAR}

1986.4 .1

Perfil de Zulmira

1928

16

óleo sobre tela

$62,5 \times 54 \quad x \quad \mathrm{~cm}$

Doação Maurício Segall e Oscar Klabin Segall

Data entrada: 17/05/07 Data saída: 14/10/07

Obs.:

\section{VALENTIM, RUBEM}

1979.2.313 Sem título

1968

67

acrílica sobre madeira

$63,3 \quad \times \quad 47$

Doação Theon Spanudis

Data entrada: 17/05/07

$\times 7$

$\mathrm{cm}$

Obs.:

1990.6.1

71

1990.6.2

70

Emblema I

1989

serigrafia em cores sobre papel

$\begin{array}{llll}100,1 \quad \text { x } 70,2 & x & c m \\ \text { Doação artista } & & \\ \text { Data entrada: } & 17 / 05 / 07 & & \text { Data saída: } 14 / 10 / 07\end{array}$

Obs.:

Emblema II

serigrafia em cores sobre papel

$100,2 \times 70,3 \quad x$

Doação artista

Data entrada: 17/05/07 Data saída: 14/10/07

Obs.: 
Obs.:

VATER, REGINA

1989.24.140 65,2

O que é a Arte? São Paulo responde

1978

off set sobre pape

$26,7 \quad x \quad 21,8 \quad \mathrm{~cm}$

Doação Cacilda Teixeira da Costa e Annateresa Fabris

Data entrada: 17/05/07 Data saída: 14/10/07

Obs.: exposta em vitrine

2007.2.1.1/12

PlayFEUIlagem

1974

40

fotografia pb sobre papel
$16,7 \times 22,6$
$x$
Doação artista
Data entrada: 17/05/07 Data saída: 14/10/07
Obs.:

\section{ZÍLIO, CARLOS}

valise com pregos de aço, off set sobre cartão, datilografia e fotocópia sobre pape

$200 \times 150 \times 150 \quad \mathrm{~cm}$

Doação artista

Data entrada: 17/05/07_ Data saída: 14/10/07

Obs.: instalação exposta em vitrine

1976.39.1.1/5 Para um Jovem de Brilhante Futuro

valise com pregos de aço, off set sobre cartão, datilografia e fotocópia sobre papel

$200 \times 150 \quad \times 150 \quad \mathrm{~cm}$

Doação artista

Data entrada: 17/05/07_ Data saída: 14/10/07

Obs.: instalação exposta em vitrine

1976.39.1.1/5 Para um Jovem de Brilhante Futuro

$1973 / 74$

50

valise com pregos de aço, off set sobre cartão, datilografia e fotocópia sobre pape

$200 \times 150 \quad \times 150 \quad \mathrm{~cm}$

Doação artista

Data entrada: 17/05/07 Data saída: 14/10/07

Obs.: instalação exposta em vitrine

1976.39.1.1/5

\section{Para um Jovem de Brilhante Futuro}

$1973 / 74$

50

valise com pregos de aço, off set sobre cartão, datilografia e fotocópia sobre papel
200
x 150
$\mathrm{cm}$

Doação artista

Data entrada: 17/05/07 Data saída: 14/10/07

Obs.: instalação exposta em vitrine

1976.39.1.1/5

\section{Para um Jovem de Brilhante Futuro}

$1973 / 74$

valise com pregos de aço, off set sobre cartão, datilografia e fotocópia sobre papel

$200 \times 150 \quad \mathrm{~cm}$

Doação artista

Data entrada: 17/05/07 Data saída: 14/10/07

Obs.: instalação exposta em vitrine

Obras NÃO catalogadas que participam desta exposição:

Vera Chaves BARCELLOS

64) $90 \mathrm{dc} .4 .170 .1 / 8$ Testarte, 1974 - 7 fotos/textos e 1 texto/capa

66,2) 90dc.3.250 Testarte III - o que há por detrás, 1977 - 1 questionário preenchido pelo público (exposta em vitrine)

Attila CSERNIK

39) 90dc.4.168.1/8 Experimentos, 1974 - 4 textos e 4 fotos pb

Felipe EHRENBERG 
54) 90dc.3.365.1 Intersimiose - Permutações de um mesmo Tema, 1977

55) $90 \mathrm{dc} .3 .365 .2 \quad$ Eleições no México, 1977

56) 90dc.3.416 Símbolos+Sinais=a Flecha e alguns de seus usos, 1972/77

Valcarcel MEDINA

43) 90dc.3.238 A Sala Vinçon, 1975

59) 90dc.3.323.1/12 Exame, 1975 - 12 pranchas

Antoni MUNTADAS

66,1) 90dc.3.407.1/6 On Subjectivity: 50 fotografias de "The Best of Life", sd - 3 fotos, 1 texto, 1 questionário vazio +8 preenchidos (exposta em vitrine)

Julio PLAZA

52) 90dc.4.81 Semiologia Urbana, 1971 - impresso

53) 90dc.4.82 Semiologia do Cotidiano, 1971 - impresso

Féliks PODSIADLY

47) 90dc.3.375.1/12 Metamorfose, sd - 12 fotos $\mathrm{pb}$

Jean Paul THENOT

61) 90dc.3.409.1/10 Sobre as Implicações Sócio-econômicas da Obra de Arte, 1970/74 - (apenas 4 cartões off set $\mathrm{pb})$

Obras da Coleção Edemar Cid Ferreira/Banco Santos que participam desta exposição:

Aristides ALVES

9) Cachoeira, Bahia, 1978 - impressão a partir de arquivo digital

Rafael ASSEF

24) Sem título, 2000 - fotografia em cores em gelatina e prata

Alioune BÂ

19,11) Djabi, 1994 - fotografia pb em gelatina e prata

19,12) Moda, 1998 - fotografia pb em gelatina e prata

Gian Paolo BARBIERI

23) Torso com Polvo, Seychelles, 1998 - fotografia pb em gelatina e prata

Carol BECKWITH e Angela FISHER

2) Noiva Turkana, Kenya, c.1985/95 (série Cerimônias da África) - impressão a partir de arquivo digital

3,11) Mulher Himba, Namíbia, c.1985/95 (séire Cerimônias da Àfrica) - impressão a partir de arquivo digital

3,12) Mãe e Criança Himba, Namíbia, c.1985/95 (séire Cerimônias da Àfrica) - impressão a partir de arquivo digital

Luiz BRAGA

8) Tajás, 1988 - foto em cores em gelatina e prata

Mário CRAVO NETO

22,11 ) Figura Voodoo, 1988 - fotografia pb em gelatina e prata

22,12 ) "Hands before Face", 1990 - fotografia pb em gelatina e prata

26) Miscigens 2, 2000 - fotografia pb em gelatina e prata

Pisco DEL GAISO

32) Sem título (Índia Guajá), 1992 - fotografia em cores em gelatina e prata

J. R. DURAN

27,12) Fabrícia, 2001 fotografia pb em gelatina e prata

Delphine FAWUNDU-BUFORD

25) Esperando pacientemente, 2002 - fotografia pb em gelatina e prata

Misha GORDIN

27,11) Multidão \# 55, 2001 - fotografia pb em gelatina e prata

Jean MANZON

33) Sem título (Índios Kalapalo), 1947 - fotografia pb em gelatina e prata

34,11) Sem título (Aldeia Xavante), 1944 - fotografia pb em gelatina e prata

34,12) Sem título (Índios Kalapalo), 1947 - fotografia pb em gelatina e prata

William Louis Henry SKEEN

21) Grupo de Mulheres Rodiya, Ceilão, séc. XIX - foto em albumina

Pierre VERGER

20,11) Pappete, Tahiti, 1933 - fotografia pb em gelatina e prata 
20,12) Luang Probang, Laos, 1938 - fotografia pb em gelatina e prata

Materiais NÃO pertencentes ao Acervo ou à documentação MAC USP:

89) fotografia de Flávio de Carvalho filmando - Expedição do Rio Negro ou Experiência no 4

97) Vitrine de documentos:

a) lista de funcionários e indígenas integrantes da expedição

b) lista de integrantes da expedição do SPI

c) mapa da expedição - Raymond Frajmund

d) desenho

e) diário da expedição - Raymond Frajmund

f) dicionário Xirianã-Francês - Raymond Frajmund

g) "A grande aventura nos confins da Amazônia" - Diário da Noite, 27/08/58

h) "Deusa Branca: farsa na selva" - Última Hora, 02/12/58

i) "Flavio de Carvalho realiza a sua 'Experiência no 4' " - Revista do Globo, 20/9 a 3/10/58

Obs. Geral:" Embora a exposição tenha terminado em 14/10/2007, as curadoras solicitaram a permanência do conjunto exposto na Galeria 1 (posição 72 a 91), que só foi desmontado em 11/02/2008 
MAC USP Ibirapuera

CURADOR: Helouise Costa

DATA: $10 / 07 / 08-28 / 09 / 08$

Documentado por: Cida Bernardo, Cristina Cabral, Fernando Piola

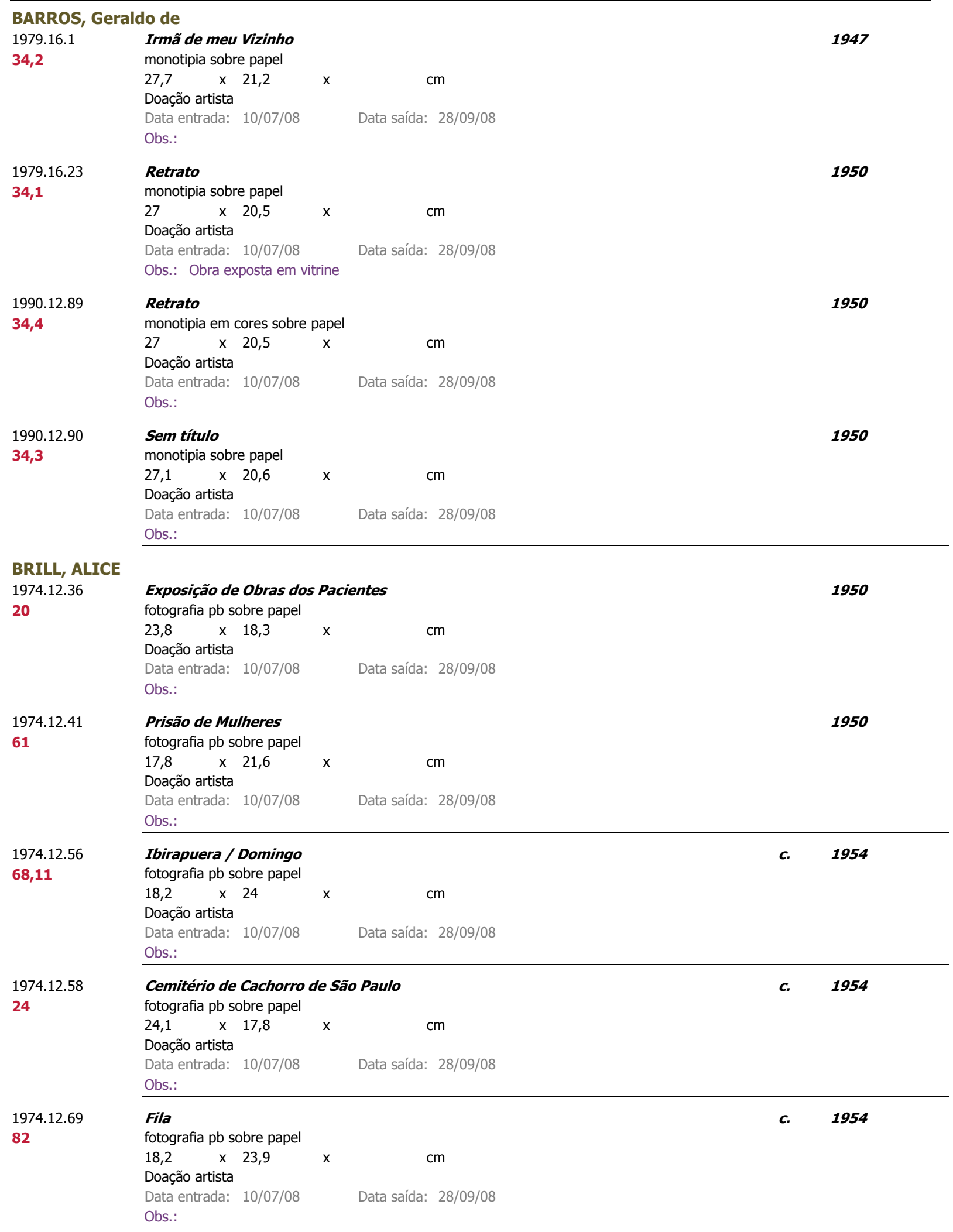




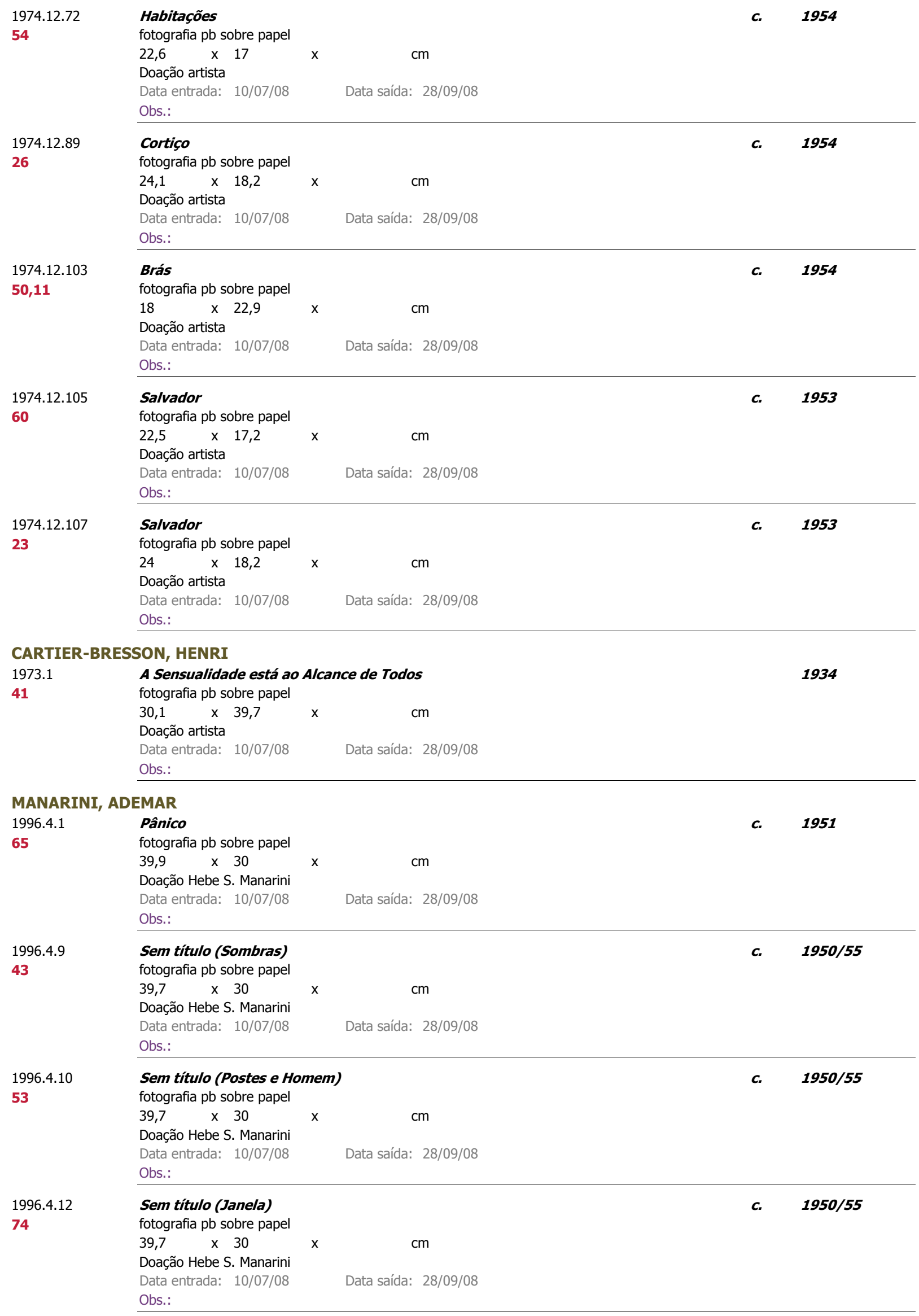




\section{ROSENTHAL, HILDEGARD}

fotografia pb sobre papel
62,5 $x \quad 43,8$
$x$
$\mathrm{cm}$

Doação artista

Data entrada: 10/07/08

Data saída: 28/09/08

Obs.:

1974.26 .50

Ateliê de Seggall / Lucy Citti Ferreira pousando para "Moça com Sanfona"

1941

15 fotografia pb sobre papel

$\begin{array}{llll}50,5 \quad \text { x } 64 & \text { x } & \text { cm } \\ \text { Doação artista } & & \\ \text { Data entrada: } & 10 / 07 / 08 & & \text { Data saída: }\end{array}$

Obs.:

1974.26.52 Ateliê de Seggall / Retratos de Lucy

1942

22

fotografia pb sobre papel

$\begin{array}{llll}43,7 & \times 63 \quad \mathrm{~cm}\end{array}$

Doação artista

Data entrada: 10/07/08 Data saída: 28/09/08

Obs.:

1974.26.53 Ateliê da Osirarte / Paulo Rossi Osir, Hilde Weber e Alfredo Volpi

1942

14 fotografia pb sobre papel
$52,3 \times 61,7$
$x$
$\mathrm{cm}$
Doação artista
Data entrada: 10/07/08 Data saída: 28/09/08
Obs.:

Obras NÃO pertencentes ao Acervo MAC USP que participam desta exposição:

Jorge de LIMA

93 Isto Pode Ser / O Olho dos Lusíadas, 1939 - Arquivo IEB USP

94 Dr. J., 1939 - Arquivo IEB USP

95 A Poesia Abandona a Ciência à sua Própria Sorte, 1939 - Arquivo IEB USP

96 Mulher com Máscara, 1939 - Arquivo IEB USP

97 Mulher, Paródia da Ressurreição de Lázaro, 1939 - Arquivo IEB USP

98 Mulher em Traje de Gala, 1939 - Arquivo IEB USP

99 Sala de Reuniões, 1939 - Arquivo IEB USP

100 Mulhere sem Rosto, Casaco de Pele, 1939 - Arquivo IEB USP

101 Manequim de Mulher sem Rosto, 1939 - Arquivo IEB USP

102 O Julgamento do Tempo, 1939 - Arquivo IEB USP

103 Mulher com Perfil de Gorila, 1939 - Arquivo IEB USP

Obras da Coleção Edemar Cid Ferreira que participam desta exposição:

Berenice ABBOTT

56 Estação Pensilvania, Nova York, 1935

Laure ALBIN-GUILLOT

121 Narciso, 1934

127 Sem título, s.d.

Manuel ALVAREZ BRAVO

9 Frida Kahlo com Globo, 1938

120 Sem título ( México ), c. 1940

Emmy ANDRIESSE

12 Jean Arp ( Paris ), 1948

Richard AVEDON

125 Sem título ( Dorian Leigh com Casaco Dior, Av. Montaigne ), 1949

Geraldo de BARROS

27 Homenagem a Stravinsky ( Série Fotoforma ), 1949

28 A Menina do Sapato ( Série Fotoforma ), 1949

33 Auto-retrato, 1949

119 Nu, 1946

Lucienne BLOCH

10 Frida Kahlo em frente a Painel Inacabado de Rivera, 1933

Thomas BOUCHARD

113 Dançarina, s.d. 
Margaret BOURKE-WHITE

62 Prisioneiros de Buchenwald, 1945

131.1 Capa do Álbum "Twelve Soviet Photoprints"

131.2 Esperando a Vez, Clínica de Crianças, Moscou, c. 1931

131.3 Bebes Bolcheviques na Creche, Fábrica de Automóveis, AMO, c. 1931

131.4 Estudantes de Medicina: Tiflis, c. 1931

132.1 Cel. Hugh L. Cooper, Engenheiro - Chefe Consultor em Dnieprostrol, c.1931

132.2 Para as Fundações de Mina de Ferro, Montanha de Material Magnético, c. 1931

132.3 Brigadeiro de Choque, c. 1931

133.1 Controladora de Trânsito: Moscou, c. 1931

133.2 Tia-avó de Stalin, c.1931

133.3 Tovarisch Mikhail, Pedreiro, c. 1931

133.4 Movimento em Cadeia: Machine Dance. Escola de Balé de Moscou, c. 1931

Bill BRANDT

$123 \mathrm{Nu}$, Campden Hill, Londres, 1950

\section{BRASSAÏ}

1 Pablo Picasso, 1932

2 Salvador Dali, 1933

18 Moça, Bronze de Picasso, s.d.

19 A Serenata ou a Aurora (Quadro de Picasso), 1946

21 Coleção Braive, s.d.

25 Pintura naif sobre um muro, déc.1930

38 Bijou no Bar de la Lune ( Montmatre ), 1932

39 A Briga no Salão do Bar Quartel - Saisons, c.1932

40 Bela da Noite ( Quartier Italie ), c.1932

105 Pequena Sala de Balé, 1943

110 Clotilde de Sakharoff, 1930

Athos BULCÂO

84 A Vésoera da Boda, 1952/54

85 A Invasão dos Marcianos, 1952

86 Toureiro Morto, 1952/54

87 Na Praça São Marcos, 1952/54

88 Sábado no Purgatório, 1952/54

89 O Fumador de Ópio, 1953

90 O Lança-chamas, 1952/54

91 Ao Lado de Guermantes, 1952

92 O Olho de Moscou, 1952/54

Cornell CAPA

104 Escola de Balé, Moscou, 1958

Henri CARTIER-BRESSON

3 Picasso, s.d.

Lucien CLERGUE

77 O Grande Desfile, 1955

Imogen CUNNINGHAM

122 Triângulos, s.d.

Robert DOISNEAU

63 Sem título (Paris no Fim da Segunda Guerra), s.d.

Harold EDGERTON

115 Sem título, s.d.

Gisele FREUND

17 André Breton em um Mercado de Pulgas, 1958

Thomaz FARKAS

31 Telhas, 1941

51 Sem título, déc.1940

52 Ministério da Educação, 1945

106 Balé Juventude, s.d.

108 Balé Juventude, s.d.

109 Balé Juventude, s.d.

Robert FRANK

68.12 Atlântico, 1952 
Ormond GIGLI

45 Freiras, Rio de Janeiro, 1945

Philippe HALLSMAN

114 Marilyn Saltando, 1959

Martha HOIMES

16 Jackson Pollock em seu Estúdio, Long Island, 1949

Paul HORST

126 Espartilho Mainboucher, 1939

André KERTÉSZ

4 Chagall em Família, 1933

76 Sem título (Escolares), 1931

124 Distorção \# 74, 1933

Germaine KRULL

64 Os Ferroviários-Manifestação a Favor da República (Madri), c.1930

Kineo KUWABARA

67 Praia de Kamakuro, Kanagawa, 1934

Jacques-Henri LARTIGUE

129.11 Sr. Folletête, Secretário de Papai com seu Cachorro Tupy, 1912

129.12 Carro de Corrida: Bunny III, 1912

129.21 Deauville: Daisy Spéranza, 1916

129.22 Primeiro Vôo de Gabriel com o Planador Archedeacon, 1904

130.11 Capa do Álbum de Fotografias

130.12 Minha Prima Simone, 1913

130.21 Zissou Dirigindo o seu "Bob de 4 Rodas" com Oléo e Louis com Passageiros, 1910

Jean LECOQ

30 A Aranha, s.d.

47 Manobras, s.d.

49 A Espera, s.d.

50.12 Sinais Fechados, s.d.

66 Guarda-sóis, s.d.

Hebert LIST

44 Sem título, s.d.

55 Sem título (Roma), s.d.

57 São Pedro, Roma, s.d.

59 Sem título, s.d.

75 Sem título, s.d.

German LORCA

73 Circo de Cavalinhos, 1949

83 À Procura de Emprego, 1951

Dora MAAR

$118 \mathrm{Nu}$, déc.1930

MAN RAY

5 Gisele Prassinos Lendo seus Poemas para os Surrealistas, 1934

13 René Magritte, s.d.

35.1 O Mundo, 1931

35.2 A Cidade, 1931

35.3 Sem título, 1931

35.4 A Casa, 1931

35.5 Sala de Jantar, 1931

36.1 Cozinha, 1931

36.2 Lingerie, 1931

36.3 A Brisa, 1931

36.4 Sem título, 1931

36.5 Banheiro, 1931

42 Barbette, 1926

117 Juliet, 1945

Jean MANZON

79 Getúlio Vargas, c.1944

80 Getúlio Vargas, c.1944 
Etienne-Jules MAREY

128.1 Vôo de Pelicano (5 Imagens por Segundo), 1887

128.2 Vôo de Gaivota, 1887

Gjon MILI

116 Nu Descendo a Escada, 1942

Barbara MORGAN

107 Martha Graham (Balé American Provincials), 1935

Larry MORRIS

48 Third Avenue, Nova York, 1955

Carl MYDANS

78 Winston Churchill, 1955

Albert RENGER-PATSCH

6 Mary Wigman, 1934

Leni RIE FENSTAHL

111 Sem título (Olimpíada de Berlim), 1936

112 Sem título (Olimpíada de Berlim), 1936

Alexander RODTCHENKO

37 Moça com Leica, 1934

ROSENTHAL

81 O Menino Jornaleiro, 1939

Eugene SMITH

46 Sem título (Esperando pelos sobreviventes do Andrea Doria), 1956

58 Sem título (Da Fotorreportagem Enfermeira Parteira Revista Life), 1951

Edward STEICHEN

11 Brancusi em seu Atelier, 1925

Carl VAN VECHTEN

8 Diego Rivera, 1932

Pierre VERGER

70 Salvador, Bahia, 1946

71 Salvador, Bahia, 1946

72 Shangai, China, 1937

WEEGEE

32 Bette Davis-Distorção, déc. 1950

Edward WESTON

29 Yucca a Pedra de Granito (Wonderlands of Rocks), 1937

Materiais de apoio:

a) Projeção de publicações

b) Vitrine com publicações

Obs. Geral: 


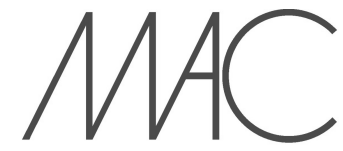

MUSEU DE ARTE CONTEMPORÂNEA

\section{"Fotógrafos da Cena Contemporânea" Curadoria: Helouise Costa}

\section{Espaço: MAC USP Sede (G2, G3 e G4) Previsão de abertura: 19 de novembro de 2011 LISTA DE OBRAS}

\begin{tabular}{|c|c|c|c|c|}
\hline Artista & Título da obra & Técnica & Dimensões & $\begin{array}{l}\text { Dados do } \\
\text { artista }\end{array}$ \\
\hline Claudio Edinger & $\begin{array}{c}\text { rio, } 2002 \\
\text { Barra da Tijuca, } 2002\end{array}$ & $\begin{array}{l}\text { fotografia - foto } \\
\text { pb (selenium), } \\
\begin{array}{c}\text { Pigmento sobre papel } \\
\text { fotográfico }\end{array}\end{array}$ & $\begin{array}{c}55 \times 44 \times \mathrm{cm} \\
55 \times 44 \times \mathrm{cm}\end{array}$ & $\begin{array}{l}\text { Rio de Janeiro, RJ, } \\
\text { Brasil, } 1952\end{array}$ \\
\hline Claudio Edinger & $\begin{array}{l}\text { rio, } 2002 \\
\text { Leblon, } 2003\end{array}$ & $\begin{array}{c}\text { fotografia - foto pb } \\
\text { (selenium), } \\
\text { Pigmento sobre papel } \\
\text { fotográfico }\end{array}$ & $\begin{array}{l}44 \times 56 \times \mathrm{cm} \\
44 \times 55 \times \mathrm{cm}\end{array}$ & $\begin{array}{c}\text { Rio de Janeiro, RJ, } \\
\text { Brasil, } 1952\end{array}$ \\
\hline Claudio Edinger & $\begin{array}{c}\text { rio, } 2002 \\
\text { Ipanema, } 2001\end{array}$ & $\begin{array}{l}\text { fotografia - foto pb } \\
\text { (selenium), } \\
\text { Pigmento sobre papel } \\
\text { fotográfico }\end{array}$ & $\begin{array}{l}40 \times 56 \times \mathrm{cm} \\
40 \times 56 \times \mathrm{cm}\end{array}$ & $\begin{array}{l}\text { Rio de Janeiro, RJ, } \\
\text { Brasil, } 1952\end{array}$ \\
\hline Claudio Edinger & $\begin{array}{c}\text { s/título, } 2002 \\
\text { Ipanema - Posto 6, } 2002\end{array}$ & $\begin{array}{l}\text { fotografia - foto pb } \\
\text { (selenium), } \\
\text { Pigmento sobre papel } \\
\text { fotográfico }\end{array}$ & $\begin{array}{l}44 \times 56 \times \mathrm{cm} \\
44 \times 56 \times \mathrm{cm}\end{array}$ & $\begin{array}{c}\text { Rio de Janeiro, RJ, } \\
\text { Brasil, } 1952\end{array}$ \\
\hline Claudio Edinger & $\begin{array}{c}\text { rio, } 2002 \\
\text { Corcovado, } 2001\end{array}$ & $\begin{array}{l}\text { fotografia - foto PB } \\
\text { Pigmento sobre papel }\end{array}$ & $\begin{array}{c}44 \times 55 \times \mathrm{cm} \\
44 \times 55 \times \mathrm{cm}\end{array}$ & $\begin{array}{l}\text { Rio de Janeiro, RJ, } \\
\text { Brasil, } 1952\end{array}$ \\
\hline
\end{tabular}

$\overline{\text { Rua Praça do Relógio, } 160}$ • tel.: + 551130913039 • Cidade Universitária • CEP: 05508-050 • São Paulo • SP • Brasil 


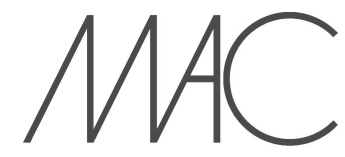

MUSEU DE ARTE CONTEMPORÂNEA da Universidade de São Paula

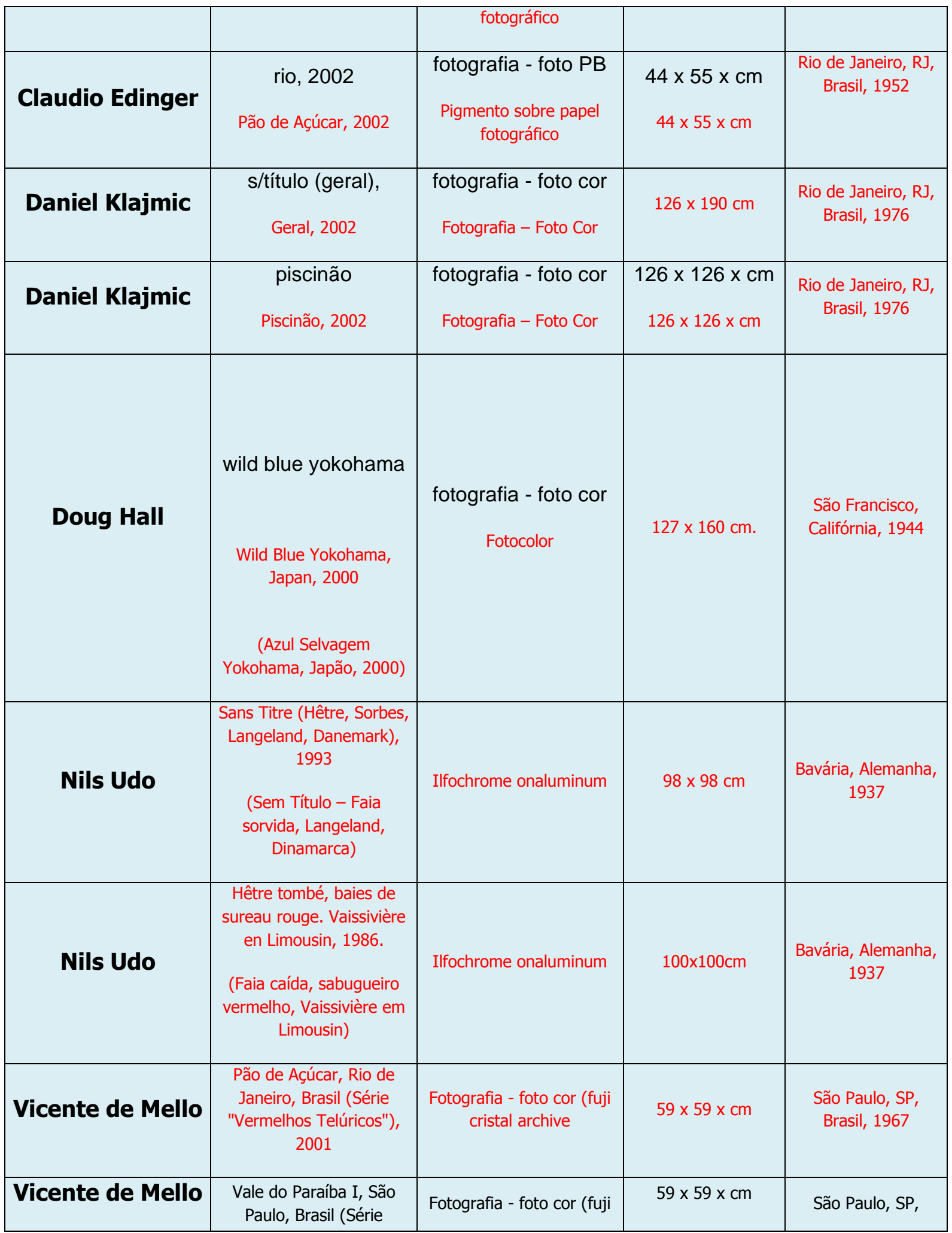

Rua Praça do Relógio, 160 • tel.: + 551130913039 • Cidade Universitária • CEP: 05508-050 • São Paulo • SP • Brasil

Lista Fotógrafos Da Cena Contemporânea 20111022 


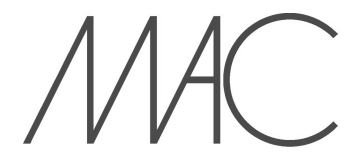

MUSEU DE ARTE CONTEMPORÂNEA da Universidade de São Paulo

\begin{tabular}{|c|c|c|c|c|}
\hline & $\begin{array}{c}\text { "Vermelhos Telúricos"), } \\
2001\end{array}$ & cristal archive) & & Brasil, 1967 \\
\hline Vicente de Mello & $\begin{array}{l}\text { Sierra Nevada, Espanha } \\
\text { (Série "Vermelhos } \\
\text { Telúricos"), } 2001\end{array}$ & $\begin{array}{l}\text { Fotografia - foto cor (fuji } \\
\text { cristal archive), }\end{array}$ & $59 \times 60 \times \mathrm{cm}$ & $\begin{array}{l}\text { São Paulo, SP, } \\
\text { Brasil, } 1967\end{array}$ \\
\hline $\begin{array}{c}\text { Walter } \\
\text { Niedermayr }\end{array}$ & $\begin{array}{l}\text { Grande Motte IV } \\
\text { (quadriptico), } 1997\end{array}$ & Type C-Prints & $86 \times 106 \times \mathrm{cm}$ & $\begin{array}{c}\text { Bolzano, Itália, } \\
1952\end{array}$ \\
\hline $\begin{array}{c}\text { Walter } \\
\text { Niedermayr }\end{array}$ & $\begin{array}{l}\text { Grande Motte IV } \\
\text { (quadriptico), } 1997\end{array}$ & Type C-Prints & $86 \times 106 \times \mathrm{cm}$ & $\begin{array}{c}\text { Bolzano, Itália, } \\
1952\end{array}$ \\
\hline $\begin{array}{c}\text { Walter } \\
\text { Niedermayr }\end{array}$ & $\begin{array}{l}\text { Grande Motte IV } \\
\text { (quadriptico), } 1997\end{array}$ & Type C-Prints & & $\begin{array}{c}\text { Bolzano, Itália, } \\
1952\end{array}$ \\
\hline $\begin{array}{c}\text { Walter } \\
\text { Niedermayr }\end{array}$ & $\begin{array}{l}\text { Grande Motte IV } \\
\text { (quadriptico), } 1997\end{array}$ & Type C-Prints & $86 \times 106 \times \mathrm{cm}$ & $\begin{array}{c}\text { Bolzano, Itália, } \\
1952\end{array}$ \\
\hline uaco neji & $\begin{array}{l}\text { Ícaro After Fall, } 1994 \\
\text { (Ícaro depois da queda) }\end{array}$ & fotografia - foto PB & $40 \times 40 \times \mathrm{cm}$ & \\
\hline $\begin{array}{c}\text { Gian Paolo } \\
\text { Barbieri }\end{array}$ & $\begin{array}{l}\text { Torso con polpo, } \\
\text { Seychelles, } 1998 \\
\text { (Torso com polvo, } \\
\text { Seychelles), } 1988\end{array}$ & $\begin{array}{c}\text { Stampa ai Sali d'argentio } \\
\text { vintage }\end{array}$ & $40 \times 30 \mathrm{~cm}$ & Milão, Itália, 1938 \\
\hline Judy Dater & $\begin{array}{l}\text { Self-Portrait with Stone, } \\
1982 \\
\text { (Autorretrato com pedra) }\end{array}$ & Gelatin Silver Print & $36,8 \times 46,9 \times \mathrm{cm}$ & $\begin{array}{l}\text { Los Angeles, EUA, } \\
1941\end{array}$ \\
\hline $\begin{array}{l}\text { Benedetta } \\
\text { Bonichi }\end{array}$ & A Francis Bacon, 2000 & $\begin{array}{l}\text { Radiografia sobre papel } \\
\text { Emulsionado }\end{array}$ & $226 \times 141 \times \mathrm{cm}$ & Alba, Itália, 1968 \\
\hline $\begin{array}{l}\text { Benedetta } \\
\text { Bonichi }\end{array}$ & A Sereia, 2001 & $\begin{array}{c}\text { Radiografia sobre papel } \\
\text { Emulsionado }\end{array}$ & $141 \times 248 \times \mathrm{cm}$ & Alba, Itália, 1968 \\
\hline Alioune Bâ & Djabi, 1994 & Gelatin Silver Print & $40,5 \times 30,5 \mathrm{~cm}$ & $\begin{array}{c}\text { Bamako, Malian, } \\
1959\end{array}$ \\
\hline Alioune Bâ & Moda, 1998 & Gelatin Silver Print & $40,5 \times 30,5 \mathrm{~cm}$ & $\begin{array}{c}\text { Bamako, Malian, } \\
1959\end{array}$ \\
\hline Cris Bierrenbach & Desafio, 2003 & $\begin{array}{l}\text { Fotografia - Foto } \\
\text { Daguerreótipo }\end{array}$ & $12 \times 10 \times \mathrm{cm}$ & São Paulo, SP, 1964 \\
\hline
\end{tabular}

Rua Praça do Relógio, 160 • tel.: + 551130913039 • Cidade Universitária • CEP: 05508-050 • São Paulo • SP • Brasil

Lista Fotógrafos Da Cena Contemporânea 20111022 


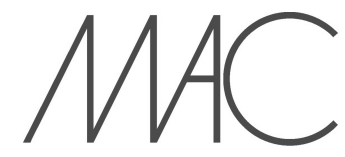

MUSEU DE ARTE CONTEMPORÂNEA da Universidade de São Paulo

\begin{tabular}{|c|c|c|c|c|}
\hline & & Edição: 1/1 (+PA) & & \\
\hline Cris Bierrenbach & Fist, 2003 & $\begin{array}{l}\text { Fotografia - Foto } \\
\text { Daguerreótipo } \\
\text { Edição: } 1 / 1 \text { (+PA) }\end{array}$ & $12 \times 10 \times \mathrm{cm}$ & São Paulo, SP, 1964 \\
\hline Cris Bierrenbach & Love, 2003 & $\begin{array}{l}\text { Fotografia - Foto } \\
\text { Daguerreótipo } \\
\text { Edição: } 1 / 1 \text { (+PA) }\end{array}$ & $10 \times 12 \times \mathrm{cm}$ & São Paulo, SP, 1964 \\
\hline Cris Bierrenbach & Ruptura, 2003 & $\begin{array}{l}\text { Fotografia - Foto } \\
\text { Daguerreótipo } \\
\text { Edição: } 1 / 1 \text { (+PA) } \\
\text { (Díptico) }\end{array}$ & $12 \times 10 \times \mathrm{cm}$ & São Paulo, SP, 1964 \\
\hline Cris Bierrenbach & Sem Título (costas), 2003 & $\begin{array}{c}\text { Fotografia - Foto } \\
\text { Daguerreótipo } \\
\text { Edição : PA (+ 1/1) } \\
\text { Tríptico }\end{array}$ & $25 \times 19 \times \mathrm{cm}$ & São Paulo, SP, 1964 \\
\hline Cris Bierrenbach & Sem Título (frontal), 2003 & $\begin{array}{c}\text { Fotografia - Foto } \\
\text { Daguerreótipo } \\
\text { Edição : PA (+ 1/1) } \\
\text { Tríptico }\end{array}$ & $25 \times 19 \times \mathrm{cm}$ & São Paulo, SP, 1964 \\
\hline Cris Bierrenbach & Sem Título (perfil), 2003 & $\begin{array}{c}\text { Fotografia - Foto } \\
\text { Daguerreótipo } \\
\text { Edição : PA (+ 1/1) } \\
\text { Tríptico }\end{array}$ & $24 \times 19 \times \mathrm{cm}$ & São Paulo, SP, 1964 \\
\hline Felipe Goifman & Brazil, Xikrin Indians & Película Fuji Velvia $35 \mathrm{~mm}$ & $30 \times 40 \times \mathrm{cm}$ & $\begin{array}{c}\text { Belo Horizonte, MG, } \\
\text { Brasil, } 1966\end{array}$ \\
\hline $\begin{array}{l}\text { Jean-Luc } \\
\text { Moulène }\end{array}$ & $\begin{array}{l}\text { We Were Here and } \\
\text { There, } 1998 \\
\text { (Estamos aqui e alí) }\end{array}$ & $\begin{array}{c}\text { Fotografia - Foto Cor } \\
\text { (cibachrome s/ plexiglas), }\end{array}$ & $122 \times 190 \mathrm{~cm}$ & $\begin{array}{c}\text { Reims, França, } \\
1955\end{array}$ \\
\hline $\begin{array}{l}\text { Jean-Luc } \\
\text { Moulène }\end{array}$ & $\begin{array}{l}\text { We Were Here and } \\
\text { There, } 1998 \\
\text { (Estamos aqui e alí) }\end{array}$ & $\begin{array}{l}\text { Fotografia - Foto Cor s/ } \\
\text { Acrílico (cibachrome) }\end{array}$ & $142,6 \times 122,9 \mathrm{~cm}$ & $\begin{array}{c}\text { Reims, França, } \\
1955\end{array}$ \\
\hline John Coplans & $\begin{array}{l}\text { Interlocking Fingers n. } 22 \\
\text { - Self portrait } 8 \propto 0 \\
\text { interlocking fingers n. 22, } \\
2000 \\
\text { (Dedos Entrelaçados n. }\end{array}$ & Fotografia - Foto PB & $78 \times 61 \times \mathrm{cm}$ & $\begin{array}{c}\text { Londres, Inglaterra, } \\
1920 \\
\text { Nova York, EUA, } \\
2003\end{array}$ \\
\hline
\end{tabular}

Rua Praça do Relógio, 160 • tel.: + 551130913039 • Cidade Universitária • CEP: 05508-050 • São Paulo • SP • Brasil

Lista Fotógrafos Da Cena Contemporânea 20111022 


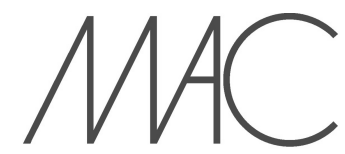

MUSEU DE ARTE CONTEMPORÂNEA da Universidade de Sáo Paulo

\begin{tabular}{|c|c|c|c|c|}
\hline & $\begin{array}{c}22 \text { - Autorretrato } 8 \infty 0 \\
\text { dedos entrelaçados n. } 22 \text { ) }\end{array}$ & & & \\
\hline $\begin{array}{c}\text { Mario Cravo } \\
\text { Neto }\end{array}$ & Figura Voodoo, 1988 & Fotografia - Foto PB & $40 \times 40 \times \mathrm{cm}$ & $\begin{array}{c}\text { Salvador, BA, } \\
\text { Brasil, } 1947 \\
\text { Salvador, BA, } 2000\end{array}$ \\
\hline $\begin{array}{c}\text { Mario Cravo } \\
\text { Neto }\end{array}$ & $\begin{array}{l}\text { Hands Before Face, } 1990 \\
\text { (Mãos sobre o rosto) }\end{array}$ & Fotografia - Foto PB & $40 \times 40 \times \mathrm{cm}$ & $\begin{array}{c}\text { Salvador, BA, } \\
\text { Brasil, } 1947 \\
\text { Salvador, BA, } 2000\end{array}$ \\
\hline Misha Gordin & $\begin{array}{l}\text { Doubt (Série Dúvida) \#6, } \\
\text { 1994-1995 }\end{array}$ & Gelatin Silver Print & $\begin{array}{c}58 \times 44 \times \mathrm{cm} \\
\left(17.25 \times 22.75^{\prime \prime}\right)\end{array}$ & Riga, Rússia, 1946 \\
\hline Odires Mlászho & $\begin{array}{l}\text { Nu em Transe (Série } \\
\text { Serpentina), } 2002\end{array}$ & $\begin{array}{c}\text { Ampliação Fotográfica } \\
\text { Digital }\end{array}$ & $100 \times 69 \mathrm{~cm}$ & $\begin{array}{l}\text { Mandirituba, PR, } \\
\text { Brasil, } 1960\end{array}$ \\
\hline Rafael Assef & $\begin{array}{c}\text { Matemática Áurea III } \\
\text { p.a., } 2000\end{array}$ & Fotografia - Foto Cor & $175 \times 125,7 \times \mathrm{cm}$ & $\begin{array}{c}\text { São Paulo, SP, } \\
\text { Brasil, } 1970\end{array}$ \\
\hline Rafael Assef & Roupa no. 5, 2002 & $\begin{array}{c}\text { Fotografia - Foto Cor } \\
\text { (digital em papel fujifex, } \\
\text { díptico), }\end{array}$ & $82 \times 82 \times 7 \mathrm{~cm}$ & $\begin{array}{l}\text { São Paulo, SP, } \\
\text { Brasil, } 1970\end{array}$ \\
\hline Rafael Assef & Roupa no. 5, 2002 & $\begin{array}{c}\text { Fotografia - Foto Cor } \\
\text { (digital em papel fujkifex, } \\
\text { díptico), }\end{array}$ & $104 \times 78 \times 7 \mathrm{~cm}$ & $\begin{array}{l}\text { São Paulo, SP, } \\
\text { Brasil, } 1970\end{array}$ \\
\hline Arthur Omar & $\begin{array}{l}\text { Sem Título ("O Seio } \\
\text { Barbado") }\end{array}$ & Fotografia - Foto Cor & $88 \times 108 \mathrm{~cm}$ & $\begin{array}{l}\text { Poços de Caldas, } \\
\text { MG, Brasil, } 1948\end{array}$ \\
\hline Arthur Omar & $\begin{array}{l}\text { Sem Título ("O Seio } \\
\text { Barbado") }\end{array}$ & Fotografia - Foto Cor & $88 \times 108 \mathrm{~cm}$ & $\begin{array}{l}\text { Poços de Caldas, } \\
\text { MG, Brasil, } 1948\end{array}$ \\
\hline Jan Saudek & $\begin{array}{l}\text { Pavla Poses for the First } \\
\text { and Last Time, } 1978 \\
\text { (Pavla Poses para a } \\
\text { Primeira e Última Vez) }\end{array}$ & $\begin{array}{c}\text { Hand Colored Silver } \\
\text { Gelatin Print }\end{array}$ & $\begin{array}{c}39 \times 28 \times \mathrm{cm} \\
\left(16 \times 17^{\prime \prime}\right)\end{array}$ & $\begin{array}{l}\text { Praga, República } \\
\text { Checa, } 1935\end{array}$ \\
\hline Jan Saudek & Jana Drap \# 360 & $\begin{array}{l}\text { Fotografia - Foto Cor } \\
\text { (colorizada) }\end{array}$ & $38 \times 29 \times \mathrm{cm}$ & \\
\hline Hudinilson Jr & $\begin{array}{l}\text { Exercício de me ver, II, c. } \\
\qquad 1982\end{array}$ & Fotografia PB sobre papel & $17,9 \times 24,1 \mathrm{~cm}$ & $\begin{array}{l}\text { São Paulo, SP, } \\
\text { Brasil, } 1957\end{array}$ \\
\hline Hudinilson Jr & $\begin{array}{l}\text { Exercício de me ver, II, c. } \\
1982\end{array}$ & Fotografia PB sobre papel & $24,1 \times 17,9 \mathrm{~cm}$ & $\begin{array}{c}\text { São Paulo, SP, } \\
\text { Brasil, } 1957\end{array}$ \\
\hline
\end{tabular}

Rua Praça do Relógio, 160 • tel.: + 551130913039 • Cidade Universitária • CEP: 05508-050 • São Paulo • SP • Brasil

Lista Fotógrafos Da Cena Contemporânea 20111022 


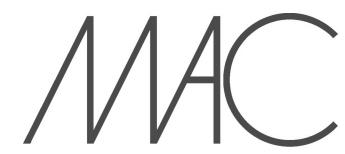

MUSEU DE ARTE CONTEMPORÂNEA da Universidade de São Paulo

\begin{tabular}{|c|c|c|c|c|}
\hline $\begin{array}{c}\text { Kishin } \\
\text { Shinoyama }\end{array}$ & $\begin{array}{l}\text { The Birth 1, } 1968 \\
\text { (O Nascimento 1) }\end{array}$ & $\begin{array}{c}\text { Vintage Silver Gelatin } \\
\text { Print }\end{array}$ & $\begin{array}{c}41 \times 42 \times \mathrm{cm} \\
\left(24 \times 23^{\prime \prime}\right)\end{array}$ & $\begin{array}{c}\text { Tóquio, Japão, } \\
1940\end{array}$ \\
\hline Andres Serrano & $\begin{array}{c}\text { A History of Sex (Head), } \\
1996 \\
\text { (A História do Sexo - } \\
\text { Cabeça) }\end{array}$ & $\begin{array}{c}\text { Fotografia - Foto Cor } \\
\text { (cibachrome, silicone e } \\
\text { plexiglas), }\end{array}$ & $114,6 \times 95,9 \mathrm{~cm}$ & $\begin{array}{c}\text { Nova York, EUA, } \\
1950\end{array}$ \\
\hline $\begin{array}{c}\text { Rankin } \\
\text { (John Rankin } \\
\text { Waddell) }\end{array}$ & $\begin{array}{c}\text { Annie + Stephen Snog, } \\
2000\end{array}$ & Lambda Print & $165,8 \times 124,8 \mathrm{~cm}$ & $\begin{array}{c}\text { Galsgow, Escócia, } \\
1966\end{array}$ \\
\hline $\begin{array}{c}\text { Antonio } \\
\text { Guerreiro }\end{array}$ & Dzi Croquettes 1, 1973 & Fotografia - Foto PB & $99 \times 70 \times \mathrm{cm}$ & $\begin{array}{c}\text { Madri, Espanha, } \\
1947\end{array}$ \\
\hline $\begin{array}{c}\text { Antonio } \\
\text { Guerreiro }\end{array}$ & Dzi Croquettes 2, 1973 & Fotografia - Foto PB & $94 \times 66 \times \mathrm{cm}$ & $\begin{array}{c}\text { Madri, Espanha, } \\
1947\end{array}$ \\
\hline $\begin{array}{c}\text { Antonio } \\
\text { Guerreiro }\end{array}$ & Dzi Croquettes 4, 1973 & Fotografia - Foto PB & $99 \times 71 \times \mathrm{cm}$ & $\begin{array}{c}\text { Madri, Espanha, } \\
1947\end{array}$ \\
\hline $\begin{array}{l}\text { Antonio } \\
\text { Guerreiro }\end{array}$ & Nu estolas, 1972 & Fotografia - Foto PB & $100 \times 55 \times \mathrm{cm}$ & $\begin{array}{c}\text { Madri, Espanha, } \\
1947\end{array}$ \\
\hline $\begin{array}{l}\text { Ed van der } \\
\text { Elsken }\end{array}$ & $\begin{array}{l}\text { Paris, 1954. Saint } \\
\text { Germain de Près. Vali } \\
\text { Meyers, } 1954\end{array}$ & $\begin{array}{c}\text { Fotografia - Foto PB } \\
\text { In Pencil on de Reverse, } \\
\text { Printed Later }\end{array}$ & $40,5 \times 30,3 \mathrm{~cm}$ & $\begin{array}{c}\text { Amsterdam, } \\
\text { Holanda, } 1925 \\
\\
\text { Edam, Holanda, } \\
1990\end{array}$ \\
\hline Fuyuki Hattori & Sem Título, 1988 & $\begin{array}{l}\text { Fotografia - Foto Cor } \\
\text { (cibachrome) }\end{array}$ & $73,2 \times 55 \mathrm{~cm}$ & $\begin{array}{l}\text { Sapporo, Hokkaido, } \\
\text { Japão, } 1955\end{array}$ \\
\hline $\begin{array}{c}\text { Joel Peter- } \\
\text { Witkins }\end{array}$ & $\begin{array}{l}\text { Eunuch, } 1983 \\
\text { (Eunuco) }\end{array}$ & Gelatin Silver Print & $36,5 \times 37,5 \mathrm{~cm}$ & $\begin{array}{c}\text { Nova York, EUA, } \\
1939\end{array}$ \\
\hline $\begin{array}{c}\text { Joel Peter- } \\
\text { Witkins }\end{array}$ & $\begin{array}{l}\text { The Wife of Cain, } 1981 \\
\text { (A Esposa de Caim) }\end{array}$ & Gelatin Silver Print & $70 \times 70 \mathrm{~cm}$ & $\begin{array}{c}\text { Nova York, EUA, } \\
1939\end{array}$ \\
\hline Kiyoshi Koishi & $\begin{array}{l}\text { Nude on The Cross } \\
\text { (Nu na Cruz) }\end{array}$ & Fotografia - Foto PB & $43 \times 32 \times \mathrm{cm}$ & $\begin{array}{l}\text { Osaka, Japão, } 1908 \\
\text { Moji Fukouka, } \\
\text { Japão, } 1957\end{array}$ \\
\hline
\end{tabular}

$\overline{\text { Rua Praça do Relógio, } 160}$ • tel.: + 551130913039 • Cidade Universitária • CEP: 05508-050 • São Paulo • SP • Brasil

Lista Fotógrafos Da Cena Contemporânea 20111022 


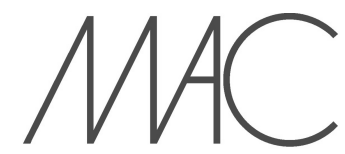

MUSEU DE ARTE CONTEMPORÂNEA da Universidade de São Paulo

\begin{tabular}{|c|c|c|c|c|}
\hline Lucien Clergue & $\begin{array}{l}\text { Les Larmes des Anges, } \\
1996 \\
\text { (Lágrimas dos Anjos) }\end{array}$ & Fotografia - Foto PB & $25 \times 34 \times \mathrm{cm}$ & Arles, França, 1934 \\
\hline Lucien Clergue & $\begin{array}{l}\text { La Chute des Anges - } \\
\text { Milton's Lost Paradise } \\
\text { (A queda dos anjos - O } \\
\text { Paraíso Perdido de } \\
\text { Milton) }\end{array}$ & Fotografia - Foto PB & $32 \times 23 \times \mathrm{cm}$ & Arles, França, 1934 \\
\hline Nobuyoshi Araki & $\begin{array}{l}\text { Sem Título (Nu } \\
\text { Feminino), } 1984\end{array}$ & Fotografia - Foto PB & $26 \times 32 \times \mathrm{cm}$ & $\begin{array}{c}\text { Tóquio, Japão, } \\
1959\end{array}$ \\
\hline Nobuyoshi Araki & Sem Título, 1983 & Fotografia - Foto PB & $58 \times 46 \times \mathrm{cm}$ & $\begin{array}{c}\text { Tóquio, Japão, } \\
1959\end{array}$ \\
\hline Nobuyoshi Araki & $\begin{array}{l}\text { Personal Sentimentalism } \\
\text { in Photography, } 2000\end{array}$ & Gelantin Silver Print, & $124,5 \times 101,6 \mathrm{~cm}$ & $\begin{array}{c}\text { Tóquio, Japão, } \\
1959\end{array}$ \\
\hline Nobuyoshi Araki & Sem Título, 1997 & Fotografia - Foto PB & $58 \times 46 \times \mathrm{cm}$ & $\begin{array}{c}\text { Tóquio, Japão, } \\
1959\end{array}$ \\
\hline Oliviero Toscani & Kissing-Nun, 1992 & Fotografia - Foto Cor & $50 \times 59 \times \mathrm{cm}$ & Milão, Itália, 1942 \\
\hline Pierre Molinier & $\begin{array}{c}\text { Autoportrait 2/2, } \\
\text { (Autorretrato) }\end{array}$ & $\begin{array}{l}\text { Fotografia - Foto PB } \\
\text { (díptico), }\end{array}$ & $22 \times 17 \times \mathrm{cm}$ & $\begin{array}{c}\text { Agen, França, } 1900 \\
\text { - Bordeaux, } \\
\text { França, } 1976\end{array}$ \\
\hline Pierre Molinier & $\begin{array}{l}\text { Autoportrait avec éperon } \\
\text { d'amour, } 1975 \\
\text { (Autorretrato com } \\
\text { Esporão de Amor) }\end{array}$ & Fotografia - Foto PB & $12 \times 18 \times \mathrm{cm}$ & $\begin{array}{l}\text { Agen, França, } 1900 \\
\text { - Bordeaux, } \\
\text { França, } 1976\end{array}$ \\
\hline Pierre Molinier & $\begin{array}{l}\text { Autoportrait dans I'atelier } \\
\text { (Autorretrato no Atelier) }\end{array}$ & Fotografia - Foto PB & $7 \times 12 \times \mathrm{cm}$ & $\begin{array}{l}\text { Agen, França, } 1900 \\
\text { - Bordeaux, } \\
\text { França, } 1976\end{array}$ \\
\hline Pierre Molinier & $\begin{array}{c}\text { Autoportrait } \\
\text { Fhotomontage } \\
\text { (Autorretrato } \\
\text { Fotomontagem) }\end{array}$ & $\begin{array}{l}\text { Fotografia - Foto PB } \\
\text { (díptico) }\end{array}$ & $23 \times 17 \times \mathrm{cm}$ & $\begin{array}{l}\text { Agen, França, } 1900 \\
\text { - Bordeaux, } \\
\text { França, } 1976\end{array}$ \\
\hline Pierre Molinier & $\begin{array}{l}\text { Oh! Marie Mère de Dieu, } \\
1965 \\
\text { (Oh! Maria Mãe de Deus) }\end{array}$ & Fotografia - Foto PB & $11,5 \times 8,3 \mathrm{~cm}$ & $\begin{array}{l}\text { Agen, França, } 1900 \\
\text { - Bordeaux, } \\
\text { França, } 1976\end{array}$ \\
\hline
\end{tabular}

$\overline{\text { Rua Praça do Relógio, } 160}$ • tel.: + 551130913039 • Cidade Universitária • CEP: 05508-050 • São Paulo • SP • Brasil

Lista Fotógrafos Da Cena Contemporânea 20111022 


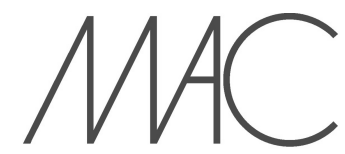

MUSEU DE ARTE CONTEMPORÂNEA da Universidade de São Paulo

\begin{tabular}{|c|c|c|c|c|}
\hline Pierre Molinier & $\begin{array}{c}\text { Amours, } 1966 . \\
\text { (Amor) }\end{array}$ & $\begin{array}{l}\text { Fotografia - Foto PB } \\
\text { Epreuve argentique } \\
\text { d'époque. Tampon }\end{array}$ & $17,3 \times 12,2 \mathrm{~cm}$. & $\begin{array}{l}\text { Agen, França, } 1900 \\
\text { - Bordeaux, } \\
\text { França, } 1976\end{array}$ \\
\hline $\begin{array}{c}\text { Stuart Lester } \\
\text { Rankin }\end{array}$ & (Anthony Agbje), & Fotografia - Foto PB & $142,8 \times 114,6 \mathrm{~cm}$ & $\begin{array}{c}\text { Liverpool, } \\
\text { Inglaterra, } 1946\end{array}$ \\
\hline $\begin{array}{c}\text { Stuart Lester } \\
\text { Rankin }\end{array}$ & $\begin{array}{c}\text { Alex Mc Faydan (male } \\
\text { nude, kilt), }\end{array}$ & Fotografia - Foto PB & $100 \times 123 \times \mathrm{cm}$ & $\begin{array}{c}\text { Liverpool, } \\
\text { Inglaterra, } 1946\end{array}$ \\
\hline Fábio Cabral & Série Erógena & Fotografia - Foto PB & $30 \times 40 \times \mathrm{cm}$ & $\begin{array}{c}\text { Rio de Janeiro, RJ, } \\
\text { Brasil, } 1958\end{array}$ \\
\hline Fábio Cabral & Série Erógena & Fotografia - Foto PB & $30 \times 40 \times \mathrm{cm}$ & $\begin{array}{c}\text { Rio de Janeiro, RJ, } \\
\text { Brasil, } 1958\end{array}$ \\
\hline Fábio Cabral & Série Erógena & Fotografia - Foto PB & $30 \times 40 \times \mathrm{cm}$ & $\begin{array}{c}\text { Rio de Janeiro, RJ, } \\
\text { Brasil, } 1958\end{array}$ \\
\hline Fábio Cabral & Série Erógena & Fotografia - Foto PB & $30 \times 40 \times \mathrm{cm}$ & $\begin{array}{c}\text { Rio de Janeiro, RJ, } \\
\text { Brasil, } 1958\end{array}$ \\
\hline Fábio Cabral & Série Erógena & Fotografia - Foto PB & $30 \times 40 \times \mathrm{cm}$ & $\begin{array}{c}\text { Rio de Janeiro, RJ, } \\
\text { Brasil, } 1958\end{array}$ \\
\hline Fábio Cabral & Série Erógena & Fotografia - Foto PB & $30 \times 40 \times \mathrm{cm}$ & $\begin{array}{c}\text { Rio de Janeiro, RJ, } \\
\text { Brasil, } 1958\end{array}$ \\
\hline Fábio Cabral & Série Erógena & Fotografia - Foto PB & $30 \times 40 \times \mathrm{cm}$ & $\begin{array}{c}\text { Rio de Janeiro, RJ, } \\
\text { Brasil, } 1958\end{array}$ \\
\hline Fábio Cabral & Série Erógena & Fotografia - Foto PB & $30 \times 40 \times \mathrm{cm}$ & $\begin{array}{c}\text { Rio de Janeiro, RJ, } \\
\text { Brasil, } 1958\end{array}$ \\
\hline Fábio Cabral & Série Erógena & Fotografia - Foto PB & $30 \times 40 \times \mathrm{cm}$ & $\begin{array}{c}\text { Rio de Janeiro, RJ, } \\
\text { Brasil, } 1958\end{array}$ \\
\hline Fábio Cabral & Série Erógena & Fotografia - Foto PB & $30 \times 40 \times \mathrm{cm}$ & $\begin{array}{c}\text { Rio de Janeiro, RJ, } \\
\text { Brasil, } 1958\end{array}$ \\
\hline Fábio Cabral & Série Erógena & Fotografia - Foto PB & $30 \times 40 \times \mathrm{cm}$ & $\begin{array}{c}\text { Rio de Janeiro, RJ, } \\
\text { Brasil, } 1958\end{array}$ \\
\hline Fábio Cabral & Série Erógena & Fotografia - Foto PB & $30 \times 40 \times \mathrm{cm}$ & $\begin{array}{c}\text { Rio de Janeiro, RJ, } \\
\text { Brasil, } 1958\end{array}$ \\
\hline Adriana Varejão & $\begin{array}{c}\text { Canibal e Nostálgica, } \\
1998\end{array}$ & Fotografia Digitalizada & $43,3 \times 32,2 \mathrm{~cm}$ & $\begin{array}{c}\text { Rio de Janeiro, RJ, } \\
\text { Brasil, } 1964 .\end{array}$ \\
\hline
\end{tabular}

Rua Praça do Relógio, 160 • tel.: + 551130913039 • Cidade Universitária • CEP: 05508-050 • São Paulo • SP • Brasil

Lista Fotógrafos Da Cena Contemporânea 20111022 


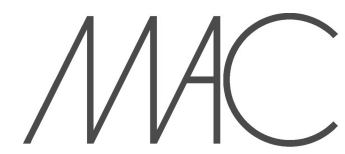

MUSEU DE ARTE CONTEMPORÂNEA da Universidade de São Paulo

\begin{tabular}{|c|c|c|c|c|}
\hline Brígida Baltar & $\begin{array}{c}\text { A Coleta da Neblina, } \\
1996 / 2005\end{array}$ & C-print & $70 \times 100 \mathrm{~cm}$ & $\begin{array}{c}\text { Rio de Janeiro, RJ, } \\
\text { Brasil, } 1959 .\end{array}$ \\
\hline Brígida Baltar & $\begin{array}{c}\text { A Coleta da Neblina, } \\
1996 / 2001\end{array}$ & Fotografia & $70 \times 100 \mathrm{~cm}$ & $\begin{array}{c}\text { Rio de Janeiro, RJ, } \\
\text { Brasil, } 1959 .\end{array}$ \\
\hline Brígida Baltar & $\begin{array}{c}\text { A Coleta da Neblina, } \\
1996 / 2005\end{array}$ & C-print & $70 \times 100 \mathrm{~cm}$ & $\begin{array}{c}\text { Rio de Janeiro, RJ, } \\
\text { Brasil, } 1959 .\end{array}$ \\
\hline Brígida Baltar & A Coleta da Neblina, 2001 & Fotografia & $40 \times 60 \mathrm{~cm}$ & $\begin{array}{c}\text { Rio de Janeiro, RJ, } \\
\text { Brasil, } 1959 .\end{array}$ \\
\hline Janaina Tschäpe & $\begin{array}{l}\text { Dani I, Série After the } \\
\text { Rain, } 2003 \\
\text { (Dani, Série Depois da } \\
\text { Chuva) }\end{array}$ & Cibachrome & $102 \times 127 \mathrm{~cm}$ & $\begin{array}{c}\text { Munique, } \\
\text { Alemanha, } 1973 .\end{array}$ \\
\hline Janaina Tschäpe & $\begin{array}{l}\text { Lívia 5, Série After the } \\
\text { Rain, } 2003 \\
\text { (Líva 5i, Série Depois da } \\
\text { Chuva) }\end{array}$ & Cibachrome & $106,1 \times 131,5$ & $\begin{array}{c}\text { Munique, } \\
\text { Alemanha, } 1973\end{array}$ \\
\hline $\begin{array}{l}\text { Vanessa } \\
\text { Beecroft }\end{array}$ & $\begin{array}{l}\text { VB-65 Performance } \\
\text { Show, } 1998\end{array}$ & $\begin{array}{l}\text { Fotografia - Foto cor } \\
\text { (Vibracolor), }\end{array}$ & $90 \times 119 \times \mathrm{cm}$ & $\begin{array}{l}\text { Genova, Itália, } \\
1969 .\end{array}$ \\
\hline Dave Muller & $\begin{array}{l}\text { Série en el Cielo, } 2001 \\
\text { (Série no Céu) }\end{array}$ & Fotografia - Foto Cor & $41 \times 51 \times \mathrm{cm}$ & $\begin{array}{l}\text { São Francisco, EUA, } \\
1964\end{array}$ \\
\hline Gabriel Orozco & $\begin{array}{l}\text { Série en el Cielo, } 2001 \\
\text { (Série no Céu) }\end{array}$ & Fotografia - Foto Cor & $41 \times 51 \times \mathrm{cm}$ & $\begin{array}{l}\text { Jalapa, México, } \\
1962 .\end{array}$ \\
\hline Glenn Ligon & $\begin{array}{l}\text { Série en el Cielo, } 2001 \\
\text { (Série no Céu) }\end{array}$ & Fotografia - Foto Cor & $41 \times 51 \times \mathrm{cm}$ & $\begin{array}{c}\text { Nova York, EUA, } \\
1960 .\end{array}$ \\
\hline $\begin{array}{c}\text { Janet Cardiff \& } \\
\text { Georges Bures } \\
\text { Miller }\end{array}$ & $\begin{array}{l}\text { Série en el Cielo, } 2001 \\
\text { (Série no Céu) }\end{array}$ & Fotografia - Foto Cor & $41 \times 51 \times \mathrm{cm}$ & $\begin{array}{l}\text { Brussels, Canadá, } \\
\text { 1957/Vegreville, } \\
\text { Canada, em } 1960\end{array}$ \\
\hline Jeff Wall & Série en el Cielo, 2001 & Fotografia - Foto Cor & $41 \times 51 \times \mathrm{cm}$ & Vancouver, Canadá, \\
\hline
\end{tabular}

$\overline{\text { Rua Praça do Relógio, } 160}$ • tel.: + 551130913039 • Cidade Universitária • CEP: 05508-050 • São Paulo • SP • Brasil

Lista Fotógrafos Da Cena Contemporânea 20111022 


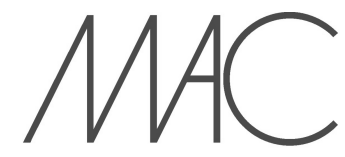

MUSEU DE ARTE CONTEMPORÂNEA da Universidade de São Paulo

\begin{tabular}{|c|c|c|c|c|}
\hline & (Série no Céu) & & & 1946. \\
\hline Koo Jeong-a & $\begin{array}{l}\text { Série en el Cielo, } 2001 \\
\text { (Série no Céu) }\end{array}$ & Fotografia - Foto Cor & $41 \times 51 \times \mathrm{cm}$ & Seul, Coréia, 1967. \\
\hline Olafur Eliasson & $\begin{array}{l}\text { Série en el Cielo, } 2001 \\
\text { (Série no Céu) }\end{array}$ & Fotografia - Foto Cor & $41 \times 51 \times \mathrm{cm}$ & $\begin{array}{c}\text { Copenhagen, } \\
\text { Dinamarca, em } \\
1967 .\end{array}$ \\
\hline Paul Mccarthy & $\begin{array}{l}\text { Série en el Cielo, } 2001 \\
\text { (Série no Céu) }\end{array}$ & Fotografia - Foto Cor & $41 \times 51 \times \mathrm{cm}$ & $\begin{array}{c}\text { Salt Lake City, EUA, } \\
1945 .\end{array}$ \\
\hline $\begin{array}{c}\text { Rirkrit } \\
\text { Tiravanija }\end{array}$ & $\begin{array}{l}\text { Série en el Cielo, } 2001 \\
\text { (Série no Céu) }\end{array}$ & Fotografia - Foto Cor & $41 \times 51 \times \mathrm{cm}$ & $\begin{array}{c}\text { Buenos Aires, } \\
\text { Argentina, } 1961\end{array}$ \\
\hline VALIE EXPORT & $\begin{array}{l}\text { Série en el Cielo, } 2001 \\
\text { (Série no Céu) }\end{array}$ & Fotografia - Foto Cor & $41 \times 51 \times \mathrm{cm}$ & Linz, Austria, 1940 \\
\hline Vik Muniz & $\begin{array}{l}\text { Série en el Cielo, } 2001 \\
\text { (Série no Céu) }\end{array}$ & Fotografia - Foto Cor & $41 \times 51 \times \mathrm{cm}$ & $\begin{array}{l}\text { São Paulo, SP, } \\
\text { Brasil, } 1961\end{array}$ \\
\hline Bob Kolbrener & $\begin{array}{c}\text { Sharon - Cliff Wall, CO, } \\
1998\end{array}$ & $\begin{array}{l}\text { Gelatin silver print with } \\
\text { selenium toning }\end{array}$ & $40 \times 50 \times \mathrm{cm}$ & $\begin{array}{c}\text { St. Louis, EUA, } \\
1942\end{array}$ \\
\hline
\end{tabular}

Rua Praça do Relógio, 160 • tel.: + 551130913039 • Cidade Universitária • CEP: 05508-050 • São Paulo • SP • Brasil 
Exposição "Coleções sob Guarda" (abertura prevista: 12/01/2010) MAC Ibirapuera - espaço não climatizado

\begin{tabular}{|c|c|c|c|}
\hline artista & título da obra & técnica & Dimensões \\
\hline cordeiro do maranhão & savana, 2000 & pintura & \\
\hline cordeiro do maranhão & a fartura, 2001 & pintura s/ tela & \\
\hline cordeiro do maranhão & oca 1 (pandeirão), & $\begin{array}{l}\text { escultura em metal, } \\
\text { provavelmente ferro }\end{array}$ & $236 \times 89 \times 56 \mathrm{~cm}$ \\
\hline cordeiro do maranhão & oca 2 (salto alto), & escultura em ferro & $158 \times 61 \times 53 \mathrm{~cm}$ \\
\hline cordeiro do maranhão & oca 3 (pescador), & $\begin{array}{l}\text { escultura em metal, } \\
\text { provavelmente ferro }\end{array}$ & $139 \times 194 \times 151 \mathrm{~cm}$ \\
\hline cordeiro do maranhão & $\begin{array}{c}\text { oca } 4 \text { (tambor de } \\
\text { crioula) }\end{array}$ & $\begin{array}{l}\text { escultura em metal, } \\
\text { provavelmente ferro }\end{array}$ & $109 \times 56 \times 56$ \\
\hline cordeiro do maranhão & arrastão, 2001 & pintura óleo s/ tela & \\
\hline cordeiro do maranhão & a forja, 2001 & pintura óleo s/ tela & $109 \times 148 \times \mathrm{cm}$ \\
\hline cordeiro do maranhão & o abate, 2000 & acrílico s/ tela - & \\
\hline 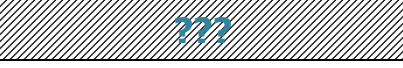 & S & & \\
\hline aldemir martins & gato, 1978 & pintura óleo s/ tela & $83 \times 103$ \\
\hline aldemir martins & s/título (gato), 1965 & pintura óleo s/ tela & $45 \times 29$ \\
\hline aldemir martins & s/título (gato), 1967 & $\begin{array}{c}\text { pintura a óleo s/ } \\
\text { tela }\end{array}$ & $47 \times 39$ \\
\hline 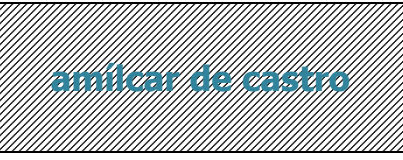 & 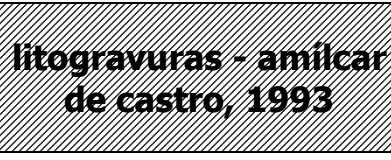 & 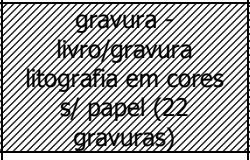 & 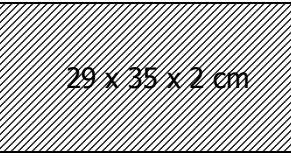 \\
\hline amílcar de castro & s/título, 1997 & gravura - litogravura & \\
\hline amílcar de castro & s/título, 1997 & gravura - litogravura & $84 \times 113$ \\
\hline amílcar de castro & s/título, 1997 & gravura - litogravura & $83,5 \times 112,5$ \\
\hline amílcar de castro & s/título, & escultura - ferro & $29 \times 39 \times 45 \mathrm{~cm}$ \\
\hline amílcar de castro & s/título, 1989 & pintura s/ tela & Mancha $140 \times 200 \mathrm{~cm}$ \\
\hline antônio gomide & s/título & lápis s/ papel - & $76 \times 100$ \\
\hline antônio gomide & s/título, & $\begin{array}{c}\text { lápis integral s/ } \\
\text { papel }\end{array}$ & $76 \times 100$ \\
\hline antônio helio cabral & s/título, 2004 & $\begin{array}{c}\text { gravura litografia s/ } \\
\text { papel }\end{array}$ & $42 \times 36$ \\
\hline $\begin{array}{c}\text { antônio henrique do } \\
\text { amaral }\end{array}$ & tekhne I, 2000 & $\begin{array}{c}\text { pintura grafite, } \\
\text { pastel seco, pastel } \\
\text { oleoso, óleo s/ } \\
\text { papel } \\
\end{array}$ & $117 \times 193$ \\
\hline arcangelo ianelli & s/título, & granito negro & $100 \times 22 \times 24,5$ \\
\hline arcangelo ianelli & s/título, & mámore branco & $95 \times 35 \times 20 \mathrm{~cm}$ \\
\hline arnaldo ferrari & estrutura 11, 1968 & latex s/ cartolina & $37,5 \times 62$ \\
\hline beatriz de carvalho & s/título, & $\begin{array}{c}\text { óleo e massa corrida } \\
\mathrm{s} / \text { tela }\end{array}$ & \\
\hline 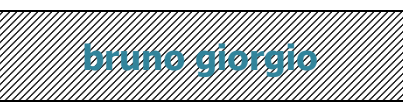 & w & 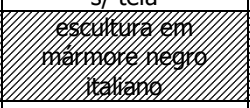 & 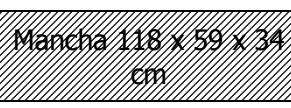 \\
\hline bruno giorgio & $\begin{array}{l}\text { s/título (figura } \\
\text { feminina se } \\
\text { penteando), }\end{array}$ & $\begin{array}{c}\text { escultura em bronze } \\
\text { patinado }\end{array}$ & $74 \times 12 \times 25 \mathrm{~cm}$ \\
\hline burle marx & s/título, 1951 & pintura óleo s/ tela & \\
\hline
\end{tabular}




\begin{tabular}{|c|c|c|c|}
\hline carlito carvalhosa & s/título, 1985 & óleo e cera s/ tela & $190 \times 230$ \\
\hline cildo meireles & quadro negro, 1986 & $\begin{array}{l}\text { acrílica e crayon s/ } \\
\text { lona }\end{array}$ & $\begin{array}{c}\text { Mancha } 200 \times 200 \times \\
\mathrm{cm}\end{array}$ \\
\hline cildo meireles & muro, 1986 & $\begin{array}{l}\text { acrílica e crayon s/ } \\
\text { lona }\end{array}$ & $\begin{array}{c}\text { Mancha } 200 \times 200 \times \\
\text { cm }\end{array}$ \\
\hline 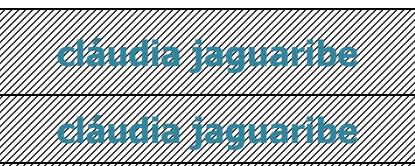 & 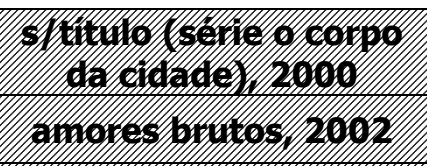 & 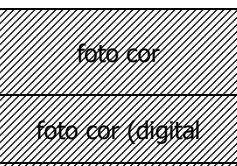 & 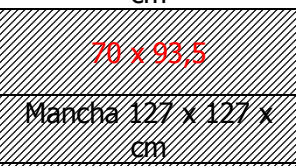 \\
\hline 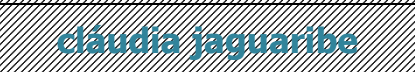 & 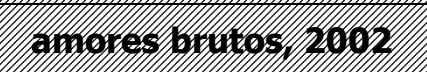 & 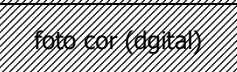 & 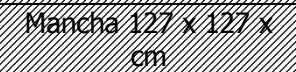 \\
\hline 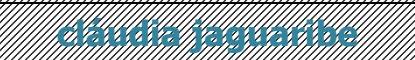 & canand = 2003 & 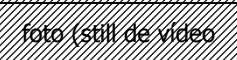 & \\
\hline claudio fonseca & o pescador I, 1986 & óleo s/ tela & $\begin{array}{c}\text { Mancha } 200 \times 160 \times \\
\text { cm }\end{array}$ \\
\hline cláudio tozzi & s/título, 2000/02 & $\begin{array}{c}\text { acrílica s/ tela } \\
\text { colada s/ madeira }\end{array}$ & $\begin{array}{c}\text { Mancha } 100 \times 175 \times \\
\mathrm{cm}\end{array}$ \\
\hline clovis graciano & $\begin{array}{c}\text { menino na cadeira, } \\
1979\end{array}$ & pintura óleo s/ tela & \\
\hline clovis graciano & s/título, 1972 & $\begin{array}{c}\text { desenho grafite s/ } \\
\text { papel }\end{array}$ & \\
\hline dudi maia rosa & principiante, & $\begin{array}{c}\text { encáustica e } \\
\text { recortes de } \\
\text { aglomerado de } \\
\text { madeira s/ fibra de } \\
\text { vidro } \\
\end{array}$ & $\begin{array}{c}\text { Mancha } 147 \times 130 x \\
\text { cm }\end{array}$ \\
\hline eduardo sued & s/título, 1986 & óleo s/ tela - & $\begin{array}{c}\text { Mancha } 140 \times 197 \times \\
\text { cm }\end{array}$ \\
\hline emanoel araújo & s/título, & metal policromado & $\begin{array}{c}\text { Mancha } 278 \times 66 \times 84 \\
\mathrm{~cm}\end{array}$ \\
\hline emanoel araújo & s/título, & $\begin{array}{l}\text { acrílica s/ papel s/ } \\
\text { madeira }\end{array}$ & $\begin{array}{c}\text { Mancha } 169 \times 172 \times 18 \\
\mathrm{~cm}\end{array}$ \\
\hline 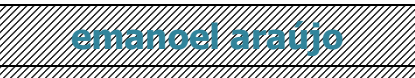 & 徖 & 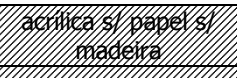 & \\
\hline emmanuel nassar & a língua, 1993 & acrílica s/ tela & $\begin{array}{c}\text { Mancha } 148 \times 200 \times \\
\text { cm }\end{array}$ \\
\hline eric lee klingman & $\begin{array}{c}\text { s/título (suspense), } \\
2002\end{array}$ & pintura óleo s/ tela & Mancha $157 \times 86 \times \mathrm{cm}$ \\
\hline -1, & W. & 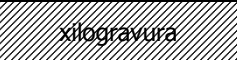 & \\
\hline glauco rodrigues & $\begin{array}{c}\text { menino txucarramãe } \\
\text { lareado em foto de w. } \\
\text { vesco vow puttkramer, } \\
1974\end{array}$ & pintura & $65,5 \times 55$ \\
\hline guilherme de faria & rapina, 1980 & gravura & $78 \times 58$ \\
\hline heitor dos prazeres & s/título, 1966 & óleo s/ tela & Mancha $51 \times 52 \times \mathrm{cm}$ \\
\hline helenos ou holenos (?) & s/título, 1973 & $\begin{array}{c}\text { papel s/ placa de } \\
\text { eucautex }\end{array}$ & $100 \times 175$ \\
\hline ivald granato & mr plural 200, 1980 & acrílica s/tela & $151 \times 110$ \\
\hline ivald granato & $\begin{array}{l}\text { série tecnologia x } \\
\text { inteligência, } 2000\end{array}$ & $\begin{array}{c}\text { acrílica, tinta } \\
\text { metálica e pastel } \\
\text { oleoso } \mathrm{s} / \text { tela } \\
\end{array}$ & $\begin{array}{c}\text { Mancha } 100 \times 175 \times \\
\mathrm{cm}\end{array}$ \\
\hline ivald granato & $\begin{array}{l}\text { série tecnologia } x \\
\text { inteligência, } 2000\end{array}$ & $\begin{array}{c}\text { acrílica, tinta } \\
\text { metálica, crayon e } \\
\text { pastel oleoso s/ tela }\end{array}$ & $\begin{array}{c}\text { Mancha } 100 \times 175 \times \\
\mathrm{cm}\end{array}$ \\
\hline joão câmara fillho & cristo, & $\begin{array}{l}\text { óleo s/ madeira } \\
\text { (tecido ?) }\end{array}$ & $220 \times 129$ \\
\hline josé alberto nemer & s/título, 1991 & guache e desenho & $46 \times 40$ \\
\hline josé alberto nemer & s/título, 1991 & $\begin{array}{c}\text { guache e desenho } \\
\text { s/ papel }\end{array}$ & Mancha $46 \times 40 \times \mathrm{cm}$ \\
\hline josé roberto aguilar & $\begin{array}{c}\text { s/título (tecnologia e } \\
\text { ecologia), } 2000\end{array}$ & $\begin{array}{l}\text { acrílica s/ plotagem } \\
\text { s/ tela }\end{array}$ & $96 \times 176$ \\
\hline josé roberto aguilar & mulher brasileira, 1980 & acrílica s/ tela & \\
\hline leda catunda & rio e mata, 2000 & $\begin{array}{l}\text { pintura (tecido, } \\
\text { plástico, tinta a } \\
\text { óleo) }\end{array}$ & $100 \times 175$ \\
\hline
\end{tabular}




\begin{tabular}{|c|c|c|c|}
\hline luis áquila & $\begin{array}{c}\text { s/título (pintura } \\
\text { abstrata com } \\
\text { pinceladas irregulares), }\end{array}$ & óleo s/ tela & $132 \times 152,5$ \\
\hline manabu mabe & s/título, 1988 & $\begin{array}{l}\text { pintura óleo s/ } \\
\text { madeira }\end{array}$ & $102 \times 103$ \\
\hline marcia goldstein & $\begin{array}{c}\text { s/título (mulher } \\
\text { homem sem cabeça), } \\
1981\end{array}$ & acrílica s/ tela & $\begin{array}{c}\text { Mancha } 165 \times 250 \times \\
\mathrm{cm}\end{array}$ \\
\hline marcos coelho benjamim & s/título, 1993 & $\begin{array}{l}\text { tinta metálica s/ } \\
\text { recortes de zinco s/ } \\
\text { aglomerado de } \\
\text { madeira }\end{array}$ & $\begin{array}{l}\text { Mancha } 200 \times 100 \times \\
\mathrm{cm}\end{array}$ \\
\hline 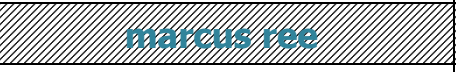 & s. & 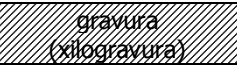 & \\
\hline mário zanini & s/título, & pintura óleo s/ tela & \\
\hline 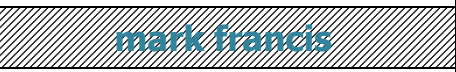 & 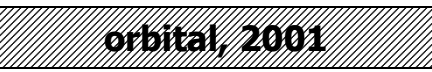 & 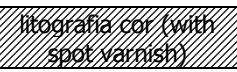 & \\
\hline martins porangaba & serenata, 1989 & acrílica s/ tela & $90 \times 100$ \\
\hline michael thrush & s/título, 2001 & óleo s/ madeira & $122 \times 122$ \\
\hline mira schendel & $\begin{array}{c}\text { a criação do mundo } \\
\text { (série de } 8 \text { desenhos), } \\
1965\end{array}$ & $\begin{array}{l}\text { desenho com lápis } \\
\text { litográfico s/ papel }\end{array}$ & Mancha $47 \times 23 \times \mathrm{cm}$ \\
\hline roberto magalhães & cena doméstica, 1988 & acrílica s/ tela & $\begin{array}{c}\text { Mancha } 100 \times 100 \times \\
\mathrm{cm}\end{array}$ \\
\hline rubens gerchman & internet, & acrílica s/ tela & Mancha $86 \times 200 \times \mathrm{cm}$ \\
\hline santuza andrade & s/título, 2000 & guache s/ papel & Mancha $54 \times 54 \times \mathrm{cm}$ \\
\hline santuza andrade & s/título, 2000 & guache s/ papel & Mancha $54 \times 54 \times \mathrm{cm}$ \\
\hline sérgio ferro & $\begin{array}{c}\text { les anges de } \\
\text { l'apocalypse, } 1992 \\
\end{array}$ & $\begin{array}{l}\text { acrílica, óleo e } \\
\text { crayon s/ tela }\end{array}$ & $196 \times 260$ \\
\hline sergio niculitcheff & s/título, & pintura s/ tela & $\begin{array}{c}\text { Mancha } 201 \times 148 \times \\
\mathrm{cm}\end{array}$ \\
\hline sérgio teles & s/título, 1985 & óleo s/ madeira & $88 \times 105$ \\
\hline silvia aude jábali & s/título, 2001 & pintura s/ tela & $\begin{array}{c}\text { Mancha } 200 \times 145 \times \\
\mathrm{cm}\end{array}$ \\
\hline silvia aude jábali & s/título, 2002 & acrílica s/ tela & Mancha $100 \times 2 \times \mathrm{cm}$ \\
\hline silvia aude jábali & s/título, & acrílica s/ tela & $\begin{array}{c}\text { Mancha } 199 \times 143 \times \\
\text { cm }\end{array}$ \\
\hline silvio oppenheim & s/título, 2000 & $\begin{array}{l}\text { pintura técnica } \\
\text { mista }\end{array}$ & Mancha $164 \times 98 \times \mathrm{cm}$ \\
\hline 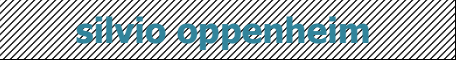 & - & 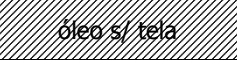 & 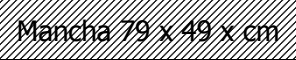 \\
\hline silvio oppenheim & s/título, 2000 & $\begin{array}{l}\text { acrílico e colagem } \\
\text { s/tela }\end{array}$ & $\begin{array}{c}\text { Mancha } 175 \times 100 x \\
\text { cm }\end{array}$ \\
\hline 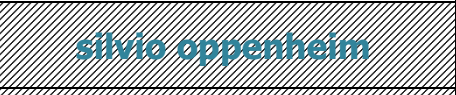 & 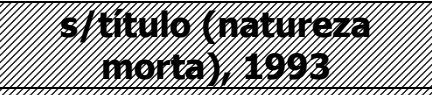 & S & \\
\hline : & -1 & 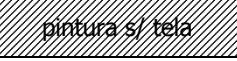 & \\
\hline silvio oppenheim & 1998,1998 & pintura s/ tela & $188 \times 168$ \\
\hline silvio oppenheim & s/título, 1993 & $\begin{array}{c}\text { pintura técnica } \\
\text { mista }\end{array}$ & $\begin{array}{l}\text { Mancha } 180 \times 120 \times \\
\text { cm }\end{array}$ \\
\hline siron franco & brasil, 1990 & óleo s/ tela & $\begin{array}{c}\text { Mancha } 155 \times 135 \times \\
\mathrm{cm}\end{array}$ \\
\hline siron franco & s/título, & óleo s/ tela & $120 \times 72$ \\
\hline siron franco & $\begin{array}{c}\text { título proibido no } 2, \\
1979\end{array}$ & óleo s/ tela & Mancha $2 \times 1 \times \mathrm{cm}$ \\
\hline tae-kyoung lee & s/título, 2002 & pintura óleo s/ tela & pintura óleo s/ tela \\
\hline thierry cauwet & s/título, 1982 & foto cor & Mancha $45 \times 61 \times \mathrm{cm}$ \\
\hline tikashi fukushima & $\begin{array}{c}\text { composição em } \\
\text { vermelho, }\end{array}$ & óleo s/ tela & \\
\hline tomoshige kusuno & $\begin{array}{c}\text { lâmina de serra até } \\
\text { corta nosso universo, } \\
2000\end{array}$ & $\begin{array}{c}\text { óleo s/ recortes de } \\
\text { tle e juta colados s/ } \\
\text { aglomerado de } \\
\text { madeira }\end{array}$ & \\
\hline
\end{tabular}




\begin{tabular}{|c|c|c|c|}
\hline tomoshige kusuno & $\begin{array}{c}\text { dia e noite cheirando } \\
\text { mal, } 2000\end{array}$ & $\begin{array}{l}\text { grafite, pastel, } \\
\text { crayon e guache s/ } \\
\text { tela colada s/ } \\
\text { madeira }\end{array}$ & \\
\hline yasun ou kasun (?) & $\begin{array}{c}\text { s/título (slow new } \\
\text { working), } 1997\end{array}$ & pintura óleo s/ tela & \\
\hline CONTRERAS & Sem título, 2004 & $\begin{array}{c}\text { acrílica, cal e } \\
\text { cimento sobre lona }\end{array}$ & $\begin{array}{l}\text { moldura: madeira - } \\
130 \times 194,7 \times 4,5 \mathrm{~cm}\end{array}$ \\
\hline D. MEATTI & Sem título, s.d. & óleo sobre tela & $\begin{array}{c}\text { moldura: madeira } \\
\text { dourada - } 101,5 \times 71,5 \\
\times 3 \mathrm{~cm}\end{array}$ \\
\hline GIANNOTTI, Marco & Sem título, 2003 & guache sobre papel & $\begin{array}{c}\text { moldura: madeira } \\
\text { pintada }-57 \times 71,5 \times \\
3,3 \mathrm{~cm}\end{array}$ \\
\hline GIANNOTTI, Marco & Sem título, 2003 & guache sobre papel & $\begin{array}{c}\text { moldura: madeira } \\
\text { pintada - } 56,8 \times 71,5 \times \\
3 \mathrm{~cm} \\
\end{array}$ \\
\hline GOMIDE, Antônio & Torso Feminino, s.d. & pastel sobre papel & $\begin{array}{c}\text { moldura: madeira } \\
\text { entalhada }-83,5 \times 69,8 \\
\times 7 \mathrm{~cm} \\
\end{array}$ \\
\hline NECKEL, Helena & Roxene, 2006 & $\begin{array}{c}\text { acrílica e tinta } \\
\text { industrial sobre } \\
\text { aglomerado de } \\
\text { madeira }\end{array}$ & $\begin{array}{c}\text { moldura: madeira } \\
\text { pintada - } 98,8 \times 213,8 \\
\text { x } 5 \mathrm{~cm}\end{array}$ \\
\hline Nelson & Sem título, s.d. & $\begin{array}{l}\text { linoleografia sobre } \\
\text { papel }\end{array}$ & $\begin{array}{c}\text { moldura: madeira } \\
\text { pintada - } 34,1 \times 48,8 \times \\
3,2 \mathrm{~cm}\end{array}$ \\
\hline Nelson & Sem título, s.d. & $\begin{array}{l}\text { linoleografia sobre } \\
\text { papel }\end{array}$ & $\begin{array}{c}\text { moldura: madeira } \\
\text { pintada - } 48,8 \times 34,2 \times \\
3,2 \mathrm{~cm}\end{array}$ \\
\hline & - & 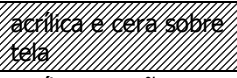 & 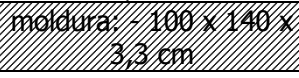 \\
\hline RAMOS PINTO, A. & Cmeianisela, 2003 & $\begin{array}{l}\text { acrílica, carvão e } \\
\text { tinta industrial sobre } \\
\text { lona vinílica } \\
\end{array}$ & $\begin{array}{c}\text { moldura: }-180 \times 110 \times \\
3,3 \mathrm{~cm}\end{array}$ \\
\hline RAMOS PINTO, A. & Cidade Marfim, 2004 & \begin{tabular}{|l|} 
acrílica e tinta \\
industrial sobre lona \\
vinílica \\
\end{tabular} & $\begin{array}{c}\text { moldura: madeira } \\
\text { pintada - } 183 \text { x } 113 \times \\
5,2 \mathrm{~cm} \\
\end{array}$ \\
\hline SACILOTTO, Luiz & Sem título, s.d. & acrílica sobre tela & $\begin{array}{c}\text { madeira pintada - 92,3 } \\
\times 92,3 \times 4 \mathrm{~cm} \\
\end{array}$ \\
\hline SISTER, Sérgio & Sem título, 2000 & acrílica sobre tela & $\begin{array}{c}\text { moldura: }-140,5 \times \\
85,5 \times 2,5 \mathrm{~cm} \\
\end{array}$ \\
\hline TOLEDO, Amélia & Sem título, 2005 & acrílica sobre juta & $\begin{array}{c}\text { moldura: }-135,3 \times \\
98,3 \times 3,7 \mathrm{~cm}\end{array}$ \\
\hline VILELA, Fernando & Sem título, 2005 & $\begin{array}{l}\text { xilografia em cores } \\
\text { sobre papel }\end{array}$ & $\begin{array}{c}\text { moldura: madeira } \\
\text { pintada }-99 \times 133 \times 3 \\
\mathrm{~cm}\end{array}$ \\
\hline $\begin{array}{l}\text { DI CAVALCANTI, } \\
\text { Emiliano }\end{array}$ & Sem título, 1963 & óleo sobre tela & $\begin{array}{c}\text { moldura: madeira } \\
\text { dourada - } 110 \times 91 \times \\
4,5 \mathrm{~cm} \\
\end{array}$ \\
\hline $\begin{array}{c}\text { DI CAVALCANTI, } \\
\text { Emiliano }\end{array}$ & Carnaval, 1968 & óleo sobre tela & $\begin{array}{c}\text { moldura: madeira } \\
\text { dourada - } 102 \times 137 \times \\
5,3 \mathrm{~cm}\end{array}$ \\
\hline $\begin{array}{c}\text { DI CAVALCANTI, } \\
\text { Emiliano }\end{array}$ & $\begin{array}{c}\text { Retrato de Marina } \\
\text { Montini, } 1972\end{array}$ & óleo sobre tela & $\begin{array}{l}\text { moldura: madeira - } \\
130 \times 95 \times 6 \mathrm{~cm} \\
\end{array}$ \\
\hline $\begin{array}{c}\text { DI CAVALCANTI, } \\
\text { Emiliano }\end{array}$ & Sem título, 1974 & óleo sobre tela & $\begin{array}{c}\text { moldura: madeira } \\
\text { patinada - } 93 \times 80,7 \times \\
6,8 \mathrm{~cm}\end{array}$ \\
\hline 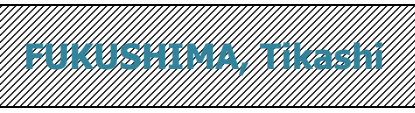 & 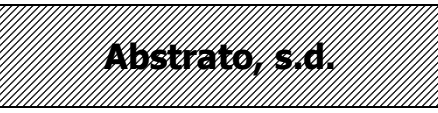 & 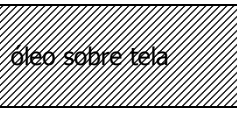 & 约1 \\
\hline LACOURT, Jean-Pierre & Eternity Bar, 1995 & óleo sobre tela & 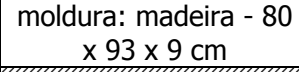 \\
\hline V & 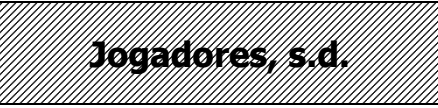 & 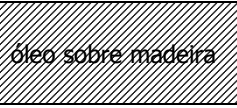 & 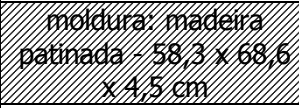 \\
\hline MIRÓ, Joan & $\begin{array}{c}\text { A Cantora Careca (La } \\
\text { Cantatrice Chauve), s.d. }\end{array}$ & $\begin{array}{l}\text { água-tinta em } \\
\text { cores, relevo e } \\
\text { colagem sobre } \\
\text { papel } \\
\end{array}$ & $\begin{array}{c}\text { moldura: madeira } \\
\text { dourada - } 162 \times 126 \times \\
5 \mathrm{~cm}\end{array}$ \\
\hline MIRÓ, Joan & Le Predicateur, s.d. & $\begin{array}{l}\text { água-tinta em cores } \\
\text { e relevo sobre papel }\end{array}$ & $\begin{array}{c}\text { moldura: madeira } \\
\text { dourada e laqueada - } \\
182 \times 142 \times 5 \mathrm{~cm} \\
\end{array}$ \\
\hline MIRÓ, Joan & Sem título, s.d. & $\begin{array}{l}\text { água-tinta em cores } \\
\text { sobre papel }\end{array}$ & $\begin{array}{l}\text { moldura: madeira } \\
\text { dourada e laqueada - } \\
90 \times 125 \times 5 \mathrm{~cm}\end{array}$ \\
\hline
\end{tabular}




\begin{tabular}{|c|c|l|c|}
\hline PORTINARI, Cândido & $\begin{array}{c}\text { Sem título (Estudo da } \\
\text { Capela de Brodósqui), } \\
\text { s.d. }\end{array}$ & $\begin{array}{c}\text { aquarela e grafite } \\
\text { sobre papel }\end{array}$ & $\begin{array}{c}\text { moldura: madeira } \\
\text { pintada }-45 \times 54 \times 4,8 \\
\mathrm{~cm}\end{array}$ \\
\hline
\end{tabular}

Legenda

Obra retirada da exposição 
MUSEU DE ARTE CONTEMPORÂNEA

Nome da Exposição:

Lista de obras:

Local:

Período da exposição:

Período de produção e pós-produção: 


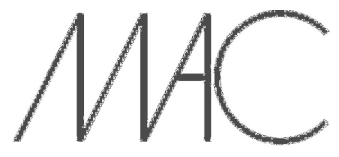

MUSEU DE ARTE CONTEMPORÂNEA

\begin{tabular}{|c|c|c|c|c|c|c|c|}
\hline Artista & Imagem & Título da obra & $\begin{array}{c}\text { Técnica e } \\
\text { Dimensões }\end{array}$ & $\begin{array}{c}\text { Valor para efeito de } \\
\text { seguro em } R \$ \text { (US\$ = } \\
1,59)\end{array}$ & Procedência: & $\begin{array}{l}\text { Necessidade de } \\
\text { conservação }\end{array}$ & $\begin{array}{l}\text { Necessidade } \\
\text { Museográfica }\end{array}$ \\
\hline $\begin{array}{l}\text { Man Ray } \\
\text { 1890,Filadélfia, } \\
\text { EUA } \\
\text { 1976, Paris, } \\
\text { França }\end{array}$ & & $\begin{array}{l}\text { O Mundo, } 1931 \\
\text { Album Eletricité }\end{array}$ & $\begin{array}{l}\text { fotografia } \\
\text { rayografia, fotograma } \\
26,3 \times 21 \times \mathrm{cm}\end{array}$ & $\mathrm{R} \$ 44.520,00$ & $\begin{array}{l}\text { Coleção sob } \\
\text { Guarda Provisória }\end{array}$ & $\begin{array}{l}\text { Estabilidade } \\
\text { temperatura e umidade } \\
\text { do ar } \\
\text { Temperatura: } 20 \text { a } 22^{\circ} \mathrm{C} \\
\text { Umidade Relativa do ar: } \\
55 \text { a } 57 \% \\
70 \text { a } 100 \text { lux (com } \\
\text { proteção UV) }\end{array}$ & Vitrine \\
\hline $\begin{array}{l}\text { Man Ray } \\
\text { 1890,Filadélfia, } \\
\text { EUA } \\
\text { 1976, Paris, } \\
\text { França }\end{array}$ & & $\begin{array}{l}\text { Banheiro, } 1931 \\
\text { Album Eletricité }\end{array}$ & $\begin{array}{l}\text { fotografia } \\
\text { rayografia, fotograma } \\
26 \times 20,3 \times \mathrm{cm}\end{array}$ & $\mathrm{R} \$ 44.520,00$ & $\begin{array}{l}\text { Coleção sob } \\
\text { Guarda Provisória }\end{array}$ & $\begin{array}{l}\text { Estabilidade } \\
\text { temperatura e umidade } \\
\text { do ar } \\
\text { Temperatura: } 20 \text { a } 22^{\circ} \mathrm{C} \\
\text { Umidade Relativa do ar: } \\
55 \text { a } 57 \% \\
70 \text { a } 100 \text { lux (com } \\
\text { proteção UV) }\end{array}$ & Vitrine \\
\hline
\end{tabular}

Rua Praça do Relógio, 160 • tel.: + 551130913039 • Cidade Universitária • CEP: 05508-050 • São Paulo • SP • Brasil 


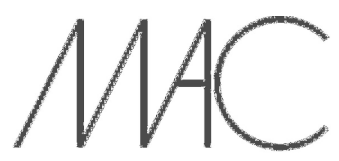

MUSEU DE ARTE CONTEMPORÂNEA
da Univesisdoded de Sáo Paul

\begin{tabular}{|c|c|c|c|c|c|c|}
\hline $\begin{array}{l}\text { Man Ray } \\
\text { 1890,Filadélfia, } \\
\text { EUA } \\
\text { 1976, Paris, } \\
\text { França }\end{array}$ & $\begin{array}{l}\text { a brisa, } 1931 \\
\text { Album Eletricité }\end{array}$ & $\begin{array}{l}\text { fotografia } \\
\text { rayografia, fotograma } \\
26 \times 20,9 \times \mathrm{cm}\end{array}$ & $\mathrm{R} \$ 44.520,00$ & $\begin{array}{l}\text { Coleção sob } \\
\text { Guarda Provisória }\end{array}$ & $\begin{array}{l}\text { Estabilidade } \\
\text { temperatura e umidade } \\
\text { do ar } \\
\text { Temperatura: } 20 \text { a } 22^{\circ} \mathrm{C} \\
\text { Umidade Relativa do ar: } \\
55 \text { a } 57 \% \\
70 \text { a } 100 \text { lux (com } \\
\text { proteção UV) }\end{array}$ & Vitrine \\
\hline $\begin{array}{l}\text { Man Ray } \\
\text { 1890,Filadélfia, } \\
\text { EUA } \\
\text { 1976, Paris, } \\
\text { França }\end{array}$ & $\begin{array}{l}\text { sala de jantar, } \\
1931 \\
\text { Album Eletricité }\end{array}$ & $\begin{array}{l}\text { fotografia } \\
\text { rayografia, fotograma } \\
26,1 \times 20,5 \times \mathrm{cm}\end{array}$ & $\mathrm{R} \$ 44.520,00$ & $\begin{array}{l}\text { Coleção sob } \\
\text { Guarda Provisória }\end{array}$ & $\begin{array}{l}\text { Estabilidade } \\
\text { temperatura e umidade } \\
\text { do ar } \\
\text { Temperatura: } 20 \text { a } 22^{\circ} \mathrm{C} \\
\text { Umidade Relativa do ar: } \\
55 \text { a } 57 \% \\
70 \text { a } 100 \text { lux (com } \\
\text { proteção UV) }\end{array}$ & Vitrine \\
\hline $\begin{array}{l}\text { Man Ray } \\
\text { 1890,Filadélfia, } \\
\text { EUA } \\
\text { 1976, Paris, } \\
\text { França }\end{array}$ & $\begin{array}{l}\text { cozinha, } 1931 \\
\text { Album Eletricité }\end{array}$ & $\begin{array}{l}\text { fotografia } \\
\text { rayografia, } \\
\text { fotograma, } \\
20 \times 26 \times \mathrm{cm}\end{array}$ & $R \$ 44.520,00$ & $\begin{array}{l}\text { Coleção sob } \\
\text { Guarda Provisória }\end{array}$ & $\begin{array}{l}\text { Estabilidade } \\
\text { temperatura e umidade } \\
\text { do ar } \\
\text { Temperatura: } 20 \text { a } 22^{\circ} \mathrm{C} \\
\text { Umidade Relativa do ar: } \\
55 \text { a } 57 \% \\
70 \text { a } 100 \text { lux (com } \\
\text { proteção UV) }\end{array}$ & Vitrine \\
\hline
\end{tabular}




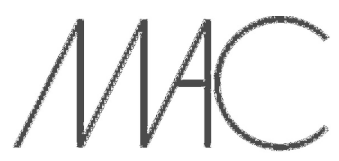

MUSEU DE ARTE CONTEMPORÂNEA
da Univesisdoded de Sáo Paul

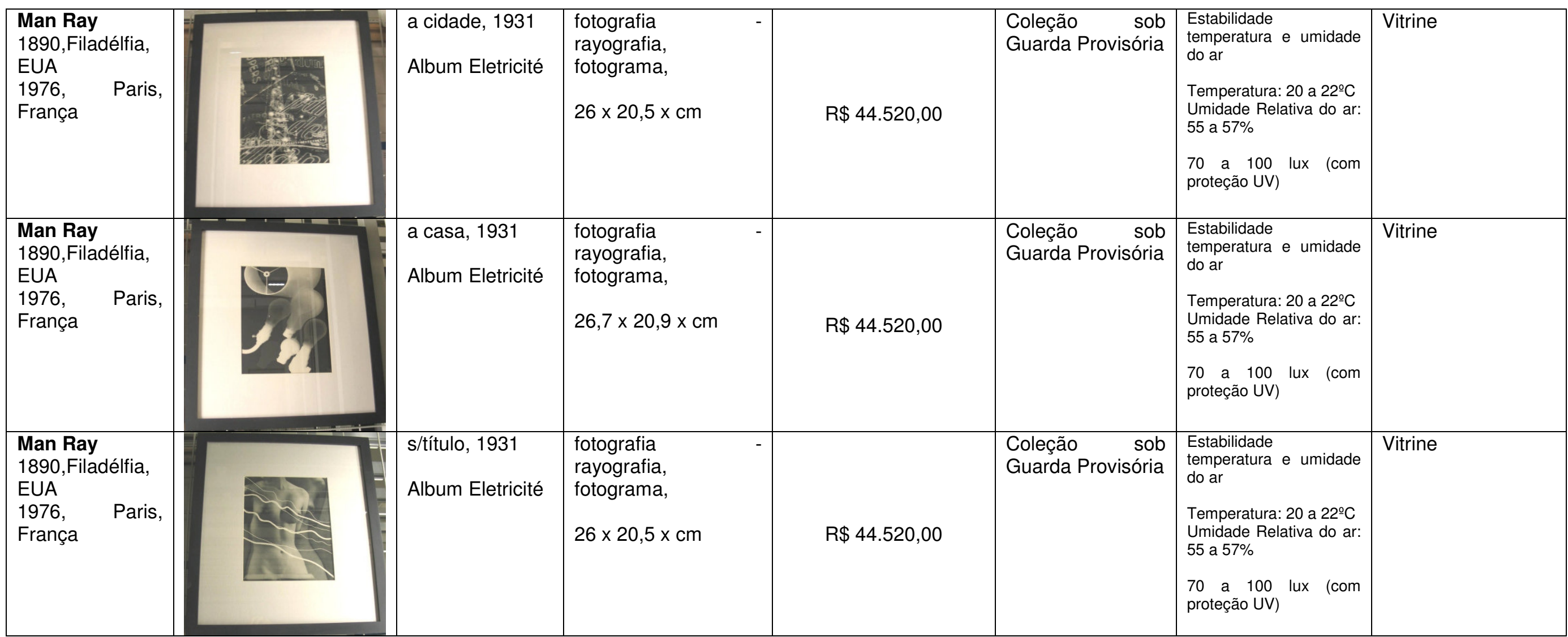

Rua Praça do Relógio, 160 • tel.: + 551130913039 • Cidade Universitária • CEP: 05508-050 • São Paulo • SP • Brasil 


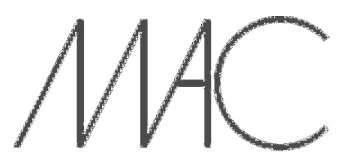

MUSEU DE ARTE CONTEMPORÂNEA
da Univesisdoded de Sáo Paul

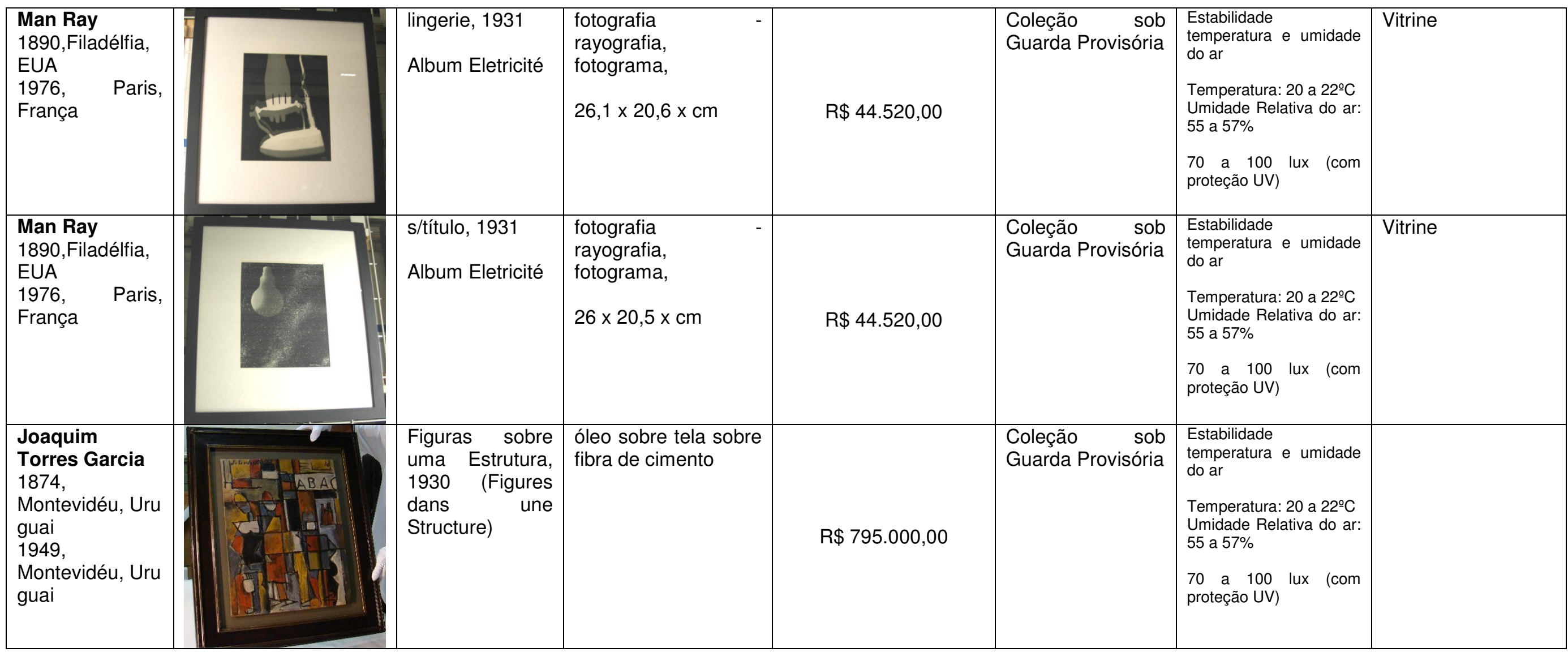

Rua Praça do Relógio, 160 • tel.: + 551130913039 • Cidade Universitária • CEP: 05508-050 • São Paulo • SP • Brasil 


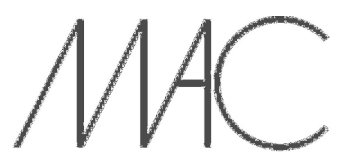

MUSEU DE ARTE CONTEMPORÂNEA

\begin{tabular}{|c|c|c|c|c|c|c|}
\hline $\begin{array}{l}\text { Damien Hirst } \\
\text { 7/06/1965, } \\
\text { Bristol, } \\
\text { Inglaterra }\end{array}$ & 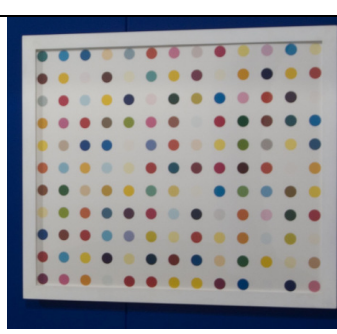 & $\begin{array}{l}\text { aldosterone } 18, \\
21 \text { diacetate, } 3 \\
\text { (0-carboxy- } \\
\text { methyl), } 1992\end{array}$ & $\begin{array}{l}\text { Técnica mista } \\
118,7 \times 139 \mathrm{~cm}\end{array}$ & $\mathrm{R} \$ 556.500,00$ & $\begin{array}{l}\text { Coleção sob } \\
\text { Guarda Provisória }\end{array}$ & $\begin{array}{l}\text { Estabilidade } \\
\text { temperatura e umidade } \\
\text { do ar } \\
\text { Temperatura: } 20 \text { a } 22^{\circ} \mathrm{C} \\
\text { Umidade Relativa do ar: } \\
55 \text { a } 57 \% \\
70 \text { a } 100 \text { lux (com } \\
\text { proteção UV) }\end{array}$ \\
\hline $\begin{array}{l}\text { Roberto } \\
\text { Sebastian } \\
\text { Matta } \\
\text { Santiago, Chile, } \\
1911 \\
\text { Paris, França, } \\
2002\end{array}$ & 8 & $\begin{array}{l}\text { La Glaive et La } \\
\text { parole }\end{array}$ & $86 \times 60 \mathrm{~cm}$ & 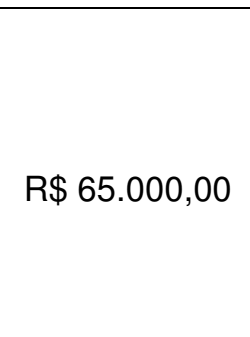 & $\begin{array}{l}\text { Coleção sob } \\
\text { Guarda Provisória }\end{array}$ & $\begin{array}{l}\text { Estabilidade } \\
\text { temperatura e umidade } \\
\text { do ar } \\
\text { Temperatura: } 20 \text { a } 22^{\circ} \mathrm{C} \\
\text { Umidade Relativa do ar: } \\
55 \text { a } 57 \% \\
70 \text { a } 100 \text { lux (com } \\
\text { proteção UV) }\end{array}$ \\
\hline $\begin{array}{l}\text { Sandro Chia } \\
\text { 20/04/1946 } \\
\text { Florença, Itália }\end{array}$ & & $\begin{array}{l}\text { From Dusk Till } \\
\text { Dawn }\end{array}$ & $\begin{array}{l}\text { Óleo s/ tela } \\
160 \times 100 \mathrm{~cm}\end{array}$ & 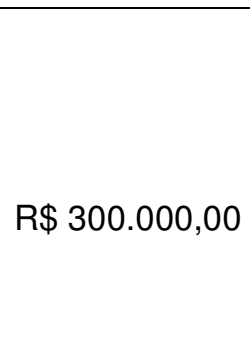 & $\begin{array}{l}\text { Coleção sob } \\
\text { Guarda Provisória }\end{array}$ & $\begin{array}{l}\text { Estabilidade } \\
\text { temperatura e umidade } \\
\text { do ar } \\
\text { Temperatura: } 20 \text { a } 22^{\circ} \mathrm{C} \\
\text { Umidade Relativa do ar: } \\
55 \text { a } 57 \% \\
70 \text { a } 100 \text { lux (com } \\
\text { proteção UV) }\end{array}$ \\
\hline
\end{tabular}




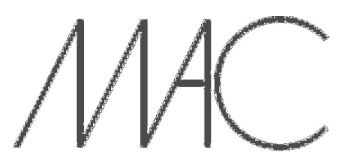

MUSEU DE ARTE CONTEMPORÂNEA

\begin{tabular}{|c|c|c|c|c|c|c|}
\hline $\begin{array}{l}\text { Nelson Leirner } \\
\text { São Paulo, SP, } \\
\text { Brasil, } 1932\end{array}$ & 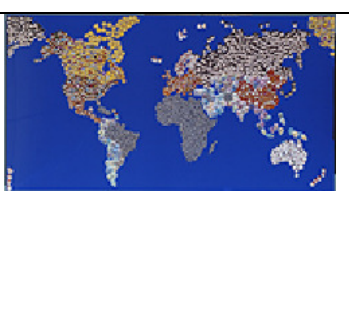 & $\begin{array}{ll}\text { Assim é... } & \text { Se } \\
\text { Lhe Parece } & \end{array}$ & $120 \times 222 \mathrm{~cm}$ & $\mathrm{R} \$ 20.000,00$ & $\begin{array}{lr}\text { Coleção sob } \\
\text { Guarda Provisória }\end{array}$ & $\begin{array}{l}\text { Estabilidade } \\
\text { temperatura e umidade } \\
\text { do ar } \\
\text { Temperatura: } 20 \text { a } 22^{\circ} \mathrm{C} \\
\text { Umidade Relativa do ar: } \\
55 \text { a } 57 \% \\
70 \text { a } 100 \text { lux (com } \\
\text { proteção UV) }\end{array}$ \\
\hline $\begin{array}{l}\text { Nelson Leirner } \\
\text { São Paulo, SP, } \\
\text { Brasil, } 1932\end{array}$ & & $\begin{array}{l}\text { Ready Made - } \\
\text { Você Faz Parte } \\
\text { II }\end{array}$ & $\begin{array}{l}\text { Máscaras de } \\
\text { chimpanzés } \\
\text { espelho recortado no } \\
\text { formato de uma das } \\
\text { máscaras. } \\
131,50 \times 131,50 \mathrm{~cm}\end{array}$ & $\mathrm{R} \$ 25.000,00$ & $\begin{array}{l}\text { Coleção sob } \\
\text { Guarda Provisória }\end{array}$ & $\begin{array}{l}\text { Estabilidade } \\
\text { temperatura e umidade } \\
\text { do ar } \\
\text { Temperatura: } 20 \text { a } 22^{\circ} \mathrm{C} \\
\text { Umidade Relativa do ar: } \\
55 \text { a } 57 \% \\
70 \text { a } 100 \text { lux (com } \\
\text { proteção UV) }\end{array}$ \\
\hline $\begin{array}{l}\text { Cindy Sherman } \\
\text { 19/01/1954, } \\
\text { Nova Jersey, } \\
\text { EUA }\end{array}$ & & $\begin{array}{l}\text { Doll with Mask, } \\
\text { 1987/1992 }\end{array}$ & $\begin{array}{l}\text { fotografia - foto cor, } \\
60 \times 50 \times \mathrm{cm}\end{array}$ & 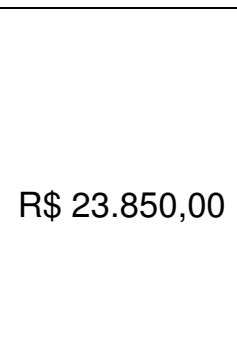 & $\begin{array}{l}\text { Coleção sob } \\
\text { Guarda Provisória }\end{array}$ & $\begin{array}{l}\text { Estabilidade } \\
\text { temperatura e umidade } \\
\text { do ar } \\
\text { Temperatura: } 20 \text { a } 22^{\circ} \mathrm{C} \\
\text { Umidade Relativa do ar: } \\
55 \text { a } 57 \% \\
70 \text { a } 100 \text { lux (com } \\
\text { proteção UV) }\end{array}$ \\
\hline
\end{tabular}




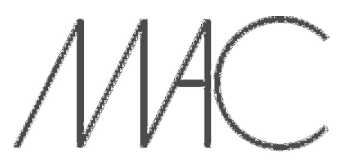

MUSEU DE ARTE CONTEMPORÂNEA

\begin{tabular}{|c|c|c|c|c|c|}
\hline $\begin{array}{l}\text { Cindy Sherman } \\
\text { 19/01/1954, } \\
\text { Nova Jersey, } \\
\text { EUA }\end{array}$ & $\begin{array}{l}\text { Doll with Mask, } \\
1987\end{array}$ & $\begin{array}{l}\text { fotografia - foto cor, } \\
61 \times 50 \times \mathrm{cm}\end{array}$ & 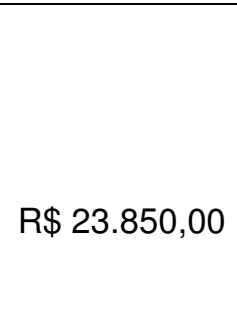 & $\begin{array}{lr}\text { Coleção sob } \\
\text { Guarda Provisória }\end{array}$ & $\begin{array}{l}\text { Estabilidade } \\
\text { temperatura e umidade } \\
\text { do ar } \\
\text { Temperatura: } 20 \text { a } 22^{\circ} \mathrm{C} \\
\text { Umidade Relativa do ar: } \\
55 \text { a } 57 \% \\
70 \text { a } 100 \text { lux (com } \\
\text { proteção UV) }\end{array}$ \\
\hline $\begin{array}{l}\text { Cindy Sherman } \\
\text { 19/01/1954, } \\
\text { Nova Jersey, } \\
\text { EUA }\end{array}$ & $\begin{array}{l}\text { sem título } \\
\text { no.123, } 1983\end{array}$ & $\begin{array}{l}\text { fotografia - foto cor, } \\
88 \times 60 \times \mathrm{cm}\end{array}$ & 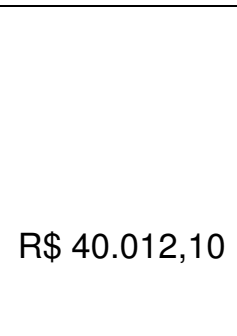 & $\begin{array}{lr}\text { Coleção sob } \\
\text { Guarda Provisória }\end{array}$ & $\begin{array}{l}\text { Estabilidade } \\
\text { temperatura e umidade } \\
\text { do ar } \\
\text { Temperatura: } 20 \text { a } 22^{\circ} \mathrm{C} \\
\text { Umidade Relativa do ar: } \\
55 \text { a } 57 \% \\
70 \text { a } 100 \text { lux (com } \\
\text { proteção UV) }\end{array}$ \\
\hline
\end{tabular}




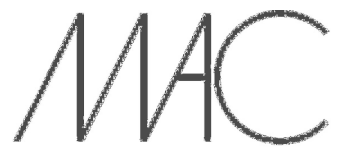

MUSEU DE ARTE CONTEMPORÂNEA

\begin{tabular}{|c|c|c|c|c|c|c|}
\hline $\begin{array}{l}\text { David Hockney } \\
\text { 1937, Bradford, } \\
\text { Inglaterra }\end{array}$ & org 89 & $\begin{array}{l}\text { Gregory and } \\
\text { Shinro \# 9, } 1983\end{array}$ & $\begin{array}{l}\text { fotografia - foto cor } \\
\text { (colagem), } 85 \times 85 \times \\
\mathrm{cm}\end{array}$ & $\mathrm{R} \$ 9.540,00$ & $\begin{array}{l}\text { Coleção sob } \\
\text { Guarda Provisória }\end{array}$ & $\begin{array}{l}\text { Estabilidade } \\
\text { temperatura e umidade } \\
\text { do ar } \\
\text { Temperatura: } 20 \text { a } 22^{\circ} \mathrm{C} \\
\text { Umidade Relativa do ar: } \\
55 \text { a } 57 \% \\
70 \text { a } 100 \text { lux (com } \\
\text { proteção UV) }\end{array}$ \\
\hline $\begin{array}{l}\text { Misha Gordin } \\
\text { 1946, Riga, Letônia }\end{array}$ & 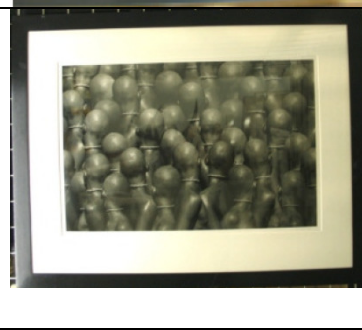 & $\begin{array}{l}\text { Multidão \# 55, } \\
2001\end{array}$ & $\begin{array}{l}\text { fotografia - foto pb, } \\
63 \times 95 \times \mathrm{cm}\end{array}$ & $\mathrm{R} \$ 13.515,00$ & $\begin{array}{lr}\text { Coleção sob } \\
\text { Guarda Provisória }\end{array}$ & $\begin{array}{l}\text { Estabilidade } \\
\text { temperatura e umidade } \\
\text { do ar } \\
\text { Temperatura: } 20 \text { a } 22^{\circ} \mathrm{C} \\
\text { Umidade Relativa do ar: } \\
55 \text { a } 57 \% \\
70 \text { a } 100 \text { lux (com } \\
\text { proteção UV) }\end{array}$ \\
\hline
\end{tabular}

